UNIVERSIDADE DE SÃO PAULO

FACULDADE DE FILOSOFIA, LETRAS E CIÊNCIAS HUMANAS

DEPARTAMENTO DE GEOGRAFIA

PROGRAMA DE PÓS GRADUAÇÃO EM GEOGRAFIA HUMANA

CARLOS EDUARDO FONSECA

A importância da escala do problema no processo de aprendizagem da migração nordestina na metrópole paulistana

(Versão corrigida)

SÃO PAULO

2018 
CARLOS EDUARDO FONSECA

\title{
A importância da escala do problema no processo de aprendizagem da migração nordestina na metrópole paulistana
}

\author{
Versão corrigida
}

Tese apresentada ao Programa de PósGraduação em Geografia Humana da Faculdade de Filosofia, Letras e Ciências Humanas da Universidade de São Paulo como um dos requisitos para obtenção do título de Doutor em Geografia Humana.

Orientador: Prof ${ }^{a} \mathrm{Dr}^{\mathrm{a}}$ Maria Eliza Miranda.

Versão corrigida. De acordo,

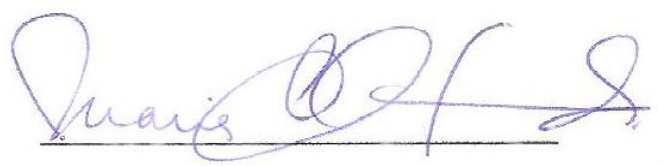

Prof. ${ }^{a}$. Dra. Maria Eliza Miranda (orientadora)

$23 / 11 / 2018$

SÃO PAULO

2018 
Autorizo a reprodução e divulgação total ou parcial deste trabalho, por qualquer meio convencional ou eletrônico, para fins de estudo e pesquisa, desde que citada a fonte.

Catalogação na Publicação

Serviço de Bíblioteca e Documentação

Faculdade de Filosofia, Letras e Ciências Humanas da Universidade de São Paulo

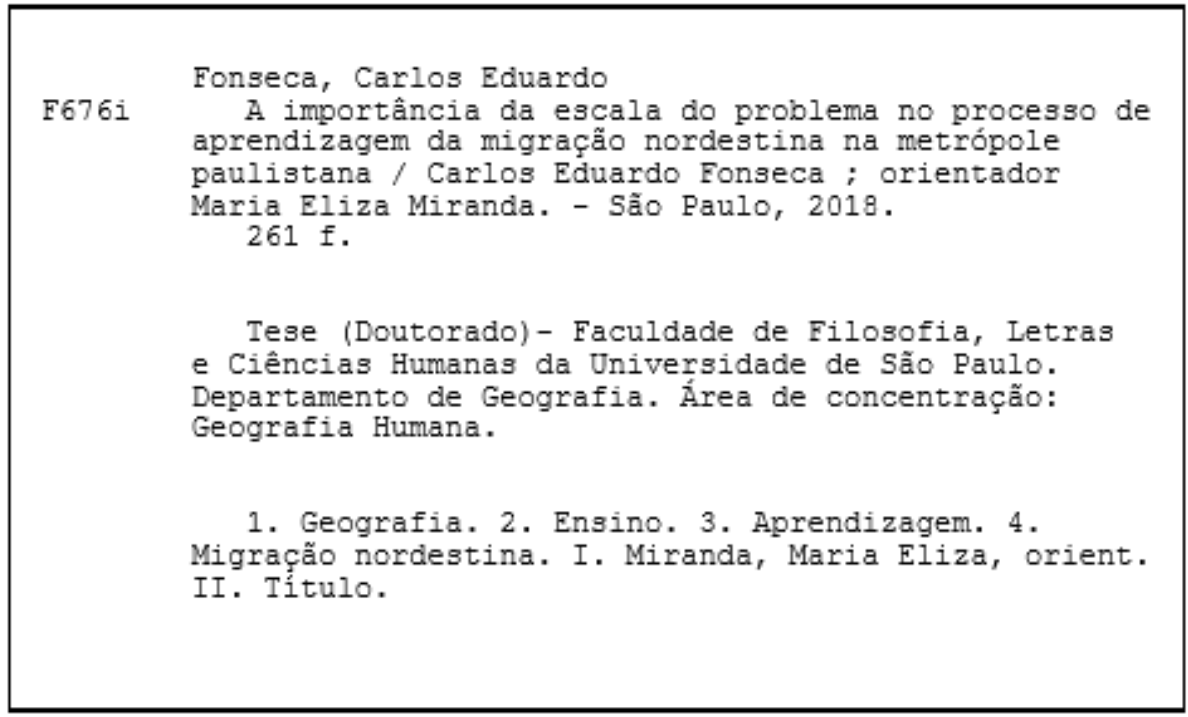


Nome: FONSECA, Carlos Eduardo.

Título: A importância da escala do problema no processo de aprendizagem da migração nordestina na metrópole paulistana.

Tese apresentada ao Programa de PósGraduação em Geografia Humana da Faculdade de Filosofia, Letras e Ciências Humanas da Universidade de São Paulo para obtenção do título de Doutor em Geografia Humana.

Aprovado.

Versão corrigida.

Prof. a . Dra. Maria Eliza Miranda (Orientadora)

Depto. ${ }^{\circ}$. de Geografia FFLCH/USP

Assinatura:

Prof.

Depto. ${ }^{\circ}$

Julgamento:

Assinatura:

Prof.

Depto. ${ }^{\circ}$

Julgamento:

Assinatura:

Prof. ${ }^{\mathrm{a}}$.

Depto. ${ }^{\circ}$.

Julgamento:

Assinatura: 
Para Célia e Ozório, meus horizontes. 


\section{AGRADECIMENTOS}

À minha orientadora Prof. a Dra. Maria Eliza Miranda, por ter acreditado em mim desde o ingresso na Pós, por meio de um acirrado processo seletivo. Sua sabedoria, conhecimento, inteligência, sagacidade, energia e poder de mediação me servem cotidianamente como fonte de inspiração.

À minha mãe Célia, por ter acreditado em meus sonhos, me dando forças e ânimo sempre.

A meu pai Ozório, pelo exemplo de vida, luta e retidão.

À Camila, pelo apoio e força.

À Rebeca, pela motivação de sempre.

À Ana Cristina, pelo companheirismo, amor, respeito e dedicação.

À Márcia, pela prontidão e força.

À Tania, pelas longas discussões pedagógicas.

À Prof. a Dra. Marísia Margarida Santiago Buitoni, pela sabedoria imensurável e dedicação à docência.

Às valorosas contribuições dos professores José Bueno Conti e Rodrigo Valverde no exame de qualificação, que com uma sabedoria imensurável possibilitaram novos olhares em relação ao trabalho que começava a se estruturar.

Ao Prof. Dr. Edson Cabral, meu orientador durante o mestrado na PUC-SP, pela seriedade, rigor científico, retidão e prontidão.

Aos colegas do grupo de estudos da pós-graduação.

À Luiza Ferez pela valorosa contribuição e auxílio com o cruzamento dos dados do Questionário de Caracterização do Aluno. Meu muito obrigado.

À diretora Ana Cleide de Farias, que não hesitou em momento algum para que eu pudesse realizar a pesquisa de doutorado e ainda deu total suporte nas vezes em que seu apoio fora necessário.

Aos amigos e colegas da E.E. Dr. Ayres Neto, que direta ou indiretamente contribuíram para essa minha empreitada, mas, sobretudo, a vice-diretora Fernanda e a coordenadora Edna que contribuíram de modo significativo para que eu pudesse dedicar-me à pesquisa, compreendendo minhas ausências quando se fizeram necessárias e minhas demandas em relação à aplicação da Sequência Didática e demais atividades envolvendo o corpo discente. 
Aos amigos queridos José Cláudio, Roselaine, Artur, Lourdinha, Moacir, Carlos Carota, Izidoro, Trindade, Deusdete, entre outros que sempre torceram por mim.

$\mathrm{E}$ aos queridos alunos e alunas que no decorrer desta empreitada foram os sujeitos centrais, motivando-me e dado significado e sentido naquilo que acredito e possibilitando-me a cada dia ver de modo mais claro a importância de ser professor.

À Deus, Jesus Cristo, minha Nossa Senhora e meus santos de fé, simplesmente por tudo que têm feito em minha vida. 
"Enviamos nossos filhos às escolas não somente para que encham suas cabeças, mas principalmente para que o façam bem. Esperamos dos professores que ensinem nossos filhos e filhas literatura, matemática, línguas mortas ou vivas, história, geografia, ciências físicas e naturais, mas também exigimos que esses professores lhes desenvolvam as faculdades intelectuais ainda embrionárias [...]. Vamos tentar demonstrar como a geografia responde às exigências num ensino que mais procura formar a mente do que entulhar o cérebro". (PIERRE MONBEIG, 1956) 


\section{RESUMO}

FONSECA, Carlos Eduardo. A importância da escala do problema no processo de aprendizagem da migração nordestina na metrópole paulistana. 2018. $261 \mathrm{f}$. Tese (Doutorado em Geografia Humana) - Departamento de Geografia da Faculdade de Filosofia, Letras e Ciências Humanas da Universidade de São Paulo, São Paulo, 2018.

O presente trabalho trata sobre a insuficiência do ensino e da aprendizagem de geografia na educação básica apoiado na categoria lugar sem conexões com outras escalas de tempo e espaço do problema estudado. Atualmente, crianças e adolescentes em idade escolar encontram-se num meio técnico-científico-informacional e sociedade em rede, sendo, inclusive, considerados "nativos digitais". No entanto, enfrentam dificuldades intelectuais para resolver problemas colocados pela contemporaneidade e estão expostos à estímulos diretos com pouca ou nula mediação humana, o que pode comprometer seu desenvolvimento intelectual e cognitivo. A geografia, enquanto conhecimento científico e disciplina escolar, pode contribuir substancialmente para o desenvolvimento desses jovens escolares, mas se focada em estudos limitados de um dado recorte espacial, sem conexões com outras escalas de tempo e espaço do problema estudado, será insuficiente. Esta pesquisa utilizou-se da aplicação de uma sequência didática em quatro turmas de oitavas séries e apoiou-se nos aportes teóricos de Lev Semionovitch Vigotski e Reuven Feuerstein, com a Psicologia da Aprendizagem e a Teoria da Experiência de Aprendizagem Mediada, respectivamente. Num primeiro momento os estudantes responderam a três questões-problema referentes à migração nordestina no país, porém a fizeram propositadamente sem qualquer tipo de mediação do professor. Noutro momento, após terem realizado atividades didático-pedagógicas em que o professor se utilizara dos três critérios universais da Teoria da Experiência de Aprendizagem Mediada de Feuerstein e de algumas das premissas de Vigotski, apoiando-se, sobretudo, em diferentes recursos pedagógicos e modalidades de linguagem, os estudantes refizeram as três questões. Paralelamente às atividades da sequência didática, os estudantes realizaram entrevistas com migrantes nordestinos do Distrito de Pedreira, zona sul da capital paulista, a fim de que pudessem ter contato com as memórias e representações de mundo dessas pessoas, num mundo de meio técnico-científicoinformacional e significativas injustiças de toda a ordem. O objetivo de tal atividade fora que pudessem aprender geografia enquanto conhecimento científico, trabalhando com escalas de tempo e espaço que não somente restrita ao "lugar do aluno", mas que pudessem transcender a noção de lugar enquanto espaço territorialmente isolado, fragmentado, com pouca ou nula conexão com outras escalas espaciais e temporais, de outros lugares. Obtivemos que os alunos apresentaram seus conhecimentos espontâneos fortemente atrelados ao lugar e ao que lhe é mais próximo, mas após serem mediados, demonstraram que começaram paulatinamente a operar cognitiva e intelectualmente conectando outras escalas do problema estudado, neste caso, a migração nordestina na metrópole paulistana.

Palavras-chave: Lugar. Escala. Migrantes nordestinos. Ensino de geografia. Aprendizagem Mediada. 


\begin{abstract}
FONSECA, Carlos Eduardo. The importance of the scale of the problem on the learning process regarding the north-eastern migration towards the paulistana metropolis. 2018. 261 f. Tese (Doutorado em Geografia Humana) - Departamento de Geografia da Faculdade de Filosofia, Letras e Ciências Humanas da Universidade de São Paulo, São Paulo, 2018.

The current work discusses the insufficiency of teaching and learning geography in basic education grounded on the category of the surroundings without other space time scales over the studied issue or phenomenon. Nowadays, school-aged children and teenagers are in a technical-scientific-informational medium and a network society, even being known as "digital natives". Although, they go through intellectual hardships to fathom problems placed by contemporaneity and are exposed to direct stimuli with little to no human mediation, what can havoc their cognitive and intellectual development. Geography as science and a subject can substantially contribute to the development of this student youth, yet will be insufficient when focused on limited studies within a certain spacial trim. This research applied a didactic sequence on four eighth grades and based itself on Lev Semionovitch Vigotski's and Reuven Feuerstein's theoretical works about the Learning Psychology and the Mediated Learning Experience Theory, respectively. Firstly, the students answered to three questions involving migration from the north-east in the country, whereas on purpose there wasn't any mediation from the teacher. In another moment, after having done the didacticpedagogical activities in which the teacher used the three universal criteria from the Feuerstein's Mediated Learning Experience Theory and some of the Vigotski's premisses, overall relying on different pedagogical resources and language models, students redid such questions. Parallel to the activities from the didactic sequence, the students interviewed north-eastern migrants in the Distrito de Pedreira, south zone of the paulista capital, so that they could have contact with the memories and world representations from these people in a globalized planet with considerable injustice and all its types. The activity's goal was to learn geography as a scientific knowledge, dealing with space and time scales not restricted to the "student's surroundings", but transcendent to the notion of place as an isolated, fragmented territory, with scarce to nonexistent connection with other scales from other places. We found the students presented their spontaneous knowledge strongly associated to their surroundings, but progressively demonstrated to relate other scales from the studied issue, the northeastern migration to the paulistana metropolis.
\end{abstract}

Key-words: Surroundings. Scale, North-eastern migrants. Geography teaching. Mediated learning. 


\section{LISTA DE FIGURAS}

Figura 1 - Localização do Distrito de Pedreira na Grande São Paulo ........................... 90

Figura 2 - Entrada principal da E.E. Dr. Ayres Neto, no Distrito de Pedreira .............. 91

Figura 3 - Estados de origem dos entrevistados ...................................................... 99

Figura 4 - Modelo de Experiência de Aprendizagem Mediada (EAM) ..................... 129

Figura 5 - Alunos durante aprendizagem mediada com audiovisuais ....................... 146

Figura 6 - Amostragem de cenas de Lamento Sertanejo ......................................... 147

Figura 7 - Amostragem de cenas de Vida Maria ..................................................... 147

Figura 8 - Sala de leitura e alunos em atividade de leitura a partir da EAM .............. 150

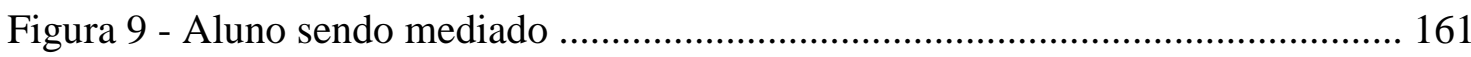

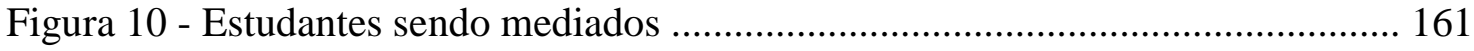

Figura 11 - Atividades com instrumento na modalidade simbólica ........................... 164

Figura 12 - Atividades na modalidade simbólica em sala de leitura ......................... 165

Figura 13 - Aluna realizando dissertação (elaboração final 2) .................................. 203

Figura 14- Nuvem com as palavras mais utilizadas pelos estudantes das quatro turmas que realizaram as três elaborações .................................................................... 210

Figura 15 - Exemplo de eixo tempo-espaço para apoiar nossas análises dos textos .. 214

Figura 16 - Aluno entrevistando colega seu colega de turma .................................... 227

Figura 17 - Aluno realizando entrevista com grupo de colegas ................................ 228

Figura 18 - Aluna sendo entrevistada pelo professor ............................................. 228

Figura 19 - Aluno sendo entrevistado por professor ............................................. 229 


\section{LISTA DE QUADROS}

Quadro 1 - Rotina das alunas 63

Quadro 2 - Rotina dos alunos 63

Quadro 3 - Respostas dos alunos em relação à rotina diária 63

Quadro 4 - Respostas dos alunos em relação à rotina diária 64

Quadro 5 - Respostas dos alunos em relação à rotina diária 64

Quadro 6 - Respostas dos alunos em relação à rotina diária 67

Quadro 7 - Critérios para categorizar alunos matriculados das salas partícipes 92

Quadro 8 - Faixa etária de quando migraram para metrópole 100

Quadro 9 - Profissão ou ocupação das entrevistadas 106

Quadro 10 - Profissão ou ocupação dos entrevistados 107

Quadro 11 - Informações básicas sobre a Sequência Didática 140

Quadro 12 - Resposta à questão-problema inicial da Sequência Didática 141

Quadro 13 - Resposta de aluno à segunda questão-problema da elaboração inicial .. 142

Quadro 14 - Respostas a questão do instrumento de comparação e identificação que pedia para o aluno identificar os objetos da primeira imagem (Criança Morta) .......... 156

Quadro 15 - Resposta à questão do instrumento de comparação e identificação ......... 158

Quadro 16 - Resposta à questão do instrumento de comparação e identificação ......... 159

Quadro 17 - Resposta à questão do instrumento de comparação e identificação ......... 159

Quadro 18 - Resposta à questão do instrumento de comparação e identificação ......... 160

Quadro 19 - Fragmentos de respostas de estudantes à atividade contendo gráfico .... 163

Quadro 20 - Resposta à $1^{\mathrm{a}}$ questão da elaboração inicial da Seq. Didática .................. 168

Quadro 21 - Resposta à $1^{\text {a }}$ questão da elaboração final (1) da Seq. Didática .............. 168

Quadro 22 - Resposta a $1^{\text {a }}$ questão da elaboração inicial da Seq. Didática ................. 169

Quadro 23 - Resposta à $1^{\text {a }}$ questão da elaboração final (1) da Seq. Didática .............. 169

Quadro 24 - Resposta do aluno à $1^{\text {a }}$ questão da elaboração inicial da Seq. Didática .. 170

Quadro 25 - Resposta à $1^{\mathrm{a}}$ questão da elaboração final (1) da Seq. Didática ............... 171

Quadro 26 - Resposta à $1^{\text {a }}$ questão da elaboração inicial da Sequência Didática ........ 172

Quadro 27 - Resposta à $1^{a}$ questão da elaboração final (1) da Sequência Didática ..... 172

Quadro 28 - Resposta à $2^{\text {a }}$ questão da elaboração inicial de Sequência Didática ......... 173

Quadro 29 - Resposta à $2^{\text {a }}$ questão da elaboração final (1) da Sequência Didática ..... 174 
Quadro 30 - Resposta do aluno à 2a questão da elaboração inicial de Seq. Didática .. 174

Quadro 31 - Resposta à $2^{\text {a }}$ questão da elaboração final (1) da Sequência Didática ..... 175

Quadro 32 - Resposta do aluno a $2^{\text {a }}$ questão da elaboração inicial da Seq. Didática .. 176

Quadro 33 - Resposta à $2^{\text {a }}$ questão da elaboração final (1) da Sequência Didática ..... 176

Quadro 34 - Resposta do aluno a $2^{\text {a }}$ questão da elaboração inicial da Seq. Didática .. 177

Quadro 35 - Resposta à 2a questão da elaboração final (1) da Sequência Didática ..... 177

Quadro 36 - Resposta do aluno a $3^{\text {a }}$ questão da elaboração inicial da Seq. Didática .. 178

Quadro 37 - Resposta a $3^{\text {a }}$ questão da elaboração final (1) da Sequência Didática ..... 179

Quadro 38 - Resposta à $3^{\mathrm{a}}$ questão da elaboração inicial da Sequência Didática ......... 180

Quadro 39 - Resposta aluno a $3^{\mathrm{a}}$ questão da elaboração final (1) da Seq. Didática .... 180

Quadro 40 - Resposta aluno a $3^{\text {a }}$ questão da elaboração inicial da Seq. Didática ....... 181

Quadro 41 - Resposta do aluno à $3^{\mathrm{a}}$ questão da elaboração final (1) ......................... 182

Quadro 42 - Resposta a $3^{\text {a }}$ questão da elaboração inicial da Seq. Didática ................. 182

Quadro 43 - Resposta a $3^{a}$ questão da elaboração final (1) da Seq. Didática .............. 183

Quadro 44 - Categorias dos fatores de repulsão, por nós utilizadas na análise das respostas dos alunos à primeira questão problema ................................................... 184

Quadro 45 - Categorias dos fatores de atração, por nós utilizadas na análise das respostas dos alunos à primeira questão problema .................................................... 184

Quadro 46 - Categorias dos fatores de repulsão, por nós utilizadas na análise das respostas dos alunos a segunda questão problema ...................................................... 185

Quadro 47 - Categorias dos fatores de atração, por nós utilizadas na análise das respostas dos alunos a segunda questão problema .................................................. 186

Quadro 48 - Modelo usado para trabalhar saldos ..................................................... 197

Quadro 49 - Fragmento de elaboração textual final no 2 do aluno na Seq. Didática... 204

Quadro 50 - Fragmento de elaboração textual final $n^{\circ} 2$ do aluno ............................. 205

Quadro 51 - Fragmento de elaboração textual final no 2 do aluno na Seq. Didática ... 205

Quadro 52 - Fragmento de elaboração textual final $n^{\circ} 2$ do aluno na Seq. Didática .. 206

Quadro 53 - Fragmento de elaboração textual final no 2 do aluno na Seq. Didática .. 206

Quadro 54 - Fragmento de elaboração textual final no 2 na Seq. Didática ................. 207

Quadro 55 - Fragmento de elaboração textual final no 2 do aluno na Seq. Didática .. 208

Quadro 56 - Critérios utilizados na análise das dissertações sobre Vida Maria ......... 213 


\section{LISTA DE GRÁFICOS}

Gráfico 1 - Total de alunos por sala que exercem atividade remunerada 65

Gráfico 2 - Cruzamento de dados sobre "para que os alunos utilizam a internet" e "o que gostam de ler". 69

Gráfico 3 - Tempo diário que o aluno assiste TV 71

Gráfico 4 - Tempo diário que o aluno assiste TV e tempo dedicado aos estudos fora da aula 71

Gráfico 5 - Totais de alunos por série e as condições de matrícula 92

Gráfico 6 - Somatória das quatro turmas em relação à matrícula 93

Gráfico 7 - Ano de nascimento dos alunos frequentes no período de 2016 94

Gráfico 8 - Ano de nascimento dos alunos que abandonaram os estudos .................... 94

Gráfico 9 - Sexo dos estudantes frequentes por série ............................................... 95

Gráfico 10 - Total de alunos que realizou entrevista com nordestinos ........................ 96

Gráfico 11 - Quantidade de duplas e trios que realizaram a entrevista ....................... 97

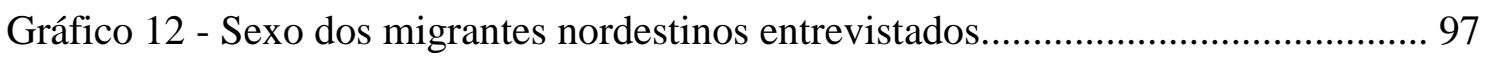

Gráfico 13 - Perfil etário dos migrantes participantes da pesquisa ............................. 99

Gráfico 14 - Empregabilidade das mães dos estudantes ............................................ 108

Gráfico 15 - Empregabilidade dos pais dos estudantes ............................................. 109

Gráfico 16 - Correlação entre escolaridade e renda mensal dos entrevistados ............ 109

Gráfico 17 - Grau de escolaridade das mulheres entrevistadas ................................ 111

Gráfico 18 - Grau de escolaridade dos homens entrevistado ..................................... 111

Gráfico 19 - Escolaridade das mães dos estudantes das quatro turmas participantes da

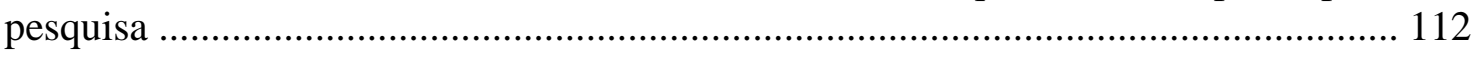

Gráfico 20 - Escolaridade dos pais dos alunos das turmas participantes .................... 113

Gráfico 21 - Pessoas com nível superior ou graduando em casa ............................... 113

Gráfico 22 - A metrópole e as oportunidade de empregabilidade .............................. 114

Gráfico 23 - Impactos positivos ou negativos provenientes das novas tecnologias .... 116

Gráfico 24 - Dificuldades financeiras entre os entrevistados .................................... 118

Gráfico 25 - Alunos que realizaram atividade com o instrumento de identificação e comparação

Gráfico 26 - Total de alunos que conseguiu identificar objetos e apontar sua utilidade na imagem da obra Criança Morta 157

Gráfico 27 - Alunos que apontaram semelhanças e diferenças. 160 
Gráfico 28 - Primeira questão inicial e final da $8^{\text {a }}$ série A, fatores de repulsão e atração identificados nas respostas dos alunos 187

Gráfico 29 - Segunda questão inicial e final da $8^{\text {a }}$ série A, fatores de repulsão e atração identificados nas respostas dos alunos 188

Gráfico 30 - Primeira questão inicial e final da $8^{\text {a }}$ série B, fatores de repulsão e atração identificados nas respostas dos alunos 189.

Gráfico 31 - Segunda questão inicial e final da $8^{\mathrm{a}}$ série $\mathrm{B}$, fatores de repulsão e atração identificados nas respostas dos alunos 190

Gráfico 32 - Primeira questão inicial e final da $8^{\text {a }}$ série $C$, fatores de repulsão e atração identificados nas respostas dos alunos 191

Gráfico 33 - Segunda questão inicial e final da $8^{\mathrm{a}}$ série $\mathrm{C}$, fatores de repulsão e atração identificados nas respostas dos alunos

Gráfico 34 - Primeira questão inicial e final da 8 série D, fatores de repulsão e atração identificados nas respostas dos aluno 193

Gráfico 35 - Segunda questão inicial e final da $8^{\text {a }}$ série D, fatores de repulsão e atração identificados nas respostas dos alunos 194

Gráfico 36 - Tipos de migração abordadas pelas quatro turmas na terceira questão... 196

Gráfico 37 - Evolução das respostas dos estudantes da $8^{\mathrm{a}}$ série $\mathrm{A}$ 198

Gráfico 38 - Evolução das respostas dos estudantes da $8^{\mathrm{a}}$ série $\mathrm{B}$ 199

Gráfico 39 - Evolução das respostas dos estudantes da $8^{\mathrm{a}}$ série $\mathrm{C}$ 199

Gráfico 40 - Evolução das respostas dos estudantes da $8^{\mathrm{a}}$ série D 200

Gráfico 41 - Quantidade de alunos que mais utilizou determinadas palavras-chave na dissertação final 209

Gráfico 42 - Alunos participantes das elaborações inicial, final 1 e dissertação 212

Gráfico 43 - Correlação espaço-temporal e nível de resposta dos estudantes 215

Gráfico 44 - Assimilação ou não assimilação dos textos de apoio e impacto disso nas produções textuais 216

Gráfico 45 - Desempenho na dissertação geral dos estudantes 217

Gráfico 46 - Desempenho na dissertação por turmas ( $8^{\mathrm{a}}$ séries $\mathrm{A}, \mathrm{B}, \mathrm{C}$ e D) 218 


\section{LISTA DE SIGLAS E ABREVIATURAS}

EAM: Experiência de Aprendizagem Medida.

FFLCH: Faculdade de Filosofia, Letras e Ciências Humanas.

IBGE: Instituto Brasileiro de Geografia e Estatística.

LDB: Lei de Diretrizes e Bases da Educação.

LEMADI: Laboratório de Ensino e Material Didático de Geografia da FFLCH.

MCE: Modificabilidade Cognitiva Estrutural.

MEC: Ministério da Educação.

NE: Nordeste.

PCN: Parâmetros Curriculares Nacionais.

PISA: Programme for International Student Assessment.

PNAD: Pesquisa Nacional por Amostra de Domicílios.

SE: Sudeste.

UNESCO: Organização das Nações Unidas para Educação, Ciência e Cultura. USP: Universidade de São Paulo. 


\section{SUMÁRIO}

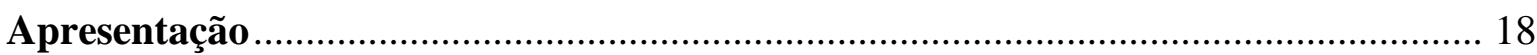

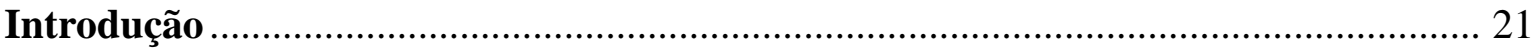

Capítulo 1 - O mundo contemporâneo da sociedade em rede e do meio técnico-científico-

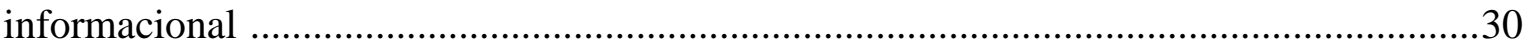

1.1. As redes em tempos de meio técnico-científico-informacional ..............................30

1.2. Um tempo de espaços conectados e problemas globais .......................................41

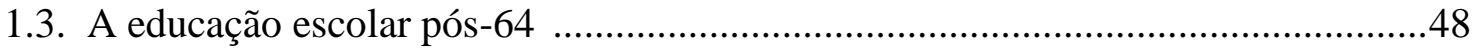

Capítulo 2 - A insuficiência do ensino de geografia apoiado na categoria lugar sem conexão

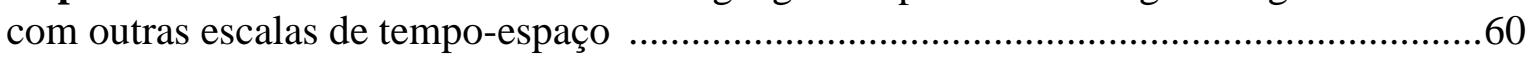

2.1. Limitações do ensino circunscrito ao "lugar do aluno" .......................................60

2.2. A importância de se construir uma representação de mundo .................................72

2.3. Para além da realidade concreta e imediata do aluno ............................................79

Capítulo 3 - Representações de mundo de migrantes nordestinos entrevistados pelos estudantes .89

3.1. Breve caracterização da escola e das turmas da pesquisa ...................................89

3.2. Entrevista com migrantes nordestinos ................................................................95

3.3. A ocupação dos entrevistados e percepções sobre o mundo do trabalho .................106

Capítulo 4 - As contribuições de Lev Vigotski e Reuven Feuerstein para os processos de aprendizagem

4.1. Os aportes teóricos de Vigotski para a compreensão da dimensão psicológica do ser humano

4.2. Feuerstein e a Teoria da Experiência de Aprendizagem Mediada .........................128

Capítulo 5 - Aplicação da Sequência Didática em diferentes modalidades de linguagem 137

5.1. A elaboração inicial dos estudantes e o conhecimento espontâneo

5.2. Diferentes recursos de apoio pedagógico no processo de Experiência de Aprendizagem Mediada

5.3. Mediação nas modalidades simbólica e figurativa

Capítulo 6 - Análise das elaborações dos estudantes em relação às questões-problema ...166

6.1. Verificando os avanços entre as elaborações inicial e final $n^{\circ} 1$...........................166

6.2. Os fatores de repulsão e atração migratória nas respostas dos alunos .....................183

6.3. Evolução das respostas das elaborações por aluno .............................................. 197

Capítulo 7 - Verificando as aprendizagens após a Sequência Didática .............................202

7.1. A dissertação final e a noção de tempo-espaço ..................................................202

7.2. Análise do desempenho dos alunos nas produções textuais ....................................211

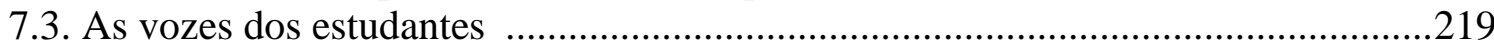

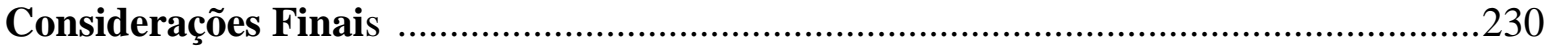

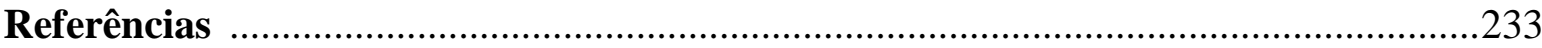

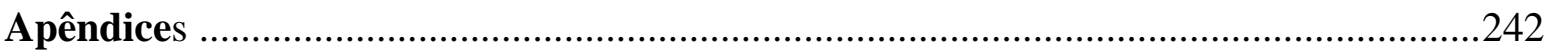

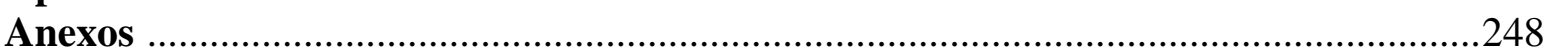




\section{APRESENTAÇÃO}

Desenvolver uma pesquisa de doutorado em Geografia Humana voltada às questões de ensino e aprendizagem de crianças e adolescentes da educação básica, é certamente tarefa desafiadora, sobretudo, levando em conta que o pesquisador é o professor. Ser aceito num acirrado processo seletivo para desenvolver um projeto de pesquisa sob orientação da $\operatorname{Prof}^{\mathrm{a}} \operatorname{Dr}^{\mathrm{a}}$ Maria Eliza Miranda, profunda conhecedora das teorias mais sofisticadas em termos de psicologia da aprendizagem e do desenvolvimento humano, da geografia e da realidade da escola pública, fora um desafio certamente imensurável.

Sendo aluno de escola pública em região periférica da capital paulista durante todo o ensino fundamental e médio, cursando universidade de economia privada e oriundo de família com modestas condições financeiras, o sonho de atuar no magistério, o amor à docência e a crença na possibilidade de um mundo melhor serviram-me como mola propulsora para que eu pudesse almejar um trabalho de doutorado atrelado às questões mais fundamentais daquilo que envolve a sala de aula: o aluno e o seu processo de aprendizagem.

Assim, para desenvolver este trabalho, partimos da problemática de que ensino no Brasil, principalmente a partir do golpe de 1964, tem sido permeado por práticas tecnicistas, que pouco consideram em relação a dimensão psicológica do aluno no processo de ensino e aprendizagem. Do mesmo modo, a geografia ensinada na educação básica, se mantém tributária de práticas prescritivas, não sobrelevando o desenvolvimento das funções intelectuais dos estudantes. Centrada majoritariamente na transmissão de conteúdos, tende a enfatizar o ensino restrito ao lugar, com poucas conexões à outras escalas de tempo e espaço, limitando, assim, as visões e representações de mundo dos estudantes.

Portanto, nossa tese é de que o ensino de geografia limitado à categoria lugar não faz conexões com outras escalas do problema estudado, pois apenas há o "lugar do aluno" numa escala isolada, desconsiderando os fenômenos inscritos noutras escalas espaço-temporais, sendo insuficiente para que o aluno construa uma representação de mundo. Ou seja, o ensino de geografia restrito ao que é mais "próximo" e "imediato" do

estudante, circunscrito a uma escala de tempo e espaço apenas do "concreto" e desconectada de outras escalas não possibilita uma aprendizagem significativa. 
Consequentemente, este trabalho justifica-se, pois atualmente, crianças e adolescentes, imersos numa sociedade de meio técnico-científico-informacional, considerados "nativos digitais", apesar de deterem uma série de habilidades com recursos tecnológicos, apresentam dificuldades para resolver questões colocadas pela contemporaneidade, pois encontram-se expostos à estímulos diretos com pouca mediação humana. E a geografia é um conhecimento que pode contribuir significativamente para que o aluno desenvolva noções de tempo e espaço que não somente do imediatismo do "aqui" e "agora".

A tese está dividida em sete capítulos, sendo que no primeiro deles apresentamos os referenciais que tratam da complexidade do mundo contemporâneo, de uma sociedade em rede em seus variados aspectos, com contrastes, desigualdades e disparidades numa era de comunicação instantânea, em que se altera, sobretudo, a importância do lugar enquanto lócus de relações e sociabilidade face a face, em que as relações de pertencimento e afetividade perdem efeito. Ainda abordamos o paradoxo em que jovens escolares são considerados "nativos digitais" em tempos de meio técnicocientífico-informacional, mas deparam-se com dificuldades intelectuais ao lidar com questões colocadas pela contemporaneidade.

No segundo capítulo discorremos sobre a insuficiência do ensino de geografia na educação básica limitado a categoria lugar sem conexões com outras escalas de tempo e espaço do problema ou fenômeno estudado. A virtualidade e o ciberespaço envolvem o cotidiano de jovens em idade escolar, que se encontram inscritos numa dimensão de tempo e espaço em que as relações face a face não mais se consubstanciam como em épocas passadas, pois podem estar, ainda que de modo insuficiente, em múltiplas territorialidades e não apenas circunscritos ao "lugar do aluno". Neste capítulo também apresentamos a rotina dos alunos partícipes da pesquisa.

O terceiro capítulo traz uma breve caracterização da escola e das quatro turmas partícipes da pesquisa e também trata das entrevistas realizadas por esses estudantes com migrantes nordestinos do Distrito de Pedreira, zona sul da capital paulista. O objetivo da atividade fora de que os estudantes pudessem ter contato com as memórias destes migrantes e suas representações de mundo.

No quarto capítulo abordamos algumas das premissas de Lev Vigotski e de Reuven Feuerstein e a contribuição desses pesquisadores para o entendimento de como se estrutura e se processa o pensamento no ser humano, assim como as contribuições da 
Teoria da Experiência de Aprendizagem Mediada, fundamental para tornar as aprendizagens significativas.

O plano empírico da pesquisa no tocante à aplicação da Sequência Didática é abordado a partir do quinto capítulo, onde apresentamos o modo como apoiamo-nos na perspectiva sociocultural de Vigotski e nos três critérios universais da Teoria da Experiência de Aprendizagem Mediada de Feuerstein, assim como de determinados recursos pedagógicas e de linguagem visando apoiar o desenvolvimento cognitivo e intelectual dos estudantes.

No sexto capítulo apresentamos as elaborações iniciais e finais dos alunos em relação às três questões-problema que tiveram contato antes de serem mediados, e noutro momento a refizeram após um processo de aprendizagem mediada que se dera no decorrer da Sequência Didática. Neste capítulo interpretamos e analisamos alguns resultados em relação às aprendizagens dos estudantes.

O sétimo capítulo trata da dissertação final que os estudantes realizaram tendo que atender ao enunciado de uma questão-problema e pensar na vida da personagem Maria (da animação Vida Maria) em dois contextos espaciais e temporais distintos. Analisamos os resultados em relação às aprendizagens buscando verificar se efetivamente os alunos começaram a operar por conceitos científicos e, sobretudo, pensar numa escala de tempo e espaço não somente circunscrita à um determinado lugar, sem conexões com outras escalas de tempo e espaço.

Efetivamente, consideramos o ser humano enquanto seres capazes de aprender, de se modificar e acima de tudo, de poder atuar reflexivamente, ativamente, criticamente e conscientemente no mundo, podendo torná-lo melhor para as atuais e futuras gerações. 


\section{INTRODUÇÃO}

Considerando que no presente século tornou-se comum nos meios intelectual, acadêmico e midiático expressões como sociedade do conhecimento, era da informação e sociedade em rede, em um mundo com elevado grau de complexidade dos avanços técnicos, científicos e informacionais, há que se observar de que modo tais transformações vem se apresentando na educação básica.

Paradoxalmente, crianças e adolescentes, considerados "nativos digitais", adquirem habilidades para realizar tarefas variadas integradas simultaneamente operando aparelhos digitais eletrônicos, acessando e criando perfis em redes sociais e munidos de habilidades com as ferramentas virtuais. Todavia, deparam-se com obstáculos intelectuais quando solicitados a problematizar questões referentes às mudanças econômicas, sociais, políticas e culturais que o mundo atravessa, com dificuldades para transformar a informação em conhecimento.

Evidencia-se, assim, a necessidade de a escola e os professores, sobretudo de geografia, trabalharem visando a formação de um sujeito criativo, crítico e que saiba comunicar e expressar suas ideias, com maiores níveis de abstração e pensando para além de uma escala circunscrita ao imediato daquilo que lhe é "mais próximo", mas buscando a conexão entre escalas de tempo e espaço para além do "lugar do aluno". Trata-se de jovens que demandam ser mediados, não pela tecnologia, mas por um ser humano e, nesse tocante, os professores tem sobrelevada importância com o trabalho desenvolvido em sala de aula.

Não se pretende, contudo, responsabilizar exclusivamente os professores pela baixa qualidade do ensino de geografia e das dificuldades de aprendizagem dos estudantes da educação básica do país, pois a desorganização pedagógica apresenta histórico de longa data. Pierre Monbeig (1945) apontou em meados do século passado que os problemas do ensino de geografia não seriam culpa dos professores, mas oriundos de outras instâncias ${ }^{1}$.

\footnotetext{
${ }^{1}$ Pierre Monbeig (1945, p. 163) tratando da geografia no ensino secundário, faz uma precisa análise das condições de trabalho do professor, que naquele período já apresentava longas jornadas e ordenados insuficientes, assim como dificuldades em ter acesso a bons materiais usados nos países mais avançados. Conforme o autor, "se o ensino da geografia permanece defeituoso, a falta não é dos que dele estão encarregados, mas das instituições. A maioria dos professores [...] não receberam um ensino especial de geografia”. MONBEIG, Pierre. A geografia no ensino secundário. Boletim Geográfico. v. 2, n. $26,1945$.
} 
A falta de mediação humana torna-se um obstáculo para que crianças e adolescentes tenham suas capacidades intelectuais e cognitivas desenvolvidas de modo eficiente. Por outro lado, a formação de professores avançara timidamente nas últimas décadas no sentido de atentar para a importância em conhecer o modo como os alunos funcionam cognitivamente nessa era tecnológica e das redes.

Ocorre que as crianças e adolescentes, atualmente tem acesso a conhecimentos e informações de diversos tipos, e estão expostos a eles, sem mediação, especialmente pelos meios de comunicação de diversos suportes tecnológicos, especialmente tecnologias de informação, com acesso a WEB, redes sociais e jogos eletrônicos² (MIRANDA, 2013, p. 4).

Considerando a história da educação no Brasil, é possível afirmar que a aprendizagem mediada nunca fora a preocupação daqueles que se ocupavam em lidar com as questões pedagógicas. Além disso, não muito diferente dos dias atuais, o ensino estivera majoritariamente centrado na concepção do bom professor como sendo aquele que detivesse com maestria e excelência o domínio dos conteúdos de sua disciplina e mantivesse a ordem e o disciplinamento de suas turmas. Aos alunos, não cabia lidar com reflexões, pois não se fomentavam espaços para debates, questionamentos e problematizações ${ }^{3}$.

A necessidade de um processo educativo com a aprendizagem sendo mediada, sobretudo pela presença humana, mostra-se de modo mais evidente desde as últimas décadas, principalmente em função das transformações pelas quais o mundo vem passando. No entanto, pesquisadores no século passado já demonstravam preocupação com essa questão, como o suíço Jean Piaget e mais especificamente o bielorrusso Lev Semionovitch Vigotski e o romeno Reuven Feuerstein; os dois últimos, inclusive, com aportes teóricos que subsidiam a presente pesquisa.

As transformações em escala mundial, tais como a automatização do trabalho nas indústrias e a mecanização no campo, a criação de novos empregos e a extinção de outros, o crescimento da economia informal, do subemprego e da precarização do

\footnotetext{
${ }^{2}$ MIRANDA, Maria E. A reinvenção da prática docente: interfaces e aproximações para a ressignificação da prática docente. In: $14^{\circ}$ EGAL - Encontro de Geógrafos da América Latina, 2013, Lima - PERU. Situación y Perspectivas de la Enseñanza - Aprendizaje de la Geografía en América Latina, 2013.

${ }^{3}$ Maria José Garcia Werebe (1968, p. 147) ao tratar sobre a ausência de uma orientação pedagógica renovada, aponta que os "métodos didáticos usados e o clima pedagógico reinante sempre foram os mais tradicionais. Aulas teóricas e abstratas, professores severos, distantes e exigentes, disciplina rigorosa e rígida, tais eram as características da escola do passado". WEREBE, M. J. G. Grandezas e misérias do ensino no Brasil: corpo e alma do Brasil. $3^{\text {a }}$ ed. São Paulo: Difusão Europeia, 1968.
} 
trabalho, são questões que se apresentam na realidade de jovens em idade escolar, que vivenciam as contradições da contemporaneidade. Lidar com questões de significativa complexidade e da realidade dos jovens escolares é imprescindível para que possam constituir uma representação de si, do outro e do mundo, para além de uma escala circunscrita apenas num tempo e espaço do lugar em que vivem. Trata-se de um tempo presente demasiado complexo e um tempo futuro incerto.

Joan Ferrés (1996) destaca que os objetivos da escola devem estar focalizados no futuro e não no presente, pois a sociedade tem se transformado de forma vertiginosa, ao passo que a escola se mantém ancorada no passado em relação aos objetivos e métodos de ensino ${ }^{4}$.

Por consequência, torna-se de tamanha irresponsabilidade considerar que sendo os jovens nativos digitais, podem ficar ao bel prazer dos recursos midiáticos, que por si só construirão com autonomia e pertinência seus conhecimentos, deixando à própria tecnologia a função de mediá-los.

Em um mundo complexo e com significativos avanços nos meios técnicos, científicos e informacionais, parece ser cada vez mais necessário que os jovens sejam mediados, com critérios $^{5}$ previamente definidos para que se possa atingir o desenvolvimento de suas capacidades intelectuais. E o ensino de geografia pode contribuir para a expansão do campo mental do aluno, tornando as aprendizagens efetivas. Todavia, a geografia ensinada na educação básica, não avançou nas últimas décadas, por manter-se centrada em determinadas concepções que não contribui significativamente para o desenvolvimento cognitivo do aluno, tornando-o crítico, problematizador, criativo e inovador.

A ênfase nas práticas pedagógicas atribuídas à categoria lugar, considerando que focalizando naquilo que é mais "próximo" e imediato do aluno, pouco considerando em relação a conexões com outras escalas de tempo e espaço do fenômeno estudado, as aprendizagens serão significativas, não encontra sustentação na atualidade. Trata-se de uma geografia do cotidiano que tende a enfatizar as práticas diárias de trabalho, de relações de convívio e sociabilidade face a face, circunscritas ao entorno de um dado território, delimitado e restrito local de moradia, da escola, do bairro ou da cidade do aluno.

\footnotetext{
${ }^{4}$ FERRÉS, Joan. Vídeo e educação. $2^{a}$ ed. Porto Alegre: Artes Médicas, 1996.

5 Reuven Feuerstein define no mínimo três critérios universais da Teoria da Experiência de Aprendizagem Mediada, sendo intencionalidade/reciprocidade, significado e transcendência. Tais questões serão tratadas de modo mais específico no decorrer do trabalho.
} 
O estudo restritivo ao lugar sem conexão com outras escalas de tempo e espaço do problema estudado pelo aluno, resulta numa estreita e limitada visão de mundo, por tratar-se de uma geografia focada nos fenômenos restritos de determinado recorte espacial. Convém lembrar, que geógrafos ${ }^{6}$ do final do século XIX e do século XX, tinham clareza e nitidez sobre as limitações de estudos focalizados no lugar devido à fragmentação com que os fenômenos se apresentavam. Para Jean Brunhes (1962, p. 38):

Donde se segue que nunca devemos limitar nossa visão a uma só ordem de fenômenos. Assim, então, o menor estudo geográfico - se pretende ser completo - não se pode restringir a observar fatos isolados; não há sobre a crosta terrestre compartimentos estanques; pode haver divisões, mas não há cercas ${ }^{7}$.

Max Sorre (1984) também lançava críticas à geografia estritamente focada no local, tida como corográfica ${ }^{8}$. O autor almejava que houvesse, tal como num sistema ecológico, uma conexão entre os diversos atributos da natureza: físicos, humanos, biológicos em um complexo sistema geográfico.

Elisée Reclus (1985) pensava de modo abrangente nas diferenciadas áreas da superfície terrestre, não restringindo seu "olhar" de modo específico ao lugar como ponto de partida, pois sua visão tinha alcance global; enfatizava que após o homem conhecer o mundo, a geografia não mais teria que "percorrer terras longínquas", assim, dedicar-se-ia à região em que mora, atentando-se aos detalhes que esta oferece ${ }^{9}$.

Paul Vidal de La Blache (2002, p. 145) escrevendo no final do século XIX, atentava para o cuidado de o geógrafo não se fechar num estudo local.

\begin{abstract}
Se nada existe isoladamente no organismo terrestre, se em todo lugar repercutem as leis gerais, de modo que não se possa tocar uma parte sem provocar todo um encadeamento de causas e de efeitos, a tarefa do geógrafo toma caráter diferente daquele que às vezes lhe é atribuído. Qualquer que seja a fração da Terra que estude, ele não pode nela se fechar. Um elemento geral se introduz em todo estudo local. Não há, de fato, área em que a fisionomia não dependa de influências múltiplas e longínquas ${ }^{10}[\ldots]$.
\end{abstract}

Desse modo, defendemos a tese de que ensino de geografia limitado à categoria lugar não faz conexões com outras escalas do problema estudado, pois apenas há o

\footnotetext{
${ }^{6}$ Aqui nos referimos à Jean Brunhes, Max Sorre, Elisée Reclus e Paul Vidal de La Blache.

${ }^{7}$ BRUNHES, Jean. Geografia Humana. Rio de Janeiro: Editora Fundo de Cultura, 1962.

${ }^{8}$ SORRE, Maximiliem. Fundamentos da geografia humana. In: MAGALE, Januário Francisco. (Org.). Max Sorre: geografia. São Paulo: Ática, 1984.

9 RECLUS, Élisée. A natureza da geografia. In: ANDRADE, Manuel Corrêa de. Élisée Reclus: geografia. São Paulo: Ática, 1985.

${ }^{10}$ LA BLACHE, Paul Vidal de. O Princípio da Geografia Geral. Geographia: Revista do Programa de Pós-Graduação em Geografia da UFF. Niterói/Rio de Janeiro, UFF/EGG, nº 6, ano III, p. 135-147, 2002.
} 
"lugar do aluno" numa escala isolada, desconsiderando os fenômenos inscritos noutras escalas espaço-temporais, sendo insuficiente para que o aluno construa uma representação de mundo. Ou seja, o ensino de geografia restrito ao que é mais "próximo" e "imediato" do estudante, circunscrito a uma escala de tempo e espaço apenas do "concreto" e desconectada de outras escalas não possibilita uma aprendizagem significativa.

Apesar de não ser pretensão de se ensinar geografia na educação básica para formar geógrafos, o ensino desse campo do saber é fundamentalmente necessário por contribuir para que o aluno tenha uma visão abrangente de mundo, podendo elaborar representações ${ }^{11}$ dos variados fenômenos que se dão na superfície terrestre, assim como das diversas conexões que há entre os variados fenômenos geográficos em diferentes escalas de tempo e espaço.

Ademais, é preciso que se busque na geografia ensinada na educação básica conhecer as dimensões psicológicas do aluno, tendo os professores aportes teóricos que lhes subsidiem a compreender o modo como o conhecimento se processa e como o pensamento se estrutura em crianças e adolescentes. Do mesmo modo, faz-se necessário que o professor reflita sobre qual é o seu papel e a sua importância enquanto mediador da aprendizagem, assim como da geografia que é ensinada.

Trata-se, para isso, de um modo de o professor não ficar preso num pedagogismo de um sistema tecnicista e positivista que considera suficiente ao educador dominar com excelência os conteúdos de sua disciplina, que estará em condições de desenvolver intelectual e cognitivamente seus alunos. Dada à complexidade do mundo contemporâneo, torna-se cada vez mais insuficiente o conhecimento parcial e fragmentado em seu campo do saber. Além das questões psicológicas, o percurso ou formação filosófica tem muito a contribuir no sentido de o professor ter clareza em relação às concepções de geografia que pretende trabalhar e de aluno que deseja formar.

Após o golpe civil militar ${ }^{12}$, ocorrido no Brasil no ano 1964, e a consequente expansão e massificação do modelo de escola pautado num sistema fundamentalmente

\footnotetext{
${ }^{11}$ Em Miranda (2010) vemos a importância da geografia enquanto conhecimento científico que trabalha com a representação de mundo e das relações que há no mundo. MIRANDA, M. E. Contribuição ao debate atual sobre a formação de professores no Brasil: pela formação de futuras gerações na perspectiva da reconstrução do sócio-cultural. Revista do Departamento de Geografia, n. 20, p. 11-22, 2010.

${ }^{12} \mathrm{O}$ termo golpe civil militar foi empregado por René Armand Dreifuss, na obra "1964: A conquista do Estado", pois o autor uruguaio considerava ter havido efetiva participação de pessoas da sociedade e do empresariado na orquestração daquilo que se consubstanciou num verdadeiro golpe à democracia. DREIFUSS, René Armand. 1964: A conquista do Estado: ação política, poder e golpe de classe. $3^{\mathrm{a}}$ ed. Petrópolis: Vozes, 1981.
} 
tecnicista, o país continuou com sérios problemas em termos de avanços em relação à qualidade do ensino e das aprendizagens escolares. Materiais didático-pedagógicos e programas curriculares, consubstanciar-se-iam como políticas prescritivas sobrelevando práticas pedagógicas mecanicistas, por meio de orientações técnicas e conteúdos descontextualizados, em detrimento de uma concepção educacional que considerasse o processo de aprendizagem, a dimensão psicológica do aluno e este, sobretudo, como sujeito em formação.

O ensino de geografia, da maneira como tem sido apresentado na educação básica, demonstra o grande déficit de formação psicológica e filosófica dos professores, o que acaba por expressar e apoiar práticas em sala de aula que não potencializam ${ }^{13} \mathrm{o}$ desenvolvimento intelectual e cognitivo do aluno de modo efetivo, carecendo de aprendizagem mediada e assemelhando o ensino ao modelo fordista de produção, ao invés de um modo de pensar mais refinado e que considere o aluno como sujeito complexo em processo de formação.

No mundo contemporâneo é cada vez mais necessário que se forme um sujeito com capacidades intelectuais, de abstração, criticidade, raciocínio e representações de mundo, sobretudo em tempos de meio técnico-científico-informacional, onde os problemas tendem a ser cada vez mais de ordem global, o que enseja a necessidade de se trabalhar com mais escalas de tempo e espaço que não apenas naquilo que é limitado ao local. O filósofo Edgar Morin (2011) ao entender o homem como ser complexo e com suas ambivalências, o vê como sendo multidimensional, numa era planetária e de incertezas ${ }^{14}$, em que é vital o conhecimento do mundo.

\footnotetext{
A era planetária necessita situar tudo no contexto planetário. O conhecimento do mundo como mundo é necessidade ao mesmo tempo intelectual e vital. É o problema universal de todo cidadão do novo milênio: como ter acesso às informações sobre o mundo e como ter a possibilidade de articulá-las e organizá-las? Como percebe e concebe o contexto, o global [...], o multidimensional, o complexo? ${ }^{15}$ (MORIN, 2011, p. 33).
}

\footnotetext{
${ }^{13}$ Conforme Rafael Yus (2002, p. 109): “o propósito da educação é alimentar o crescimento do potencial intelectual, emocional, físico, artístico e espiritual de toda pessoa". O autor ainda focaliza na necessidade de se pensar para o século XXI uma educação integral e holística. YUS, Rafael. Educação integral: uma educação holística para o século XXI. Porto Alegre: Artmed, 2002.

${ }^{14}$ Anthony Giddens (1996) também aborda as incertezas e os riscos atuais que nos defrontamos, como os associados ao aquecimento global, a superpopulação do planeta, a poluição ou desertificação em larga escala, ao desgaste da camada de ozônio (apesar de o problema já parecer resolvido e compreendido), ao rompimento da economia global, as doenças geradas por influências tecnológicas etc. GIDDENS, A. Para além da esquerda e da direita. São Paulo, Editora da Unesp, 1996.

${ }^{15}$ MORIN, Edgar. Os sete saberes necessários à educação do futuro. $2^{\mathrm{a}}$ ed. São Paulo: Cortez; Brasília, DF: UNESCO, 2011.
} 
Os problemas mundiais acentuam-se significativamente, o que evidencia a necessidade de a escola e o ensino serem repensados, rompendo com estudos estanques e isolados, fragmentados e descontextualizados, mas que contemplem a interdisciplinaridade ${ }^{16}$, a conexão entre escalas de tempo e espaço, e possibilitem ao jovem escolar compreender o mundo contemporâneo e as relações estabelecidas nessa era das redes, de meio técnico-científico-informacional e de problemas globais.

Se discutimos problemas globais, então falamos de características intrínsecas da própria modernidade. Assim como o Homo sapiens surgiu na África e, no entanto, a espécie humana não é "africana", a civilização superior nasceu primeiro na Ásia, mas não é "asiática". Da mesma forma, a modernidade foi gerada na Europa, mas neste momento não é nem "ocidental” nem "europeia". Tornou-se global ${ }^{17}$ (HELLER, 1999, p. 14).

Portanto, o aluno da era contemporânea, se depara cotidianamente com uma realidade próxima, mas que lhe é insuficiente para compreensão dos problemas que há no mundo e para a constituição de uma visão e representação de mundo, se limitada apenas ao "seu lugar". No caso dos estudantes sujeitos desta pesquisa, residem no distrito de Pedreira, em área periférica da zona sul da capital de São Paulo, vizinhos do município de Diadema, outrora palco da industrialização paulista. Sua realidade é de um lugar em que há o movimento de trabalhadores do setor de serviços, as diaristas, auxiliares de limpeza, domésticas, manobristas, seguranças, porteiros, trabalhadores da construção civil, comerciantes etc., vinculados ora ao setor informal da economia, ora ao trabalho parcial e a subcontratação. Ou seja, se limitados apenas a uma escala do lugar, sem conexões com outras escalas de tempo e espaço, a compreensão do mundo será limitada e insuficiente.

Portanto, em nossa perspectiva teórico-metodológica buscamos subsídios em Lev Vigotski e Reuven Feuerstein, pois tratam-se de pesquisadores que tiveram contribuição significativa no decorrer do século XX, ao lado de Jean Piaget, para a compreensão de como se estrutura e processa o pensamento no ser humano, assim como os processos de aprendizagem. Em Vigotski buscamos aportes em relação a compreensão do desenvolvimento dos indivíduos por meio do significado da palavra e

\footnotetext{
${ }^{16}$ Yus (2002) considera interdisciplinaridade a integração de duas ou mais disciplinas para tratarem de determinado problema ou tema, de modo que, momentaneamente as fronteiras disciplinares desaparecem. $\mathrm{O}$ autor ainda focaliza incentivar o espírito cooperativo, questionando o sistema e podendo mudar consciências visando posturas positivas e propositivas. YUS, Rafael. Educação integral: uma educação holística para o século XXI. Porto Alegre: Artmed, 2002.

${ }^{17}$ HELLER, Agnes. Uma crise global da civilização: os desafios futuros. In: HELLER, Agnes et al. A crise dos paradigmas em ciências sociais e os desafios para o século XXI. Rio de Janeiro: Contraponto, 1999.
} 
do uso de signos na formação de conceitos científicos; e de Feuerstein buscamos aportes na Teoria da Experiência de Aprendizagem Mediada.

Faz-se mister destacar que, fora aplicada uma Sequência Didática em quatro turmas de oitavas séries no decorrer do quarto bimestre de 2016 e concomitantemente os alunos realizaram entrevistas com a população migrante nordestina, onde apoiamonos nas concepções de Ana Maria Marques Camargo Marangoni ${ }^{18}$ (2008) para o uso de questionários fechados e abertos, assim como nas contribuições de Gilson Luiz Volpato et $a l^{19}$ (2013) em relação ao trabalho científico, detendo-nos mais aos aspectos qualitativos do que meramente aos quantitativos, porém, sem desconsiderá-los.

Ademais, o presente trabalho se caracteriza por comungar de uma visão transdisciplinar, ao fazer um esforço em lidar com outros autores que não apenas e estritamente da ciência geográfica. Hilton Japiassu (2012) elucida a possibilidade em se ter um novo campo de conhecimento quando não se é estabelecida uma hierarquização entre as problematizações e os diversos modos de experimentação, com uma perspectiva que circule entre ciências humanas e filosofia, resultando numa transdisciplinaridade.

\begin{abstract}
O sonho é o de ter uma transdisciplinaridade capaz de abrir um novo campo ao conhecimento em que os esquemas nocionais possam circular da filosofia às ciências humanas sem estabelecer uma hierarquia entre esses diversos modos de experimentação e problematização. Porque eis o grande desafio de hoje lançado ao pensamento e à educação: superar a contradição entre, de um lado, os problemas cada vez mais globais, interdependentes e planetários e, do outro a persistência de um conhecimento privilegiando os saberes fragmentados, parcelados e compartimentados ${ }^{20}$ (JAPIASSU, 2012, p. 30).
\end{abstract}

Consideramos o aluno enquanto um sujeito inscrito num tempo e espaço de uma era tecnológica e virtual, onde o lugar já não é mais de uma geografia dos lugares fixos, mas de um tempo e espaço não só comprimido, mas fluído e de múltiplas territorialidades. Portanto, a escolha da temática da migração nordestina, em nossa sequência didática, justifica-se por tratar-se de um fenômeno que direta ou indiretamente está presente na realidade destes alunos. Trata-se de um fenômeno complexo, pois lida não somente com o "lugar do aluno", mas permite que se trabalhe com a conexão da escala do lugar com outras escalas de tempo e espaço.

\footnotetext{
${ }^{18}$ MARANGONI, Ana Maria Marques Camargo. Questionários e entrevistas: algumas considerações. In: VENTURI, Luis Antonio Bittar. (Org.). Praticando Geografia: técnicas de campo e laboratório. São Paulo: Oficina de textos, 2008.

${ }^{19}$ VOLPATO, Gilson L; BARRETO, R. E; UENO, H. M; VOLPATO, E. de S. N; GIAQUINTO, P. C \& FREITAS. G. de. Dicionário crítico para redação científica. Botucatu: Best Writing, 2013.

${ }^{20}$ JAPIASSU, Hilton. A crise das ciências humanas. São Paulo: Editora Cortez, 2012.
} 
Convém lembrar que a delimitação histórica e espacial dos entrevistados pelos estudantes contribuiu para que eles pudessem ter uma caracterização do passado dessas pessoas, de suas origens, das motivações e dos fatores que as compeliram a migrar para a região metropolitana de São Paulo. Do mesmo modo, puderam ter contato com as memórias e representações de mundo dessa população, sobretudo, quando se reportavam à escala de um outro tempo e espaço.

Acreditamos que é possível ao aluno do ensino fundamental aprender geografia e desenvolver o pensamento complexo e começar a elaborar sua concepção e representação de mundo. 


\section{CAPÍTULO 1 O MUNDO CONTEMPORÂNEO DA SOCIEDADE EM REDE E DO MEIO TÉCNICO-CIENTÍFICO-INFORMACIO- NAL}

Para uma melhor compreensão do mundo contemporâneo em que se amplia a cada dia a ideia de que o mundo estaria menor, dada a instantaneidade com que as informações são veiculadas e os fluxos de pessoas, capitais e mercadorias deslocam-se no espaço geográfico, é necessário que se reflita como tais transformações se manifestam no tempo e espaço e na construção de mundo de crianças e adolescentes. $\mathrm{O}$ ensino de geografia apoiado na categoria lugar é insuficiente quando destituído de conexões com outras escalas do problema estudado, desconsiderando os fenômenos inscritos noutras escalas de tempo-espaço e restrito apenas ao "lugar do aluno". São "nativos" de uma era digital e de meio técnico-científico-informacional, o que enseja a necessidade de um aprendizado de geografia que conecte outras escalas do problema estudado possibilitando uma aprendizagem significativa.

\subsection{AS REDES EM TEMPOS DE MEIO TÉCNICO-CIENTÍFICO- INFORMACIONAL}

O mundo com conexões de diferentes regiões do globo terrestre, apresentando inovações tecnológicas, científicas e informacionais, possibilitando maiores velocidades nos meios de transportes e ampliando o acesso a informações de modo mais instantâneo e abrangente, se dá graças aos avanços da cibernética. A sociedade parece estar imersa num grande emaranhado formado por pontos e nós que se comunicam e intercambiam como numa imensa rede que funciona intensa e incessantemente.

Um fenômeno ocorrido do "outro lado" do mundo pode parecer tão familiar ou próximo, em razão do grau da qualidade e perfeição audiovisual, da rapidez da informação e da comunicação em tempo real. As relações sociais realizam-se de modo cada vez mais crescente por meio das redes virtuais, com mensagens instantâneas, trocas de arquivos, compartilhamentos de informações e a sensação de se estar sempre correndo contra o tempo numa sociedade pós-industrial, tomada por cabos de fibras óticas, imagens de satélites e ondas eletromagnéticas, por entre o turbilhão de dados e mensagens transmitidas em segundos. Na realidade a sociedade mundial encontra-se imersa numa cultura da convergência, como bem pondera o estudioso norte-americano Henry Jenkins (2009, p. 29): 
Por convergência, refiro-me ao fluxo de conteúdos através das múltiplas plataformas de mídia, à cooperação entre múltiplos mercados e ao comportamento migratório dos públicos dos meios de comunicação, que vão a quase qualquer parte em busca das experiências de entretenimento que desejam. Convergência é uma palavra que consegue definir transformações tecnológicas, mercadológicas, culturais e sociais, dependendo de quem está falando e do que imaginam estar falando ${ }^{21}$.

A sensação de um tempo mais acelerado e de um encurtamento das distâncias entre os diversos pontos da superfície terrestre modificou a noção ingênua de que o planeta é tão extenso quanto fazia crer os relatos de épocas passadas. O desenvolvimento tecnológico tornou possível ao homem acessar os mais longínquos, inóspitos e recôncavos territórios da superfície terrestre, não mais o fazendo por meio de viagens intermináveis como no período em que as naus povoavam mares pouco navegados. Ademais, se não o faz fisicamente, a possibilidade em realizá-lo virtualmente está dada, o que não significa tratar-se de um mundo irreal ou imaginário.

As estruturas sociais passaram a ser penetradas por uma nova lógica que se impõe como código ou norma de conduta, direta ou indiretamente, influenciando no que diz respeito ao padrão de felicidade das pessoas, aferindo o grau de bem-estar pelo poder de consumo, levando os indivíduos numa busca infindável por status e visibilidade, seja por meio de uma exposição da vida privada em redes sociais, ou pelo culto ao individualismo e egocentrismo numa sociedade cada vez mais competitiva.

O século XXI tem presenciando uma expressão que acaba por caracterizá-lo como uma sociedade em rede. Cotidianamente, a palavra "rede" vem sendo usada nas mais diversas situações, desde as redes neurais ${ }^{22}$, como as redes sociais, possibilitada pela rede mundial de computadores, as redes de transportes, de fibra ótica, a rede urbana, a virtual, a rede geográfica, de supermercados, a rede telefônica, de ensino, as redes de profissionais da área da saúde, a rede comunitária, entre outras.

Na geografia, Pierre Monbeig ${ }^{23}$ (1984) em meados do século passado já tratava das redes, atentando-se principalmente à relevância das redes ferroviárias para a efetivação dos fluxos de mercadorias.

\footnotetext{
${ }^{21}$ JENKINS, H. Cultura da convergência. $2^{\mathrm{a}}$ ed. São Paulo: Aleph, 2009.

${ }^{22}$ Conforme Miranda (2013, p. 17): "Na verdade, hoje sabemos que o cérebro humano é constituído de uma neurofuncionalidade estrutural em redes neurais que tem implicações para inúmeros aspectos que caracterizam os processos cognitivos". MIRANDA, M. E. A reinvenção da prática docente: interfaces e aproximações para a ressignificação da prática docente. In: 14 ${ }^{\circ}$ EGAL - Encontro de Geógrafos da América Latina, 2013, Lima - PERU. Situación y Perspectivas de la Enseñanza - Aprendizaje de la Geografía en América Latina, 2013.

${ }^{23}$ MONBEIG, P. Pioneiros e fazendeiros de São Paulo. São Paulo: Hucitec, 1984.
} 
De acordo com o sociólogo espanhol Manuel Castells (1999, p. 565), criador da expressão sociedade em rede:

Redes constituem a nova morfologia social de nossas sociedades e a difusão da lógica de redes modifica de forma substancial a operação e os resultados dos processos produtivos e de experiência, poder e cultura. Embora a forma de organização social em redes tenha existido em outros tempos e espaços, o novo paradigma da tecnologia da informação fornece a base material para sua expansão penetrante em toda a estrutura social. Além disso, eu afirmaria que essa lógica de redes gera uma determinação social em nível mais alto que a dos interesses sociais específicos expressos por meio das redes: o poder dos fluxos é mais importante que os fluxos do poder ${ }^{24}$.

E ainda conforme o mesmo autor, as redes são definidas como um interconectado conjunto de nós, tal como a rede de fluxos financeiros globais, os mercados de bolsas de valores, a rede política que governa a Europa, composta por conselhos comissários e ministros; as redes formadas por gangues, pelas instituições que se articulam para lavagem de dinheiro em todo o mundo, pelos estúdios e sistemas televisivos e pela rede global transmitindo sinais com equipamentos móveis.

Milton Santos (2012, p. 264) ressalta os pontos que suportam as redes:

Os suportes das redes encontram-se, agora, parcialmente no território, nas forças naturais dominadas pelo homem (o espectro eletromagnético) parcialmente nas forças recentemente elaboradas pela inteligência e contidas nos objetos técnicos (por exemplo, o computador...). Desse modo, quando o fenômeno da rede se torna absoluto, é abusivamente que ele conserve esse nome. Na verdade, nem há mais propriamente redes; seus suportes são $\operatorname{pontos}^{25}$.

A criação das redes sociais permitindo a comunicação virtual ${ }^{26}$ e quase instantânea entre os indivíduos - ainda que de modo desigual entre as diferentes partes do globo - traz profundas alterações na sociedade contemporânea. Estar conectado à rede mundial de computadores tornou-se quase que uma determinação, fazendo com que aqueles que não disponham de tais canais de comunicação e recursos tecnológicos, pareçam, ainda que paradoxalmente, antissociais, defasados e parados no tempo. Os sistemas técnicos nesse período de meio técnico-científico-informacional tornam-se mundiais ainda que sua distribuição seja desigual, como assevera Milton Santos (2013, p. 39), ao destacar que:

\footnotetext{
${ }^{24}$ CASTELLS, M. A sociedade em rede: a era da informação: economia, sociedade e cultura. vol.1. $6^{\mathrm{a}}$ ed. São Paulo: Paz e Terra, 1999.

${ }^{25}$ SANTOS, M. A natureza do espaço: técnica e tempo, razão e emoção. $4^{a}$ ed. São Paulo: Editora da Universidade de São Paulo, 2012.

${ }^{26}$ Para Pierre Lévy (1999, p. 47), o virtual refere-se a “toda entidade 'desterritorializada', capaz de gerar diversas manifestações concretas em diferentes momentos e locais determinados, sem, contudo, estar ela mesma presa a um lugar ou tempo particular”. LÉVY, P. Cibercultura. São Paulo: Editora 34, 1999.
} 
[...] os sistemas técnicos criados recentemente se tornaram mundiais, mesmo que sua distribuição geográfica seja, como antes, irregular e o seu uso social seja, como antes, hierárquico. Mas, pela primeira vez na história do homem, defrontamo-nos com um único sistema técnico [...] superpondo-se aos sistemas técnicos precedentes, como um sistema técnico hegemônico, utilizado pelos atores hegemônicos da economia, da cultura e da política ${ }^{27}$.

Os aparelhos celulares passaram a realizar funções variadas e complexas, tal como um microcomputador portátil, facilitando a comunicação entre os indivíduos e possibilitando-os a se integrar à rede. Recursos computacionais, antes restritos aos países bélicos e hegemônicos, tornaram-se passíveis de serem utilizados pelo cidadão comum, sendo o GPS, por exemplo, uma ferramenta comumente presente na vida dos indivíduos.

A popularização da internet tem se apresentado como uma revolução, principalmente após as pessoas fazerem uso da tecnologia digital adentrando o ciberespaço. Ou, conforme Pierre Lévy (1999, p. 32), o "novo espaço de comunicação, de sociabilidade, de organização e de transação, mas também novo mercado da informação e do conhecimento ${ }^{28}$ ".

Castells (1999) destaca que a internet tivera a capacidade de fazer com que grandes meios de comunicação entrassem em curto-circuito, pois se tratando de um tipo de comunicação não vertical, possibilita que as pessoas se comuniquem como queiram, onde a comunicação não e midiatizada pelos grandes meios de comunicação.

A partir desse cenário de redes, a noção de "lugar" enquanto lócus de interação, sociabilidade e comunicação "face a face", vem perdendo o caráter que tivera em tempos passados. As novas formas de sociabilidade tornam-se mais virtualizadas e aos poucos o lugar passa a não ter o mesmo significado que tivera outrora, como pode ser visto em Castells (2003, p. 105, 106), ao evidenciar que:

[...] a sociabilidade baseada no lugar foi de fato uma fonte importante de apoio e interação social, tanto em sociedades agrícolas quanto nos primeiros estágios da era industrial - com a ressalva adicional de que essa sociabilidade era fundada não só em vizinhança, mas em locais de trabalho. Essa forma de comunidade territorialmente definida não desapareceu do mundo em geral, mas certamente desempenha papel pequeno na estruturação das relações sociais para a maioria da população em sociedades desenvolvidas [...] a proximidade geográfica perdeu sua preeminência na configuração das relações sociais em muitas dessas áreas afligidas pela pobreza há pelo menos vinte anos ${ }^{29}$.

\footnotetext{
${ }^{27}$ SANTOS, M. Técnica, espaço, tempo: globalização e meio técnico-científico-informacional. $5^{\text {a }}$ ed. São Paulo: Edusp, 2013.

${ }^{28}$ LÉVY, P. Cibercultura. São Paulo: Editora 34, 1999.

${ }^{29}$ CASTELLS, M. A galáxia da internet: reflexões sobre a internet, os negócios e a sociedade. Rio de Janeiro: Zahar, 2003.
} 
As redes, na contemporaneidade, apresentam-se com acentuado grau de complexidade moldando novas configurações territoriais, formas de comunicação e interação, mas não se dando de modo homogêneo no espaço geográfico. Para Santos (2013), emaranhadas em diferentes níveis e escalas, as redes desiguais, formam o espaço global, sobrepondo-se umas às outras, de modo a constituir um espaço banal, ou seja, o espaço de todos os homens, ações, firmas e instituições; resumindo, é o espaço geográfico, sendo as redes originárias dos fixos e fluxos ${ }^{30}$. Para este autor:

Animadas por fluxos, que dominam seu imaginário, as redes não prescindem de fixos - que constituem suas bases técnicas - mesmo quando esses fixos são pontos. Assim, as redes técnicas são estáveis e, ao mesmo tempo, dinâmicas. Fixos e fluxos são intercorrentes, interdependentes ${ }^{31}$ (SANTOS, 2012, p. 221).

As grandes metrópoles representam de modo visível os fluxos constantes de pessoas, mercadorias e capitais. O mercado empresarial movimentando virtualmente imensas remessas de lucros; os fluxos de informações oriundas de pontos estratégicos do planeta, difundidas de acordo com os interesses dos agentes hegemônicos, aumentam seu poder de persuasão entre as grandes massas. Os fixos proliferam-se diariamente pelas metrópoles, dando novas feições a antigos espaços com a força que ergue $e$ destrói coisas belas $^{32}$, num cenário cada vez mais tomado pela tecnologia.

De acordo com Ignacio Ramonet (2001), os fluxos nesse processo de grande velocidade da mundialização, tem se apresentado de modo menos material, como por exemplo, dados informáticos, acesso à internet, telecomunicações, mensagens eletrônicas etc ${ }^{33}$.

A "empresa global" de hoje deixou de ter centro, ela é um organismo sem corpo nem coração, não passa de uma rede constituída por diferentes elementos complementares, disseminados através do planeta e que, articulando-se uns aos outros, obedecem a duas palavras chave: rentabilidade e produtividade (RAMONET, 2001, p, 49).

Em que pese as tecnologias da informação e comunicação terem sido utilizadas por restritos setores militarizados das grandes potências mundiais, não se pode associar sua gênese como algo de uso exclusivo para fins bélicos. François Caron (2002) reportando-se as décadas de 60 e 70, do século passado, enfatiza o fato de a informática ter dado respostas para ao menos duas dificuldades comuns do sistema técnico: a

\footnotetext{
30 SANTOS, M. Técnica, espaço, tempo: globalização e meio técnico-científico-informacional. $5^{\mathrm{a}}$ ed. São Paulo: Edusp, 2013.

${ }^{31}$ Idem. A natureza do espaço: técnica e tempo, razão e emoção. São Paulo: Edusp, 2012.

${ }^{32}$ Referência à música "Sampa”, de Caetano Veloso, gravada em 1978.

${ }^{33}$ RAMONET, Ignacio. Geopolítica do caos. 4ª ed. Petrópolis, RJ: Vozes, 2001.
} 
regulação dos fluxos de pessoas, mercadorias e informações no interior das redes, assim como, as dificuldades para se organizar e gerenciar os dados cadastrais gigantescos e informações estatísticas engendradas numa sociedade de massa ${ }^{34}$.

A rede que passa a ser a base constitutiva dos tempos recentes, não se trata de algo estanque ou fixo, ao contrário, se apresenta fluída e destituída de qualquer rigidez. Para Claude Raffestin (1993), a rede surge flexível e de fios seguros, moldando-se de acordo com as situações concretas, sendo móvel, inacabada, proteiforme, tirando assim sua força no espaço e no tempo, adaptando-se às variações temporais ${ }^{35}$.

O desenvolvimento técnico-científico-informacional, somado às crises econômicas mundiais da década de 1970, transformou o espaço geográfico e o modo de produção capitalista, que se aproveitou dos meios de comunicação e transportes para espalhar-se pelas diversas regiões do globo terrestre de acordo com seus interesses econômicos, havendo uma reestruturação econômica com a passagem do regime fordista de produção para o regime de acumulação flexível. Giovanni Alves (2011) apontou esse período como o momento em que foi estabelecida uma nova base tecnológica, sociometabólica e organizacional da exploração do trabalhador ${ }^{36}$.

Todas essas transformações em escala mundial, com profundas alterações nas formas de se conceber o tempo e o espaço, passam a exigir novas reflexões e discussões no sentido de se tentar compreender qual modelo de escola vigora na contemporaneidade e com qual concepção de alunos, de escola e de sociedade os professores estão desenvolvendo suas atividades didático-pedagógicas.

Refletir sobre como tem se dado o processo de ensino-aprendizagem de geografia na educação básica, em tempos de meio técnico-científico-informacional e sociedade em rede, torna-se uma necessidade, principalmente devido às mudanças pelas quais o planeta vem passando e a importância da geografia enquanto ciência que contribuiu substancialmente para as noções e compreensão do eixo tempo-espaço. Aliás, noções tão caras ao campo científico, dadas as diferentes formas de se conceber o tempo e o espaço desde os sinais de rupturas que emergiram na sociedade europeia a partir do período conhecido e identificado como modernidade. De acordo com o sociólogo britânico Anthony Giddens (1991, p. 11), a modernidade:

\footnotetext{
${ }^{34}$ CARON, François. História contemporânea e desenvolvimentos tecnocientíficos. In: MORIN, Edgar. A religação dos saberes: o desafio do século XXI. $2^{\text {a }}$ ed. Rio de Janeiro: Bertrand Brasil, 2002.

${ }^{35}$ RAFFESTIN, Claude. Por uma geografia do poder. São Paulo: Ática, 1993.

36 ALVES, Giovanni. Trabalho e subjetividade: o espírito do toyotismo na era do capitalismo manipulatório. São Paulo: Boitempo, 2011.
} 
[...] refere-se a estilo, costume de vida ou organização social que emergiram na Europa a partir do século XVII e que ulteriormente se tornaram mais ou menos mundiais em sua influência. Isto associa a modernidade a um período de tempo e a uma localização geográfica inicial, mas por enquanto deixa suas características principais guardadas em segurança numa caixa preta ${ }^{37}$.

Diante desse quadro de complexidade e redes em que o mundo está envolto, cabe-nos questionar a forte tendência de considerar que estudando o "lugar do aluno", o "imediato" e o que lhe é mais "próximo" fisicamente, pouco ou nada considerando de outras escalas de tempo e espaço, pedagogicamente estarão mais propensos a efetivação de aprendizagens significativas. Seria como se o universo contemplado pelos alunos da educação básica estivesse estritamente centrado e limitado à uma dada realidade territorial relacionada aos habitantes do lugar em que vivem.

A vertente da geografia escolar que evoca a construção do conhecimento centrada na realidade imediata do aluno, ou seja, focalizada na categoria lugar, geralmente aponta a necessidade de se trabalhar com tal perspectiva pelo fato de estarem os professores desenvolvendo suas atividades a partir de uma interpretação global, sem maiores relações e conexões com o "lugar do aluno". Entretanto, tal afirmativa não encontra sustentação, pois o que se pode constatar de acordo com Simone Marassi Prado ${ }^{38}$ ao analisar os enunciados de professores de geografia da educação básica é que:

[...] temos uma pista sobre uma tendência muito disseminada e percebida nas falas dos professores: a ideia de que o ensino de conteúdos de Geografia tem de ser feito a partir da relação escalar entre o local e o global. Em outras palavras, o ensino se inicia pela compreensão da realidade próxima do aluno, apresentando as contradições produzidas e reproduzidas pelas relações capitalistas de produção e, assim, o aluno desenvolveria um pensamento crítico, tornando-se um cidadão (PRADO, 2014, p. 81).

A afirmação serve para corroborar o que se tem percebido nas últimas quatro décadas em relação ao ensino de geografia no Brasil e nas práticas escolares cotidianas, em que pouco tem considerando em relação às mudanças sociais, culturais e políticas que o mundo vem passando em tempos de meio técnico-científico-informacional ${ }^{39}$.

\footnotetext{
${ }^{37}$ GIDDENS, Anthony. As consequências da modernidade. São Paulo: Editora Unesp, 1991.

38 PRADO, Simone Marassi. Formação do professor de geografia: vozes e discursos da escola e da universidade. Dissertação de mestrado. Faculdade de Filosofia, Letras e Ciências Humanas da Universidade de São Paulo, 2014.

${ }^{39}$ Célestin Freinet (1979, p. 21) destacou no final dos anos 1970 as transformações pelas quais o mundo passara, apontando as diferenças entre o jovem de 1962 e o do início do século referente. O autor afirma que as transformações e evoluções radicais ocorrem num ritmo constante, de modo que: "No basta com decir, como ciertos pedagogos, que esta evolución no impede en absoluto segir funcionando como antes,
} 
$\mathrm{Na}$ era da sociedade em redes, não é suficiente que a realidade vivida pelos alunos seja concebida apenas numa perspectiva de práticas cotidianas atreladas às relações de sociabilidade de vizinhança, relações face a face ou de uma geografia de "pertencimento" ao lugar de convívio com sentimentos de afetividade. Ainda que tais situações ocorram, se dão de modo parcial e fraccionado em tempos atuais. Se o ensino de geografia ficar restrito ao "lugar do aluno", pouco ou nada conectando do lugar à outras escalas de tempo e espaço do fenômeno ou problema estudado, ter-se-á tão somente uma leitura fragmentada, parcial e disjuntiva da realidade.

Em tempos de avanços tecnológicos, científicos e informacionais é preciso um ensino de geografia que considere o desenvolvimento das funções intelectuais do aluno, o pensamento científico e a disciplina enquanto uma ciência que trabalha com sistemas de representação do mundo e da representação das relações que há no mundo ${ }^{40}$. Conforme assevera Maria Eliza Miranda (2012, p. 63, 64):

O ensino de geografia não tem conseguido, na verdade, desenvolver o interesse
na possibilidade de apoiar a aprendizagem e o desenvolvimento das funções
intelectuais implicadas nas diversas concepções que existem nas pesquisas
geográficas, incluindo-se aqui a própria representação do mundo, subestimando
o valor que a aprendizagem do pensamento científico da geografia e das
demais ciências humanas tem para o desenvolvimento sociocultural das futuras
gerações que atualmente se encontram em idade escolar ${ }^{41}$.

Ter uma representação de mundo e buscar caminhos para desenvolvê-la nas atuais e futuras gerações é fundamental nesse tempo em que a compreensão de tempo e espaço torna-se cada vez mais complexa e ao mesmo tempo mais necessária, pois presenciamos um "desencaixe" nas noções espaço temporais. Giddens (1991) apresenta o conceito de "desencaixe", para explicitar as alterações na noção de tempo e espaço provenientes do progressivo avanço dos meios de transportes e sistemas técnicos e científicos. A ideia que outrora vigorava de espaço concreto passa a diluir-se devido à noção de espaço virtual, modificando o modo como os indivíduos se comunicam e se relacionam. Para o sociólogo britânico, há atualmente a prevalência de indefinidas extensões de tempo-espaço, contribuindo para que o local perca a característica de interação, sendo o ciberespaço um exemplo de tais transformações nas relações entre os lugares.

ya que la cultura sigue siendo, según ellos, inmutable y eterna”. FREINET, Célestin. Las técnicas audiovisuales. $3^{\text {a }}$ ed. Barcelona: Editorial Laia, 1979.

${ }^{40}$ MIRANDA, M. Eliza. Contribuição ao debate atual sobre a formação de professores no Brasil: pela formação de futuras gerações na perspectiva da reconstrução do sócio-cultural. Revista do Departamento de Geografia, n. 20, p. 11-22, 2010.

${ }^{41}$ Idem. A atualidade de Pierre Monbeig e o direito de aprender geografia. Revista do Departamento de Geografia, p. 56/67, 2012. 
As mudanças trazidas com advento das novas tecnologias da comunicação principalmente a partir do pós-Segunda Guerra e do pós-fordismo, têm alterado notadamente as relações entre as pessoas gerando, inclusive, novas formas de comportamento e sociabilidade. Assim, em um mundo complexo há que se pressupor novas perspectivas em relação à dimensão da categoria lugar no ensino de geografia, ou seja, buscar a conexão desta categoria com outras escalas espaço-temporais.

$\mathrm{O}$ advento da Revolução Industrial ${ }^{42}$ e os ideários da Revolução Francesa no século XVIII serviram como marcos temporais que evidenciaram o distanciamento entre tempo e espaço. Conforme Giddens (1991, p. 26, 27):

O dinamismo da modernidade deriva da separação do tempo e do espaço e de sua recombinação em formas que permitem o "zoneamento" tempo-espacial preciso da vida social; do desencaixe dos sistemas sociais (um fenômeno intimamente vinculado aos fatores envolvidos na separação tempo-espaço); e da ordenação e reordenação reflexiva das relações sociais à luz das contínuas entradas (inputs) de conhecimento afetando as ações de indivíduos e grupos ${ }^{43}$.

A rapidez com que se processam as mudanças tecnológicas e o modo como diferentes partes do mundo vem se conectando, sobretudo pelos meios virtuais e com a expansão da internet, acaba por gerar impactos nas formas de sociabilidade e nos modos de se conceber as noções de tempo e espaço.

Para Giddens (1991), a invenção do relógio mecânico, datando em seus primórdios no final do século XVIII, e sua propagação para as demais regiões do globo foi de significado essencial para a humanidade culminando com a separação entre tempo e espaço. Para este autor, o cálculo do tempo por meio do relógio mecânico acarretou uma uniformidade na organização social do tempo.

O tempo ainda estava conectado com o espaço (e o lugar) até que a uniformidade de mensuração do tempo pelo relógio mecânico correspondeu à uniformidade na organização social do tempo [...]. Um de seus principais aspectos é a padronização em escala mundial dos calendários. Todos seguem atualmente o mesmo sistema de datação [...]. Um segundo aspecto é a padronização do tempo através de regiões. Mesmo no final do século XIX, áreas diferentes dentro de um único Estado geralmente tinham "tempos" diferentes, enquanto entre as fronteiras dos países a situação era ainda mais caótica (GIDDENS, 1991, p. 29).

\footnotetext{
${ }^{42}$ Pierre George (1991) destaca a indústria moderna como fruto da conjunção entre progresso científico, descobertas técnicas, racionalismo moderno e Europa Ocidental, impulsionados pelo grande comércio que se dera nos séculos XVII e XVIII, resultando em grandes acúmulos de capitais bancários na Inglaterra, principalmente, e em menor proporção em nações como Alemanha, França e países baixos. GEORGE, P. Geografia industrial do mundo. $6^{\text {a }}$ ed. Rio de Janeiro: Bertrand Brasil, 1991.

${ }^{43}$ GIDDENS, Anthony. As consequências da modernidade. São Paulo: Editora Unesp, 1991.
} 
Ao enfatizar que no passado o tempo mantinha-se conectado com o espaço e com o lugar, o autor ressalta o que considera como o "esvaziamento do espaço", sendo decorrente do "esvaziamento do tempo"; e ainda aponta a compreensão de lugar a partir da modernidade.

\begin{abstract}
"Lugar" é melhor conceitualizado por meio da ideia de localidade, que se refere ao cenário físico da atividade social como situado geograficamente. Nas sociedades pré-modernas, espaço e tempo coincidem amplamente, na medida em que as dimensões espaciais da vida social são, para a maioria da população, e para quase todos os efeitos, dominadas pela "presença" - por atividades localizadas. O advento da modernidade arranca crescentemente o espaço do tempo fomentando relações entre outros "ausentes", localmente distantes de qualquer situação dada ou interação face a face. Em condições de modernidade, o lugar torna-se cada vez mais fantasmagórico: isto é, os locais são completamente penetrados e moldados em termos de influências sociais bem distantes deles ${ }^{44}$ (GIDDENS, 1991, p. 28, 29).
\end{abstract}

Na pré-modernidade os lugares apresentavam particularidades e características específicas dos que neles viviam, com pouca influência externa e havendo forte coincidência na dimensão do tempo e espaço graças às relações estabelecidas entre os membros daquela localidade. Em que pese ser possível considerar que já existiam entre os membros de uma dada comunidade em períodos remotos sistemas de redes, estas se davam num tempo lento, como podemos verificar em Santos (2012, p. 264, 265):

\begin{abstract}
No primeiro momento, as redes existentes serviam a uma pequena vida de relações. O espectro do consumo era limitado. Exceto para uns poucos indivíduos, as sociedades locais tinham suas necessidades localmente satisfeitas. Os itens trocados eram pouco numerosos e as trocas pouco frequentes. A competitividade entre grupos territoriais era praticamente inexistente, em períodos normais. O tempo era vivido como um tempo lento ${ }^{45}$.
\end{abstract}

Além das limitações vividas pelas populações remotas em sociedades locais, como o consumo limitado, os itens trocados que eram pouco numerosos e as trocas pouco frequentes, além da lentidão do tempo e a competitividade praticamente inexistente, como se verifica na citação supracitada, encontramos noutro geógrafo, Paul Claval (2006, p. 122) os apontamentos em relação às dificuldades enfrentadas por populações tradicionais que se deparavam com constrangimentos em nível local, não somente em relação aos transportes, mas dadas as onerações para se abrigarem, alimentarem e vestirem, podendo apenas contar com os recursos próximos ${ }^{46}$.

\footnotetext{
${ }^{44}$ GIDDENS, Anthony. As consequências da modernidade. São Paulo: Editora Unesp, 1991.

${ }^{45}$ SANTOS, M. A natureza do espaço: técnica e tempo, razão e emoção. $4^{a}$ ed. São Paulo: Editora da Universidade de São Paulo, 2012.

${ }^{46}$ CLAVAL, Paul. História da Geografia. Lisboa/Portugal: Edições 70, 2006.
} 
A revolução da mobilidade libertou os grupos humanos dos constrangimentos locais que outrora os reprimiam. Os produtos necessários à vida humana podem vir de longe; os dejectos e as águas sujas são lançados para fora das áreas habitadas. As concentrações da população libertaram-se assim das tradicionais formas de poluição ${ }^{47}$.

Ainda de acordo com este autor, com a modernidade, passou a haver uma reestruturação nas relações sociais e o lugar perdera a importância que tivera noutras épocas devido as definições de tempo e espaço e aos avanços tecnológicos, científicos e comunicacionais

David Harvey (2014) caracteriza o período da modernidade sublinhando o que chama de compressão do tempo-espaço ${ }^{48}$, onde há um aparente encolhimento do mundo, dado o encurtamento das distâncias e dos tempos, visíveis, por exemplo, nas viagens percorridas de um ponto a outro no espaço geográfico. Para o geógrafo britânico, com o desenvolvimento dos sistemas técnicos, de informação, comunicação e transportes, é como se o espaço estivesse se comprimindo, de modo a tornar-se uma "espaçonave" planetária e uma "aldeia global"49 de telecomunicações, sem barreiras espaciais num acelerado ritmo de vida.

Diante do exposto é preciso admitir as limitações de uma geografia quando estritamente calcada no lugar de vivência dos estudantes com pouca ou nula conexão com outras escalas do fenômeno ou problema estudado. Para Giddens (1991, p. 29), não é simplesmente o que se apresenta na cena que estrutura o local, pois "'a forma visível do local oculta as relações distanciadas que determinam sua natureza”.

Giddens (1991) argumenta que a compreensão da separação entre tempo e espaço é necessária para que se possa entender o processo de desencaixe, que se refere ao "deslocamento" em contextos locais de interação e relações presentes na sociedade e sua consequente reestruturação no tempo-espaço por meio de extensões indefinidas. $\mathrm{O}$ autor, trata do que chama de fichas simbólicas, que diz respeito aos meios de intercâmbio que circulam sem considerar as individualidades ou grupos em particular, tais fichas podem ser representadas pelo dinheiro, por exemplo, usado como mecanismo de desencaixe.

\footnotetext{
${ }^{47}$ CLAVAL, Paul. História da Geografia. Lisboa/Portugal: Edições 70, 2006.

${ }^{48}$ Harvey argumenta que o uso da palavra "compressão" (ao se referir à questão do tempo-espaço) decorre da interpretação que fizera, pois, a história do sistema capitalista tem dado mostras de uma aceleração do ritmo da vida e das barreiras espaciais, que estão sendo superadas, dando a ideia de um encolhimento do espaço com interdependências econômicas e ecológicas. HARVEY, D. Condição pósmoderna: uma pesquisa sobre as origens da mudança cultural. 25a ed. São Paulo: Editora Loyola, 2014.

${ }^{49}$ A expressão "aldeia global" fora cunhada pelo filósofo canadense Herbert Marshall McLuhan (19111980) em sua obra "A galáxia de Gutenberg", de 1962, ao se referir às novas tecnologias e ao encurtamento das distâncias que possibilitam ao mundo uma interligação entre todos.
} 
No capitalismo, mais precisamente a partir do pós-fordismo, as relações sociais ganharam outra dimensão, alterando os modos de vida e as formas de consumo, modificando a sociabilidade e as interações locais. Os contatos possibilitados pelos sistemas virtuais conectando pontos distantes do planeta em uma sociedade que se apresenta em redes, fez com que os lugares não se consubstanciassem apenas num espaço físico fixo. Nas palavras de Michel Serres (2017, p. 25, 26):

As mencionadas novas tecnologias alteram nossos vínculos, as vizinhanças, o saber e os modos de acesso a ele. $\mathrm{O}$ conectivo substitui o coletivo. $\mathrm{O}$ mais ignorante de nós tem hoje acesso bastante fácil a maior quantidade de conhecimentos que o maior sábio do mundo ontem ${ }^{50}$.

O ciberespaço emerge do "desencaixe", onde as relações sociais, econômicas e culturais não mais se dão fazendo parte apenas de um dado contexto local, graças aos deslocamentos de relações que se reestruturam para além de um tempo-espaço circunscrito a uma dada localidade isolada.

\subsection{UM TEMPO DE ESPAÇOS CONECTADOS E PROBLEMAS GLOBAIS}

As gerações escolares atuais encontram-se imersas em jogos e comunidades virtuais se deparando com imagens representando paisagens diversas do espaço geográfico que lhes possibilitam "viver" outros mundos. Lidam, por meio de plataformas digitais com variadas localidades e temporalidades quase que simultaneamente, entretanto, com pouca mediação humana, na maioria das vezes expostas a estímulos diretos. Assim, há de se refletir se seriam todos que vivendo num determinado lugar, encontrar-se-iam efetivamente territorializados, considerando que as relações sociais cotidianas têm ultrapassado os limites físicos da cidade, município, estado ou país em que vivem.

Atualmente, o estar online e integrado à rede, virtualmente conectado, poderia ensejar de algum modo um determinado tipo de deseterritorialização? ${ }^{51}$. Não pretendemos neste trabalho enveredar para esta discussão, especificamente, mas apenas suscitar uma breve reflexão. Assim, recorremos à Pierre Lévy (1996, p. 21):

\footnotetext{
${ }^{50}$ SERRES, Michel. Tempo de crise. Rio de Janeiro: Bertrand Brasil, 2017.

51 Haesbaert (2008) considera como desterritorialização, tanto a destruição de marcos históricos, simbólicos, identitários, concreto, material, político-econômico, tal qual a destruição de fronteiras e antigos laços econômicos. Já Pierre Lévy (1996) em O que é Virtual?, entende pelo conceito, a desterritorialização por meio de ambientes virtuais.
} 
Quando uma pessoa, uma coletividade, um ato, uma informação se virtualizam, eles se tornam "não-presentes", se desterritorializam [...]. A sincronização substitui a unidade de lugar, e a interconexão, a unidade de tempo. Mas, novamente, nem por isso, o virtual é imaginário. Ele produz efeitos [...]. Os operadores mais desterritorializados, mais desatrelados de um enraizamento espaço-temporal preciso, os coletivos mais virtualizantes do mundo contemporâneo são os da tecnocracia, das finanças e dos meios de comunicação. São também os que estruturam a realidade social com mais força, e até com mais violência ${ }^{52}$.

Compreendemos que o ensino de geografia limitado à categoria lugar sem conexões com outras escalas de tempo e espaço, não é suficiente para uma aprendizagem significativa, sobretudo num mundo em que as transformações técnicas, científicas e informacionais se dão de modo acelerado, exigindo que os indivíduos construam representações de mundo em escalas de tempo-espaço que transcendam o imediato e aquilo que lhe é mais "próximo".

O estudo do lugar, postula este como sendo a referência mais imediata da realidade do estudante, o que faz supor que os alunos teriam maiores facilidades para uma aprendizagem significativa por tratar-se de um espaço do entorno e cotidiano de suas vidas. Entretanto, o conceito de cotidiano, contemporaneamente, não deve ser tomado como sinônimo de espaço vivido ${ }^{53}$, ou seja, aquele considerado em contato com a realidade próxima do aluno.

Lemos e Lévy (2010, p. 105) pensando na sociedade atual que se apresenta em espaços conectados, apontam que "sobre o novo território virtual, as proximidades são semânticas e não mais necessariamente e unicamente geográficas ou institucionais" ${ }^{\text {"54 }}$.

$\mathrm{O}$ ciberespaço tem se tornado para muitos indivíduos um espaço de contatos e realidades virtuais cotidianas, não estando atrelado estritamente à um espaço físico. Rogério Haesbaert (2007) ${ }^{55}$ discutindo o conceito de território considera que este não se limita ao espaço físico, podendo ser simbólico ou cultural.

Os adolescentes virtualmente conectados e integrados às mídias digitais, têm se sociabilizado de modo diverso quando comparados aos jovens de décadas passadas. Para Renato Ortiz (1994), é possível que se fale de relações sociais planetarizadas, que

\footnotetext{
${ }^{52}$ LÉVY, Pierre. O que é o virtual? 1 1 ed. São Paulo: Editora 34, 1996.

${ }^{53}$ Conforme Almeida e Passini (2011, p. 26): "O espaço vivido refere-se ao espaço físico, vivenciado através do movimento e do deslocamento. É apreendido pela criança através de brincadeiras ou de outras formas ao percorrê-lo, delimitá-lo, ou organizá-lo segundo seus interesses”. In: ALMEIDA, R. D. de; PASSINI, E. Y. O espaço geográfico: ensino e representação. $5^{\text {a }}$ ed. São Paulo: Contexto, 2011.

${ }^{54}$ LEMOS, André; LÉVY, Pierre. O futuro da internet: em direção a uma ciberdemocracia planetária. São Paulo: Paulus, 2010.

${ }^{55}$ HAESBAERT, R. Concepções de território para entender a desterritorialização. In: SANTOS, M. et al. Território, territórios: ensaios sobre o ordenamento territorial. Niterói: Lamparina, 2007.
} 
ainda não se espalham pelo planeta de modo homogêneo, compondo parte de um mundo real e imaginário ${ }^{56}$. Já as considerações de Dreifuss (2003, p. 119) sustentam que:

Os indivíduos integrados nessas culturas e sociedades em rede, fazem parte dos dois bilhões de pessoas que 'passeiam' virtualmente, por meio de textos, imagens e sons emitidos por um sistema cibernético de comunicação colossal, com recursos que são comuns a todos os espaços do mundo, interligando os mais variados lugares e pessoas de todas as partes. Dentro dessas websocieties e webcultures, as comunidades [...] de viajantes [...] a maioria sem nunca se ver $[\ldots]$ e talvez nunca chegar a estar fisicamente juntas ${ }^{57}$.

Essa virtualidade pode não ter um lugar fixo, porém faz parte da realidade de um significativo número de indivíduos, transcendendo a realidade "palpável” do lugar enquanto espaço concreto, delimitado, circunscrito ao entorno do "lugar do aluno". Se o virtual for considerado como algo que não apresenta concretude do ponto de vista físico, dada a sua imaterialidade, é possível afirmar que a realidade, o cotidiano e o vivido na contemporaneidade não se restringem somente ao "próximo", à escala do lugar isolado ou ao contato físico de relações face a face. O mundo da conexão e integração de pessoas de diversos lugares, do estar online, seja em redes sociais ou aplicativos como o WhatsApp, tem sido a realidade cotidiana de diversos alunos da educação básica, em que pese as modestas condições socioeconômicas de muitos desses jovens escolares.

Considerando que Vigotski ${ }^{58}$ (2007) conceitua o ser humano como um indivíduo cultural que se constitui e se desenvolve por meio das interações sociais com outrem, fazendo uso dos símbolos e signos como instrumentos mediadores, é preciso que se reflita que outras formas de sociabilidade e comunicação tem permeado o cotidiano de crianças e adolescentes em idade escolar em tempos de meio técnico-científicoinformacional e sociedade em rede.

Convém, todavia, considerar que o fato de as relações virtuais e a conectividade digital se acentuarem sobremaneira nesta era de sociedade em rede, não deve significar o fim das fronteiras ou até mesmo da geografia. Ao analisar as questões concernentes ao ciberespaço, por exemplo, tido como espaço destituído de limites físicos ou fronteiriços, devido à sua virtualidade, há que se atentar para não considerar como a emergência de um possível "fim da geografia" ou do espaço geográfico, substituídos por uma cronografia.

\footnotetext{
${ }^{56}$ ORTIZ, Renato. Mundialização e cultura. São Paulo: Brasiliense, 1994.

${ }^{57}$ DREIFUSS, R. A. Tecnobergs globais, mundialização e planetarização. In: MORAES, D. de. (Org.). Por uma outra comunicação: mídia, mundialização cultural e poder. Rio de Janeiro: Record, 2003.

${ }^{58}$ VIGOTSKI, L. S. A formação social da mente: o desenvolvimento dos processos psicológicos superiores. $7^{\mathrm{a}}$ ed. São Paulo: Martins Fontes, 2007.
} 
O fato de os avanços tecnológicos terem possibilitado uma evolução nos meios de transportes e uma redução significativa no tempo de viagem, fez com que estudiosos vislumbrassem o fim da geografia. Paul Virilio (1984, p. 63) evidencia que:

O movimento não é mais indexado de acordo com a métrica mas com a velocidade do som. Há trinta anos, por exemplo, levava-se vinte e quatro horas para ir de Paris a Nova York. Agora leva-se três horas e meia. No final do século, com o jato de hidrogênio, levar-se-á apenas meia hora. Mas, ao mesmo tempo, ainda se leva três horas e meia para ir de Paris à ilha de Córsega. Portanto, há uma desregulagem da distância que cria distâncias-tempo para substituir distâncias-espaço. A geografia é substituída pela cronografia ${ }^{59}$.

Afirmações como a supracitada servem para evidenciar a necessidade de a geografia ensinada nas escolas romper com visões equivocadas como a do referido autor. Ora, se as distâncias-espaços estão sendo substituídas por distâncias-tempo, há que se indagar sobre quais espaços se dão os fluxos constantes em velocidades cada vez maiores. Afirmar que a geografia seria substituída pela cronografia é falho, por desconsiderar que não há tempo sem espaço e nem espaço sem tempo.

Zygmunt Bauman (1999) ao tratar da categoria mundo, considera que as distâncias não têm tanta relevância como tiveram num tempo anterior, do mesmo modo, as noções de fronteira perderam significado. Para este autor, com a compressão do mundo, a geografia tem perdido o valor fulcral e o espaço perdera a dimensão que lhe era atribuída quando eram realizados planejamentos pelos Estados hegemônicos ${ }^{60}$.

O mesmo autor apresenta os conceitos de "elites extraterritoriais", referindo-se às pessoas que devido às condições econômicas tem a possibilidade de se deslocar de maneira constante, sendo estes uma minoria que não dependem do espaço; e os "vagabundos", com parcos recursos econômicos e fixados ao lugar, cumprindo os ditames do mercado de trabalho.

Para o Primeiro Mundo, o mundo dos globalmente móveis, o espaço perdeu sua qualidade restritiva e é facilmente transposto tanto na sua versão "real" como na sua versão "virtual". Para o Segundo Mundo, o da "localidade amarrada", daqueles impedidos de se mover e assim fadados a suportar passivamente qualquer mudança que afete a localidade onde estão presos, o espaço real está se fechando rapidamente. É um tipo de provação que se torna ainda mais penosa pela insistente exibição na mídia da conquista do espaço e do "acesso virtual" a distâncias que permanecem teimosamente inacessíveis na realidade efetiva (BAUMAN, 1999, p. 96).

\footnotetext{
59 VIRILIO, P. Discussão e liberdade de movimento. In: VIRILIO, P; LOTRINGER, Sylvere. Guerra pura: a militarização do cotidiano. São Paulo: Brasiliense, 1984.

${ }^{60}$ BAUMAN, Z. Globalização: as consequências humanas. Rio de Janeiro: Jorge Zahar, 1999.
} 
Ainda conforme o autor supracitado, as pessoas do Primeiro Mundo vivem constantemente "sem tempo", como se tivesse todo tempo tomado, ao passo que as pessoas do mundo oposto, tem uma abundância de tempo inútil e redundante, sem ter com o que preencher esse tempo, num tempo em que nada acontece.

\begin{abstract}
Os habitantes do Primeiro Mundo vivem no tempo; o espaço não importa para eles, pois transpõem instantaneamente qualquer distância [...]. Os habitantes do Segundo Mundo, ao contrário, vivem no espaço, um espaço pesado, resistente, intocável, que amarra o tempo e o mantém fora do controle deles. O tempo deles é vazio: nele "nada acontece". Para eles, só o tempo virtual da TV tem uma estrutura, um "horário" - o resto do tempo escoa monotonamente, chegando e partindo sem exigir nada e aparentemente sem deixar vestígio [...] o tempo não tem poder sobre esse espaço real demais a que estão confinados os habitantes do Segundo Mundo (BAUMAN, 1999, p. 97).
\end{abstract}

Levando em consideração que a população do Distrito de Pedreira, região periférica da capital paulista, que sente os efeitos perversos da reestruturação produtiva com quadros típicos de subemprego, trabalho informal, terceirizado, parcial ou em duplas ou triplas jornadas, podemos considerar que mantém um tempo vazio? Um tempo em que nada acontece?

$\mathrm{O}$ fato de o mundo apresentar-se globalizado, no entanto, não significa que as fronteiras estejam perdendo importância ou que o espaço geográfico não tenha o significado que tivera outrora. Ademais, tudo isso, contribui para a necessidade de que a categoria mundo passe a ser mais valorizada, sobretudo, nos bancos escolares e mais especificamente no ensino de geografia. Assim, discordamos de Bauman no tocante à valia da ciência geográfica, pois consideramos que a geografia apresenta valor fulcral mais do que nunca e deve ser requerida sobremaneira para a compreensão e representação do mundo, como bem enfatiza Paul Claval (2011, p. 377):

\footnotetext{
Não existem saberes sobre a sociedade, a economia, a vida política ou a cultura que se constituíssem em um universo a-espacial [...]. As sociedades são fenômenos espaciais. As ciências que permitem compreender sua natureza e seu funcionamento devem levar em consideração os meios ambientes e as distâncias: elas têm necessidade de geografia ${ }^{61}$.
}

Ao entender que o jovem tem também seu cotidiano permeado por relações sociais em comunidades virtuais, podendo interagir com pessoas de porções distantes de onde ele se encontra, sem um contato personalizado face a face, ou que pode em questões de horas viajar para um ponto distante de onde reside, não significa que as

${ }^{61}$ CLAVAL, Paul. Epistemologia da geografia. Florianópolis: Editora da UFSC, 2011. 
questões temporais estejam suplantando as espaciais. Desse modo, não parece crível a possibilidade de a geografia e o espaço estarem apartados do tempo. Conforme Antônio Carlos Vitte (2008, p. 46):

A revolução einsteiniana sobre o espaço e o tempo, a globalização da economia e o renascimento da geografia cultural, colocaram para a discussão no meio acadêmico da geografia a necessidade de repensarmos a complexidade do real e neste, o sentido do espaço geográfico, sendo impossível agora, pensarmos a geografia e o espaço separado do tempo ${ }^{62}$.

As diversas facilidades propiciadas pelos meios de transportes, verificável facilmente pelos constantes fluxos de pessoas, capitais, mercadorias e informações, confere ao espaço geográfico sobrelevada importância em tempos recentes e não o contrário. Tomando mais uma vez de empréstimo a expressão de Claval (2006, p. 120): "A geografia torna-se mais importante que nunca ${ }^{63}$ ".

A evidência de que a geografia não está com seu fim decretado, pode ser clarificada quando se percebe a dimensão espacial do mundo pós-moderno. Ainda recorrendo à Claval (2006, p. 120), temos que "a maior novidade epistemológica é que os problemas espaciais se tornam cada vez mais importantes na sociedade e no pensamento modernos".

Se por um lado o mundo globalizado é permeado por políticas neoliberais, resultando em grandes contrastes sociais, políticos e econômicos, com ações hegemônicas reconfigurando os mais diversos territórios e fazendo assim insurgir reações de contestação às ações dominantes, em busca de preservar suas identidades, crenças e valores, por outro lado, há que se considerar a necessidade em não se deter ao isolamento ou a repulsa pelo "outro", mas buscar uma cultura de paz, solidariedade e de cooperação mundiais. Disso decorre a inevitabilidade de o ensino de geografia trabalhar com categorias mais abrangentes que não somente restrita à escala do lugar.

Recorrendo ao importante relatório elaborado por Jacques Delors (1998, p. 35), no final da década dos anos do 90 do século passado, temos que:

Hoje em dia, grande parte do destino de cada um de nós, quer o queiramos quer não, joga-se num cenário em escala mundial. Imposta pela abertura das fronteiras econômicas e financeiras, impelidas por teorias do livre comércio, reforçadas pelo desmembramento do bloco soviético, instrumentalizada pelas novas tecnologias da informação a interdependência planetária não cessa de aumentar, no plano econômico, científico, cultural e político ${ }^{64}$.

\footnotetext{
62 VITTE, Antônio Carlos. A geografia física no Brasil: um panorama quantitativo a partir de periódicos nacionais (1928-2006). Revista da ANPEGE. v. 4, 2008.

${ }^{63}$ CLAVAL, Paul. História da Geografia. Lisboa/Portugal: Edições 70, 2006.

64 DELORS, Jacques. Educação: um tesouro a descobrir. Relatório para UNESCO da Comissão Internacional sobre educação para o século XXI. São Paulo: Cortez, 1998.
} 
Em que pese a relevância de o ensino de geografia se ater às questões atreladas aos desmandos do mercado e das políticas neoliberais que aprofundam visivelmente o fosso entre os mais ricos e os mais empobrecidos, há uma teia de relações complexas que precisam ser consideradas, para que não se incorra no risco de suprimir o conhecimento científico em função de explicações pautadas somente pelo viés economicista. Ortiz (1994) atenta para o cuidado que se deve ter ao pensar o mundo para que não se caia em reducionismos ao inclinar-se em análises fortemente economicistas, como tem sido recorrente em estudos que explicam a história mundial como uma evolução do capitalismo. Aliás, conforme pondera Claval (2006, p. 120):

Por causa da crescente mobilidade e das novas facilidades de comunicação o mundo evoluiu: as velhas lutas entre classes foram substituídas por bens de prestígio ou pelo acesso à cultura. E isto que dá ao espaço um papel crescente na sociedade contemporânea. A geografia torna-se mais pertinente que nunca.

As questões que se apresentam no mundo contemporâneo são complexas, interdisciplinares e de ordem global. As últimas três décadas do século XX foram marcadas por transformações profundas no cenário mundial. Giddens (2000) assinala um verdadeiro mundo em descontrole ${ }^{65}$, com mudanças climáticas e globais e num momento em que os avanços da ciência e da tecnologia, ainda que visem evitar tais problemas, acabam contribuindo para criá-los.

Vivemos hoje em um mundo de incerteza artificial, onde o risco difere muito dos períodos anteriores no desenvolvimento das instituições modernas. Isso, em parte, é uma questão de abrangência. Agora alguns são riscos de "grande consequência" - os perigos que representam afetam potencialmente a todos, ou a um grande número de pessoas, sobre a face do planeta ${ }^{66}$ (GIDDENS, 1996, p. 93).

Os tempos de ciberespaço, de meio técnico-científico-informacional e sociedade em rede, exigem a necessidade de um pensamento complexo, que permita ao indivíduo a capacidade de contextualizar, relacionar, religando os diferentes saberes e dimensões da vida, num paradigma que transcenda ao imediato mais próximo e concreto. Recorrendo à Morin (2005, p. 90): “O imediato em si não permite o ato de conhecer e isso porque uma certa distância sempre se faz necessária. Foi a nossa cultura que nos forneceu a distância que tornou possível o conhecimento do universo ${ }^{67}$ ".

${ }^{65}$ GIDDENS, Anthony. Mundo em descontrole: o que a globalização está fazendo de nós. Rio de Janeiro: Record, 2000.

${ }^{66}$ (Idem). Para além da esquerda e da direita. São Paulo, Editora da Unesp, 1996.

67 MORIN, E. In: MORIN, E; ALMEIDA, M. da C; CARVALHO, E. A. de. (Orgs.). Educação e complexidade: os sete saberes e outros ensaios. $3^{\mathrm{a}}$ ed. São Paulo: Cortez, 2005. 
Vivemos o paradoxo da evolução técnico-científica, dos avanços comunicacionais, ainda imperando o medo, a insegurança ${ }^{68}$, os totalitarismos e as incertezas, levando à necessidade de uma nova consciência mundial. A geografia poderá ajudar? Certamente que sim. No entanto, é preciso que seu ensino busque lidar com diferentes escalas dos problemas e fenômenos estudados, transcendendo a noção de que a aprendizagem significativa se dá ao lidar com o concreto e imediato ao aluno. No mundo contemporâneo, para que os jovens possam efetivamente constituir uma representação de mundo, é necessário que não fiquem restritivos somente à escala do lugar, sem conexões com outras escalas de tempo e espaço.

\subsection{A EDUCAÇÃO ESCOLAR PÓS-64}

Um dos grandes desafios para a educação do século XXI, principalmente em relação à educação básica é tornar o ensino de crianças e adolescentes algo significativo e pertinente, principalmente nesse tempo de meio técnico-científico-informacional e sociedade em rede, em que os desafios a serem enfrentados e os problemas apresentados, se dão, sobretudo, em escala global, o que vem evidenciar a importância e a necessidade de se aprender geografia. Contraditoriamente, de tempos em tempos emergem discussões a respeito se não da eliminação ou da não obrigatoriedade da referida disciplina na grade curricular ou de sua fusão à outras disciplinas correlatas, o que vem a expor os riscos e danos que uma dada "reforma" curricular pode causar na formação das novas gerações de estudantes.

O paradoxo que se vive na atualidade refere-se ao fato de os avanços técnicos, científicos e informacionais estarem adentrando na vida de significativa parcela da população mundial, principalmente dos mais jovens, possibilitando que estes indivíduos estejam inscritos numa nova dimensão de tempo e espaço, na era do ciberespaço, o que suscita a importância da geografia enquanto disciplina a ser ensinada. No entanto, em se tratando do espaço escolar, a atenção dada pelo poder público ao ensino de geografia tem sido esmorecedora. Porém, tal quadro desolador não se trata de algo recente.

Refletir sobre tais questões nos remete as décadas de 60 e 70 do século passado, quando as políticas neoliberais adentram a esfera escolar e a visão pedagógica reinante

\footnotetext{
${ }^{68}$ Para Morin (2011, p. 72): "Não existem apenas inovações e criações. Existem também destruições. Estas podem trazer novos desenvolvimentos: assim, os avanços da técnica, da indústria e do capitalismo levaram a destruição de civilizações tradicionais" MORIN, E. Os sete saberes necessários à educação do futuro. $2^{\mathrm{a}}$ ed. São Paulo: Cortez; Brasília, DF: UNESCO, 2011.
} 
se fazia em função de atender ao âmbito mercadológico. O golpe de 1964 e o ideal de aumentar o número de vagas nas escolas a serem oferecidas às crianças e adolescentes, se fizeram sem se atentar a qualificação dos professores e não considerando o aluno como um sujeito que necessitava ser intelectual e cognitivamente mediado. Na década seguinte, com a lei 5692/71, assinada pelo então presidente Emílio Garrastazu Médici, dentre as reformas apresentadas em relação ao ensino se deu a implantação de Estudos Sociais na grade curricular.

As disciplinas de Geografia e História foram retiradas do currículo oficial, pois de acordo com o governo vigente, tratavam-se de disciplinas subversivas e fortemente ideologizadas. Conforme Miranda ${ }^{69}$ (2012, p. 66), prevalecia “autoritariamente, um modo de pensar que descaracterizou a importância da Geografia, e por que não dizer da História também, como disciplinas autônomas, que foram reduzidas a Estudos Sociais”.

Marísia Buitoni (2010) explicita o grande esvaziamento que se dera na qualidade de ensino devido a reforma curricular com base na lei $\mathrm{n}^{\circ} 5692 / 71$, gerando a resistência por parte de estudantes, professores, instituições acadêmicas, entidades científicas, culturais, políticas e da Associação dos Geógrafos Brasileiros. De acordo com autora:

Somando-se às alterações processadas na década de 1970, a influência da pedagogia tecnicista predominou sobre as demais, valorizando o fazer e burocratizando a escola com o preenchimento diário de formulários exigidos por coordenadores pedagógicos indicados fora da comunidade escolar, que faziam o gerenciamento, sobretudo, da rotina docente ${ }^{70}$ (BUITONI, 2010, p. 12, 13).

José Bueno Conti (1976, p. 57) aponta como a geografia foi lançada à "uma condição cada vez mais inexpressiva nos currículos escolares"71.

Os Estudos Sociais correspondem a um setor do currículo, cujo conteúdo é difuso e mal determinado, discutindo-se até mesmo se se trata de uma área de estudo ou de simples disciplina. Ora aparecem como sinônimo de Geografia Humana, ora usurpam o lugar das Ciências Sociais ou da História ou, então, pretendem se impor como uma espécie de aglutinação de todas as ciências humanas (CONTI, 1976, p. 58).

Ademais, geografia dentro do que fora tido como Estudos Sociais, aparecia como uma ciência fragilizada, limitada, em que o estudo do meio fora fortemente vulgarizado, e o que consideravam como aprendizagem se referia majoritariamente ao

\footnotetext{
${ }^{69}$ MIRANDA, M. Eliza. A atualidade de Pierre Monbeig e o direito de aprender geografia. Revista do Departamento de Geografia, p. 56/67, 2012.

${ }^{70}$ BUITONI, Marísia Margarida Santiago (Coord.). Geografia: ensino fundamental. v. 22. Brasília: Ministério da Educação, Secretaria de Educação Básica, 2010.

${ }^{71}$ CONTI, J. B. A Reforma do Ensino de 1971 e a situação da Geografia. Boletim Paulista de Geografia, São Paulo, n. 51, p. 57-70, 1976.
} 
estudo do "lugar do aluno", como forma de possibilitar que esse tivesse meios de saber como lidar e atuar nesse seu espaço territorialmente delimitado.

Se é paradoxal pensar que a perda de espaço da geografia no currículo oficial se dava num momento em que o mundo passava por importantes transformações e fenômenos dos mais diversos ocorriam em diferentes partes do planeta, o que por si só já seria suficiente para demonstrar a necessidade de se aprender geografia, a mesma estranheza deve ser gerada atualmente quando em tempos de cibercultura há quem não considere a aprendizagem de geografia como algo pertinente.

Não diferente dos dias atuais, a educação, servindo aos interesses do mercado e qualificando os indivíduos para adentrar no mundo do trabalho era uma das máximas do governo autoritário ditatorial. Se por dentro das fábricas vigorava o modelo fordista de produção, com a rigidez do trabalho alienado e fragmentado, assim se constituía a educação básica no país, com políticas educacionais que almejavam formar mão de obra voltada à um saber fazer, ao invés de uma formação plena do ser humano. Para Maurício Tragtenberg (2004, p. 78):

A qualificação para o trabalho passa a ser controlada por este. Na medida em que o capital detém o conhecimento, ele funda uma distribuição diferencial de saber que legitima a existente na esfera do poder. Constituindo-se em qualificações genéricas, a força de trabalho pode ser formada fora do processo produtivo: na escola ${ }^{72}$.

As mudanças se deram também no âmbito do ensino superior, pois nos anos 60 surgiram as chamadas licenciaturas curtas de Letras, Ciências e Estudos Sociais, que conforme Conti (1976, p. 60) "seriam responsáveis pelo rebaixamento acentuado no nível do ensino".

Trata-se de um período da história do Brasil em que o Estado tivera sob seu domínio autoritário e repressor tanto a educação de nível elementar quanto a superior. De acordo com Tragtenberg (2004. p. 80), o Estado convertia a universidade em reprodutora dos seus ditames, por meio...

[...] da manutenção da produção intelectual nos limites da comunidade acadêmica [...]. O Estado realiza a 'conversão' de cursos que surgiram incialmente vinculados à prática social (cursos de Ciências Sociais) em meros e raquíticos esqueletos: Estudos Sociais. O curso de pós fica reduzido a ser pósde-alguma-coisa. Pela implantação de Estudos Sociais e consequente esvaziamento dos cursos de Filosofia, História, Geografia e Ciências Sociais, o Estado reproduz as relações sociais dominantes, usando instrumentos burocráticos o poder que a legislação lhe confere.

\footnotetext{
72 TRAGTENBERG, M. Sobre educação, política e sindicalismo. Editora Unesp, 2004.
} 
A retirada de Geografia e História do currículo oficial trouxe profundos prejuízos à aprendizagem, pois trata-se de ciências que lidam com o eixo espaçotemporal, tão fundamental e necessário ao desenvolvimento humano.

A eliminação da Geografia e da História do currículo concorreria para empobrecer a formação humanística da juventude, comprometendo de forma grave seu preparo integral e equivaleria ao fracasso do ensino em si mesmo, o qual visa preparar futuros cidadãos munidos de um rico pano de fundo de cultura, no qual nem a Geografia, nem a História podem estar ausentes. E a adoção dos Estudos Sociais da maneira como vem sendo preconizada corresponderia a uma verdadeira supressão dos estudos geográficos e históricos em nível de $1^{\circ}$ grau $^{73}$ (CONTI, 1976, p. 61).

Tal quadro, desolador, era assegurado graças às condições de exceção que o país vivia. Prevalecia a pedagogia tecnicista, a passividade do aluno e a primazia do ensino baseado no padrão estímulo-resposta, com nula atenção as questões de teor social e humanista.

\begin{abstract}
A aula tecnicista é invadida por materiais de instrução programada e instrução modelar, técnicas e recursos audiovisuais e forte utilização do livro didático, enfatizando a tendência de reprodução da realidade por modelos pré definidos, fortalecendo a ideologia política do momento. Há também a utilização dos multimeios para a educação de massa, nos moldes do ensino supletivo e da teleducação, e a avaliação escolar em função somativa, que reproduz os interesses da política dominante no momento, visando ao controle sistemático e contínuo. Sempre, ao final do processo, há a ênfase no produto acabado, desconsiderando a educação como processo $^{74}$ (SILVA, 2011, p. 34).
\end{abstract}

No final da década de 1970 emergia na educação a pedagogia histórico-crítica, preocupada com a emancipação dos sujeitos. De acordo com Silva (2011), em relação ao referido modelo de ensino, não se detinham numa oposição entre a cultura popular e erudita, contudo, valorizavam a passagem das experiências imediatas para o saber sistematizado, sempre focando no interesse dos alunos, para que pudessem efetivamente participar de modo crítico das atividades.

A década dos anos 80 estava nitidamente marcada pelas teorias de cunho crítico e social, em parte decorrente do processo de abertura política que começava timidamente se configurar em fins da década anterior, por outro lado, os movimentos pela redemocratização do país influenciaram as concepções didático-pedagógicas.

Com o fim do período militar e o processo de redemocratização, ocorre uma grande acomodação de um aparente tecnicismo, culminando em meados dos anos 90

73 CONTI, J. B. A Reforma do Ensino de 1971 e a situação da Geografia. Boletim Paulista de Geografia, São Paulo, n. 51, p. 57-70, 1976

${ }^{74}$ SILVA, Edileuza Fernandes da. A aula no contexto histórico. In: VEIGA, Ilma Passos Alencastro. (org.). Aula: gênese, dimensão, princípios e práticas. $2^{\mathrm{a}}$ ed. Campinas, SP: Papirus, 2011. 
com a Lei de Diretrizes e Bases da Educação Nacional (LDB) e com a publicação dos Parâmetros Curriculares Nacionais (PCN). Apesar das intenções em avançar nas questões pedagógicas no sentido de contemplar uma base curricular comum, valorizando as especificidades regionais, a interdicisplinaridade e os temas transversais, pouco se avançou em termos de uma proposta que considerasse efetivamente os aspectos cognitivos dos alunos.

Ademais, há de se indagar se a escola atual ainda se mantém tributária do modelo fordista de produção; sobretudo, se pensarmos em salas de aula cuja centralidade está na figura do professor, destituído de um papel de mediador da aprendizagem, mas como "único" detentor do conhecimento, paradoxalmente num período de meio técnico-científico e informacional e sociedade em rede.

O mundo assistiu a partir dos anos 70 do século passado os sinais de saturação do modelo fordista de produção e acumulação, numa passagem para o modelo de acumulação flexível do capitalismo, alterando profundamente não apenas o modelo de produção, mas a flexibilidade e novas competências exigidas por seus empregadores.

Com o toyotismo - nome dado ao modelo de produção do sistema toyota em que o trabalhador deve ser polivalente, multifuncional e flexível - a produção se utilizara de novas técnicas tanto em relação ao sistema gerencial quanto ao produtivo. Benjamin Coriat (1994, p. 53) ressalta a polivalência do trabalhador que num sistema de produção diferente do modelo taylorista norte americano vai...

[...] proceder através da destruição dos saberes operários complexos e da decomposição em gestos elementares, a via japonesa vai avançar pela desespecialização dos profissionais para transformá-los não em operários parcelares, mas em plurioperadores, em profissionais polivalentes ${ }^{75}$.

O regime de acumulação flexível não se limitara apenas aos sistemas produtivos ou alterações que consubstanciara nas relações trabalhistas, mas também adentrara na esfera escolar. A educação nesse contexto, ora se apresenta como num modelo fordista de produção, ora com ares de acumulação flexível. Os documentos e diretrizes curriculares, apoiados em orientações internacionais, evidenciam a necessidade de uma formação integral do aluno, contemplando sua preparação para o mundo do trabalho e apontam a necessidade em se desenvolver habilidades e competências. Mas será que efetivamente tem sido desenvolvida nas escolas habilidades e competências para a vida,

\footnotetext{
${ }^{75}$ CORIAT, Benjamin. Pensar pelo avesso: o modelo japonês de trabalho e organização. Rio de Janeiro: Revan: UFRJ, 1994.
} 
para a autonomia intelectual e o senso crítico do estudante? Estaríamos todos efetivamente engajados e capacitados para lidar as dificuldades de aprendizagem, com os processos de aprendizagem dos alunos, com as especificidades de cada um e em busca da equidade? Ou estaríamos como num modelo de produção flexível, atentandonos aos mais aptos e desconsiderando os com maiores dificuldades?

De acordo com Castells (1999, p. 519, 520):

Quando as exigências por flexibilidade são acrescidas numa corrida por eficácia e produtividade, as empresas buscam eliminar os inaptos e aqueles incapacitados diante das necessidades de qualificação frente às transformações tecnológicas. O que criou relação entre melhoria da qualificação e aumento da capacidade de se tornar empregável ${ }^{76}$.

Para Kuenzer (2016, p. 3) a educação no atual período de acumulação flexível aparece como um projeto dotado de uma lógica em que ainda vigora a desigual distribuição da educação, no entanto, de um modo diferenciado, tal como uma educação instrumental.

[...] o discurso da acumulação flexível sobre a educação aponta para a necessidade da formação de profissionais flexíveis, que acompanhem as mudanças tecnológicas decorrentes da dinamicidade da produção científico tecnológica contemporânea, ao invés de profissionais rígidos, que repetem procedimentos memorizados ou recriados por meio da experiência ${ }^{77}$

As mudanças do mundo atual necessitam ser pensadas pelo professor de geografia que tem fundamental importância enquanto mediador em sala de aula. Assim como defendemos não ser suficiente explicar e atribuir os males do mundo como decorrentes tão somente do modelo capitalista de produção e acumulação, não podemos acomodar um ensino que atenda as demandas e aos desmandos do capital, numa formação que mais conforma e adapta do que emancipa. Daí a importância de se perguntar sempre qual o papel da escola.

[...] seria o papel da escola preparar indivíduos para a nova organização do mundo do trabalho, formando sujeitos competentes, competitivos $\mathrm{e}$ consumidores? Ou possibilitar o acesso e o desenvolvimento de saberes e de competências necessárias para inserção dos aprendentes como cidadãos críticos, participativos, propositivos numa sociedade em transformação? A escola básica deve treinar os alunos e alunas para a seleção do vestibular ou prepara-los para a vida, para além do mercado? ${ }^{78}$ (SILVA. J, 2003, p. 7, 8).

\footnotetext{
${ }^{76}$ CASTELLS, Manuel. A sociedade em rede: a era da informação: economia, sociedade e cultura. vol.1. 6a ed. São Paulo: Paz e Terra, 1999.

77 KUENZER, A. Z. Trabalho e escola: a aprendizagem flexibilizada. XI Anped Sul - Reunião Científica Regional da Anped: educação, movimentos sociais e políticas governamentais, UFPR, Curitiba, 24-27 jul. 2016.

78 SILVA, J. F. da. Introdução: avaliação do ensino e da aprendizagem numa perspectiva formativa reguladora. In: SILVA, J. F. da; HOFFMANN, J; ESTEBAN, M. T. (Orgs.). Práticas avaliativas e aprendizagens significativas: em diferentes áreas do currículo. Porto Alegre: Mediação, 2003.
} 
Além de se perguntar sobre o papel da escola, do professor, do aluno, não se pode perder de vista a relevância da geografia para a constituição de uma visão e representação de mundo das gerações escolares atuais e futuras. Se a retirada de geografia e história do programa curricular, com a implantação de Estudos Sociais, serviu-nos como exemplo do descalabro que se configurou na educação com a supressão de duas disciplinas tão fundamentais ao desenvolvimento humano, torna-se não crível que em tempos recentes pairam nos debates e em propostas vindas de setores governamentais reformas curriculares que literalmente desconsideram, novamente, a geografia e outras disciplinas da Base Nacional Comum Curricular (BNCC).

Apesar de não ser possível nem intenção de problematizar neste trabalho sobre a reforma atual, consideramos pertinente, ainda que de modo sucinto uma breve consideração sobre a flexibilidade do currículo. De acordo com a página eletrônica do Ministério da Educação (MEC), em seu portal E-Cidadania, temos que a atual reforma educacional:

Promove alterações na estrutura do ensino médio, última etapa da educação [...]. Dá autonomia aos sistemas de ensino para definir a organização das áreas de conhecimento, as competências, habilidades e expectativas de aprendizagem definidas na BNCC.

A referida reforma recai num paradoxo aos brasileiros: na pretensão de flexibilizar o currículo para ampliar as possibilidades dos jovens, abre margem para uma fragmentação, uma especialização precoce do estudante em determinada área que lhe interessa (ou seja, não as áreas em que poderia ser deficitário, em que mais precisaria se dedicar), após cumprir a parte "comum" do currículo - porém, esta já não contém a divisão disciplinar que conhecemos, aglutinando disciplinas de humanas, assim como as de natureza em áreas, para que no meio do curso, o aluno escolha seu "itinerário formativo", sua área, dando continuidade aos estudos de Língua Portuguesa e Matemática, também.

Simultaneamente, defende-se o interesse do aluno em estudar o que deseja e a imposição por parte do MEC do que ele deveria desejar, evidente pela manutenção de Português e Matemática nos três anos, na defesa de que por ser o básico da aprendizagem e os jovens brasileiros terem apresentado resultados aquém do esperado no Programme for International Student Assessment (PISA) 2015, é algo a ser reforçado. Não obstante serem as disciplinas com mais aulas no currículo brasileiro, estaria o problema na quantidade ou na qualidade do ensino das mesmas? 
Outra vez, recai-se no lugar. Ao invés de, concomitantemente, atender aos alunos das fases iniciais em recursos tecnológicos e financeiros para escolas com boas infraestruturas, profissionais e, consequentemente, melhores aulas, foca-se numa flexibilização que fragmenta, voluntaria ao aluno a importância que deveria atribuir a uma determinada ciência, que tem conhecimento a lhe oferecer, e que propicia que o estudante forneça algo de volta ao mundo. Ele deve-se limitar ao que the traz mais facilidade, gosto e conforto, nada que o desafie realmente e que o faça efetivamente ter uma outra perspectiva.

Podemos recorrer à Milton Santos e à sua atualidade:

Corremos o risco de ver o ensino reduzido a um simples processo de treinamento, a uma instrumentalização das pessoas, a um aprendizado que se exaure precocemente ao sabor das mudanças rápidas e brutais das formas técnicas e organizacionais do trabalho exigidas por uma implacável competitividade.

E ainda:

Daí, a difusão acelerada de propostas que levam a uma profissionalização precoce, à fragmentação da formação e à educação oferecida segundo diferentes níveis de qualidade, situação em que a privatização do processo educativo pode constituir um modelo ideal para assegurar a anulação das conquistas sociais dos últimos séculos. A escola deixará de ser o lugar de formação de verdadeiros cidadãos e tornar-se-á um celeiro de deficientes cívicos $^{79}$.

A reforma, como um todo, não é o mérito da questão aqui, apenas seu impacto principal. São muitos os detalhes que poderiam ser abordados, desde o processo histórico-político da reforma às votações, consultas públicas, dados e propagandas questionáveis, financiamentos privados, personalidades conservadoras ensejando a proposta e os movimentos estudantis contrários a ela.

Ademais, diante de um cenário de incertezas e obscurantismo, não se pode perder de vista o papel do professor enquanto um mediador da aprendizagem, que incentive a criatividade, a imaginação e considere o aluno enquanto centralidade da aula. Para isso, é preciso romper com velhos paradigmas e concepções que não consideram o aprendizado como um processo.

Para Piaget (1972, p. 124), a escola se preocupava mais com uma formação tradicional de gerações ascendentes, em detrimento de formar espíritos críticos, inventivos e inteligentes. Tratando dos professores, o pesquisador ainda destaca que: 79 SANTOS, M. Os deficientes Cívicos. Folha de São Paulo. Caderno Mais!, Sessão Brasil 500 d. C. p.
5-8, 24 jan.1999b. 
[...] as concepções antigas faziam com que eles fossem simples transmissores de conhecimentos comuns, elementares ou médios, sem possibilidade de iniciativas e muito menos de descobertas, de onde a sua posição subalterna ${ }^{80}$.

A criatividade e o conhecimento científico precisam ser fomentados no espaço escolar, para que se possa finalmente romper com o status tecnicista que desde a ditadura militar mantém forte presença nas práticas pedagógicas. Ferrés (1996) já denunciava uma escola que marginaliza os sentimentos, a fantasia, a criatividade e a imaginação, reduzindo o aluno à passividade da aceitação de conteúdos.

É importante que a geografia ensinada na educação básica, transcenda o "lugar do aluno", o "imediato" e aquilo que lhe é "mais próximo", não se restringindo somente ao lugar enquanto espaço territorialmente demarcado e isolado, mas conectado à outras escalas espaciais e temporais do problema ou fenômeno estudado, contribuindo, assim para a construção de uma representação de mundo dos estudantes. Assim, como para o desenvolvimento da mente, pois recorrendo a Kropotkin (2014, p. 33):

Sem dúvida alguma, raramente pode existir outra ciência que possa tornar-se tão atrativa como a geografia, nem um instrumento tão poderoso para o desenvolvimento geral da mente, para familiarizar o estudante com o autêntico método de raciocínio científico, e para despertar o gosto por todas as ciências naturais ${ }^{81}$.

O ensino de geografia torna-se cada vez mais necessário e no Brasil isto já estava posto em meados do século XX, quando Pierre Monbeig apontava em $O$ papel e o valor do ensino de geografia e de sua pesquisa, a contribuição desta ciência para o enriquecimento das mentes jovens e sua formação. Maria Eliza Miranda (2012, p. 55) fazendo aproximações entre Monbeig, Edgar Morin e Piaget, assevera que:

Se considerarmos o contexto em que viveu e escreveu sobre o ensino de Geografia na escola, situamos Monbeig atualizado e observador arguto de seu tempo sobre os avanços das pesquisas lideradas por Piaget que já havia, desde a primeira metade do século XX, impulsionado as concepções sobre a estrutura do pensamento e formulado sua teoria do desenvolvimento humano, e cujas ideias revolucionaram as concepções de epistemologia genética a qual considera que o potencial cognitivo humano se desenvolve após o nascimento, tendo que se aprender a pensar, o que acontece também nas interações e relações com o meio ${ }^{82}$.

Passado mais de meio século desde que Monbeig salientara a importância do ensino de geografia para o enriquecimento das mentes dos jovens e de Kropotkin no século XIX ressaltar a relevância da geografia para o desenvolvimento geral da mente,

\footnotetext{
${ }^{80}$ PIAGET, J. Psicologia e pedagogia. $2^{\text {a }}$ ed. Rio de Janeiro/São Paulo: Editora Foresense, 1972.

${ }^{81}$ KROPOTKIN, Piotr. O que a geografia deveria ser. In: RECLUS, É; KROPOTKIN, Piotr. Escritos sobre educação e geografia. $1^{a}$ ed. São Paulo: Terra Livre, 2014.

${ }^{82}$ MIRANDA, M. Eliza. A atualidade de Pierre Monbeig e o direito de aprender geografia. Revista do Departamento de Geografia, p. 56/67, 2012.
} 
como possibilitar no mundo contemporâneo de avanços nos campos da cibernética e da neurociência, que as gerações escolares aprendam geografia e se desenvolvam intelectual e cognitivamente?

Se o objetivo da educação é que o aluno se emancipe, tenha autocrítica, senso crítico, construa conceitos científicos, não sendo um sujeito passivo frente às transformações que o mundo vive e diante da avalanche de "informações" a que se submete cotidianamente, muitas vezes destituídos de mediação humana, há de se pensar no valor da geografia como conhecimento que pode contribuir significativamente para o desenvolvimento do aluno. São sujeitos que estão imersos no mundo digital e midiático, onde as relações de sociabilidade não são mais face a face e seu universo nem sempre é circunscrito ao seu lugar de morada enquanto espaço físico e concreto.

Jenkins (2009) utiliza-se da expressão cultura participativa, que se refere ao oposto da passividade dos espectadores frente aos meios de comunicação, mas participantes ativos que a partir de um conjunto de regras, interagem, sem haver a concepção de papeis separados entre os produtores e os consumidores de mídia ${ }^{83}$.

Por considerarmos a relevância dos fatores culturais e o homem enquanto sujeito social que se constitui a partir das interações e mediações com os outros, postulamos a geografia enquanto uma necessidade para o desenvolvimento cognitivo e intelectual do aluno. Para que possa constituir uma representação de mundo, que não seja centrada somente no individualismo e numa escala somente do "seu lugar", mas que possa colocar-se também num referencial do outro, numa escala de maior abrangência, de uma era planetária ${ }^{84}$.

\begin{abstract}
A nova cultura do conhecimento surge ao mesmo tempo em que nossos vínculos com antigas formas de comunidade social estão se rompendo, nosso arraigamento a geografia física está diminuindo, nossos laços com a família estendida, ou mesmo com a família nuclear, estão se desintegrando, e nossas alianças com Estados-nações estão sendo redefinidas. Entretanto, novas formas de comunidade estão surgindo: essas novas comunidades são definidas por afiliações voluntárias, temporárias e táticas, e reafirmadas através de investimentos emocionais e empreendimentos intelectuais comuns. Os membros podem mudar de um grupo a outro, à medida que mudam seus interesses, e podem pertencer a mais de uma comunidade ao mesmo tempo (JENKINS, 2009, p. 56, 57).
\end{abstract}

\footnotetext{
${ }^{83}$ JENKINS, Henry. Cultura da convergência. $2^{\mathrm{a}}$ ed. São Paulo: Aleph, 2009.

${ }^{84}$ Para Heloísa Cardoso (1988, p. 73): "A dimensão planetária dos problemas atuais do homem exige uma abordagem pluridimensional em seu equacionamento". CARDOSO, H. Supervisão: um exercício de democracia ou de autoritarismo? In: ALVES, Nilda. (Coord.). Educação e supervisão: o trabalho coletivo na escola. $4^{a}$ ed. São Paulo: Cortez/Autores Associados, 1988.
} 
Conforme Ferrés (1996), as novas gerações cresceram num ambiente que fora convertido pelos meios de comunicação de massa, em que estes impõem uma visão histórica e de mundo e a escola não teria se dado conta dessa situação, culminando com alunos que ao deixarem a escola não dominam de modo mínimo e racional o uso desses $\operatorname{meios}^{85}$. Para Freinet (1979, p. 21): “Si quiere preparar al niño para su papel de hombre en la sociedad de mañana, la educación tiene que tener en cuenta estas transformaciones decisivas e irreversibles ${ }^{86}$ ",

A torrente de imagens publicitárias fomentando o consumo, sem reais compromissos éticos com a sustentabilidade; a aquisição de bens materiais supérfluos; os ditames da moda, as programações televisivas de caráter duvidoso, a mercantilização da música, da arte, são razões suficientes para que o professor não se restrinja a uma postura unicamente de denúncia, mas conforme explicitaria Morin (2004, p. 78):

[...] tornar conhecidos os modos de produção dessa cultura. Seria preciso mostrar como o tratamento dado às imagens filmadas ou televisionadas, notadamente pela montagem, pode arbitrariamente, dar a impressão de realidade [...]. O mestre poderia situar e comentar os programas assistidos e os jogos praticados pelos alunos fora da classe ${ }^{87}$.

O que se evidencia em tempos atuais é um modelo de educação preocupado em conformar e adaptar o aluno à realidade vigente, com um forte componente de apelo ao individualismo, em detrimento de uma educação para a vida. Assim, como podemos pensar numa aprendizagem de geografia que transcenda o lugar enquanto espaço delimitado, isolado e sem conexões com outras escalas de tempo e espaço? Como compreender e atuar no mundo se restrito apenas ao seu lugar? Recorrendo à Castells (2003b, p. 278, 279), temos que:

O grande problema que se coloca é como, a partir do local, se pode controlar o global; como, a partir de minha vivência e de minha relação com meu mundo local - que é onde estou, onde vivo -, posso opor-me à globalização à destruição do meio ambiente, ao massacre do Terceiro Mundo em termos econômicos? Como fazê-lo? A internet permite a articulação dos projetos alternativos locais através de protestos globais, que acabam aterrissando em algum lugar, como por exemplo em Seattle, Washington, Praga etc., e que se constituem, se organizam, se desenvolvem a partir da conexão da internet, ou seja, da conexão global de movimentos locais e de vivências locais. A internet é a conexão global-local, que a nova forma de controle e de mobilização da nossa sociedade ${ }^{88}$.

\footnotetext{
${ }^{85}$ FERRÉS, Joan. Vídeo e educação. $2^{\mathrm{a}}$ ed. Porto Alegre: Artes Médicas, 1996.

${ }^{86}$ FREINET, Célestin. Las técnicas audiovisuales. $3^{\text {a }}$ ed. Barcelona: Editorial Laia, 1979.

${ }^{87}$ MORIN, Edgar. A cabeça bem-feita: repensar a reforma, reformar o pensamento. $9^{a}$ ed. Rio de Janeiro: Bertrand Brasil, 2004.

${ }^{88}$ CASTELLS, Manuel. Internet e sociedade em rede. In: MORAES, Dênis de. (org.). Por uma outra comunicação. Rio de Janeiro: Record, 2003 b.
} 
Jacques Delors (1998) enfatiza como uma das tarefas essenciais da educação fazer com que a interdependência real se transforme em solidariedade, possibilitando que as pessoas tenham meios para compreenderem a si e aos outros, por meio de um maior conhecimento do mundo. De acordo com este autor, supõe-se, por outro lado, que seja ultrapassada a tendência dos indivíduos se fecharem em si mesmos, mas que em escala mundial possam compreender uns aos outros respeitando as diversidades ${ }^{89}$.

Compreender uns aos outros e não perder o referencial do outro, não se isolar, atomizar, limitar, mas transcender para além do lugar restritivo e delimitado, descentralizando da visão estreita apenas do "aqui", do "agora", do "imediato" e do que é mais "próximo". Num tempo de redes, cibercultura e meio técnico-científicoinformacional é preciso que a geografia ensinada contribua para que crianças e adolescentes constituam uma visão e representação de mundo, com noções de tempo e espaço para além do lugar.

89 DELORS, Jacques. Educação: um tesouro a descobrir. Relatório para UNESCO da Comissão Internacional sobre educação para o século XXI. São Paulo: Cortez, 1998. 


\section{CAPÍTULO 2 A INSUFICIÊNCIA DO ENSINO DE GEOGRAFIA APOIADO NA CATEGORIA LUGAR SEM CONEXÃO COM OUTRAS ESCALAS DE TEMPO-ESPAÇO}

O ensino de geografia na educação básica, tem se apoiado na categoria lugar no processo de ensino-aprendizagem, pouco articulando a escala lugar à outras escalas de tempo e espaço, sobrelevando o "lugar do aluno" e limitando-se a uma escala de um espaço circunscrito, delimitado e isolado. Neste capítulo tratamos sobre a insuficiência do ensino de geografia quando restrito ao que considera o "lugar do aluno", aquilo que lhe é imediato e mais "próximo" pouco conectando de outras escalas do problema ou fenômeno estudado, numa geografia centrada em uma perspectiva apoiada acentuadamente na percepção sensorial em detrimento da percepção analítica.

\subsection{LIMITAÇÕES DO ENSINO CIRCUNSCRITO AO "LUGAR DO ALUNO"}

A vertente da geografia escolar que enfatiza a categoria lugar no processo de ensino-aprendizagem mantém-se presente não somente nos anos iniciais da educação básica, mas perfazem o ensino fundamental II e o ensino médio. Tal perspectiva parte da premissa de que as aprendizagens são mais significativas se considerar o lugar de vivência do aluno e os sentimentos de pertencimento em relação aquele espaço, contribuem sobremaneira para o desenvolvimento do estudante como cidadão crítico, autônomo e atuante na sociedade contemporânea. Tal concepção defende, geralmente, o uso dos sentidos e do imaginário subjetivo como elementos constitutivos de saberes.

Apesar de haver, por parte de determinados autores ${ }^{90}$ que se debruçam sobre o ensino de geografia, a justificativa de que o estudo do lugar de vivência do aluno ou da realidade que lhe é mais próxima trata-se de apenas uma das possiblidades no ensino visto que não descartam outras escalas de análise - o que se tem verificado em muitas práticas escolares é a prevalência do ensino calcado no "concreto" e naquilo que é mais "próximo" do aluno. Trata-se de uma perspectiva de que aprendendo a fazer a leitura do lugar em que vivem, os alunos estarão em condições de realizar a leitura do mundo.

\footnotetext{
${ }^{90}$ KAERCHER, N. A. A geografia é o nosso dia-a-dia. In: CASTROGIOVANNI, A. C. et al. Geografia em sala de aula: práticas e reflexões. $3^{\mathrm{a}}$ ed. Porto Alegre: Editora da Universidade/UFRGS/Associação dos Geógrafos Brasileiros. São Paulo/Porto Alegre, 2001. E também: CALLAI, H. C. Estudar o lugar para compreender o mundo. In: CASTROGIOVANNI. A. C. et al. Geografia em sala de aula: práticas e textualizações no cotidiano. $11^{\circ}$ ed. Porto Alegre: Mediação, 2014.
} 
De acordo com Helena Copetti Callai (2001, p. 61):

Entendemos que, partindo do lugar em que se vive, é mais fácil compreender os fenômenos. É mais fácil organizar as informações, podendo-se teorizar, abstrair do concreto, na busca de explicações, de comparações, de extrapolações $^{91}$.

A geografia escolar que advoga que a aprendizagem se torna mais eficiente partindo do que for mais próximo do estudante, demonstra em sua constituição forte influência da educação intuitiva que a partir do século XVIII teve visibilidade, partindo da Europa e se expandindo para outras regiões. O "lugar" representava mais do que um ponto de localização, pois carregava sentidos atrelados aos vínculos afetivos e aos sentimentos de pertencimento.

A geografia ensinada, quando apoiada na categoria lugar pouco se articulando à outras escalas de tempo e espaço, pode incorrer num ensino essencialmente positivista e fragmentado, que pouco se atém às questões concernentes à dimensão psicológica do aluno e aos processos de estruturação do pensamento ao longo da aprendizagem.

Apesar de ser apontada a necessidade de se fazer correlações entre os elementos constitutivos do "lugar do aluno" com outras escalas geográficas, não necessariamente de um trabalho em círculos concêntricos, o que se verifica é uma abordagem tratando dos aspectos locais, tendo o "concreto" como elemento principal. Aliás, a forte ênfase dada especificamente pela geografia ao estudo da cidade ou do município, pouco considerando de outras escalas, já estava presente em publicações brasileiras do fim da década de 80 do século passado.

Estudar o município é importante e necessário para o aluno, na medida em que
ele está vivendo ali estão o espaço e o tempo delimitados, permitindo que se
faça a análise de todos os aspectos da comunidade do lugar [...]. É uma escala
de análise que permite que tenhamos próximos de nós todos aqueles elementos
que expressam as condições sociais, econômicas, políticas do nosso mundo. É
uma totalidade considerada no seu conjunto, de todos os elementos ali
existentes, mas que, como tal, não pode perder de vista a dimensão de outras
escalas de análise (CALLAI e ZARTH, 1988, p. 11) ${ }^{92}$.

Considerar que o estudo do município torna o aprendizado de geografia mais significativo, pois o aluno estuda algo que vivencia cotidianamente numa realidade de

\footnotetext{
${ }^{91}$ CALLAI, H. C. O ensino de geografia: recortes espaciais para análise. In: CASTROGIOVANNI, A. C. et al. Geografia em sala de aula: práticas e reflexões. $3^{\text {a }}$ ed. Porto Alegre: Editora da Universidade/UFRGS/Associação dos Geógrafos Brasileiros - Seção Porto Alegre, 2001.

92 CALLAI, Helena Copetti \& ZARTH, Paulo Afonso. O estudo do município e o ensino de história e geografia. Ijuí: UNIJUÍ, 1988.
} 
sua vida concreta, demonstra-se insuficiente em tempos recentes. Primeiro, pelo fato de não ser todos os estudantes que possuem necessariamente moradia fixa no município em que vivem, sendo comum os casos de alunos recém-chegados à escola, as vezes oriundos de porções longínquas da metrópole ou estado. Segundo, que no atual período de globalização e considerando a ocupação de seus familiares, é possível que ao encontrar trabalho, sejam compelidos a mudarem de endereço em função da proximidade do emprego de seus responsáveis ou de fatores outros que direta ou indiretamente influenciam em seu local de moradia.

O lugar no ensino de geografia é tido, geralmente, como espaço delimitado territorialmente, na maioria das vezes não ultrapassando os limites da cidade ou do município. Porém, também aparece em escalas menores, como no caso do bairro. De acordo com Callai (2014, p. 109, 110):

O bairro, a parte da cidade que não pode ser entendida a não ser no seu interior, é um dos lugares que está mais próximo do aluno, no qual ele convive com outras pessoas. Esse é um espaço que ele pode percorrer por completo e que tem grande significado para a sua vida, inclusive do ponto de vista da afetividade ${ }^{93}$.

Partir da premissa de que o bairro é um dos lugares que está mais próximo do aluno demonstra insuficiência em termos de análise geográfica e no tocante ao ensino de geografia, pois isso não assegura que o indivíduo o conheça totalmente. Se existem lugares em que as crianças acessam ou brincam livremente pelas ruas e calçadas, há por outro lado, locais cada vez mais segregados, onde crianças e adolescentes passam a maior parte do tempo dentro de suas casas.

Se analisarmos algumas das palavras mais utilizadas pelos estudantes que responderam ao Questionário de Caracterização do Aluno ${ }^{94}$, no tocante às suas rotinas diárias, podemos ver que dentre as palavras que mais se destacam aparecem "casa", "escola" e "curso", tanto entre os meninos quanto as meninas, o que nos dá mostras de que seu cotidiano não se faz percorrendo o bairro por completo, mantendo um convívio face a face com outras pessoas ou possuindo necessariamente um sentimento de pertencimento por aquele lugar. As palavras que mais apareceram em suas respostas podem ser vistas nos quadros a seguir.

\footnotetext{
${ }^{93}$ CALlAI, H. C. Estudar o lugar para compreender o mundo. In: CASTROGIOVANNI. A. C. et al. Geografia em sala de aula: práticas e textualizações no cotidiano. 11 ${ }^{\circ}$ ed. Porto Alegre: Mediação, 2014. ${ }^{94}$ Questionário elaborado pela Prof ${ }^{a}$ Dra. Maria Eliza Miranda, do Departamento de Geografia da Faculdade de Filosofia, Letras e Ciências Humanas (FFLCH) da Universidade de São Paulo (USP), em seu Círculo de Pesquisas com professores da Educação Básica.
} 
Quadro 1 - Rotina das alunas

\begin{tabular}{|l|c|}
\hline \multicolumn{1}{|c|}{ Palavra } & $\begin{array}{c}\text { Número de } \\
\text { vezes que } \\
\text { aparece }\end{array}$ \\
\hline Casa & 47 \\
\hline Escola & 33 \\
\hline Curso & 21 \\
\hline Faço & 17 \\
\hline Arrumo & 16 \\
\hline Banho & 16 \\
\hline Durmo & 16 \\
\hline Mãe & 14 \\
\hline Almoço & 12 \\
\hline Ajudo & 8 \\
\hline Irmão & 7 \\
\hline Arrumar & 6 \\
\hline
\end{tabular}

Fonte: Organizado pelo autor com base no Quest. de Caracterização do Aluno

\section{Quadro 2 - Rotina dos alunos}

\begin{tabular}{|l|c|}
\hline \multicolumn{1}{|c|}{ Palavra } & $\begin{array}{c}\text { Número de } \\
\text { vezes que } \\
\text { aparece }\end{array}$ \\
\hline Casa & 43 \\
\hline Escola & 31 \\
\hline Curso & 18 \\
\hline Jogo & 18 \\
\hline TV & 14 \\
\hline Bola & 13 \\
\hline Celular & 13 \\
\hline Computador & 12 \\
\hline Assisto & 12 \\
\hline Almoço & 10 \\
\hline Assistir & 10 \\
\hline Jogar & 9 \\
\hline
\end{tabular}

Fonte: Organizado pelo autor com base no Quest. de Caracterização do Aluno

As palavras "casa" e "escola", citadas 90 e 64 vezes, respectivamente, por meninos e meninas, nos dão mostras de uma rotina diária em que não se tem muitas opções de lazer ou demais formas de sociabilidade pelo bairro. Em que pese ser comum aos meninos realizarem atividades domésticas, percebemos no caso das alunas, que se dedicam mais a tais atividades e menos às atividades recreativas. Vide o uso das palavras "arrumo", “ajudo", "irmão" e "arrumar", enquanto os meninos evidenciam "jogo", "tv", "bola”, “celular", “computador” e "jogar”. A palavra jogar, tem sido por eles empregada não apenas em referência ao futebol, mas principalmente em relação aos jogos de internet e outros recursos virtuais. Ou seja, estão sociabilizando mais pelos meios digitais do que pelas relações face a face no bairro em que vivem, e tanto meninos quanto meninas.

\section{Quadro 3 - Respostas dos alunos em relação à rotina diária}

\begin{tabular}{|l|l|}
\hline $\begin{array}{l}\text { Rebeca Valentim } \\
\text { Nunes, } 8^{\mathrm{a}} \mathrm{A} .\end{array}$ & $\begin{array}{l}\text { Eu fico a maior parte do dia em casa, vou para a minha avó, } \\
\text { para minha tia, para a igreja, curso de inglês. }\end{array}$ \\
\hline $\begin{array}{l}\text { Artur Pereira de } \\
\text { Alcântara, } 8^{\mathrm{a}} \mathrm{A} .\end{array}$ & $\begin{array}{l}\text { Eu fico mais em casa, mechendo em redes sociais pelo } \\
\text { celular e pelo computador. }\end{array}$ \\
\hline $\begin{array}{l}\text { Patrícia Vitória } \\
\text { Moreira da Silva, } \\
8^{\mathrm{a} B} .\end{array}$ & $\begin{array}{l}\text { Chegar em casa, assistir tv, comer, mexer no computador, } \\
\text { mexer no celular e ir dormir }\end{array}$ \\
\hline $\begin{array}{l}\text { Guilherme } \\
\text { Gomes da Silva, } \\
8^{\mathrm{a} B} .\end{array}$ & $\begin{array}{l}\text { Asistir, dormir, mexer no celular. } \\
\text { Assisto tv. } \\
\text { Gosto de jogar no celular ouvir música assistir vídeo e etc. }\end{array}$ \\
\hline
\end{tabular}

Fonte: Acervo Questionário de Caracterização do Aluno. 
Em que pese apontarem atividades atreladas à igreja, cursos de inglês ou visitações à parentes, suas atividades cotidianas estão muito mais restritas às suas casas e às relações sociais por meio de aparelhos digitais. Os enunciados evidenciam aspectos de uma realidade paradoxal, pois ao mesmo tempo em que estão "imersos" em redes sociais digitais interagindo com muitos "outros", nem sempre do lugar onde vivem, encontram-se numa rotina fortemente circunscrita ao lugar. Por isso enfatizamos a necessidade de a geografia ensinada lidar com a conexão entre as escalas de tempo e espaço que transcenda os aspectos restritos e delimitados do "lugar do aluno".

\section{Quadro 4 - Respostas dos alunos em relação à rotina diária}

\begin{tabular}{|c|c|}
\hline $\begin{array}{l}\text { Inácio José dos Santos } \\
\text { Neto, } 8^{\mathrm{a}} \mathrm{C} \text {. }\end{array}$ & $\begin{array}{l}\text { Quando chego em casa troco de roupa faço meus afazeres } \\
\text { como lavar a louça ou varrer a casa depois vou assistir tv } \\
\text { e quando chega um pouco a tarde tomo banho. }\end{array}$ \\
\hline $\begin{array}{l}\text { Luiz Fernando Matias } \\
\text { Pereira, } 8^{\mathrm{a}} \mathrm{C} \text {. }\end{array}$ & Escola casa de casa pra escola mais nada \\
\hline $\begin{array}{l}\text { Luiz Augusto da Silva } \\
\text { Santos, } 8^{a} \mathrm{D} \text {. }\end{array}$ & Fico em casa durmo escuto musica como \\
\hline $\begin{array}{l}\text { Vinícius Carlos dos } \\
\text { Santos Oliveira, } 8^{\mathrm{a}} \mathrm{D} .\end{array}$ & $\begin{array}{l}\text { Chego da escola almoço, ajudo minha mãe e depois fico } \\
\text { o resto do dia no computador. }\end{array}$ \\
\hline
\end{tabular}

Fonte: Acervo Questionário de Caracterização do Aluno

Há estudantes que desempenham tarefas que exigem responsabilidades típicas da vida adulta, tais como nos trechos seguintes.

\section{Quadro 5 - Respostas dos alunos em relação à rotina diária}

\begin{tabular}{|l|l|}
\hline $\begin{array}{l}\text { Flávia Cristina } \\
\text { Correia dos Santos, } \\
8^{\mathrm{a} A} .\end{array}$ & $\begin{array}{l}\text { Minha rotina diaria é acordar de manhã e fazer café para a } \\
\text { minha mãe, depois vou me arrumar para vim para escola, } \\
\text { vou para escola, quando chego da escola tomo banho, } \\
\text { almoço, e me arrumo para fazer um bico para ajudar minha } \\
\text { mãe, depois vou direto pro curso, e vou para casa descança } \\
\text { para voltar a estuda no outro dia de manhã. }\end{array}$ \\
\hline $\begin{array}{l}\text { Cleiton dos Santos } \\
\text { Santana, } 8^{\mathrm{a} B} \text { B }\end{array}$ & Saio da escola ivo trabalha mecamnico \\
\hline $\begin{array}{l}\text { João Vitor Bonfim, } \\
8^{\mathrm{a} B} .\end{array}$ & $\begin{array}{l}\text { Chego em casa 12:40 almoço depois vou trabalhar das } \\
13: 00 \text { até as 17:00 ai vou pra casa tomo banho janto e vou } \\
\text { namora e dpois assisto tv ou vou assistir filme no } \\
\text { computado. }\end{array}$ \\
\hline $\begin{array}{l}\text { Vitória Cordeiro } \\
\text { Rosa Araújo, } 8^{\mathrm{a}} \mathrm{C} .\end{array}$ & $\begin{array}{l}\text { Chego da escola vou trabalhar saiu umas 16:30 do trabalho } \\
\text { vou pra casa e deito ese nao tiver trabalhos escolares }\end{array}$ \\
\hline $\begin{array}{l}\text { Joice Silva dos } \\
\text { Santos, } 8^{\mathrm{a} D} \mathrm{D} .\end{array}$ & $\begin{array}{l}\text { Bom, ao chegar da escola, faço comida para meus irmãos, } \\
\text { levo minha irmã a escola, chego e me arrumo para o curso. }\end{array}$ \\
\hline
\end{tabular}

Fonte: Acervo Questionário de Caracterização do Aluno. 
Além dos estudantes que se dedicam às atividades diárias domésticas temos aqueles que realizam atividades remuneradas fora de casa, como podemos verificar no gráfico a seguir. Os dados mostram que em todas as salas há alunos que trabalham, sendo dois na $8^{\mathrm{a}}$ série $\mathrm{A}$, quatro na $8^{\mathrm{a}}$ série $\mathrm{B}$, seis na $8^{\mathrm{a}}$ série $\mathrm{C}$ e um na $8^{\mathrm{a}}$ série $\mathrm{D}$.

\section{Gráfico 1 - Total de alunos por sala que exercem atividade remunerada}

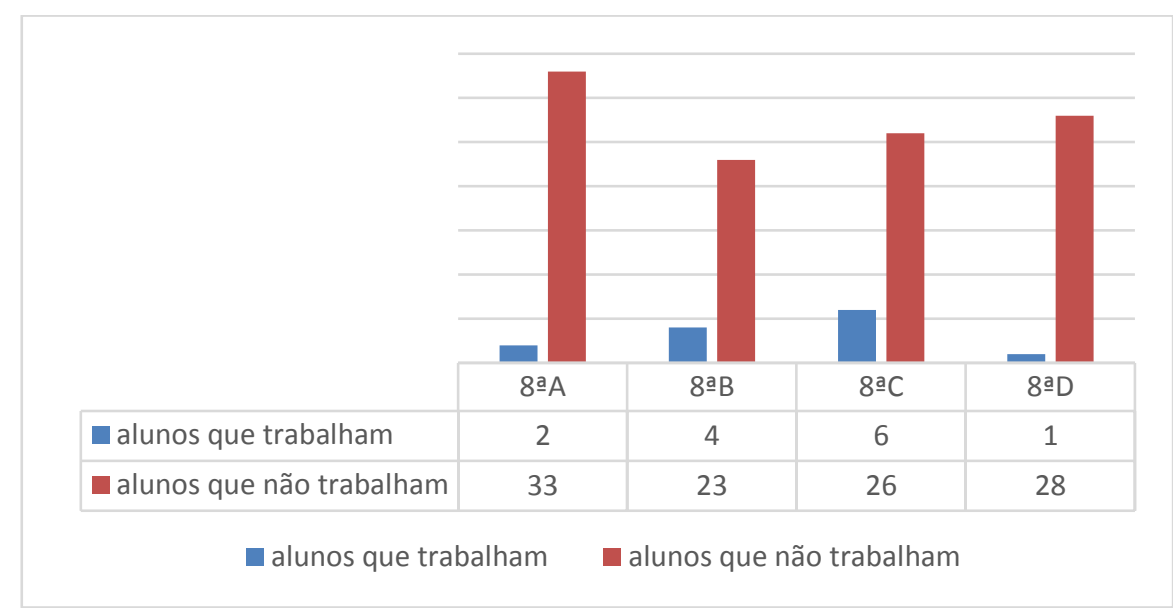

Fonte: Organizado pelo autor com base no Questionário de Caracterização do Aluno elaborado pela $\operatorname{Prof}^{a}$ Dr $^{a}$ Maria Eliza Miranda.

Seria possível afirmar que um jovem em idade escolar que faz o trajeto escolacasa-curso ou trabalho, conhece o bairro pelo fato de este ser um dos lugares mais próximos do aluno? Não estariam muitos deles conectados com pessoas de outros lugares por meio das redes sociais digitais e por jogos virtuais? Seria pertinente uma aprendizagem de geografia em tempos de ciberespaço focada nos aspectos mais concretos e imediatos ao aluno, na escala do lugar pouco buscando conectar-se à outras escalas de tempo e espaço?

Tais questionamentos nos leva a refletir sobre esse jovem do mundo contemporâneo, que vive num emaranhado de informações, comunicando-se de modo quase que instantâneo com outros "ausentes", compartilhando arquivos, músicas, jogos, fotos, vídeos, mas, que paradoxalmente, carece de noções espaço-temporais que transcendam a dimensão do imediato, do "seu lugar" e que lhe permita constituir uma representação de mundo que articule e conecte diferentes escalas de espaço e de tempo.

No atual período de meio técnico-científico-informacional crianças e adolescentes tendem a estar imersas na convergência dos meios midiáticos e de comunicação, na maioria das vezes realizando um significativo número de tarefas dentro de suas casas. De acordo com Jenkins (2009, p. 44): 
Um adolescente fazendo a lição de casa pode trabalhar ao mesmo tempo em quatro ou cinco janelas no computador: navegar na internet, ouvir e baixar arquivos MP3, bater papo com amigos, digitar um trabalho e responder emails, alternando rapidamente as tarefas. E fãs de um popular seriado de televisão podem capturar amostras de diálogos no vídeo, resumir episódios, discutir sobre roteiros, criar fan fiction (ficção de fã), gravar suas próprias trilhas sonoras, fazer seus próprios filmes - e distribuir tudo isso ao mundo inteiro pela internet ${ }^{95}$.

Apesar da não pretensão em generalizar que as atuais gerações escolares efetivamente lidam com diferentes plataformas e mídias digitais de modo eficiente, sobretudo, considerando que nem todos têm meios de acesso para isso, há um quase consenso de que o acesso à internet tem se tornado comum até mesmo para as pessoas de baixa renda. Por outro lado, apesar de estarem expostos à estímulos diretos oriundos dos recursos digitais, com pouca mediação humana, operam por meio de um aparelho celular um significativo número de tarefas possibilitadas por uma quantidade sem fim de aplicativos.

Em se tratando do ensino de geografia para as gerações atuais e considerando a complexidade do mundo, afirmar, que o bairro se trata de um lugar que apresenta grande significado do ponto de vista da afetividade é algo que deve ser relativizado, pois há de se indagar se são todos os moradores que sentem afeto pelo bairro onde vivem $^{96}$. Como pensar nos diversos casos de migrantes que almejam por questões diversas, sejam elas afetivas, sociais, culturais, políticas ou econômicas, regressar e viver com parentes que deixaram noutras porções do estado ou país? O que dizer, por exemplo, de pessoas que habitam áreas inóspitas ou de riscos e desejam um lugar melhor para viver?

Apesar de não ser objeto neste capítulo de tratar sobre os migrantes nordestinos do Distrito de Pedreira, zonal sul da capital paulista, entrevistados pelos estudantes (o assunto será tratado em capítulo subsequente), vale destacar que apesar de terem apontado gostar de morar no referido distrito, ao serem solicitados a responder se gostariam de morar noutro lugar, de um total de 47 entrevistados, 28 deles afirmaram que sim, ao passo que 14 disseram não e 5 deles não responderam à questão. Ou seja, $59 \%$ deles gostariam de viver em outro lugar.

\footnotetext{
95 JENKINS, Henry. Cultura da convergência. $2^{\text {a }}$ ed. São Paulo: Aleph, 2009.

${ }^{96}$ Paul Claval (2014, p. 46) se utiliza do exemplo de pessoas que almejam recomeçar a vida do zero, saindo do lugar onde vivem em direção a outros lugares, como "se dar a chance de construir uma vida longe de um passado penoso, longe dos lugares em que o futuro parecia sombrio e ameaçador". CLAVAL, P. Terra dos Homens: a geografia. 1a ed. São Paulo: Contexto, 2014.
} 
Ademais, não são raros os estudantes que evidenciam em produções textuais ou mesmo em momentos de dialogia, seus projetos em relação às perspectivas de empregabilidade, constituição familiar ou futuro acadêmico, o desejo de fixar-se não num único lugar apenas, mas viver noutras cidades, estados ou países. Muitos destes jovens se inspiram em youtubers ${ }^{97}$, o que acaba os estimulando a não se sentirem satisfeitos com o lugar onde vivem, aumentando suas perspectivas de emigrar ou viajar $^{98}$ para outros lugares.

Retomando o Questionário de Caracterização do Aluno, obtivemos que a maioria dos estudantes se utilizam do aparelho celular e demais recursos com mídias digitais, com a possibilidade de acessar diferentes aplicativos. As redes sociais, aliás, foram apontadas pelos estudantes como fazendo parte de suas rotinas para além da frequência à escola.

\section{Quadro 6 - Respostas dos alunos em relação à rotina diária}

\begin{tabular}{|c|c|}
\hline $\begin{array}{l}\text { Mariana Alves } \\
\text { de Souza, } 8^{\mathrm{a}} \mathrm{A} \text {. }\end{array}$ & $\begin{array}{l}\text { Eu tenho curso de inglês duas vezes na semana. Passo horas nas } \\
\text { redes sociais, ajudo nos afazeres de casa, leio e assisto tv todos } \\
\text { os dias. }\end{array}$ \\
\hline $\begin{array}{l}\text { Isabella de } \\
\text { Souza Abreu, } \\
8^{a} \text { B. }\end{array}$ & $\begin{array}{l}\text { depois que eu chego da escola eu arrumo a casa, depois eu } \\
\text { almoço e vou mexer no computador ai fico algumas horas e } \\
\text { depois vou ver televisão e mexer no celular, ai tomo banho acabo } \\
\text { dormindo e depois a acordo como de novo e fico no computador. }\end{array}$ \\
\hline $\begin{array}{l}\text { Thais Serafim } \\
\text { Rodrigues de } \\
\text { Sousa, } 8^{\mathrm{a}} \mathrm{C} \text {. }\end{array}$ & $\begin{array}{l}\text { [...] fora a segunda meus dias são iguais faço tarefas de casa (de } \\
\text { vez em quando eu estudo), fico me distraindo lendo, } \\
\text { conversando por redes sociais. }\end{array}$ \\
\hline $\begin{array}{l}\text { Aislan Oliveira } \\
\text { Santos, } 8^{a} \mathrm{D} .\end{array}$ & Vou para casa mecho no conputador e durno \\
\hline
\end{tabular}

Fonte: Acervo Questionário de Caracterização do Aluno.

\footnotetext{
${ }^{97}$ Jenkins (2009) pondera que nesse momento atual, a convergência se dá também pelo fato de as pessoas estarem assumindo o controle das mídias, de modo que por meio de múltiplas plataformas e canais de mídia, fluem as fantasias, memórias, relacionamentos e desejos. JENKINS, H. Cultura da convergência. $2^{a}$ ed. São Paulo: Aleph, 2009.

${ }^{98}$ Valendo-se de Claval (2014) percebe-se que o indivíduo se encontra localmente num conjunto de relações sociais, onde lhe são atribuídas determinadas obrigações frente a outras pessoas, porém, em outro local - em viagem, por exemplo - acabam-se os vínculos e longe de casa defronta-se com novas possibilidades e experiências inéditas. CLAVAL, P. Terra dos Homens: a geografia. $1^{\text {a }}$ ed. São Paulo: Contexto, 2014.
} 
Em tempos de meio técnico-científico-informacional não é suficiente considerar que ensinar geografia a crianças e adolescentes considerando que no bairro tudo ela conhece ou que por ser um espaço que lhe é mais próximo as aprendizagens serão significativas. A sociabilidade em tempos recentes, não tem mais se dado exclusivamente por relações cotidianas face a face, basta perceber o número de pessoas que por meio da internet passam a maior parte do tempo virtualmente conectadas a pessoas distantes.

[...] à medida que se desenvolvem em nossas sociedades projetos individuais, projetos para dar sentido à vida a partir do que se é e do que se quer ser, a Internet possibilita tal conexão, ultrapassando os limites físicos do cotidiano, tanto no lugar de residência quanto no trabalho, e gera redes de afinidades (CASTELLS, 2003b, p. 274).

O bairro, enquanto espaço físico delimitado, não tem mais para os indivíduos o sentido de pertencimento como tivera em sociedades anteriores e as gerações atuais, ao estarem online, acabam por acessar àquilo que mais lhes chama atenção em termos de interesses. Castells (2003b, p. 274) exemplifica os laços eletivos como formado por aqueles que procuram pessoas que tenham gostos ou tendências parecidas ${ }^{99}$.

\footnotetext{
A tendência que se desenvolve vai em direção à diminuição da sociabilidade de base comunitária física tradicional. Há uma tendência para a diminuição da relação baseada no bairro. Há um declínio da vida social dentro do trabalho [...]. A sociabilidade está se transformando através daquilo que alguns chamam de privatização da sociabilidade, que é a sociabilidade entre pessoas que constroem laços eletivos, que não são os que trabalham ou vivem em um mesmo lugar, que coincidem fisicamente, mas pessoas que se buscam.
}

Na mesma direção aponta Jenkins (2009), ao considerar que o jovem do mundo atual participa das comunidades virtuais direcionando seu foco para aquilo que mais atrai suas necessidades e desejos.

Conforme o gráfico 2, elaborado com base no cruzamento de dados obtidos por meio do Questionário de Caracterização do Aluno, é possível perceber algumas características dos jovens escolares que participaram da pesquisa. Com o cruzamento dos dados das questões "Para que você utiliza a internet" e "O que você gosta de ler", obtivemos que a maioria dos sujeitos da pesquisa utiliza a internet para acessar as redes sociais, ouvir música, pesquisar trabalhos escolares e assistir à filmes e vídeos, sendo que este grupo, ao responder sobre o que gostam de ler, indicaram novamente as redes

${ }^{99}$ CASTELLS, M. Internet e sociedade em rede. In: MORAES, Dênis de. (org.). Por uma outra comunicação. Rio de Janeiro: Record, 2003 b. 
sociais. Assim, é importante observar como as redes sociais tem permeado o cotidiano de crianças e adolescentes.

Gráfico 2 - Cruzamento de dados sobre "para que os alunos utilizam a internet" e "o que gostam de ler"

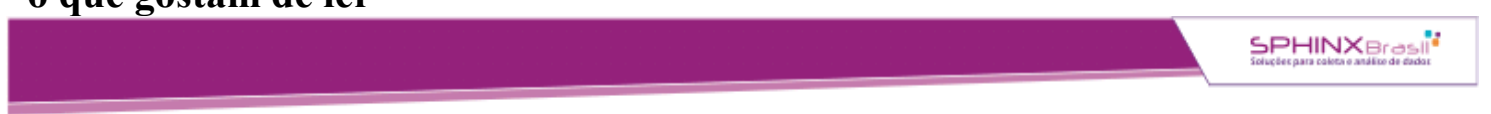

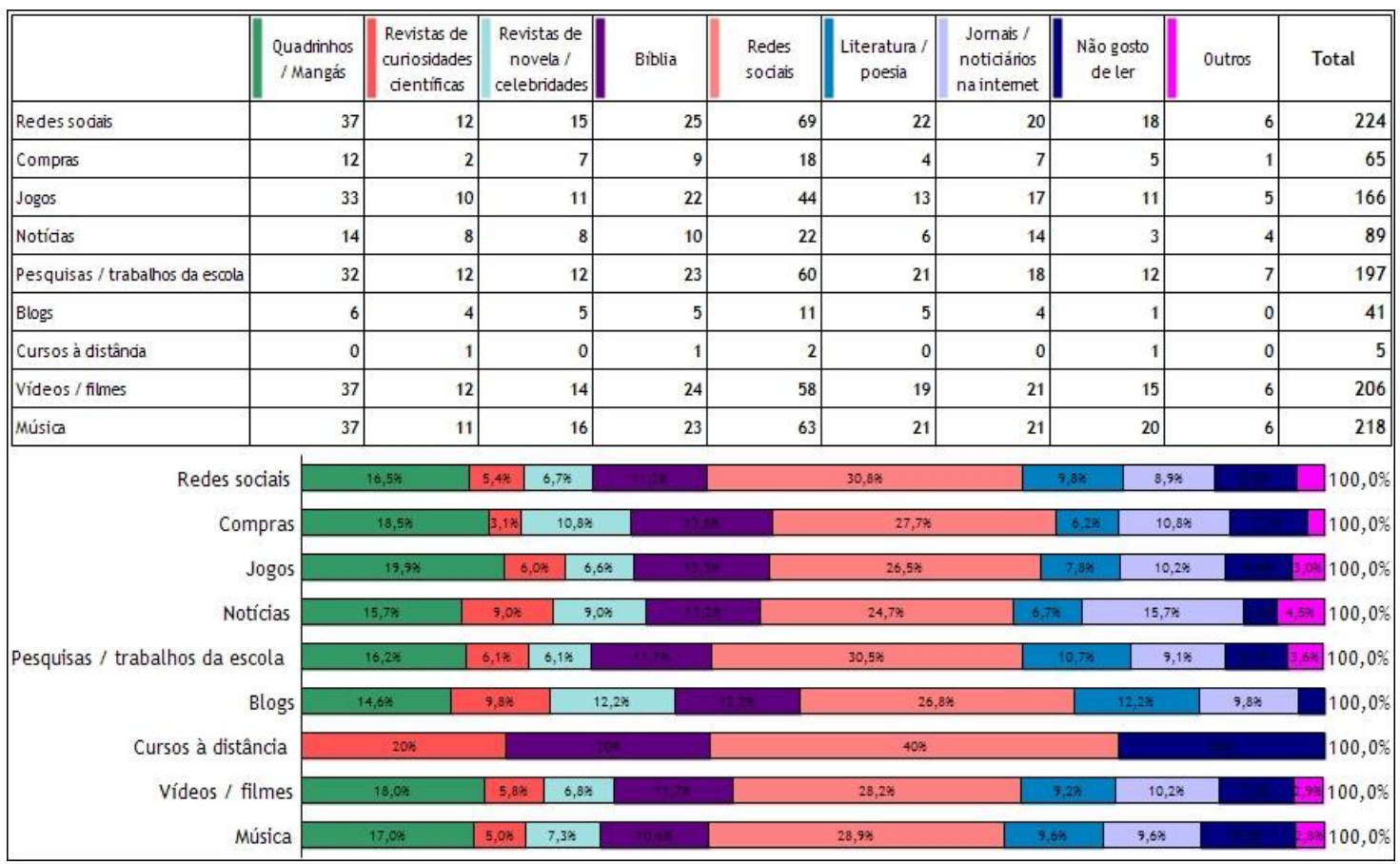

Autor do gráfico: Carlos Eduardo Fonseca

Colaboração Técnica: Luiza Grieco Feres - LEMADI - DG

Programa de Pós-Graduação de Geografia Humana/USP

Ainda conforme os dados apresentados no gráfico, temos que a leitura de quadrinho e mangás também se destaca dentre aqueles que utilizam as redes sociais, gostam de jogos e filmes pela internet. Os que menos gostam de ler usam a internet para cursos à distância. Já os que mais leem revistas de curiosidades são os que fazem cursos à distância, assim como são os que mais leem a Bíblia. Também é o único grupo que não lê revistas de fofoca.

O uso em grande escala por crianças e adolescentes dos recursos digitais, majoritariamente com o intuito de acessar as redes sociais, vêm corroborar a afirmação de que os contatos face a face estão efetivamente se diluindo de modo exponencial. Bauman \& Donskis (2014) enfatizam como o mundo contemporâneo encontra-se fortemente marcado pelo uso das redes sociais, num tipo de individualismo que acaba por prescindir de uma real presença do outro. Ainda conforme os autores: 
[...] a modernidade líquida transformou-nos numa comunidade global de consumidores [...]. Na era do Facebook, as nações estão se tornando unidades extraterritoriais com uma língua e uma cultura comuns [...]. Uma nação parece um conjunto de indivíduos dotados de mobilidade com uma lógica de vida baseada em avanços e recuos. Tudo é uma questão de saber se você está online ou off-line com respeito aos problemas de seu país e aos debates em torno deles, em vez de decidir de uma vez por todas se vai permanecer naquele lugar ou votar nos mesmos atores políticos pelo resto de sua vida. Ou você está on ou está off. Esse é o plebiscito diário numa sociedade líquida moderna ${ }^{100}$ (BAUMAN \& DONSKIS, 2014, p. 57).

$\mathrm{O}$ acesso de crianças e adolescentes às redes sociais, muitas delas acompanhando ou seguindo determinadas emergentes celebridades no mundo dos youtubers, algumas, inclusive, com a pretensão em fazer seus próprios vídeos ao invés de apenas seguir ou compartilhar seus novos ídolos, não se dá exclusivamente por este canal de comunicação. Na cultura da convergência, os adolescentes não estão somente expostos ao Facebook, Instagram, WhatsApp, mas aos programas televisivos que estão integrados às diversas mídias ${ }^{101}$, nos fazendo aqui recorrer ao conceito de narrativa transmidiática trazido por Jenkins (2009, p. 135).

Na forma ideal de narrativa transmidiática, cada meio faz o que há de melhor a fim de que uma história possa ser introduzida num filme, ser expandida pela televisão, romances e quadrinhos; seu universo possa ser explorado em games ou experimentado como atração de um parque de diversões. Cada acesso à franquia deve ser autônomo, para que não seja necessário ver o filme para gostar do game, e vice-versa. Cada produto determinado é um ponto de acesso à franquia como um todo.

Dentro de suas casas, imersos em jogos eletrônicos e virtuais, podem interagir com pares localizados em pontos distantes de onde se encontram, do mesmo modo, que também se utilizam da televisão, contrariando as previsões daqueles que estimaram que seus dias estavam contados devido o advento das novas tecnologias da informação e comunicação. Com a narrativa trasmidiática e a cultura da convergência, a integração entre as diferentes mídias já se tornou uma realidade.

Por meio do Questionário de Caracterização do Aluno, obtivemos que um total de um pouco mais que $90 \%$ dos estudantes assistem televisão, sendo que desse total, $35,8 \%$ apontaram assistir a tevê por mais de 3 horas por dia, enquanto que $21,1 \%$ assistem entre uma e duas horas diárias e $22 \%$ menos de 1 hora por dia, como podemos ver no gráfico a seguir:

\footnotetext{
${ }^{100}$ BAUMAN, Zygmunt; DONSKIS, Leonidas. Cegueira Moral. Rio de Janeiro: Editora Zahar, 2014.

${ }^{101}$ Para Jenkins (ibidem, p. 97): "Os fãs têm visto no ar mais programas que refletem seus gostos e interesses, os programas estão planejados para maximizar elementos que exercem atração sobre os fãs; e esses programas tendem a permanecer por mais tempo no ar, pois em casos extremos, têm mais chance de serem renovados".
} 
Gráfico 3 - Tempo diário que o aluno assiste TV

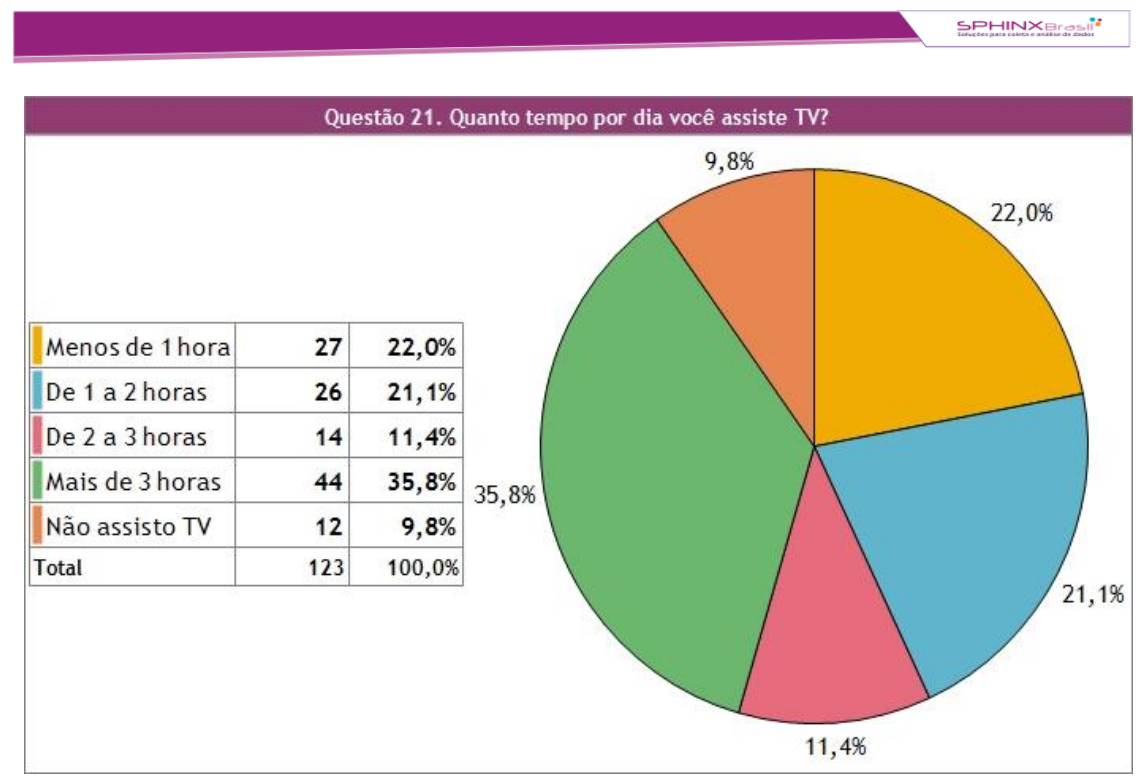

Autor do gráfico: Carlos Eduardo Fonseca

Colaboração Técnica: Luiza Grieco Feres - LEMADI - DG

Programa de Pós-Graduação de Geografia Humana/USP

Os dados ainda nos dão um indicativo preocupante, que se refere ao fato de significativa parte dos alunos não estarem estudando fora do horário de aula, sendo que muitos destes (50\%), assistem a mais de três horas de tevê por dia.

\section{Gráfico 4 - Tempo diário que o aluno assiste TV e tempo dedicado aos estudos fora da aula}

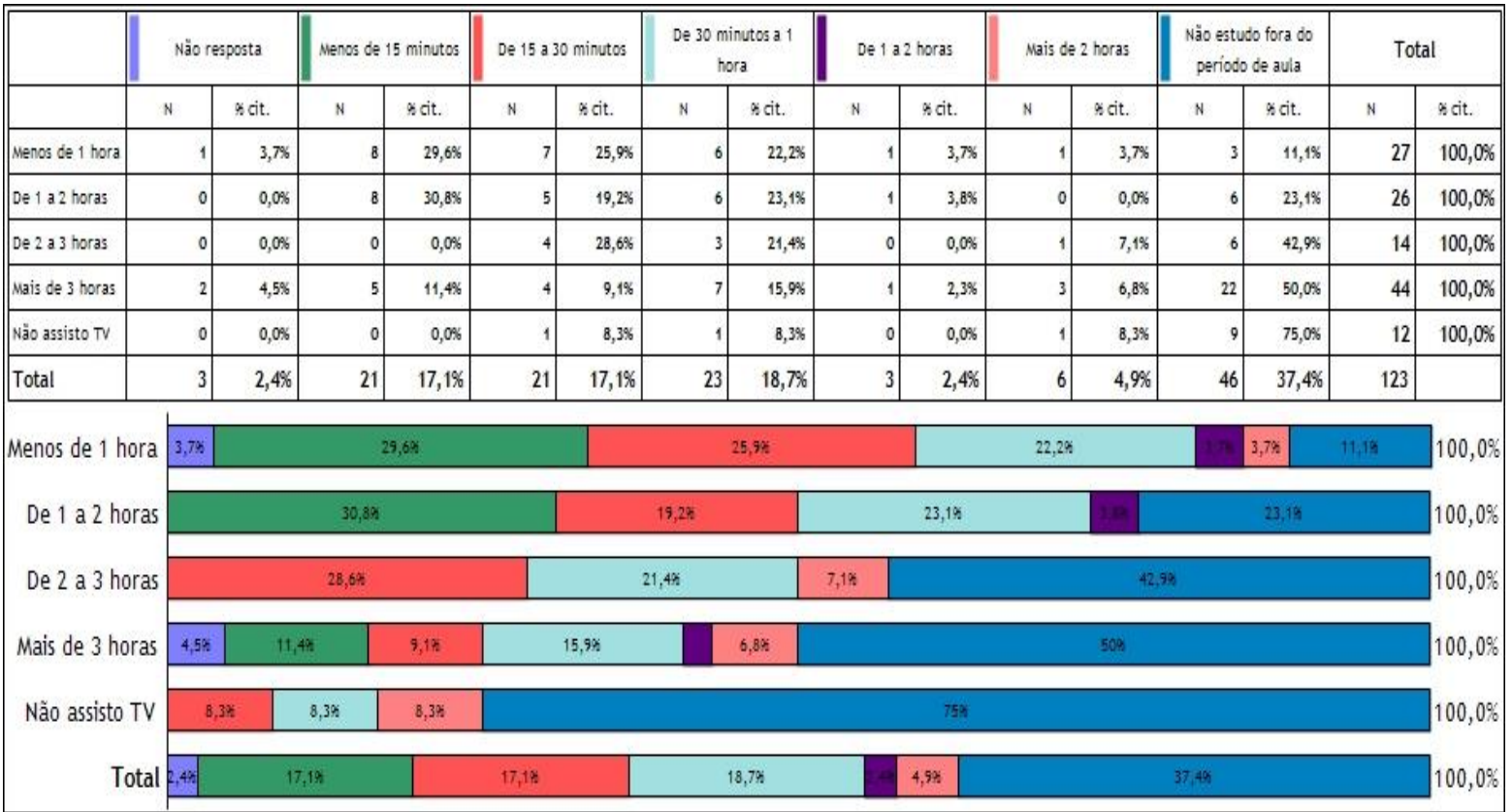

Autor do gráfico: Carlos Eduardo Fonseca

Colaboração Técnica: Luiza Grieco Feres - LEMADI - DG

Programa de Pós-Graduação de Geografia Humana/USP 
Os que mais não informaram o tempo de estudo foram aqueles que mais assistiam tv, entretanto, os que assistem por menos de 1 hora foram os segundos que mais não informaram. Todas as outras categorias deram alguma outra resposta que não "não resposta". Há uma correlação entre aqueles que não estudam fora da aula e o tempo que assistem tv, mas ela é rompida somente com aqueles que não assistem tv. $\mathrm{O}$ mesmo vale em relação ao tempo de estudo "de 30 minutos - 1 hora".

Os dados servem para corroborar a ideia de que os jovens estão se integrando às redes virtuais e sociais, acessam a internet e ainda tem a televisão como um dos meios para passar o tempo. Conectados e interagindo online, é como se estivessem em mais de um lugar ao mesmo tempo, quiçá em múltiplas territorialidades de um ambiente virtual.

O ensino de geografia não pode prescindir de tais reflexões, sobretudo, nessa era de meio técnico-científico-informacional, principalmente se pretende desenvolver intelectual e cognitivamente crianças e adolescentes, possibilitando que estes possam construir uma representação de mundo.

\subsection{A IMPORTÂNCIA DE SE CONSTRUIR UMA REPRESENTAÇÃO DE MUNDO}

O termo desterritorialização tem sido empregado por autores que acreditam haver não apenas uma mudança física e de deslocamento de pessoas de um lugar a outro, mas alterações decorrentes do advento das ciências tecnológicas, da informação e da comunicação, que retiram do espaço geográfico a dimensão territorial. Haesbaert (2007) defende a tese contrária, ao considerar que neste processo existe uma reterritorialização ${ }^{102}$ ao se criarem novos vínculos e relações com comunidades virtuais que podem aproximar pessoas em pontos distantes da superfície terrestre.

A complexidade do mundo atual dá mostras da necessidade de um ensino de geografia que transcenda o lugar como sinônimo de "próximo" e "concreto" do aluno, articulando-o a outras escalas espaço temporais, assim como superar o estudo que focaliza em demasia o bairro ou a cidade, mas se atentar à complexidade com que os fenômenos geográficos se manifestam e relacionam em diferentes tempos e espaços.

\footnotetext{
102 Haesbaert (2007, p. 169) enfatiza que "a produção do espaço envolve sempre, concomitantemente, a desterritorialização e a re-territorialização". HAESBAERT, Rogério. Concepções de território para entender a desterritorialização. In: SANTOS, Milton et al. Território, territórios: ensaios sobre o ordenamento territorial. Niterói: Lamparina, 2007.
} 
Aliás, a cidade refere-se a uma dimensão espacial fortemente considerada por dada tendência na geografia ensinada na educação básica, tendo sua importância sobrelevada por tratar-se de uma realidade mais "próxima" e "imediata" do aluno, em que este pode se utilizar das percepções sensoriais, vivências cotidianas, da observação atenta e de sua subjetividade para efetivamente compreender os processos que permeiam dada porção espacial. No entanto, consideramos insuficiente tal perspectiva, pois, indagamos o que efetivamente seria o "próximo" e "imediato" do aluno em tempos de conectividade e sociedade em rede.

Lana de Souza Cavalcanti (2013) aponta que o professor ao dar início a uma nova temática cuja referência seja a cidade, o faz explorando as percepções que os alunos possuem em relação às suas vivências sobre o espaço vivido, de modo que percebam aproximações e distanciamentos em relação às manifestações identitárias e expressões de diversidade nos grupos de pessoas ${ }^{103}$. Conforme a autora, abordando as possibilidades em se utilizar das práticas da juventude de viver na cidade, é possível trabalhá-las quanto à circulação pelos espaços até às atividades que a escola permite: descrever a paisagem, as imagens e observar os lugares.

\begin{abstract}
A atenta observação de elementos da paisagem permite, por meio da análise de suas formas, apreender seu conteúdo. Orientando-se, assim, a observação, colocando em alerta os sentidos - visão, audição, tato, olfato, paladar consegue-se imaginar a vida que anima essa espacialidade. A observação e a compreensão dessas formas servem para dar caminhos de análises do espaço, fazendo emergir aspectos objetivos e subjetivos, naturais e sociais, que dão significados e sentidos aos elementos da paisagem (CAVALCANTI, 2013, p. $75)$.
\end{abstract}

A partir do trecho supracitado, podemos ponderar se o aluno, por meio da observação de elementos da paisagem e analisando suas formas conseguirá apreender seu conteúdo de modo significativo construindo uma representação de mundo, sem que lhe tenham sido colocadas problematizações. Terá uma efetiva aprendizagem ou uma aprendizagem fragmentada e insuficiente, por se consubstanciar muito mais por meio de uma exposição direta à estímulos não intencionais?

Partir da premissa, como tem sido proposto pela geografia ensinada às crianças e adolescentes, de focalizar o concreto do lugar vivido pelo aluno sem buscar ou pouco considerando a conexão da escala do lugar com outras escalas, não significa efetivamente que a geografia tornar-se-á mais próxima, como defendem alguns autores.

\footnotetext{
${ }^{103}$ CAVALCANTI, Lana de Souza. A cidade ensinada e a cidade vivida: encontros e reflexões no ensino de Geografia. In: CAVALCANTI, L. S. (org.). Temas de geografia na escola básica. $1^{a}$ ed. Campinas, SP: Papirus, 2013.
} 
Conforme Laudenides Pontes dos Santos (2012, p. 108):

\begin{abstract}
Ao resgatar o lugar que o aluno mora, suas vivências, suas relações com o espaço e com a sociedade, a geografia torna-se mais próxima, pois pode ultrapassar a teoria trazida nos livros, uma vez que pode ser associada ao convívio social e alargar as possibilidades de ensino. Aproveitar a fala e as experiências dos alunos é considera-lo sujeito ativo no processo de ensinoaprendizagem, não mais como um receptor de informações prontas, mas como um sujeito que pode contribuir para a construção do conhecimento ${ }^{104}$.
\end{abstract}

Não discordamos da importância de se resgatar o lugar que o aluno mora, suas vivências, suas relações com o espaço e com a sociedade, assim como aproveitar a fala e as experiências dos alunos, sobretudo se essa prática pedagógica buscar conexões com outras escalas de tempo e espaço. Porém, afirmar que ao trabalhar com o lugar que o aluno mora torna a geografia mais próxima, não pode ser tomado como uma generalização, pois o interesse e significado que o estudante confere a esse campo do conhecimento não necessariamente vincula-se ao fato de estudar uma geografia atrelada àquilo que lhe esteja próximo ou que inevitavelmente faça parte de seu cotidiano "concreto".

A interação de jovens contemporâneos imersos nas redes sociais, tem possibilitado novas formas de comunicação que os torna inscritos numa nova dimensão de tempo e espaço que precisa ser problematizada, pois não se refere ao cotidiano do espaço físico e concreto, assim como tem se dado numa dimensão da instantaneidade, do imediatismo do aqui e agora. Tal quadro suscita a necessidade de a geografia ensinada buscar as conexões da escala do lugar com outras escalas de tempo-espaço do fenômeno ou problema estudado.

A aprendizagem de geografia torna-se significativa não pela proximidade com o objeto "concreto", mas pelo uso adequado de critérios devidamente estabelecidos, selecionados e dirigidos pelo professor durante o processo de aprendizagem mediada em sala de aula e, sobretudo, da atenção dada pelo educador a importância dos processos de aprendizagem do estudante. Ou seja, a dimensão psicológica do aluno. Mais uma vez é preciso recorrer à Pierre Monbeig (1945, p. 168) que em meados do século passado já era detentor de uma visão ampla em relação a um ensino de geografia que contemplasse uma escala maior do que o entorno ou local de vivência do aluno e se atentava detidamente às questões referentes aos aspectos intelectuais e aos processos de aprendizagem dos estudantes para a constituição de uma representação de mundo.

\footnotetext{
${ }^{104}$ SANTOS, Laudenides Pontes dos. A relação da geografia e o conhecimento cotidiano vivido no lugar. In: Geografia: Ensino \& Pesquisa, vol. 16, n. 3, set/dez. 2012.
} 
Nos últimos anos de ensino primário, o mestre pode esperar mais de seus alunos: de oito a onze anos, já é possível dar uma ideia esquemática do mundo. Isso corresponde a um afastamento gradual das lições de cousas com exemplos puramente locais que prevaleciam no primeiro estágio; já se apela a faculdade de imaginação das crianças que, baseando-se em suas experiências pessoais e utilizando imagens bem selecionadas pode criar uma representação sumária do mundo ${ }^{105}$

É preciso que seja levado em consideração no ensino de geografia o desenvolvimento intelectual e cognitivo do aluno, o conhecimento científico e uma representação de mundo e das relações que há no mundo, como assevera Maria Eliza Miranda $^{106}$ (2010).

O estar "perto" ou "longe", "próximo" ou "distante", tem se tornado algo bastante complexo no mundo contemporâneo, onde se ampliam as transformações nas dimensões do tempo e espaço. Giddens (2000) ressalta que algo deve estar se modificando na natureza das experiências cotidianas, quando se torna mais familiar a imagem do líder sul africano Nelson Mandela, do que a imagem do próprio vizinho de porta $^{107}$. Esta afirmação vai ao encontro das ponderações do geógrafo Roberto Lobato Corrêa (2008) quando assinala que os lugares sagrados, muitos deles localizados em porções distantes, tornam-se próximos em virtude da afetividade que lhes é conferida ${ }^{108}$.

O interesse por fenômenos ocorridos distantes de onde os indivíduos se encontram fora uma característica que marcara crianças e jovens. Conforme Kropotkin (2014, p. 58), escrevendo em fins do século XIX: “[...] a leitura favorita de uma criança sempre será um livro de viagens distantes, ou a história de um Robinson Crusoé ${ }^{109}$ ".

Saber trabalhar tendo como ponto de partida os fenômenos e eventos geográficos não circunscritos somente ao entorno do aprendiz, estava posto no final do século XIX, por àquele que com uma visão monista de homem postulava por uma geografia que pudesse realmente desenvolver os aspectos intelectuais e cognitivos dos estudantes, considerando, ainda, o professor como um indivíduo que ativamente incidia sobre os processos de aprendizagem do aluno, de modo que:

\footnotetext{
${ }^{105}$ MONBEIG, Pierre. A geografia no ensino secundário. Boletim Geográfico. v. 2, n. 26, 1945.

${ }^{106}$ MIRANDA, M. E. Contribuição ao debate atual sobre a formação de professores no Brasil: pela formação de futuras gerações na perspectiva da reconstrução do sócio-cultural. Revista do Departamento de Geografia, n. 20, p. 11-22, 2010

${ }_{107}$ GIDDENS, A. Mundo em descontrole: o que a globalização está fazendo de nós. Rio de Janeiro: Record, 2000.

${ }^{108}$ CORRÊA, R. L. Espaço, um conceito-chave da geografia. In: CASTRO, I. E. de; GOMES, P. C da Costa; CORRÊA, R. L. Geografia: conceitos e temas. $11^{\circ}$ ed. Rio de Janeiro: Bertrand Brasil, 2008.

${ }^{109}$ KROPOTKIN, Piotr. O que a geografia deveria ser. In: RECLUS, É; KROPOTKIN, Piotr. Escritos sobre educação e geografia. $1^{a}$ ed. São Paulo: Terra Livre, 2014.
} 
[...] nada é mais fácil que despertar os poderes de comparação de uma mente jovem contando-lhes histórias de países distantes, de suas plantas e animais, de sua paisagem e fenômenos, desde que plantas e animais, ventanias e furacões, erupções vulcânicas e tempestades estejam conectados ao homem. Essa é a tarefa do geógrafo na primeira infância: por intermédio do homem interessar as crianças nos principais fenômenos da natureza, despertar-lhe o desejo de conhecê-los e compreendê-los ${ }^{110}$ (KROPOTKIN, 2014, p. 37, 38).

Em 20 de julho de 1969, num contexto de Guerra Fria, os meios de comunicação transmitiam astronautas estadunidenses pisando pela primeira vez em solo lunar. Naquele momento as atenções de parte da população de diversos países estavam centradas nas cenas que mostravam um feito histórico: homens a $384.400 \mathrm{~km}$ de distância da Terra.

Se chegar à Lua antes deste evento, tratava-se de algo presente nos clássicos de Júlio Verne, a partir daquele dia o satélite natural da Terra passou a ter intenso significado para um grande número de indivíduos, despertando sonhos, desejos e fantasias em relação a um futuro como astronauta, cosmonauta ou viajante lunar. Claval (2014, p. 61) assinala que "para dar um sentido a sua existência, os homens sonham com o que se passa além do horizonte visível e constroem outros mundos ${ }^{111}$ ".

É possível despertar o interesse e a atenção de crianças e adolescentes sem partir da dimensão concreta, pelo contrário, as epopeias gregas, por exemplo, atravessaram séculos com histórias que não se restringiam aos recortes territoriais das cidades representadas, despertando forte interesse nos jovens.

Jacques Labeyrie (2002) tratando sobre grandes descobrimentos em relação ao universo e as diversas evoluções no campo da comunicação, aponta a impressão que é dada às pessoas de que a superfície terrestre está encolhendo, sendo possível em questão de dois dias transportarem-se para o mais longínquo ponto do planeta. Ressalta, ainda, o interesse de jovens escolares por questões que não necessariamente restritas ao "concreto".

A maioria das crianças que frequentam a escola e às quais são ensinadas essas conquistas recentes do conhecimento e não tem, ao que parece, nenhuma dificuldade para interessar-se pelas mesmas e dominá-las. [...] elas se apaixonam de bom grado por conhecimentos tão abstratos quanto a metafísica e até mesmo pela física quântica ou ainda pelas novas ciências biológicas ${ }^{112}$ (LABEYRIE, 2002, p. 34).

\footnotetext{
${ }^{110}$ KROPOTKIN, Piotr. O que a geografia deveria ser. In: RECLUS, É; KROPOTKIN, Piotr. Escritos sobre educação e geografia. $1^{a}$ ed. São Paulo: Terra Livre, 2014.

${ }^{111}$ CLAVAL, Paul. Terra dos Homens: a geografia. $1^{a}$ ed. São Paulo: Contexto, 2014.

${ }^{112}$ LABEYRIE, J. Introdução ao estado atual do mundo. In: MORIN, Edgar. A religação dos saberes: o desafio do século XXI. $2^{\text {a }}$ ed. Rio de Janeiro: Bertrand Brasil, 2002.
} 
A concepção no ensino de geografia de que a criança apresenta maior interesse pela ciência geográfica e consequentemente a aprendizagem se efetiva graças ao estudo daquilo que lhe é mais "próximo", necessita ser revista, pois se apoia em argumento retórico e inclusive ideológico, às vezes. Tomando como exemplos os depoimentos de geógrafos brasileiros tratando do seu interesse inicial pela geografia, temos que não foram os fatores ou elementos limitados e restritos à escala do lugar de onde viviam que os estimularam a adentrar nesse campo científico, mas formas de representação com uma escala mais abrangente.

\begin{abstract}
Lembro que quando tinha 8-10 anos de idade, debruçava-me sobre os Atlas e ficava vendo os mapas com países, rios, cidades e montanhas. Com essa idade sabia localizar os então 48 estados norte americanos, os rios da Alemanha e as capitais europeias. Cheguei mesmo a inventar um país que tinha área, rios, montanhas e uma distribuição de sua produção. Chamava-se Gotávia. De onde vem esse nome? Inspirado nas histórias em quadrinhos do Batman [...] cuja cidade chamava-se Gotham City. Gostava de aprender sobre o mundo, sobre as diferenças espaciais. Por isso, em um primeiro momento quis ser oficial da marinha, porque acreditava poder conhecer o mundo ${ }^{113}$ (CORREAA, 2005, $p$. 1).
\end{abstract}

O fascínio de Roberto Lobato Corrêa fora por representações de lugares que não o seu lugar de vivência, apenas. Criara uma cidade imaginária permeada por área, rios, montanhas e uma distribuição de sua produção; e gostava de aprender sobre o mundo, sobre as diferenças espaciais. O interesse em conhecer mundo não fora específico de Corrêa, pois despertou a curiosidade de Maria Adélia de Souza, que quando menina se sentia inquieta em tentar entender e descobrir o que é o mundo. Quando indagada sobre como se dera seu interesse pela geografia, apontara:

[...] por uma inquietação que eu sempre tive, desde menina, para descobrir o que é o mundo, por que o mundo existe; e tive a sorte de ter um excelente professor de geografia, naquele tempo, no curso ginasial e no científico (...). Quando menina eu sempre tive uma preocupação com mundo, em saber o que o mundo é, o que a gente faz no mundo, por que ele é de uma maneira ou de outra $[\ldots]^{114}$ (SOUZA, 2007, p. 1).

Além de enfatizar a inquietação que lhe acometera em tentar descobrir o que é o mundo e por que o mundo existe, a geógrafa aponta a figura de seu professor, a quem atribuiu significativa importância nos estudos geográficos. Sua narrativa serve para que

${ }^{113}$ CORRÊA, Roberto Lobato. Entrevista. In: Revista Discente Expressões Geográficas. Florianópolis: $\mathrm{SC}, \mathrm{n}^{\circ} 1$, p. 01-14, jun/2005.

${ }^{114}$ SOUZA, Maria Adelia Aparecida de. In: Entrevista. Revista Discente Expressões Geográficas. Florianópolis: SC, $\mathrm{n}^{\mathrm{o}}$ 03, p. 01-19, maio/2007. 
se pondere até que ponto focalizar o ensino de geografia a escala do lugar, com pouca ou nula conexão a outras escalas é suficiente para uma aprendizagem significativa. $\mathrm{O}$ interesse por fenômenos e eventos que ocorrentes noutras escalas, também se fez presente na infância do geógrafo Armem Mamigonian (1987, p. 131) que se encantara pelo mapa do continente europeu durante a Segunda Guerra Mundial:

\begin{abstract}
Meu padrasto assinava o 'Estado de São Paulo' e para acompanhar a Segunda Guerra mundial ele ouvia rádio [...] e tinha pregado na sala de jantar, junto ao rádio, um mapa minucioso da Europa, o palco principal dos conflitos. Este mapa era um deslumbramento, nele descobri que Portugal ficava na Europa, coisa que eu não podia entender, pois se falava em Portugal com tanta familiaridade [...] que para mim este país tinha que estar geograficamente próximo do Brasil. Ficava horas vendo o mapa $[\ldots]^{115}$.
\end{abstract}

Os enunciados dos geógrafos supracitados revelam que a categoria mundo os atraia fortemente. Se no passado seus interesses se dirigiam à espaços distantes, por que os atuais estudantes da educação básica, teriam maior interesse pelo lugar em que vivem sem conexões com outras escalas do problema estudado?

Conforme Almeida (2008), a não ser pelas singulares feições que assumem os problemas de ordem global, não se pode falar mais de modo estrito do local, pois os territórios, barreiras alfandegárias e nacionalidades estão sendo ultrapassados por fundamentalismos, bactérias, modelos econômicos e desastres ecológicos ${ }^{116}$.

Apesar de não estarem tratando do ensino de geografia, mas pensando numa educação para a mudança temos em Andy Hargreaves et al (2001, p. 109) reportando-se à pesquisa de Keiran Egan, que "o que interessa aos jovens não é, de modo algum, o seu mundo próximo - não a comunidade local ou a poluição do lago. O que geralmente lhe interessa é um mundo imaginado de fantasia ${ }^{117}$ ".

Milton Santos (1998) salientou o interesse que percebia em estudantes secundaristas pela geografia, apontando a necessidade que os jovens possuíam em tentar entender e conhecer os mistérios relativos ao mundo que a eles estava se apresentando.

Acho que os adolescentes querem entender esse novo mundo, que aflora tão cheio de confusão e mistério, e a geografia aparece como uma possibilidade de enfrentar esse grande mistério ${ }^{118}$ (SANTOS. M, 1998).

\footnotetext{
115 MAMIGONIAN, Armen. Entrevista. In: Geosul, n. 3, $1^{\circ}$ sem, 1987.

${ }^{116}$ ALMEIDA, Maria da Conceição de. Introdução: mapa inacabado da complexidade. In: SILVA, Aldo Dantas da; GALENO, Alex. (Orgs.). Geografia: ciência do complexus: ensaios transdisciplinares. $2^{\mathrm{a}}$ ed. Porto Alegre: Sulina, 2008.

117 HARGREAVES, Andy; EARL, Lorna; RYAN, Jim. Educação para mudança: recriando a escola para adolescentes. Porto Algre: Artmed Editora, 2001.

${ }^{118}$ SANTOS, Milton. Entrevista. Canal Ciência: portal de divulgação científica e tecnológica.

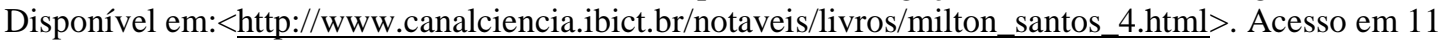
de abril de 2016.
} 
Limitar o ensino e a aprendizagem de geografia aos aspectos mais visíveis do lugar, enquanto categoria isolada, escala desconectada e do imediato mais próximo, desconsiderando outras escalas de tempo e espaço, significa limitar o desenvolvimento cognitivo e intelectual dos alunos, numa geografia intuitiva, descritiva e pautada majoritariamente na percepção sensorial, num processo didático pedagógico insuficiente e superficial.

\subsection{PARA ALÉM DA REALIDADE CONCRETA E IMEDIATA DO ALUNO}

A concepção de ensino de geografia apoiado na categoria lugar acaba por incidir numa visão limitada de mundo do estudante, pois geralmente, fica restrita ao "lugar do aluno", ao invés de buscar conexões com outras escalas do problema. É limitante quando se utiliza sobremaneira da percepção sensorial no processo de aprendizagem, detendo-se mais aos estímulos diretos de uma observação direta.

A tendência em trabalhar com o entorno dos estudantes, com aquilo que lhe é mais próximo, imediato e concreto, desde as séries iniciais de escolarização, aparece de modo mais acentuado a partir da década de 80 do século passado ganhando maior relevância com o decorrer dos anos. O apelo à uma geografia partindo da realidade mais imediata do aluno pode ser verificado em Maria Teresa Nidelcoff $(1980$, p. 11, 12) ao argumentar a necessidade de se iniciar os estudos:

[...] pelo seu próprio meio para em seguida estender o olhar para outros meios diferentes. O primeiro passo da criança na Geografia está na percepção da vida que se agita à sua volta. Resumindo: fazer o "estudo do meio" é, em parte, fazer Geografia, empregando o método que esta emprega: a observação direta. Através do estudo de seu meio a criança vai adquirir: as noções geográficas básicas, um vocabulário geográfico, as primeiras noções de cartografia ${ }^{119}$.

A autora ao propor que a criança tenha o seu próprio meio como ponto de partida, utilizando-se da percepção da vida que se agita à sua volta e enfatizando que fazer geografia significa em parte empregar a observação direta, acaba por evidenciar dois problemas básicos que se constatam ainda hoje na geografia escolar: a ausência do professor enquanto um potencial mediador da aprendizagem e o ensino meramente calcado na experiência da observação direta, sem estímulos orientados à elaboração de significados.

${ }^{119}$ NIDELCOFF, Maria Teresa. A escola e a compreensão da realidade. $3^{\text {a }}$ ed. São Paulo: Editora Brasiliense, 1980. 
Faltou à geógrafa considerar que o aluno somente terá noções geográficas básicas, um vocabulário geográfico e as primeiras noções de cartografia, se for adequadamente mediado pelo professor e não exposto à estímulos diretos, apenas apoiado em observações realizadas através do estudo de seu meio. Ademais, nos apoiamos em Monbeig (1956, p. 8), ao ponderar que "a geografia não é uma ciência de fatos isolados simples, passíveis de serem conhecidos por si e em si ${ }^{120}$ ".

Daí a importância de aportes como da Teoria da Experiência de Aprendizagem Mediada (EAM) ao invés da simples exposição de crianças e adolescentes à estímulos diretos, como aponta o psicólogo Alex Kozulin (2000, p. 77, 78):

\begin{abstract}
En el aprendizaje directo, el niño interacciona con el entorno. Esta interacción puede adoptar la forma de un aprendizaje por observación, por ensayo y error, por condicionamiento o mediante cualquier otra actividad en la que el niño interaccione directamente con ciertos estímulos. En una situación de aprendizaje mediado, un adulto o un compañero más capacitado se sitúa <entre> el entorno y el niño, modificando radicalmente las condiciones de la interaciión. El mediador seleciona, modifica, amplifica e interpreta objetos y procesos para el niño ${ }^{121}$.
\end{abstract}

Considerar no processo de ensino-aprendizagem que a curiosidade dos alunos e a observação direta da realidade mais próxima, sobretudo se destituída de determinados critérios de análise, são suficientes para a aprendizagem do indivíduo, incorrerá tão somente numa aprendizagem limitada e de baixos níveis de abstração. Monbeig (1956, p. 20) já acrescentava "ser desejável que o ensino venha esclarecer e ordenar a confusão que as informações diretas criam nos cérebros jovens".

Em que pese este tipo de atividade em determinado recorte espacial sobrelevar os sentidos visuais do aluno no intuito de que ele possa compreender alguns fenômenos geográficos, com insuficiente ou nula mediação humana, não o apoiará na estruturação do pensamento, pois estará focado na observação direta. Beyer (1996) ${ }^{122}$ enfatiza que a interposição de uma pessoa munida de intencionalidade, entre o aluno e os elementos do mundo exterior, é significativa em sua influência sobre o desenvolvimento infantil.

Nidelcoff (1980, p. 9) ressalta a importância do estudo do meio por possibilitar à criança "conhecer e analisar a maneira pela qual vivem os homens com os quais estamos em contato".

120 "MONBEIG, Pierre. Papel e valor do ensino da geografia e de sua pesquisa. IBGE - Conselho Nacional de Geografia, Rio de Janeiro, 1956.

${ }^{121}$ KOZULIN, Alex. Instrumentos psicológicos: la educación desde una perspectiva sociocultural. Barcelona: Paidós, 2000.

122 BEYER, Hugo Otto. O fazer psicopedagógico: a abordagem de Reuven Feuerstein a partir de Vygotsky e Piaget. Porto Alegre: Mediação, 1996. 
Contudo, em tempos recentes, há de se questionar que homens são estes. Seriam estes indivíduos entrevistados pelos estudantes possibilitando aos alunos ter contato com suas memórias e representações de mundo ou simplesmente comporiam uma paisagem para que os jovens os observassem? Ademais, o estudo do meio ou trabalho de campo, necessita de critérios previamente estabelecidos, para que possa transcender a ideia de algo restritivo e limitado apenas ao lugar e possa efetivamente apoiar as aprendizagens.

Para Bernard Kaiser (2006), em trabalhos de campo é necessário o cuidado com estudos em compartimentos estanques, pois é importante que se tenha resultados que considerem a análise global da sociedade, sendo a análise de uma situação algo complexo e que não se deve dar de modo cartesiano. Para este autor é preciso saber observar, registrar e compreender os fenômenos que estão sendo interpretados e articulando sempre o local/global.

Notemos também que a cena social é sempre incompleta, que nela inexistem certos atores. E, sobretudo, que é difícil pronunciar-se claramente sobre a natureza e sobre a escala dos fenômenos observados localmente. A separação entre o que é específico, às vezes folclórico, e o que é significativo, não se coloca sempre claramente ${ }^{123}$ (KAISER, 2006, p. 101).

A citação acima serve para ilustrar as limitações e problemas de estudos estritamente locais quando isolados, restritivos e desconsiderando outras escalas dos fenômenos observados localmente, pois a cena social é sempre incompleta e inexistem certos atores, o que torna a aprendizagem pouco significativa. Serve como contraponto a visão quase que determinista que paira em algumas vertentes da geografia escolar ao considerar que o global está no local, afirmativa que não deixa de ter fundamento e relevância, no entanto, tomada sem ressalvas e ponderações corre o risco de se transformar em dogmatismos e discurso retórico ideológico.

De acordo com Jean Brunhes (1962), a explicação dos fatos naturais e humanos com base na observação e análise é algo bastante delicado, em que pese ser indispensável ao geógrafo, não é suficiente, pois há a necessidade de uma cultura filosófica, econômica e histórica forte ${ }^{124}$, sobretudo em relação à geografia humana.

Não se trata de desconsiderar o uso da observação nas atividades de estudos do meio ou demais atividades didático-pedagógicas de geografia, mas sublinhamos as limitações decorrentes de tal perspectiva quando destituída de critérios e planejamento.

${ }^{123}$ KAISER, Bernard. O geógrafo e a pesquisa de campo. In: Boletim Paulista de Geografia, São Paulo, n. 84, p. 93-104, 2006.

${ }^{124}$ BRUNHES, Jean. Geografia Humana. Rio de Janeiro: Editora Fundo de Cultura, 1962. 
Quando feita sob o crivo de métodos científicos, com o rigor de pesquisa e conhecimento em relação aos processos intelectuais e cognitivos dos alunos, pode-se resultar em aprendizagens significativas. Para que a observação não redunde em algo obsoleto, vazio e destituído de sentido, apoiamo-nos em Monbeig (1945), ao considerar a geografia como a arte de saber ver as paisagens, a fotografia e o mapa, por meio da observação, porém de um modo analítico, metódico e preciso.

Esse estudo analítico das paisagens ou de suas representações, que é feito por uma leitura atenciosa e precisa, constitui um excelente exercício de observação; os alunos aprendem assim a constatar as semelhanças e diferenças depois de um exame metódico. Quanto mais estiverem habituados a esse exercício [...] tanto melhor adquirirão hábitos mentais que, fora da escola e da geografia, lhes serão valiosos ${ }^{125}$ (MONBEIG, 1945, p. 167).

É interessante notar que se trata de um texto escrito há mais de 70 anos e o autor se aproxima das concepções de Reuven Feuerstein ao indicar o estudo analítico, com uma leitura atenciosa e precisa durante o processo de observação, levando o aluno a trabalhar com comparações e diferenciações no intuito de desenvolver as capacidades cognitivas e os hábitos mentais, por meio de um exame metódico daquilo que estuda. Vale ressaltar, que estas correlações já estavam postas de forma inédita por Maria Eliza Miranda em "A atualidade de Pierre Monbeig e o direito de aprender geografia" 126.

Além de a atividade de observação desenvolvida com os estudantes não se restringir ao plano da percepção sensorial, Monbeig trabalhou com a concepção de transcendência, pois considerava a aquisição de hábitos mentais para que lhes fossem valiosos fora da escola e da geografia. E ainda vemos no mesmo autor a preocupação em relação à estudos limitados à análise do cenário e do concreto:

[...] é absolutamente indispensável que o geógrafo não se limite à análise do cenário, à apreensão do concreto. A paisagem não exterioriza todos os elementos constituintes do complexo. Nem sempre nela se encontrarão expressos com clareza os modos de pensar, as estruturas financeiras que são, entretanto, parcelas apreciáveis do complexo geográfico. Outro perigo - a limitação do campo de estudo geográfico à paisagem arrisca a levar o pesquisador à uma única estrada da descrição. Ele olha, observa minuciosamente e com perfeito espírito científico mas tende a esquecer o essencial: a explicação ${ }^{127}$ (MONBEIG, 1956, p. 12).

Passado mais de meio século desde que o autor teceu suas considerações em relação às limitações de estudos restritos à apreensão do concreto, ainda temos práticas

${ }^{125}$ MONBEIG, Pierre. A geografia no ensino secundário. Boletim Geográfico. v. 2, n. 26, 1945.

${ }^{126}$ MIRANDA, Maria Eliza. A atualidade de Pierre Monbeig e o direito de aprender geografia. Revista do Departamento de Geografia, p. 56/67, 2012.

127 MONBEIG, Pierre. Papel e valor do ensino da geografia e de sua pesquisa. IBGE - Conselho Nacional de Geografia, Rio de Janeiro, 1956 
didático-pedagógicas que supervalorizam e dimensionam estudos acentuadamente limitados ao lugar sem buscar conexões com outras escalas de tempo e espaço.

Dadas as transformações pelas quais o mundo vem passando, desde a passagem do fordismo para o regime de acumulação flexível e os avanços técnicos, científicos e informacionais, a interposição de um mediador humano entre o aluno e o objeto de conhecimento torna-se fundamental para que o desenvolvimento intelectual e cognitivo seja assegurado, caso contrário, ter-se-á apenas acúmulo de informações descontextualizadas e destituídas de significado. Daí a necessidade em se avançar para além das questões estritamente ligadas ao cotidiano "concreto", de relações face a face, que pouco se atém à uma escala maior de análise. Kropotkin $(2014$, p. 66) bradara há mais de um século sobre o desenvolvimento da mente.

[...] quando falo de "desenvolvimento geral": a capacidade e o gosto por pensar sobre temas acima das baixezas de nossa vida cotidiana, o desenvolvimento mais amplo da mente, a capacidade para perceber as causas dos fenômenos, para raciocinar sobre elas ${ }^{128}$ (KROPOTKIN, 2014, p. 66).

$\mathrm{O}$ autor demonstra estar acima de uma visão estritamente focada sobre a vida cotidiana, pois enfatiza a necessidade em se atentar para o desenvolvimento amplo da mente, para que se possa perceber as causas dos fenômenos e raciocinar sobre eles. Observa-se aqui uma aproximação deste autor com Monbeig (1956), que apontou na segunda metade do século passado a contribuição da geografia no sentido de enriquecer a formação e a mente dos jovens, assim como sendo um instrumento útil à coletividade.

Ainda vemos a pertinência de Monbeig ${ }^{129}(1956$, p. 17, 18) ao evidenciar a importância do estudo de geografia para além da simples observação e o papel do professor enquanto mediador, ainda que não tenha se utilizado dessa expressão.

\begin{abstract}
Não só a faculdade de observação aproveita o ensino da geografia, mas também a espírito crítico, pois o jovem interrogado sobre uma carta ou uma fotografia é obrigado a escolher entre o essencial e o secundário. Aprende assim a raciocinar com método e exercitar-se na escolha de dados apresentados à sua observação. Ao mesmo tempo sua mente habitua-se a reconhecer as relações entre fatos [...]. Em tudo isso o professor fugirá como da peste do uso de termos eruditos e excessivamente técnicos [...]. Sua posição é a mesma de todos os professores de ginásio, cuja missão não é recrutar especialista desta ou daquela matéria, mas de colaborar com todos os seus colegas na formação de mentes capazes de pensar e de criticar.
\end{abstract}

\footnotetext{
${ }^{128}$ KROPOTKIN, Piotr. O que a geografia deveria ser. In: RECLUS, É; KROPOTKIN, Piotr. Escritos sobre educação e geografia. $1^{\mathrm{a}}$ ed. São Paulo: Terra Livre, 2014.

129 Para uma melhor compreensão da contribuição de Pierre Monbeig para o ensino de geografia, recomendamos a leitura de MIRANDA, Maria Eliza. A atualidade de Pierre Monbeig e o direito de aprender geografia. Revista do Departamento de Geografia, p. 56/67, 2012.
} 
Num período em que o ensino conteudista apresentava-se como sinônimo de excelência, o autor destaca a importância da relação entre professor e aluno, apontando a necessidade de um ponto de contato para que pudesse haver significado na aprendizagem. Também evidenciava a relevância de se acompanhar as transformações do mundo, ressaltando, assim, uma escala maior, mais global, no ensino de geografia.

Convém que o ensino acompanhe as transformações do globo [...]. Para um mundo moderno convém um ensino moderno e a geografia é uma interrogação permanente do mundo [...]. Os alunos encontrarão aí uma prova de que a vida não para à porta da classe, a qual deixará de ser um meio artificial (MONBEIG, 1956, p. 20).

Se consideramos que o dia a dia dos jovens em idade escolar é permeado tão somente pelo que lhes é imediato, ou seja, pelas relações de vizinhança, de proximidade e observação direta ou indireta de fenômenos físicos locais, solevando as percepções sensoriais, por exemplo, a aprendizagem será insuficiente e limitada.

Apesar de os alunos participantes de nossa pesquisa serem oriundos de famílias de média e baixa renda, com familiares empregados no setor informal da economia e situação socioeconômica bastante modesta, é preciso levar em conta que o cotidiano de significativa parte destas crianças e adolescentes tem sido permeado pela comunicação em tempo quase real, graças ao acesso aos meios eletrônicos e virtuais ${ }^{130}$.

Passados mais de trinta anos desde a publicação de Nidelcoff (1980) ressaltando a necessidade de se estudar o entorno e a realidade mais imediata como ponto de partida $^{131}$, é possível encontrar ressonância com pensamentos similares, como pode ser notado em Cavalcanti (2013, p. 146, 147):

Outra atividade importante e particularmente necessária na aprendizagem de Geografia é a da observação. Ligada a funções psíquicas de um plano mais sensorial, a observação é fundamental para produzir motivações, com base na problematização do real observado e, consequentemente, possibilitar a construção do conhecimento [...]. A paisagem problematizada, por meio de uma observação direta do lugar de vivência do aluno ou de uma observação indireta de uma paisagem representada, pode fornecer elementos importantes para a construção do conhecimento referente à espacialidade nela materializada $^{132}$.

\footnotetext{
${ }^{130}$ De acordo com Giddens (1996, p. 96), "a comunicação eletrônica instantânea por todo o globo não só é possível, mas quase que imediatamente começa a entrar na vida de milhões de pessoas. Não é só o fato de todos agora poderem ver as mesmas imagens ao mesmo tempo, a comunicação global instantânea penetra o tecido da experiência cotidiana e começa a reestruturá-lo - embora ela, por sua vez, também seja reestruturada, em um processo contínuo". GIDDENS, A. Para além da esquerda e da direita. São Paulo, Editora da Unesp, 1996.

${ }^{131}$ NIDELCOFF, M. T. A escola e a compreensão da realidade. $3^{\text {a }}$ ed. São Paulo: Ed. Brasiliense, 1980.

${ }^{132}$ CAVALCANTI, L. de S. A cidade ensinada e a cidade vivida: encontros e reflexões no ensino de Geografia. In: CAVALCANTI, L. S. (org.). Temas de geografia na escola básica. $1^{a}$ ed. Campinas, SP: Papirus, 2013.
} 
O estudo pautado na observação a partir de um plano mais sensorial pode gerar equívocos e distorções nas aprendizagens, visto que a percepção dos sentidos não necessariamente representa a realidade. Edgar Morin (2005, p. 81, 82) enfatiza que "geralmente, nossa percepção contém uma parte alucinatória na qual reconstituímos objetos e seres que percebemos ${ }^{133}$ ".

O trabalho com estudantes da educação básica, restritivo à uma escala local ou pouco buscando conexões com outras escalas de tempo e espaço do problema estudado, majoritariamente apoiado na percepção sensorial, incorre no risco de limitar a visão do aluno e trazer interpretações distorcidas e falseadas do que se pretende trabalhar.

Morin (1986) salienta que "devemos desconfiar do testemunho dos "nossos olhos', pois não são os nossos olhos que veem, é o nosso espírito, por intermédio dos nossos olhos"134. Esta afirmação está em conformidade com a ponderação feita por David Harvey (2014) anos mais tarde, ao enfatizar a fantasia e a ficção, produzindo mapas mentais e espaços como verdadeiras miragens daquilo que supostamente seria real, dada a experiência subjetiva do indivíduo levado pelos domínios da percepção e da imaginação ${ }^{135}$.

A percepção sensorial é um complexo sistema que pode trazer informações distorcidas ao cérebro humano, causando sensações de conforto ou desconforto por meio dos sentidos. Em relação à percepção visual, a ilusão de ótica é um exemplo dos tipos de distorções e erros que podem acometer o cérebro humano, fazendo com que o sujeito creia que aquilo que visualiza trata-se de algo real.

Todas as percepções são, ao mesmo tempo, traduções e reconstruções cerebrais com base em estímulos e sinais captados e codificados pelos sentidos. Daí resultam, sabemos bem, os inúmeros erros de percepção, que nos vêm de nosso sentido mais confiável, o da visão. Ao erro de percepção acrescenta-se o erro intelectual [...]. Esse conhecimento, ao mesmo tempo tradução e reconstrução, comporta a interpretação, que introduz o risco do erro na subjetividade do conhecedor, de sua visão do mundo e de seus princípios de conhecimento ${ }^{136}$ (MORIN, 2011, p. 19, 20).

A percepção sensorial é fundamental para o desenvolvimento humano e pode auxiliar o indivíduo em diversas situações de sobrevivência, assim como em determinadas etapas do processo de ensino-aprendizagem, todavia, o que se atenta em

${ }^{133}$ MORIN, Edgar. In: MORIN, Edgar; ALMEIDA, Maria da Conceição; CARVALHO, Edgard Assis de. (Orgs.). Educação e complexidade: os sete saberes e outros ensaios. 3ª ed. São Paulo: Cortez, 2005.

${ }^{134}$ MORIN, Edgar. Para sair do século XX. Rio de Janeiro: Editora Nova Fronteira, 1986.

${ }^{135}$ HARVEY, David. Condição pós-moderna: uma pesquisa sobre as origens da mudança cultural. $25^{\text {a }}$ ed. São Paulo: Editora Loyola, 2014.

${ }^{136}$ MORIN, Edgar. Os sete saberes necessários à educação do futuro. $2^{\mathrm{a}}$ ed. São Paulo: Cortez; Brasília, DF: UNESCO, 2011. 
relação às falsas percepções são os riscos que podem acarretar gerando ilusões e cegueiras do conhecimento como assinalou Morin.

Uma das características presentes na geografia ensinada, tem sido a de que o aluno vivendo num dado lugar possuí o conhecimento desse recorte espacial, pois ali está inscrito o seu cotidiano. Ou seja, tendo contato diário com pessoas da sua localidade, do entorno de sua casa e escola, haveria além das relações face a face um sentimento de pertencimento e de afetividade em relação ao "seu lugar". Assim, seria mais adequado aos professores desenvolverem atividades com seus alunos focando naquilo que lhe é mais próximo, pois o aluno conheceria o que há naquele recorte territorial e o modo como as pessoas estariam organizadas.

Acreditamos, não ser possível assegurar efetivamente que os estudantes tenham o conhecimento, ainda que de senso comum ${ }^{137}$, de como os indivíduos de um dado lugar se organizam tanto em relação às suas atividades diárias como em relação a uma complexa dinâmica que se inscreve nos lugares com diferentes escalas de tempo-espaço.

Por outro lado, confirmando a hipótese de as crianças terem em relação ao lugar onde vivem o conhecimento do modo como se organizam as atividades, ou seja, "como é o lugar", há de se considerar, que não necessariamente a aprendizagem de geografia se efetivará, pois, para elas isso não será novidade. Vigotski (2009, p. 331) enfatiza que:

[...] na escola a criança não aprende o que sabe fazer sozinha, mas o que ainda não sabe e lhe vem a ser acessível em colaboração com o professor e sob sua orientação. O fundamental na aprendizagem é justamente o fato de que a criança aprende o novo. Por isso, 'a zona de desenvolvimento imediato', que determina esse campo das transições acessíveis à criança, é a que representa o momento mais determinante na relação da aprendizagem com o desenvolvimento $^{138}$.

Os apontamentos de Vigotski ao considerar que a criança não aprende o que sabe fazer sozinha, mas o que ainda não sabe, serve para que se reflita até que ponto a geografia na educação básica deve focar no ensino do lugar pouco se conectando à outras escalas, considerando que o aluno conhece esse "seu lugar". Há de se ponderar se o aluno tem o conhecimento científico sobre os aspectos e fenômenos que compõem uma dada realidade ou se o que tem é o conhecimento espontâneo (fundamental para apoiar os conceitos científicos).

\footnotetext{
${ }^{137}$ De acordo com Jarbas Novelino Barato (2002, p. 40), o senso comum refere-se ao "discurso ingênuo baseado exclusivamente na percepção imediata dos fenômenos. É o 'bom senso' tão elogiado e decantado como virtude. É a forma corriqueira e acrítica de abordar a realidade". BARATO, J. N. Escritos sobre tecnologia educacional \& educação profissional. São Paulo: Editora SENAC, 2002.

${ }^{138}$ VIGOTSKI, L. S. A construção do pensamento e da linguagem. Tradução: Paulo Bezerra. $2^{\mathrm{a}}$ ed. São Paulo: Editora Martins Fontes, 2009.
} 
Não é possível afirmar que as crianças e adolescentes seguramente conheçam o lugar onde moram, sobretudo quando muitas delas podem migrar de um lugar a outro em curto espaço de tempo. Por outro lado, se possuem ainda que incipientes saberes sobre o local que lhe é próximo, não terão necessariamente interesse em aprendê-lo, pois desejarão aprender o que ainda não sabem.

Vigotski (2009) ao especificar que a criança aprende o que lhe vem a ser acessível em colaboração com o professor e sob sua orientação, clarifica a necessidade e a importância da figura de um mediador humano no processo de ensinoaprendizagem. Assim, evidencia-se aproximações com a concepção de Feuerstein, de que não é suficiente uma aprendizagem por meio de estímulos diretos ${ }^{139}$, sem mediação humana e de modo espontâneo ${ }^{140}$.

Crianças e adolescentes encontram-se num mundo tomado pela complexidade tecnológica e midiática com pouca mediação humana. Em que pese serem considerados nativos digitais, estão expostos à um "bombardeio" de estímulos diretos, oriundos de diversas fontes.

Ademais, têm sido feitas interpretações insuficientes em relação ao que Vigotski trata como conceitos espontâneos e conceitos científicos, sobretudo quando enfatizam que se valorize o "vivido" que se passa na rua, no bairro, no "imediato", "próximo" e "concreto", como se apenas isso estivesse relacionado aos conhecimentos espontâneos que a criança constrói. Para Vigotski, a construção de conceitos não está restrita às experiências estritamente focalizadas numa realidade concreta. $\mathrm{O}$ autor assinala o que considera como conceito, sendo que...

[...] em sua forma natural e desenvolvida, pressupõe não só a combinação e a generalização de determinados elementos concretos da experiência mas também a discriminação, a abstração e $\mathrm{o}$ isolamento de determinados elementos e, ainda, a habilidade de examinar esses elementos discriminados e abstraídos fora do vínculo concreto e fatual em que são dados na experiência ${ }^{141}$ (VIGOTSKI, 2009, p. 220).

\footnotetext{
139 “A criança que está apenas exposta a estímulos não será beneficiada se não houver alguém que agregue conhecimento a isso, um mediador. Quando a criança olha para uma lâmpada e chamamos a sua atenção para a forma, a cor, estamos mediando. Caso contrário, ela vai olhar sem entender nada". FEUERSTEIN, Reuven. Entrevista à Rita Moraes. Direito à inteligência. Revista Isto É. Edição 1545, 12 de maio de 1999.

${ }^{140}$ Algumas das premissas e concepções de Vigotski e Feuerstein serão tratadas no capítulo 4 deste trabalho.

${ }^{141}$ VIGOTSKI, Lev Semenovich. A construção do pensamento e da linguagem. $2^{\mathrm{a}}$ ed. São Paulo: Martins Fontes, 2009.
} 
Tem sido recorrente na geografia ensinada considerar o cotidiano e os conhecimentos espontâneos dos estudantes atrelados às impressões que eles têm em relação aos caminhos que percorrem diariamente no trajeto casa-escola-curso-igreja, por exemplo, com a ideia de se "ler" a paisagem e aquilo que lhes é mais próximo. Porém, há aí uma situação paradoxal, pois o que seria em tempos de meio técnico-científicoinformacional o "mais próximo"? Seria o que fisicamente não está distante? Ou poderia ser os muitos "outros" dos contatos online e das redes sociais "desterritorializados" e nas "múltiplas territorialidades" do ciberespaço?

Ademais, considerando a relevância e a necessidade de um pertinente ensino de geografia e de uma aprendizagem efetivamente significativa, questionamos se ao defender que o aluno já conhece o lugar em que vive e com isso sua aprendizagem tende a ser mais eficiente, não estaria havendo atividades em vãs repetições, ao invés de um trabalho pautado em problematizações.

Gaston Bachelard (1996, p. 23) já denunciava que:

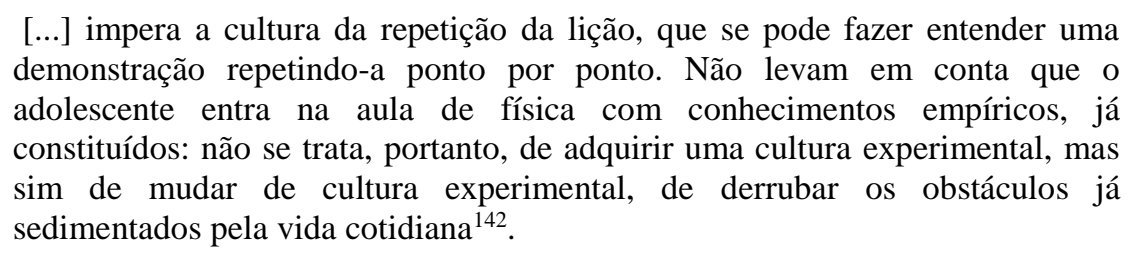

Indivíduos em idade escolar possuem conceitos espontâneos, e a partir destes conceitos, na escola, em contato com um saber sistematizado, começam um processo de elaboração e construção de conceitos científicos ${ }^{143}$. Conquanto, é preciso cuidado para não considerar os conceitos espontâneos somente como aqueles saberes do senso comum restritos ao espaço concreto, do lugar em que vivem. Um aluno pode apresentar conceitos espontâneos ou cotidianos sobre fenômenos geográficos que ocorrem noutras regiões do espaço terrestre com base em noticiários que lida cotidianamente por meio da televisão e da internet.

\footnotetext{
${ }^{142}$ BACHELARD, Gaston. A formação do espírito científico: contribuição para uma psicanálise do conhecimento. Rio de Janeiro: Contraponto, 1996.

${ }^{143}$ Vigotski (2010, p. 539) salienta que: "[...] todo conceito científico deve apoiar-se em uma série de conceitos espontâneos que germinam até chegar à escola e transformá-los em científicos". VIGOTSKI, Lev Semenovich. Psicologia pedagógica. $3^{\text {a }}$ ed. São Paulo: Ed WMF Martins Fontes, 2010.
} 


\section{CAPÍTULO 3 REPRESENTAÇÕES DE MUNDO DE MIGRANTES NORDESTINOS ENTREVISTADOS PELOS ESTUDANTES}

Paralelamente a participação na Sequência Didática, que será tratada em capítulos subsequentes, estudantes de quatro turmas de $8^{\text {a }}$ séries realizaram entrevistas com migrantes nordestinos residentes na capital paulista, mais especificamente no Distrito de Pedreira. Os depoimentos dos entrevistados possibilitaram aos alunos, ter parcialmente, uma caracterização do passado e memória destas pessoas, assim como de suas visões e representações de mundo, de como estão inseridos no mercado de trabalho em tempos de globalização e reestruturação produtiva e perceber as representações destes migrantes em relação às décadas passadas e ao mundo atual.

\subsection{BREVE CARACTERIZAÇÃO DA ESCOLA E DAS TURMAS DA PESQUISA}

A realização das entrevistas ocorreu no decorrer do $4^{\circ}$ bimestre de 2016 , com o objetivo de que os estudantes pudessem entrar em contato com pessoas que vivenciaram um processo de migração da região Nordeste em direção a região Sudeste do país, mais especificamente à metrópole paulistana e perceber suas representações em relação às motivações e fatores que contribuíram para que esse processo migratório se efetivasse, assim como em relação às mudanças e transformações que se verifica nesse cenário atual de meio técnico-científico-informacional.

Trata-se de uma atividade que possibilita ao estudante entrar em contato com as representações de mundo de migrantes numa outra escala que não estritamente a do "lugar do aluno" ou da dimensão circunscrita de uma dada base territorial do entorno da escola. Acreditamos que isso contribui para que o aluno demande um maior nível de abstração, não ficando restrito aos aspectos concretos de uma geografia do "próximo" e do "imediato", sem conexões com outras escalas de tempo e de espaço.

Apesar de o processo de migração englobar na metrópole paulistana pessoas de diversas origens do país e do exterior, optamos por realizar as entrevistas exclusivamente com nordestinos, pois significativa parcela dos estudantes da escola em questão são netos ou filhos dessa população migrante, que assim como as demais, tivera significativo papel na constituição da metrópole de São Paulo. 
A E. E. Dr. Ayres Neto, localiza-se no Parque Dorotéia, bairro integrante do Distrito de Pedreira, na zona sul da capital paulista, em região limítrofe com o município de Diadema, como podemos ver na figura abaixo. A unidade escolar comportava em 2016 em torno de 2.700 alunos e apesar de ter um público bastante heterogêneo, houve sempre certa prevalência de atender a um público com condições socioeconômicas bastante modestas da periferia da cidade. O distrito apresenta uma área territorial de $18,06 \mathrm{Km}^{2}$ e um total populacional de 158. 656 habitantes, conforme os dados do Censo (IBGE, 2010).

\section{Figura 1 - Localização do Distrito de Pedreira na Grande São Paulo}

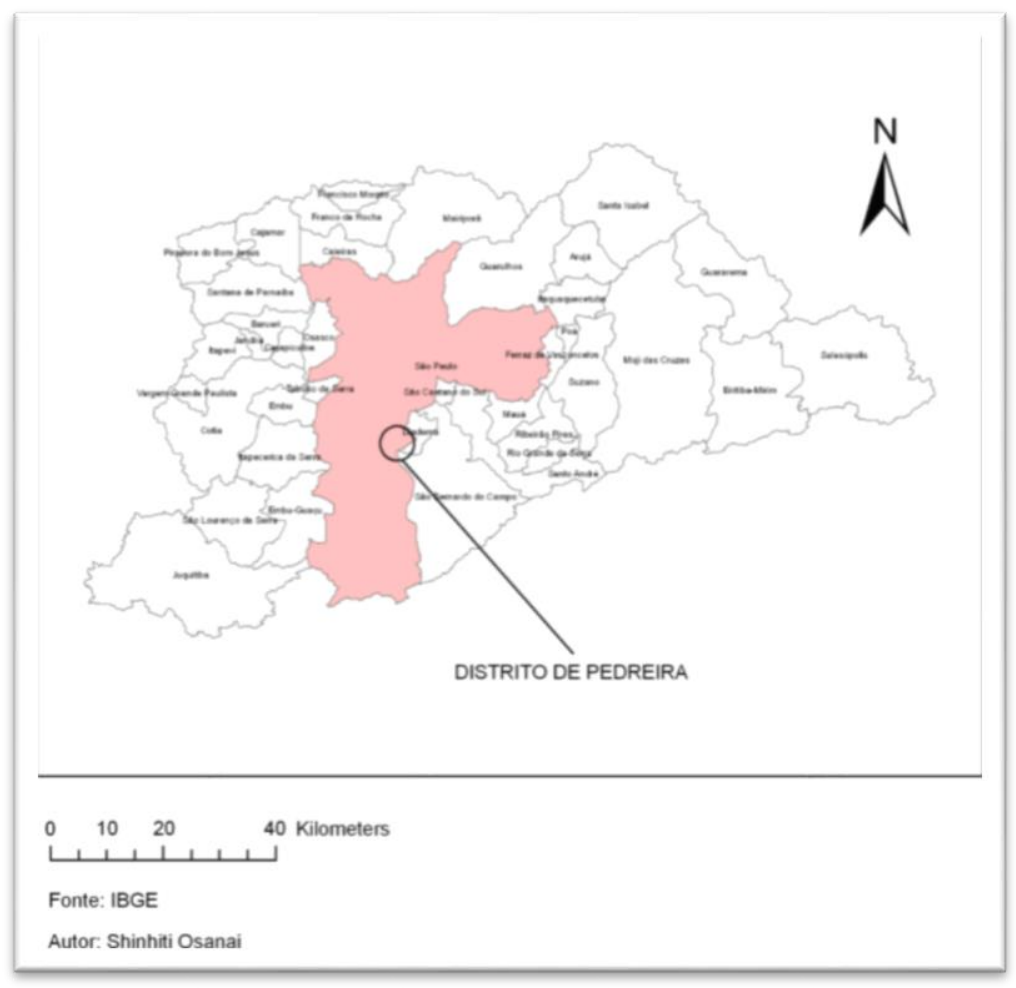

Autor: OSANAI, Shiniti (2009).

Há na região significativa carência em relação à equipamentos urbanos e insuficiência de recursos básicos essenciais, como supermercados de grande porte, hospitais, áreas para atividades recreativas etc. Os bairros que compõem a região de Pedreira começaram a se formar desde o final dos anos 30 do século XX, porém, a partir dos anos 90, houve aumento da população que induzida por políticas populistas ocuparam loteamentos em área de manancial, desconsiderando as questões ambientais. A escola está próxima a áreas com favelas e loteamentos irregulares, sendo visível em determinados pontos a degradação da cobertura vegetal e lançamento de lixos em locais inapropriados. 
Apesar de a quase totalidade dos discentes da E. E. Ayres Neto residirem na cidade de São Paulo, parte significativa tem suas necessidades de consumo, lazer e saúde, atendidas em Diadema, que apresenta uma dinâmica que serve como polo de atração para determinadas atividades da população de Pedreira, além das relações que ambas populações mantêm entre si. Na figura 2 vemos a entrada principal da escola.

\section{Figura 2 - Entrada principal da E.E. Dr. Ayres Neto, no Distrito de Pedreira}

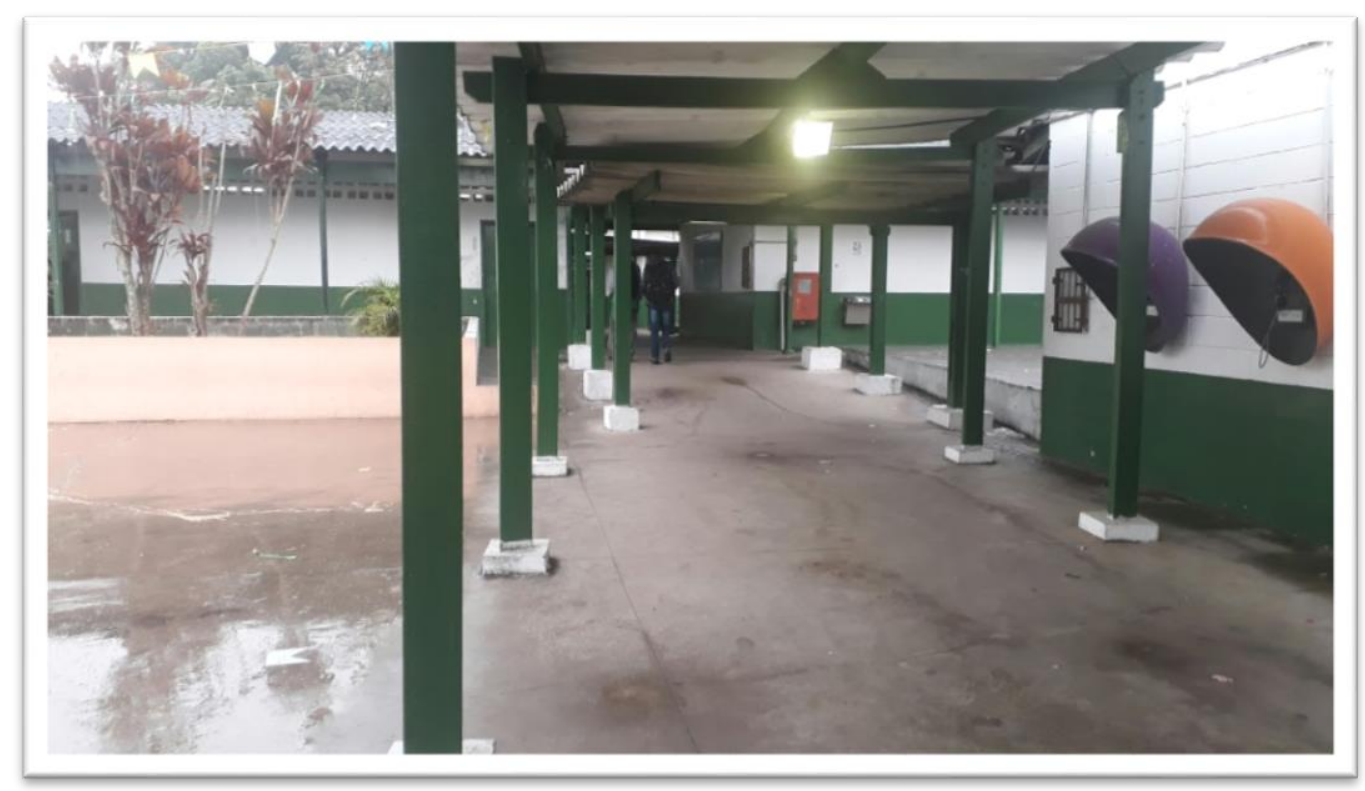

Autor: Gabriel Mendes Juvino (2018).

Diadema, que compõe a Região do Grande ABC paulista fora tida como cidade dormitório logo após a instalação de grandes montadoras automobilísticas em São Bernardo do Campo, a partir da década de 1950, quando houve um surto industrial no país. À medida que a cidade crescia aumentava o número de migrantes, sobretudo, oriundos de estados nordestinos que buscavam empregos na construção civil, unidades fabris e montadoras de veículos automotores. Atualmente a região vive os efeitos da reestruturação produtiva, o que vem causando transformações, principalmente, nos tipos de empregabilidade.

$\mathrm{O}$ processo de desconcentração industrial, intensificado no $\mathrm{ABC}$ paulista de modo mais veemente a partir dos anos 90, com a saída de unidades fabris para outros estados ou municípios, refletiu não somente em desemprego, mas em novas ocupações, principalmente no setor terciário, além de ter aumentando a informalidade do trabalho. Direta ou indiretamente, não só os migrantes entrevistados pelos estudantes, mas possivelmente os familiares dos próprios alunos, sentem os efeitos das transformações do meio técnico-científico-informacional em suas vidas. 
Para uma melhor caracterização das quatro $8^{\mathrm{a}}$ séries que participaram da pesquisa, optamos por apresentar por turmas a composição das salas em relação a quantidade de estudantes nos utilizando dos seguintes critérios:

\section{Quadro 7 - Critérios para categorizar alunos matriculados das salas partícipes}

\begin{tabular}{l|l}
\hline Matriculados & $\begin{array}{l}\text { Todos que compõem a lista oficial, desde os } \\
\text { alunos frequentes como os transferidos e os } \\
\text { que abandonaram a escola. }\end{array}$ \\
\hline Transferidos & $\begin{array}{l}\text { Aqueles que foram transferidos para outra } \\
\text { unidade escolar. }\end{array}$ \\
\hline Abandono & $\begin{array}{l}\text { Alunos que abandonaram a escola, } \\
\text { interrompendo os estudos no referido ano. }\end{array}$ \\
\hline Frequentes & $\begin{array}{l}\text { Alunos que frequentam regularmente a } \\
\text { escola, apesar de terem faltas intercaladas. }\end{array}$ \\
\hline
\end{tabular}

Fonte: Elaborado pelo autor (2018).

Ao observar o gráfico 5 é possível perceber que a evasão escolar ainda é uma realidade desoladora, pois apesar de todos os esforços de políticas públicas para que a criança e o adolescente não somente tenham direito ao acesso à escola, mas que seja assegurada a sua permanência, os dados em nossa pesquisa apontam que em todas as turmas aqui tratadas há situação de evasão escolar.

\section{Gráfico 5 - Totais de alunos por série e as condições de matrícula}

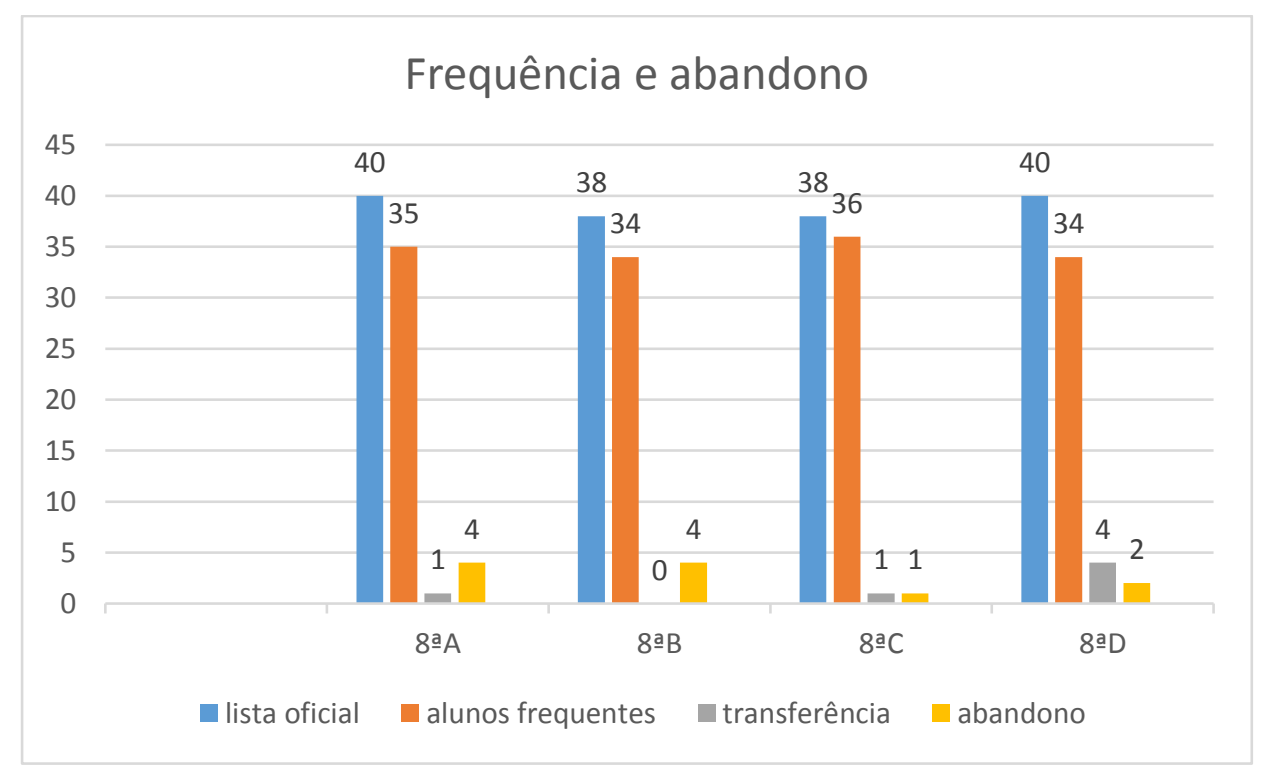

Fonte: Elaborado pelo autor (2018). 
Na $8^{\text {a }}$ série A, temos um total de 40 estudantes matriculados, havendo uma transferência e 4 abandonos, resultando, assim num total de 35 alunos frequentes. Na $8^{\text {a }}$ serie $\mathrm{B}$, o número de matriculados chegou a 38 , no entanto, os dados indicam 4 abandonos, resultando em um total de 34 alunos frequentes. Apesar de as séries seguintes apresentarem uma redução no total de abandonos, a evasão não deixou de aparecer. A $8^{\mathrm{a}}$ série $\mathrm{C}$, com 38 estudantes matriculados, tivera 1 aluno transferido e um abandono, chegando ao valor de 36 estudantes frequentes. Já na $8^{\text {a }}$ série $\mathrm{D}$, com 40 alunos matriculados, tivera 4 transferências e dois abandonos, totalizando 34 alunos frequentes.

Somando os dados das quatro turmas, temos que dentre um total de 156 alunos matriculados, tivemos 6 transferências e 11 abandonos. Assim, consideramos para esta amostra um total de $89 \%$ dos estudantes considerados frequentes (gráfico 6) em relação a lista oficial. No entanto, é preciso ressaltar que dentre os frequente há incidência de alunos faltosos, o que acaba por afetar o processo de aprendizagem.

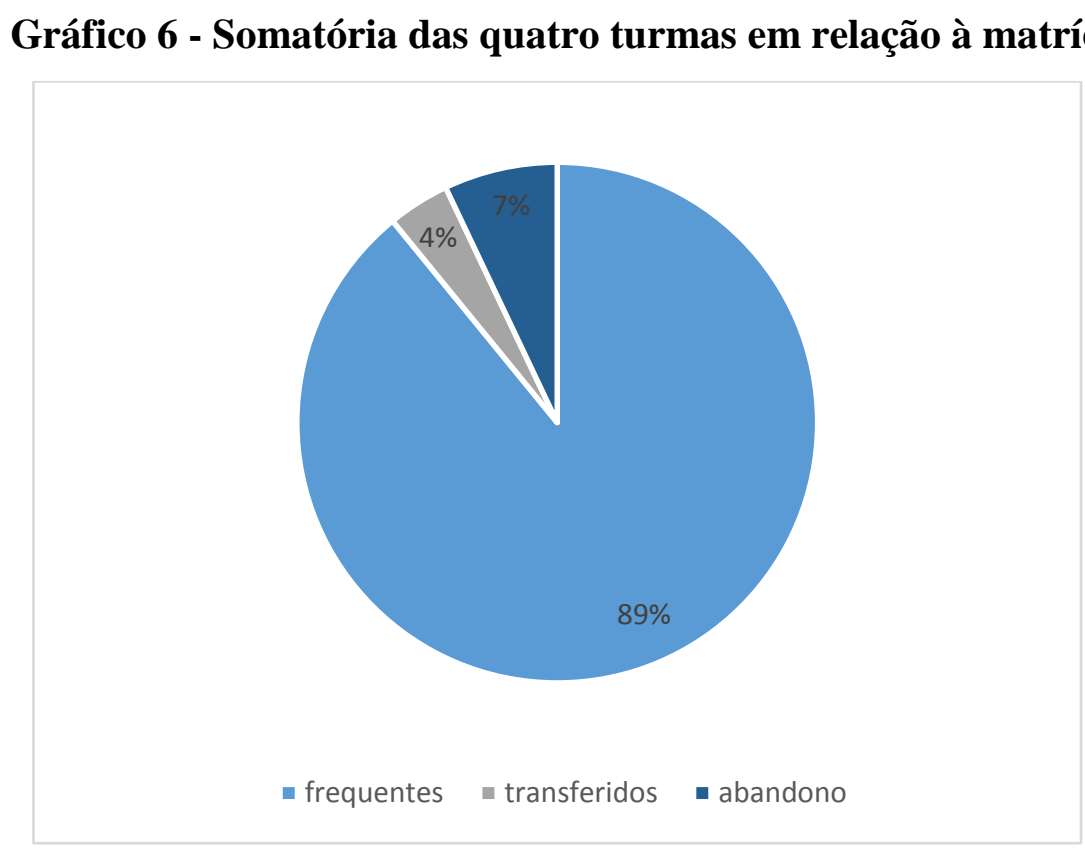

Fonte: Elaborado pelo autor (2018).

Uma característica que percebemos ao analisar os alunos frequentes das quatro turmas, é que a maioria dos estudantes se matricularam na educação básica em idade adequada, pois conforme podemos verificar no gráfico 7 , indicando o ano em que os estudantes nasceram, percebemos a prevalência do ano de 2002, ou seja, estavam na época da pesquisa com a idade de 14 anos. 
Gráfico 7 - Ano de nascimento dos alunos frequentes no período de 2016

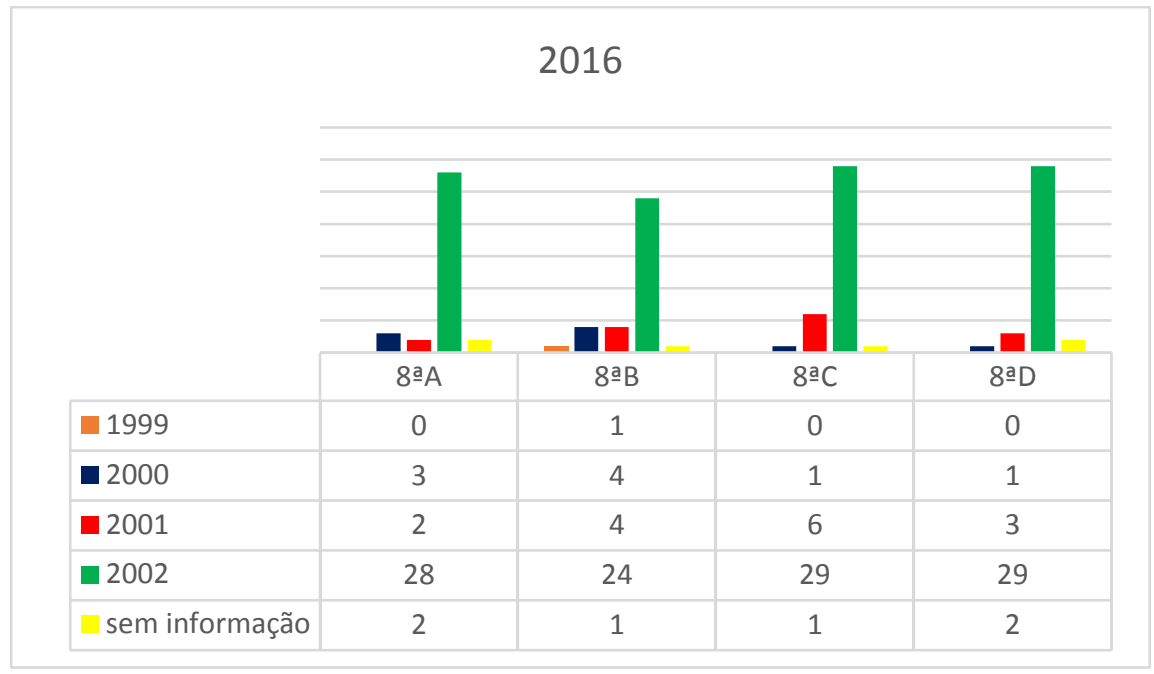

Fonte: Elaborado pelo autor (2018).

$\mathrm{Na} 8^{\mathrm{a}}$ série A, $82 \%$ dos estudantes nasceram em 2002, sendo que apenas 2 foram nascidos em 2001 e 3 no ano 2000. Ainda nesta mesma turma não temos dados de 1 aluno. Em relação a $8^{\mathrm{a}}$ série $\mathrm{B}$, de 32 alunos frequentes, 23 tinham a idade de 14 anos, 1 teria nascido em 1999, 3 no ano 2000, 4 em 2001 e não há dados de um estudante. Na $8^{\text {a }}$ série $\mathrm{C}, 82 \%$ dos estudantes encontra-se em idade correspondente à referida série, havendo 1 aluno nascido em 2000, 6 em 2001 e não há dados de um estudante. A $8^{\text {a }}$ série D, apresenta entre os alunos frequentes um estudante nascido em 2000, 3 em 2001 e 27 em 2002.

Entre os alunos que abandonaram os estudos temos a evidência de que apresentam defasagem de idade escolar, como podemos verificar no gráfico seguinte.

Gráfico 8 - Ano de nascimento dos alunos que abandonaram os estudos

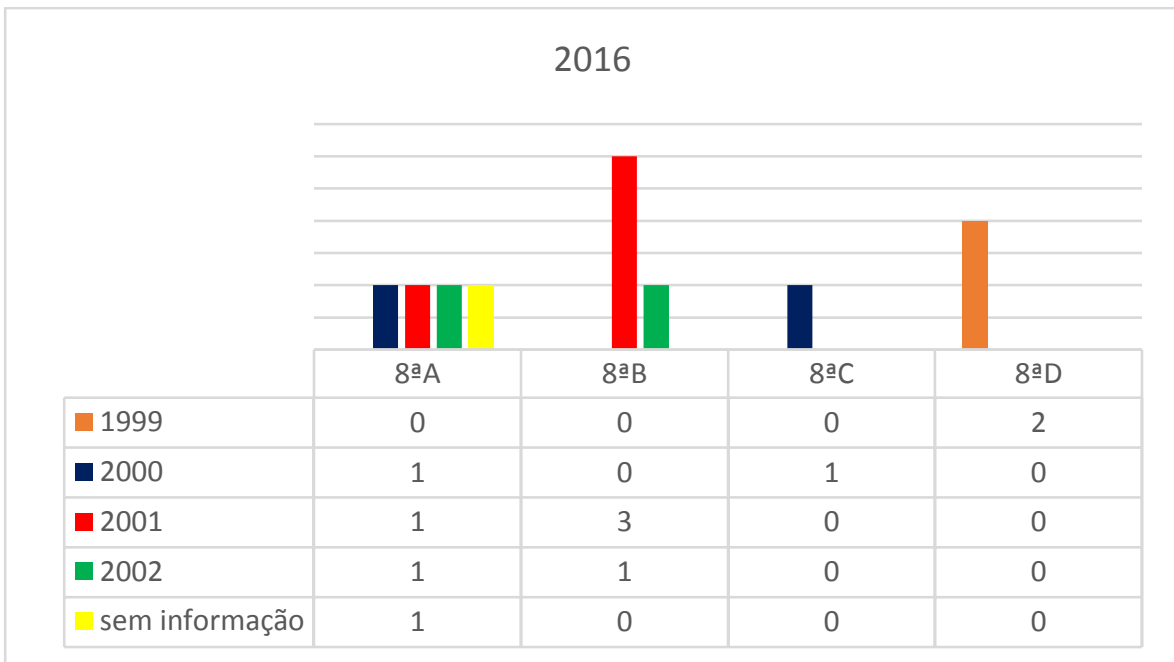

Fonte: Elaborado pelo autor (2018). 
O gráfico anterior aponta que apesar de haver entre os abandonos alunos com a idade considerada adequada à série correspondente, como nos casos das $8^{\mathrm{a}}$ séries $\mathrm{A}$ e $\mathrm{B}$, em todas elas haviam também alunos nascidos antes desse ano e que abandonaram os estudos. A $8^{\text {a }}$ série D, computara dois alunos nascidos em 1999, portanto com 17 anos, que interromperam os estudos. A $8^{\mathrm{a}}$ série $\mathrm{C}$ tivera a menor incidência de abandono, com um aluno de 16 anos. Os dados da pequena amostra indicam a prevalência de abandono dentre os estudantes que apresentam idade acima da média dos colegas de turma.

Em relação a distribuição dos estudantes por sexo, é possível observar com base no gráfico 9, haver equilíbrio entre os sexos masculino e feminino quando consideramos o total das quatro turmas, em que obtivemos o valor de 70 meninas e 69 meninos.

\section{Gráfico 9 - Sexo dos estudantes frequentes por série}

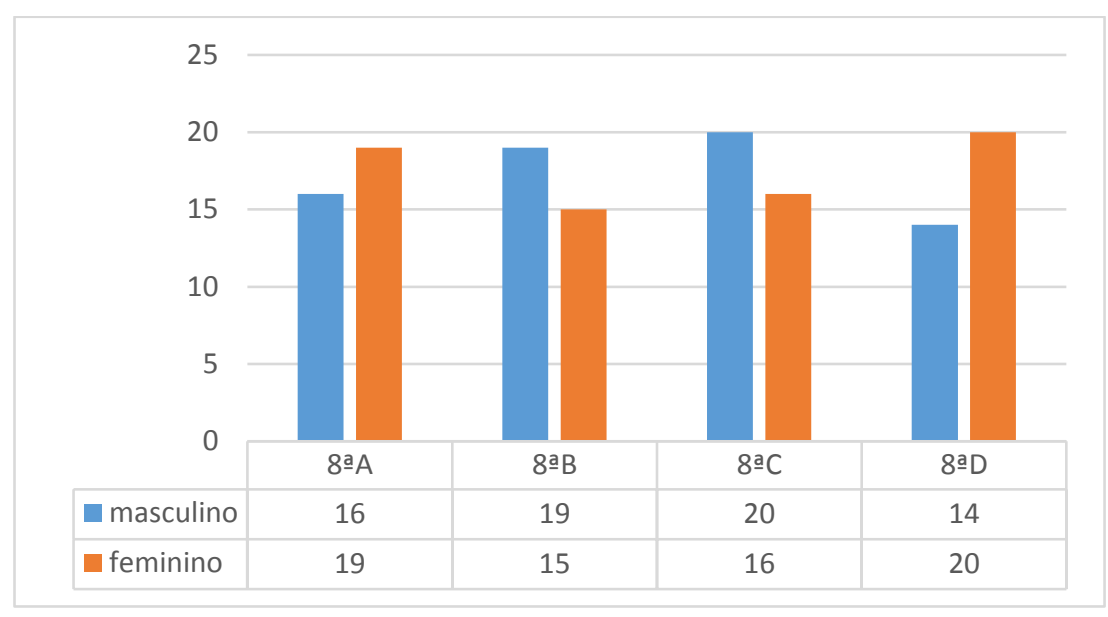

Fonte: Elaborado pelo autor (2018).

Com relação ao sexo dos alunos que abandonaram os estudos dentre os 4 casos da $8^{\mathrm{a}}$ série $\mathrm{A}$, foram dois meninos e duas meninas. $\mathrm{O}$ mesmo ocorrendo na $8^{\mathrm{a}}$ série $\mathrm{B}$. No entanto, na $8^{\mathrm{a}}$ série $\mathrm{C}$ tivemos um caso de abandono e na $8^{\mathrm{a}}$ série $\mathrm{D}$, dois casos, exclusivamente do sexo masculino.

\subsection{ENTREVISTA COM MIGRANTES NORDESTINOS}

Antes de entregarmos aos estudantes as folhas contendo as trinta perguntas que compuseram o questionário - tal como um roteiro - especificamos que a atividade deveria ser realizada a partir de determinados critérios. Em duplas ou trios ${ }^{144}$, os alunos tiveram de entrevistar um migrante nordestino que tivesse, preferencialmente, 30 anos

\footnotetext{
144 Alguns trabalhos foram realizados individualmente por estudantes que alegaram razões variadas para isso. Houve, também, casos de duplas que entrevistaram mais de uma pessoa, e dada a relevância das informações, decidimos por considerá-las para compor a caracterização do perfil destes migrantes.
} 
ou mais. Fora sugerido que, se possível, gravassem o áudio ${ }^{145}$ do diálogo com os entrevistados a fim de que as respostas pudessem ser posteriormente transcritas pelos próprios alunos. O prazo dado para a atividade foi de um mês e meio.

Em relação a participação ativa dos estudantes na realização das entrevistas, resultou-se no seguinte quadro, como podemos ver no gráfico abaixo:

\section{Gráfico 10 - Total de alunos que realizou entrevista com nordestinos}

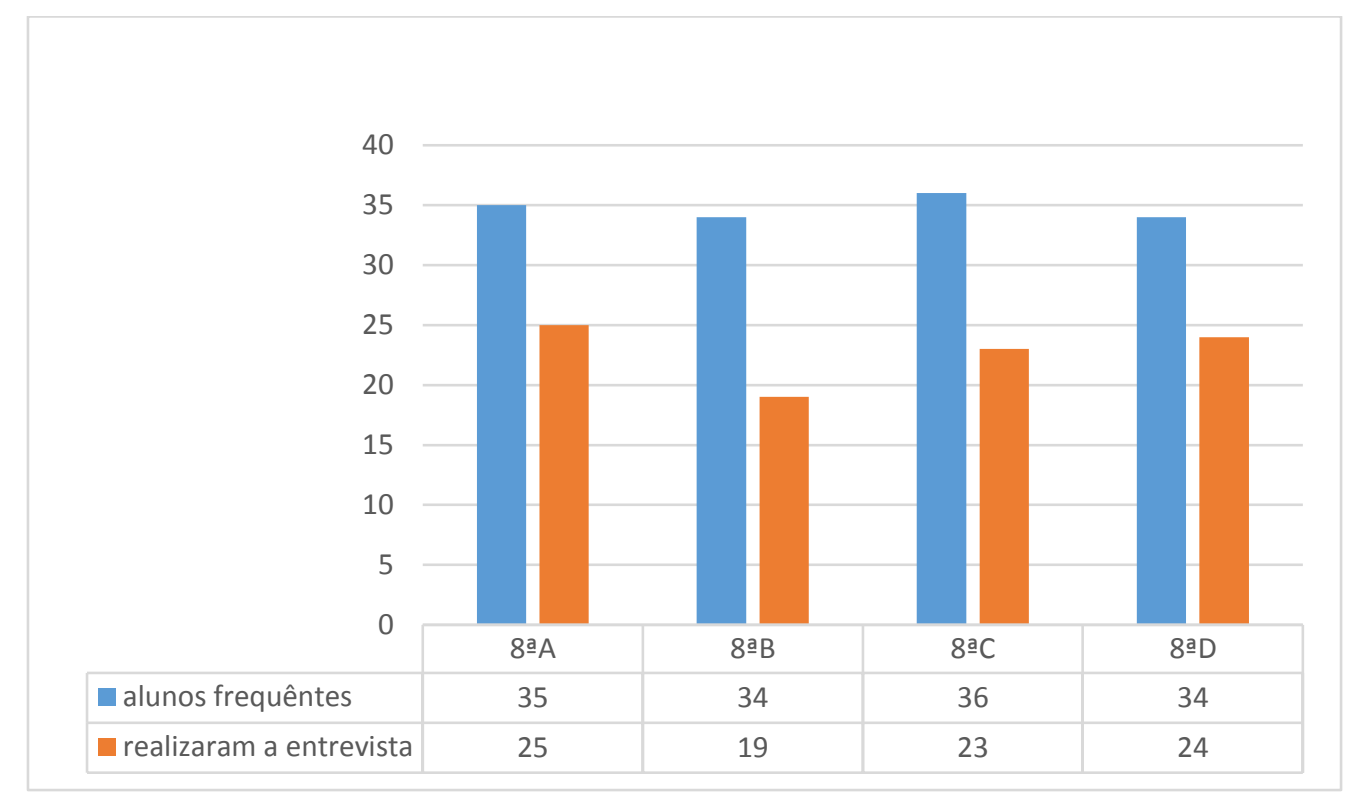

Fonte: Elaborado pelo autor (2018).

Dos 139 alunos que compõem as quatro turmas participantes da entrevista com um migrante nordestino, obtivemos a participação de 91 alunos que efetivamente a realizou. Ou seja, um total de 48 estudantes não realizou essa atividade, o que nos leva a questionar diversos fatores, como, por exemplo, por que não teriam entrevistado algum nordestino, haja vista que parte significativa dos residentes de onde moram é composta por nordestinos, muitos deles, inclusive, sendo seus familiares.

Apesar de ter sido sugerido que a atividade fosse realizada em duplas ou trios, nem todos os estudantes assim o fizeram. Como podemos ver no gráfico da próxima página, obtivemos o seguinte quadro em relação aos que realizaram a atividade individualmente, com um parceiro ou em trio.

\footnotetext{
145 Conforme Marangoni (2008, p. 173), “A técnica de entrevistas tem como necessidade básica o registro das informações obtidas, que poderá ser feito principalmente por meio de anotações, gravação de voz, e/ou gravação de imagem e voz". MARANGONI, A. M. M. C. Questionários e entrevistas: algumas considerações. In: VENTURI, Luis Antonio Bittar. (Org.). Praticando Geografia: técnicas de campo e laboratório. São Paulo: Oficina de textos, 2008.
} 


\section{Gráfico 11 - Quantidade de duplas e trios que realizaram a entrevista}

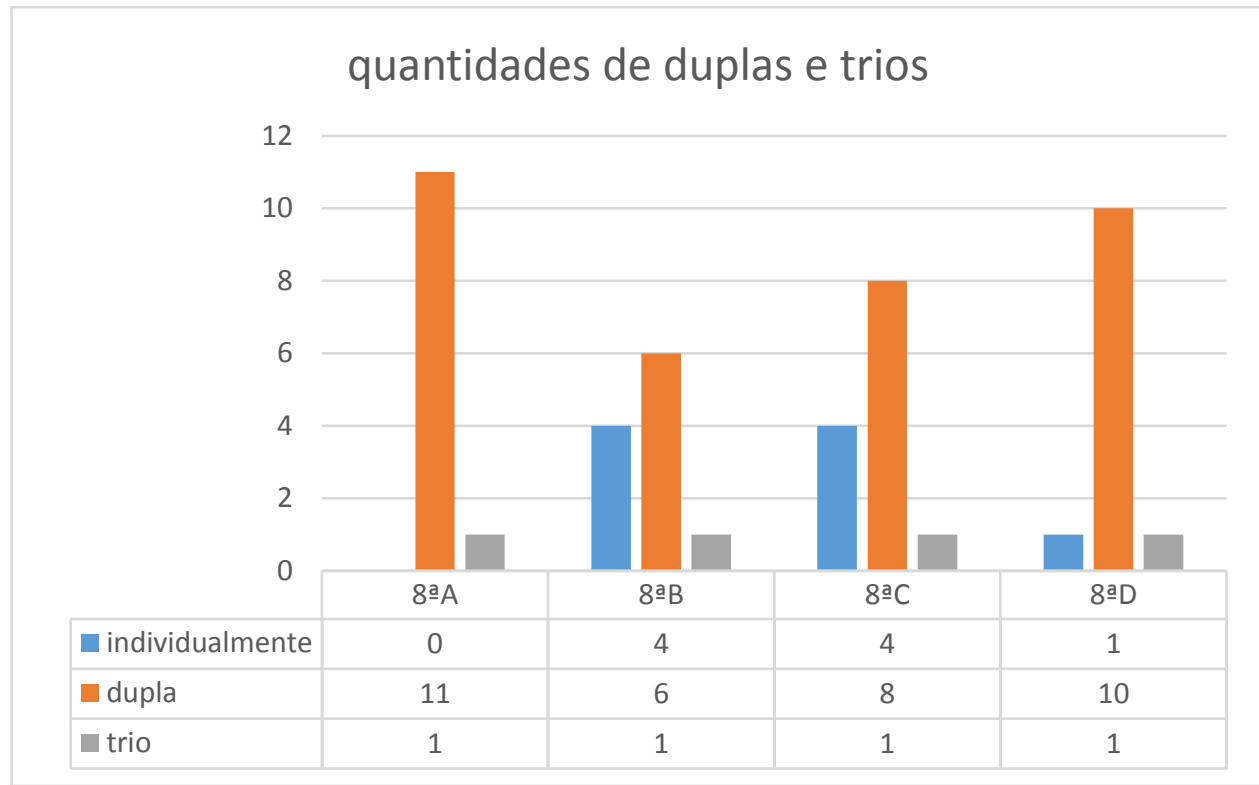

Fonte: Elaborado pelo autor (2018).

De um universo de 91 alunos que realizaram a atividade, obtivemos um total de 51 pessoas entrevistadas. No entanto, 4 delas não foram aqui consideradas, pois não eram naturais da região Nordeste do país, destoando do que fora especificado aos estudantes. Portanto, tivemos um total de 47 entrevistados, sendo 29 mulheres e 18 homens (gráfico 12) que serviram como amostra válida para nossas análises que antecedem a discussão a respeito da Sequência Didática.

\section{Gráfico 12 - Sexo dos migrantes nordestinos entrevistados}

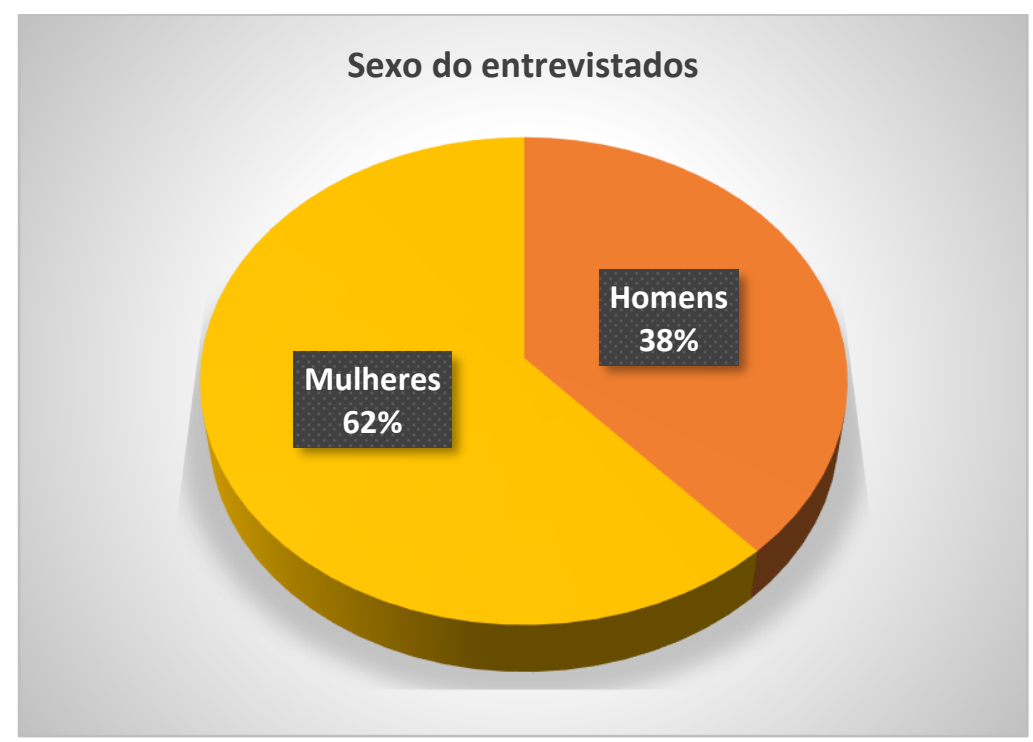

Fonte: Elaborado pelo autor a partir de entrevista realizada por estudantes com migrantes nordestinos em 2016. 
Apesar de o total de 47 entrevistados parecer quantitativamente uma pequena amostra, cabe-nos ressaltar, que o foco da atividade neste caso fora o nível de detalhamento daquilo verificávamos, assim, comungamos da concepção de Volpato et al (2013, p. 146, 147):

Parte-se do pressuposto [...] que o conhecimento detalhado de uma pequena amostra revele processos gerais do todo que a circunda. Assim, perde-se na quantidade da amostra, mas se ganha no detalhamento dentro da amostra, sem a preocupação com validade externa dos resultados para toda a população ${ }^{146}$.

Utilizamo-nos nas entrevistas ${ }^{147}$, com roteiros pré-estabelecidos, a concepção defendida por Marangoni (2008, p. 167) ao tratar de recursos eficazes que melhor nos permite conhecer a realidade:

Entre tais recursos estão os que permitem obter dados e informações relativos às pessoas, aos grupos sociais, às relações sociais e econômica interpessoais e intergrupais, e às inter-relações individuais e grupais com o meio ambiente. Há uma grande diversidade de instrumentos que melhor viabilizam a utilização de várias técnicas de obtenção de dados e informações.

Foi entregue aos estudantes um roteiro com 30 perguntas sendo, a maioria, questões abertas de caráter qualitativo, no entanto, os jovens foram orientados para que durante o processo de entrevista acrescentassem - se houvesse a necessidade - questões correlatas ao contexto do que estava sendo proferido pelo entrevistado ${ }^{148}$. Marangoni (2008) enfatiza que o roteiro é um instrumento básico nas entrevistas, no entanto, é necessário haver adaptabilidade e flexibilidade, independentemente de existirem questões básicas que se repetem, devido a experiência, ao comportamento do entrevistado e do potencial de informações.

Dos 47 migrantes partícipes da pesquisa, 16 deles encontravam-se na faixa etária dos 40 aos 49 anos; 12 declararam ter idade entre os 30 e 39 anos e 8 encontravam-se na faixa dos 50 aos 59 anos. Um total de 8 pessoas estava entre as idades de 60 e 69 anos. Somente um pesquisado tinha abaixo de 30 anos. O gráfico 13 nos permite uma melhor visualização da faixa etária dos entrevistados.

${ }^{146}$ VOLPATO, Gilson L; BARRETO, R. E; UENO, H. M; VOLPATO, E. de S. N; GIAQUINTO, P. C \& FREITAS. G. de. Dicionário crítico para redação científica. Botucatu: Best Writing, 2013.

147 Conforme Marangoni (2008, p. 172), “[...] as entrevistas são indispensáveis à obtenção direta de informações essencialmente qualitativas, embora possam fornecer também informações de caráter quantitativo".

148 De acordo com Schneuwly (2002, s/p) “[...] outra dica é, perguntar algo sobre o que o entrevistado acabou de falar, e não apenas emendar uma questão da lista na outra”. SCHNEUWLY, Bernard. Entrevista. In: Nova Escola: entrevista com Bernard Schneuwly. Nov, 2002. 
Gráfico 13 - Perfil etário dos migrantes participantes da pesquisa

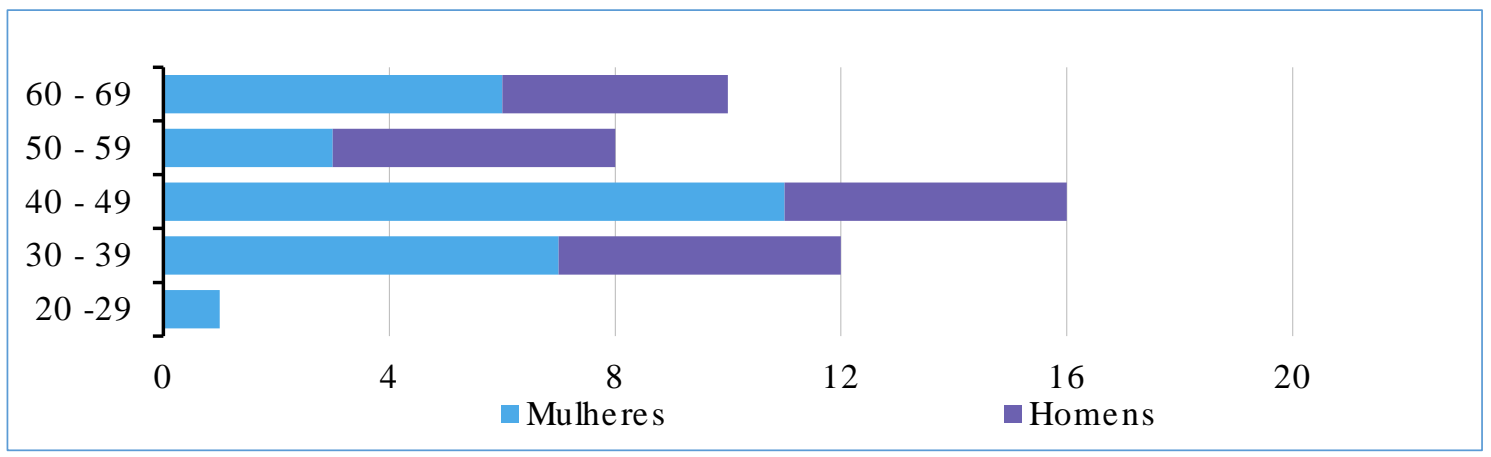

Fonte: Elaborado pelo autor a partir de entrevista realizada por estudantes com migrantes nordestinos no ano de 2016.

Dos entrevistados, 18 deles responderam ter nascido no estado da Bahia; 14 em Pernambuco; 7 no Ceará e 3 no estado de Alagoas. Duas pessoas declararam ter nascido na Paraíba; uma pessoa em Sergipe, uma no Rio Grande do Norte e outra no estado do Maranhão. O mapa evidencia a prevalência de migrantes originários do estado da Bahia, perfazendo um total de 38\%; seguido pela prevalência dos migrantes dos estados de Pernambuco e Ceará, com $30 \%$ e $15 \%$, respectivamente.

Figura 3 - Estados de origem dos entrevistados

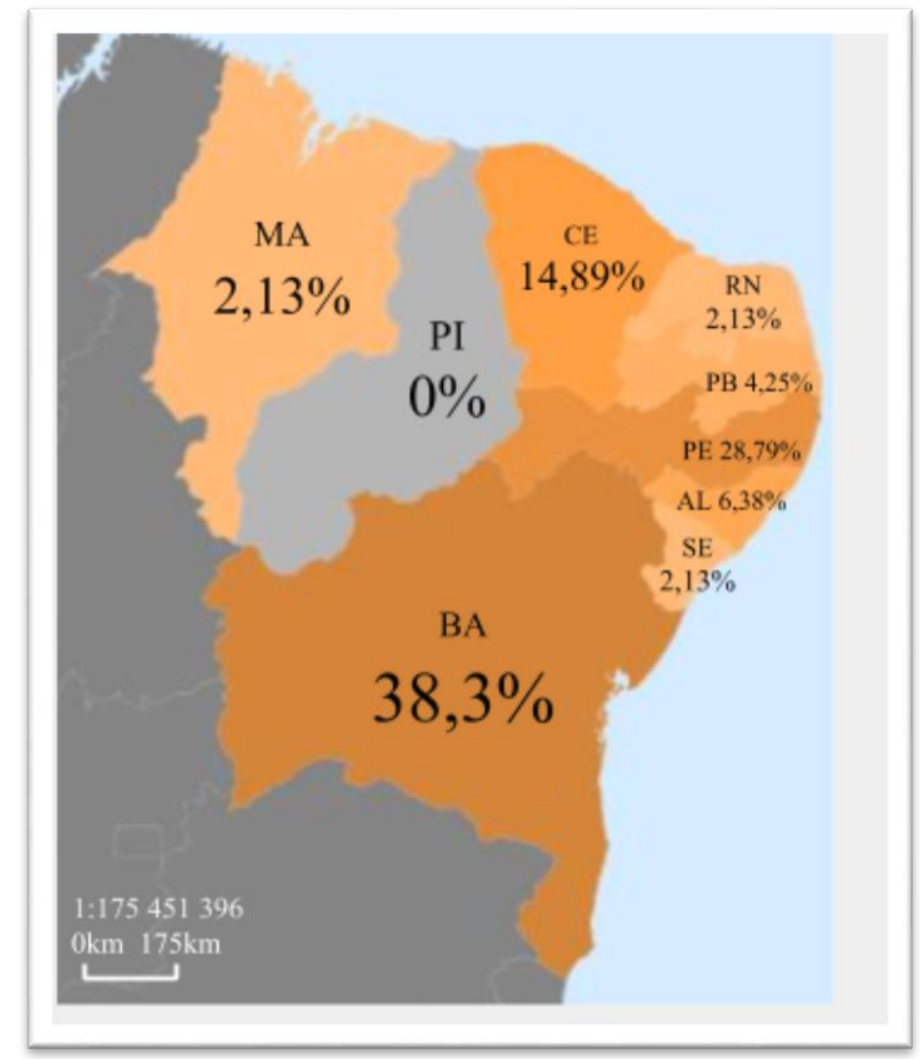

Autor: Camila Fonseca Amorim da Silva (2018). 
Os entrevistados não precisavam ser parentes dos estudantes para participar da pesquisa, no entanto, identificamos em alguns trabalhos aproximações por meio dos sobrenomes, o que nos sugeriu a possibilidade de haver grau de parentesco entre eles. Em que pese a maioria dos alunos das quatro turmas partícipes terem nascido na capital paulista ou no município de Diadema, parte expressiva é filha ou neta de migrantes oriundos de estados da região Nordeste do país.

Significativa parte dos migrantes entrevistados declarou ter migrado para a metrópole paulistana ainda jovens. Ao serem indagados com qual idade saíram de suas cidades de origem, o perfil etário predominante foi o que compreende entre 21 e 25 anos, seguido pela faixa etária de 16 aos 20 anos, como pode ser observado no quadro 8.

Quadro 8 - Faixa etária de quando migraram para metrópole

\begin{tabular}{|c|c|}
\hline IDADE & INDIVÍDUOS \\
\hline $0-5$ & 1 \\
\hline $6-10$ & 5 \\
\hline $11-15$ & 3 \\
\hline $16-20$ & 15 \\
\hline $21-25$ & 19 \\
\hline $26-30$ & 4 \\
\hline A partir de 31 & 0 \\
\hline
\end{tabular}

Fonte: Organizado pelo autor a partir de entrevista realizada por estudantes com migrantes nordestino em 2016.

Considerando que a maioria dos entrevistados tem idades entre 30 e 49 anos e que migraram para a região Sudeste na faixa dos 20 anos, é possível que, ao chegaram na metrópole de São Paulo, o cenário já não era das típicas fábricas com bairros operários tal como ocorrera com os migrantes que rumavam para a capital paulista e adjacências nas décadas de 50, 60 e 70 do século passado. Muitos dos entrevistados, ao chegar à metrópole conheceram a região sob a égide do processo de reestruturação produtiva, com forte redução na oferta do trabalho industrial ${ }^{149}$.

\footnotetext{
149 Antunes \& Alves (2004) apontam que, com a retração do taylorismo/fordismo no processo de reestruturação produtiva do capital, assiste-se à diminuição do proletariado industrial, manual, tradicional, fabril, estável e especializado, assumindo o emprego formas de trabalho desregulamentadas e reduzindo acentuadamente o número de trabalhadores estáveis. ANTUNES, R; ALVES, G. As mutações no mundo do trabalho na era da mundialização do capital. In: Educ. Soc., Campinas, vol. 25. n. 87, p. 335-351, maio/agos. 2004. Caderno Cedes.
} 
Ao serem indagados de o porquê muitos nordestinos terem escolhido a metrópole paulistana para morar nas décadas de 1950, 60 e 70150, obtivemos os seguintes apontamentos:

"Vieram atrás de emprego, uma vida melhor. Foi os nordestinos que levantaram São Paulo” (baiano, 31 anos, pedreiro).

"No Nordeste as condições eram muito precárias, só tinha trabalho na roça e então eles vieram para São Paulo em busca de um trabalho melhor" (pernambucana, 46 anos, balconista).

"A seca e a falta de trabalho" (baiana, 31 anos, supervisora em loja).

"Porque a metrópole de São Paulo tinha mais oportunidades de emprego" (baiana, 43 anos, diarista).

A balconista, de 46 anos, ao relatar que as condições eram muito precárias no Nordeste, onde só tinha trabalho na roça fazendo com que os nordestinos viessem para São Paulo em busca de um trabalho melhor, nos remete ao processo presenciado no país, principalmente a partir dos anos 60, com o forte êxodo rural em direção às cidades consideradas mais desenvolvidas ${ }^{151}$, fazendo com que o país pudesse ter a população urbana superando a rural pela primeira vez.

Alguns entrevistados demonstraram a representação que têm do processo migratório nordestino acentuado a partir dos anos 50, com o processo de industrialização da metrópole paulistana que se acentuava naquela época.

"Porque aqui tinham muitas fábricas e indústrias e era emprego fácil e mão de obra barata” (alagoano, 44 anos, auxiliar de garçom).

"Porque naquela época tinham muitas fábricas e eles precisavam de funcionários" (baiana, 62 anos, costureira).

\footnotetext{
150 A migração nordestina em direção ao estado de São Paulo antecede os anos 1950, quando os migrantes buscavam trabalho nas atividades com o café e outras formas agrícolas. No entanto, escolhemos esse período, por tratar-se do momento em que há um forte impulso no setor industrial de São Paulo, quando a industrialização "pesada" carecia de forte número de trabalhadores. Conforme Negri (1996, p. 101): "A primeira fase da industrialização pesada (1955-1967) consolidou a expansão industrial brasileira e sua concentração em São Paulo, aí instalando grande parte da nova capacidade produtiva metal-mecânica". NEGRI, B. Concentração e desconcentração industrial em São Paulo (1880-1990). Campinas, Editora da Unicamp, 1996.

${ }^{151}$ Manuel Correia de Andrade (1964) apontava as condições socioeconômicas repulsivas na qual estava inserido o nordestino, imerso em precárias condições de pobreza, tendo como sentido emigrar para o Sudeste, sobretudo, São Paulo ou Rio de Janeiro; ou o norte do Paraná, Maranhão ou Brasília, em busca de melhores oportunidades de trabalho. ANDRADE, M. C. A terra e o homem no Nordeste. $2^{\mathrm{a}}$ ed. São Paulo: Brasiliense, 1964.
} 
"Porque aqui tinha muitas indústrias. Era uma grande região cheia de oportunidades e trabalho" (baiana, 50 anos, diarista).

"Porque nesta época São Paulo tinha bastante emprego, então muitos nordestinos saíram de lá para tentar a vida aqui, principalmente nas indústrias, muitos conseguiram" (baiano, 65 anos, aposentado).

"A necessidade que fez a maioria vir pra São Paulo. Antigamente São Paulo era o lugar onde mais tinha trabalho, hoje está dificil porque as indústrias estão fechando as portas, várias empresas mandando muita gente embora [...]" (pernambucano, 69 anos, aposentado e exmanobrista).

As respostas evidenciam representações com uma noção temporal, de um momento em que as perspectivas de empregabilidade eram promissoras, dadas as características de uma região Sudeste que oferecia possibilidades de trabalho. Para Goldenstein \& Seabra (1982), a região Sudeste, e mais especificamente São Paulo, já tinham as condições prévias necessárias para que pudesse se renovar de acordo com a ideologia desenvolvimentista do plano de metas, com um acelerado crescimento; atraindo unidades fabris atreladas aos novos ramos que a economia brasileira se utilizara e tornando a região indutora da redefinição territorial do trabalho ${ }^{152}$.

Fora na capital paulista e adjacências, com o fortalecimento das atividades industriais ${ }^{153}$ e da necessidade de mão de obra barata, que se passou a verificar um forte movimento migratório de nordestinos. Além disso, o Nordeste passava por um período crítico devido às secas que assolavam determinadas áreas do semiárido. Conforme Wilson Cano (2008, p. 201):

\begin{abstract}
No período da industrialização, que convivia com moderado grau de modernização agrícola, era a grande São Paulo que atraia maior número de migrantes de outros estados e do interior paulista em busca de emprego e de melhor nível de vida. Dava-se, portanto, um 'esvaziamento' demográfico do interior, que reforçava a metropolização da cidade de São Paulo ${ }^{154}$.
\end{abstract}

\footnotetext{
${ }^{152}$ GOLDENSTEIN, L; SEABRA, M. Divisão territorial do trabalho e nova regionalização. Revista do Departamento de Geografia. São Paulo, n. 1. p. 21-47, 1982.

${ }^{153}$ Conforme Negri (1996, p. 86): "Neste período, assiste-se a uma aceleração da concentração industrial em São Paulo, que em 1949, passa a deter 48,9\% do VTI brasileiro, chegando em 1956, a 52,2\%. O crescimento industrial da Grande São Paulo foi o principal responsável por isso, com sua participação, naquele VTI, passando de $29,3 \%$ para $34,8 \%$, no período de 1939/56, enquanto o interior, embora reduzisse sua participação na indústria de São Paulo, ganhava peso no total da indústria nacional". NEGRI, B. Concentração e desconcentração industrial em São Paulo (1880-1990). Campinas, Editora da Unicamp, 1996.

${ }^{154}$ CANO, Wilson. Desconcentração produtiva regional do Brasil, 1970-2005. São Paulo: Editora UNESP, 2008.
} 
O processo de industrialização verificado na referida metrópole não se deu do mesmo modo como fora nos países mais desenvolvidos, mas com grandes contrastes como aponta Milton Santos (1990, p. 13):

\begin{abstract}
Metrópole de um país subdesenvolvido industrializado, São Paulo é, certamente, o melhor exemplo, no Terceiro Mundo, de uma situação de modernidade incompleta. Nela se justapõem traços de opulência, devido à pujança da vida econômica e suas expressões materiais, e sinais de desfalecimento, graças ao atraso das estruturas sociais e políticas. Tudo o que há de mais moderno pode aí ser encontrado, ao lado das carências mais gritantes ${ }^{155}$.
\end{abstract}

Os anos 80 podem ser caracterizados como a "década perdida", devido à desaceleração da economia que o país vivenciava, imerso numa crise econômica e social, com altas taxas de desemprego, num período de fomento à produção flexibilizada ${ }^{156}$, refletindo na redução do fluxo migratório de nordestinos em direção à metrópole paulistana. Cano (2008) reforça com números, as possíveis reduções na capacidade receptora de São Paulo para atrair migrantes, pois entre os anos de 1980 1991, recebera 1,1 milhão de migrantes (havendo uma média por ano de 97,3 mil frente aos 282 mil da década anterior), sendo que, do Nordeste, fora $67 \%$ do total, porém $54 \%$ menor quando comparado à década de 1970-80.

Uma dupla de alunas perguntara a seu interlocutor se ele considerava que em sua época São Paulo era onde tinha mais oportunidade de emprego. O entrevistado apontou sua experiência no final dos anos 70, considerando-a bastante promissora.

"Cheguei aqui no dia 19 de novembro de 76, dia 26 de janeiro de 77 eu comecei a trabalhar. Na minha época tinha emprego, a inflação não era tão alta; eu lembro que na época eu ganhava trezentos e poucos cruzeiros, comprei um barraco, trouxe minha mulher pra cá; eu fazia compras, enchia dois carrinhos de comida e não gastava a metade. É vindo os iludidos e voltando os arrependidos. Eu não me arrependo de ter vindo pra cá, eu não sei como estaria vivendo se estivesse lá, foi São Paulo que me deu oportunidade, hoje tenho meu cantinho graças à Deus" (pernambucano, 69 anos, aposentado e ex-manobrista).

\footnotetext{
${ }^{155}$ SANTOS, Milton. Metrópole corporativa fragmentada: o caso de São Paulo: Nobel, 1990.

${ }^{156}$ Giovanni Alves (2005) intitula a década de 80 como sendo das inovações capitalistas, de novos modos de gestar a força de trabalho, da desconcentração industrial e produção flexibilizada em que passa a haver um predomínio do toyotismo, sobretudo, conduzido por grupos e corporações transnacionais. ALVES, G. O novo (e precário) mundo do trabalho: reestruturação produtiva e crise do sindicalismo. São Paulo: Boitempo, 2005.
} 
Ao serem interrogados sobre o que estaria levando a região do $\mathrm{ABC}$ paulista a não mais ter um expressivo número de indústrias como tivera em tempos passados, alguns dos entrevistados fizeram os seguintes apontamentos:

"Porque nesses lugares os impostos são muito altos" (cearense, 40 anos, cabeleireira desempregada).

"As indústrias e fábricas estão tudo mudando para o interior para cortar os gastos" (cearense, 38 anos, diarista).

"Porque o custo de vida está alto. Houve muitos aumentos de impostos e muitas fábricas fecharam e faliram” (baiana, 50 anos, diarista).

"[...] estão procurando abrir indústrias em lugares que traga mais lucro” (baiano, 34 anos, serralheiro).

"Porque muitas fábricas faliram ou se deslocaram para o interior, por conta da alta inflação" (baiano, 65 anos, aposentado).

Ao afirmarem que nesses lugares os impostos são muito altos e que as indústrias e fábricas estão mudando para o interior para cortar os gastos, percebemos que há uma compreensão, ainda que superficial, da saída das indústrias relacionada a busca por vantagens fiscais e mão de obra barata ${ }^{157}$, como no exemplo a seguir.

"[...] deixa eu lembrar aqui. A Phillips, a Telefônica, saíram daqui e foram para Manaus; lá as coisas são mais baratas. Uma empresa de costura grande que tinha em Santo André foi pro Ceará, porque lá é tudo mais barato e ainda tinha cinco anos de carência, porque o governo queria gerar emprego" (pernambucano, 69 anos, aposentado e exmanobrista).

O processo de desconcentração da indústria contribuiu para uma redução na atração de migrantes nordestinos na metrópole paulistana e uma tendência à mudança de sentido do fluxo migratório. De acordo com Baeninger ${ }^{158}$ (1998), na metade dos anos 70 já se verificava no país, de modo mais visível no estado de São Paulo a desconcentração econômica e populacional como dois movimentos interligados, implicando a partir dos anos 80 numa mudança no sentido e direção dos fluxos migratórios.

157 Conforme Antunes (2015, p. 126) “[...] sob imposição da concorrência internacional, passaram a buscar, além de isenções fiscais, níveis mais rebaixados de remuneração da força de trabalho, combinados com uma força de trabalho sobrante, sem experiência sindical e política, pouco ou nada taylorizada e fordizada e carente de qualquer trabalho". ANTUNES, R. Adeus ao Trabalho? Ensaio sobre as metamorfoses e a centralidade do mundo do trabalho. 16a ed. São Paulo: Cortez, 2015.

${ }^{158}$ BAENINGER, R. A nova configuração urbana no Brasil: desaceleração metropolitana e redistribuição da população. In: Encontro Nacional de Estudos Populacionais da ABEP, II. Caxambu, Anais. 1998. 
As mudanças no paradigma da indústria, que se manifestam na crescente diminuição da absorção de mão-de-obra, já revelam o deslocamento do eixo explicativo da migração via industrialização. Se nos anos 70, principalmente, os destinos migratórios apresentavam estreita relação com o dinamismo industrial das regiões do interior [...], agora as evidências empíricas apontam a necessidade de mudanças nas abordagens sobre as migrações - em particular no caso paulista (BAENINGER, 2005, p. 90) $)^{159}$.

De acordo com Paul Singer (2004), no período do boom da industrialização da cidade de São Paulo havia um expressivo contingente de trabalhadores oriundos da região Nordeste, que exportava, conforme alguns autores capital humano. A partir de 1981, quando houve a cessação do crescimento industrial, verificou-se uma reversão na exportação da mão de obra, ficando significativo número de trabalhadores sem emprego e, assim, retornando a seus estados de origem ${ }^{160}$. Conforme Baeninger (2012, p. 84):

A compreensão das migrações do Nordeste passa, necessariamente, pela nova realidade da região Sudeste. Os movimentos migratórios, do início do século 21, transformaram os grandes Estados de atração populacional dos anos 1970 São Paulo e Rio de Janeiro - em áreas de perdas migratórias. Nas PNADs 2006, 2008 e 2009 é possível identificar que a imigração para São Paulo diminui para 765.469 em 2001-2006 para 621.058 entre 2003-2008, chegando a 535.376 migrantes nacionais para o período 2004-2009 - quando, no período 1995-2000, esta migração ainda havia sido de 1.223. 809 migrantes interestaduais $^{161}$.

O período em que se verifica o início de um maior fluxo de retorno de migrantes nordestinos saindo de São Paulo em direção a seus estados de origem, coincidem com o momento em que o estado de São Paulo perde participação relativa na produção industrial em nível nacional, datando do início dos anos 70.

No âmbito brasileiro, é possível identificar que, a partir da década de 1980, os deslocamentos de população iniciam uma fase de mudanças no sentido das correntes principais, com antigos espaços de atração migratória perdendo expressão. Rompe-se o processo bipolar da distribuição espacial no Brasil, que se mantinha desde o início do século XX. De modo que surgem novos eixos de deslocamentos envolvendo expressivos contingentes populacionais [...] $\left(\right.$ OLIVEIRA, 2011, p. 11, 12) ${ }^{162}$

Cano (2008) reportando-se aos anos de 1980, considera que as secas menos intensas na região nordestina e a elevada desconcentração produtiva dos anos 1970 e 80,

\footnotetext{
${ }^{159}$ BAENINGER, R. São Paulo e suas migrações no final do século 20. São Paulo em perspectiva. v. 19, n. 3, p. 84-96, jul/set, 2005.

${ }^{160}$ SINGER, P. Os últimos 40 dos 450 anos de São Paulo. In: SZMRECSÁNYI, Tamás (Org.). História econômica da cidade de São Paulo. São Paulo: Globo, 2004.

${ }^{161}$ BAENINGER, Rosana. Rotatividade migratória: um novo olhar para as migrações internas no Brasil. In: Revista interdisciplinar da mobilidade humana. V. 20, n. 39, p. 77-100. Jul/dez. 2012.

162 OLIVEIRA, A. T. R. de. Reflexão teórica. Algumas abordagens teóricas a respeito do fenômeno migratório. In: OLIVEIRA, Luiz A. P. de; OLIVEIRA, Antonio T. R. de. (Orgs.). Reflexões sobre os deslocamentos populacionais no Brasil. Estudos e. Análises. Informações demográficas e socioeconômica. n. 4. IBGE. Rio de Janeiro, 2011
} 
somados ao aumento da violência em São Paulo e Rio de Janeiro e da urbanização na periferia nacional, foram fatores que contribuíram para que houvesse uma sensível diminuição da atração de migrantes nas áreas receptoras. Ainda de acordo com este autor, esse conjunto de situações acabou por conter o anseio de migrantes em rumar para áreas mais desenvolvidas do país. Nascimento (2015) atenta, para o fato de haver nos últimos tempos indústrias no semiárido setentrional responsáveis pela geração e novas possibilidades de emprego, tornando desnecessária a imigração para outras regiões mais industrializadas do país ${ }^{163}$.

\subsection{A OCUPAÇÃO DOS ENTREVISTADOS E PERCEPÇÕES SOBRE O MUNDO DO TRABALHO}

Dos 47 migrantes entrevistados, 35 deles disseram estar empregados, ao passo que 12 alegaram não estar trabalhando; das 5 pessoas que se declararam aposentadas, uma continua trabalhando. Um dos entrevistados declarou-se como pensionista e três pessoas não responderam se eram ou não aposentadas. Das mulheres migrantes que se encontravam no momento da entrevista empregadas obtivemos o seguinte quadro:

\begin{tabular}{l|l}
$\begin{array}{l}\text { Quadro 9 - Profissão ou ocupação das } \\
\text { entrevistadas }\end{array}$ & \\
\hline Profissão/Ocupação & Total \\
\hline Diarista & 5 \\
\hline Doméstica & 3 \\
\hline Auxiliar de limpeza & 3 \\
\hline Costureira & 2 \\
\hline Pedagoga - recepcionista & 1 \\
\hline Cabeleireira & 1 \\
\hline Bordadeira e secretária & 1 \\
\hline Saladeira & 1 \\
\hline Balconista & 1 \\
\hline Supervisora em loja & 1 \\
\hline Técnica de enfermagem & 1 \\
\hline Fonte: Elaborado pelo autor (2016). & \\
\hline
\end{tabular}

\footnotetext{
${ }^{163}$ NASCIMENTO, Tiago Carlos Lima do. O caminho para as secas: as imigrações para o semiárido setentrional. Dissertação de mestrado. Universidade Federal do Rio Grande do Norte. Departamento de Ciências Autuarias. Programa de Pós-Graduação em Demografia, 2015.
} 
Dentre as entrevistadas havia uma que não trabalhava e não tinha profissão, duas estavam desempregadas, sendo uma delas cabeleireira. Também havia uma pensionista e três aposentadas que já teriam trabalhado com venda de perfumes, em metalúrgica e como diarista. As informações do quadro evidenciam uma prevalência de mulheres empregadas em atividades voltadas ao trabalho doméstico, mais especificamente atrelado à limpeza.

Entre os homens partícipes as ocupações e profissões apontadas foram as que compõem o seguinte quadro.

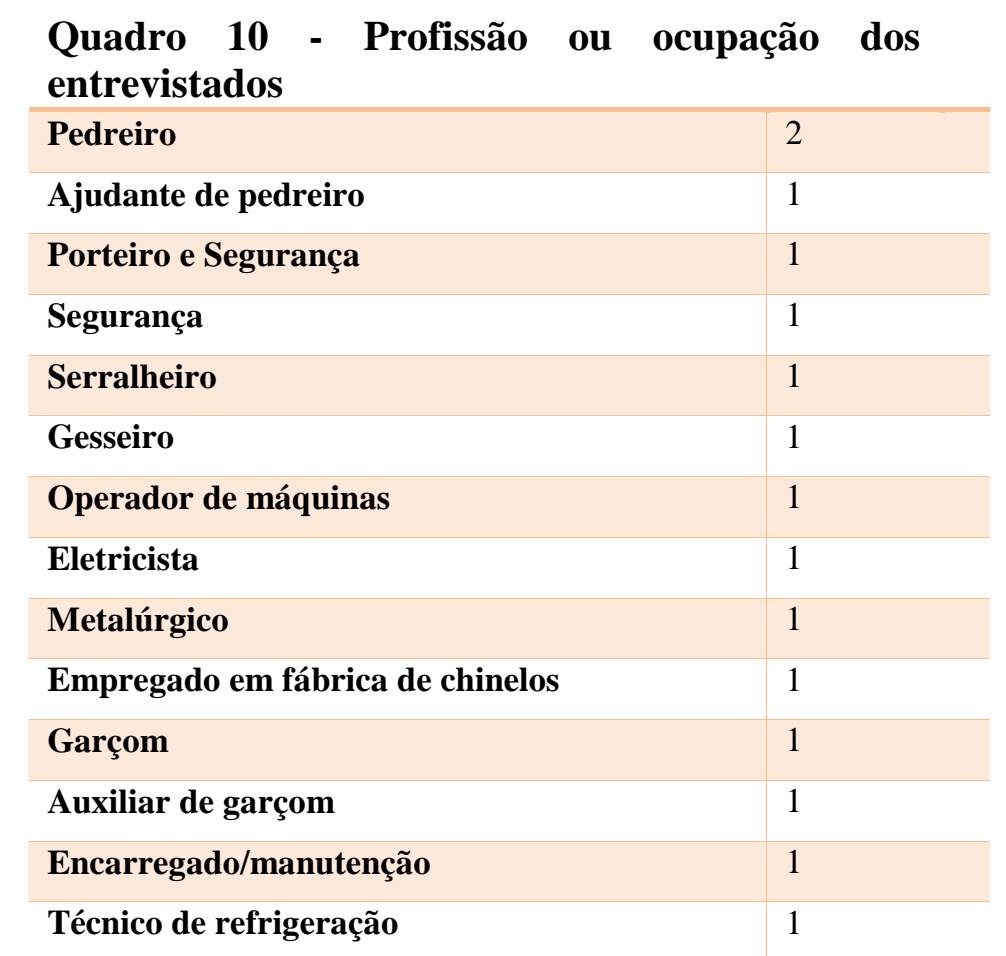

Fonte: Elaborado pelo autor (2016).

Ainda entre os entrevistados tínhamos uma pessoa que disse não estar trabalhando e não respondeu sobre sua profissão; três aposentados, dentre eles um ex manobrista; outro que não falou sobre qual era a sua profissão e um terceiro que ainda trabalhara como montador de eletrodomésticos.

A ocupação dos nordestinos entrevistados encontra fortes aproximações com as profissões dos responsáveis pelos estudantes partícipes da pesquisa. Os alunos puderam especificar com o que seus pais e mães trabalhavam por meio do Questionário de Caracterização do Aluno. Trata-se de profissões e ocupações que nem sempre exige alto grau de escolaridade, sendo que em algumas delas, os direitos trabalhistas podem não ser plenamente assegurados. 
Com base no questionário anteriormente citado obtivemos que em relação as mães dos jovens escolares, 27 delas são empregadas domésticas; 18 são diaristas; 9 auxiliares de limpeza; 5 cozinheiras e 3 operadoras de caixa. Em menor proporção, manicure, cabeleireira, copeira, dona de comércio, vendedora, secretária, recepcionista, balconista, segurança, cuidadora de criança, publicitária, atendente de telemarketing, assim como mães que se ocupam em atividades atreladas à gastronomia, serviço gráfico e transporte escolar. Um total de 18 estudantes disseram não saber a profissão de suas mães ou com o que elas trabalham.

Obtivemos que $70 \%$ das mães dos estudantes encontram-se empregadas; $13 \%$ desempregadas e $16 \%$ não trabalham, como pode se ver no gráfico 14 .

\section{Gráfico 14 - Empregabilidade das mães dos estudantes}

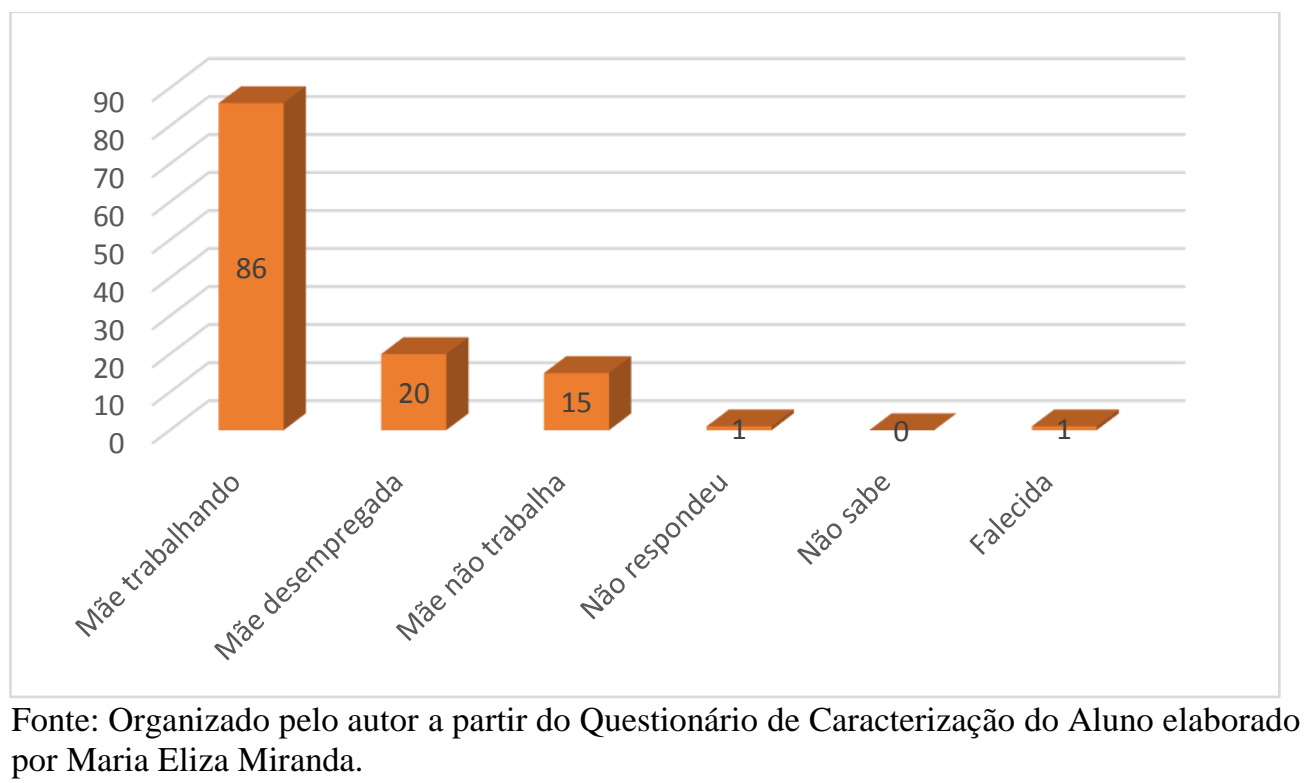

Sobre as ocupações de seus pais, 20 alunos disseram não saber com o que o pai trabalha ou já trabalhou. Um total de 11 pais foram apontados como pedreiros; 8 porteiros; 5 como eletricistas, 5 operadores de máquinas, 4 seguranças, 4 motoristas de ônibus; 3 vendedores, 2 gerentes de vendas, 3 caminhoneiros; 2 vigilantes, 2 motoristas de Uber, 2 motoristas particulares, 2 garçons, 2 metalúrgicos, 2 funileiros e 2 pintores. Em menor proporção apareceram trabalhador que se dedica ao ferro velho, operador de guindaste, técnico de refrigeração, fruteiro, logística, montador de som automotivo, encarregado, açougueiro, transporte escolar, mecânico, vendedor de peixes, carpinteiro, costureiro, cabeleireiro, confeiteiro, dono de banca de jornal, gari e manipulador químico. 
Ainda em relação aos pais dos estudantes evidencia-se que, um total de $85 \%$ estão empregados, $4 \%$ desempregados; $5 \%$ não trabalham; 5\% dos estudantes não souberam responder e $2 \%$ deixaram a questão sem resposta.

\section{Gráfico 15 - Empregabilidade dos pais dos estudantes}

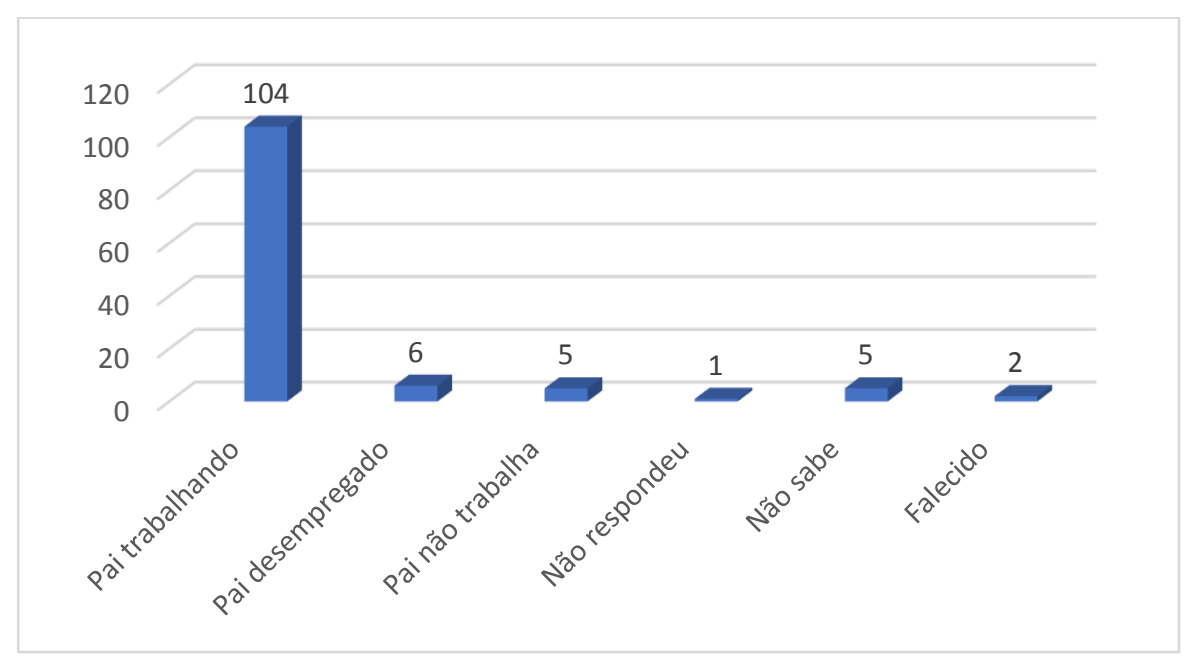

Fonte: Organizado pelo autor a partir do Questionário de Caracterização do Aluno elaborado por Maria Eliza Miranda.

A aproximação das respostas dos migrantes nordestinos com as do questionário de caracterização respondido pelos estudantes, se dá justamente pelo fato de os estudantes serem em maioria descendentes de migrantes nordestinos.

Se compararmos o nível de escolaridade destes migrantes participantes da pesquisa com a renda mensal que declararam, é possível perceber que os salários mais baixos encontram relação com o baixo nível de escolaridade, ao passo que uma melhor formação tende a possibilitar salários melhores, como é possível verificar no gráfico 16.

\section{Gráfico 16 - Correlação entre escolaridade e renda mensal dos entrevistados}

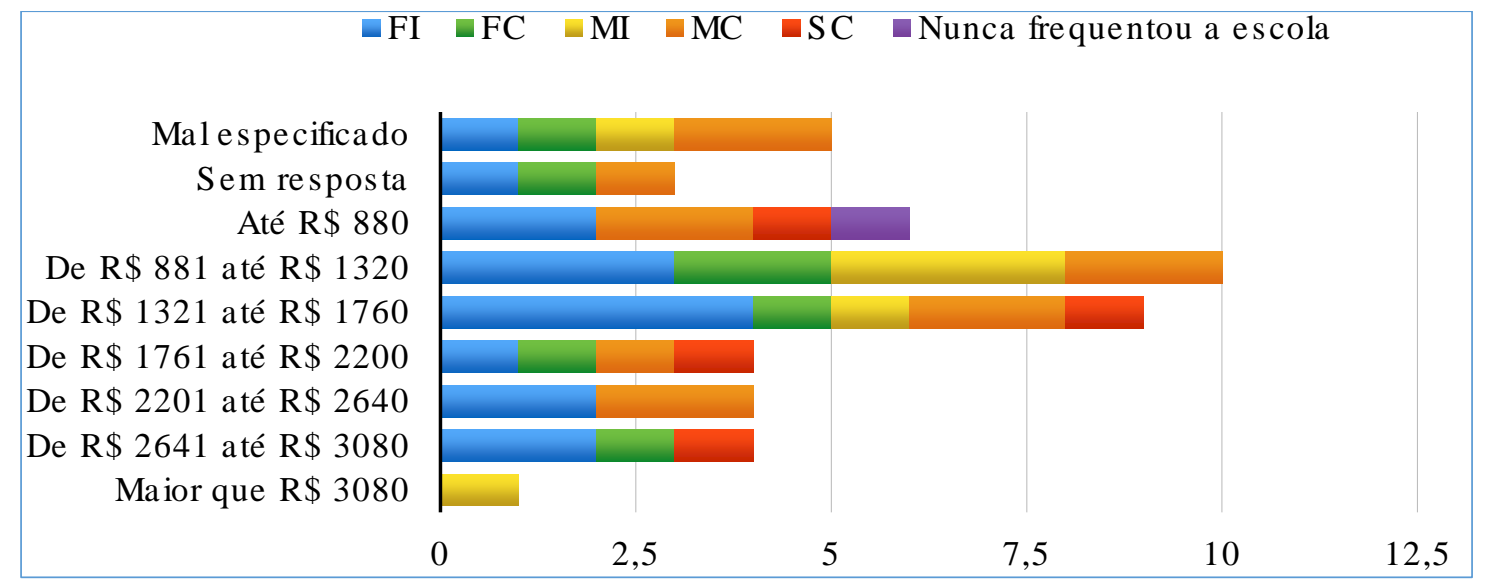

Fonte: Elaborado pelo autor a partir de entrevista realizada por estudantes com migrantes nordestinos em 2016. 
Os próprios entrevistados comentaram a respeito da quantidade de trabalhadores ocupados no setor de serviços. Seus enunciados atribuem a prevalência das ocupações supracitadas majoritariamente à baixa escolaridade.

"Porque hoje em dia está muito difícil arrumar emprego melhor que esses" (cearense, 43 anos, doméstica).

"Por falta de oportunidade e estudo, ou seja, baixa escolaridade" (pernambucana, 37 anos, saladeira).

"Porque foi a única oportunidade que tiveram" (alagoana, 62 anos, pensionista, dona do lar).

"Hoje em dia empresas grandes não dão oportunidade" (pernambucana, 63 anos, aposentada, ex-diarista).

"Acredito que por não ter muito o que oferecer 'pras' empresas para exercer um grande cargo; não ter muito estudo" (baiana, 49 anos, doméstica).

"Por falta de estudo, cursos, faculdade, não conseguem um emprego melhor" (pernambucano, 46 anos, gesseiro).

"Porque essas profissões são mais fáceis de conseguir emprego, ainda mais para as pessoas que não terminaram os estudos" (baiano, 31 anos, pedreiro).

"Primeiro porque não tem mais empregos nas indústrias por elas terem indo embora de São Paulo, então o que sobrou foi casas de família, obras civis e serviços particulares" (baiana, 69 anos, aposentada, exmetalúrgica).

As narrativas dos entrevistados evidenciam a ideia de que a baixa escolaridade pode trazer obstáculos em termos de oportunidades de emprego, num momento em que as exigências do mercado de trabalho ampliam-se significativamente. Os poucos anos de estudos apontados pelos entrevistados ao justificarem a quantidade de pessoas empregadas no setor de serviços, também é verificado neles mesmos. De acordo com o gráfico 17 , um total de $35 \%$ das mulheres entrevistadas possui o ensino médio completo, enquanto $10 \%$ não chegou a concluir esse nível de ensino. $24 \%$ não terminou o ensino fundamental e somente $14 \%$ conseguiu concluí-lo. Em relação ao nível superior $^{164}$, um total de $14 \%$ das entrevistadas afirmou tê-lo concluído. E ainda 3\% respondeu nunca ter ido à escola.

${ }_{164}$ Apesar de termos considerado a resposta de duas participantes que disseram ter nível superior completo, consideramos ter havido algum tipo de equívoco, pois sem termos a pretensão de fazer juízo de 


\section{Gráfico 17 - Grau de escolaridade das mulheres entrevistadas}

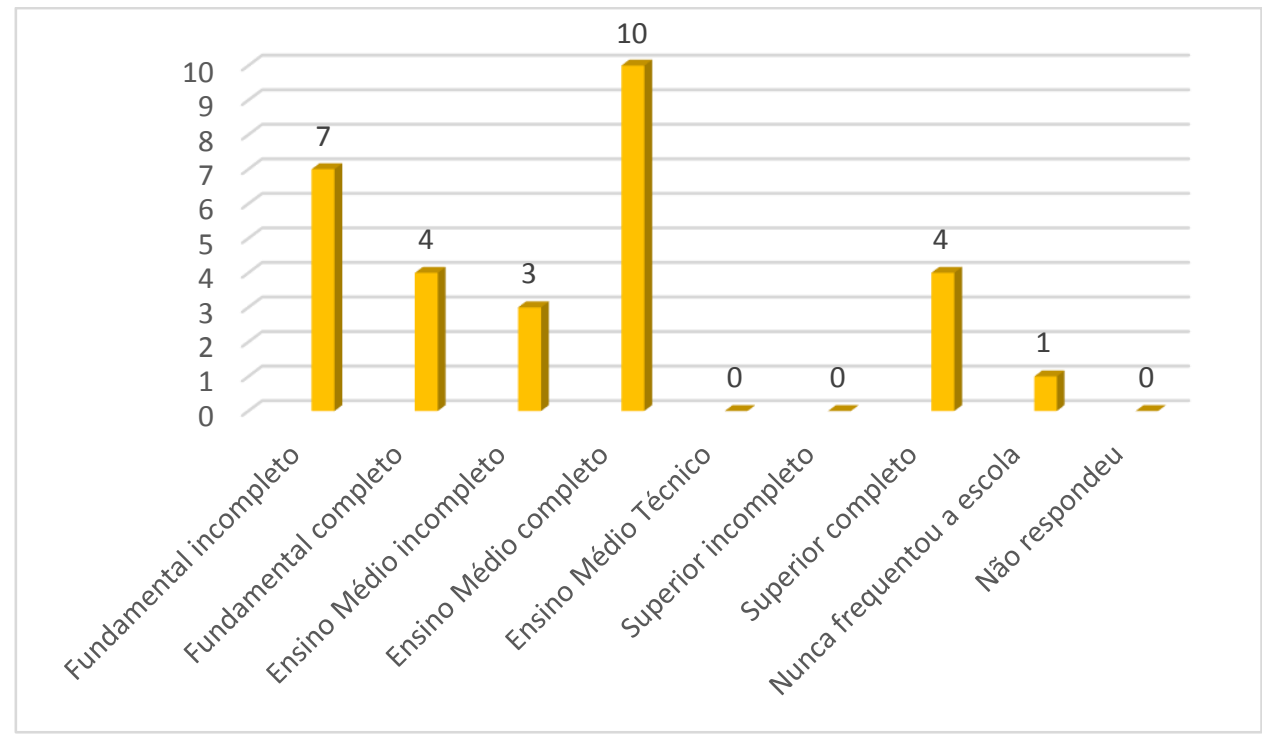

Fonte: Elaborado pelo autor a partir de entrevista realizada por estudantes com migrantes nordestinos em 2016.

Em relação aos homens participantes da entrevista (gráfico 18), apenas um total de $11 \%$ terminou o ensino médio, ao passo que tivemos o mesmo percentual em relação aos que não chegaram a concluí-lo. E ainda $56 \%$ não terminou o ensino fundamental, sendo que apenas $22 \%$ chegou a finalizá-lo. Nenhum deles possui nível superior.

\section{Gráfico 18 - Grau de escolaridade dos homens entrevistados}

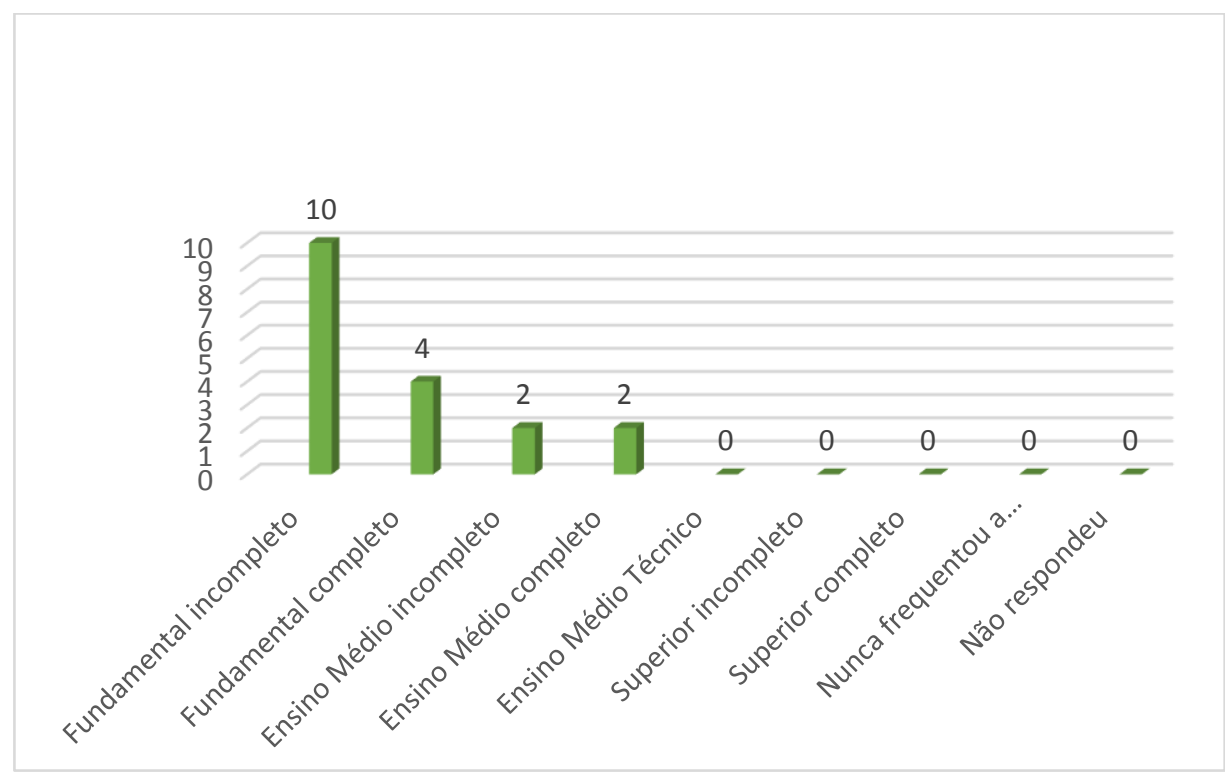

Fonte: Elaborado pelo autor a partir de entrevista realizada por estudantes com migrantes Nordestinos em 2016.

valor, as demais respostas mostravam-se imprecisas, superficiais, calcadas no senso comum, assim como as profissões apontadas por estas entrevistadas, o que mostra haver uma incoerência em suas respostas. 
Considerando que, efetivamente, em tempos recentes, a baixa escolaridade apresenta uma série de obstáculos em termos de empregabilidade e ascensão socioeconômica, buscamos verificar também a escolaridade dos responsáveis pelos estudantes integrantes das quatro turmas de $8^{\text {a }}$ séries, a fim de verificar se há aproximações com os níveis de estudo apresentados pelos migrantes entrevistados. De acordo com o Questionário de Caracterização do Aluno, obtivemos que a maioria das mães não concluiu o ensino médio, como pode ser verificado no gráfico abaixo.

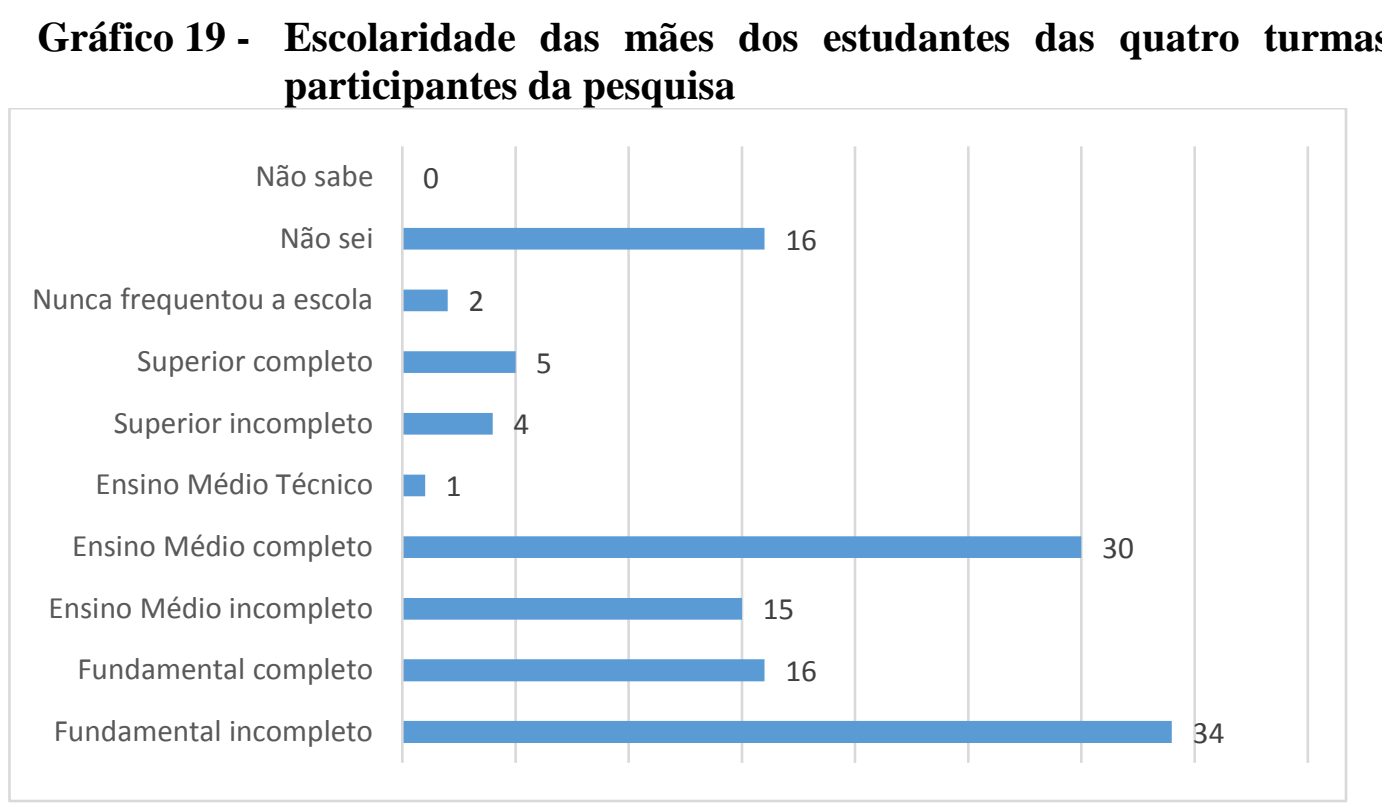

Fonte: Organizado pelo autor a partir do Questionário de Caracterização do Aluno elaborado por Maria Eliza Miranda

De um universo de 123 alunos, 5 apontaram que suas mães possuem nível superior completo e 4 estudantes disseram que a responsável tem o superior incompleto. Dezesseis alunos responderam não saber o nível de escolaridade de suas mães. Chama atenção o fato de 34 mães não terem concluído o ensino fundamental e 15 não terem terminado o ensino médio. Somente 30 finalizaram o ensino secundário e 16 o fundamental completo. Duas mães nunca frequentaram a escola.

Em relação aos pais dos estudantes, é possível perceber - com base no gráfico 20, da página seguinte - que tiveram menos anos de escolaridade quando comparado às mães dos alunos. Obtivemos que 37 não terminaram o ensino fundamental, ao passo que 17 não concluiu o ensino médio. Um total de 14 pais terminou o fundamental e $18 \mathrm{o}$ ensino médio. Concluíram a graduação 6 pais e 2 tem o superior incompleto. Um total de 27 alunos não soube especificar o nível de escolaridade de seus pais. 


\section{Gráfico 20 - Escolaridade dos pais dos alunos das turmas participantes}

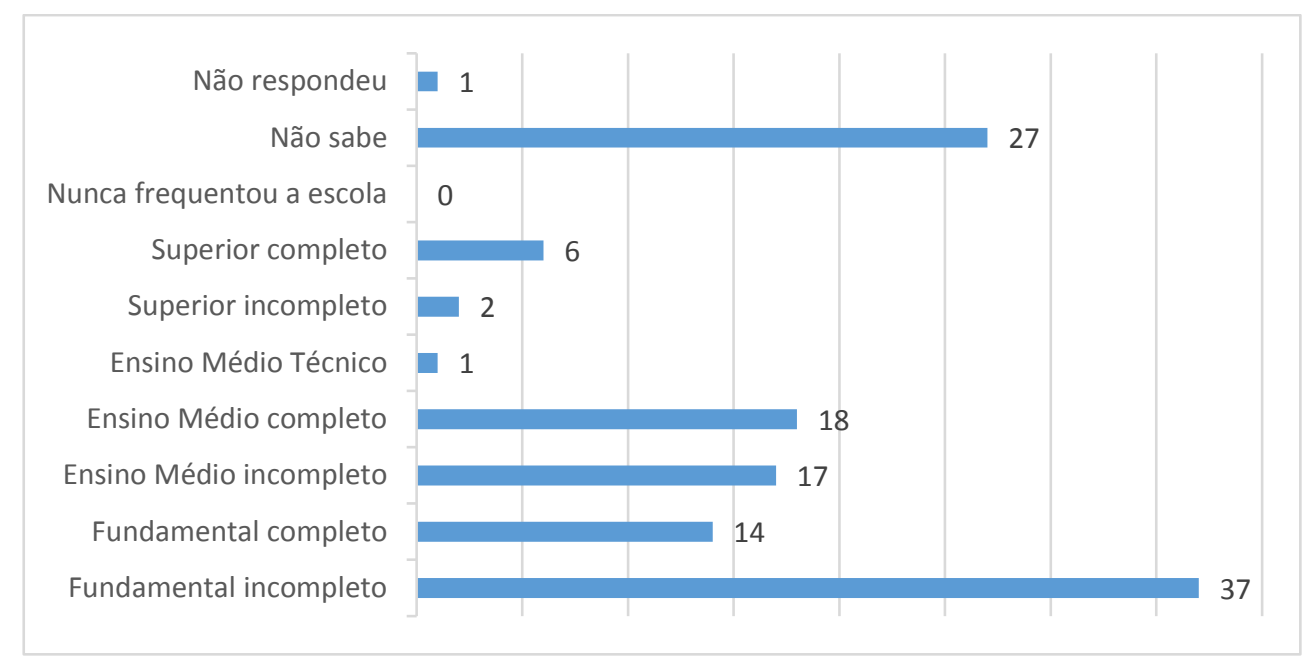

Fonte: Organizado pelo autor a partir do Questionário de Caracterização do Aluno elaborado por Maria Eliza Miranda.

Os dados obtidos referentes ao nível de escolaridade, tanto dos entrevistados pelos alunos como pelas respostas dos estudantes sobre os anos de estudos de seus responsáveis, evidenciam como ainda é curto o tempo de estudo dessa população pesquisada, que nos dá mostras de o quanto ainda é difícil a permanência na escola e o ingresso num curso de nível superior.

Noutra pergunta feita aos migrantes nordestinos, buscávamos identificar se havia na casa do entrevistado alguém que cursara ou que estivesse em curso universitário. Apenas 30\% respondeu ter alguém em sua residência que cursara ou estivesse frequentando curso de nível superior. Um total de $66 \%$ dos entrevistados não tem em casa pessoas com nível superior ou que o estivesse cursando.

\section{Gráfico 21 - Pessoas com nível superior ou graduando em casa}

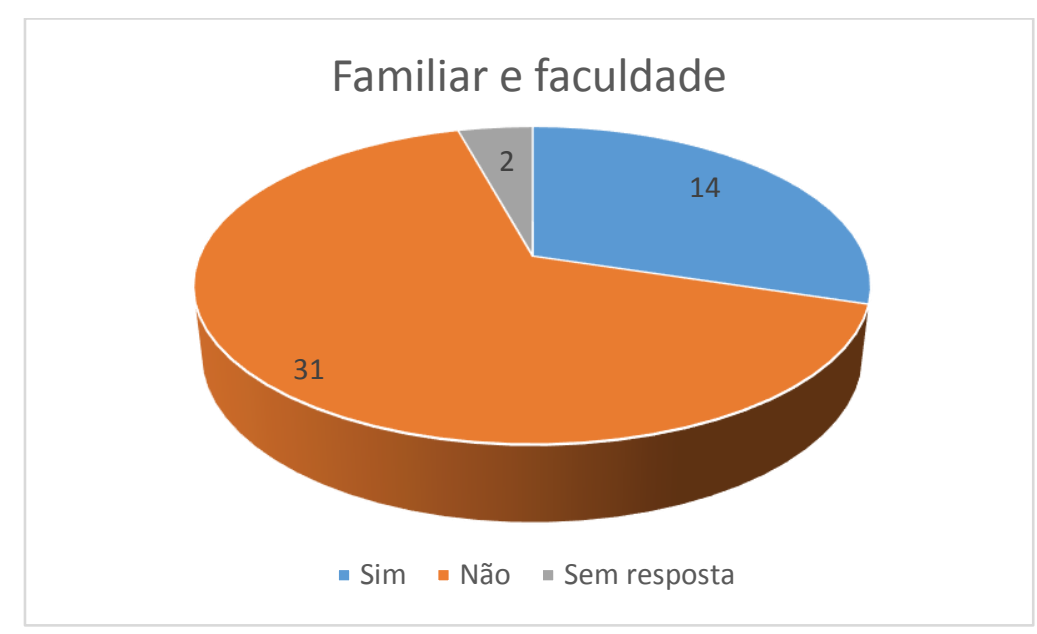

Fonte: Elaborado pelo autor (2016). 
O processo de reestruturação produtiva ocorrente na região metropolitana de São Paulo, com a implantação de novas tecnologias industriais, tem implicado em novas formas de trabalho e de empregabilidade. Nessa era da conectividade e conhecimento, há de um lado, aqueles que exercem os serviços terceirizados, os subempregados e, consequentemente precarizados; do outro, os mais escolarizados, com nível superior, alocados em funções de supervisão e gestão, conhecedores das tecnologias da informação e comunicação. Ricardo Antunes (2009) pontua que, enquanto ocorre a absorção dos desempregados do mundo industrial no setor de serviços, há, todavia, fortes mutações no sistema de gestão, organizacional e tecnológico que acabam por incidir sobre o trabalhador, cada vez mais submetido à lógica dos mercados e à racionalidade do capital ${ }^{165}$.

Indagados se a metrópole de São Paulo oferece possibilidades de emprego a todos (gráfico 22), mais da metade dos migrantes (55\%), disseram considerar que não há tais possibilidades; em torno de um terço (28\%) responderam acreditar que há possibilidades de emprego; $6 \%$ responderam que depende, enquanto $11 \%$ não responderam à questão.

\section{Gráfico 22 - A metrópole e as oportunidade de empregabilidade}

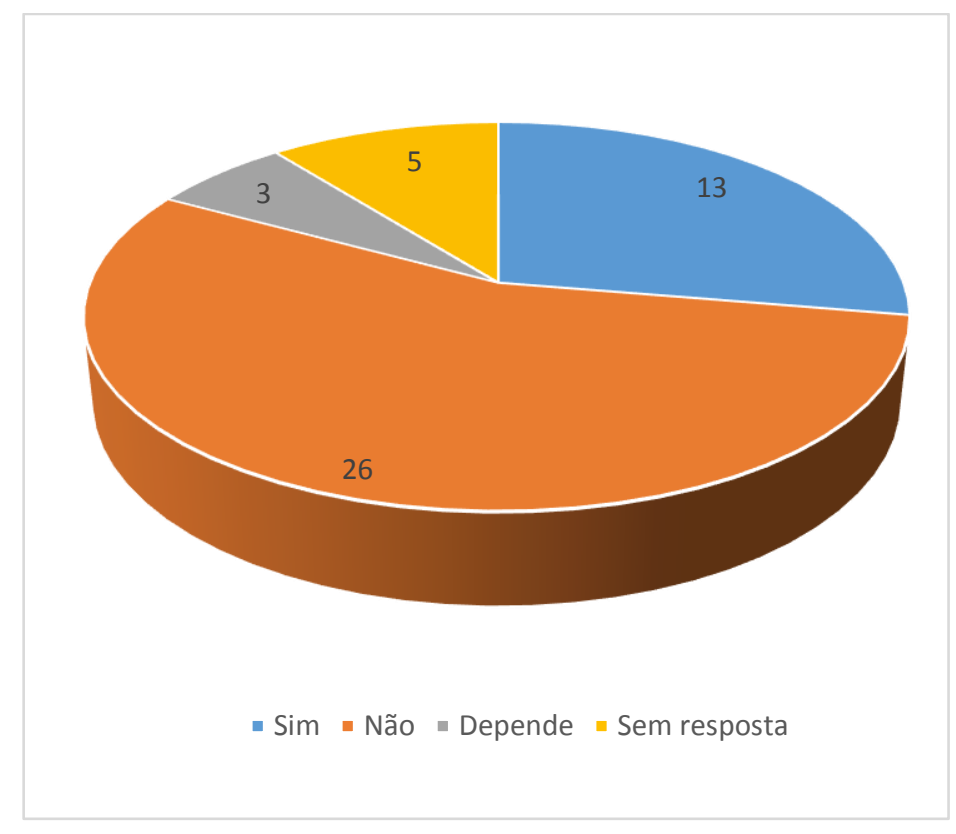

Fonte: Elaborado pelo autor (2016).

165 ANTUNES, R. Século XXI: nova era da precarização estrutural do trabalho? In: ANTUNES, R; BRAGA, Ruy. (Orgs.). Infoproletários: degradação real do trabalho virtual. São Paulo: Boitempo, 2009. 
Os enunciados dos entrevistados dão mostras de que a baixa escolaridade se apresenta como um empecilho para obtenção de uma vaga de emprego, principalmente no período atual em que as tecnologias têm adentrado as empresas em substituição aos trabalhadores $^{166}$.

"[...] hoje em dia as empresas preferem quem tem estudo avançado e os pobres não tem tanto acesso à faculdade" (baiana, 45 anos, desempregada).

"[...] porque tem muita gente e pouco emprego; na verdade, antigamente tinha mais oportunidades. Hoje em dia as empresas estão substituindo pessoas pela tecnologia” (pernambucana, 37 anos, saladeira).

"[...] muito trabalho antigamente, mas hoje em dia não, porque eles estão substituindo 'nós' pelas máquinas" (pernambucano, 53 anos, pedreiro).

"Não, claro que não. Por isso mesmo as indústrias não existem mais. $O$ pessoal começa o que tem e pega um ou dois empregados, depois não consegue pagar" (baiana, 69 anos, aposentada, ex-metalúrgica).

“Já teve, hoje em dia não tem mais" (maranhense, 37 anos, bordadeira).

"Não, muitos lugares precisam de até pelo menos o primeiro grau completo e muitas pessoas não tem” (cearense, 38 anos, diarista).

“Antes, há 10 anos atrás, tinha. Agora não tem mais” (alagoano, 44 anos, auxiliar de garçom).

Para outros participantes, as oportunidades existem, no entanto, tudo depende da dedicação, do esforço e vontade própria das pessoas, como afirmam a seguir.

"Sim, só é ter força de vontade, ir à luta e trabalhar" (pernambucana, 41 anos, auxiliar de limpeza).

"Sim. São Paulo é uma área que qualquer coisa consegue dinheiro. Só não trabalha quem não quer, porque São Paulo tem muitas empresas" (baiano, 33 anos, encanador).

\footnotetext{
166 Antunes $(2015$, p. 33, 34) discorre sobre um período em que o fordismo e taylorismo já não se apresentam como únicos, pois acabam mesclando-se com outras formas de produção ou até mesmo sendo substituídos pelo toyotismo. Seria o avanço com grandes saltos tecnológicos, "a automação, a robótica e a microeletrônica invadiram o universo fabril, inserindo-se e desenvolvendo-se nas relações de trabalho e de produção do capital. Vive-se, no mundo da produção, um conjunto de experimentos, mais ou menos intensos, mais ou menos presentes, mais ou menos tendenciais, mais ou menos embrionários". ANTUNES, Ricardo. Adeus ao Trabalho? Ensaio sobre as metamorfoses e a centralidade do mundo do trabalho. 16 ed. São Paulo: Cortez, 2015.
} 
Se considerarmos que além de haver entre os entrevistados quase metade que afirma ter alguém desempregado em casa e que $66 \%$ afirma não ter em sua residência alguém que já cursara ou esteja em curso de nível superior, é possível que o cenário futuro de empregabilidade para os destituídos de trabalho e de escolarização, seja também no trabalho precarizado, como aponta Pierre Bourdieu (1998, p. 123, 124):

\begin{abstract}
A precariedade atua diretamente sobre aqueles que ela afeta e indiretamente sobre todos os outros pelo temor que ela suscita e que é metodicamente explorado pelas estratégias de precarização, com a introdução da famosa 'flexibilidade'. Começa-se assim a suspeitar que a precariedade seja o produto de uma vontade política, e não de uma fatalidade econômica, identificada com a famosa 'mundialização'. A precariedade se inscreve num modo de dominação de tipo novo, fundado na instituição de uma situação generalizada e permanente de insegurança, visando obrigar os trabalhadores à submissão, à aceitação da exploração. Apesar de seus efeitos se assemelharem muito pouco ao capitalismo selvagem das origens, esse modo de dominação é absolutamente sem precedentes, motivando alguém a propor aqui o conceito ao mesmo tempo muito pertinente e muito expressivo de "flexploração" 167 .
\end{abstract}

Quando perguntados se acreditam que as novas tecnologias trazem mais impactos positivos ou negativos, 29 migrantes disseram que os impactos são negativos; apenas 5 atribuíram às novas tecnologias impactos positivos. Um total de 10 pessoas disseram que depende e três participantes não responderam à questão.

\title{
Gráfico 23 - Impactos positivos ou negativos provenientes das novas tecnologias
}

Novas tecnologias: impactos positivos ou negativos?

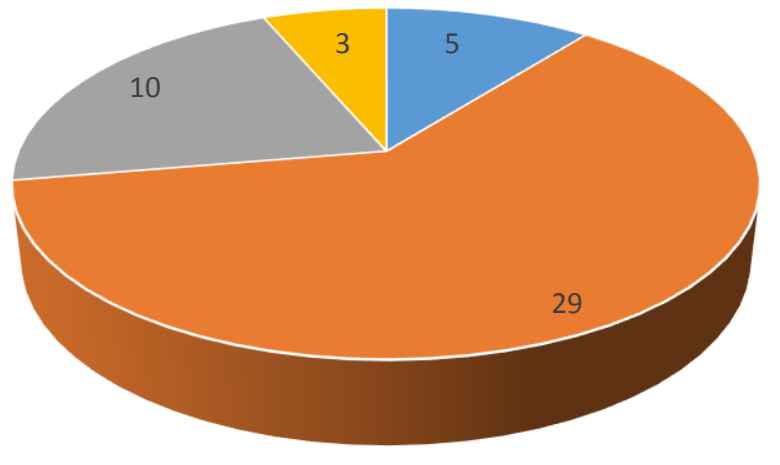

- Positivos $\because$ Negativos $\square$ Depende $\backsim$ Sem resposta

Fonte: Elaborado pelo autor a partir de entrevista realizada por estudantes com migrantes nordestinos em 2016.

${ }^{167}$ BOURDIEU, Pierre. Contrafogos. Rio de Janeiro: Zahar, 1998. 
Dentre as falas podemos destacar o uso da palavra "máquina" como sendo uma das responsáveis pela substituição dos trabalhadores.

"Com a tecnologia as pessoas estão ficando desempregadas. No setor onde era para estar quatro ou cinco pessoas, está uma grande máquina operando" (baiana, 43 anos, diarista).

"Beneficios que facilitaram trabalhos que demoravam muito tempo e impactos negativos porque algumas máquinas assumiram o lugar dos trabalhadores" (baiano, 34 anos, serralheiro).

"Negativos porque as pessoas estão ficando desempregadas, por conta das máquinas estarem tomando os lugares delas nas fábricas” (baiana, 41 anos, diarista).

"Impactos negativos. Tiraram os funcionários para colocar máquinas" (baiano, 31 anos, pedreiro).

As empresas dotadas de novas tecnologias têm tornando o trabalhador do setor industrial desnecessário para realizar determinadas funções. Alves (2005) aponta no plano das qualificações operárias, as que estariam sendo tidas como "obsoletas", levando o trabalhador a uma permanente exclusão do mercado de trabalho ou seu ingresso se dando nos setores mais arcaicos da economia ${ }^{168}$.

Os entrevistados consideram que os benefícios e vantagens se deram para os proprietários das empresas, pois o aumento do desemprego e as dificuldades financeiras oriundas deste, deu-se justamente em função do uso de maquinários mais avançados.

"Trouxe pra quem tem empresa, que é dono [...] mas, pra quem é peão não trouxe, porque tão ficando tudo sem emprego" (baiana, 49 anos, doméstica).

"Trouxe beneficios para as empresas e maleficios para a população devido as demissões" (alagoano, 44 anos, garçom).

"Pra mim trouxeram mais pontos positivos, porque sem esse maquinário estaríamos atrasados demais; tem que ter" (cearense, 59 anos, metalúrgico).

"Ambos, porque facilitou o trabalho nas fábricas, mas deixou muitos desempregados" (alagoano, 44 anos, garçom).

"Eu acho que por uma parte foi bom, mas agora os robôs tomaram os empregos" (baiana, 69 anos, aposentada e ex-metalúrgica).

${ }^{168}$ ALVES, Giovanni. O novo (e precário) mundo do trabalho: reestruturação produtiva e crise do sindicalismo. São Paulo: Boitempo, 2005. 
Algumas das mulheres entrevistadas apontaram as dificuldades financeiras que chegaram a enfrentar em suas trajetórias de vida.

"[...] quando fiquei sem emprego em indústria e tive que trabalhar como diarista; o marido desempregado e dois filhos para criar" (baiana, 50 anos, diarista).

"[...] tinha um filho para cuidar e separada do marido - não que isso seja o motivo por o qual eu passava dificuldade e sim pelo fato dele não pagar pensão - e isso me fazia ter um pouco mais de dificuldade por pagar aluguel [...]" (baiana, 49 anos, doméstica).

"Sim, quando eu fiquei viúva com três filhos pequenos para criar" (alagoana, 62 anos, pensionista).

"[...] a maior dificuldade que passamos foi a falta de alimento; o pai ficou desempregado. Não tínhamos condição financeira" (maranhense, 37 anos, bordadeira).

Verificamos nos depoimentos, tanto dos homens quanto das mulheres, um quadro de precarização dos trabalhadores decorrente do regime de acumulação flexível e da reestruturação produtiva, que se expande em escala global $^{169}$.

Dos 47 nordestinos entrevistados, 35 deles afirmaram já ter enfrentado dificuldades financeiras, ao passo que 11 indivíduos disseram que não. Apenas uma pessoa deixou de responder a essa questão, como pode ser visto no gráfico 24.

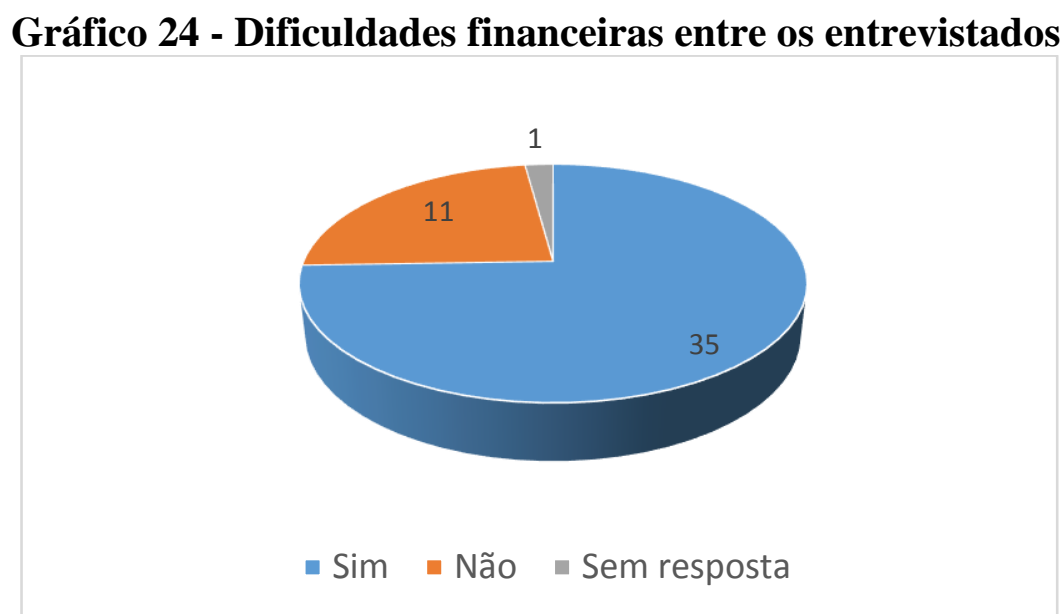

Fonte: Elaborado pelo autor a partir de entrevista realizada por migrantes Nordestinos em 2016.

169 Conforme Antunes \& Alves (2004, p. 337) tratam-se dos "terceirizados, subcontratados, part-time, entre tantas outras formas assemelhadas, que se expandem em escala global”. ANTUNES, R.; ALVES, G. As mutações no mundo do trabalho na era da mundialização do capital. In: Educ. Soc., Campinas, vol. 25. n. 87, p. 335-351, maio/agos. 2004. Caderno Cedes. 
Os migrantes nordestinos, sujeitos das entrevistas realizadas pelos estudantes de quatro turmas de oitavas séries, vivenciam as contradições do meio técnico-científicoinformacional e da sociedade em rede. Ademais, a entrevista fora uma tentativa e um esforço, em possibilitar, ainda que parcialmente, que os estudantes pudessem ter contato com aspectos de uma realidade, que é ao mesmo tempo a sua realidade, mas não somente sua, pois apresenta universalidade, sendo ocorrente em outras escalas, e que é insuficiente se não conectada às escalas de outros de lugares, tempos e espaços. 


\section{CAPÍTULO 4 AS CONTRIBUIÇÕES DE LEV VIGOTSKI E REUVEN FEUERSTEIN PARA OS PROCESSOS DE APRENDIZAGEM}

As concepções do bielorrusso Lev Semionovitch Vigotski e do romeno Reuven Feuerstein nos serviram como eixos estruturadores e aportes teóricos para aplicação da Sequência Didática de nossa pesquisa, que será tratada em capítulos subsequentes. Os referidos autores são fundamentais para a compreensão das aprendizagens, principalmente no tocante à questão da linguagem, da mediação por meio dos signos, do modo como o pensamento se estrutura e se processa, assim como da atividade prática e da mediação humana. No Brasil as teorias de Vigotski passaram a fazer parte das discussões envolvendo professores a partir de meados da década de 1980 e as concepções de Feuerstein somente em décadas mais recentes. A importância dos autores para o desenvolvimento cognitivo e intelectual de crianças e adolescentes, nos leva a tecer algumas considerações a respeito de suas teorias, lembrando que fora o psicólogo Alex Kozulin quem fez as aproximações entre Jean Piaget, Vigotski e Feuerstein.

\subsection{OS APORTES TEÓRICOS DE VIGOTSKI PARA A COMPREENSÃO DA DIMENSÃO PSICOLÓGICA DO SER HUMANO}

Vigotski destacou-se por seus trabalhos ao lado dos colegas pesquisadores russos Aleksei Nikolaievitch Leontiev e Aleksandr Romanovitch Luria nas primeiras décadas do século XX. Seus escritos foram proibidos por vinte anos pelo regime stalinista soviético, sendo permitidas suas publicações somente em $1956^{170}$. Apesar de marxista, fora proibido em seu país por ser considerado um perigo pelo governo autoritário vigente.

Zoia Prestes (2012) reportando-se ao autoritarismo de Stálin, ressalta que com o seu fortalecimento no poder na década de 1930, todas as produções científicas obrigatoriamente tinham que passar pelo crivo da censura, manifestando seus fundamentos marxistas para que efetivamente pudessem ser publicadas ${ }^{171}$. Desse modo, apenas em 1955, após mais de vinte anos da morte de Vigotski, Luria e Leontiev conseguiram publicar e republicar os trabalhos do colega pesquisador.

\footnotetext{
${ }^{170}$ PRESTES, Z. Quando não é quase a mesma coisa: traduções de Lev Semionovitch Vigotski no Brasil. Campinas, SP: Autores Associados, 2012.

171 Alex Kozulin (2000) ressalta que devido ao interesse de Vigotski pela análise intercultural da cognição, pela psicologia da Gestalt e pela psicanálise, fora considerado um antimarxista, errôneo e eclético pelo regime stalinista. KOZULIN, A. Instrumentos psicológicos: la educación desde una perspectiva sociocultural. Barcelona: Paidós, 2000.
} 
Em meados da década de 1920 o grupo liderado por Vigotski se debruçou acerca do comportamento e da consciência humana, apoiados no materialismo histórico e dialético, sobrelevando a relevância da cultura e da história no desenvolvimento humano. Conforme Prestes ${ }^{172}$ (2012) tivera início nos anos vinte, com a teoria históricocultural, pesquisas referentes à gênese da consciência e a condição social do indivíduo, levando à novas interpretações concernentes à estrutura das funções psicológicas superiores e sua origem, diferenciando totalmente da psicologia que vigorava na época.

Apesar disso, as concepções decorrentes das teorias comportamentalistas assentavam-se num padrão fragmentado, atomístico, como se os fenômenos estudados pela psicologia estivem separados. Beyer (1996) enfatiza que o período em que Vigotski realizou suas pesquisas, adquiriu considerável visibilidade, em que pese ter prevalecido no âmbito da psicologia soviética as teorias comportamentalistas que privilegiavam a associação estímulo-resposta, destacando nomes como Ivan Pavlov e John B. Watson, dentre outras importantes figuras da Gestalt ${ }^{173}$.

$\mathrm{O}$ século XX fora de grandes avanços no campo da psicologia, pois além das contribuições de Vigotski, o pesquisador suíço Jean Piaget, percebeu - avançando nas concepções da estrutura do pensamento - que quando as crianças estavam em contato com determinados objetos ou em contato com contos e histórias, interiorizavam essas ações num processo que transitava da ação ao pensamento ${ }^{174}$. De acordo com Kozulin (2000, p. 53):

[...] Piaget y Vygotsky estaban de acuerdo era relación existente entre la acción y el pensamiento. La psicologia mentalista clásica suponía la primacía del pensamiento sobre la acción, de modo que la acción sólo se veía como un pensamiento realizado. Se suponía que una persona debía tener primero una idea de una solución dada antes de poder plasmarla en un acto concreto. El pensamiento, a su vez, se veía principalmente como una representación de la realidad y no como un médio para actuar sobre ella.

Vigotski atribuía significativa relevância às interações, destacando que estas não ocorriam de modo espontâneo, mas por mediações. A mediação fora concebida como o recurso para que se desse o desenvolvimento das atividades mentais mais complexas e

172 PRESTES, Zoia. Quando não é quase a mesma coisa: traduções de Lev Semionovitch Vigotski no Brasil. Campinas, SP: Autores Associados, 2012.

${ }^{173}$ BEYER, H. O. O fazer psicopedagógico: a abordagem de Reuven Feuerstein a partir de Vygotsky e Piaget. Porto Alegre: Mediação, 1996.

${ }^{174}$ Para Jean Piaget (2012, p. 20-21), “[...] a passagem da ação ao pensamento ou do esquema sensório motor ao conceito não se realiza sob a forma de uma revolução brusca, mas pelo contrário, sob a forma de uma diferenciação lenta e laboriosa, ligadas às transformações da assimilação". PIAGET, J. Epistemologia genética. $4^{\mathrm{a}}$ ed. São Paulo: Editora WMF Martins Fontes, 2012. 
elaboradas, tais como pensamento, memória, atenção, fala e imaginação, tratadas por Vigotski como funções psíquicas superiores.

Seus estudos consideram as condições sociais em que as crianças estão submetidas, tendo elevada importância para o desenvolvimento de suas estruturas cognitivas, pois o contexto social e histórico em que o indivíduo se vê imerso, o leva a passar por uma série de mediações que se dão, sobretudo, pela cultura ${ }^{175}$.

Vigotski considerava que a aprendizagem impulsionava o desenvolvimento da criança e do adolescente. Ocorre que Piaget, na época do bielorrusso, não se detinha às questões correlatas à educação e a aprendizagem, pois dedicava-se a cognição humana. Anos mais tarde o pesquisador suíço passa a se dedicar às questões atreladas à educação, partindo da premissa de que desenvolvimento e aprendizagem não estavam implicados, pois, o indivíduo deveria passar por determinados níveis maturacionais de desenvolvimento para que pudesse efetivamente operar determinados problemas. Vigotski, ao contrário, procurou a imbricação entre desenvolvimento e aprendizagem, considerando que esta, sendo fomentada e estimulada mais cedo, acabava por potencializar o desenvolvimento do indivíduo. Conforme Vigotski (2010, p. 523):

\begin{abstract}
Piaget separa o processo de aprendizagem do processo de desenvolvimento, estes se revelam desproporcionais, e isto significa que na escola ocorrem na criança dois processos independentes entre si: o processo de desenvolvimento e $o$ de aprendizagem. $O$ fato de a criança estudar e o fato de a criança desenvolver-se não tem nenhuma relação entre si. Mas se tomarmos o desenvolvimento mental da criança do ponto de vista do conteúdo e do material do pensamento, mantendo a posição de Piaget teremos de parar de investigar a relação entre os processos de desenvolvimento e aprendizagem ${ }^{176}$.
\end{abstract}

Vigotski trabalhava com a concepção de que a aprendizagem era decorrente das interações sociais, onde o indivíduo era fortemente influenciado por seu meio. $\mathrm{O}$ pesquisador partira do pressuposto de que a criança estando em interação com outras pessoas passava a assimilar os significados, as definições e as ideias, internalizando-as, para depois ressignificá-las construindo seus próprios conceitos.

De acordo com Kozulin (2002), se não houver a mediação de modo adequado, para que as crianças efetivamente compreendam os significados dos símbolos como instrumentos cognitivos, a aprendizagem não se concretiza, pois nestas condições os signos não terão utilidade alguma. Para este autor, o uso de textos e sinais unicamente

175 De acordo com Cristiano Mauro A. Gomes (2002), Vigotski sempre enfatizava em seu percurso teórico o papel da mediação e da cultura, pois para ele só havia sentido uma ação humana. GOMES, C. M. A. Feuerstein e a construção mediada do conhecimento. Porto Alegre: Artmed, 2002.

${ }^{176}$ VIGOTSKI, L. S. Psicologia pedagógica. 3ª ed. São Paulo: Ed WMF Martins Fontes, 2010. 
dispostos aos indivíduos, desprovidos de mediação, não asseguram a sua apropriação como instrumentos psicológicos. O autor exemplifica a dimensão dos pais e professores como potenciais mediadores no processo de alfabetização das crianças, sendo que sem esta intervenção torna-se insuficiente apenas a escrita ou a classe de mediadores simbólicos ${ }^{177}$.

Dada à importância dos instrumentos simbólicos, com os quais as pessoas lidam cotidianamente e a relevância que apresentam para que os indivíduos passem a desenvolver-se cognitivamente, a fala, torna-se de significado preponderante durante o processo de aprendizagem.

Vigotski (2008, p. 7) avulta que: “A transmissão racional e intencional de experiência e pensamento a outros requer um sistema mediador, cujo protótipo é a fala humana, oriunda da necessidade de intercâmbio durante o trabalho" 178 .

O autor supracitado percebeu que a palavra se apresenta à criança comportando uma dada sonoridade e um determinado signo, todavia, os significados se diferenciam de acordo com as diversas situações em que é empregada. Com o tempo passam por processos intelectuais expressando novos significados, chegando à consciência no período da adolescência, momento em que o indivíduo tem a capacidade da generalização da palavra empregando-a em variados contextos e com significados diferentes.

O pesquisador atentou em seus estudos, de modo mais sobrelevado, para a diferença existente entre o pensamento de uma criança de três anos e de um adolescente, pois devido ao pensamento por conceitos, o indivíduo compreende a realidade, aos outros e a si, sendo uma "revolução" produzida na consciência e no pensamento do jovem $^{179}$. Para Vigotski, não se trata de...

[...] nenhum exagero afirmar que identificar operações intelectuais que surgem na puberdade com o pensamento de uma criança de três anos, como fazem muitos psicólogos, tem tão pouco fundamento quanto negar que a segunda idade escolar é a época do amadurecimento sexual apenas com base no fato de que os elementos da futura sexualidade [...] já se revelam na criança na fase da amamentação $^{180}$ (VIGOTSKI, 2009, p. 168).

177 KOZULIN. A. O conceito de atividade na psicologia soviética: Vygotsky, seus discípulos, seus críticos. In: DANIELS, Harry. (Org.). Uma introdução a Vygotsky. São Paulo, SP: Edições Loyola, 2002.

${ }^{178}$ VIGOTSKI, Lev Semenovich. Pensamento e Linguagem. $4^{\mathrm{a}}$ ed. São Paulo: Martins Fontes, 2008.

${ }^{179}$ Kozulin (Ibidem, p. 113) aponta que na concepção de Vigotski, se compreende "(...) a construção da consciência de fora para dentro por meio da relação com os outros".

${ }^{180}$ VIGOTSKI, L. S. A construção do pensamento e da linguagem. $2^{\mathrm{a}}$ ed. São Paulo: Martins Fontes, 2009 
Vigotski (2008) explicita que na fase mais prematura da infância tem início o desenvolvimento de processos que por fim ocasionam na formação de conceitos, porém, a base psicológica do processo de formação de conceitos, constituída por funções intelectuais que se combinam, vai amadurecendo e configurando-se de modo a desenvolver-se somente na puberdade ${ }^{181}$. Para o autor, o que se tem no adolescente antes dessa idade são formações intelectuais parecidas com os verdadeiros conceitos que ainda estão por surgir

As mediações pela cultura entre os indivíduos, aos poucos são internalizadas, possibilitando o desenvolvimento das funções psíquicas superiores. Vigotski evidencia em seus estudos a importância dos fatores histórico-culturais e do acúmulo de significados para o desenvolvimento do indivíduo, entretanto, não desconsidera a relevância dos fatores biológicos, como pode ser verificado em Prestes (2012, p. 21):

Vigotski não negava a importância do biológico no desenvolvimento humano, mas afirmava que é ao longo do processo de assimilação dos sistemas de signos que as funções psíquicas biológicas se transformam em novas funções, em funções psíquicas superiores. Para ele, todo processo psíquico possui elementos herdados biologicamente e elementos que surgem na relação e por influência do meio ${ }^{182}$.

O autor acima enfoca a característica psicológica das relações humanas como possibilidade para o desenvolvimento dos processos psíquicos superiores. Assim, defende que o conhecimento se manifesta a partir das relações interpessoais, ou seja, do contato do indivíduo com outras pessoas, para que em seguida se efetive a internalização no sujeito, num processo de reconstrução, diferentemente de uma cópia da realidade. Conforme Kozulin (2002, p. 117), “o princípio construtor das funções superiores reside fora do indivíduo - nas ferramentas psicológicas e nas relações interpessoais ${ }^{183}$,"

Se forem estimuladas as interações que ocorrem em sala de aula, há que se considerar que o aluno se encontra num espaço em que lida com relações de sociabilidade, podendo internalizar informações, para que possa então ressignificá-las. De acordo com Beyer (1996), é por meio das interações do indivíduo com o grupo

\footnotetext{
${ }^{181}$ VIGOTSKI, L. S. Pensamento e Linguagem. $4^{\text {a }}$ ed. São Paulo: Martins Fontes, 2008.

182 PRESTES, Z. Quando não é quase a mesma coisa: traduções de Lev Semionovitch Vigotski no Brasil. Campinas, SP: Autores Associados, 2012.

${ }^{183}$ KOZULIN. A. O conceito de atividade na psicologia soviética: Vygotsky, seus discípulos, seus críticos. In: DANIELS, Harry. (org.). Uma introdução a Vygotsky. São Paulo, SP: Edições Loyola, 2002.
} 
cultural do qual faz parte, que se dão os processos interpsíquicos, sendo que gradativamente ocorre por meio da mediação pela cultura, a construção pelo indivíduo das estruturas linguísticas e cognitivas. Nas palavras do autor:

[...] os processos cognitivos superiores são chamados justamente de processos culturais devido à ênfase nas situações de mediação psicológico-cultural da aprendizagem. Os assim denominados instrumentos psicológicos, constituídos pelos signos, símbolos e pelos discursos humanos, formam a mais importante classe dos mediadores. As ferramentas psicológicas são orientadas internamente, no sentido de mudança dos processos psicológicos individuais ${ }^{184}$ (BEYER, 1996, p. 53).

Convém lembrar a importância da fala para Vigotski no processo de estruturação do pensamento. De acordo com Solange Jobim Souza (2008, p. 132), "Vygotsky parte da premissa de que a função primordial da fala, tanto na criança quanto nos adultos, é o contato social. A fala mais primitiva da criança é, portanto, essencialmente social"185. Na mesma direção aponta Prestes (2012, p. 21) ao ponderar que:

\begin{abstract}
As pesquisas mostraram que as funções psíquicas especificamente humanas, como o pensamento lógico, a memória consciente e a vontade, não se apresentam prontas ao nascer. Elas formam-se durante a vida como resultado da apreensão da experiência social acumulada pelas gerações precedentes, ao dominarem-se os recursos de comunicação e de produção intelectual (antes de tudo, por meio da fala), que são elaborados e cultivados pela sociedade.
\end{abstract}

A teoria desenvolvida por Vigotski procurou cobrir amplamente a questão da relação entre o pensamento e a fala. Prestes (2012) em estudo minucioso sobre as traduções de Vigotski e as deturpações provenientes de tais equívocos, aponta que no Brasil, a palavra "fala" fora traduzida por "linguagem", o que de certo modo, trouxe consideráveis incorreções.

As premissas do referido psicólogo dão conta de que as pessoas estão em frequentes interações, sendo a mediação uma constante nessas relações, ora no contato entre indivíduos, ora com os signos. Consequentemente, a aprendizagem se processa nas condições de trocas interpessoais e intrapessoal. As capacidades intelectuais das crianças se desenvolvem na medida em que interiorizam os elementos da cultura, por meio dos signos e das ferramentas simbólicas.

\footnotetext{
${ }^{184}$ BEYER, Hugo Otto. O fazer psicopedagógico: a abordagem de Reuven Feuerstein a partir de Vygotsky e Piaget. Porto Alegre: Mediação, 1996.

185 SOUZA, Solange Jobim. Infância e linguagem: Bakhtin, Vygotsky e Benjamim. Campinas, São Paulo: Papirus, 2008.
} 
De acordo com Vitor da Fonseca (1998), as pessoas em torno da criança, não são simples e passivos objetos de seu desenvolvimento, mas indivíduos que agem ativamente, selecionando, filtrando, regulando e guiando as condutas do mediatizado ${ }^{186}$.

Pensando nas relações que se desenvolvem em sala de aula, consideramos que o aluno se encontra em um processo de constantes interações com seus colegas e professores, em que as relações interpessoais e o contato com objetos, signos e valores de uma dada cultura são internalizados, reelaborados e adquirem ressignificações, formando suas representações de mundo. Assim, a escola deve ser pensada como espaço privilegiado para o desenvolvimento intelectual do ser humano, para que de fato possam nela ter a possibilidade de serem iniciados no sistema de elaboração de conceitos científicos, assim como, compreender, atuar, agir e transformar o mundo.

O ensino de geografia, se apoiado em uma perspectiva que leve em conta dimensão psicológica do aluno, pode contribuir para apoiar o desenvolvimento das funções intelectuais dos jovens escolares. De acordo com Pierre Monbeig (1956, p. 16), "[...] o ensino de geografia é passível de auxiliar a expansão das funções intelectuais dos jovens. Deve ficar bem claro ser esse o papel fundamental do ensino" ${ }^{\text {"187. }}$

O conceito não se trata de algo que se desenvolve de modo imediato, pois exige um processo que demanda tempo para se desenvolver. Desse modo, os conceitos não têm sua origem no indivíduo somente no momento em que estes passam a frequentar a escola ou em contato com o conhecimento sistematizado, pois sua interação com outros possibilita a construção de conhecimentos espontâneos (ou cotidianos). Para Vigotski (2010, p. 523, 524): “O conceito tem uma história de desenvolvimento muito longa. $\mathrm{Na}$ criança, ele se desenvolve muito antes que a criança ingresse na escola" ${ }^{188}$.

$O$ ingresso da criança na escola representa um novo caminho para $o$ desenvolvimento de seus conceitos, pois ali ela se encontra num processo de assimilação e de construção de conceitos, estando em contato com objetos das ciências. $\mathrm{Na}$ escola a criança efetivamente entra em contato com os conceitos científicos.

Nas aulas a criança aprende a estabelecer relações lógicas entre conceitos, mas é como se o movimento germinasse para dentro, ou seja, vincula-se à experiência que, neste sentido, existe na criança. Os conceitos "científico" e "espontâneo" parecem encontrar-se em um nível no sentido de que não se pode

\footnotetext{
${ }^{186}$ FONSECA, Vitor da. Aprender a aprender: a educabilidade cognitiva. Porto Alegre: Artmed, 1998. 187 MONBEIG, Pierre. Papel e valor do ensino da geografia e de sua pesquisa. IBGE - Conselho Nacional de Geografia, Rio de Janeiro, 1956.

188 VIGOTSKI, L. Semenovich. Psicologia pedagógica. $3^{\mathrm{a}}$ ed. São Paulo: Ed WMF Martins Fontes, 2010.
} 
separar nos pensamentos da criança os conceitos adquiridos na escola dos conceitos adquiridos em casa ${ }^{189}$ (VIGOTSKI, 2010, p. 527, 528).

Vale ressaltar que conceito se trata de algo não passível de ser ensinado, pois se refere a uma ideia. Equivocadamente, há profissionais da educação que afirmam ensinar conceitos científicos em sala de aula, quando, na realidade, o que ocorre é o professor trabalhar com os estudantes o significado e o sentido de determinadas palavras.

Para Vigotski (2010, p. 528) o desenvolvimento do conceito científico na criança se dá a partir do momento em que ela consegue definir verbalmente um determinado conceito. Em idade escolar e em contato com o conhecimento científico, a criança se utiliza dos conceitos espontâneos no processo de assimilação dos novos conceitos.

Entretanto, apesar dessa contraposição, pareceu-me que ambos os processos de desenvolvimento - dos conceitos espontâneos e dos científicos - estão internamente ligados da maneira mais profunda. Estão interligados porque o desenvolvimento dos conceitos espontâneos na criança deve atingir certo nível para que ela possa assimilar em linhas gerais os conceitos científicos ${ }^{190}$.

Conhecer os pressupostos dessa teoria e sua perspectiva sociocultural é fundamental para que professores possam pensar na dimensão psicológica de seus alunos como sujeitos em desenvolvimento, sobretudo em relação à importância da zona de desenvolvimento imediato ${ }^{191}$, que refere-se a distância entre aquilo que a criança consegue realizar ou solucionar de forma independente - nível de desenvolvimento real - e o que pode realizar somente com o auxílio de pessoas mais capazes e experientes, que a orienta ou colabora na solução de um determinado problema - sendo este o nível de desenvolvimento potencial.

A zona de desenvolvimento imediato é o ponto ideal para que professores atuem no processo de ensino-aprendizagem.

Para Vigotski, a zona de desenvolvimento imediato é tida como um dos aspectos mais essenciais da aprendizagem, por possibilitar que diversos processos internos de desenvolvimento possam operar com as crianças interagindo com as pessoas que constituem seu ambiente ou em cooperação com outras pessoas.

\footnotetext{
189 (Ibidem, 527, 528).

190 VIGOTSKI, L. Semenovich. Psicologia pedagógica. $3^{\mathrm{a}}$ ed. São Paulo: Ed WMF Martins Fontes, 2010.

${ }^{191}$ Significativo número de autores que traduziram Vigotski no Brasil se utilizaram do termo zona de desenvolvimento proximal. Zoia Prestes (2012), no entanto, afirma que a tradução mais próxima do termo zona blijaichego razvitia é zona de desenvolvimento iminente. No entanto, optamos por usar no presente trabalho o termo zona de desenvolvimento imediato, conforme tradução de Paulo Bezerra pela editora Martins Fontes.
} 
Supondo que uma parte do desenvolvimento de onde começou o desenvolvimento dos conceitos científicos seja a zona de desenvolvimento imediato. Sob orientação do pedagogo tornam-se possíveis operações mentais que são impossíveis na solução relativamente autônoma da criança. As operações e formas que surgem na criança sob orientação, posteriormente propiciam um desenvolvimento da sua atividade independente (VIGOTSKI, 2010, p. 539).

A sala de aula torna-se um espaço propício à sociabilidade e interação entre crianças e adolescentes contribuindo para que o desenvolvimento cognitivo se realize, dado que é na esfera de ação ocorrente em sala de aula, que o professor poderá mobilizar os estudantes por meio de atividades que os potencialize em seu desenvolvimento intelectual, para isso fazendo uso de signos, símbolos e demais recursos e modalidades de linguagem que o auxilie no processo de mediação.

Por considerarmos que os jovens escolares da atualidade, em sua maioria, imersos numa sociedade em rede, da era da informação e da comunicação quase que instantânea e conectados às redes sociais digitais, acreditamos que não é suficiente considerar apenas como conhecimentos espontâneos aquilo que corresponde ao seu imediato e mais "próximo", como temos visto na geografia escolar.

Conhecer a teoria de Vigotski e considerá-la como aporte teórico a fim de subsidiar uma concepção e prática didático-pedagógica pode trazer resultados promissores em relação a um processo de aprendizagem efetivo e significativo.

\subsection{FEUERSTEIN E A TEORIA DA EXPERIÊNCIA DE APRENDIZAGEM MEDIADA}

Em relação às concepções de Reuven Feuerstein, daremos ênfase apenas a Teoria da Experiência de Aprendizagem Mediada (EAM) ${ }^{192}$, pois se trata da teoria que fundamenta a aprendizagem mediada e que se constitui numa concepção de aprendizagem que apoia a elaboração de significados com o apoio do professor enquanto mediador dos processos de aprendizagem individual e em grupo. Trata-se de uma complexa e sofisticada teoria que se realiza mediante determinados critérios universais, todavia, aqui serão abordados apenas os três primeiros deles (intencionalidade/reciprocidade, significado e transcendência). Consideramos que atualmente, a mediação humana tem se tornado mais do que necessária. Recorrendo a Victor da Fonseca (1998, p. 63) temos que:

\footnotetext{
192 A partir desse momento também nos referenciaremos a Teoria da Experiência de Aprendizagem Mediada de Reuven Feuerstein como EAM.
} 
A mediatização é uma estratégia de intervenção que subentende uma interferência humana, uma transformação, uma adaptação, uma filtragem dos estímulos do mundo exterior para o organismo do indivíduo mediatizado. $\mathrm{O}$ indivíduo mediatizado, como sistema autoplástico, isto é, como sistema emocional e cognitivo (...) é modificado estruturalmente pelo efeito de certas condições de atenção, de percepção, de focagem e de seleção, que são decorrentes da intervenção do mediatizador ${ }^{193}$.

Feuerstein et al (2014) consideram que devem ser conhecidos os fatores proximais e distais que cercam a vida dos indivíduos, sendo que os primeiros se relacionam à presença ou ausência de EAM na pessoa, ao passo que os fatores distais estão atrelados às influências que o sujeito sofre em seu meio, às emoções, à hereditariedade etc. Os autores enfatizam em relação aos fatores proximais a importância do mediador humano, que se interpõe entre o estímulo e o mediado ${ }^{194}$.

Gomes (2002) assevera que antes da Teoria da EAM, Piaget considerava o modelo $\mathrm{S}-\mathrm{O}-\mathrm{R}$, onde "S" representa o estímulo, "O" o organismo e "R" a resposta ao estímulo. Feuerstein, no entanto, acrescentou ao modelo proposto por Piaget o mediador humano, entendido pela letra "H", ficando então S-H-O-H-R.

La EAM, en la cual la interacción del humano con su ambiente es mediada por otra persona que actúa intencionalmente. Esto transforma los tres componentes de E-O-R de manera significativa en una combinación compatible, donde $\mathrm{H}$ es humano mediador, $\mathrm{O}$ es el organismo o sujeto del aprendizaje, $\mathrm{R}$ es la respuesta y $\mathrm{E}$ representa los estímulos; $\mathrm{H}$ se interpone entre $\mathrm{E}$ y $\mathrm{O}$, así como entre O y $\mathrm{R}^{195}$ (FEUERSTEIN, 2002, p. 138).

Destarte, o maior número de experiências de EAM a que uma criança for submetida com a intervenção de um mediador, melhor será o seu desenvolvimento, pois será potencializada a Modificabilidade Cognitiva Estrutural (MCE).

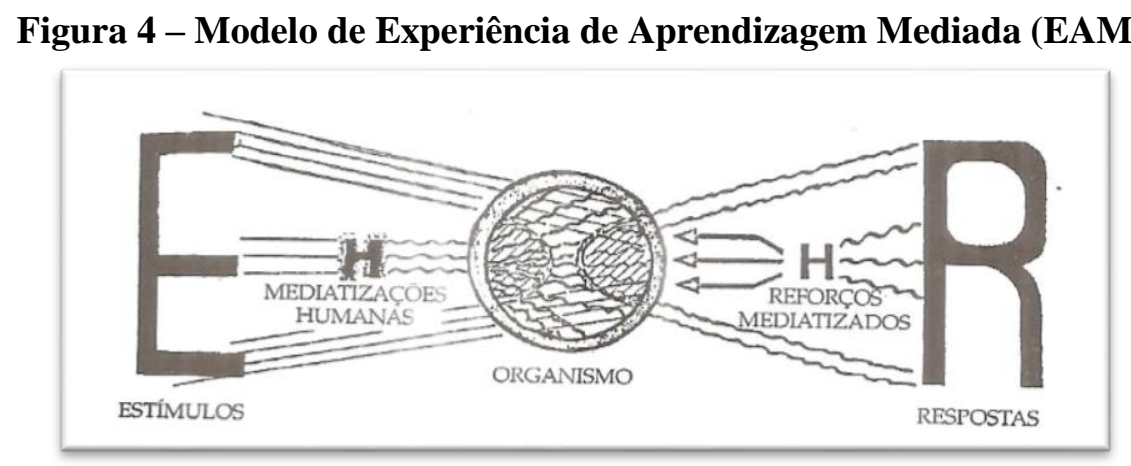

Fonte: FONSECA, Vitor da. Aprender a aprender. Porto Alegre, Artmed, 1998, p. 61.

\footnotetext{
${ }^{193}$ FONSECA, Vitor da. Aprender a aprender: a educabilidade cognitiva. Porto Alegre: Artmed, 1998. ${ }^{194}$ FEUERSTEIN, Reuven; FEUERSTEIN, Rafael S; FALIK, L. H. Além da inteligência: aprendizagem mediada e a capacidade de mudança do cérebro. Petrópolis, Rio de Janeiro: Editora Vozes, 2014.

195 FEUERSTEIN, Reuven. Entrevista à CASADOS, Sergio Noguez. El desarrollo del potencial de aprendizaje. Entrevista a Reuven Feuerstein. In: Revista electrónica de investigación educativa. Vol. 4, n. 2, 2002 .
} 
De acordo com Fonseca (1998), é fundamental para o desenvolvimento cognitivo a exposição direta aos estímulos, entretanto, é a própria cultura, ou seja, a mediação que possibilita à ascensão às funções cognitivas superiores. Para este autor, é pela EAM que se resulta na maturação do organismo e na Modificabilidade Cognitiva Estrutural, e não apenas pela pura presença de estímulos. O autor enfatiza como exemplo, o fato de não bastar que uma pessoa esteja exposta à chuva para que compreenda o fenômeno da vaporização, ou ao sol para que entenda a função do sistema cósmico; é preciso aprendizagem mediada para que se evite a privação cultural $^{196}$. Na mesma direção Gomes (2002, p. 60) avulta que:

[...] a falta de um mediador (ser humano), ou mediadores intencionados, que se interponha entre o organismo e o mundo e que filtre, organize, selecione, organize os significados culturais, possibilitando ao indivíduo transcender os estímulos e as experiências de vida, provoca uma síndrome denominada [...] de privação cultural. Ela impede o desenvolvimento cognitivo e afetivo adequado e reduz o nível de modificabilidade e flexibilidade mental ${ }^{197}$.

A privação cultural não está relacionada às questões de cunho socioeconômico ou a cultura à qual o indivíduo pertence, mas, sobretudo a falta de mediação no sujeito. Também é preciso esclarecer que mediação e interação não são necessariamente sinônimos. Gomes (2002, p. 69) destaca que "ao enfatizar a privação cultural como uma pobreza nas interações sociais, é importante também sublinhar que nem toda interação social propicia o impulsionamento da estrutura cognitiva”.

A falta de EAM pode acarretar baixo desempenho cognitivo nos alunos, sobretudo se o professor centrar seu foco apenas nos conteúdos, numa exposição direta sem intervir com intencionalidade ou não propondo problematizações no decorrer das atividades. Da Ros (2002) considera que a Síndrome da Privação Cultural se manifesta por meio de uma performance cognitiva retardada, proveniente de uma cultura onde os produtos essenciais não teriam sido transmitidos ao indivíduo, muito menos $\operatorname{mediados}^{198}$.

A geografia se caracteriza como conhecimento complexo e pode ser expressa por uma série de elementos gráficos, cartográficos, imagéticos e textuais, podendo o professor se utilizar de tais modalidades de linguagem como instrumentos mediadores visando uma aprendizagem significativa. Se o professor considerar que por meio da

\footnotetext{
${ }^{196}$ FONSECA, Vitor da. Aprender a aprender: a educabilidade cognitiva. Porto Alegre: Artmed, 1998. ${ }^{197}$ GOMES, C. M. A. Feuerstein e a construção mediada do conhecimento. P. Alegre: Artmed, 2002. ${ }^{198}$ DA ROS, Silvia Zanatta. Pedagogia e mediação em Reuven Feuerstein: o processo de mudanças e adultos com história de deficiência. São Paulo: Plexus Editora, 2002
} 
EAM (que não está relacionada especificamente à geografia ou a outra disciplina, mas trata-se de uma avançada e sofisticada teoria) seguindo adequadamente os critérios universais da EAM, com a crença de que o aluno pode modificar-se cognitivamente, os resultados da aprendizagem poderão ser significativos.

Assim, não há justificativas para concepções que asseveram que partindo do lugar e do real concreto ou ficando circunscrito ao estudo delimitado e isolado do "lugar do aluno", este aprenderá geografia, pois se torna claro que os problemas decorrentes da aprendizagem transcendem a questão de partir do imediato mais próximo ou de nele permanecer sem buscar conexões com outras escalas de tempo e espaço, como se asseguradamente o todo estivesse na parte. Ademais, são práticas de ensino que acabam por enfocar sobremaneira os conteúdos e a exposição dos alunos à estímulos diretos, com pouca ou nula Experiência de Aprendizagem Mediada.

As concepções de Vigotski e de Feuerstein contribuem para que o professor possa compreender a dimensão psicológica do aluno e perceber que a aprendizagem não se processa nem se efetiva de modo mecânico, rígido e fragmentado como num sistema de produção fordista. Também não se pode considerar o ser humano, sujeito complexo, com suas individualidades, ambivalências e especificidades, meramente como um ser tão somente útil a se adaptar e conformar ao sistema de produção flexível.

O primeiro critério universal da EAM refere-se à intencionalidade/reciprocidade. Para que a mediação possa ocorrer de forma efetiva, torna-se fundamental a existência por parte do mediador da intenção em modificar cognitivamente o mediado. Segundo Beyer (1996, p. 96).

\footnotetext{
Intencionalidade significa o propósito de intermediar, o que inclui a disponibilidade da criança em aceitar o ato da mediação. Há um trabalho conjunto entre a criança e o mediador, onde ambos interagem ativamente, embora a iniciativa na situação de aprendizagem provenha, sempre, do mediador $^{199}$.
}

Pensando nas aulas de Geografia, a intencionalidade durante o processo de EAM pode ocorrer, por exemplo, quando o professor solicita ao aluno que identifique determinados elementos em um mapa, gráfico ou ilustração, atentando para determinados aspectos, selecionando algumas informações, ou quando o professor reformula seu enunciado para que o estudante possa melhor compreendê-lo. A

199 BEYER, Hugo Otto. O fazer psicopedagógico: a abordagem de Reuven Feuerstein a partir de Vygotsky e Piaget. Porto Alegre: Mediação, 1996. 
intencionalidade do professor enquanto um potencial mediador o leva a intervir na aprendizagem do aluno interpretando e isolando determinados estímulos. No entanto, a reciprocidade apenas se consubstancia quando o professor obtém retorno do estudante, percebendo em suas respostas ou ao modo como ele reage a algum problema, assim como o seu nível de motivação. A EAM não se trata de um processo de mão única. De acordo com Da Ros (2002, p. 34):

O processo de mediação não é uma via de mão única. Como ele se dá no processo relacional, é importante considerar que, por questões externas ou internas aos sujeitos, nem sempre ocorre reciprocidade ao que é proposto pela mediação, fato que impossibilita a interação ${ }^{200}$.

Ainda de acordo com a autora, pode-se considerar que a reciprocidade ocorre no momento em que o mediador partilha com seu interlocutor sua intencionalidade, isto é, dispondo ao estudante processos didáticos que lhes serão úteis no momento em que tomar suas decisões.

Em sala de aula, esse critério é fundamental, pois o professor pode buscar intencionalmente meios para que os estudantes se apropriem do que está sendo proposto nas situações-questões-problema. Na EAM faz parte do processo didático a dimensão afetiva, sendo importante que professor elogie os avanços dos estudantes, valorizandoos e ao mesmo tempo respeitando seu tempo para pensar e processar o pensamento.

O segundo critério da EAM refere-se ao critério do significado. É possível compreendê-lo quando há o objetivo de imprimir relevância naquilo que está sendo estudado. A criança passa a ver significado em determinadas crenças, valores, situações que ocorrem numa determinada cultura, geralmente da qual pertencem, assim como ver significado, importância e relevância noutras culturas. Além disso, neste critério, há forte relação com o âmbito afetivo por envolver mediador e mediado com a crença de que é possível compartilhar significados que podem ser desconhecidos pelo aluno.

Quando o professor manifesta, por exemplo, a importância de se estudar o processo de arrefecimento de migrantes nordestinos em direção a metrópole paulistana e não apenas o bairro do aluno desconectado de outras escalas de tempo e espaço refletindo sobre as condições de trabalho, que direta ou indiretamente afetam a população, o estudante tende a ver significado nestas temáticas, pois trata-se de algo que não se refere apenas ao imediato e mais "próximo", mas à vida. Portanto, é fundamental

\footnotetext{
${ }^{200}$ DA ROS, Silvia Zanatta. Pedagogia e mediação em Reuven Feuerstein: o processo de mudanças e
} adultos com história de deficiência. São Paulo: Plexus Editora, 2002. 
que o professor imprima relevância e significado naquilo que desenvolve com os estudantes.

De acordo com Gomes (2002), a mediação do significado possibilita ao mediado elaborar novas possibilidades transcendendo e generalizando, pois, a troca de sentimentos, experiências e vivências vão além do fenômeno concreto ${ }^{201}$. Do mesmo modo, conforme as considerações de Fonseca (1998, p. 71):

\begin{abstract}
Sem significações, a transmissão cultural de umas gerações para outras não seria viável. Deixar os indivíduos na pura exploração das tarefas não lhes vai permitir atingir as significações, é preciso orientá-los no sentido de delas se apropriarem. $\mathrm{O}$ mediatizador $[\ldots]$ está incumbido, e culturalmente comprometido, de transmitir significações. Sem tais atribuições, as tarefas de aprendizagem, por si só, não produzem a desejada modificabilidade cognitiva. Só com significações inerentes às tarefas, elas penetram no indivíduo como fator energético e como razão e motivação do comportamento ${ }^{202}$.
\end{abstract}

Feuerstein et al (2014) consideram haver entre o plano cognitivo e afetivo uma ponte, sendo esta a condição básica que pode ser alcançada pela mediação do significado, pois ao expor sua leitura de mundo ao mediado, também o prepara para que possa posteriormente formar a sua visão e interpretação de mundo. Ademais...

De todas as características da Experiência de Aprendizagem Mediada, a
mediação de significado é a mais determinante (e contribui) para nossa herança
cultural. O significado reflete valores, costumes e normas que regulam e
moldam comportamentos compartilhados e herdados. Porém, acima de
qualquer experiência cultural, a qualidade mediada de significado é expressa
pela mudança que traz no aprendizado, por fazer com que seja entendido,
fortalecido, integrado e, em análise final, internalizado como sistema de
princípios cuja força guiadora está além do conteúdo específico no qual foi
adquirido $^{203}$ (FEUERSTEIN et al, 2014, p. 92).

O terceiro critério é o da transcendência, o qual permite ao mediado perceber a importância daquilo que está sendo aprendido pensando na sua aplicabilidade em outras situações ou em situações futuras. Ou seja, a aprendizagem de algo que poderá ser aplicado noutros momentos e diferentes contextos da vida, não estritamente num tempo e espaço do presente. Para Fonseca (1998), neste critério o mediador pode apresentar as relações do conteúdo com questões mais globais, despertando no mediatizado hábitos para que perceba as necessidades básicas para além do tempo presente.

201 GOMES, Cristiano Mauro Assis. Feuerstein e a construção mediada do conhecimento. Porto Alegre: Artmed, 2002.

${ }^{202}$ FONSECA, Vitor da. Aprender a aprender: a educabilidade cognitiva. Porto Alegre: Artmed, 1998. ${ }^{203}$ FEUERSTEIN, Reuven; FEUERSTEIN, Rafael S; FALIK, L. H. Além da inteligência: aprendizagem mediada e a capacidade de mudança do cérebro. Petrópolis, Rio de Janeiro: Editora Vozes, 2014. 
Convém ressaltar que o critério da transcendência não deve ser visto como uma simples transferência de ações apreendidas como assevera Gomes (2002, p. 92):

\begin{abstract}
Transcender é uma ação de transferência, a qual se demonstra na capacidade que os indivíduos têm de compreender determinada situação ou objeto e extrapolar esse aprendizado para outras situações nas quais o processo apreendido pode ser aplicado novamente. Entretanto, transcender não implica apenas transferir uma ação aprendida [...]. Em seu aspecto fundamental, o termo transcendência destaca-se por provocar uma ação (mental) que tem uma repercussão focal e momentânea, mas que também transcende o aqui e agora, propiciando uma extensão no tempo e no espaço ${ }^{204}$.
\end{abstract}

O professor em uma aula de geografia, tendo problematizado com os estudantes, por exemplo, a questão da globalização, do processo de reestruturação produtiva, dos fluxos migratórios de nordestinos em diferentes períodos, pode levá-los a fazer correlações com o desemprego, com a informalidade do trabalho, com as alterações na intensidade de fluxos migratórios, com o papel das novas tecnologias etc.; e de como tudo isso acaba por impactar direta ou indireta na realidade de crianças e adolescentes, de seus familiares e de pessoas outras, tanto de lugares próximos como distantes e em diferentes tempos e espaços. Por meio de problematizações o critério da transcendência pode tornar a aprendizagem significativa.

Da Ros (2002) destaca a transcendência como um dos critérios que permite a ampliação do campo de conhecimento do aluno, extrapolando para além do imediato, possibilitando interações que contemplam as experiências do aluno, a dimensão passada, presente e futura do conhecimento, possibilitando um leque de significados e sentidos que permite ao sujeito situar-se no tempo e contexto histórico-social.

Acreditamos ser fundamental para o processo de ensino-aprendizagem os aportes teóricos de Vigotski e de Feuerstein, que se mostraram como verdadeiras revoluções, assim como Piaget, para o tempo e contexto em que se debruçaram em suas pesquisas e, sobretudo, pela atualidade e pertinência de suas contribuições. Numa perspectiva sociocultural, é possível encontrar aspectos que aproximam Feuerstein e Vigotski ${ }^{205}$, devido ao contexto em que viveram. Para Souza (2008, p. 161):

Esses dois educadores viveram as grandes mudanças do século XX e todas as conquistas e contradições dessas mudanças. A crença na capacidade que os seres humanos têm para aprender e o respeito pela busca de identidade que caracteriza toda pessoa são os aspectos que mais os aproximam, o que os torna tão universais ${ }^{206}$.

${ }^{204}$ GOMES, C. M. A. Feuerstein e a construção mediada do conhecimento. P. Alegre: Artmed, 2002.

${ }^{205}$ A Prof ${ }^{a}$ Dr $^{a}$ Maria Eliza Miranda, do Departamento de Geografia da Universidade de São Paulo tem feito em suas atividades de pesquisa aproximações teóricas entre Feuerstein, Vigotski, Bakhtin e Morin. Ademais é umas das pioneiras na difusão de Feuerstein no Brasil.

${ }^{206}$ SOUZA, Solange Jobim. Infância e linguagem: Bakhtin, Vygotsky e Benjamim. Campinas, São Paulo: Papirus, 2008. 
Gomes (2002) identifica semelhanças entre Vigotski e Feuerstein pela crença de ambos na elaboração de metodologias de avaliação mais eficazes, no desenvolvimento da pessoa por meio da interação sociocultural e do potencial não manifesto. Para este autor, os dois souberam explorar os potenciais humanos que ainda não haviam sido contemplados pelos tradicionais métodos de pesquisa.

Tanto Vigotski quanto Feuerstein tinham consciência de que as estruturas de pensamento não eram fixas, pois apesar de haver uma base física, o pensamento se desenvolve pelo comportamento e o ser humano passa a ter condições de desenvolver seu potencial.

Apesar de suas especificidades, pois Vigotski partia de uma concepção histórico cultural e Feuerstein se detinha à questão do ambiente em relação aos processos de aprendizagem mediada, ambos se complementam.

Embora Feuerstein não afirme explicitamente que tenha como suporte teórico o trabalho de Vygotsky, ele apresenta o conceito de experiência de aprendizagem mediada como a ideia primordial de sua construção teórica. [...] ele interpreta o desenvolvimento cognitivo como o processo que se compõe da aprendizagem da criança pela interação direta com seu meio de aprendizagem da criança por meio da mediação proposital das pessoas próximas ${ }^{207}$ (BEYER, 1996, p. 93).

A perspectiva sociocultural e a consciência de que a aprendizagem ocorre por meio das mediações e das relações interpessoais pode favorecer o desenvolvimento dos estudantes quando utilizada a partir de critérios, adequados aportes teóricos e sob o crivo da ciência. Consideramos que a escola contemporânea, em tempos de meio técnico-científico-informacional, necessita ser pensada como um espaço vivo, propício às aprendizagens significativas, que vise um ensino pertinente, contextualizado e que tenha como foco o desenvolvimento humano, intelectual e cognitivo do aluno como centralidade da aula. Uma escola que busque a formação de um sujeito social, que transcenda nos mais diversos aspectos, não se restringindo a escala do imediato, mas reconhecendo a importância do outro, da alteridade, da fraternidade, mas também se atentando à sua individualidade.

Só nos tornamos plenamente sujeitos quando aceitamos como nosso ideal reconhecer-nos e fazer-nos reconhecer enquanto indivíduos - como seres individualizados, que defendem e constroem sua singularidade, dando, através de nossos atos de resistência, um sentido a nossa existência ${ }^{208}$ (TOURAINE, 2006, p. 123).

${ }^{207}$ BEYER, Hugo Otto. O fazer psicopedagógico: a abordagem de Reuven Feuerstein a partir de Vygotsky e Piaget. Porto Alegre: Mediação, 1996.

${ }^{208}$ TOURAINE, A. Um novo paradigma para compreender o mundo de hoje. Petrópolis: Editora Vozes, 2006. 
A geografia ensinada na educação básica pode fazer uso de uma forte contribuição da psicologia, pois trata-se de lidar com representações de mundo, por isso, a insuficiência de um ensino quando majoritariamente limitado ao concreto, ao "próximo" e "imediato" do aluno, sem conexões com outras escalas de tempo e espaço, sobretudo numa era de sociedade em rede.

As contribuições dos psicólogos referenciados no presente capítulo, são de suma importância para que o professor tenha aportes teóricos que subsidie sua prática didático pedagógica.

A geografia tem se mostrando cada vez mais como uma necessidade para que o ser humano possa efetivamente compreender o mundo, suas transformações, dilemas, problemas, crises, e assim, repensá-lo, problematiza-lo e transformá-lo. Enquanto disciplina escolar a geografia pode potencializar o desenvolvimento humano e as capacidades intelectuais e cognitivas de crianças e adolescentes, apoiando-os, sobretudo, em suas visões e representações de mundo. Mas para isso, não se pode prescindir de aportes teóricos como os que foram tratados neste capítulo. 


\section{CAPÍTULO 5 APLICAÇÃO DA SEQUÊNCIA DIDÁTICA EM DIFERENTES MODALIDADES DE LINGUAGEM}

No decorrer do $4^{\circ}$ bimestre de 2016, além das entrevistas realizadas pelas quatro turmas de $8^{\mathrm{a}}$ séries com migrantes nordestinos do Distrito de Pedreira, utilizamo-nos da aplicação de uma Sequência Didática por nós intitulada de "Desconcentração industrial, desindustrialização e migração de retorno", a partir da perspectiva da didática da aprendizagem mediada ${ }^{209}$. Neste capítulo, tratamos sobre os processos que permearam o plano empírico da pesquisa, mais especificamente as atividades intermediárias em diferentes modalidades de linguagem, para que possamos compreender o processo de ensino e aprendizagem inspirado em alguns dos preceitos da base teórica de Reuven Feuerstein - sobretudo os três critérios universais da Teoria da Experiência de Aprendizagem Mediada - e os aportes teóricos de Lev Vigotski.

\subsection{A ELABORAÇÃO INICIAL DOS ESTUDANTES E O CONHECIMENTO ESPONTÂNEO}

Há um quadro típico que permeia as práticas educativas em que o docente sobreleva a transmissão dos conteúdos do seu campo disciplinar, trabalhando de modo acentuado ora com cópias de textos de livros didáticos ora exercícios de fixação, sem se deter aos processos de aprendizagem, ou seja, ao caminho percorrido pelo estudante para se chegar a determinada resposta. Tal modelo, calcado numa concepção que mais se assemelha as premissas de uma educação tecnicista, pautada no padrão estímuloresposta, como propunha Skinner ${ }^{210}$, não contribui para que seja potencializado o desenvolvimento cognitivo e intelectual dos estudantes.

A aplicação da Sequência Didática considerando os três critérios universais da Teoria da Experiência de Aprendizagem Mediada de Reuven Feuerstein e os aportes teóricos de Lev. S. Vigotski, se justifica por acreditarmos na importância do processo de aprendizagem tendo o professor enquanto um mediador entre a criança ou adolescente e

\footnotetext{
209 Termo cunhado pela Prof ${ }^{a}$ Dr $^{a}$ Maria Eliza Miranda em suas pesquisas na Universidade de São Paulo, ao tratar das concepções de Reuven Feuerstein.

${ }^{210}$ Nas palavras de Piaget (1972, p. 76): "Skinner [...] decidiu somente considerar os estímulos ou inputs, manipuláveis à vontade, e as respostas observáveis ou outputs, e ater-se às suas relações diretas sem se ocupar com as conexões internas". Piaget refere-se ao modelo que ficara conhecido como organismocaixa-vazio, que se atém tão somente aos aspectos mais materiais e ao comportamento do indivíduo, sem buscar explicações para o processo de elaboração, mas detendo-se às experimentações. PIAGET, J. Psicologia e pedagogia. $2^{\text {a }}$ ed. Rio de Janeiro/São Paulo: Editora Foresense, 1972.
} 
o objeto de aprendizagem, assim, como do uso de signos e símbolos em diferentes modalidades de linguagem visando iniciar o aluno na elaboração de conceitos científicos, pois acreditamos que crianças e adolescentes encontram-se num momento profícuo para tornar os conceitos espontâneos em conceitos construídos por meio de uma aprendizagem sistematizada e mediada.

Vigotski trata dos conceitos espontâneos, que estão relacionados ao conhecimento adquirido pela criança sem que tenha ocorrido algum tipo de mediação, sendo provenientes do contato direto do indivíduo com as situações e fatos do cotidiano em que o indivíduo tem um conhecimento não sistematizado. Nesta concepção, o conceito científico apenas se estrutura enquanto tal se houver relação com o conceito espontâneo. Conforme Vigotski (2009, p. 261):

\begin{abstract}
O desenvolvimento dos conceitos espontâneos e científicos - cabe pressupor são processos intimamente interligados, que exercem influências um sobre o outro [...] o desenvolvimento dos conceitos científicos deve apoiar-se forçosamente em um determinado nível de maturação dos conceitos espontâneos, que não podem ser indiferentes à formação de conceitos científicos simplesmente porque a experiência imediata nos ensina que o desenvolvimento dos conceitos científicos se torna possível depois que os conceitos espontâneos da criança atingiram um nível próprio do início da idade escolar. Por outro lado, cabe supor que o surgimento de conceitos de tipo superior, como o são os conceitos científicos, não pode deixar de influenciar o nível dos conceitos espontâneos anteriormente constituídos, pelo simples fato de que não estão encapsulados na consciência da criança, não estão separados uns dos outros por uma muralha intransponível, não fluem por canais isolados mas estão em processo de uma interação constante, que deve redundar inevitavelmente, em que as generalizações estruturalmente superiores e inerentes aos conceitos científicos não resultem em mudança das estruturas dos conceitos científicos ${ }^{211}$.
\end{abstract}

O contato dos adolescentes de nossa pesquisa com os migrantes nordestinos do Distrito de Pedreira, possibilitou que entrassem em contato com as representações de mundo de pessoas que se reportavam à uma outra escala, que não apenas o "lugar do aluno", transcendendo para uma dimensão que não a do espaço concreto e imediato, mas de outras escalas de tempo e espaço. No entanto, apesar da importância de tal atividade - que acaba por se utilizar de uma metodologia de pesquisa (a entrevista e o questionário) - trata-se de uma experiência acerca de saberes permeados por um conhecimento não sistematizado, e mais atrelado ao senso comum e ao conhecimento espontâneo.

211 VIGOTSKI, Lev Semenovich. A construção do pensamento e da linguagem. $2^{\mathrm{a}}$ ed. São Paulo: Martins Fontes, 2009. 
O uso de diferentes modalidades de linguagem na aplicação da Sequência Didática visa justamente aproveitar os conhecimentos espontâneos para que o aluno possa ser iniciado na construção de novas representações mentais, desenvolvendo novos conceitos, níveis de abstração e de pensamento científico.

Conforme Alex Kozulin (2002, p. 121):

\begin{abstract}
Vygotsky distinguiu duas formas de experiência que davam ensejo a dois grupos de conceitos diferentes, embora inter-relacionados. O primeiro grupo, que Vygotsky designou de "científico", tem suas raízes na atividade educacional especializada e operacionalizada, que impõe à criança conceitos cientificamente definidos. O segundo grupo, que compreende conceitos que emergem da reflexão da criança sobre a experiência diária, foi chamado de "espontâneo"'12.
\end{abstract}

O uso da linguagem escrita foi solicitado no decorrer das atividades, sendo que na elaboração inicial, os alunos depararam-se com três questões-problema. Após terem realizado as atividades modulares intermediárias, entre a primeira elaboração e a elaboração final - que chamamos de elaboração final 1 (na qual responderam às três questões-problema que haviam respondido no início da sequência didática) - realizaram, uma segunda elaboração final (2) acerca da animação Vida Maria.

Trabalhamos com um encadeamento de atividades em que houve uma elaboração inicial com a mínima intervenção do professor a respeito de uma situaçãoproblema, para que em etapas subsequentes fossem propostas atividades orientadoras do tema tratado na produção inicial, a fim de que os alunos construíssem conhecimentos científicos a partir de problematizações ${ }^{213}$. Ao fim da Sequência Didática, refizeram a elaboração inicial, no entanto, tendo novos elementos para produzir suas elaborações.

Procuramos fazer a aplicação da elaboração inicial não utilizando, propositadamente, os critérios universais da Teoria da Experiência de Aprendizagem Mediada, de modo a não comprometer o diagnóstico inicial concernente aos conhecimentos espontâneos dos estudantes.

Para uma melhor visualização de como organizamos a sequência de atividades, apresentamos um quadro contendo as informações básicas a respeito da referida sequência.

${ }^{212}$ KOZULIN. Alex. O conceito de atividade na psicologia soviética: Vygotsky, seus discípulos, seus críticos. In: DANIELS, Harry. (Org.). Uma introdução a Vygotsky. São Paulo, SP: Edições Loyola, 2002.

${ }^{213}$ Para Vigotski (2010, p. 237), "a formação de conceitos surge sempre no processo de solução de algum problema que se coloca para o pensamento do adolescente". VIGOTSKI, L. S. Psicologia pedagógica. $3^{\mathrm{a}}$ ed. São Paulo: Ed WMF Martins Fontes, 2010. 


\section{Quadro 11 - Informações básicas sobre a Sequência Didática}

\begin{tabular}{|c|c|}
\hline $\begin{array}{l}\text { Título da Sequência } \\
\text { Didática }\end{array}$ & Desconcentração industrial, desindustrialização e "migração de retorno" \\
\hline Questões-problema & $\begin{array}{l}1 \text { - Durante as décadas de } 1950,1960 \text { e parte dos anos 1970, muitos } \\
\text { migrantes nordestinos deixaram suas cidades dirigindo-se a outras } \\
\text { regiões do Brasil, mais especificamente à Sudeste, sobretudo a região } \\
\text { metropolitana de São Paulo. Escreva quais foram as motivações que } \\
\text { levaram os nordestinos a saírem de onde viviam e quais fatores os } \\
\text { atraíram para a grande metrópole paulistana. } \\
2 \text { - Se entre as décadas de } 1950 \text { até o final da década de } 1970 \\
\text { verificávamos um forte fluxo de migrantes nordestinos dirigindo-se à } \\
\text { metrópole paulistana, nas últimas décadas temos visto uma significativa } \\
\text { diminuição nesse fluxo migratório e até mesmo uma inversão, ou seja, o } \\
\text { retorno de nordestinos às suas cidades de origem. Quais fatores podem } \\
\text { explicar essa mudança migratória, isto é, o movimento de retorno? } \\
\text { 3 - A artista Tarsila do Amaral pintou no ano de 1933 a obra "Operários" } \\
\text { (figura A), onde é possível perceber elementos que representavam a vida } \\
\text { urbana da época, as relações sociais e de trabalho. A figura B representa } \\
\text { a distribuição das indústrias no estado de São Paulo até os anos de } 1975 \\
\text { e depois até o ano de 1986. Por fim (figura C), há a obra "O } \\
\text { desempregado", de 1999, do artista plástico Hilário Sineiro Machado. } \\
\text { Quais relações podemos fazer entre as três imagens apresentadas. }\end{array}$ \\
\hline Escola & E.E. Dr. Ayres Neto \\
\hline Série-ano & $8^{\mathrm{a}}\left(9^{\circ}\right.$ ano $)$ \\
\hline Turma & $\mathrm{A}, \mathrm{B}, \mathrm{C}$ e D \\
\hline $\begin{array}{l}\text { Quantidade de aulas } \\
\text { previstas }\end{array}$ & 16 \\
\hline \multirow{7}{*}{ Estrutura dos módulos } & Elaboração inicial - Respondendo às três questões-problema \\
\hline & $\begin{array}{l}\text { Módulo } 1 \text { - Apresentação de slides com imagens do Nordeste; exibição } \\
\text { das músicas Lamento Sertanejo e Cidadão, exibição de matéria do } \\
\text { Programa Fantástico sobre xenofobia; exibição de vídeo sobre } \\
\text { automação do trabalho e trabalho informal em grandes metrópoles e } \\
\text { exibição da animação Vida Maria. }\end{array}$ \\
\hline & Módulo 2 - Leitura dos textos de Carlos Madeiro e Rafael Faleiros \\
\hline & $\begin{array}{l}\text { Módulo } 3 \text { - Análise das imagens Criança Morta e Retirantes de Candido } \\
\text { Portinari }\end{array}$ \\
\hline & $\begin{array}{l}\text { Módulo } 4 \text { - Análise de gráfico e "mapa" sobre migrantes nordestinos na } \\
\text { capital paulista }\end{array}$ \\
\hline & Elaboração final (1) - respondendo às três questões-problema \\
\hline & Elaboração final (2) - Dissertação sobre Vida Maria em dois contextos. \\
\hline
\end{tabular}

Fonte: Elaborado pelo autor (2018).

A elaboração inicial continha três questões versando sobre a migração nordestina na segunda metade do século passado e o recente movimento de retorno atrelado aos processos de desconcentração industrial na metrópole paulistana e a desindustrialização em alguns pontos da capital.

A problematização apresentada na modalidade verbal escrita, fora acompanhada de mais duas modalidades: simbólica (fluxos migratórios) e figurativa (obra Retirantes e charge de migrante chegando a cidade), para percebermos se os estudantes se atentariam às figuras, utilizando as evidências que elas traziam, de modo a apoiar suas respostas. 
Nosso intento com a elaboração inicial fora verificar o processo pelo qual o aluno estruturou seu raciocínio, com base em seus conhecimentos espontâneos acerca de tal temática. A questão da migração nordestina faz parte do cotidiano da maioria dos jovens participantes da pesquisa, pois muitos são descendentes de nordestinos, no entanto, possuem conhecimentos espontâneos ${ }^{214}$, não fazendo correlações do processo migratório com outros fenômenos e em diferentes escalas.

Neste capítulo não vamos nos deter às elaborações iniciais dos estudantes, pois o faremos em capítulo subsequente comparando-as às suas respectivas elaborações final, no entanto, nos utilizaremos apenas de dois exemplos de primeira elaboração, a fim de ilustrar duas situações: a) a relevância de tratar da questão da migração nordestina considerando que muitos alunos são filhos ou netos de migrantes e nem sempre tiveram contato com a memória e representações de mundo dessas pessoas; b) o pensamento espontâneo do aluno estando mais atrelado aquilo que vivencia e vê em sua realidade cotidiana, diferentemente do pensamento científico.

Assim no primeiro exemplo temos o aluno ${ }^{215}$ que reconhece que nunca perguntara a seus familiares nordestinos a razão de terem migrado para São Paulo, ao mesmo tempo em que, o que sabe, ou foi por meio de jornais ou através de sua mãe.

Quadro 12 - Resposta à questão-problema inicial da Sequência Didática

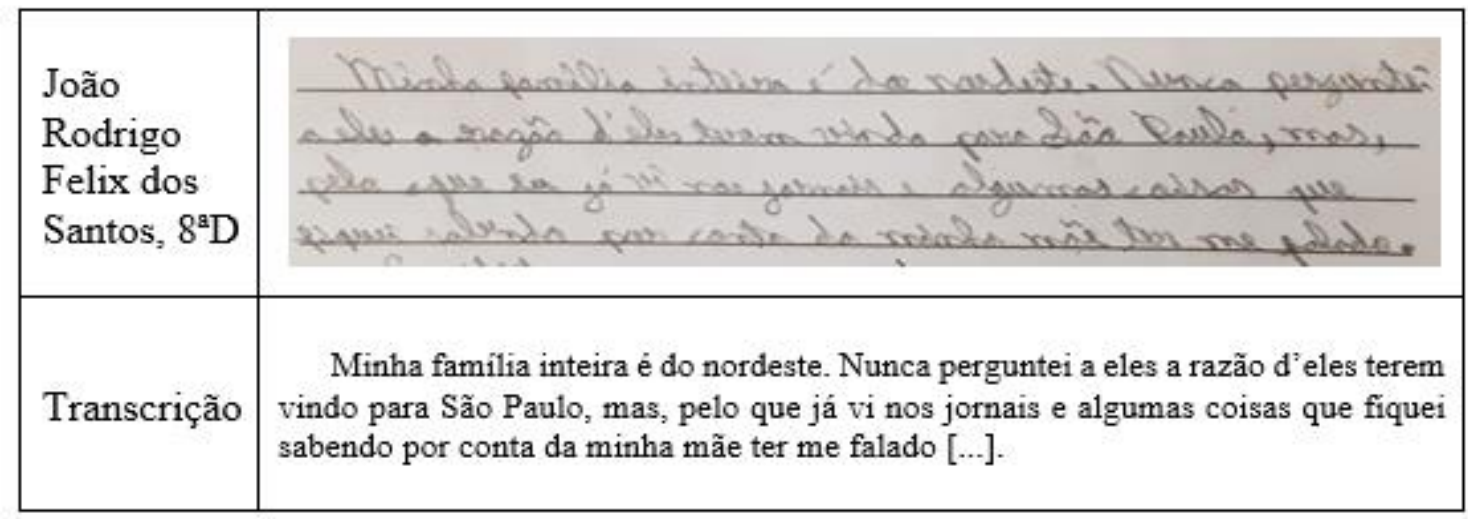

Fonte: Acervo do autor de Sequência Didática (2016).

As elaborações iniciais serviram-nos para que pudéssemos identificar as dificuldades dos estudantes e seus conhecimentos espontâneos, considerando que estes

\footnotetext{
${ }^{214}$ Alex Kozulin (2000, p. 65) destaca os conceitos científicos como estruturadores e originados de uma organização lógica e sistematizada, ao passo que os conceitos espontâneos "surgen de las proprias reflexiones de niño sobre sus experiências inmediatas y cotidianas; son ricos pero poco sistemáticos y muy dependientes del contexto". KOZULIN, A. Instrumentos psicológicos: la educación desde una perspectiva sociocultural. Barcelona: Paidós, 2000.

${ }^{215}$ Este aluno realizou a elaboração das questões-problema inicial, mas não realizou as questões finais, porém fez a dissertação final. Selecionamos seu trecho em virtude da relevância de seu apontamento.
} 
alunos não foram propositadamente mediados para a atividade com as três questões problema. Suas respostas demonstraram que, se por um lado, havia coerência em alguns enunciados e em seus saberes prévios, por outro, havia elaborações com significativos erros de escrita e palavras destituídas de sentido; respostas elaboradas de maneira impulsiva e por tentativas de ensaio e erro.

A dificuldade de escrita atrelada à falta de vocabulário demonstra que ainda não operam por conceitos, pois estes, de acordo com Vigotski (2010, p. 220):

[...] pressupõe a discriminação, a abstração e o isolamento de determinados elementos e ainda a habilidade de examinar esses elementos discriminados e abstraídos fora do vínculo concreto e factual em que são dados na experiência ${ }^{216}$.

A seguir temos o exemplo do aluno que discorre, ao tratar de uma possível migração de nordestinos à sua região de origem, apontando elementos fortemente atrelados a seu pensamento espontâneo, evidenciando aspectos percebidos numa realidade cotidiana, daquilo que lhe chega por meio da tevê, internet ou outros meios.

Quadro 13 - Resposta de aluno à segunda questão-problema da elaboração inicial

\begin{tabular}{|c|c|}
\hline $\begin{array}{l}\text { Matheus } \\
\text { Henrique } \\
\text { Brito da } \\
\text { Luz, } 8^{\mathrm{a}} \mathrm{A}\end{array}$ & 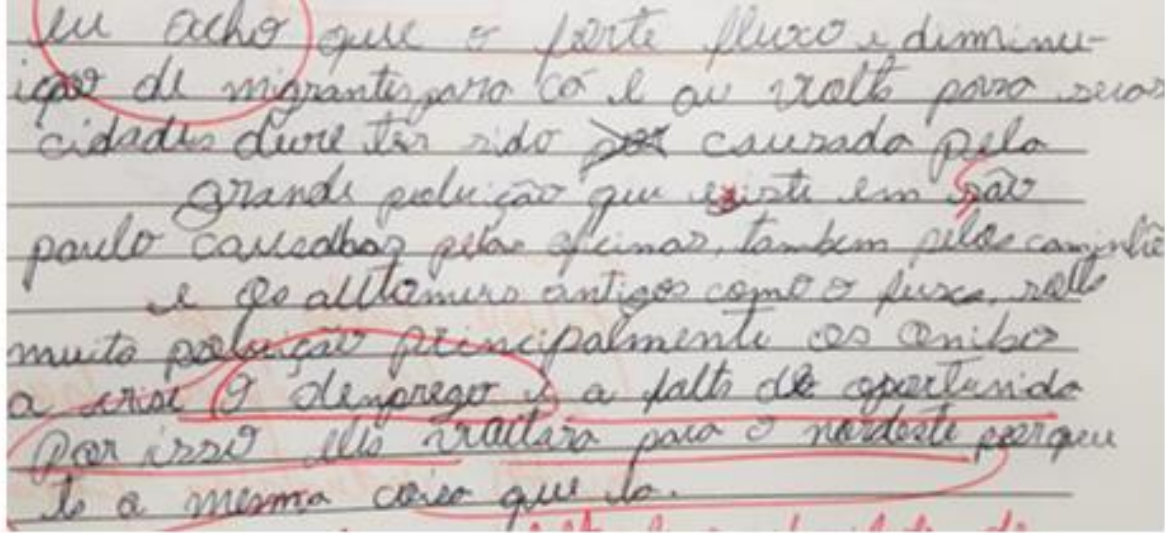 \\
\hline Transcrição & $\begin{array}{l}\text { eu acho que o forte fluxo e diminuição de migrantes para cá e a volta para suas cidades } \\
\text { deve ter sido causada pela } \\
\text { grande poluição que eziste em são Paulo causadas pelas oficinas, também pelos } \\
\text { caminhões e os automoveis antigos como o fusca, solta muita poluição principalmente } \\
\text { os onibos a crise o demprego e a falta de oportinida por isso eles voltava para o } \\
\text { nordeste porque ta a mesma coisa que la. }\end{array}$ \\
\hline
\end{tabular}

Fonte: Acervo do autor de Sequência Didática (2016).

O aluno destaca como problemas que ocasionam o processo migratório de retorno, a poluição causada pelas oficinas, caminhões e automóveis antigos e os problemas decorrentes do desemprego, pois são elementos que presencia no bairro e no

${ }^{216}$ VIGOTSKI, L. S. Psicologia pedagógica. $3^{\mathrm{a}}$ ed. São Paulo: Ed WMF Martins Fontes, 2010. 
entorno onde vive; são elaborações não sistematizadas, mas que não devem ser desconsideradas, pois estão atreladas ao seu meio sociocultural, tratando-se de um conhecimento relacionado à sua vivência.

A vivência é uma unidade na qual, por um lado, de modo indivisível, o meio,
aquilo que se vivencia está representado - a vivência sempre se liga àquilo que
está localizado fora da pessoa e, por outro lado, está representado como eu
vivendo isso, ou seja, todas as particularidades da personalidade e todas as
particularidades do meio são apresentadas na vivência, tanto aquilo que é
retirado do meio, todos os elementos que possuem relação com dada
personalidade, como aquilo que é retirado da personalidade, todos os traços do
seu caráter, traços constitutivos que possuem relação com dado acontecimento.
Dessa forma, na vivência, nós sempre lidamos com a união indivisível das
particularidades da personalidade e das particularidades da situação
representada na vivência ${ }^{217}$ (VIGOTSKI, 2010, p. 689).

Uma das razões de não comungarmos com a geografia que se pretende ensinar restrita a categoria lugar sem se fazer correlações com outras escalas espaço-temporais, refere-se ao fato de pedagogicamente limitar a visão do aluno aos aspectos mais imediatos, concretos e circunscritos à percepção sensorial, pouco considerando um nível maior de abstração ao trabalhar com escalas outras que não somente do "lugar do aluno".

Parte significativa dos estudantes elaborou suas respostas demonstrando imprecisão na compreensão do problema apresentado, assim como na coleta de informações pois, apesar de muitos terem inferido que o movimento de retorno estava mais atrelado à saudade ou a falta de emprego na metrópole paulistana, não exploraram mais do que esse universo, que aliás, é presente em suas realidades cotidianas.

Os enunciados dos estudantes evidenciam aspectos de um conhecimento adquirido por meio de suas vivências diárias num âmbito familiar e de senso comum. Desse modo, acabam internalizando de forma não sistematizada as informações adquiridas no meio sociocultural, mesclando com conhecimentos e informações que adquire por meio de programas televisivos, internet, redes sociais e outros recursos midiáticos. Conforme salienta Gomes (2002, p. 86), “nem toda interação e transmissão cultural são elementos da mediação, ou seja, nem todo processo interativo alcança o estatuto e a qualidade de mediação" ${ }^{218}$.

Suas elaborações iniciais demonstraram a falta de um vocabulário mais sofisticado; o uso inadequado de algumas palavras e conceitos; as dificuldades para explorar informações trazidas pelas modalidades simbólica, figurativa e verbal-escrita; a

\footnotetext{
${ }^{217}$ VIGOTSKI, L. Psicologia pedagógica. $3^{\text {a }}$ ed. São Paulo: Ed WMF Martins Fontes, 2010.

${ }^{218}$ GOMES, C. M. A. Feuerstein e a construção mediada do conhecimento. Porto Alegre: Artmed, 2002.
} 
falta de concentração e atenção ao que fora solicitado nos enunciados e um comportamento impulsivo ao responder as questões-problema. Isso tudo evidencia a necessidade da atenção do professor ao processo de aprendizagem, para que o aluno construa conceitos científicos. De acordo com Miranda (2013, p. 16):

\begin{abstract}
$\mathrm{Na}$ verdade, os processos de aprendizagem que acontecem ao longo da escolarização são extremamente complexos e estão implicados com o modo como os conhecimentos estão organizados $[. .$.$] os conceitos e as 'regras' de$ pensamento que os caracterizam, o processo de desenvolvimento do aluno e a aprendizagem do pensamento científico com a elaboração gradativa de conceitos científicos ${ }^{219}$.
\end{abstract}

Daí a necessidade da aprendizagem mediada com as atividades modulares da Sequência Didática visando contribuir para o desenvolvimento do aluno.

\title{
5.2 DIFERENTES RECURSOS DE APOIO PEDAGÓGICO NO PROCESSO DE EXPERIÊNCIA DE APRENDIZAGEM MEDIADA
}

Após esta primeira etapa da Sequência Didática, buscamos apresentar por meio de recursos audiovisuais, imagens, mapas, trechos de reportagens jornalísticas, clipes musicais e uma animação, atrelados às temáticas da migração nordestina e da industrialização em São Paulo, sempre entremeadas por intervenções mediadas a partir das concepções dos três critérios universais da Teoria da Experiência de Aprendizagem Mediada de Feuerstein ${ }^{220}$.

A partir dos critérios de mediação propostos por Feuerstein, o professor pode refletir e ressignificar a relação que estabelece com seus alunos, redefinindo inclusive seu próprio papel, o valor do conhecimento e a finalidade da aula, a qual passa a ser compreendida como um espaço de mediação e onde ocorrem interações entre os sujeitos implicados na aula e cujo sentido é o de garantir a aprendizagem integral e não apenas a transmissão de conceitos ou conteúdos no sentido do cumprimento de um programa curricular (MIRANDA, 2013, p. $18)$.

\footnotetext{
${ }^{219}$ MIRANDA, M. E. A reinvenção da prática docente: interfaces e aproximações para a ressignificação da prática docente. In: $14^{\circ}$ EGAL - Encontro de Geógrafos da América Latina, 2013, Lima - PERU. Situación y Perspectivas de la Enseñanza - Aprendizaje de la Geografía en América Latina, 2013.

${ }^{220}$ Conforme Feuerstein et al $(2014$, p. 92), a mediação enquanto experiência de qualidade única cria a sensibilidade, flexibilidade e prontidão no ser humano. E continua: "Para que a interação possua valor de mediação, esta deve incluir, por meio de uma atividade consciente, as características da intencionalidade e reciprocidade, a mediação da transcendência, e a busca por (e descoberta de) significado do funcionamento da mediação e de outros". FEUERSTEIN, Reuven; FEUERSTEIN, Rafael S; FALIK, Louis H. Além da inteligência: aprendizagem mediada e a capacidade de mudança do cérebro. Petrópolis, Rio de Janeiro: Editora Vozes, 2014.
} 
A interação comunicacional entre professor e aluno é fundamental no processo de aprendizagem mediada. De acordo com Gomes (2002, p. 78):

\begin{abstract}
Toda interação humana se viabiliza pela comunicação. Desse modo, pudemos analisar brevemente que a EAM tem seu foco não especificamente no conteúdo das informações, mas sim no diálogo intencional entre o emissor e o receptor da mensagem. Ambos interagem constantemente, imperando a troca de impressões, os sentimentos sobre o mundo e o intercâmbio de fatores de compreensão da realidade. A interação comunicacional e de transmissão no processo de EAM impõe a presença da mobilização cognitiva e afetiva através de uma realização dialógica, interacional entre dois ou mais seres humanos ${ }^{221}$.
\end{abstract}

O trabalho com a Sequência Didática fora pautado em diferentes modalidades de linguagem, tais como a verbal escrita, pictórica, figurativa, simbólica e a própria dialogia, como sistemas de signos e como instrumentos de mediação, buscando ir além da mera percepção sensorial visual, mas visando atingir níveis mais elaborados de abstração e de um pensamento mais complexo, pois acreditamos que:

Como resultado da história social, a linguagem transformou-se em instrumento decisivo do conhecimento humano, graças ao qual o homem pode superar os limites da experiência sensorial, individualizar as características dos fenômenos, formular determinadas generalizações ou categorias. [...] sem o trabalho e a linguagem, no homem não se teria formado o pensamento abstrato 'categorial' 222 (LURIA, 1986, p. 22).

Os alunos tiveram contato, por meio dos recursos audiovisuais, com xilografias representando famílias de retirantes no semiárido nordestino; imagens da região de caatinga, assim como retirantes migrando para a região Sudeste. Puderam ver imagens de antigas fábricas e indústrias de São Paulo a fím de perceber a relação entre a migração nordestina com o período áureo de geração de trabalho na metrópole paulistana. Posteriormente foram trabalhados os clips musicais das canções Lamento Sertanejo e Cidadão; trechos de reportagens do Programa Fantástico da Rede Globo, tratando da xenofobia sofrida por migrantes nordestinos e a animação Vida Maria ${ }^{223}$, tratando das agruras de uma criança na região semiárida do país.

Os recursos audiovisuais e as novas tecnologias são insuficientes quando utilizados em sala de aula sem a mediação humana. Ou seja, é insuficiente a exposição direta dos alunos a tais recursos, com a ausência de Experiência de Aprendizagem Mediada. Conforme Vitor da Fonseca (1998, p. 62): “A exposição direta aos estímulos é

\footnotetext{
${ }^{221}$ GOMES, C. M. A. Feuerstein e a construção mediada do conhecimento. P. Alegre: Artmed, 2002.

${ }^{222}$ LURIA, A. R. Pensamento e linguagem: as últimas conferências de Luria. Porto Alegre: Artes Médicas, 1986.

${ }^{223}$ Animação de 9 minutos, dirigida por Márcio Ramos e coproduzida com Joelma Ramos. Brasil, 2006.
} 
fundamental para o desenvolvimento cognitivo, mas a interação mediatizada, isto é, a própria cultura, é que permite o acesso à funções cognitivas superiores ${ }^{224 \text { ”. }}$

\title{
Figura 5 - Alunos durante aprendizagem mediada com audiovisuais
}

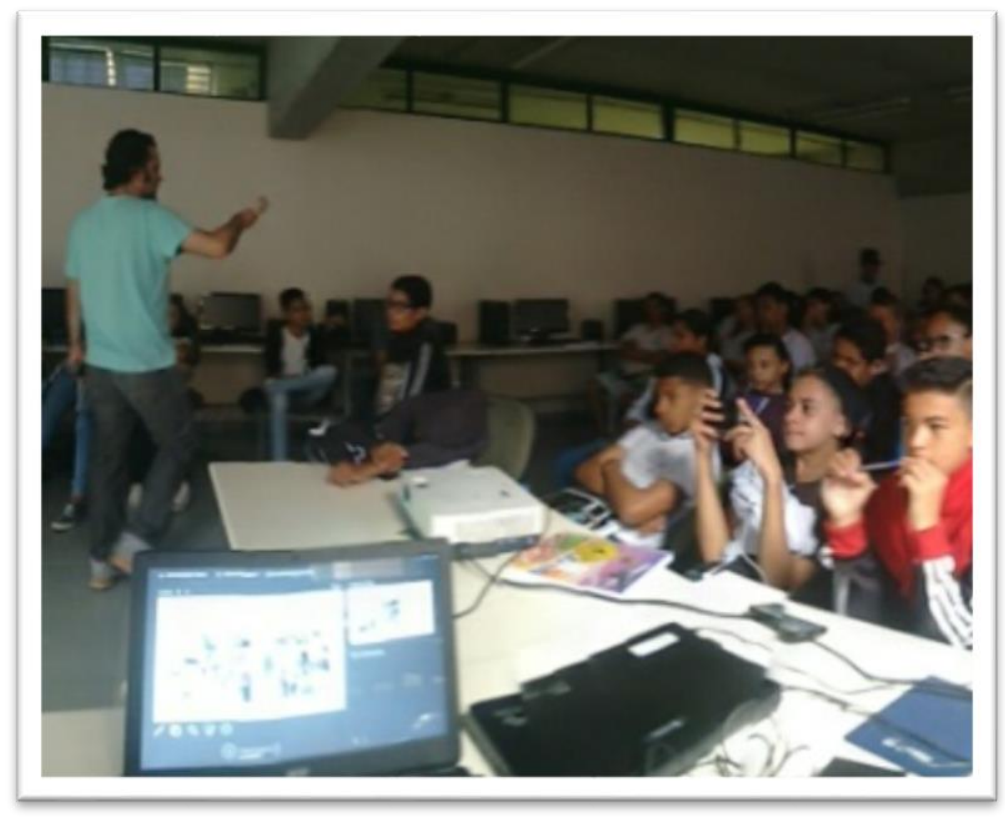

Autor: Danilo Brito Lopes (2016).

As reflexões e discussões ${ }^{225}$ com os estudantes acerca dos clipes musicais, documentário e da animação foram feitas considerando a interposição do mediador humano entre os estímulos imagéticos e as crianças e adolescentes, pois num mundo de meio técnico-científico-informacional, as tecnologias destituídas de mediação humana tiram o encantamento da aula e o significado do que se pretende que seja aprendido. Nas palavras de José Manuel Moran (1994, p. 26):

\begin{abstract}
O reencantamento, enfim, não reside principalmente nas tecnologias - cada vez mais sedutoras - mas em nós mesmos, na capacidade em tornar-nos pessoas plenas, num mundo em grandes mudanças e que nos solicita a um consumismo devorados e pernicioso. É maravilhoso crescer, evoluir, comunicar-se plenamente com tantas tecnologias de apoio. É frustrante, por outro lado, constatar que muitos só utilizam essas tecnologias nas suas dimensões mais superficiais ou autoritárias. O reencantamento, em grande parte, vai depender de nós ${ }^{226}$.
\end{abstract}

\footnotetext{
${ }^{224}$ FONSECA, V. da. Aprender a aprender: a educabilidade cognitiva. Porto Alegre: Artmed, 1998.

225 Para Castanho (2008, p. 93, 94), a discussão em sala de aula possibilita ao aluno não aceitar passivamente dada posição sem que antes realize uma profunda e multifacetada análise: "Pode ser usada durante ou após uma aula expositiva do professor ou de colegas, após um filme, uma sessão de slides, como preparação para um projeto a ser realizado. Caracteriza-se por ser uma forma de cooperação intelectual, uma vez que esclarece e detalha o assunto em questão. Em resumo, é a análise de um ponto de vista". CASTANHO, Maria E. L. M. Da discussão e do debate nasce a rebeldia. In: VEIGA, I. P. A. (Org.). Técnicas de ensino. Por que não? Campinas, SP: Papirus, 2008.

226 MORAN, José M. Inferências dos meios de comunicação no nosso conhecimento. In: Revista Brasileira de Comunicação. São Paulo: INTERCOM, vol. XVII, no. 02, 1994.
} 
O uso dos recursos audiovisuais foi feito de forma crítica, pois o mundo contemporâneo é permeado pela complexidade da informação, das redes e da comunicação, onde os jovens estão expostos de modo direto a tais recursos. Abaixo pequena amostragem de algumas cenas de Lamento Sertanejo e da animação Vida Maria.

\section{Figura 6 - Amostragem de cenas de Lamento Sertanejo}

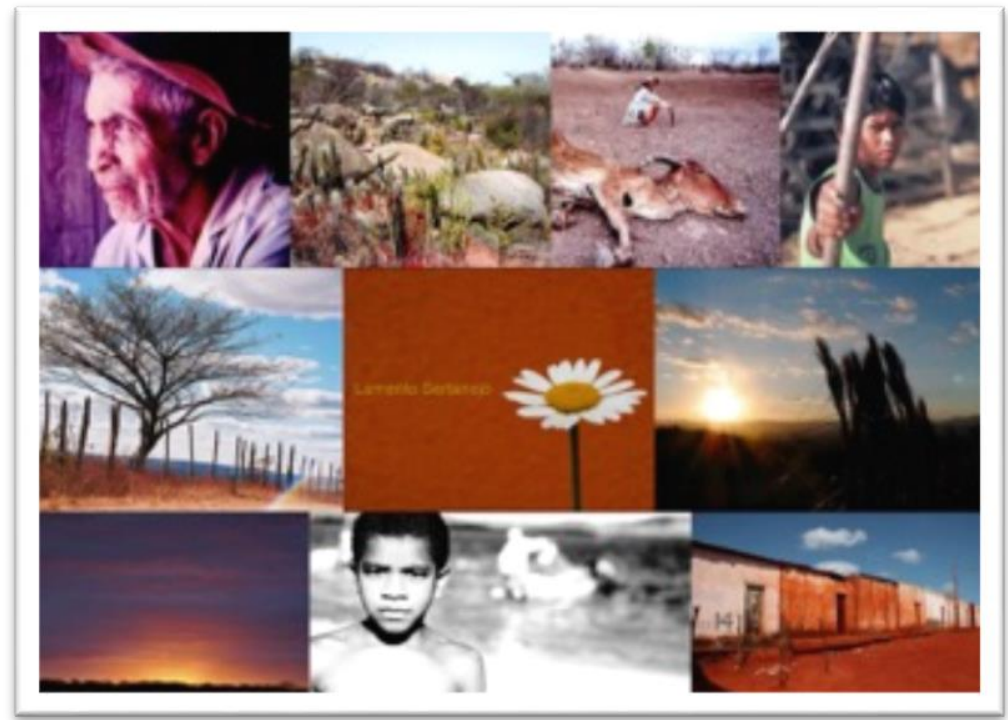

Fonte: https://www.youtube.com/watch?v=k-A-g-BfGrI

Figura 7 - Amostragem de cenas de Vida Maria

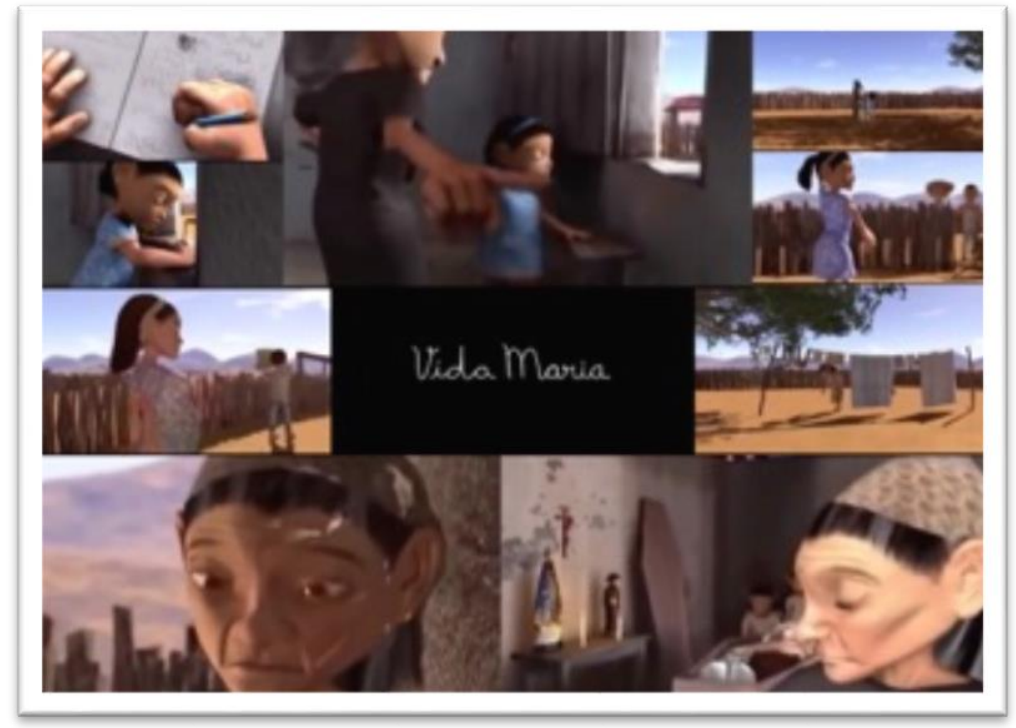

Fonte: https://www.youtube.com/watch?v=Blgzu0r-OUk

A participação dos estudantes demonstrou que o processo de raciocínio por eles utilizado estava mais voltado à uma percepção episódica da realidade. De todo modo, trabalhar com recursos visuais, num mundo permeado pela complexidade das imagens é de suma importância. De acordo com Fernando Hernández (2000, p. 52): 
[...] a cultura visual contribui para que os indivíduos fixem as representações sobre si mesmos e sobre o mundo e sobre seus modos de pensar-se. A importância primordial da cultura visual é mediar o processo de como olhamos e como nos olhamos, e contribuir para a produção de mundos ${ }^{227}$.

Em nossa Sequência Didática utilizamo-nos de atividades de leitura e escrita, de gráficos e imagens, fazendo um esforço em enriquecer as estratégias de raciocínio do aluno para que a aprendizagem pudesse ocorrer com maior eficiência e significância, evitando deixar os estudantes a uma mera exposição direta de estímulos sem mediação humana, pois conforme Vitor da Fonseca (1998, p. 71):

Deixar os indivíduos na pura exploração das tarefas não lhes vai permitir atingir as significações, é preciso orientá-los no sentido de delas se apropriarem. O mediatizador [...] está incumbido, e culturalmente comprometido de transmitir significações. Sem tais atribuições, as tarefas de aprendizagem por si só, não produzem a desejada modificabilidade ${ }^{228}$.

Tivemos como premissa propor atividades que possibilitassem ao aluno trabalhar com operações mentais como comparar (diferenciar e assemelhar) e identificar, assim como trabalhar de modo não restrito a escala do "seu lugar", mas conectando outras escalas de tempo e espaço. Tais quesitos nos são mais importantes do que simplesmente lhe dar com os conteúdos da disciplina de forma mecânica e fragmentada. Para isso é importante que o professor procure sempre novos conhecimentos e se engaje na busca de aportes teóricos, metodológicos, científicos e filosóficos. Para Miranda (2010, p. 13):

A procura inesgotável de novos conhecimentos exige uma atualização
permanente no campo da ciência que se vai ensinar e também aqueles
conhecimentos relacionados com o modo como os indivíduos aprendem, isto é,
significa, entre outros aspectos, buscar compreender a dimensão
epistemológica envolvida não apenas nos blocos de conteúdos que são
escolhidos para ensinar, mas também a dimensão psicológica envolvida no
processo de aprendizagem, que apesar de inserido num contexto social,
econômico, político, institucional e cultural, sua apropriação se dá de maneira
individual. Trata-se de desenvolver a representação do mundo, e mais do que
isso: a representação das relações que nele ocorrem ${ }^{229}$.

A geografia é uma disciplina que contribui para que jovens em idade escolar desenvolvam funções cognitivas e opere mentalmente de maneira mais eficiente, sobretudo, se o aluno experienciar durante as aulas alguns dos principais critérios

${ }^{227}$ HERNÁNDEZ, F. Cultura visual, mudança educativa e projeto de trabalho. Porto Alegre: Artes Médicas Sul, 2000.

${ }^{228}$ FONSECA, V. da. Aprender a aprender: a educabilidade cognitiva. Porto Alegre: Artmed, 1998.

229 MIRANDA, M. E. Contribuição ao debate atual sobre a formação de professores no Brasil: pela formação de futuras gerações na perspectiva da reconstrução do sócio-cultural. Revista do Departamento de Geografia, n. 20, p. 11-22, 2010. 
universais da EAM. No caso específico dos textos ${ }^{230}$ trabalhados na sala de leitura, todo o processo fora feito a partir da perspectiva dos três critérios universais da EAM.

Apesar da importância no aprendizado da leitura e da escrita, sobretudo num país em que o analfabetismo não fora erradicado e a baixa escolaridade apresenta alarmantes índices quando comparados aos países desenvolvidos, torna-se necessário ir além da alfabetização propriamente dita, chegando a um desenvolvimento social, pleno e holístico do indivíduo ${ }^{231}$. Assim, comungamos das concepções de Miranda (2010, p. 12) ao tratar das contribuições que pode ter o ensino de geografia.

[...] na aprendizagem de habilidades cognitivas envolvidas no aprimoramento de diversas competências com ênfase na competência de leitura e de escrita, compreendidas não apenas no âmbito da alfabetização propriamente dita enquanto aprendizagem da codificação e decodificação da escrita, mas no sentido mais amplo de leitura do mundo e de comunicação e expressão dessa leitura, inclusive como sistemas de representação $0^{232}$.

Considerando a relevância da leitura para o desenvolvimento cognitivo e intelectual do aluno, organizamos os estudantes durante o processo de Aprendizagem Mediada, em pequenos grupos, solicitando que um aluno realizasse a leitura de um parágrafo e outro explicasse o que compreendera. Do mesmo modo, procuramos identificar determinadas palavras-chave e compreender seu significado e sentido dentro do contexto do texto que estava sendo discutido. Conforme pondera Oliveira (1991, p. 121), a leitura é a "busca do sentido do texto"233. Para Colomer (2002, p. 31, 32):

Ler, mais do que um simples ato mecânico de decifração de signos gráficos, é antes de tudo um ato de raciocínio, já que se trata de saber orientar uma série de raciocínios no sentido da construção de uma interpretação da mensagem escrita a partir da informação proporcionada pelo texto e pelos conhecimentos do leitor e, ao mesmo tempo, iniciar outra série de raciocínios para controlar o progresso dessa interpretação de tal forma que possam detectar as possíveis incompreensões produzidas durante a leitura ${ }^{234}$.

\footnotetext{
${ }^{230}$ Os textos trabalhados foram "Em seis anos, mais de 400 mil nordestinos voltaram para cidade de origem", "Com frustração ou sucesso, nordestinos fazem caminho inverso e deixam o sul do país", ambos do jornalista Carlos Madeiro, e o artigo (adaptado) "Refletindo sobre a desindustrialização em São Paulo", do geógrafo Rafael Faleiros de Pádua (2009).

${ }^{231}$ Para Soares $(2002$, p. 45, 46), as "pessoas se alfabetizam, aprendem a ler e a escrever, mas não necessariamente incorporam a prática da leitura e da escrita, não necessariamente adquirem competência para usar a leitura e a escrita, para envolver-se com as práticas sociais da escrita". A autora assinala que o letramento é mais do que apenas ler e escrever, mas exercer e cultivar as práticas sociais em que a escrita é utilizada. SOARES, M. Letramento: um tema em três géneros. Belo Horizonte: Autêntico, 2002.

${ }^{232}$ MIRANDA, M. E. Contribuição ao debate atual sobre a formação de professores no Brasil: pela formação de futuras gerações na perspectiva da reconstrução do sócio-cultural. Revista do Departamento de Geografia, n. 20, p. 11-22, 2010.

${ }^{233}$ OLIVEIRA, Maria. Beatriz. V. de. Construção da linguagem, construção do mundo. In: VEIGA, Ilma. P. Alencastro; CARDOSO, M. H. F. (Orgs.). Escola fundamental: currículo e ensino. Campinas, SP: Papirus, 1991.
}

${ }^{234}$ COLOMER, T. Ensinar a ler, ensinar a compreender. Porto Alegre: Artmed, 2002. 
A competência leitora e escritora é exigência não apenas da disciplina de língua portuguesa, como alguns professores advogam ao justificar o fato de pouco trabalharem com atividades que demandam o uso da escrita e da leitura. Para Olga Molina (1992), na aprendizagem de todos os conteúdos escolares a leitura é fundamental, assim como seu ensino deve ser cuidado e de responsabilidade dos professores de todas as áreas e não apenas do professor de língua materna ${ }^{235}$.

$\mathrm{Na}$ imagem abaixo temos os estudantes realizando a leitura durante o processo de Experiência de Aprendizagem Mediada em sala diferente da que estão acostumados a frequentar normalmente.

\section{Figura 8 - Sala de leitura e alunos em atividade de leitura a partir da EAM}

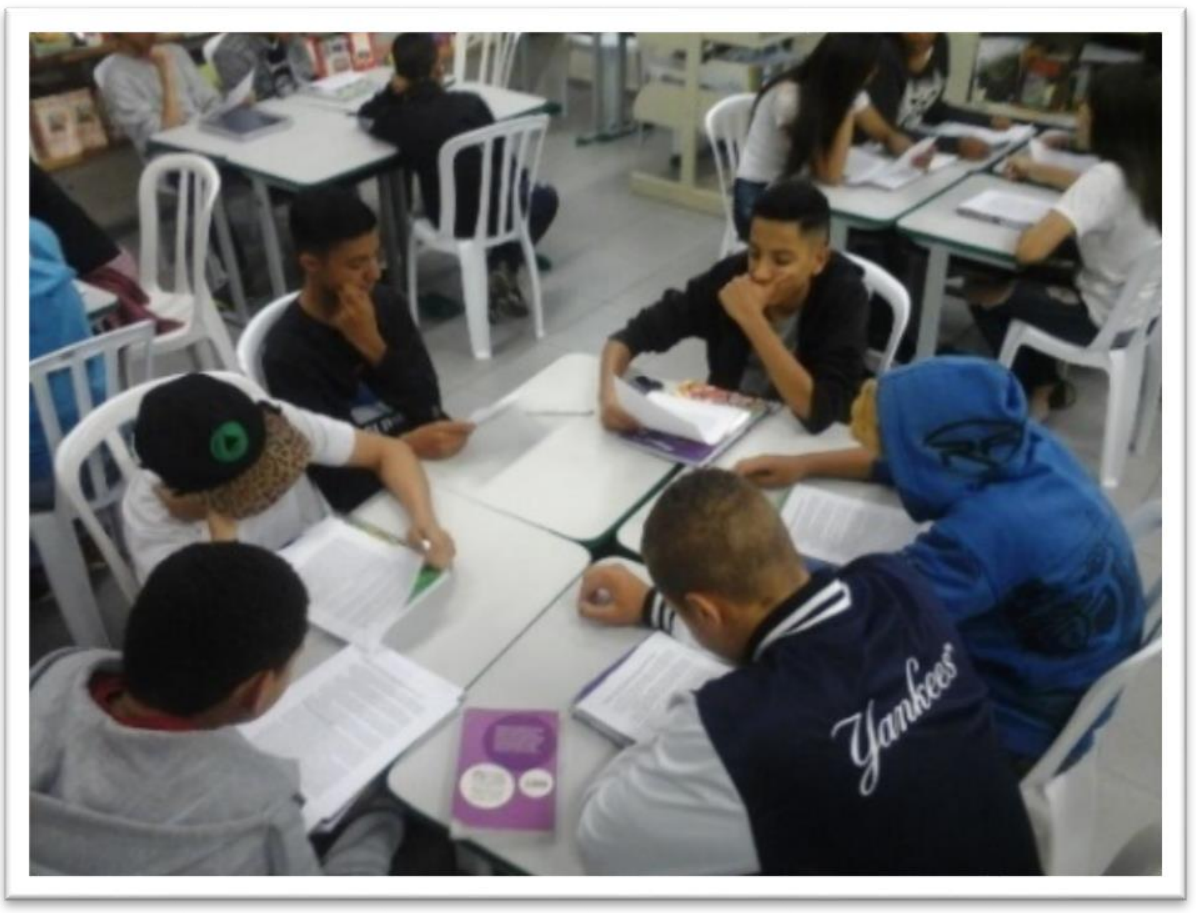

Autor: Danilo Lopes Brito (2016).

Ao solicitar que o aluno explicasse o que compreendera do trecho lido, ou o que poderia significar determinada palavra e qual o seu sentido, apoiávamo-nos na premissa de que é preciso trabalhar com o significado e sentido das palavras durante o processo de aprendizagem mediada, para que estas possam apoiar os estudantes na formação dos conceitos científicos.

\footnotetext{
${ }^{235}$ MOLINA, Olga. Ler para aprender: desenvolvimento de habilidades de estudo. São Paulo: Editora Pedagógica e Universitária Ltda, 1992.
} 
Tratamos a palavra não enquanto objeto isolado, mas como um fenômeno da linguagem e do pensamento conforme sustenta Vigotski, pois possuindo significado, acaba por tornar-se o caminho que permitirá que o aluno possa efetivamente estruturar seu pensamento. Com o significado da palavra procuramos buscar a generalização, ou seja, representar aspectos da realidade na consciência. De acordo com Vigotski (2009, p. 398):

Assim, o significado da palavra é, ao mesmo tempo, um fenômeno de discurso intelectual, embora isto não signifique a sua filiação puramente externa a dois diferentes campos da vida psíquica. O significado da palavra só é um fenômeno de pensamento na medida em que o pensamento esteja relacionado à palavra $\mathrm{e}$ nela materializado, e vice-versa, ou seja, é um fenômeno de discurso apenas na medida em que o discurso esteja vinculado ao pensamento e focalizado por sua luz. É um fenômeno do pensamento discursivo ou da palavra consciente, é a unidade da palavra com o pensamento ${ }^{236}$.

Do mesmo modo, é preciso que se diferencie o sentido da palavra e seu significado, mas também a relação que há entre ambos.

[...] o sentido é sempre uma formação dinâmica, fluída, complexa, que tem várias zonas de estabilidade variada. O significado é apenas uma dessas zonas do sentido que a palavra adquiri no contexto de algum discurso e, ademais, uma zona mais estável, uniforme e exata. Como se sabe, em contextos diferentes a palavra muda facilmente de sentido. O significado, ao contrário, é um ponto imóvel e imutável que permanece estável em todas as mudanças de sentido da palavra em diferentes contextos (VIGOTSKI, 2009. p. 465).

A medida em que as crianças e os adolescentes se deparam com novas experiências e até mesmo com o decorrer de suas vivencias, o significado da palavra tende a mudar ${ }^{237}$.

A palavra desprovida de significado não é palavra, é um som vazio. Logo, o significado é um traço constitutivo indispensável da palavra. [...] do ponto de vista psicológico o significado da palavra não é senão uma generalização ou conceito. Generalização e significado da palavra são sinônimos [...]. Consequentemente, estamos autorizados a considerar o significado da palavra como um fenômeno do pensamento (VIGOTSKI, 2009, p. 398).

A leitura e discussão dos textos ocorreu em três aulas e em dias diferentes; inicialmente numa mediação coletiva, de modo que diferentes vozes pudessem ser ouvidas e mediadas, para que posteriormente houvesse as mediações de maneira mais "individualizada", com o professor interagindo entre os estudantes que estavam divididos em pequenos grupos de 4 a 5 pessoas. Nesse momento nossa intenção fora a de dispor de uma atenção mais específica às demandas de cada estudante, nos apoiando

\footnotetext{
${ }^{236}$ VIGOTSKI, S. A construção do pensamento e da linguagem. $2^{\text {a }}$ ed. S. Paulo: Martins Fontes, 2009.

237 "O significado da palavra é inconstante. Modifica-se no processo de desenvolvimento da criança. Modifica-se também sob diferentes modos de funcionamento do pensamento. É antes uma formação dinâmica que estática" (Ibid., p. 407, 408).
} 
nos três critérios universais da EAM. A linguagem verbal oral nessa etapa da Sequência Didática tivera importância significativa, pois fora permeada por perguntas como: Quais? Por quê? Como? Pois, conforme assevera Gomes (2002, p. 231, 232):

[...] o mediador estabelece uma relação dialógica, oferece dicas ou pistas para que a pessoa atinja certo nível de tomada de consciência e mobilização cognitiva impossível de se atingir se o indivíduo for deixado sozinho. São oferecidas pistas sobretudo através de novas perguntas. Na realidade, o método interrogativo deve ser a utilização de uma cadeia complexa de perguntas que conduzam o mediado a um conflito e a uma possibilidade de mudança tanto em seu conhecimento prévio quanto em seu padrão espontâneo de raciocínio ${ }^{238}$.

O uso da linguagem verbal, como pontua Vigotski (2009) trata-se de uma forma de estruturar o pensamento sendo um mediador interno no desenvolvimento das funções psicológicas superiores $^{239}$.

Assim, consideramos que é na esfera de ação escolar, sobretudo da sala de aula, com o conhecimento sistematizado, com a aquisição da palavra, que a criança e o adolescente apoia os conceitos científicos nos espontâneos passando a desenvolver o conceito científico ${ }^{240}$.

\subsection{MEDIAÇÃO NAS MODALIDADES SIMBÓLICA E FIGURATIVA}

Noutra etapa da Sequência Didática os estudantes receberam uma folha que fora por nos utilizada como instrumento de mediação contendo duas imagens de obras do artista Cândido Portinari: "Retirantes" e "Criança Morta". As folhas contendo a atividade nas modalidades verbal e figurativa foram distribuídas aos alunos, que deveriam trabalhar em grupos de 4 ou 5 pessoas, identificando objetos nas imagens, a quantidade de pessoas e fazendo comparações (diferenciações e aproximações). De acordo com Gomes (2002, p. 140):

Comparar significa extrair uma propriedade ou característica de determinado objeto, através da identificação e da análise, e transpor essa propriedade para outro objeto, buscando similaridades e diferenças [...]. Assim, a comparação envolve a extração de um traço comparativo e a constatação de diferenças e semelhanças ${ }^{241}$.

\footnotetext{
${ }^{238}$ GOMES, C. M. A. Feuerstein e a construção mediada do conhecimento. P. Alegre: Artmed, 2002 ${ }^{239}$ VIGOTSKI, L. S. A construção do pensamento e da linguagem. $2^{\mathrm{a}}$ ed. São Paulo: Martins Fontes, 2009.

${ }^{240}$ Conforme Vigotski (2009, p. 241) "O desenvolvimento dos conceitos científicos na idade escolar é, antes de tudo, uma questão prática de imensa importância - talvez até primordial - do ponto de vista das tarefas que a escola tem diante de si quando inicia a criança no sistema de conceitos científicos". VIGOTSKI, L. S. A construção do pensamento e da linguagem. $2^{\mathrm{a}}$ ed. S. Paulo: Martins Fontes, 2009. ${ }^{241}$ GOMES, C. M. A. Feuerstein e a construção mediada do conhecimento. P. Alegre: Artmed, 2002
} 
Nos detivemos em como poderíamos ampliar os níveis de abstração no processo de aprendizagem, favorecendo o desenvolvimento de operações mentais como a identificação e a comparação, por exemplo, para que pudessem os estudantes correlacionar as condições dos nordestinos daquele período (numa escala temporal do passado) com a migração em direção a metrópole paulistana industrializada (numa escala que parte de outro lugar).

O instrumento de mediação utilizado, contendo as duas obras de Portinari, continha seis questões, sendo que para a nossa amostra optamos por trabalhar apenas com duas delas, que se referem a identificação de objetos na primeira imagem (Criança Morta) e as semelhanças e diferenças entre as duas imagens.

Em nossa sequência de atividades, tanto em relação ao instrumento de identificação e comparação, como nas demais questões utilizadas na elaboração inicial, final e dissertação, optamos por trabalhar com a resolução de problemas, por acreditar que o desenvolvimento cognitivo se dá a partir de problematizações colocadas ao aluno. De acordo com Pozo (1998, p. 17):

\begin{abstract}
A solução de problemas representa para o aluno uma demanda cognitiva e motivacional maior que a execução pelo que, muitas vezes os alunos não habituados a resolver problemas se mostram inicialmente reticentes e procuram reduzi-los a exercícios rotineiros ${ }^{242}$.
\end{abstract}

O autor supracitado, discorre sobre a importância em se gerar no aluno a atitude em buscar respostas para suas próprias questões e problemas, não mais recebendo respostas prontas, mas habituando-se a questionar, pois somente assim, a aprendizagem da solução de problemas ${ }^{243}$ será espontânea e autônoma.

Ao trabalhar com as ilustrações, buscamos desenvolver nos alunos níveis mais sofisticados de abstração do pensamento, ao lidar com uma abordagem que não se detêm aos aspectos mais imediatos e concretos das figuras, mas estimular por meio da aprendizagem mediada um pensamento mais elaborado, sempre cuidando para não nos tornarmos meros expositores das ilustrações no decorrer da aula, pois,

${ }^{242}$ POZO, J. I. A solução de problemas: aprender a resolver, resolver para aprender. (Org.). Porto Alegre: Artmed, 1998.

${ }^{243}$ Para Echeverría e Pozo (1998, p. 14): "Ensinar a resolver problemas não consiste em somente dotar os alunos de habilidades e estratégias eficazes, mas também criar neles o hábito e atitude de enfrentar a aprendizagem como um problema para o qual deve ser encontrada uma resposta". ECHEVERRÍA, M. D. P; POZO, J. I. Aprender a resolver problemas e resolver problemas para aprender. In: POZO, J. I. (Org.). A solução de problemas: aprender a resolver problemas, resolver para aprender. Porto Alegre: Artmed, 1998. 
Sobre o professor recai um novo papel importante. Cabe-lhe tornar-se o organizador do meio social, que é o único fator educativo. Onde ele desempenha o papel de simples bomba que inunda os alunos com conhecimento pode ser substituído com êxito por um manual, um dicionário, um mapa, uma excursão. Quando o professor faz uma conferência ou explica uma aula, apenas em parte está no papel de professor: exatamente naquele que estabelece a relação da criança com os elementos do meio que agem sobre ela. Onde ele simplesmente expõe o que já está pronto ${ }^{244}$ (VIGOTSKI, 2010, p. 448).

Fora solicitado aos estudantes que identificassem nas obras a quantidade de pessoas, e posteriormente os objetos que aquelas famílias possuíam na primeira imagem. A identificação, de acordo com Gomes (2002, p. 139):

[...] promove o reconhecimento e o destaque de determinado objeto frente ao campo perceptivo como um todo. Destaca um objeto do 'emaranhado' de estímulos provenientes do ambiente, definindo seu contorno e seu limite. Portanto, a identificação é uma ação mental que propicia ao indivíduo reconhecer o objeto através de suas propriedades ou características mais globais unitárias.

Além das atividades de identificação e comparação, o instrumento ainda demandava o uso do raciocínio analógico e inferencial, quando buscávamos contextualizar as condições de vida daquelas pessoas na região de semiárido que os repeliam a migrar; os objetos ali representados e as alternativas de vida na metrópole paulistana.

Algumas palavras-chave foram trabalhadas com o intuito de que aluno adquirisse novos vocabulários e pudesse formar conceitos científicos ${ }^{245}$. O instrumento nos serviu como um apoio para que buscássemos desenvolver funções cognitivas, como o controle da impulsividade e o comportamento exploratório, por exemplo.

A mediação com base no referido instrumento nos possibilitou verificar as fragilidades dos estudantes, que ora se apresentavam atreladas ao modo impulsivo de lidar com o material apresentado, ora uma tendência em solucionar as questõesproblema por uma tentativa de ensaio e erro.

Nesta atividade a participação dos estudantes, considerando-os por turmas, fora assimétrico, pois, as $8^{\mathrm{a}}$ séries $\mathrm{A}$ e $\mathrm{D}$, tiveram uma participação menor, quando comparadas às outras duas turmas da pesquisa, como podemos ver no gráfico da página seguinte.

${ }^{244}$ VIGOTSKI, Lev Semenovich. Psicologia pedagógica. $3^{\text {a }}$ ed. São Paulo: Ed WMF Martins Fontes, 2010.

${ }^{245}$ Segundo Gomes (2002, p. 115), "O conceito tem a função de extrair as propriedades, os traços dos dados, destacando-os do plano sensorial para o plano simbólico e geral”. GOMES, C. M. A. Feuerstein e a construção mediada do conhecimento. Porto Alegre: Artmed, 2002. 


\section{Gráfico 25 - Alunos que realizaram atividade com o instrumento de identificação e comparação}

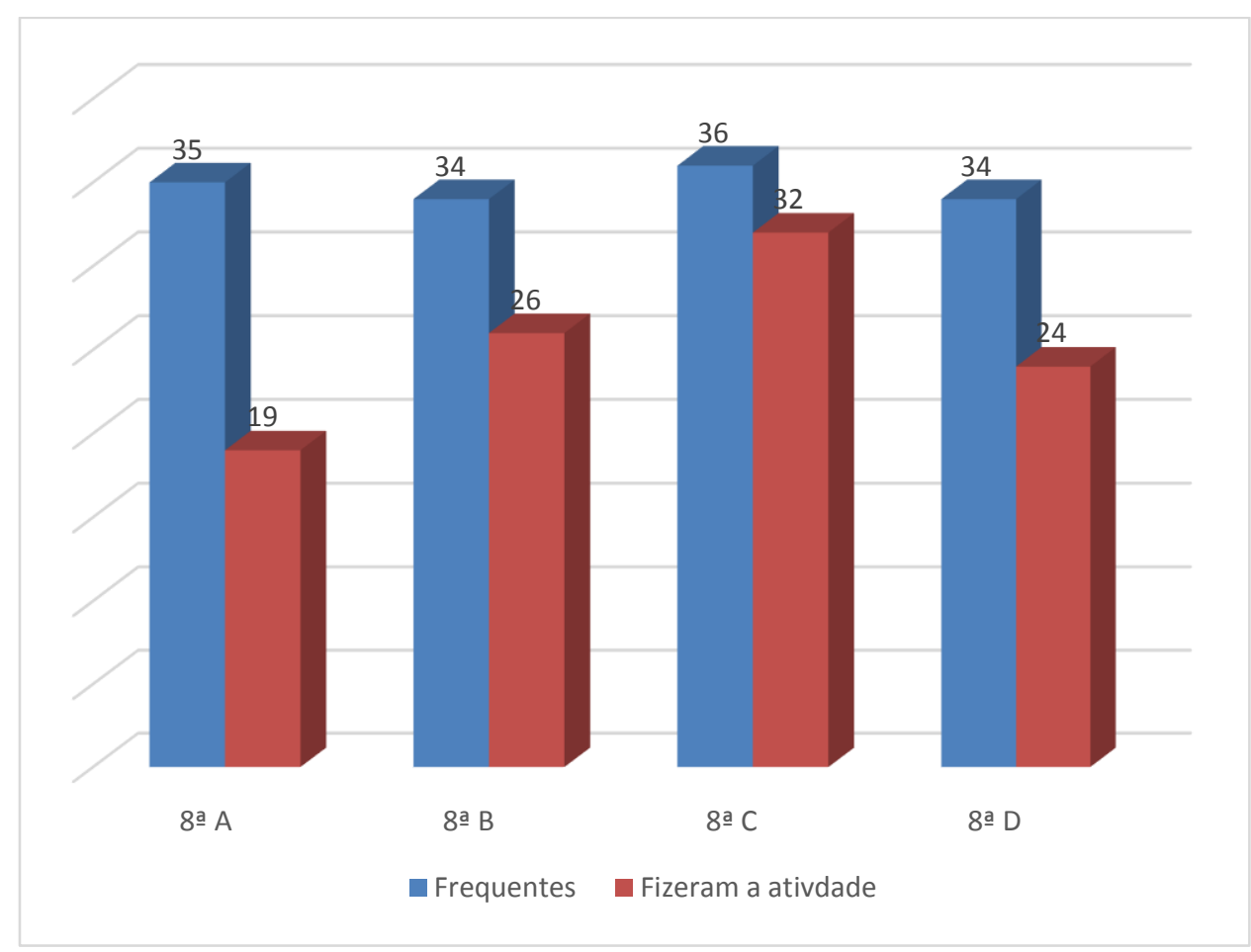

Fonte: Organizado pelo autor (2018).

De 35 alunos frequentes na $8^{\text {a }}$ série $\mathrm{A}$, somente 19 realizaram a atividade modular, ao passo que 34 alunos frequentes da $8^{\mathrm{a}} \mathrm{B}$, um total de 26 participou da atividade, sendo que na $8^{\mathrm{a}} \mathrm{C}$, dos 36 frequentes, 32 fizeram a atividade (sendo a sala que mais participou nessa modalidade de linguagem) e a $8^{a}$ série D, com seus 34 alunos frequentes, tivemos a participação de 24 deles.

Vale ressaltar, que estamos considerando como alunos frequentes aqueles que não apresentam número excessivo ou consecutivo de faltas, no entanto, a realidade da escola pública atual, ainda é caracterizada por alunos que apresentam faltas, que, ainda que intercalas, acabam por prejudicar seu aproveitamento e rendimento em termos de aprendizagem.

Numa das questões da ferramenta, solicitamos aos alunos que apontassem quais objetos conseguiam identificar na primeira imagem (Criança Morta), ao que obtivemos respostas diversas, pois alguns alunos se atentaram somente ao jarro ou vaso, outros identificaram também a mala, mas alguns se reportaram a segunda imagem, destoando do que fora solicitado na questão. Dentre algumas respostas selecionamos determinados trechos, como podemos ver no quadro seguinte. 
Quadro 14 - Respostas a questão do instrumento de comparação e identificação que pedia para o aluno identificar os objetos da primeira imagem (Criança Morta)

\begin{tabular}{|l|l|}
\hline $\begin{array}{l}\text { Nicolas } \\
\text { Grubert, } 8^{\mathrm{a}} \mathrm{A}\end{array}$ & $\begin{array}{l}\text { A gente podemos indentificar que tem uma mala e um jarro. A } \\
\text { utilidade dos objetos que está representado na imagem é que a } \\
\text { mala deve estar levando algumas trouchas de roupas e o jarro deve } \\
\text { ter algum pouco de água. }\end{array}$ \\
\hline $\begin{array}{l}\text { Paulo Vitor } \\
\text { Souza, 8 }\end{array}$ & $\begin{array}{l}\text { Eu acho que tem um baú ou uma maleta debaixo da mulher ou do } \\
\text { homem que eu acho que eles guardam os seus pertences e também } \\
\text { um jarro que eu acho que guardavam a água ou ele estava vazil. }\end{array}$ \\
\hline $\begin{array}{l}\text { Erika Vitória } \\
\text { Ricardo, } 8^{\mathrm{a}} \mathrm{C}\end{array}$ & $\begin{array}{l}\text { Muringa e a caixa, a moringa } e \text { caso eles acharem água e tals e a } \\
\text { caixa para se sentarem } e \text { o que mostram na imagem. }\end{array}$ \\
\hline $\begin{array}{l}\text { Lorrane R. } \\
\text { Lima, } 8^{\mathrm{a}} \mathrm{D}\end{array}$ & $\begin{array}{l}\text { Podemos identificar, um galão com água, e uma mala com as } \\
\text { vestimentas deles. }\end{array}$ \\
\hline
\end{tabular}

Fonte: Organizado pelo autor (2018).

A maioria dos alunos identificou os objetos trazidos na primeira imagem, porém, nem todos apontaram sua utilidade, tal como era solicitado no enunciado da questão. Percebemos durante a atividade que alguns alunos estavam com dúvidas em relação ao gênero da personagem que segura a criança morta no colo. A mala ou o baú, também gerou controvérsias, pois houve quem apontasse como sendo um túmulo ou uma caixa para se sentarem.

A aluna que se referiu ao objeto para armazenar água chamando-o de Moringa, foi perspicaz ao apontar que o objeto é para o caso de acharem água, trabalhando assim com um raciocínio lógico.

Raciocinar em nível lógico significa ir além das impressões imediatas, estabelecendo critérios e regras, relações não-visíveis diretamente, rompendo com o imediatismo do aqui e agora. Tais regras e critérios devem possuir representações da realidade que sejam flexíveis e abranjam um número de dados reversíveis e globais (GOMES, p. 122).

Para esta atividade optamos por analisar todas as salas em conjunto - para que se evite uma leitura exaustiva - assim, deixamos para o sexto capítulo as análises pormenorizadas por turmas em relação as elaborações inicial e final $n^{\circ} 1$. 
Nesta atividade da Sequência Didática com o instrumento de identificação e comparação, na modalidade figurativa, tivemos a participação de 101 estudantes. A seguir (gráfico 26) vamos analisar o total de alunos que conseguiu identificar mais de um objeto na primeira imagem trazida pela ferramenta, assim como quantos apontaram suas utilidades.

\section{Gráfico 26 - Total de alunos que conseguiu identificar objetos e apontar sua utilidade na imagem da obra Criança Morta}

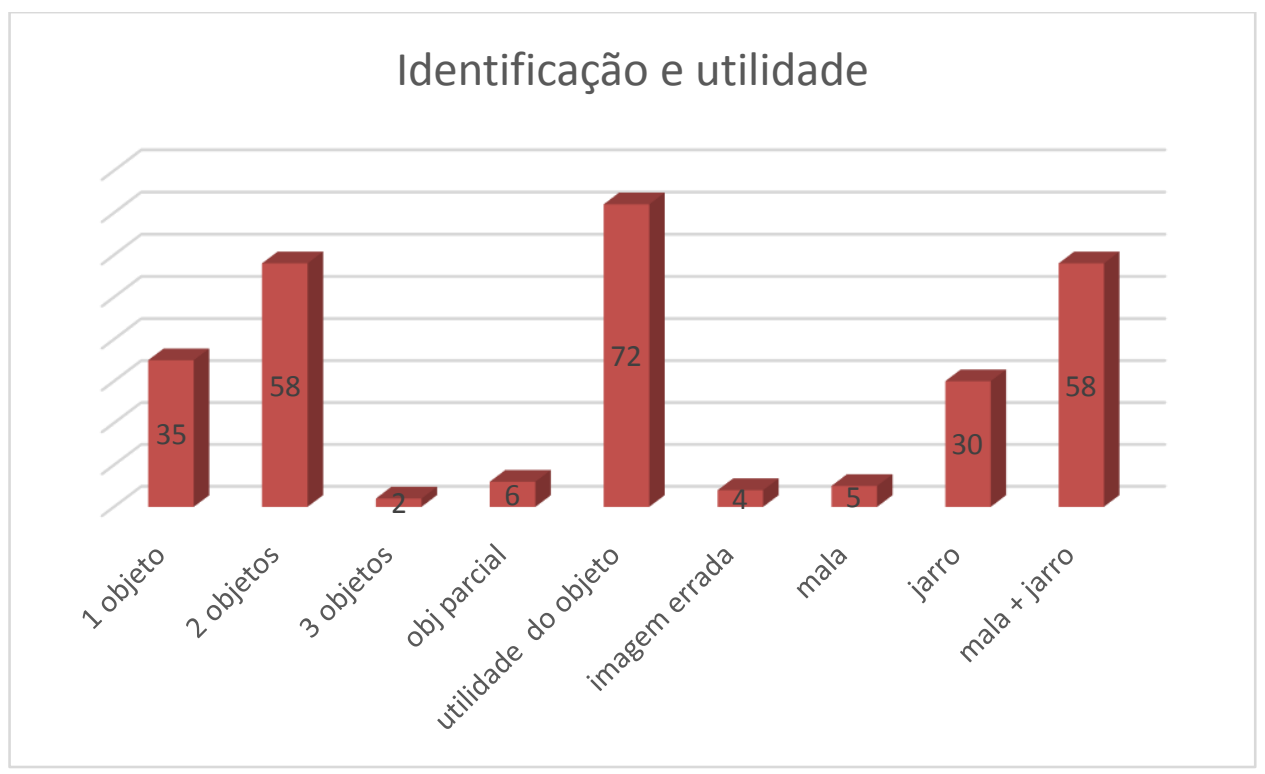

Fonte: Organizado pelo autor (2018).

Obtivemos que um total de 58 estudantes conseguiu identificar dois objetos, sendo estes a mala e o jarro, ao passo que 35 alunos apenas identificaram um objeto (30 deles o jarro e 5 alunos a mala). De um total de 101 alunos, 72 apontou a utilidade de no mínimo um dos objetos. Ainda tivemos 4 estudantes que se atentaram a imagem que não fora solicitada no enunciado. Dois alunos apontaram um terceiro objeto e 6 estudantes apontaram parcialmente algum objeto.

Noutra questão do instrumento solicitamos aos estudantes que identificassem diferenças e semelhanças entre as duas obras. Dentre algumas elaborações obtivemos que muitos estudantes apontaram somente as diferenças, não se atentando àquilo que havia de semelhante entre as imagens.

Os alunos puderam registrar suas análises nas folhas que receberam, cada qual individualmente, podendo, porém, trocar informações com os colegas de seu grupo. Conforme aponta Miranda (2010, p. 13): 
[...] o saber se constrói na mediação e troca entre iguais que vão interagindo e experimentando ter voz ativa de suas vontades e sentimentos, confrontando-se com os demais, e encontrando soluções para seus problemas por intermédio de discussões e expressões próprias de seus questionamentos ${ }^{246}$.

Entre os que responderam ao que o enunciado da questão pedia, selecionamos, como anteriormente, um fragmento de cada sala.

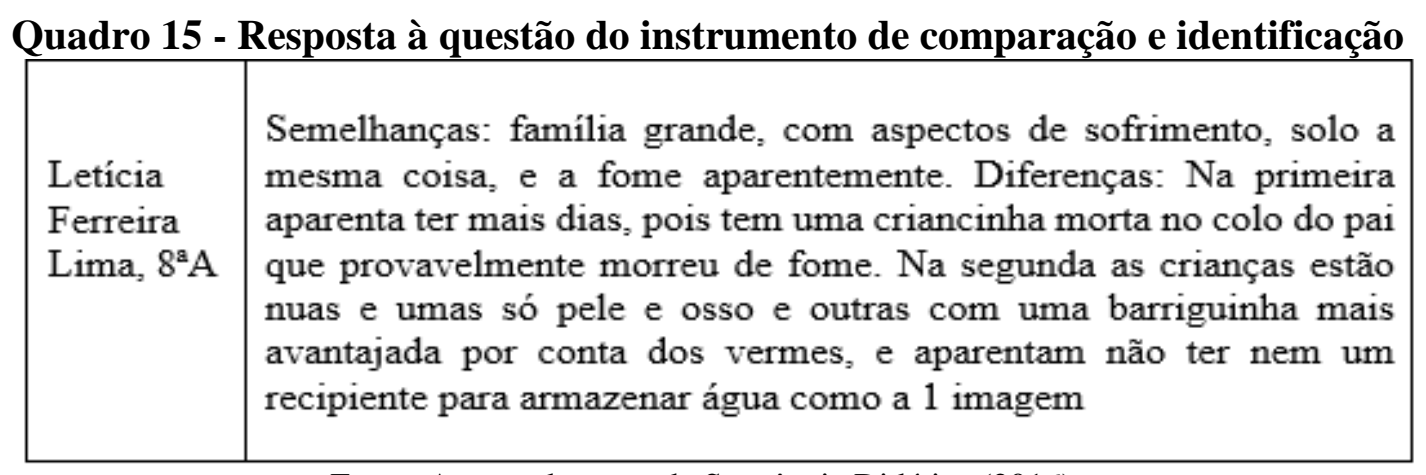

Fonte: Acervo do autor de Sequência Didática (2016).

A aluna ressaltou como semelhanças o fato de as imagens conterem famílias com aspectos de sofrimento, o solo e a fome. Em relação as diferenças o fato de haver uma criança morta no colo do pai que provavelmente teria morrido de fome. A aluna se utiliza de uma operação mental ao associar a morte ao quadro de fome. Do mesmo modo, ao apontar dentre as diferenças o fato de que na segunda imagem as crianças estavam nuas, uma delas "pele e osso" e outra "com uma barriguinha mais avantajada por conta dos vermes", a aluna se utiliza do pensamento lógico inferencial:

Essa é uma ação responsável pela descoberta de relações de causa e efeito entre os objetos. A inferência é a busca e o estabelecimento de uma causa, de uma regra causal para as 'coisas' do mundo. O mundo possui certas constâncias, certos padrões, e as inferências são as tentativas do aparato cognitivo de compreensão das relações possíveis entre os objetos e os eventos, do mundo: o que causa o quê? ${ }^{247}$ (GOMES, 2002, p. 153).

No próximo exemplo, a aluna ao apontar as semelhanças entre o "solo seco", os "ossos" e a "expressão de tristeza", também se utiliza de uma operação mental ao pontuar como diferença o fato de, na primeira imagem haver uma criança morta e de na segunda imagem a criança ainda não ter morrido.

246 MIRANDA, M. E. Contribuição ao debate atual sobre a formação de professores no Brasil: pela formação de futuras gerações na perspectiva da reconstrução do sócio-cultural. Revista do Departamento de Geografia, n. 20, p. 11-22, 2010.

247 GOMES, C. M. A. Feuerstein e a construção mediada do conhecimento. P. Alegre: Artmed, 2002. 


\section{Quadro 16 - Resposta à questão do instrumento de comparação e identificação}

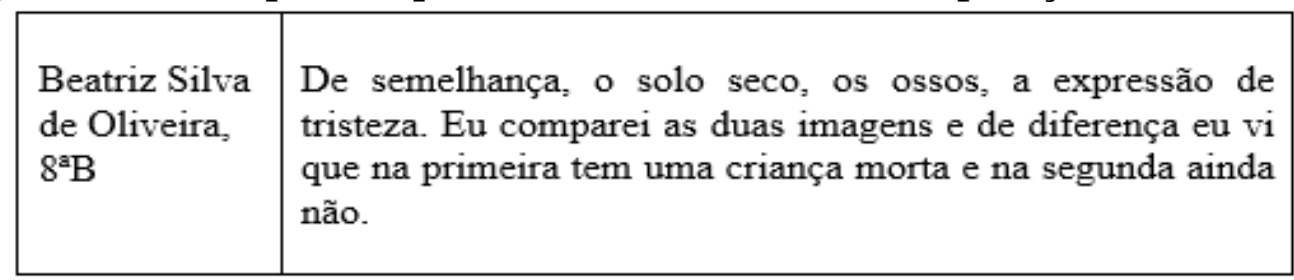

Fonte: Acervo do autor de Sequência Didática (2016).

A aluna levantou a hipótese ${ }^{248}$ de que as condições de miséria também levariam à morte a criança da segunda imagem em questão de tempo. Para Gomes (2002, p. 153):

[...] a hipótese é a compreensão de que as relações causais são complexas, variadas e multidimensionais. A hipótese é a elaboração de uma ideia que supõe em si a possibilidade de uma solução para determinado problema e, além disso, a possibilidade do erro, do engano. Assim, a formulação de uma hipótese gera outras hipóteses, gera sempre novos pontos de vista e novos enfoques sobre o problema analisado. Ambas, inferências e hipóteses, geram o conhecimento humano sobre as relações existentes entre o objeto e suas regras.

O aluno do exemplo seguinte, se atentou ao aspecto das roupas, do solo, do cansaço, como elementos que evidenciam as semelhanças entre as imagens.

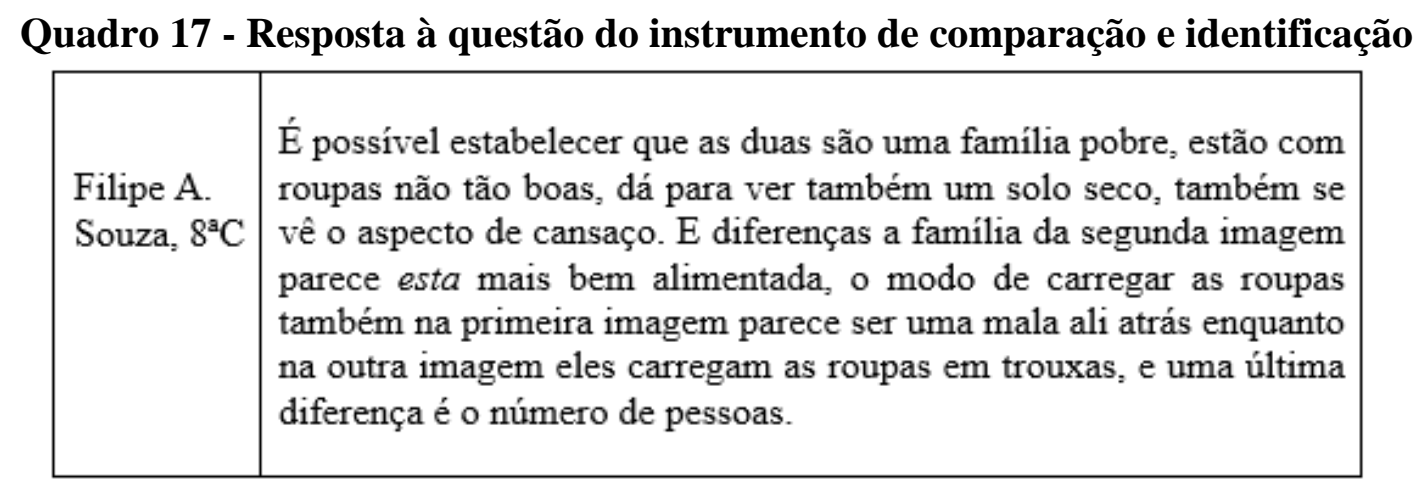

Fonte: Acervo do autor de Sequência Didática (2016).

Em relação às diferenças considerou que a família da segunda imagem parecia estar melhor alimentada, assim como o modo como transportavam as roupas, pois conforme o aluno, em uma imagem parecia haver uma mala, enquanto na outra carregavam as roupas em trouxas, além de haver a diferença no número de pessoas. $\mathrm{O}$ aluno conseguiu fazer uma análise das imagens, que conforme Gomes (2002, p. 139):

A análise é a ação mental responsável pela 'quebra' das partes do objeto destacado pela identificação. Assim como o objeto é reconhecido em seu todo pela identificação, a análise desdobra o objeto pela quebra e pelo reconhecimento de suas partes.

\footnotetext{
${ }^{248}$ Sobre o pensamento hipotético Gomes (2002, p. 124) considera que essa "função possibilita ao ser humano pensar em situações virtuais que ainda não aconteceram, mas que são prováveis”.
} 
Aliás, o número de pessoas fora apontado por demais estudantes como uma das diferenças entre as imagens, como podemos ver no exemplo seguinte.

\section{Quadro 18 - Resposta à questão do instrumento de comparação e identificação

\begin{tabular}{|l|l|}
\hline $\begin{array}{l}\text { Aline } \\
\text { Monteiro de } \\
\text { Sousa, } 8^{\mathrm{a} D}\end{array}$ & $\begin{array}{l}\text { A semelhança é que as duas imagens representam tristeza e a } \\
\text { diferença é que o número de pessoas da primeira imagem é } \\
\text { menor que o número de pessoas da segunda imagem. }\end{array}$ \\
\hline
\end{tabular}

Fonte: Acervo do autor de Sequência Didática (2016).

Alguns alunos, porém, elaboraram seus enunciados fazendo ainda uso de vocábulos mais voltados a um conhecimento espontâneo e do senso comum. No momento de socialização de suas respostas, além de terem citado a magreza das pessoas e a barriga de uma das crianças, por alguns alunos chamada de barriga d'água, um jovem identificou que o pênis de uma das crianças da pintura estava à mostra, o que, segundo o garoto, seria um indicativo da situação de pobreza daquela família. Começava-se a emergir um raciocínio hipotético inferencial, ao mesmo tempo em que assumiam uma postura não passivo-receptora, mas ativa e colaborativa entre seus pares.

Pudemos verificar nesta etapa da atividade que muitos alunos apontaram ou somente as diferenças entre as imagens, ou apenas o que havia de semelhante entre elas, ao invés de apontar o que o enunciado pedia, ou seja, as semelhanças e diferenças. De acordo com o gráfico 27, podemos verificar que do total de 101 alunos que realizou a referida atividade, tivemos um total de $44 \%$ de estudantes que apontou adequadamente as diferenças e semelhanças entre as imagens. Porém, tivemos $16 \%$ de alunos que não respondeu adequadamente à questão ou a deixou sem resposta. Também o valor de $16 \%$ referente àqueles que apenas apontaram as semelhanças, ao passo que $24 \%$ dos alunos conseguiu apresentar apenas as diferenças entre as duas imagens.

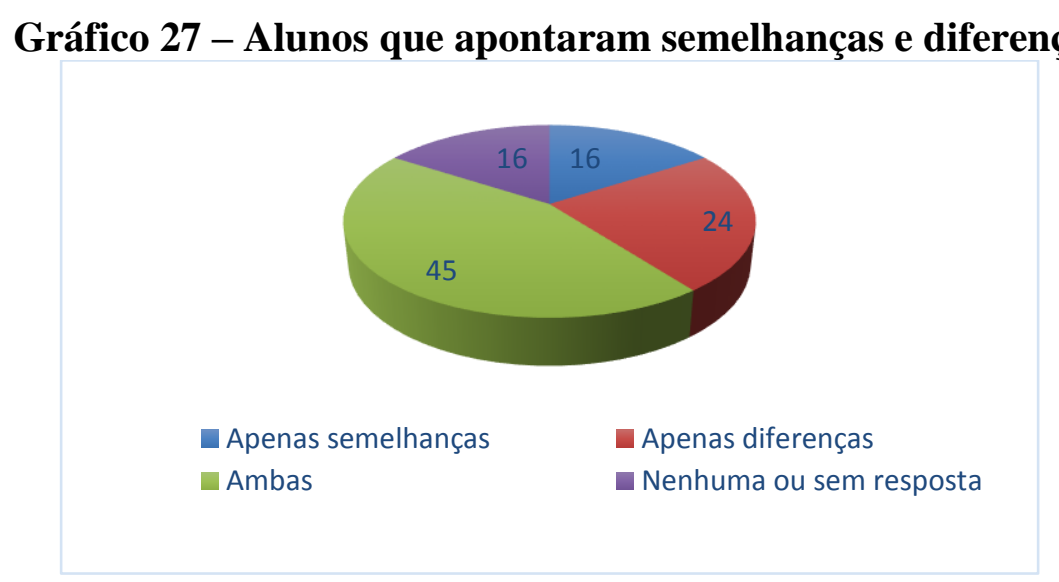

Fonte: Organizado pelo autor (2018). 
Chama atenção o fato de as diferenças terem se sobressaído em relação as semelhanças, o que nos leva a entender que efetivamente não realizaram uma análise.

O contato mais direto com o aluno se deu a partir da perspectiva da EAM e de seus três critérios universais buscando imprimir sempre significado no que estava sendo trabalhado com os estudantes.

O mediador deve fornecer seus significados para o mediado, inclusive para que ele possa elaborar novos significados e novas possibilidades, generalizando e transcendendo. Interagir pela troca de significados significa trocas experiências, vivências e sentimentos que ultrapassam o nível do fenômeno concreto que, geração após geração, os seres humanos irão compartilhar e terão uma certa identificação sobre o que é certo e o que é errado, estabelecendo um senso comum, um senso estético e ético [...]. No contexto da teoria de Feuerstein 'significado' deve ser entendido como um sentido que o indivíduo tira da vida ${ }^{249}$ (GOMES, 2002, p. 90).

A aplicação das ilustrações permitiu verificar se os alunos têm uma percepção clara e precisa ${ }^{250}$, presença de vocabulário, se souberam coletar indícios, se apresentam uma conduta comparativa e somativa e distinguem dados relevantes dos irrelevantes.

Figura 9 - Aluno sendo mediado

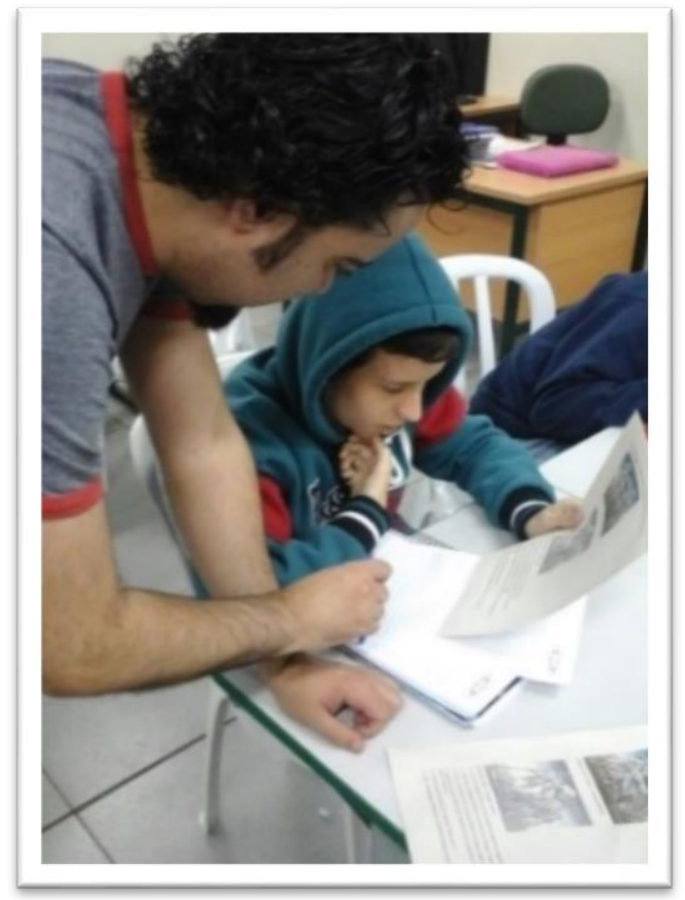

Autor: Kaique Alves dos Santos (2016).
Figura 10 - Estudantes sendo mediados

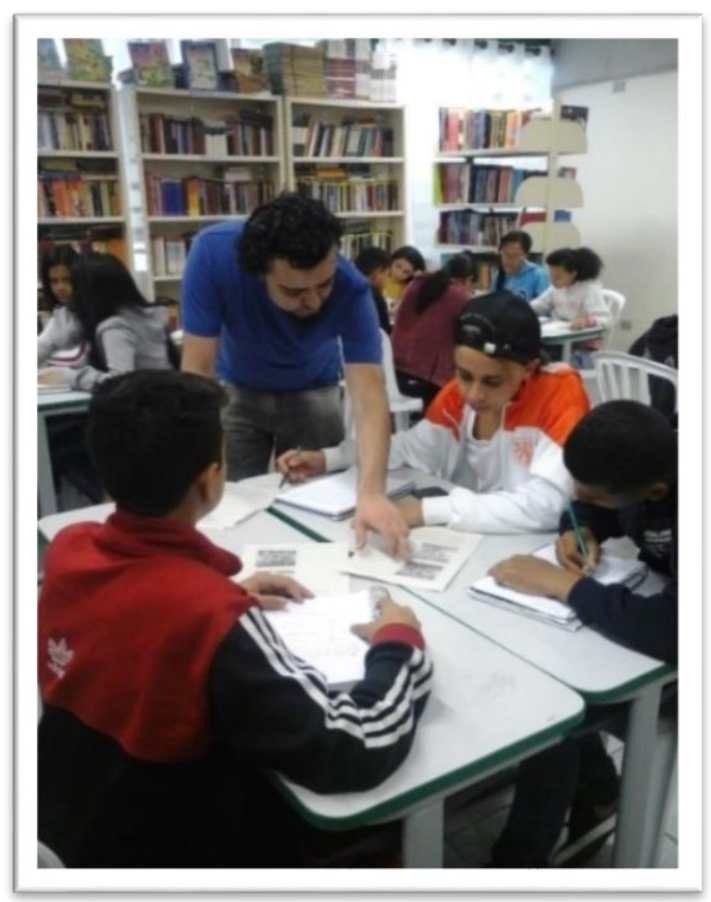

Autor: Danilo Brito Lopes (2016).

${ }^{249}$ GOMES, C. M. A. Feuerstein e a construção mediada do conhecimento. P. Alegre: Artmed, 2002.

250 "Podemos dizer que a necessidade de percepção clara e precisa é exigida em todas as atividades humanas. Contudo, sua necessidade torna-se vital especialmente nas atividades que requerem precisão e análise apurada" (Ibid., p. 114). 
Noutra etapa da Sequência Didática trabalhamos uma folha contendo um gráfico e um mapa, na modalidade simbólica. Tal escolha se justifica por defendermos a relevância de o aluno lidar com recursos didático-pedagógicos munidos de problematizações em diversas modalidades, concordando com Vieira (2007, p. 24):

Pressionado pelas mudanças, o letramento hoje não se refere, apenas, às habilidades de leitura e de escrita. O letramento típico da pós-modernidade agrega ao texto escrito inúmeros recursos gráficos, cores e, principalmente imagens. Passa a exigir do sujeito letrado habilidades interpretativas básicas que devem atender às necessidades da vida diária, como as exigidas pelos locais de trabalho do mundo contemporâneo ${ }^{251}$.

O gráfico continha os percentuais da população com idades entre 30 e 60 anos, residentes na metrópole paulistana e seus estados de origem, apontando que atualmente o maior percentual de residentes refere-se aos paulistas; o que vem clarificar que está havendo uma sutil tendência a um movimento de retorno de migrantes nordestinos à suas cidades ou região de origem, assim como uma redução no fluxo migratório sentido Nordeste-Sudeste. Por tratar se de um instrumento nas modalidades simbólica e numérica, os alunos foram solicitados a identificar, além de título e subtítulo, autor e data da matéria, os totais numéricos por estados, identificando quais naturalidades apresentavam os maiores volumes populacionais.

A referida atividade exigiu dos estudantes durante o processo de Experiência de Aprendizagem Mediada a capacidade de decodificação. De acordo com Gomes (2002, p. 145), “a decodificação é a operação mental responsável pela compreensão dos esquemas simbólicos gráficos, transformando-os em conceitos mentais".

Constituem-se em esquemas simbólicos gráficos os desenhos, os mapas e a escrita, ou seja, todas as construções notacionais usadas pela humanidade para simbolizar e esquematizar os conceitos. Sua variabilidade e quantidade é imensa [...]. Já os conceitos mentais são definidos como as representações mentais que dizem respeito aos significados construídos mentalmente. As representações mentais podem ser definidas principalmente em duas grandes formas: por meio verbal e/ou por meio de imagens, sejam visuais, auditivas, cinestésicas ${ }^{252}$.

Posteriormente detivemo-nos em trabalhar com a análise dos mapas contendo as principais correntes migratórias no Brasil nos últimos anos, o que possibilitou aos alunos verificar uma dada inversão no fluxo migratório de nordestinos. Nesta etapa da Sequência Didática já havia por parte dos estudantes um maior controle da impulsividade e modestos avanços em relação ao comportamento exploratório.

${ }^{251}$ VIEIRA, J. A. Novas perspectivas para o texto: uma visão multissemiótica. In: VIEIRA, J. A. (Org.). Reflexões sobre a língua portuguesa: uma abordagem multimodal. Petrópolis: Vozes, 2007.

${ }^{252}$ GOMES, C. M. A. Feuerstein e a construção mediada do conhecimento. P. Alegre: Artmed, 2002. 
As participações durante o processo dialógico e de aprendizagem mediada não se davam mais por tentativas de ensaio e erro, ainda que estas não tivessem cessado. No entanto, no decorrer desta atividade modular, as elaborações ainda demonstraram fragilidades quanto ao vocabulário utilizado; contudo, as elaborações começavam a demonstrar o início da formação de alguns conceitos.

\section{Quadro 19 - Fragmentos de respostas de estudantes à atividade contendo gráfico}

\begin{tabular}{|l|l|}
\hline $\begin{array}{l}\text { Layla Rocha e } \\
\text { Silva, } 8^{\mathrm{a} D} \mathrm{D} .\end{array}$ & $\begin{array}{l}\text { [...] Isso é devido a faixa de emprego que era grande ter caído, } \\
\text { por conta das tecnologias nas fabricas ter deixado muitos } \\
\text { desempregados. Agora eles voltam ou porque já são aposentados } \\
\text { ou mesmo pela falta de emprego. }\end{array}$ \\
\hline $\begin{array}{l}\text { Carlos } \\
\text { Eduardo da } \\
\text { Silva Pereira, } \\
8^{\mathrm{a}} \mathrm{C} .\end{array}$ & $\begin{array}{l}\text { No segundo gráfico "correntes migratórias principais" mostra } \\
\text { uma mensagem de retorno pois, as industrias começaram a } \\
\text { utilizar o sistema toyotista, que usa máquinas no lugar de } \\
\text { operários, apesar de tudo isso não é a principal causa, pois hoje } \\
\text { os outros estados estão valendo mais a pena [...]. }\end{array}$ \\
\hline $\begin{array}{l}\text { Giovanne de } \\
\text { Jesus Reis, } \\
8^{\mathrm{a}} \mathrm{C} .\end{array}$ & $\begin{array}{l}\text { Já na segunda imagem abaixo, nós podemos ver que o retorno } \\
\text { à origem é muito maior que a saída dos nordestinos de seu local } \\
\text { de origem. } \\
\text { É evidente que nesses ultimos tempos, o nordeste recebeu } \\
\text { uma atenção a mais, e que foram abertas varias oportunidades de } \\
\text { emprego na região nordestina, e que a miseria no nordeste é } \\
\text { muito menos que antes [...]. }\end{array}$ \\
\hline
\end{tabular}

Fonte: Acervo do autor de Sequência Didática (2016).

Dos três exemplos supracitados, temos que dois alunos ainda estão restritos ao lugar, pois atrelaram o movimento de retorno ao desemprego na metrópole, ao uso de novas tecnologias.

Outro estudante, porém, apontou que o instrumento trazia o retorno dos migrantes nordestinos à sua cidade de origem sendo maior que a saída dos nordestinos de seu local de origem. O aluno considerou outra escala que não a da metrópole paulistana. Ou seja, ao invés de pontuar somente os fatores de repulsão, tais como desemprego ou a xenofobia, por exemplo, ressaltou o fato de nos últimos tempos a região nordestina ter recebido uma maior atenção, o que fez com que fossem abertas oportunidade de emprego.

Durante todo o processo de aplicação da Sequência Didática, detivemo-nos em apoiar o processo de aprendizagem para que o aluno, além de adquirir novas palavras e de se iniciar num processo de construção de conceitos científicos e de um pensamento e 
nível de abstração mais elaborados, a trabalhar não apenas restritivo a uma escala local do problema ou fenômeno estudado, mas buscar conexões com outras escalas de tempo e de espaço.

Ademais, vale ressaltar, que parte das atividades da Sequência Didática foram realizadas em outro ambiente da unidade escolar que não propriamente a tradicional sala de aula, no intuito de podermos ter um local destoante do que cotidianamente os alunos estão habituados, visando um espaço com menos ruídos e outros tipos de interferências que impactam no tempo-espaço da aula e que acabam por comprometer as aprendizagens. Recorrendo as ponderações de Mariana Martins Lemes (2017, p. 84):

\begin{abstract}
Algumas das intervenções que ocorrem na escola impactam o tempo-espaço da aula. Denominamos tais intervenções de interferências, pois elas alteram as condições da aula, interferindo, direta ou indiretamente, na aplicação do plano de trabalho docente e na relação entre professor e alunos. [...] há diversos tipos de interferências, sendo algumas delas, inclusive, já esperadas para o ano letivo (como reuniões de pais/responsáveis e professores), enquanto outras ocorrem sem aviso prévio (como a dispensa de alunos). Essas diferentes interferências, que atendem a objetivos diversos, tendem a se acumular ao longo do ano letivo: suspendem e comprimem o tempo-espaço da aula, levando a interrupções nos planos dos professores e no trabalho desenvolvido com os alunos $^{253}$.
\end{abstract}

Os estudantes, realizaram parte das atividades em pequenos grupos, como é possível visualizar na imagem abaixo.

Fig. 11 - Atividades com instrumento na modalidade simbólica

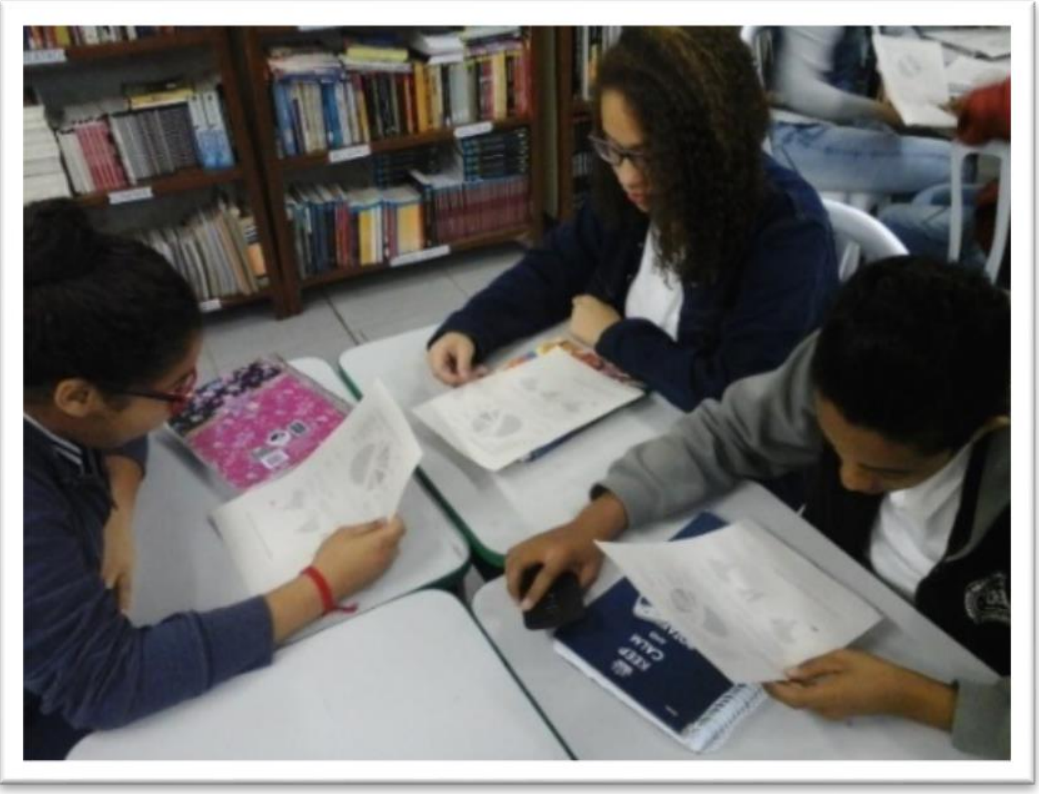

Autor: Carlos Eduardo Fonseca (2016).

253 LEMES, Mariana Martins. Interferências no tempo-espaço da aula: percepções dos professores sobre a política educacional de São Paulo. Dissertação Mestrado. Faculdade de Filosofia, Letras e Ciências Humanas da Universidade de São Paulo. Departamento de Geografia, 2017. 
Para mediação com o gráfico e o mapa, optamos por modificar o ambiente da sala de aula dispondo as carteiras em formato de "U" ${ }^{254}$, permitindo que todos pudessem ver uns aos outros e ao professor de modo mais preciso.

\section{Fig. 12 - Atividades na modalidade simbólica em sala de leitura}

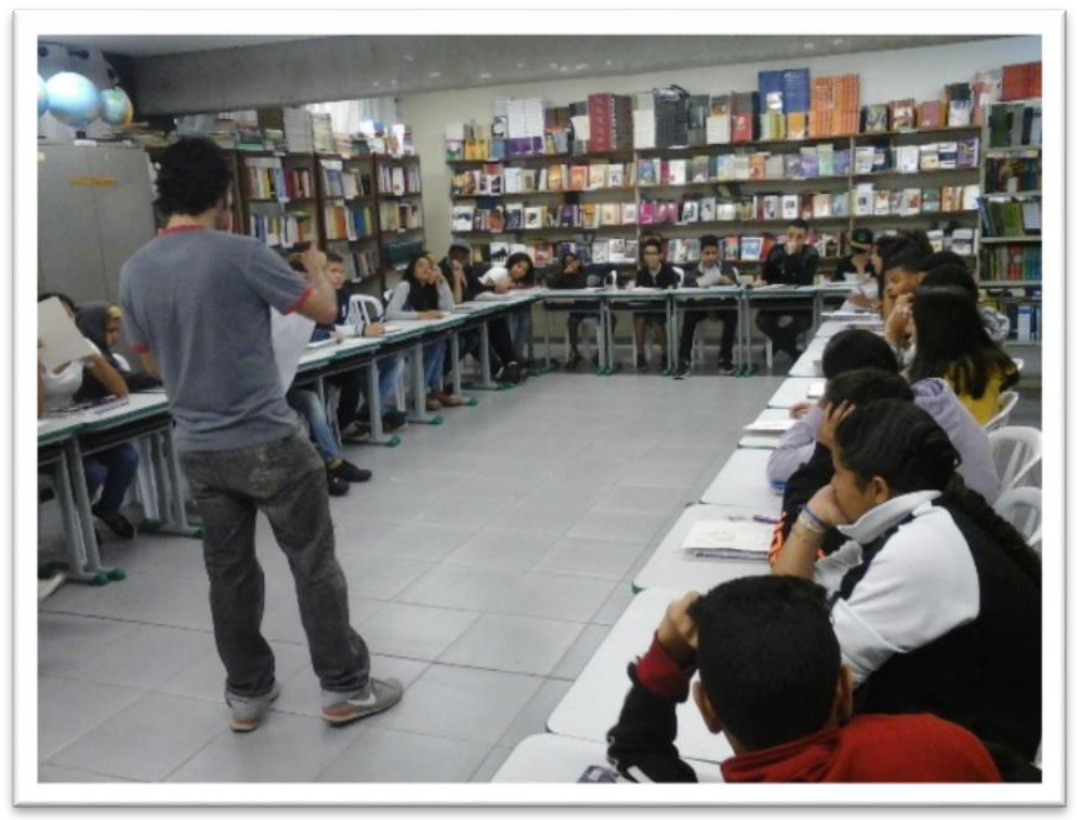

Autor: Cláudio Roberto da Silva (2016).

Durante as atividades modulares realizadas em diferentes modalidades de linguagem procuramos não perder de vista o aluno enquanto centralidade da aula e o professor enquanto um mediador no processo de aprendizagem, que, conforme Vitor da Fonseca (1998, p. 14):

[...] se situa entre o organismo do indivíduo mediatizado [...] e os estímulos (sinais, imagens, objetos, tarefas, problemas, eventos etc), de forma a selecioná-los, ampliá-los ou interpretá-los, utilizando estratégias interativas para produzir significação, para além das necessidades imediatas da situação de aprendizagem $^{255}$.

A realização da maior parte das atividades num ambiente diferente da tradicional sala de aula a que os alunos estavam acostumados e em diferentes linguagens, mostrouse tanto como uma novidade, como tornou o ambiente propício ao processo de Experiência de Aprendizagem Mediada.

\footnotetext{
${ }^{254}$ A disposição das carteiras nesse formato foi inspirada no modo como a $\operatorname{Prof}^{\mathrm{a}} \operatorname{Dr}^{\mathrm{a}}$ Maria Eliza Miranda organiza os professores em seu Grupo de Pesquisa com docentes das redes municipal e estadual de ensino, assim como em seu curso de extensão, na Universidade de São Paulo (USP).

${ }^{255}$ FONSECA, Vitor da. Aprender a aprender: a educabilidade cognitiva. Porto Alegre: Artmed, 1998.
} 


\section{CAPÍTULO 6 ANÁLISE DAS ELABORAÇÕES DOS ESTUDANTES EM RELAÇÃO ÀS QUESTÕES-PROBLEMA}

Neste capítulo tratamos da elaboração final $n^{\circ} 1$ realizada pelos estudantes ao fim da Sequência Didática, após terem tido contato com as atividades modulares que permearam a referida sequência. A elaboração final fora composta pelas três questõesproblema que tiveram contato no início das atividades. Nosso intuito fora o de verificar, a partir de suas elaborações se houve avanços na aquisição de vocabulário, no uso de conceitos científicos e principalmente se a aprendizagem fora efetivamente significativa. Do mesmo modo, buscamos verificar se a partir das atividades desenvolvidas em sala de aula, em diferentes modalidades de linguagem, com os três critérios universais da Teoria da Experiência de Aprendizagem Mediada de Feuerstein e os aportes teóricos de Vigotski, os alunos passaram operar mentalmente considerando outras escalas do problema estudado, que não somente do "seu" lugar destituído de conexões com outras escalas de tempo e espaço.

\subsection{VERIFICANDO AVANÇOS ENTRE AS ELABORAÇÕES INICIAL E FINAL No 1}

Para a realização da elaboração final $n^{\circ} 1$, os estudantes receberam o mesmo modelo-padrão de folhas, com as questões e imagens idênticas as da elaboração inicial realizada no início da Sequência Didática. No entanto, optamos por solicitar aos alunos, noutra data, que elaborassem uma produção textual referente a uma dada situação problema acerca da animação Vida Maria, de modo que pudessem se utilizar de uma folha de apoio contendo gráficos, imagens, charges e figuras, como apoio em suas elaborações. Tratou-se de um modo de verificarmos se as atividades modulares desenvolvidas durante o quarto bimestre - a partir dos três critérios universais da perspectiva da Teoria de Experiência da Aprendizagem Mediada de Reuven Feuerstein e dos aportes teóricos de Lev S. Vigotski - puderam contribuir para o desenvolvimento intelectual e cognitivo destes estudantes, na formação de conceitos científicos e de um pensamento mais complexo e elaborado, destoando de um ensino de geografia meramente circunscrito àquilo que é o mais próximo, concreto e imediato do aluno. 
Consideramos neste ponto de nossa pesquisa a escrita enquanto uma complexa atividade cultural e não como uma atividade meramente técnica, mecânica e motora ${ }^{256}$, considerando o ato de escrever, como apontara Vigotski (2007), sendo uma intrínseca necessidade a ser despertada nas crianças como algo relevante e necessário para a vida, com significado, desenvolvendo-se como uma complexa e nova forma de linguagem. $\mathrm{O}$ autor, ainda aponta criticamente a prática da linguagem escrita se dando de modo mecânico.

[...] a escrita ocupou um lugar muito estreito na prática escolar, em relação ao papel fundamental que ela desempenha no desenvolvimento cultural da criança. Ensinam-se a desenhar letras e construir palavras com elas, mas não se ensina a linguagem escrita. Enfatiza-se de tal forma a mecânica de ler o que está escrito que se acaba obscurecendo a linguagem escrita como tal ${ }^{257}$ (VIGOTSKI, 2007, p. 125).

O início da Sequência Didática com a primeira elaboração dos estudantes nos permitiu verificar seus conhecimentos espontâneos, as dificuldades de escrita, fragilidades e inconsistências em suas respostas. Na ocasião, poucos alunos se detiveram em analisar as figuras que acompanhavam os enunciados, dada a impulsividade e respostas por tentativas de ensaio e erro. Já na elaboração final $n^{\circ} 1$, ao tomarem contato com as mesmas questões, demonstraram o início de um processo de formação de conceitos, analisando as imagens e demonstrando controle da impulsividade e com poucas tentativas de respostas por ensaio e erro.

A elaboração inicial continha três questões versando sobre a migração nordestina na segunda metade do século passado e o recente movimento de retorno atrelado aos processos de desconcentração industrial na metrópole paulistana e a desindustrialização em alguns pontos da capital. A primeira questão trazia o seguinte enunciado:

1 - Durante as décadas de 1950, 1960 e parte dos anos 1970, muitos migrantes nordestinos deixaram suas cidades dirigindo-se a outras regiões do Brasil, mais especificamente à Sudeste, sobretudo a região metropolitana de São Paulo. Escreva quais foram as motivações que levaram os nordestinos a saírem de onde viviam e quais fatores os atraíram para a grande metrópole paulistana.

\footnotetext{
${ }^{256}$ Para Lima (2007, p. 40), "Quando escrevemos algo, mobilizamos várias áreas do cérebro e tomamos consciência de coisas das quais somente o pensamento (linguagem interna) não dá conta. Ou seja, várias coisas se organizam entre si no ato de escrever: a própria ação (movimento) leva à estimulação de redes neuronais já existentes e à formação de novas conexões entre os neurônios. Pode haver um reforço ou aumento da rede, com fortalecimento da memória". LIMA, E. S. (Org.). Indagações sobre currículo: currículo e desenvolvimento humano. Brasília: Ministério da Educação, Secretaria da Educ. Básica, 2007. 257 VIGOTSKI, L. S. A formação social da mente: o desenvolvimento dos processos psicológicos superiores. $7^{\mathrm{a}}$ ed. São Paulo: Martins Fontes, 2007.
} 
Antes de uma análise pormenorizada das respostas dos alunos, nos deteremos nos exemplos de uma produção inicial e final 1 de cada questão de cada turma, a fim de verificarmos se houve ou não avanços entre as elaborações. No primeiro caso temos:

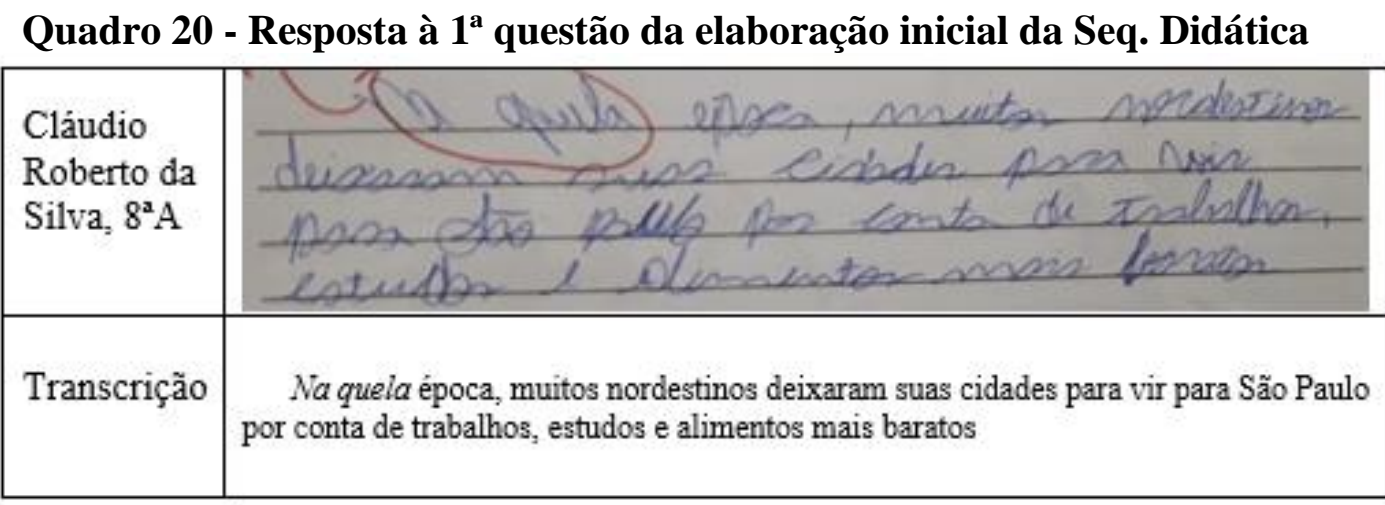

Fonte: Acervo da pesquisa de Sequência Didática do autor (2016).

Em sua primeira elaboração o aluno atribui a vinda dos nordestinos à metrópole paulistana à fatores relacionados à busca por melhores condições socioeconômicas, porém, seu texto se dá de modo genérico sem demonstrar maiores correlações com as imagens apresentadas na questão. No entanto, ao refazer noutro momento a questãoproblema, o aluno apresenta um enunciado melhor estruturado, demonstrando noções temporais e espaciais, e ainda fazendo uso dos elementos imagéticos da questão, apontando além dos fatores sociais e econômicos o fator ambiental (a seca).

Quadro 21 - Resposta à $1^{\text {a }}$ questão da elaboração final (1) da Seq. Didática

\begin{tabular}{|l|l|l|}
\hline $\begin{array}{l}\text { Cláudio } \\
\text { Roberto da }\end{array}$ & \begin{tabular}{l} 
Silva, 8'A \\
\hline Transcrição
\end{tabular} & $\begin{array}{l}\text { Mura vir a cidade grande "São Paulo". Vinha para região Suldeste por empregos } \\
\text { nas industrias de automóveis, metalurgicas, etc. } \\
\text { No quadro de Portinari "Os retirantes" mostra que é muito provavel que } \\
\text { eles estejam indo para a região Suldeste por conta da Seca, alimentos, roupas } \\
\text { e até mesmo falta de trabalho. }\end{array}$ \\
\hline
\end{tabular}

Fonte: Acervo da pesquisa de Sequência Didática elaborada pelo autor (2016). 
Ao pontuar a busca por empregos nas indústrias de automóveis e nas metalúrgicas, se utilizando da imagem de Portinari, considerando o problema da seca e da falta de alimentos e trabalho, demonstrou um pensamento mais complexo, por considerar mais elementos e fatores como responsáveis pelo movimento migratório.

No exemplo seguinte, podemos ver que o aluno apresenta mais os seus conhecimentos espontâneos em sua elaboração inicial, utilizando o exemplo de seu pai que deixara o estado do Piauí em busca de melhores oportunidades de vida.

Quadro 22 - Resposta a $1^{\text {aa }}$ questão da elaboração inicial da Seq. Didática

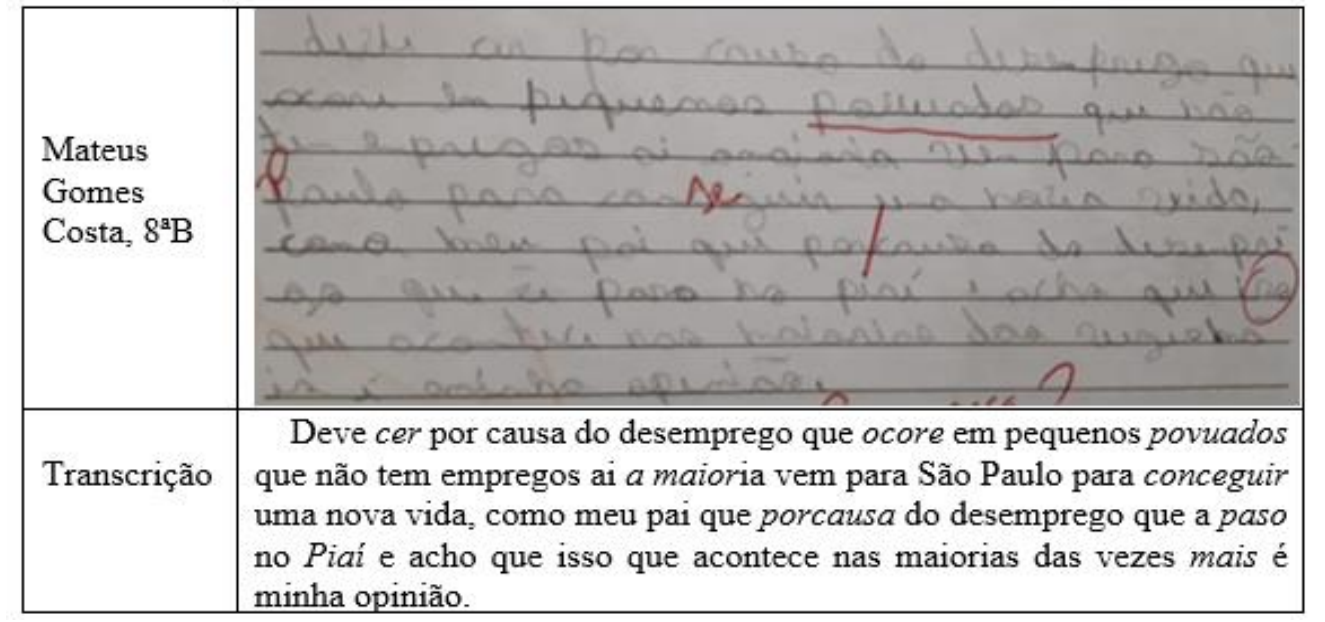

Fonte: Acervo da pesquisa de Sequência Didática elaborada pelo autor (2016).

O aluno não se atentou às informações que a questão apresentava em seu enunciado e não fez referência às imagens trazidas na problematização. Ao refazer a questão, passou a utilizar de elementos não apenas de sua vivência.

\section{Quadro 23 - Resposta à $1^{\text {a }}$ questão da elaboração final (1) da Seq. Didática}

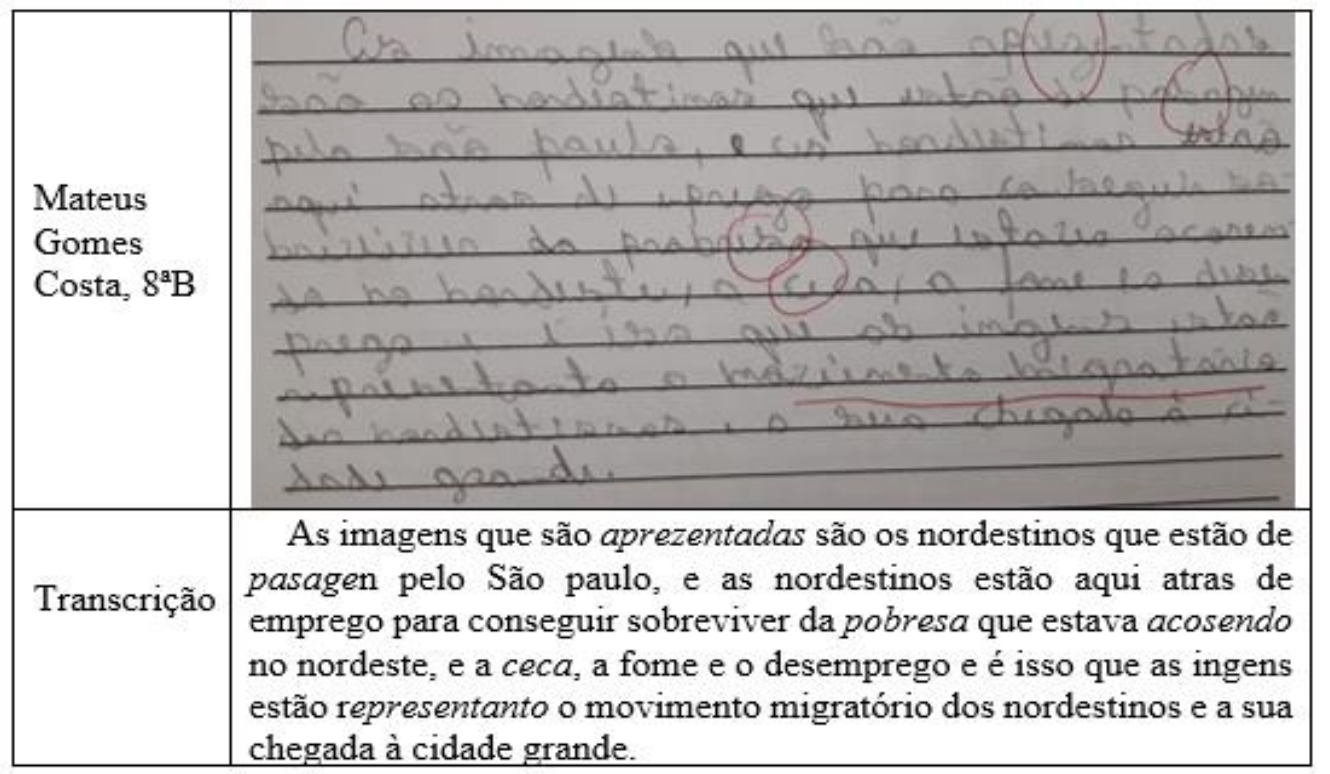

Fonte: Acervo da pesquisa de Sequência Didática elaborada pelo autor (2016). 
O aluno se utilizou das imagens ao reelaborar sua resposta apontando a busca por emprego por parte dos nordestinos em São Paulo para conseguir sobreviver da pobreza que estava acontecendo no Nordeste, a seca, a fome e o desemprego. Explorou as imagens percebendo e apontando "o movimento migratório dos nordestinos e sua chegada" à "cidade grande".

Assim, verificamos avanços no modo como o aluno estruturou o pensamento apresentando um enunciado que contém elementos da geografia, tanto de aspectos atrelados às questões sociais e econômicas, como oriundas das condições ambientais, o que não se evidenciou em sua elaboração inicial.

Noutro exemplo, um estudante aponta em sua primeira elaboração a falta de emprego e a falta de salário como fatores impulsionadores para que os nordestinos migrassem para a região Sudeste, porém não apresentou outros elementos, principalmente relacionados ao desenvolvimento da metrópole paulistana.

\section{Quadro 24 - Resposta do aluno à $1^{\text {a }}$ questão da elaboração inicial da Seq. Didática}

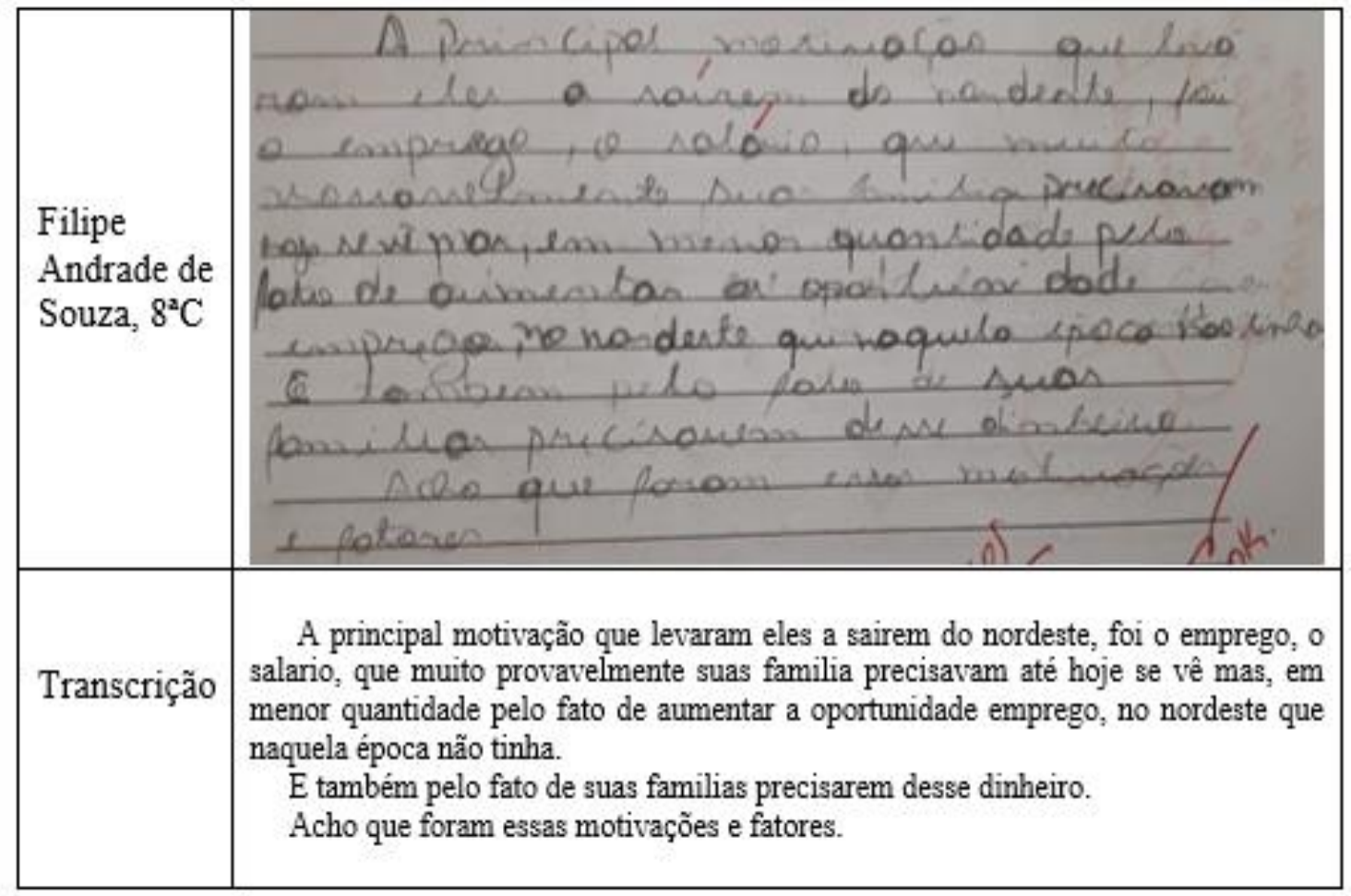

Fonte: Acervo da pesquisa de Sequência Didática elaborada pelo autor (2016).

Porém, em outro momento, ao refazer a questão-problema, o estudante fez correlações entre as condições ambientais inóspitas do Nordeste com as possibilidades que São Paulo apresentava em termos de empregabilidade, como se nota a seguir. 
Quadro 25 - Resposta à $1^{\text {a }}$ questão da elaboração final (1) da Seq. Didática

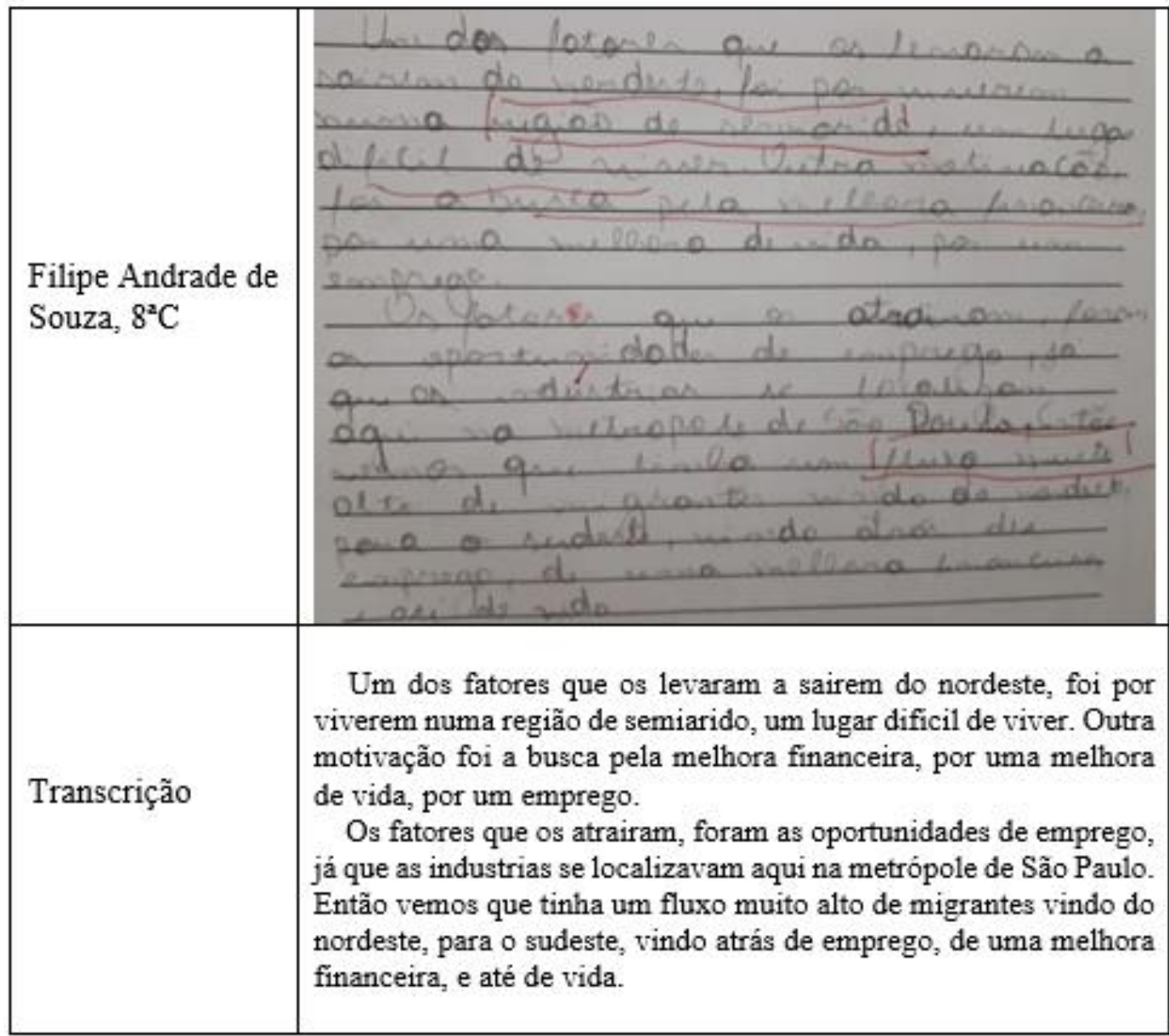

Fonte: Acervo da pesquisa de Sequência Didática elaborada pelo autor (2016).

O aluno apontou como um dos fatores que contribuiu para a migração o fato de os nordestinos "viveram numa região de semiárido", sendo "um lugar difícil de viver". Ou seja, demonstrou um pensamento que transcendeu a escala do lugar enquanto o seu imediato mais "próximo", considerando os problemas ocorridos numa outra escala, no caso, da região nordeste do país.

E ainda, ao pontuar a busca do migrante por melhoras financeiras, de vida e por emprego, demonstrou compreender o processo migratório como algo relacionado à busca por satisfazer uma demanda não atendida no lugar onde essa população estava, pois considerou "um fluxo muito alto de migrantes vindo do Nordeste", em busca de trabalho, pois as indústrias se localizavam na metrópole de São Paulo.

No exemplo seguinte, a aluna demonstra em sua elaboração inicial ter conhecimentos prévios sobre a questão, porém, seu enunciado não avançou no sentido de apontar os fatores de repulsão e de atração de modo mais específico, assim como finalizou sua resposta de um modo não compreensível. 
Quadro 26 - Resposta à $1^{\text {a }}$ questão da elaboração inicial da Sequência Didática

\begin{tabular}{|c|c|}
\hline $\begin{array}{l}\text { Emillye } \\
\text { Cirino de } \\
\text { Freitas, } 8^{2} \mathrm{D} \text {. }\end{array}$ & 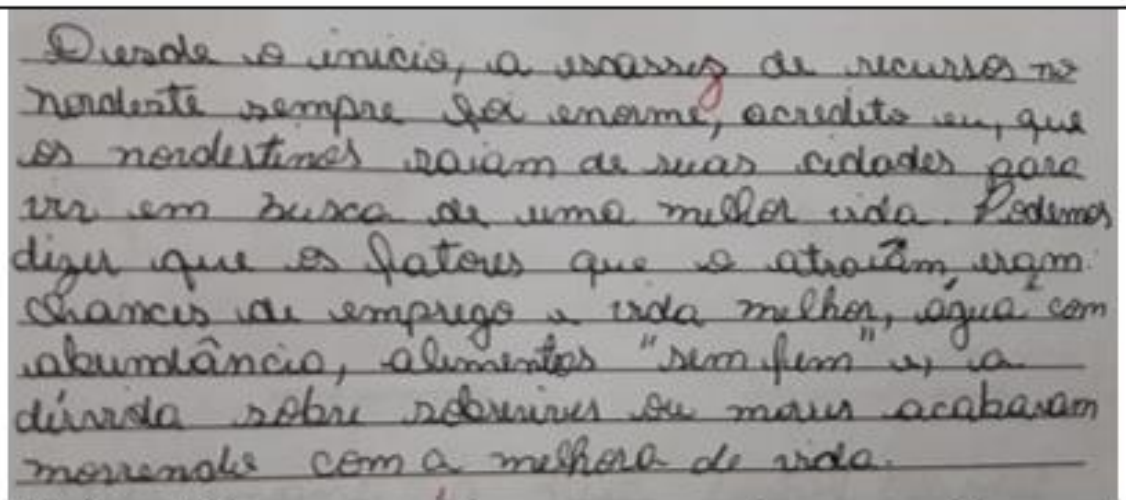 \\
\hline Transcrição & $\begin{array}{l}\text { Desde o inicio, a escasses de recursos no nordeste sempre foi enorme, } \\
\text { acredito eu, que os nordestinos saiam de suas cidades para vir em busca de } \\
\text { uma melhor vida. Podemos dizer que os fatores que o atraiam eram: chances } \\
\text { de emprego e vida melhor, água com abundância, alimentos "sem fim" e, a } \\
\text { dúvida sobre sobreviver ou morrer acabavam morrendo com a melhora de } \\
\text { vida. }\end{array}$ \\
\hline
\end{tabular}

Fonte: Acervo da pesquisa de Sequência Didática elaborada pelo autor (2016).

Já em sua elaboração final $n^{\circ} 1$, a aluna, em que pese ter generalizado a seca por todo o Nordeste, demonstrou avanços significativos em relação ao uso que fizera das imagens apresentadas na questão, sobretudo, de forma contextualizada.

\section{Quadro 27 - Resposta à $1^{\text {a }}$ questão da elaboração final (1) da Sequência Didática}

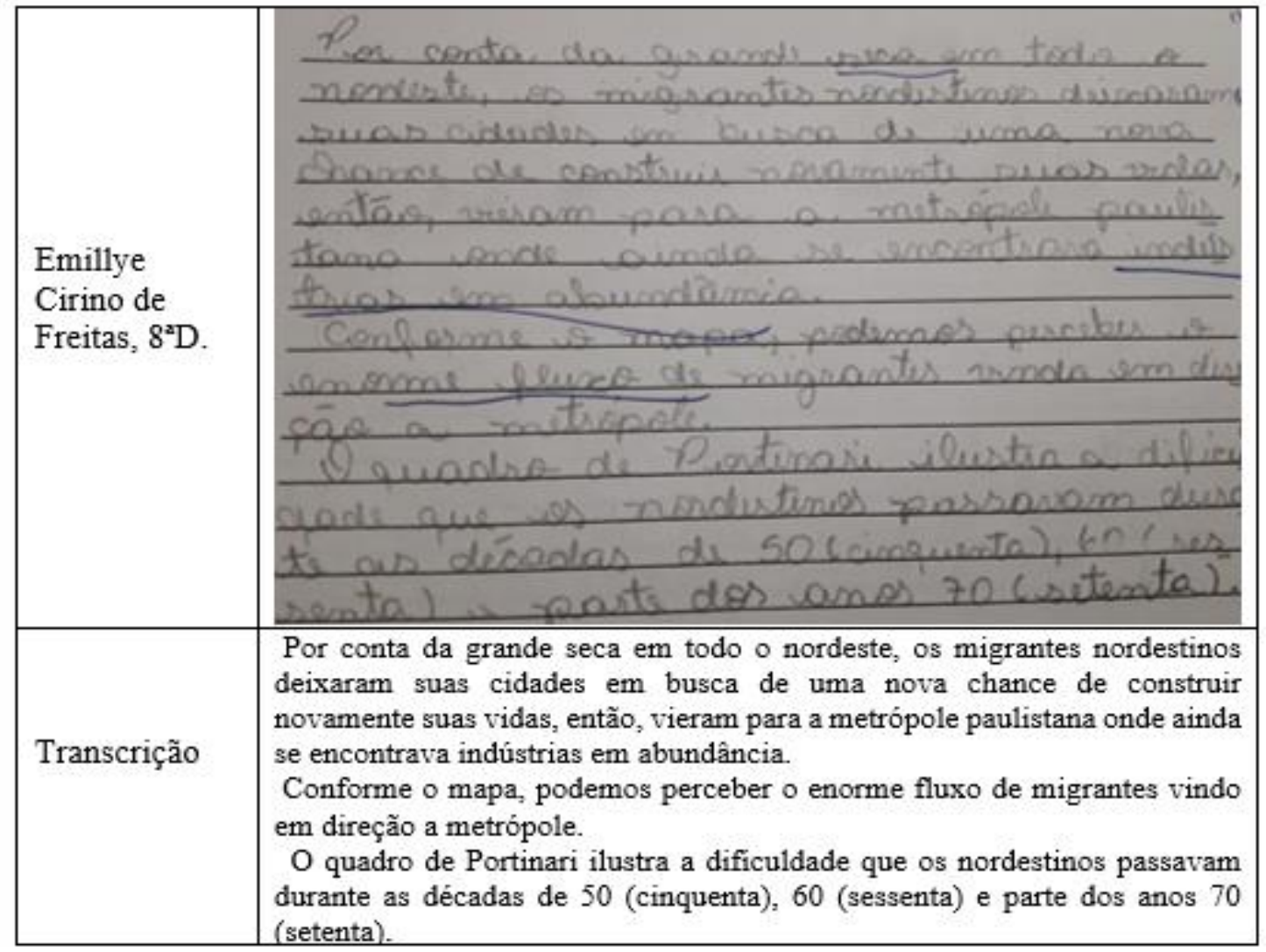

Fonte: Acervo da pesquisa de Sequência Didática elaborada pelo autor (2016). 
A segunda questão-problema versava sobre o recente movimento de retorno dos migrantes às suas cidades ou região de origem, que apesar de ser identificado no país a partir dos anos de 1980, fora acentuado em anos recentes. A questão ainda trazia as modalidades simbólica ("mapa") e figurativa (charge) com a seguinte problematização:

2 - Se entre as décadas de 1950 até o final da década de 1970 verificávamos um forte fluxo de migrantes nordestinos dirigindo-se à metrópole paulistana, nas últimas décadas temos visto uma significativa diminuição nesse fluxo migratório e até mesmo uma inversão, ou seja, o retorno de nordestinos às suas cidades de origem. Quais fatores podem explicar essa mudança migratória, isto é, o movimento de retorno?

No exemplo seguinte a aluna em sua elaboração inicial demonstra ter o entendimento de que está efetivamente havendo carência de vagas de empregos na metrópole paulistana quando comparado à períodos anteriores, assim como percebe a existencia de uma crise econominca e a concorrência por vagas de emprego que tende a tornar mais difícil a situação do migrante nordestino, fazendo com que este tente uma uma vaga de trabalho em sua cidade de origem. Conforme a aluna, no Nordeste estaria "praticamente a mesma coisa que a metrópole paulistana".

\section{Quadro 28 - Resposta à $2^{\mathrm{a}}$ questão da elaboração inicial de Sequência Didática}

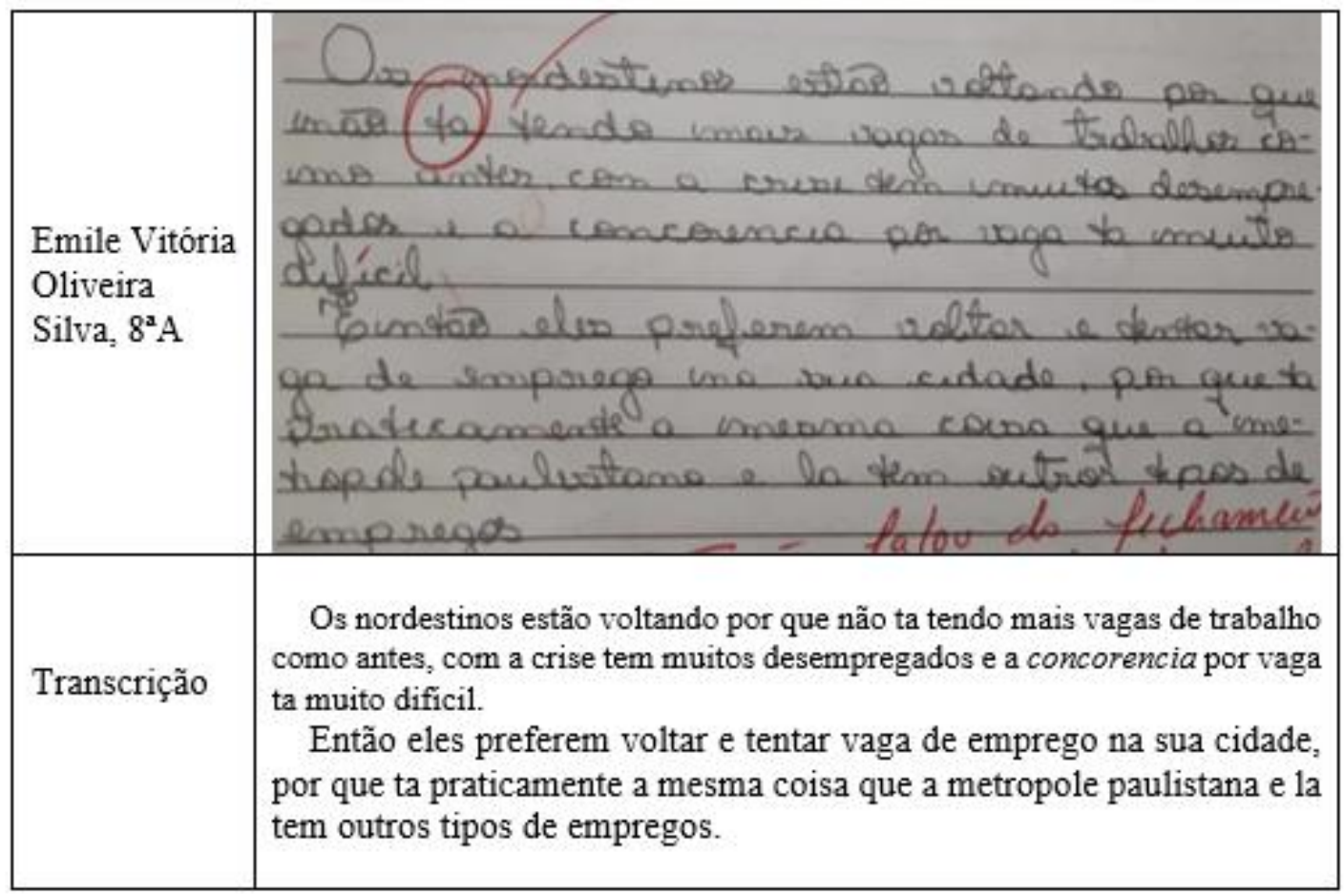

Fonte: Acervo da pesquisa de Sequência Didática elaborada pelo autor (2016).

A mesma aluna ao refazer a elaboração apresentou avanços ao explicar o movimento de retorno. 
Quadro 29 - Resposta à $2^{\mathrm{a}}$ questão da elaboração final (1) da Sequência Didática

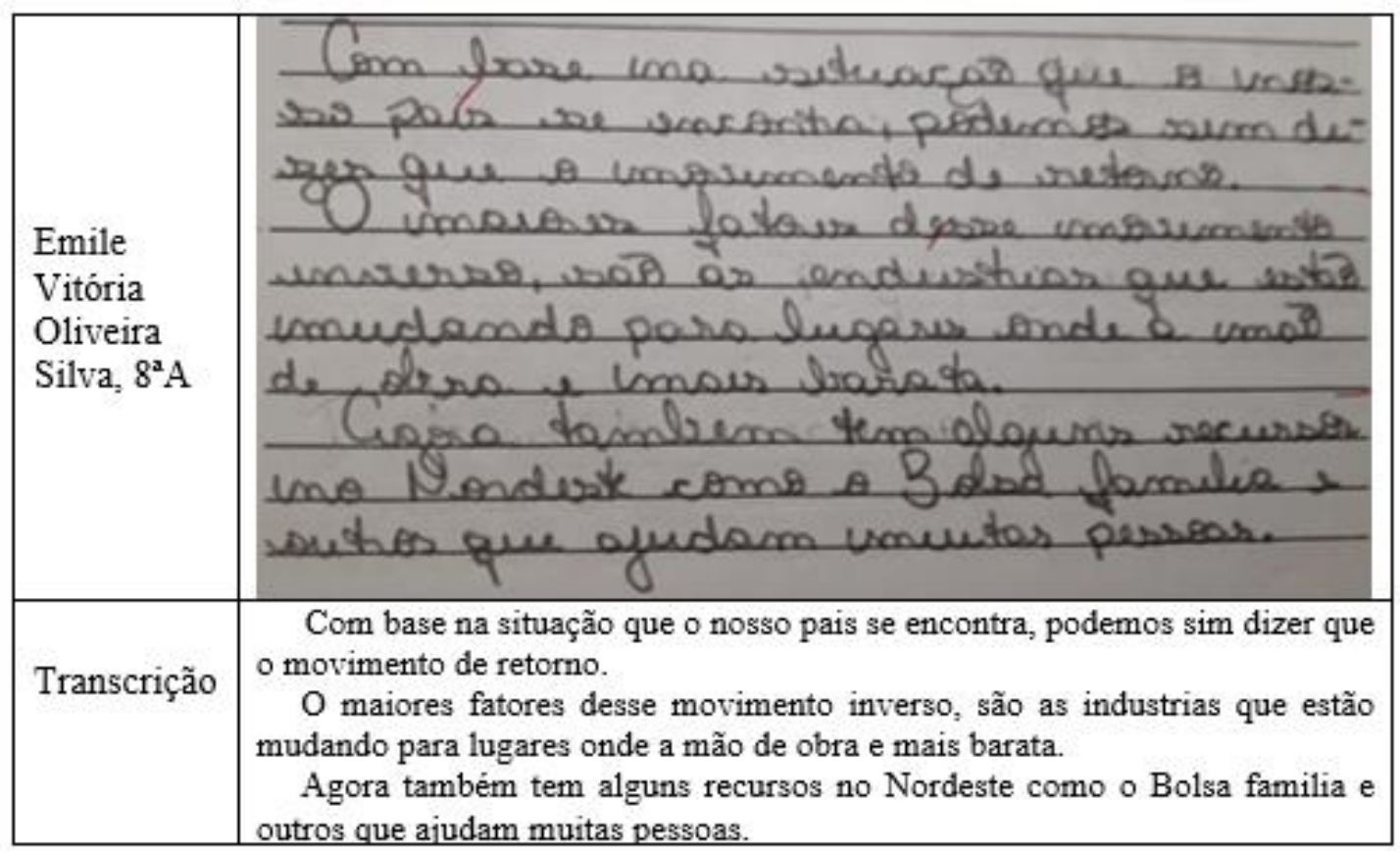

Fonte: Acervo da pesquisa de Sequência Didática elaborada pelo autor (2016).

A aluna demonstra ter compreendido o que fora problematizado em aula, ao apontar que "os maiores fatores desse movimento inverso" foram "as indústrias que estão mudando para lugares onde a mão de obra é mais barata”, assim como o fato de ter alguns recursos no Nordeste como o Bolsa Família e outros programas que ajudam a população nordesina.

Noutro exemplo uma estudante atribui o movimento de retorno ao fato de os migrantes já terem conquistado o que almejavam. Seu enunciado, no entanto, se mostra de baixa complexidade por não considerar outros elementos.

\section{Quadro 30 - Resposta do aluno à $2^{\mathrm{a}}$ questão da elaboração inicial de Seq. Didática}

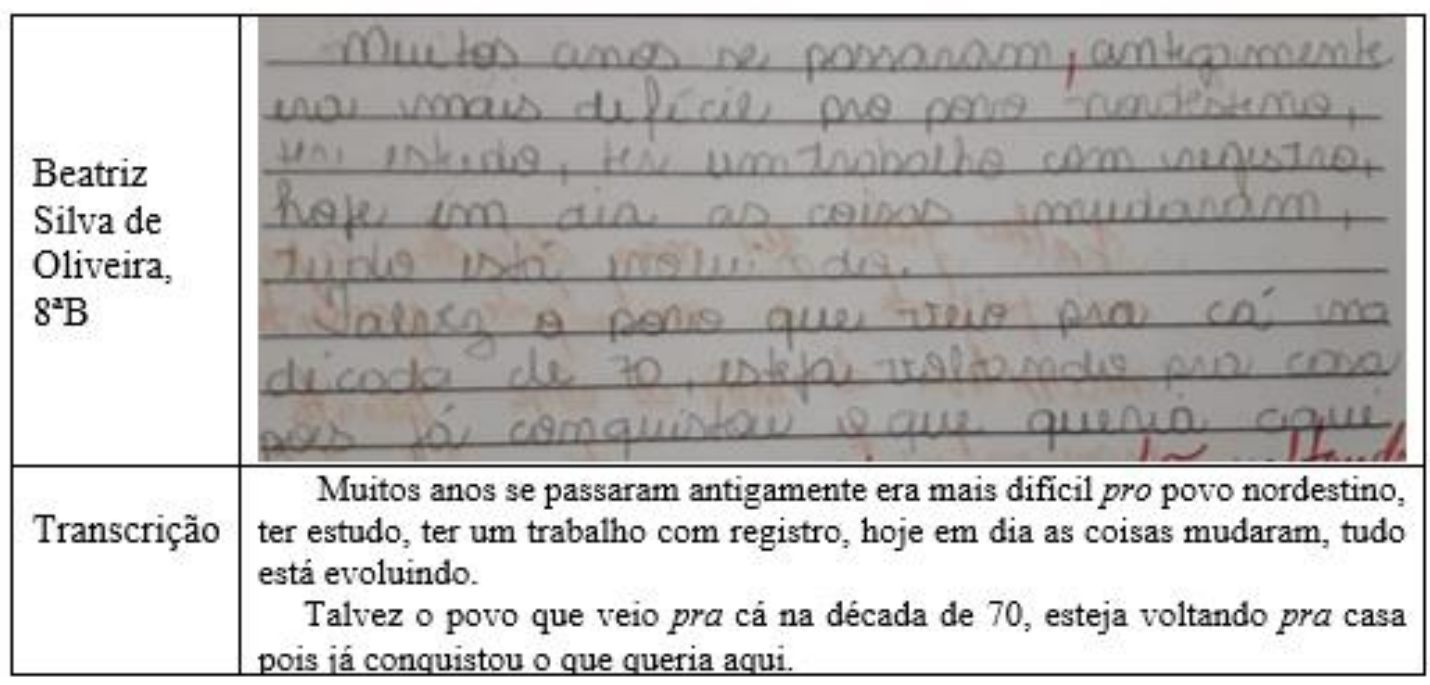

Fonte: Acervo da pesquisa de Sequência Didática elaborada pelo autor (2016). 
A mesma aluna, em sua elaboração final $n^{\circ} 1$, respondendo a mesma problematização, nos dá evidências de um enunciado mais complexo, nos fornecendo maiores elementos que demonstram que a estudante compreendeu o processo de migração de retorno como um reflexo de fenômenos outros que se davam numa escala que não somente do lugar, como podemos verificar no exemplo a seguir.

\section{Quadro 31 - Resposta à $2^{\mathrm{a}}$ questão da elaboração final (1) da Sequência Didática}

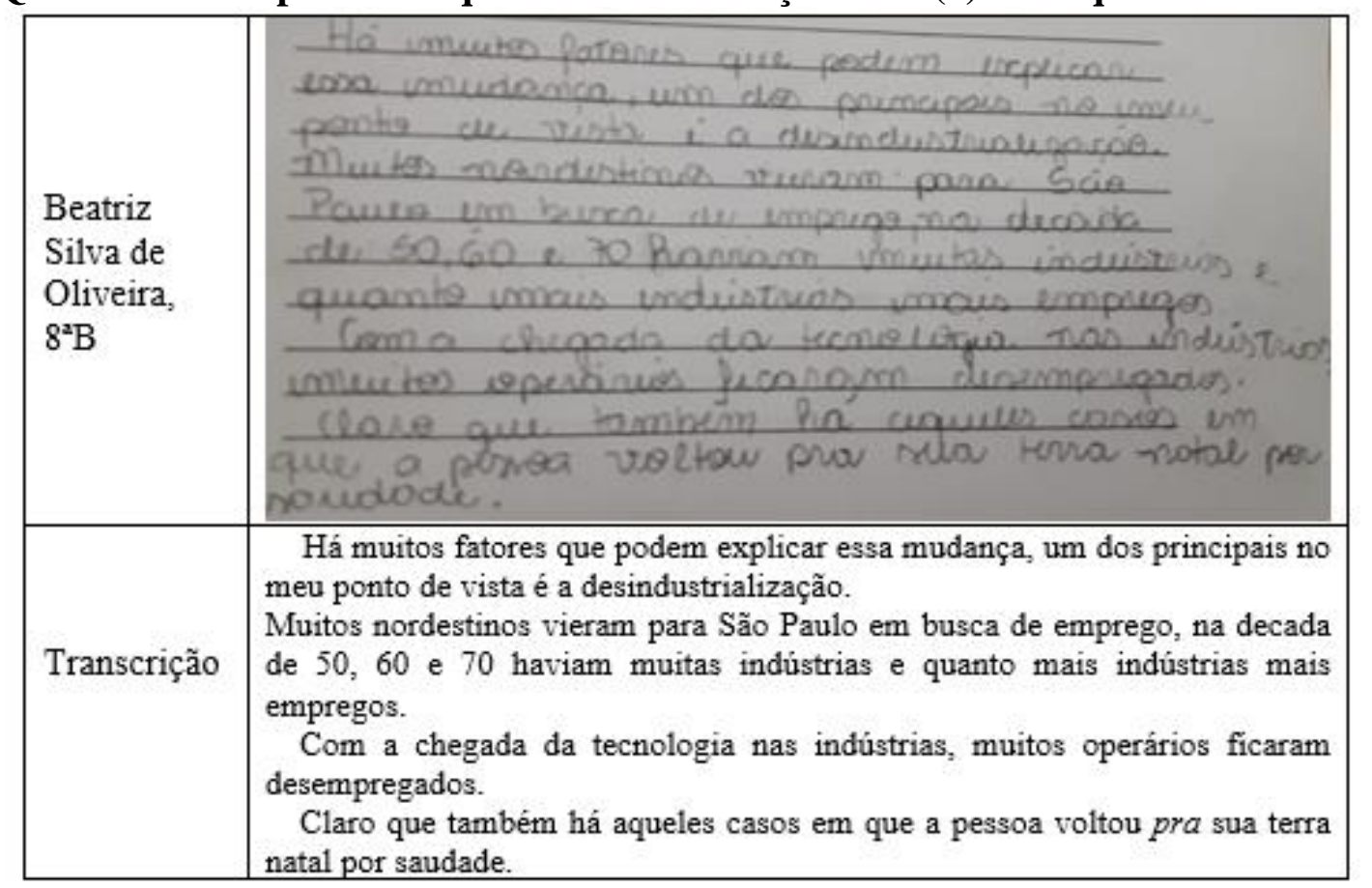

Fonte: Acervo da pesquisa de Sequência Didática do autor (2016).

É interessante observar que a aluna considera a existência de muitos fatores que podem explicar a inversão no fluxo migratório, sendo um deles a desindustrialização. A estudante contextualiza a vinda de nordestinos para São Paulo entre as décadas de 50 e 70 do século passado, num período me que havia muitas indústrias gerando postos de trabalho, porém, “com a chegada da tecnologia nas indústrias, muitos operários ficaram desempregados".

Para esta aluna, há casos em que o migrante volta para sua terra natal por motivos atrelados à saudade. Ou seja, ao indicar a saudade como algo que impulsionaria o retorno, a estudante acaba por lidar com a dimensão de uma outra escala, pois o retirante teria o objetivo de retornar à sua cidade em função de algo que deixou por lá e sente falta.

Ainda tratando das elaborações da segunda questão problema, temos noutro exemplo a elaboração de um aluno de outra turma. 
Quadro 32 - Resposta do aluno a $2^{\mathrm{a}}$ questão da elaboração inicial da Seq. Didática

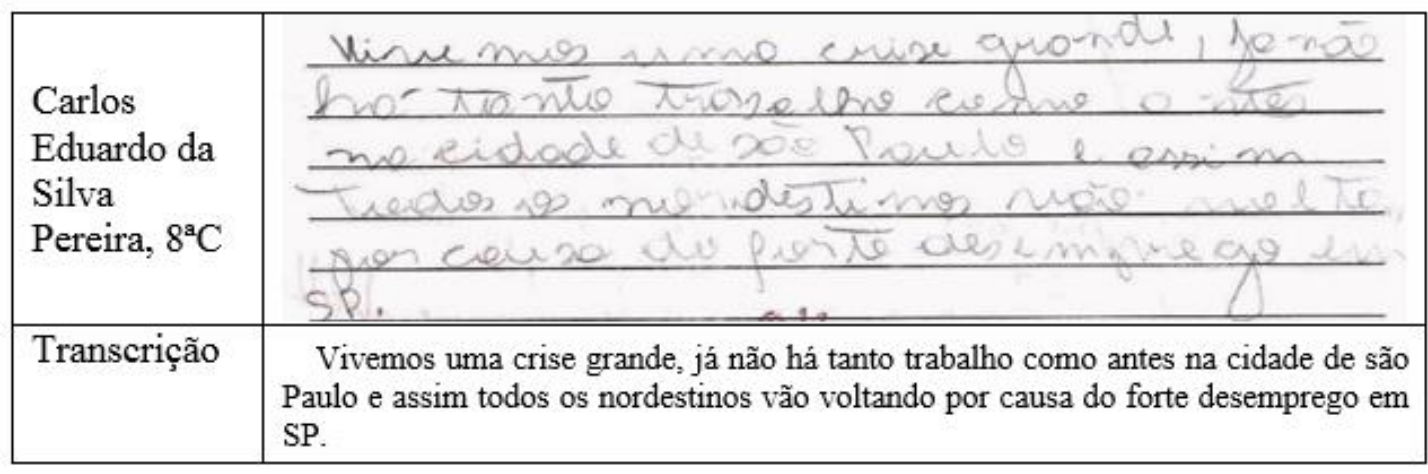

Fonte: Acervo da pesquisa de Sequência Didática elaborada pelo autor (2016).

Em sua elaboração inicial o aluno limitou-se a considerar o movimento de retorno como decorrente do forte desemprego na cidade de São Paulo, não considerando fenômenos ocorrentes na região Nordeste do país, que poderia servir como atrativos. Ou seja, limitou-se aos aspectos de uma realidade que lhe é mais próxima e imediata. No entanto, ao rafazer a elaboração, pode apontar outros aspectos não considerados em seu texto inicial.

\section{Quadro 33 - Resposta à $2^{a}$ questão da elaboração final (1) da Sequência Didática}

\begin{tabular}{|c|c|}
\hline $\begin{array}{l}\text { Carlos } \\
\text { Eduardo da } \\
\text { Silva } \\
\text { Pereira, } 8^{\mathrm{a} C}\end{array}$ & 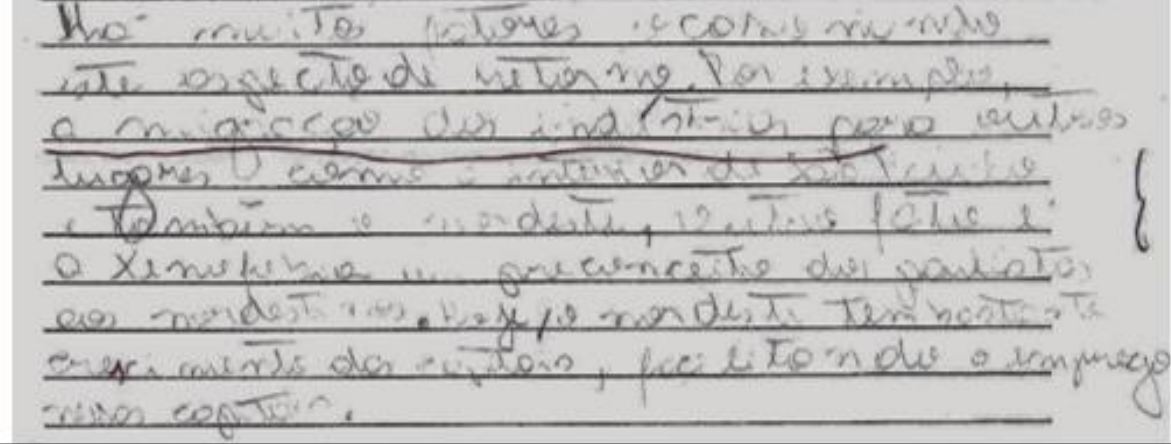 \\
\hline Transcrição & $\begin{array}{l}\text { Há muitos fatores ocasionando este aspecto de retorno. Por exemplo, a migração das } \\
\text { industrias para outros lugares como o interior de São Paulo e também o nordeste, } \\
\text { Outro fato é a xenofobia um preconceito dos paulistas aos nordestinos. Hoje o } \\
\text { nordeste tem bastante crescimento das capitais, facilitando o emprego nessas } \\
\text { capitais. }\end{array}$ \\
\hline
\end{tabular}

Fonte: Acervo da pesquisa de Sequência Didática elaborada pelo autor (2016).

É interessante observar que o aluno não limitou-se a considerar a migração de retorno como algo exclusivamente decorrente da desindustrialização, pois apontou haver "muitos fatores ocasionando este aspecto de retorno", tal como "a migração das indústrias para outros lugares como o interior de São Paulo e também o Nordeste", que 
estaria tendo um "crescimento das capitais, facitando o emprego nestes lugares". O aluno ainda destacou o problema da xenofobia como um dos responsáveis pela migração de retorno.

No próximo exemplo, apesar de parecer fragmentos simples em termos de elaboração, consideramos que houve avanços em relação a aprendizagem do aluno.

\section{Quadro 34 - Resposta do aluno a $2^{\mathrm{a}}$ questão da elaboração inicial da Seq. Didática}

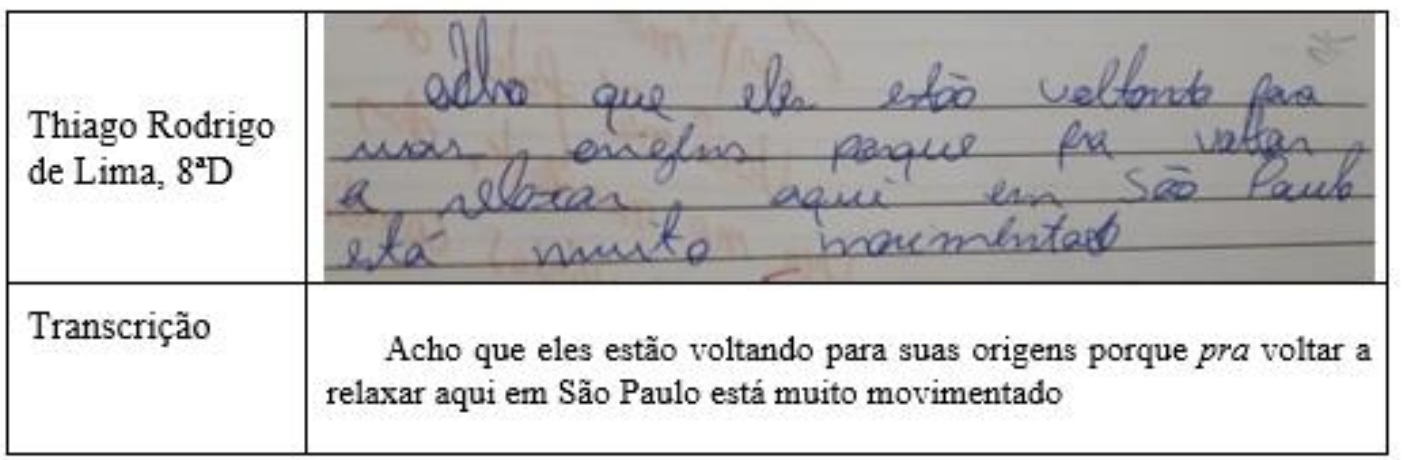

Fonte: Acervo da pesquisa de Sequência Didática elaborada pelo autor (2016).

Observa-se que o estudante, além de ter elaborado uma resposta curta, pouco complexa e sem demonstrar uma tentativa em se trabalhar com o que as imagens traziam em termos de informação, atribuiu o movimento de retorno ao fato de São Paulo estar "muito movimentado", o que levaria o migrante voltar a seu local de origem para poder "relaxar". No entanto, em sua segunda elaboração, ao lidar com a mesma situação problema, acabou por apontar o processo de desconcentração industrial, ainda que não se utilizando especificamente do termo.

\section{Quadro 35 - Resposta à $2^{a}$ questão da elaboração final (1) da Sequência Didática}

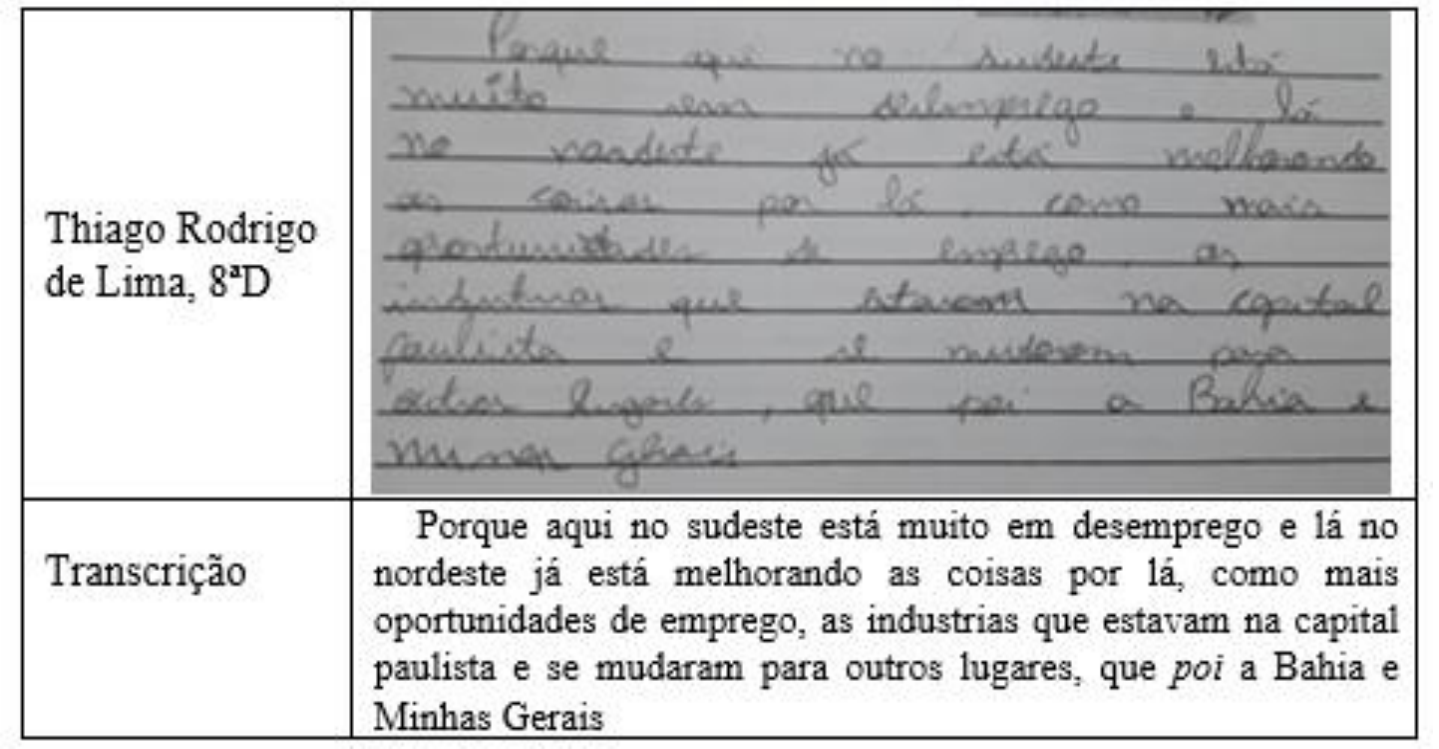

Fonte: Acervo da pesquisa de Sequência Didática elaborada pelo autor (2016). 
O aluno, diferentemente de sua elaboração inicial, passou a se utilizar de palavras como "Sudeste", "Nordeste", "capital paulista" e "indústrias". Ressaltou as melhorias no Nordeste graças às "oportunidades de emprego" e ao fato de as "indústrias que estavam na capital paulista" terem mudado "para outros lugares", tais como Bahia e Minas Gerais. Vale lembrar, que durante o processo de mediação fora tratado o fato de haver polos industriais e petroquímico no estado baiano, assim como a transferência da Ford para este estado e a implantação da Fiat em Minas Gerais.

A terceira questão fora apresentada também na modalidade verbal escrita e trazia dois elementos na modalidade figurativa e um na modalidade simbólica.

3 - A artista Tarsila do Amaral pintou no ano de 1933 a obra "Operários" (figura A), onde é possível perceber elementos que representavam a vida urbana da época, as relações sociais e de trabalho. A figura B representa a distribuição das indústrias no estado de São Paulo até os anos de 1975 e depois até o ano de 1986. Por fim (figura C), há a obra "O desempregado", de 1999, do artista plástico Hilário Sineiro Machado. Quais relações podemos fazer entre as três imagens apresentadas

No exemplo a seguir o aluno em sua elaboração inicial, ao fazer a relação entre as três imagens apresentadas na questão-problema, utilizou-se mais de uma simples descrição do que de uma relação entre o que ali estava sendo representado, como é possível notar em seu enunciado.

Quadro 36 - Resposta do aluno a $3^{\text {a }}$ questão da elaboração inicial da Seq. Didática

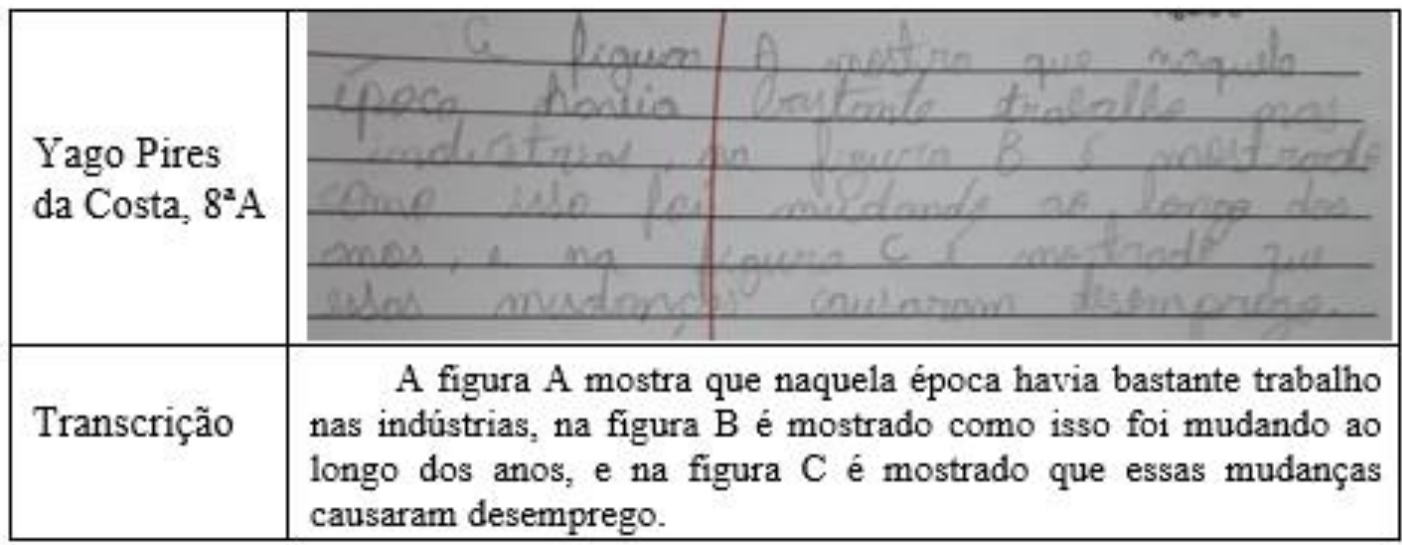

Fonte: Acervo da pesquisa de Sequência Didática elaborada pelo autor (2016).

$\mathrm{O}$ aluno apontou corretamente ao discorrer que a figura A mostra "que naquela época havia bastante trabalho nas indústrias", porém não explorou mais que esse universo, assim como se reportou a figura B como algo que estaria mostrando o modo “como isso foi mudando ao longo dos anos", até chegar na figura $\mathrm{C}$, onde estava sendo 
apresentado as "mudanças que causaram desemprego". O aluno não elaborou uma resposta mais consistente, pois ainda lhe faltavam elementos e mais fontes de informação para que pudesse constituir uma resposta com conceitos mais apropriados, o que ele conseguiu ao refazer a questão-problema noutro momento da Sequência Didática, tal como podemos ver a seguir.

\section{Quadro 37 - Resposta a $3^{\mathrm{a}}$ questão da elaboração final (1) da Sequência Didática}

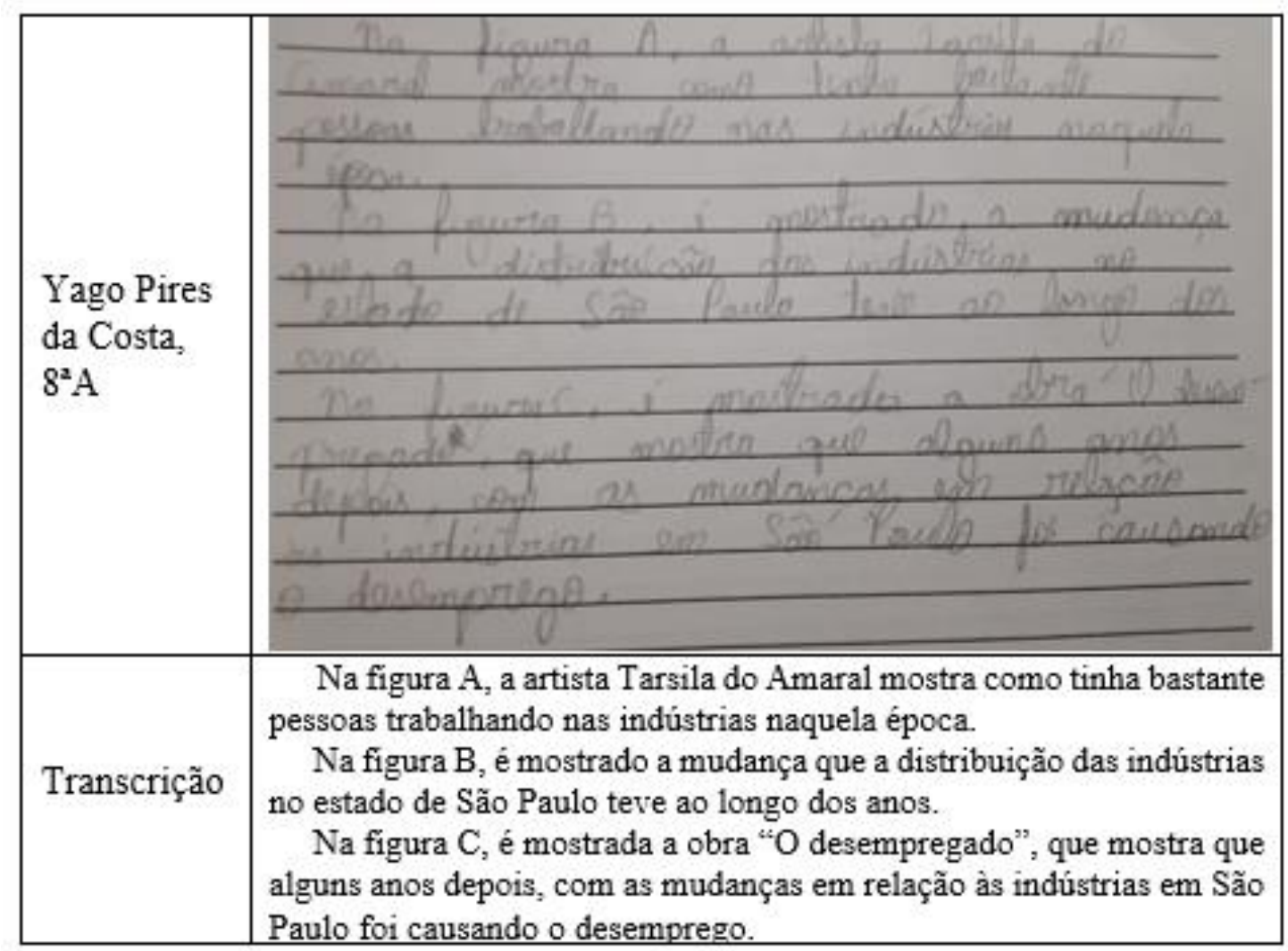

Fonte: Acervo da pesquisa de Sequência Didática elaborada pelo autor (2016).

Ao refazer a elaboração o aluno especificou que a obra apresentada na figura A, fora feita por Tarsila do Amaral, e ao se reportar a figura B, ressaltou que a imagem mostrava "a mudança que a distribuição das indústrias no estado de São Paulo" tivera "ao longo dos anos". O aluno fez a correlação entre as imagens, pois considerou que a figura C, mostra "as mudanças em relação às indústrias em São Paulo", que após alguns anos foi responsável por causar o desemprego.

No próximo exemplo o estudante apenas apontou haver vários trabalhadores nas fábricas, mas se equivocou em relação a segunda figura, pois considerou-a como representando o fluxo de nordestinos na capital paulista, quando na realidade representa a desconcentração industrial no estado. 
Quadro 38 - Resposta à $3^{\text {a }}$ questão da elaboração inicial da Sequência Didática

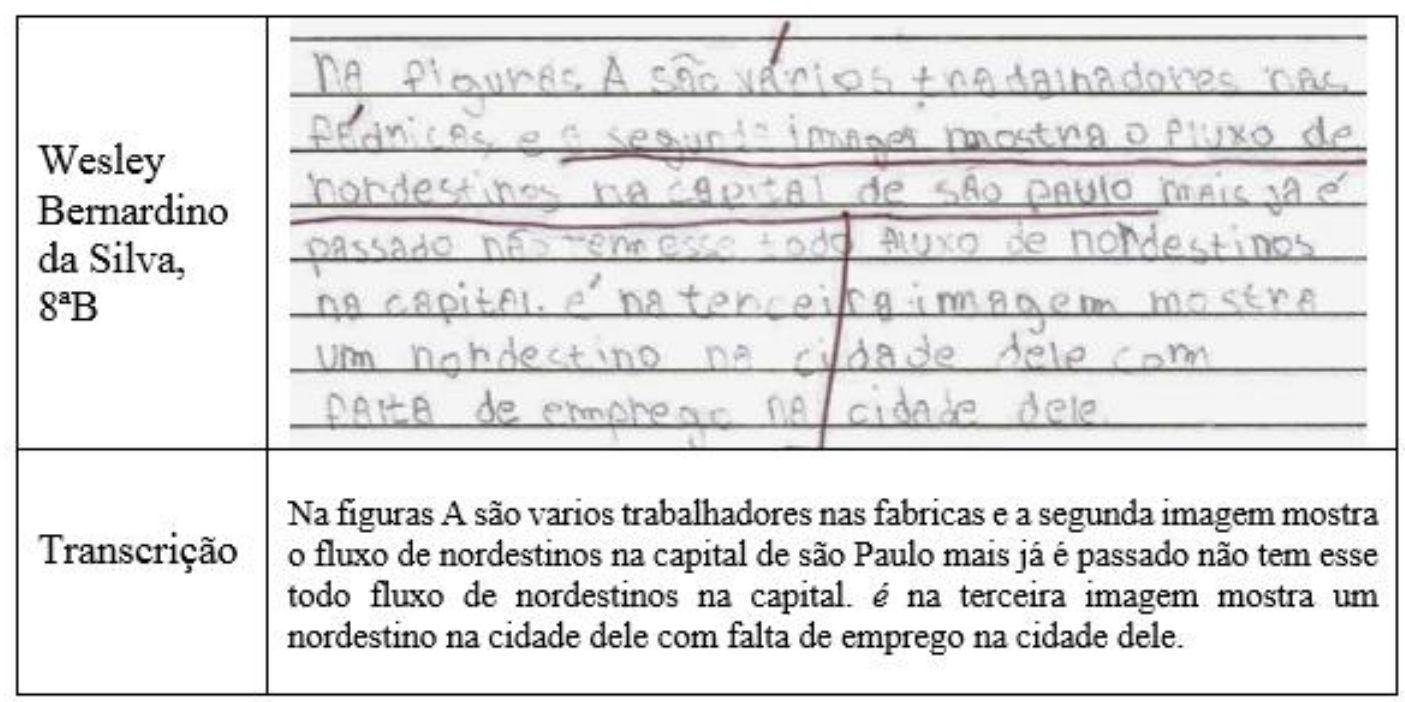

Fonte: Acervo da pesquisa de Sequência Didática elaborada pelo autor (2016).

O mesmo aluno, em sua elaboração final $n^{\circ} 1$, apesar de uma resposta sucinta e mais curta em relação a primeira elaboração, conseguiu explorar melhor o que as imagens traziam em questão de informações, como podemos ver abaixo.

\section{Quadro 39 - Resposta do aluno a $3^{\text {a }}$ questão da elaboração final (1) da Seq. Didática}

\begin{tabular}{|l|l|}
\hline $\begin{array}{l}\text { Wesley } \\
\text { Bernardino } \\
\text { da Silva, }\end{array}$ & $\begin{array}{l}\text { a } \\
8\end{array}$ \\
Transcrição & $\begin{array}{l}\text { Nas imagem eu posso ver varios trabalhadores de varias formas diferentes } \\
\text { Na segunda imagem eu vejo varias indústrias fora da capital de são Paulo, } \\
\text { é na imagem três eu vejo um nordestino sentado. }\end{array}$ \\
\hline
\end{tabular}

Fonte: Acervo da pesquisa de Sequência Didática elaborada pelo autor (2016).

Ao apontar que nas imagens é possível ver "trabalhadores de vários formas diferentes", podemos depreender que o aluno se refere à aparência das pessoas que aparecem na obra de Tarsila do Amaral, com fisionomias que representam a diversidade 
de etnias no país. O aluno ao identificar que atrás dos nordestinos havia as indústrias, se utilizou de modo mais eficiente de seu campo exploratório perceptual, e desta vez, identificou, também, na segunda figura, a presença de indústrias fora da capital, assim como um nordestino sentado, representado na terceira imagem.

Considerando o exemplo de outro estudante obtivemos o seguinte enunciado em relação à sua elaboração inicial:

Quadro 40 - Resposta do aluno a $3^{\text {a }}$ questão da elaboração inicial da Seq. Didática

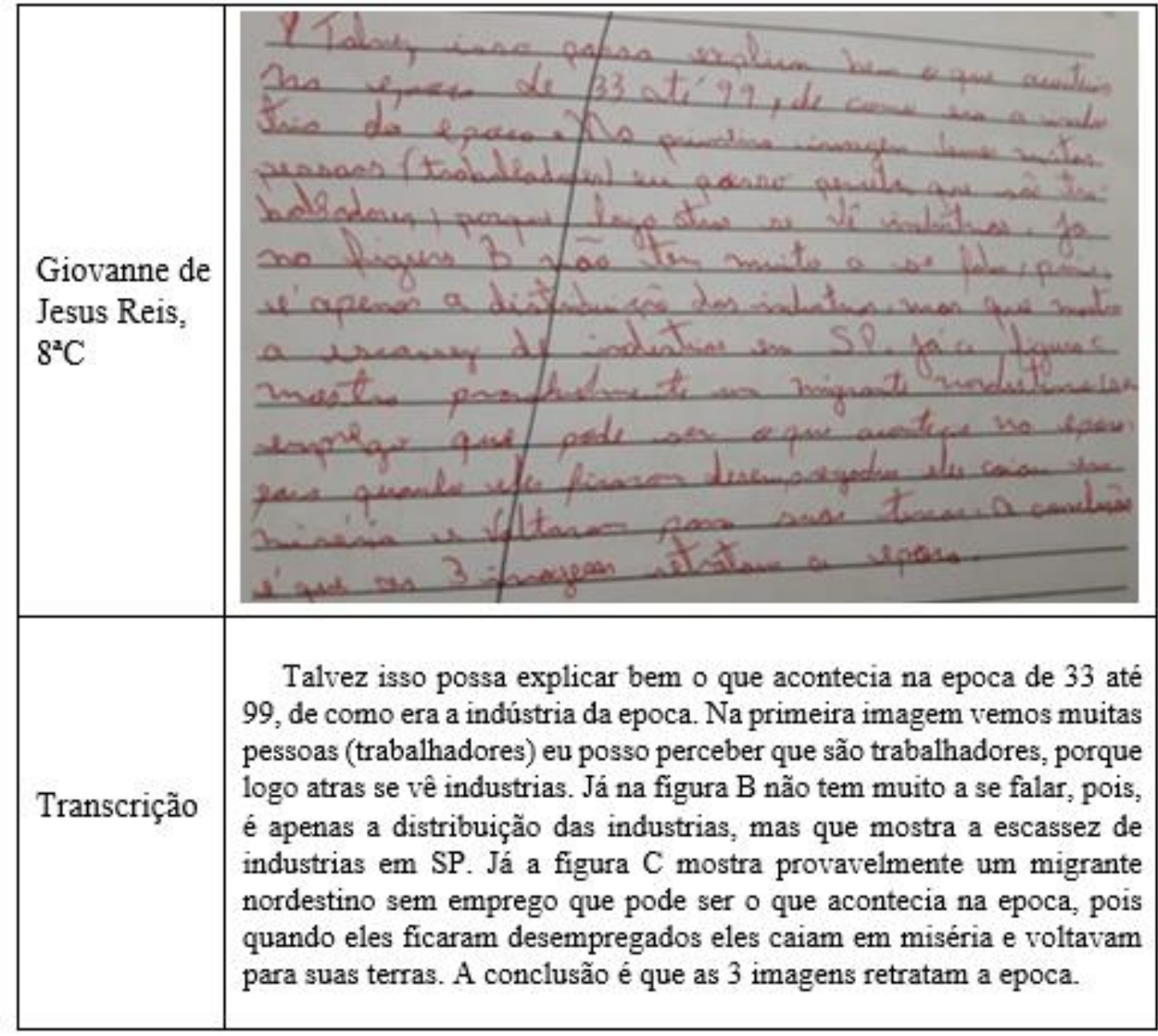

Fonte: Acervo da pesquisa de Sequência Didática do autor (2016).

No exemplo supracitado, o aluno em sua elaboração inicial se atentou às imagens inferindo que na figura C estaria "um migrante nordestino sem emprego", e que por estarem desempregados estariam voltando "para suas terras". No entanto, apesar de ter identificado na segunda imagem a "distribuição das indústrias" - sem especificar se para o interior ou fora do estado - considerou estar sendo representado a "escassez de indústrias" em São Paulo, o que não é correto. Ademais, o aluno mais descreveu as imagens do que as correlacionou. Tal situação se altera em sua elaboração final 1. 
Quadro 41 - Resposta do aluno à $3^{\text {a }}$ questão da elaboração final (1)

\begin{tabular}{|c|c|}
\hline $\begin{array}{l}\text { Giovanne } \\
\text { de Jesus } \\
\text { Reis, } 8^{2} \mathrm{C}\end{array}$ & 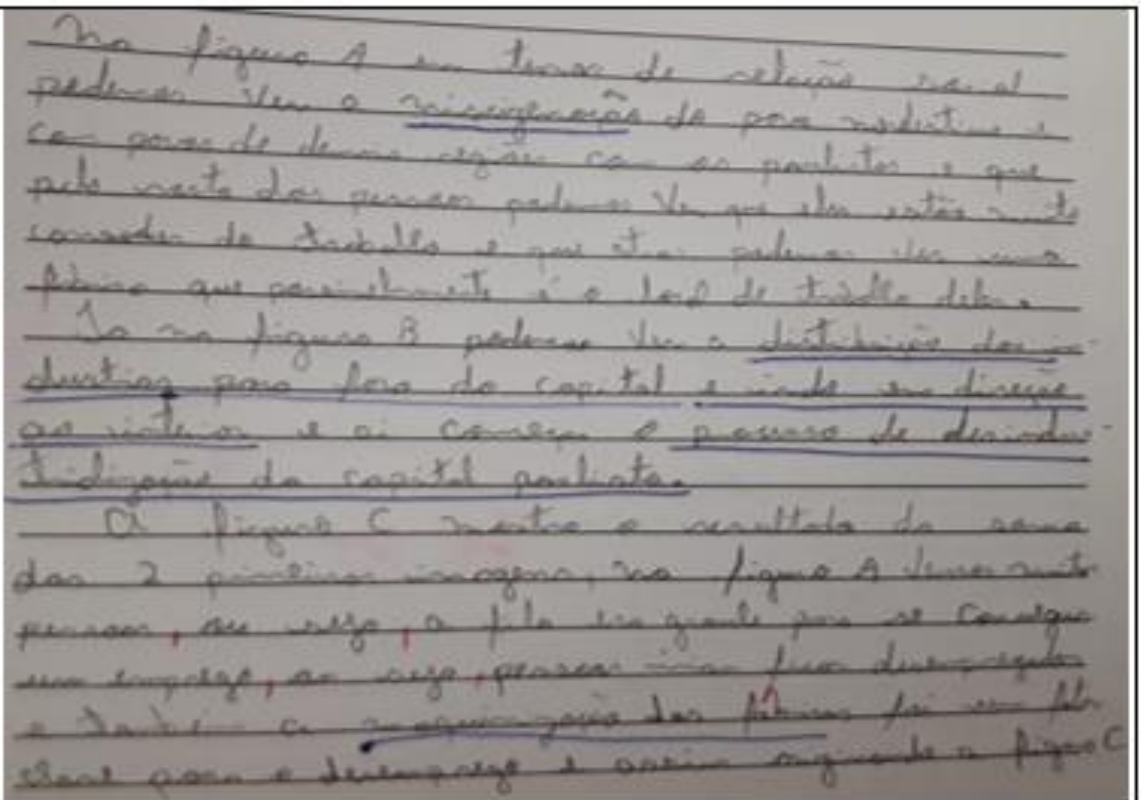 \\
\hline Transcrição & $\begin{array}{l}\text { Na figura } \mathrm{A} \text { em termos de relação social podemos ver a miscigenação do } \\
\text { povo nordestino e com povos de demais regiôes com os paulistas e que pelo } \\
\text { rosto das pessoas podemos ver que eles estão muito cansados do trabalho e } \\
\text { que atrás podemos ver uma fabrica que possivelmente é o local de trabalho } \\
\text { deles. } \\
\text { Já na figura B podemos ver a distribuição das industrias para fora da capital } \\
\text { e indo em direção ao interior e ai começou o processo de desindustrialização } \\
\text { da capital paulista. } \\
\text { A figura C mostra o resultado da soma das } 2 \text { primeiras imagens, na figura } \\
\text { A vemos muitas pessoas ou seja a fila era grande para se conseguir um } \\
\text { emprego ou seja pessoas iriam ficar desempregadas e também a maquinização } \\
\text { das fabricas foi um fator chave para o desemprego originando a figura C. }\end{array}$ \\
\hline
\end{tabular}

Fonte: Acervo da pesquisa de Sequência Didática elaborada pelo autor (2016).

Em sua reelaboração apontou "a miscigenação do povo nordestino", também inferindo haver uma fábrica que "possivelmente" seria "o local de trabalho" das pessoas representadas na imagem. Diferentemente de sua elaboração inicial, o aluno identificou “a distribuição das indústrias para fora da capital, em direção ao interior", e considerou a figura $\mathrm{C}$ como o resultado da "soma das duas primeiras imagens".

No exemplo seguinte, uma aluna em sua elaboração inicial não se utilizara das imagens, apenas explicitando que antigamente havia menos desempregados.

Quadro 42 - Resposta a $3^{\text {a }}$ questão da elaboração inicial da Seq. Didática

\begin{tabular}{|c|c|}
\hline $\begin{array}{l}\text { Natalia Vila } \\
\text { Nova, } 8^{2} \mathrm{D}\end{array}$ & 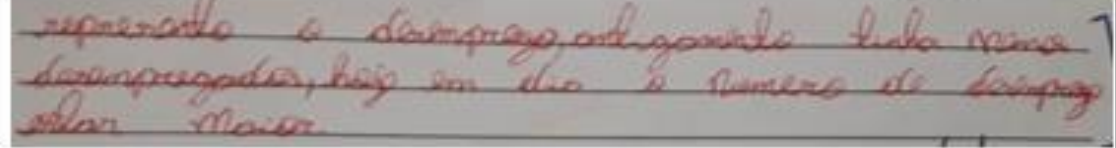 \\
\hline Transcrição & $\begin{array}{l}\text { representa o desemprego, antigamente tinha menos desempregados, hoje em } \\
\text { dia o numero de desemprego estar maior, }\end{array}$ \\
\hline
\end{tabular}

Fonte: Acervo da pesquisa de Sequência Didática elaborada pelo autor (2016). 
Ao refazer sua elaboração, a aluna passou a se atentar às informações que as imagens traziam, procurando correlacioná-las.

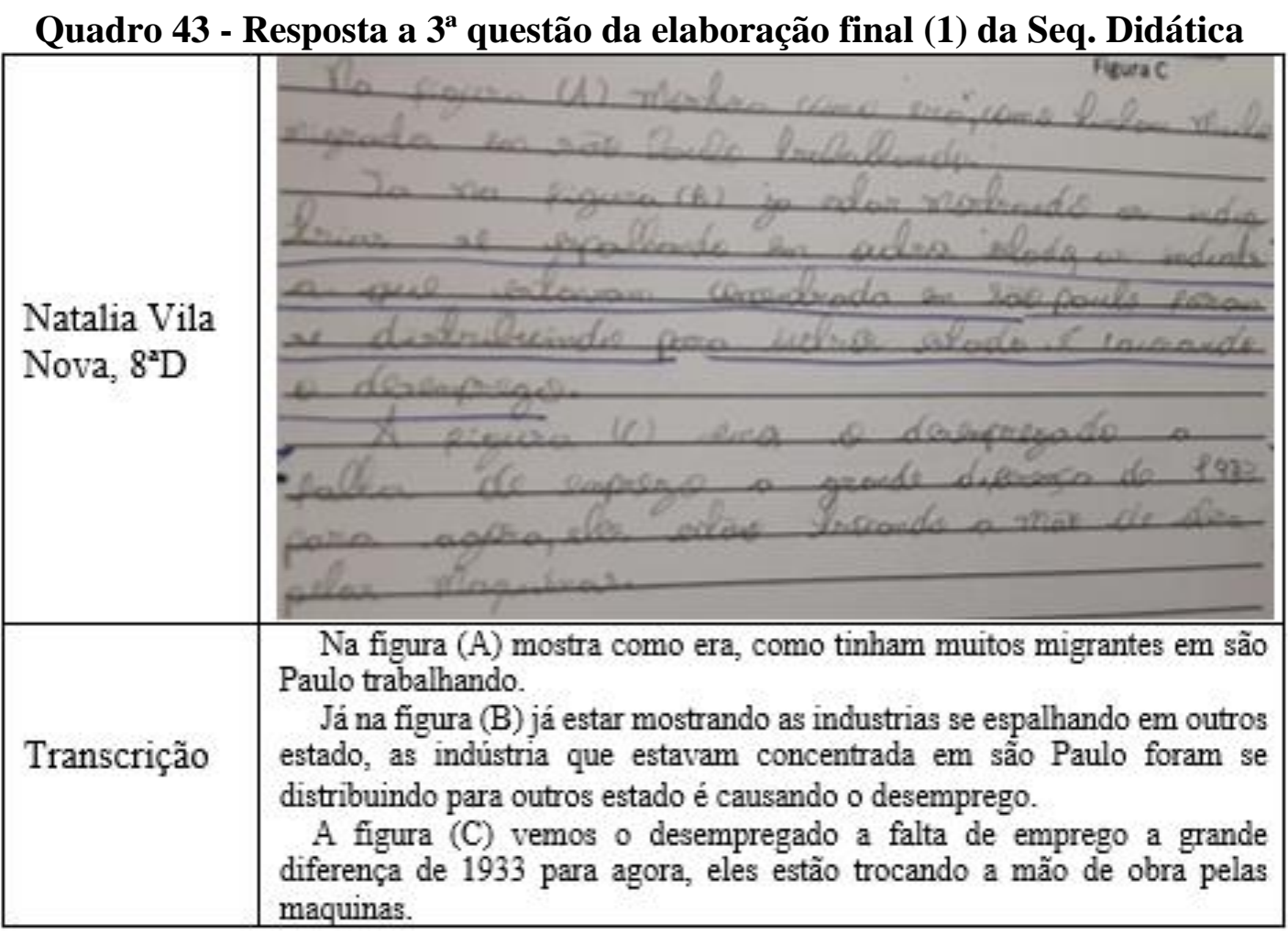

Fonte: Acervo da pesquisa de Sequência Didática elaborada pelo autor (2016).

Ao apontar que havia muitos migrantes trabalhando em São Paulo e identificar na figura B que "as indústrias que estavam concentradas em São Paulo foram se distribuindo" para outros estados, consequentemente gerando desemprego, a aluna demonstrou avanços em seu campo exploratório e perceptual e no modo como fez as correlações entre as imagens.

\subsection{OS FATORES DE REPULSÃO E ATRAÇÃO MIGRATÓRIA NAS RESPOSTAS DOS ALUNOS}

Para tratarmos da primeira questão-problema da elaboração inicial e também da mesma questão da elaboração final, elaboramos 5 categorias de análise que foram utilizadas em dois contextos considerando os fatores de repulsão e os de atração, sendo elas as categorias sociais, ambientais, econômicas, políticas e imagens. O fator repulsão, nesta questão, refere-se ao que teria motivado os migrantes nordestinos a saírem da região Nordeste do país, enquanto que os fatores de atração ao que teria contribuído para a vinda dessa população à metrópole paulistana entre as décadas de 50 e meados dos anos 70 do século passado. 
A seguir temos as subcategorias que nos auxilia na análise das respostas dos estudantes. Aqui tratando-se dos fatores ligados a repulsão dos nordestinos de suas cidades.

Quadro 44 - Categorias dos fatores de repulsão, por nós utilizadas na análise das respostas dos alunos à primeira questão problema

\begin{tabular}{|l|l|l|l|l|}
\hline Sociais & Ambientais & Econômicos & Políticos & Imagens \\
\hline Pobreza & Seca & $\begin{array}{l}\text { Carência de } \\
\text { trabalho e } \\
\text { emprego }\end{array}$ & $\begin{array}{l}\text { Exploração do } \\
\text { trabalhador }\end{array}$ & $\begin{array}{l}\text { Verificar se o } \\
\text { aluno se atentou } \\
\text { às imagens } \\
\text { apresentadas }\end{array}$ \\
\hline Miséria & Sertão & $\begin{array}{l}\text { Escassez ou } \\
\text { ausência de } \\
\text { fábricas e } \\
\text { indústrias }\end{array}$ & $\begin{array}{l}\text { Perseguições } \\
\text { políticas }\end{array}$ & \\
\hline Alimentos & Caatinga & $\begin{array}{l}\text { Carência de } \\
\text { sistemas de saúde } \\
\text { e educação }\end{array}$ & $\begin{array}{l}\text { Conflitos e } \\
\text { guerras }\end{array}$ & \\
\hline $\begin{array}{l}\text { Necessidades } \\
\text { básicas }\end{array}$ & Semiárido & $\begin{array}{l}\text { Carência } \\
\text { atividades } \\
\text { serviços }\end{array}$ & de & \\
\hline $\begin{array}{l}\text { Dificuldade } \\
\text { financeira }\end{array}$ & & & & \\
\hline $\begin{array}{l}\text { Desigualdade } \\
\text { Social }\end{array}$ & & & & \\
\hline Vida difícil & & & \\
\hline
\end{tabular}

Fonte: Organizado pelo autor (2018).

No próximo quadro temos as subcategorias ligadas aos fatores de atração, ou seja, ao que teria atraído os nordestinos à metrópole paulistana.

Quadro 45 - Categorias dos fatores de atração, por nós utilizadas na análise das respostas dos alunos à primeira questão problema

\begin{tabular}{|c|c|c|c|c|}
\hline Sociais & Ambientais & Econômicos & Políticos & Imagens \\
\hline $\begin{array}{l}\text { Ascensão } \\
\text { social }\end{array}$ & $\begin{array}{l}\text { Fuga e distância } \\
\text { da seca }\end{array}$ & $\begin{array}{l}\text { Empregabilidade e } \\
\text { trabalho }\end{array}$ & $\begin{array}{l}\text { Fuga da } \\
\text { exploração do } \\
\text { trabalho }\end{array}$ & $\begin{array}{l}\text { Verificar se o } \\
\text { aluno se } \\
\text { atentou as } \\
\text { imagens }\end{array}$ \\
\hline $\begin{array}{l}\text { Melhoria de } \\
\text { vida }\end{array}$ & $\begin{array}{l}\text { Ambiente mais } \\
\text { úmido }\end{array}$ & Fábricas e indústrias & $\begin{array}{l}\text { Fuga de conflitos e } \\
\text { discórdias políticas }\end{array}$ & \\
\hline $\begin{array}{l}\text { Crescimento } \\
\text { pessoal }\end{array}$ & $\begin{array}{l}\text { Temperaturas e } \\
\text { menores }\end{array}$ & Comércio e serviços & & \\
\hline Moradia & & $\begin{array}{l}\text { Sistema educacional e } \\
\text { de saúde }\end{array}$ & & \\
\hline \multirow[t]{2}{*}{$\begin{array}{l}\text { Formação, } \\
\text { escolarização }\end{array}$} & & $\begin{array}{l}\text { Metrópole } \\
\text { desenvolvida }\end{array}$ & & \\
\hline & & Cidade desenvolvida & & \\
\hline
\end{tabular}


É importante especificarmos que como critérios para diferenciar as categorias social e econômica, que pode num primeiro momento gerar confusões devido as suas aproximações, consideramos como social os aspectos mais relacionados ao indivíduo, como pobreza, estar desempregado, falta de oportunidades para sua família, ao passo que na categoria econômica nos detemos aos aspectos mais gerais que envolvem um número maior de indivíduos, como por exemplo, a oferta de empregos nas fábricas, nas indústrias, no comércio, nos serviços, assim como a oferta de escolas, hospitais em uma dada região.

Em decorrência da estrutura das questões 1 e 2, seus resultados serão descritos juntos e, em seguida, interpretados. Assim, elencaremos desde já as categorias utilizadas para a análise da segunda questão-problema. Vale ressaltar, que para esta questão invertemos o entendimento dos fatores de atração e repulsão, pois o foco na referida questão se dá sobre a migração de retorno de nordestinos para a região Nordeste do país. Desse modo, consideramos a repulsão a partir da metrópole paulistana, ou seja, a saída deles, e a atração a partir da região Nordeste. Portanto, nosso quadro de análise sofreu algumas alterações em relação ao anterior, pois ainda acrescentamos a categoria cultural, como é possível ver a seguir.

Quadro 46 - Categorias dos fatores de repulsão, por nós utilizadas na análise das respostas dos alunos a segunda questão problema

\begin{tabular}{|c|c|c|c|c|c|}
\hline Sociais & Ambientais & Econômicos & Políticos & Culturais & Imagens \\
\hline Pobreza & Poluição do ar & $\begin{array}{l}\text { Fechamento de } \\
\text { postos de trabalho e } \\
\text { desemprego na } \\
\text { metrópole }\end{array}$ & Corrupção & $\begin{array}{l}\text { Preconceito } \\
\text { e xenofobia }\end{array}$ & $\begin{array}{l}\text { Verificar se } \\
\text { o aluno se } \\
\text { atentou as } \\
\text { imagens } \\
\text { apresentadas }\end{array}$ \\
\hline $\begin{array}{l}\text { Falta de } \\
\text { oportunidades }\end{array}$ & Poluição sonora & $\begin{array}{l}\text { Fechamento de } \\
\text { indústrias e fábricas }\end{array}$ & $\begin{array}{l}\text { Exploração } \\
\text { do } \\
\text { trabalhador }\end{array}$ & $\begin{array}{l}\text { Não se } \\
\text { adaptar à } \\
\text { metrópole }\end{array}$ & \\
\hline $\begin{array}{l}\text { Estagnação } \\
\text { Social }\end{array}$ & Poluição visual & $\begin{array}{l}\text { Desconcentração } \\
\text { industrial }\end{array}$ & & & \\
\hline $\begin{array}{l}\text { Violência } \\
\text { urbana }\end{array}$ & $\begin{array}{l}\text { Temperatura do } \\
\text { ar e clima urbano }\end{array}$ & Desindustrialização & & & \\
\hline Moradia & & Crise econômica & & & \\
\hline Alimentos & & $\begin{array}{l}\text { Novas tecnologias } \\
\text { em substituição ao } \\
\text { trabalhador }\end{array}$ & & & \\
\hline
\end{tabular}

Fonte: Organizado pelo autor (2018).

Para a mesma questão elaboramos outro quadro para analisarmos as respostas dos estudantes a partir dos fatores de atração. 
Quadro 47 - Categorias dos fatores de atração, por nós utilizadas na análise das respostas dos alunos a segunda questão problema

\begin{tabular}{|c|c|c|c|c|c|}
\hline Sociais & Ambientais & Econômicos & Políticos & Culturais & Imagem \\
\hline $\begin{array}{l}\text { Ter apoio } \\
\text { financeiro da } \\
\text { família }\end{array}$ & $\begin{array}{l}\text { Lugar mais } \\
\text { calmo sem } \\
\text { poluição } \\
\text { sonora }\end{array}$ & $\begin{array}{l}\text { Emprego e } \\
\text { trabalho }\end{array}$ & $\begin{array}{l}\text { Fuga de } \\
\text { conflitos e } \\
\text { discórdias } \\
\text { políticas }\end{array}$ & $\begin{array}{l}\text { Saudade da } \\
\text { família }\end{array}$ & $\begin{array}{l}\text { Verificar se o } \\
\text { aluno se } \\
\text { atentou e se } \\
\text { utilizou das } \\
\text { imagens } \\
\text { apresentadas }\end{array}$ \\
\hline $\begin{array}{l}\text { Programas } \\
\text { Sociais como } \\
\text { o Bolsa } \\
\text { Família }\end{array}$ & $\begin{array}{l}\text { Ausência ou } \\
\text { pouca } \\
\text { poluição do ar }\end{array}$ & $\begin{array}{l}\text { Cidades se } \\
\text { desenvolvendo }\end{array}$ & $\begin{array}{l}\text { Distância da } \\
\text { exploração do } \\
\text { trabalhador }\end{array}$ & $\begin{array}{l}\text { Saudade da } \\
\text { cidade natal } \\
\text { ou da região } \\
\text { que vivera }\end{array}$ & \\
\hline $\begin{array}{l}\text { Prosperar } \\
\text { noutra cidade }\end{array}$ & $\begin{array}{l}\text { Clima com } \\
\text { temperaturas } \\
\text { mais elevadas }\end{array}$ & Polos industriais & & $\begin{array}{l}\text { Saudade de } \\
\text { costumes e } \\
\text { tradições }\end{array}$ & \\
\hline $\begin{array}{l}\text { Nova vida } \\
\text { noutro lugar }\end{array}$ & & $\begin{array}{l}\text { Novas } \\
\text { indústrias na } \\
\text { região }\end{array}$ & & & \\
\hline
\end{tabular}

É preciso ressaltar que a categoria cultural fora por nós utilizada possuindo dois sentidos distintos em se tratando dos fatores de repulsão e atração, sendo que no primeiro caso, consideramos o preconceito, a discriminação e a xenofobia contra os nordestinos, principalmente devido a seus hábitos e costumes na metrópole paulistana. No caso do fator atração, consideramos a categoria cultural atrelada à saudade de seus familiares, amigos, de suas cidades, tradições, hábitos e cultura.

Ademais, os critérios supracitados não se resumem a analisar o conteúdo específico da atividade, mas como através desta a mente dos jovens se processa, pelos seguintes meios:

- Quantidade de fatores apontados pelos alunos, assim como o seu tipo (repulsivo e/ou atrativo) retrata a sua habilidade em associar informações, assim como o tipo de fator mencionado retrata o que lhe chamou mais atenção - permitindonos refletir: por quê?

- Qualidade de sua resposta, em saber acentuar os aspectos que mais interferem num fenômeno;

- Relação de sua resposta com as imagens demonstra capacidade contextualizadora. 
- A alteração de todas essas variáveis no processo aponta para uma revisão de conceitos por um indivíduo que evoluiu ou involuiu.

Analisando as respostas dos alunos à primeira questão-problema, percebemos com base no gráfico 28 , que a $8^{\text {a }}$ série A manteve a incidência dos fatores de repulsão de $24,14 \%{ }^{258}$ nas duas etapas ${ }^{259}$; já os fatores de atração aumentaram 5,74\%. Dentre os que mencionaram apenas um fator, o preponderante foi o econômico $(24,14 \%)$, porém reduzido em "repulsão" e quase triplicado em "atração". Desse, seguiu-se o "social" $(10,46 \%)$, com valor quase constante em cada etapa. Considerando dois ou mais fatores e a maior incidência de respostas, há o "socioeconômico" (49,42\%), aparecendo mais que o dobro de vezes em atração, mas sem alterar a incidência. $\mathrm{O}$ ambiental, somado a outras questões, em "repulsão" se acentuou (6,89\%), e não foi demonstrado sequer uma vez como fator isolado, sendo mais atrelado com o econômico no início e unicamente com o social no final.

\section{Gráfico 28 - Primeira questão inicial e final da $8^{\text {a }}$ série A, fatores de repulsão e atração identificados nas respostas dos alunos}

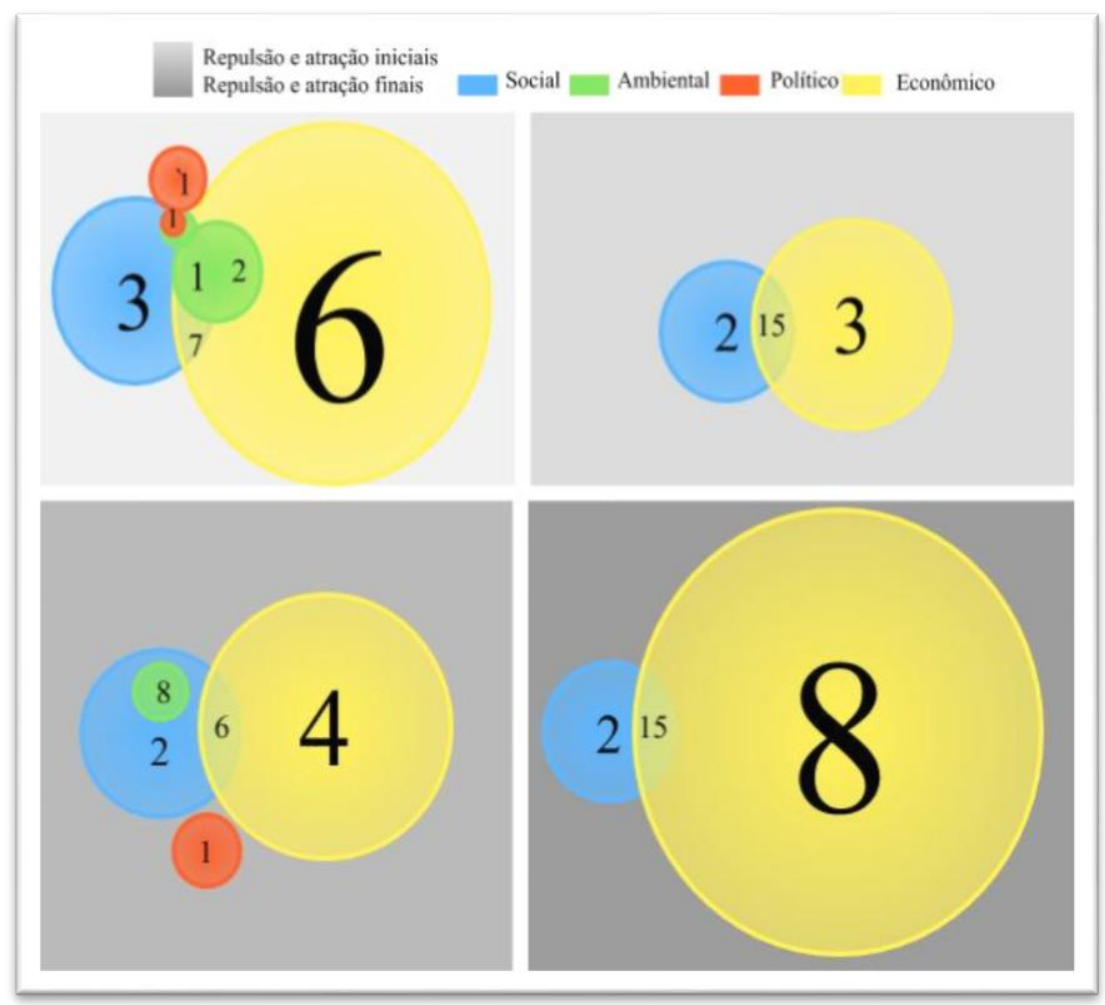

Fonte: Organizado pelo autor (2018). Programa Google Charts e JSFiddle. Colaboração técnica de Camila Fonseca Amorim da Silva.

\footnotetext{
${ }^{258}$ Os dados foram aproximados a partir da segunda casa após a vírgula.

259 A primeira linha do gráfico refere-se aos fatores de repulsão e atração da primeira questão da elaboração inicial. A segunda linha refere-se a mesma questão e aos referidos fatores, porém, da elaboração final.
} 
$\mathrm{Na}$ segunda questão (gráfico 29), houve evolução semelhante em repulsão e atração (3,23\% e 3,22\%, respectivamente), ao contrário da primeira. Dos fatores isolados, o que mais cresceu foi o econômico em "repulsão" (6,45\%). Em "atração", foi o fator cultural ${ }^{260}$ (quase constante). Dos combinados, o "econômico-cultural" se repercutiu em repulsão (crescendo 6,45\%), e se manteve quase constante em atração, reduzindo o cultural fragmentado.

Em ambas as questões, das incidências iniciais e finais de repulsão e atração, tiveram progresso relativamente semelhante $(5,74 \%$ e $8,06 \%)$, um tanto mais na segunda questão. Mais de dois conceitos reverberaram-se em pequenas quantidades.

\section{Gráfico 29 - Segunda questão inicial e final da $8^{\text {a }}$ série $A$, fatores de repulsão e atração identificados nas respostas dos alunos}

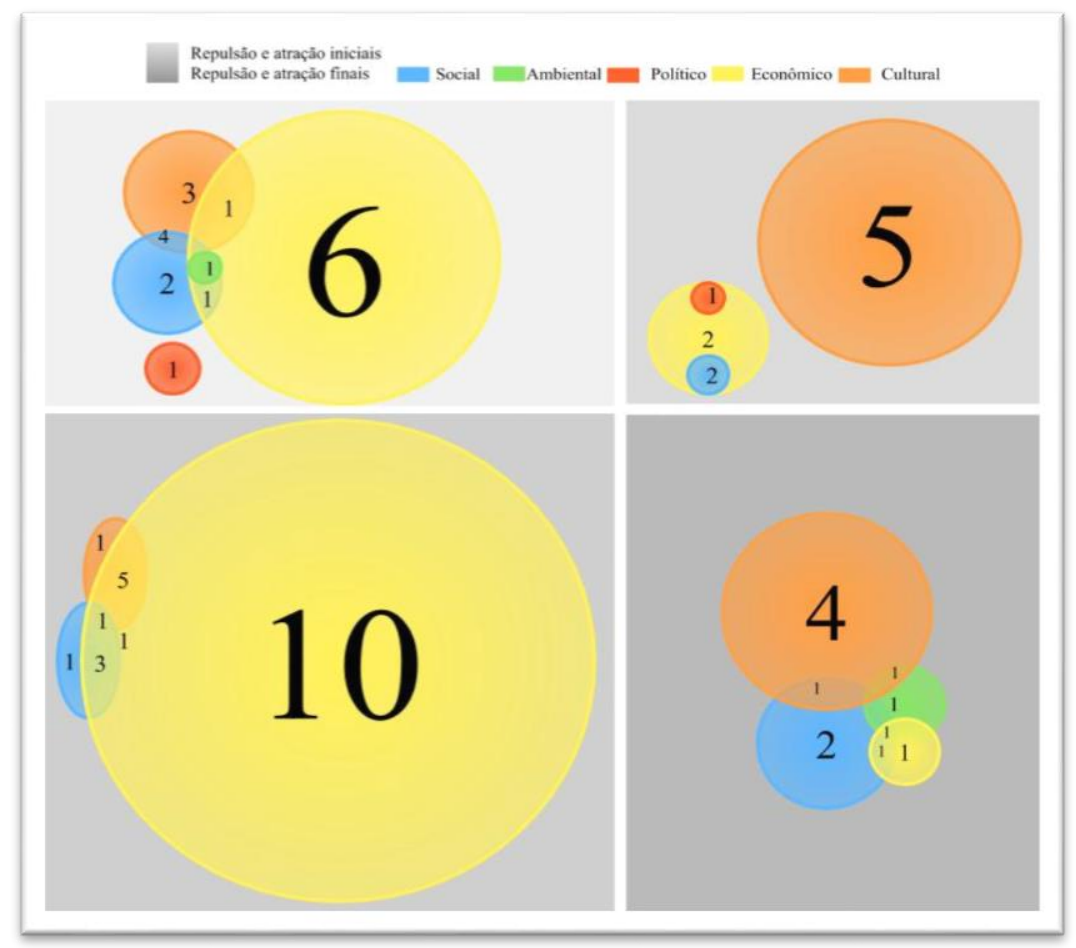

Fonte: Organizado pelo autor (2018). Programa Google Charts e JSFiddle. Colaboração técnica de Camila Fonseca Amorim da Silva.

Já na $8^{\mathrm{a}}$ série $\mathrm{B}$, conforme podemos ver no gráfico da página seguinte, a questão um apresentou um crescimento de repulsão de $10,64 \%$ (ao contrário da $8^{\mathrm{a}} \mathrm{A}$, nula, que se destacou na categoria oposta), apesar de inicialmente terem tido mais facilidade em

\footnotetext{
260 Tornou-se preponderante o aspecto cultural isolado em atração. Para os alunos, é mais associável a questão cultural de saudades do nordestino em relação à terra natal do que a mesma questão em repulsão, com cunho negativo (inadaptabilidade do migrante no meio e/ou xenofobia).
} 
identificar os de atração, o qual, entretanto, teve um sóbrio aumento de 2,13\%. Dos fatores isolados, somente na categoria de atração que houve um crescimento relativamente considerável $(5,32 \%)$, sendo o aspecto econômico, mais uma vez, o mais destacado. Dos fatores combinados, o socioeconômico se manteve quase que constante e dominante.

O tema ambiental somado a outras questões cresceu. Aqui, ninguém também apontou fatores ambientais em atração ${ }^{261}$. Nas categorias de repulsão e atração, dentre as incidências em conjunto, houve uma considerável evolução de 16,18\% e regressão de $2,94 \%$.

\section{Gráfico 30 - Primeira questão inicial e final da 8 á́rie $B$, fatores de repulsão e atração identificados nas respostas dos alunos}

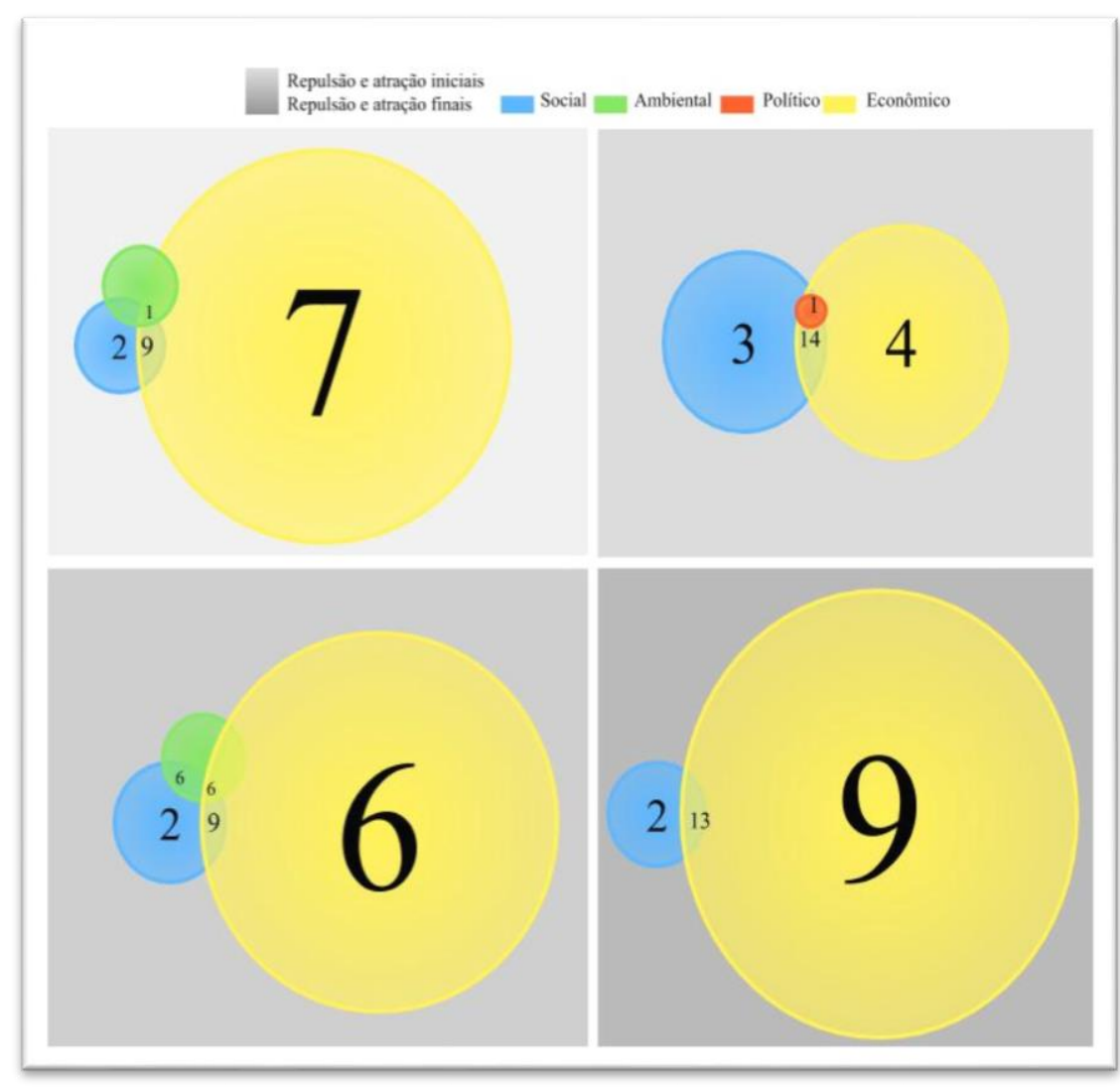

Fonte: Organizado pelo autor (2018). Programa Google Charts e JSFiddle.

Colaboração técnica de Camila Fonseca Amorim da Silva.

261 Claramente, não se esperaria que o aluno atribuísse ao Sudeste, mais precisamente à região metropolitana de São Paulo, como detentora de um fator ambiental realmente atrativo. Afinal, as diferentes faces da poluição (atmosférica, sonora, hídrica), as ilhas de calor, dentre outros fenômenos mais urbanos, não seriam os aspectos que incentivariam o nordestino deixar a sua terra, mas sim aspectos não tão ruins quanto os que viviam rotineiramente. Portanto, esperava-se esta última inferência. 
Sua segunda questão, conforme o gráfico 31, evoluiu 5,88\% em repulsão, porém regrediu 2,93\% nos fatores de atração. Dentre os fatores isolados, o econômico, outra vez, foi o que mais cresceu, superando uma duplicação. $\mathrm{O}$ fator cultural apareceu mais inicialmente em ambas as categorias, desaparecendo em repulsão. Possivelmente, com o conhecimento espontâneo, os alunos que associaram exclusivamente os aspectos culturais entendiam que o Sudeste ainda estava economicamente viável para o migrante, associando o perfil próspero do Sudeste ao nordestino da questão 1 com a questão 2, como se fosse o mesmo cenário e, portanto, se o mesmo quisesse voltar para o Nordeste, seria somente por uma questão de origem cultural, de inadaptabilidade ou preconceito sofrido no ambiente metropolitano, sendo esse motivo mais forte do que as razões para ficar.

\section{Gráfico 31 - Segunda questão inicial e final da $8^{\mathrm{a}}$ série $\mathbf{B}$, fatores de repulsão e atração identificados nas respostas dos alunos}

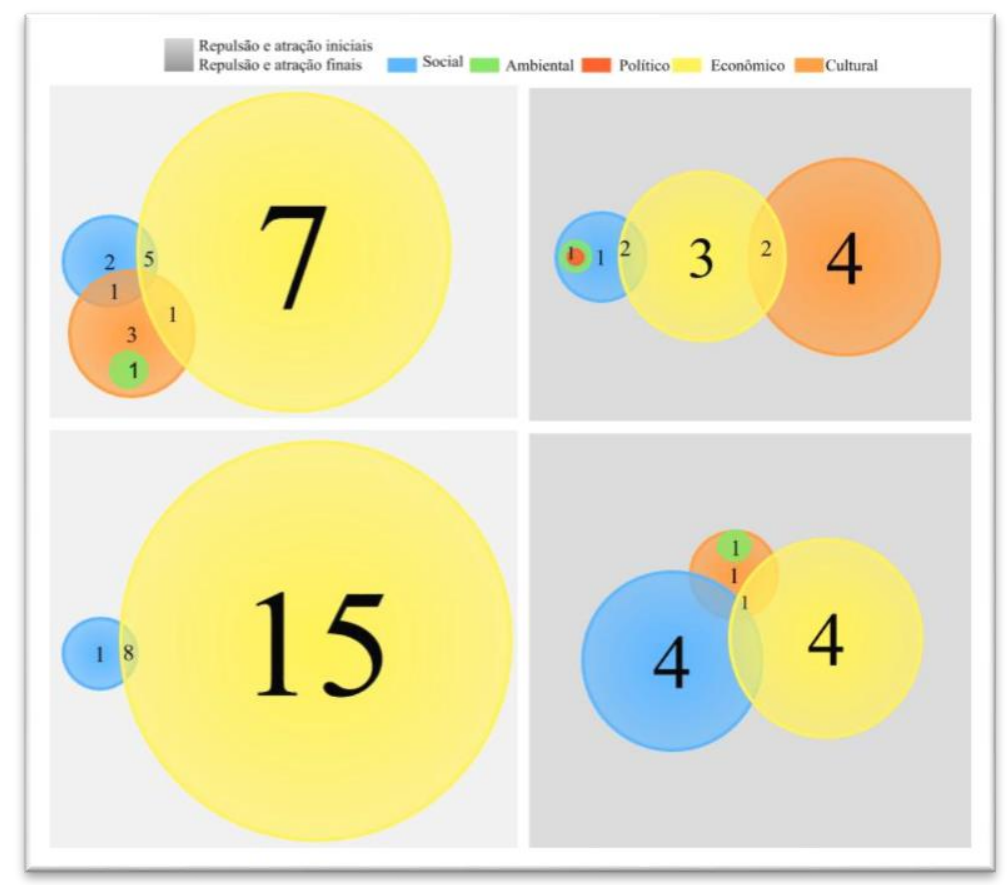

Fonte: Organizado pelo autor (2018). Programa Google Charts e JSFiddle. Colaboração técnica de Camila Fonseca Amorim da Silva.

Podemos indagar que, como o cultural zerou em repulsão e se reduziu em atração, os alunos poderiam ter notado que, ainda que o aspecto cultural exista, este não seria o motivo maior. Ainda assim, não seria necessário que menos alunos inserissem o cultural em sua resposta, mas sim que retratassem que esse não era o maior motivo. Para os alunos, os efeitos repulsivos ficaram mais evidentes do que os atrativos às terras de origem, inclusive pela incidência de respostas em geral permearem, aqui, os aspectos repulsivos. 
Das correlações entre fatores, há destaque para o socioeconômico em repulsão, crescendo 3,19\%. A associação de fatores manteve-se no aspecto repulsivo e se decaiu nos atrativos $4,41 \%$.

Mais uma vez, trabalhando as exceções, poucos alunos mencionaram mais de dois aspectos, sendo estes o social, ambiental e político em repulsão na primeira questão e social, ambiental e econômico na segunda, em iguais porcentuais $(1,06 \%)$. Analisando a $8^{\text {a }}$ série $\mathrm{C}$, como podemos ver no gráfico 32 , a sala apresentou boa evolução em repulsão $(5,71 \%)$ e atração (esta principalmente, com $11,43 \%)^{262}$.

\section{Gráfico 32 - Primeira questão inicial e final da 8 série $C$, fatores de repulsão e atração identificados nas respostas dos alunos}

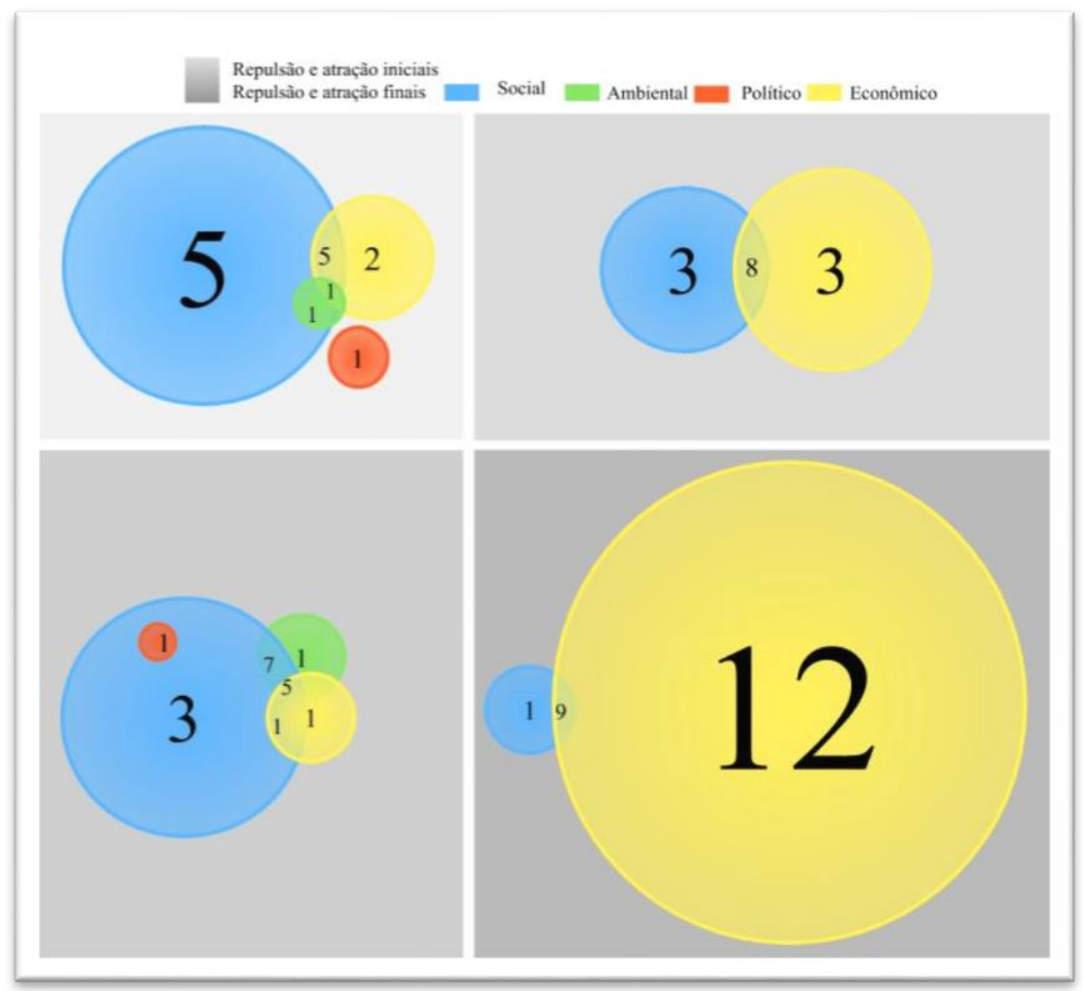

Fonte: Organizado pelo autor (2018). Programa Google Charts e JSFiddle. Colaboração técnica de Camila Fonseca Amorim da Silva.

Desta vez, isoladamente, o fator social destacou-se em "repulsão", apesar de redução (o mesmo vale para o socioeconômico nessa categoria), sendo que o econômico dominou atração na parte final, quadruplicado, equiparado com o social no início. Dos inter-relacionados, o socioambiental aumentou 8,57\% em repulsão, passando a dominar. Ainda, aumentaram as associações de fatores em todas as categorias (repulsão e atração)

\footnotetext{
${ }^{262}$ Semelhante à $8^{\mathrm{a}}$ série $\mathrm{A}$, porém em maior intensidade, a questão de atração ao Sudeste chamou-lhes mais a atenção.
} 
respectivamente, em 6,95\% e 1,39\%. Isso evidencia que, dentre os fatores associados, conseguiram evoluir mais em repulsão, ou seja, não pensando a partir do lugar nessa categoria de associações.

Os alunos fizeram mais inferências socioambientais em repulsão no final. Para eles, o impacto que a seca gera nos indivíduos os marcou mais. Entretanto, o ideal seria que tivessem mencionado os demais aspectos, ainda mais para não disseminar o senso comum de que o indivíduo é simplesmente afetado pela seca.

Outra vez, em relação à minoria, houve aqueles que inferiram mais de dois fatores $^{263}$, mas somente em repulsão, sendo mais chamativo o social, econômico e ambiental, que aumentou 5,71\%.

Da questão dois, conforme o gráfico 33, o fator fragmentado mais respondido foi o econômico, principalmente em repulsão na parte final (aumento de 8,38\%). O social foi mais mencionado no início (5,51\% superior) em repulsão, e manteve-se quase que constante em atração.

\section{Gráfico 33 - Segunda questão inicial e final da 8 ásérie $C$, fatores de repulsão e atração identificados nas respostas dos alunos}

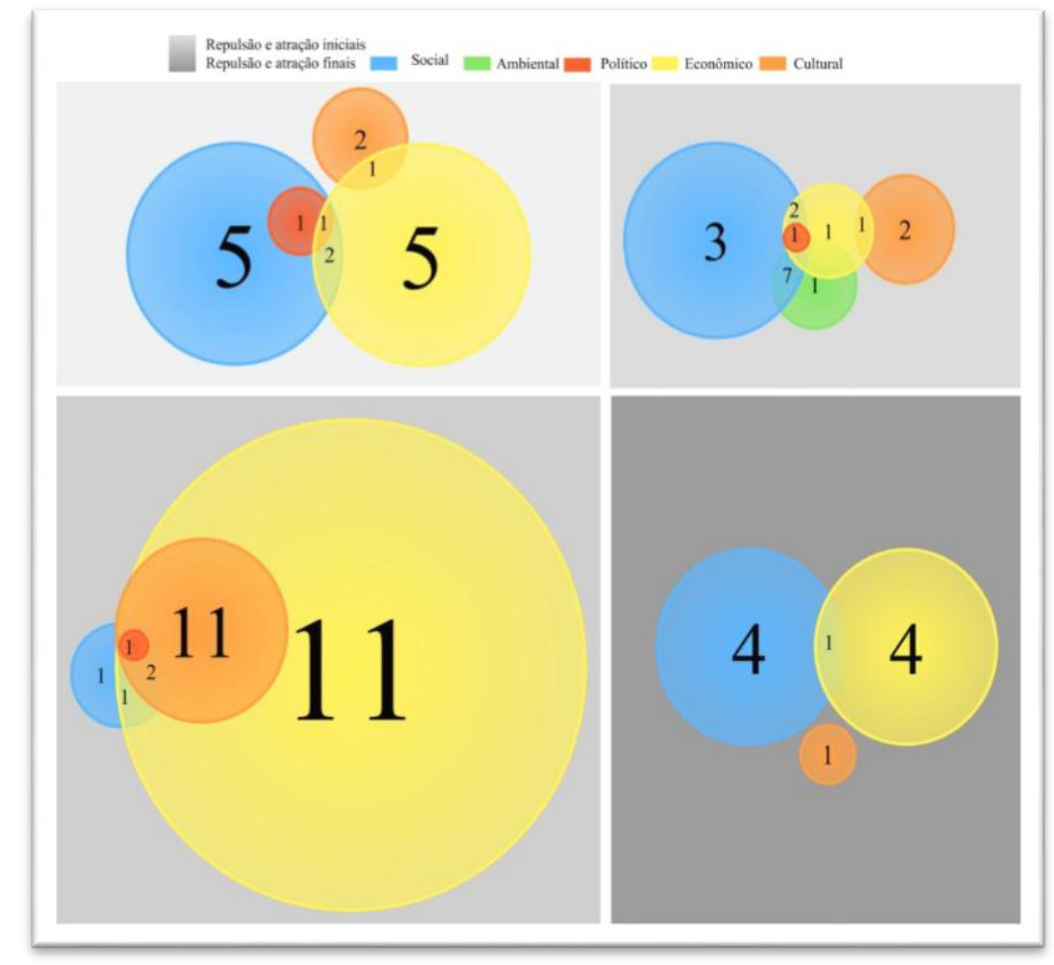

Fonte: Organizado pelo autor (2018). Programa Google Charts e JSFiddle. Colaboração técnica de Camila Fonseca Amorim da Silva.

263 Para eles, é mais fácil associar uma série de fatores negativos do que positivos. 
Dos fatores em conjunto, o cultural é o que se sobressai na repulsão (cresceu $12,5 \%$ ) de todas as salas, e quase não se destaca na atração. O socioambiental foi realçado na atração inicial $(9,72 \%)$ e desaparecera na final. Apesar de haver aqueles que mencionaram mais de dois aspectos, também foram minoritários. A princípio, os alunos cogitaram que o migrante retornava ao Nordeste por uma não mais ocorrência do fenômeno da seca; no final, notaram que o movimento de retorno, no aspecto de atração, nada tinha a ver com isso.

Por último, a $8^{\circ}$ série $\mathrm{D}$ (gráfico 34 ) regrediu relativamente em quantidade de fatores mencionados em ambas as categorias $(6,41 \%$ e $2,56 \%)$, porém progrediu em qualidade das mesmas, em relação a associação de fatores totais (avançando em repulsão e mantendo-se em atração), com crescimento de 6,41\%. Aqui, foi mais simples aos alunos notarem aspectos combinados desde o início em atração, e em menor quantidade, porém com maior variedade de aspectos, os fatores de repulsão.

\section{Gráfico 34 - Primeira questão inicial e final da $8^{\text {a }}$ série $D$, fatores de repulsão e atração identificados nas respostas dos aluno}

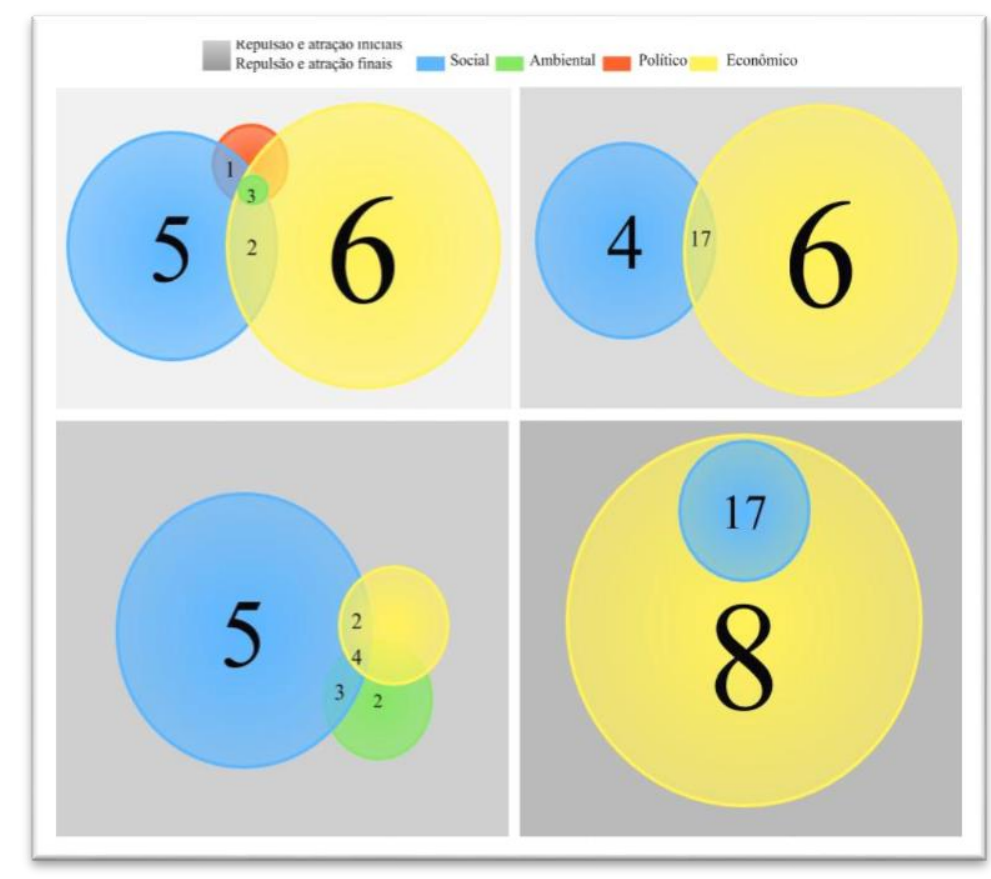

Fonte: Organizado pelo autor (2018). Programa Google Charts e JSFiddle.

Colaboração técnica de Camila Fonseca Amorim da Silva.

Considerando os aspectos isolados, tanto (e principalmente) em repulsão quanto em atração, a questão econômica se reverberou a princípio, sendo reduzida nos fatores repulsivos no fim, mas mantendo-se predominante nos aspectos atrativos, inclusive crescendo. Após este, segue-se o fator social, que aparece em proporções semelhantes, 
somente não presente no fator de atração no final. Dentre os associados, destacaram-se o socioeconômico que se manteve constante em atração $(21,79 \%)$ e o social, ambiental econômico e político no início de repulsão (3,85\%), sendo a sala que mais conseguiu mencionar os quatro fatores. Os alunos, desde o início, notaram que os fatores socioeconômicos são importantes de serem mencionados, tanto que a fragmentação conceitual do social foi substituída, em parte, por dado aspecto, ao invés de ideias sociais e econômicas fragmentadas. Essa percepção cresceu no final. Todos os alunos que mencionaram questões sociais isoladas em atração notaram que estas também decorrem de aspectos econômicos, como a empregabilidade. Entretanto, ainda havia quantidade semelhante de alunos que citaram aspectos da economia isoladamente.

Foi mais simples aos alunos contextualizarem o nordestino numa situação em que a categoria atração, inicialmente, teria a categoria social afetada pelo aspecto cultural ou esta pelo econômico. O impacto da economia no social, na vida do indivíduo, tornou-se perceptível no final da avaliação.

Partindo para a segunda pergunta, a categoria com mais incidências (totais, isoladas e associadas) foi a final de repulsão. Os alunos evoluíram tanto nos motivos repulsivos, assimilando principalmente mais questões socioeconômicas (avanço de $8,69 \%$ ); e atrativos, com acentuação de $8,69 \%$ também no quesito socioeconômico, que não havia aparecido inicialmente (apenas o econômico-cultural ou sociocultural o fizeram, cada um com aparição de 1,45\%).

\section{Gráfico 35 - Segunda questão inicial e final da $8^{\mathrm{a}}$ série $\mathrm{D}$, fatores de repulsão e atração identificados nas respostas dos alunos}

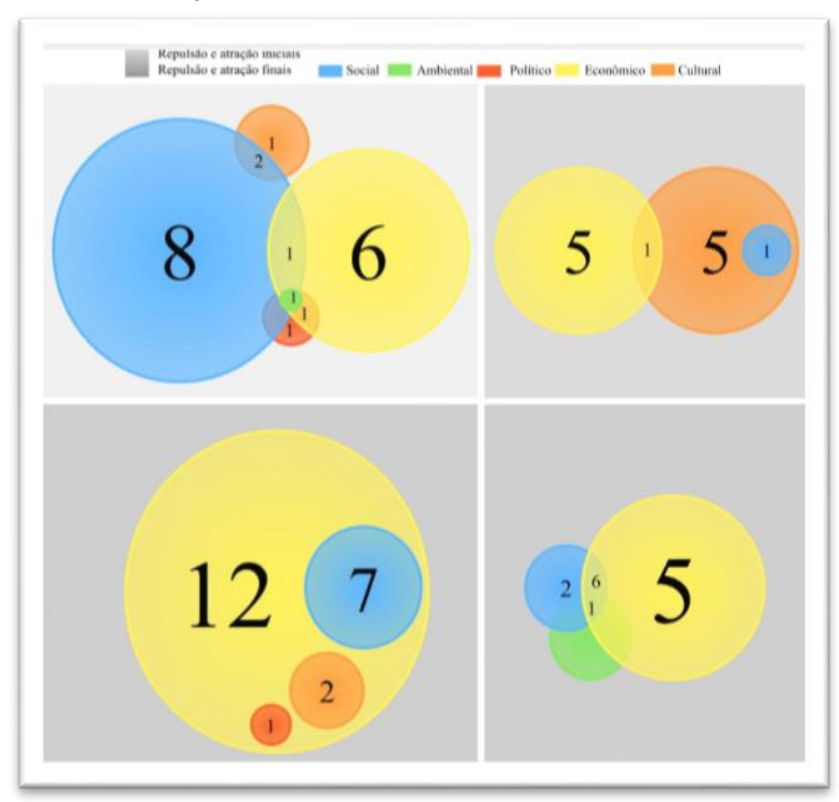

Fonte: Organizado pelo autor (2018). 
Aqui, também, o aspecto ambiental não fora sequer uma vez citado segregadamente, aparecendo, mesmo que em pequena quantidade, somado ao político, econômico e social no início de repulsão $(1,45 \%)$ e no final de atração, atrelado a questões socioeconômicas $(1,45 \%)$.

Fazendo uma análise de um modo geral das quatro turmas em relação as duas primeiras questões-problema, pudemos verificar que dos fatores isolados, o mais apontado foi o econômico, em ambas as questões. A questão socioeconômica foi a mais evidenciada dentre os fatores associados. Já a questão política foi a menos incidente. Podemos depreender que para os alunos, aquilo que afeta economicamente o indivíduo foi o ponto mais latente.

As turmas demonstraram - apesar ter uma visão com tendência ao lugar como referencial - progresso por conta do maior número de inferências feitas, em geral. Quando se perguntou o porquê de o nordestino ir ao Sudeste, os jovens indicaram mais as razões de atração ao SE do que de repulsão do Nordeste; quando se indagou o porquê do nordestino deixar o SE, pensaram predominantemente a partir dos fatores de repulsão do SE e não dos atrativos do $\mathrm{NE}$ - em ambos, pensando a partir de seu local. Ademais, eles também demonstraram maior facilidade para trabalhar com dois conceitos (destacando-se o socioeconômico) ou mais no movimento da migração nordestina ao Sudeste ao invés do movimento de retorno.

O gráfico 36 (próxima página) apresenta os tipos de migração abordadas pelos alunos na terceira questão-problema. Assim, nos utilizamos do numeral 1, para nos referirmos a migração do Nordeste para o Sudeste (típica dos anos 50 à meados dos 70), o número 2, para nos referirmos ao movimento de nordestinos da metrópole paulistana sentido a região Nordeste do país (retorno) e 0 (zero) para quem não citou nenhum dos movimentos. Usaremos "ambas" para aqueles que se reportaram aos dois tipos de processos migratórios.

Ainda que certamente mínimo, houve um progresso entre os tipos de migração abordadas por turma. Um aluno da $8^{\mathrm{a}} \mathrm{A}$ passou a mencionar a migração de retorno em sua resposta, o que inicialmente não havia ocorrido. $\mathrm{O}$ mesmo vale para a $8^{\mathrm{a}}$ série $\mathrm{B}, 3$ alunos não responderam no fim, o que reduziu a incidência de menção a um tipo de migração, apesar de ter surgido a menção à migração de retorno - dos quais dois não apresentaram conceito algum na resposta inicial, e um apenas havia abordado uma das migrações. A situação da $8^{\mathrm{a}} \mathrm{D}$ é semelhante. 
É possível que, dentre os alunos com mais dificuldade, exista aqueles que sintam que não irão aprender e, ao se depararem com um inicial problema, posteriormente desistam de enfrentá-lo.

\section{Gráfico 36 - Tipos de migração abordadas pelas quatro turmas na $3^{\text {a }}$ questão}

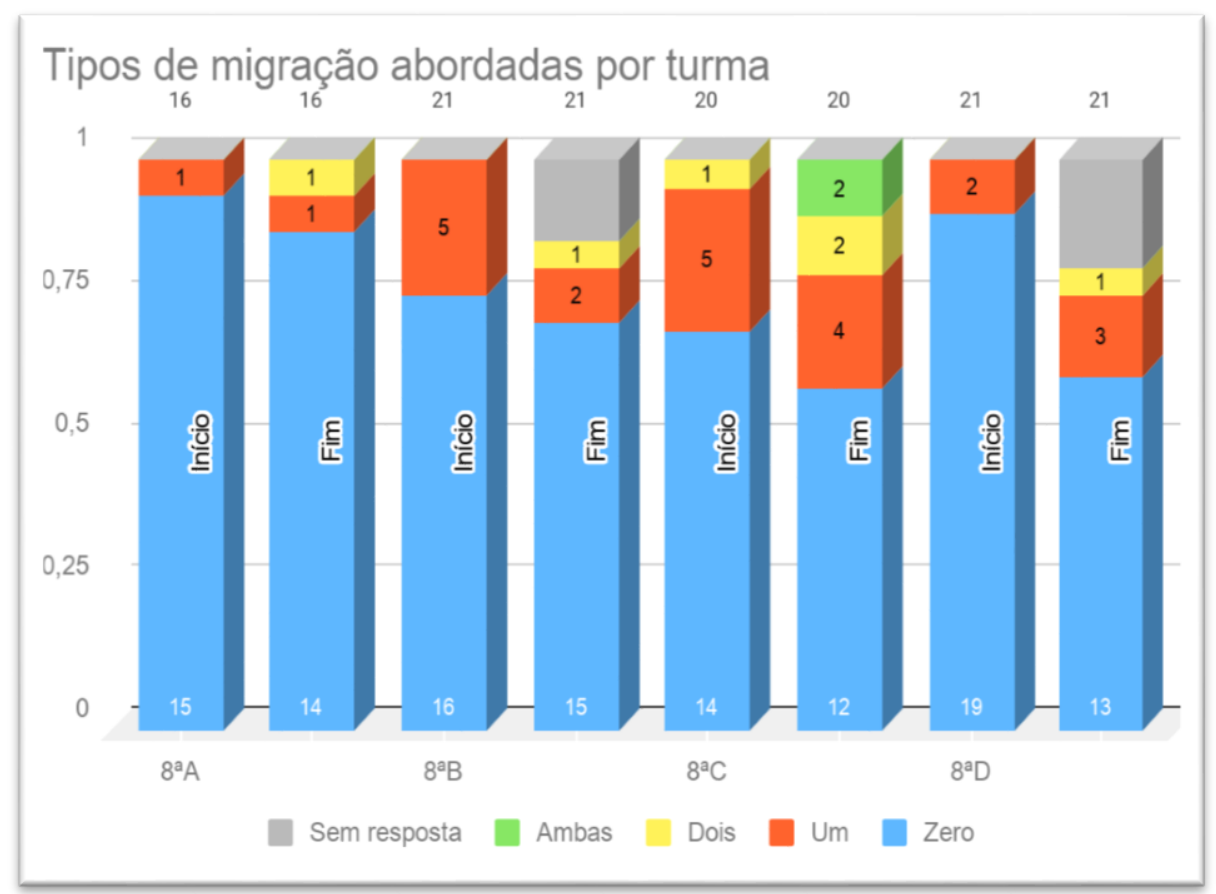

Fonte: Organizado pelo autor (2018). Programa Google Charts e JSFiddle. Colaboração técnica de Camila Fonseca Amorim da Silva.

A menção à migração de retorno evidenciou-se mais no final da atividade. É provável que, aos alunos, a vinda do nordestino para seu entorno, o próximo, o vivido, tenha sido mais simples de percepção inicialmente do que sua ida para um local distante do lugar do aluno; em contrapartida, no final, há maior compreensão de sua saída rumo à terra natal em todas as salas, ainda que seja uma pequena percepção.

A sala que melhor se desempenhou no início e no final foi a $8^{\mathrm{a}} \mathrm{C}$, com todos os alunos respondendo em todas as etapas e com menor incidência de relações incorretas (12) no final, sendo a única com quem chegou a ter respostas completas (2), englobando as migrações ao Sudeste e de retorno.

\subsection{EVOLUÇÃO DAS RESPOSTAS DAS ELABORAÇÕES POR ALUNO}

Nesta análise, considerou-se as possibilidades de os alunos apresentarem "nenhuma (N)", "parcial (P)" e "total (T)" qualidade em suas respostas. Caso não respondessem, seria considerado "sem resposta" - o que ocorreu excepcionalmente. Para 
concluirmos se uma sala progrediu, regrediu ou se manteve-se no mesmo nível em relação a aprendizagem, incorporamos a ideia de saldos, atribuindo um valor para cada nível de resposta, a fim de que tenhamos uma noção de quais perguntas e quais salas melhor se saíram, trabalhando com a ideia de progresso, isto é, aquele aluno que partiu de uma situação com menor desenvolvimento e atingiu um grande desenvolvimento no final é mais valoroso do que aquele que já havia iniciado relativamente bem, pois a variação de seu conhecimento foi maior e não tão esperada quanto àquele que já se desempenha sempre bem.

Não obstante, é impreterível considerar que, esta análise, por si só, não nos permite compreender integralmente o ponto de partida do aluno. Afinal, se uma sala começou e terminou em total, o saldo seria 0 ; se começasse em "sem resposta" e fosse para total, o número de alunos seria multiplicado por três. Noutros termos, o saldo nos mostra o avanço em relação ao estágio inicial da sala, porém sem saber em detalhes o nível que cada aluno se encontra (poderíamos cometer falácias, e dizer que a sala que progrediu de nenhuma à total estava no mesmo patamar ou até superior à sala com saldo 0 , se levássemos essa ideia num contexto qualquer). Por isso, levamos em conta os critérios "sem resposta", "nenhuma", "parcial" e "total" também, como pode ser visto abaixo.

Quadro 48 - Modelo usado para trabalhar saldos

\begin{tabular}{|l|l|l|l|l|}
\hline Início/Fim & $\mathrm{SR}$ & $\mathrm{N}$ & $\mathrm{P}$ & $\mathrm{T}$ \\
\hline $\mathrm{SR}$ & 0 & 1 & 2 & 3 \\
\hline $\mathrm{N}$ & -1 & 0 & 1 & 2 \\
\hline $\mathrm{P}$ & -2 & -1 & 0 & 1 \\
\hline $\mathrm{T}$ & -3 & -2 & -1 & 0 \\
\hline
\end{tabular}

Fonte: Elaborado pelo autor (2018).

A $8^{\mathrm{a}}$ série $\mathrm{A}$ apresentou maior facilidade inicial na questão três, onde 7 alunos tiveram qualidade parcial da resposta em toda a atividade (e 2 avançaram para total) e, 3, total (sendo que estes mantiveram o nível de resposta, além de 7 dos parciais terem ou mantido o nível e 2 evoluído para o total).

Para a leitura dos gráficos abaixo, há de se considerar que, respectivamente em cada terço deles, estão as questões 1, 2 e 3 dividas em seu início e fim. Ainda, dentro de cada terço do gráfico, o nível de desempenho do aluno (nenhuma, parcial e total inicial 
e final). Ou seja, são apresentadas as evoluções dos estudantes desde a primeira elaboração das questões-problema até as questões finais.

\section{Gráfico 37 - Evolução das respostas dos estudantes da $8^{\mathrm{a}}$ série A}

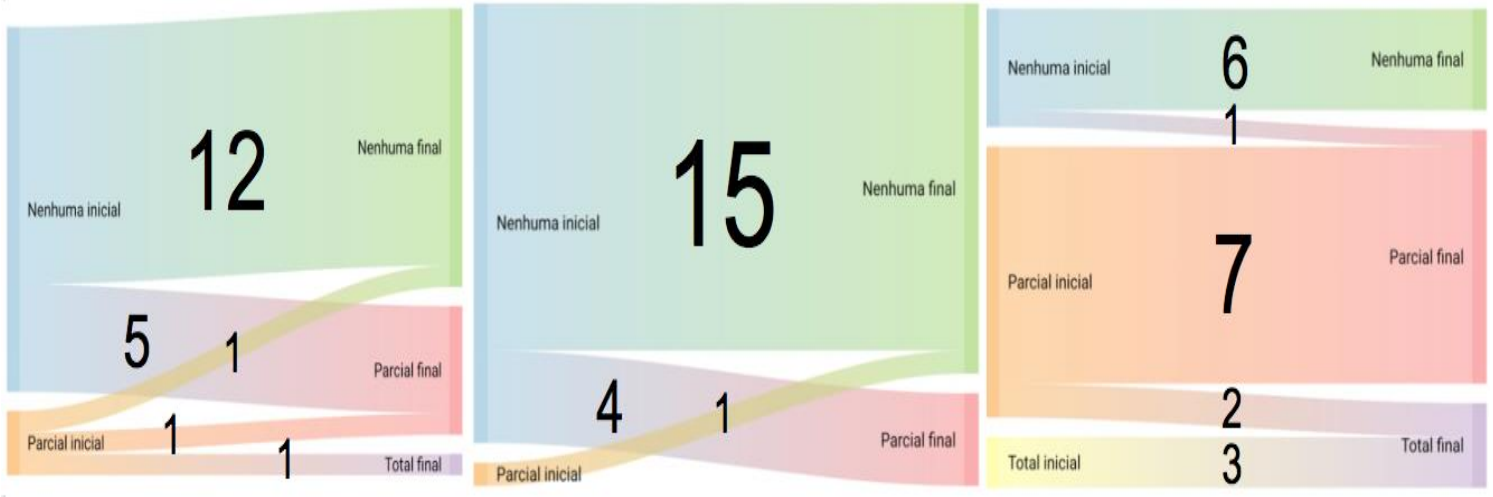

Fonte: Organizado pelo autor (2018).

A questão dois foi a que mais evidenciou dificuldade, com 15 inicialmente em "nenhuma" e o único parcial involuindo para "nenhuma". Entretanto, houve progresso, ao considerar que 4 dos que estavam em "nenhuma" passaram para "parcial", mais do que um único aluno que regrediu. A questão um foi intermediária: 12 mantiveram-se em "nenhuma", 5 ascenderam para parcial e, daqueles inicialmente parciais, em iguais quantidades (1), involuíram, se mantiveram e progrediram. O saldo resultante é positivo (5 na primeira, 3 na segunda e terceira), com mais progresso nas aprendizagens que se amadureceram do que regresso. Conclui-se que, aqui, a questão 3, que trabalhava com os aspectos da 1 e 2 transpostos para um contexto de relacionar os fenômenos com as imagens, foi melhor trabalhada por parte dos estudantes, sendo que possuem potencial para contextualização, o que pode facilitar a análise dos jovens, ao se respaldarem em assuntos relacionados, mais do que para explicar fenômenos por si só, o que exigiria que se voltassem mais para o próprio assunto.

Partindo para a $8^{\mathrm{a}}$ série $\mathrm{B}$, a questão três também foi mais simples para eles, porém não tanto quanto a $\mathrm{A}$, já que alguns alunos, ainda que a minoria (3), regrediram aqui. Nenhum manteve-se em nenhuma, sendo que um dessa categoria progrediu para total, e 4 em parcial também (sendo mais fácil a esses últimos evoluírem por já terem conhecimento prévio mais avançado do que os primeiros). A questão mais complexa foi a segunda. Na primeira, intermediária (20 não progrediram, porém não houveram regressos, diferente da turma anterior), ou seja, possuem mais facilidade em lidar com o 
movimento migratório nordestino ao Sudeste, reforçando a questão do lugar, a qual precisa ser rompida mais ainda.

Gráfico 38 - Evolução das respostas dos estudantes da $8^{\text {a }}$ série B

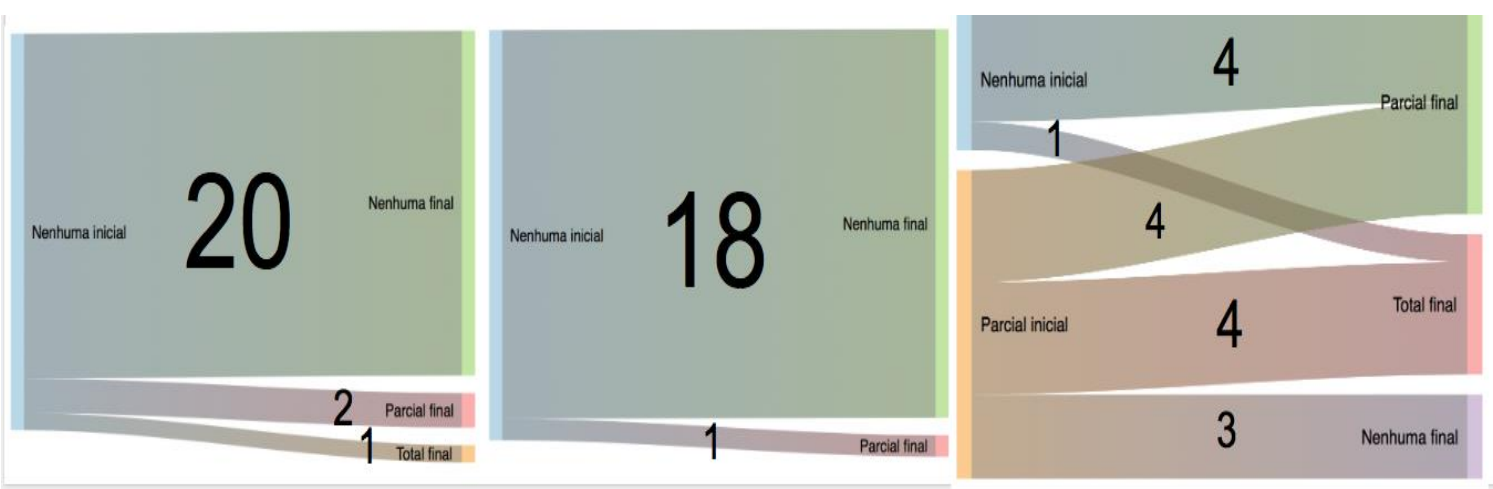

Fonte: Organizado pelo autor (2018)

A sala que melhor se saiu na terceira questão foi a $8^{\text {a }}$ série $\mathrm{C}$, com 11 de saldo, 5 "totais" (sendo 2 que estavam em "nenhuma"), "13 "parciais" e apenas 3 em "nenhuma" no final, sem regressos. Foi a turma com maior facilidade para lidar com uma questão de contextualização via imagens. Tiveram, também, a menor dificuldade na questão dois (2,25 vezes menos que a média das salas).

\section{Gráfico 39 - Evolução das respostas dos estudantes da $8^{\text {a }}$ série $\mathrm{C}$}

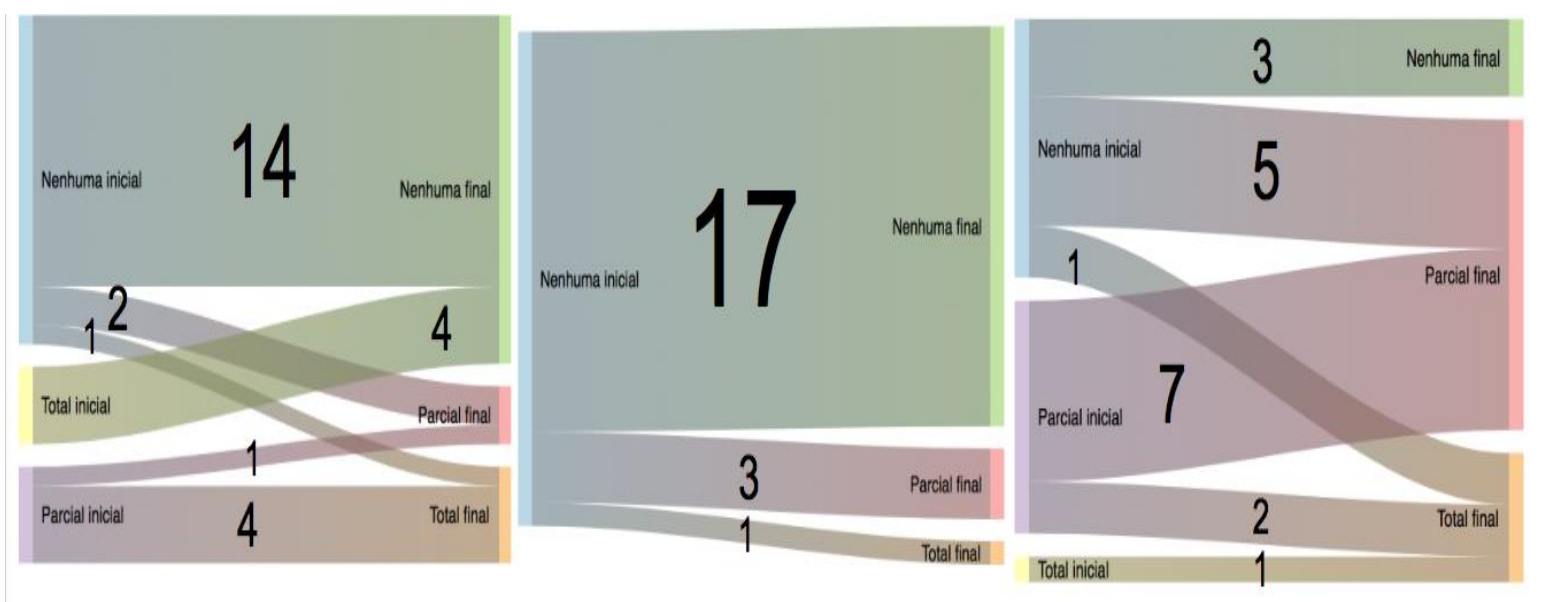

Fonte: Organizado pelo autor (2018)

A pergunta mais complexa a eles foi a primeira, sendo a única sala com 4 alunos em "total" que se direcionaram para "inicial". Por outro lado, então, tiveram dificuldade em trabalhar com mais conceitos relativos ao lugar, sendo, pois, excepcionais. A questão 3 foi a intermediária, entretanto, com menor número de alunos mantendo-se em 
nenhuma (3) e mais em parcial (7, assim como a $8^{\mathrm{a}} \mathrm{A}$ na mesma pergunta) e total (1) desde o início.

A questão dois se mostrou como uma das mais difíceis aos alunos da $8^{\mathrm{a}}$ série $\mathrm{D}$, de todas as salas, com menor progresso. Houve 20 alunos mantendo-se em "nenhuma" e apenas um aluno em "parcial". A primeira questão foi intermediária, com 6 alunos a menos em "nenhuma" e 6 que evoluíram para "parcial". Apenas um regrediu. A terceira questão foi a que mais apresentou pontos positivos: com menor número daqueles que não transcenderam "nenhuma", mais de 6 vezes inferior ao da questão dois (3). Entretanto, foi a única pergunta que 3 dos alunos que nada substancial apresentaram no início optaram por não responder no final. Da referida sala, foi a única questão com jovens na categoria "total" no final (2 de "nenhuma" e 1 de "parcial"). Aqui, segue-se que somente um aluno regrediu. Outra vez, há um saldo positivo.

\section{Gráfico 40 - Evolução das respostas dos estudantes da $8^{\text {a }}$ série D}

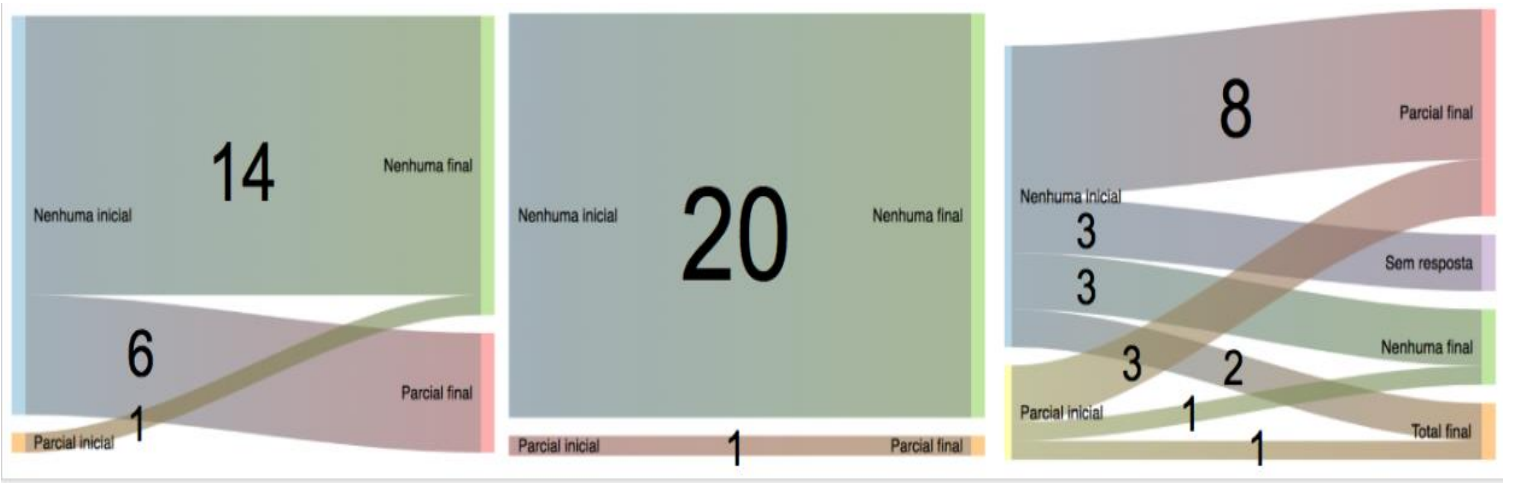

Fonte: Organizado pelo autor (2018)

Evidenciou-se que a questão mais complexa aos alunos foi a número dois, que trabalhava com o conceito do movimento de retorno.

Poderíamos assumir que, teria sido mais simples aos alunos realizar as conexões econômicas e, principalmente, socioeconômicas, em decorrência de suas realidades? Estudantes os quais, como vimos no decorrer da pesquisa e contexto no qual fizeram as atividades, são da rede pública, com pais de baixa escolaridade, com pouca leitura. Entretanto, esses mesmos alunos, apesar das dificuldades, com o pouco que o seu lugar ofereceu, muito descobrem junto a uma abordagem que transcende esse mesmo espaço e inclusive auxilia compreender o mesmo, espaço este que dificilmente, jamais ou lentamente transcenderiam se a aprendizagem fosse limitada ou estruturada somente nele, sem buscar conexões com outras escalas espaço temporais. Aqui, relacionam sua percepção na Sequência Didática com a sequência das migrações nordestinas e de suas 
vidas, convergentes ou divergentes ao que foi enfrentado pelos retirantes. São eles que demonstram, ainda que despretensiosamente, como a geografia, que a priori tratar-se-ia da descrição da Terra, pode transcender esse conceito com uma interpretação da mesma, já que não foi, não é e nem seria uma mera descrição do lugar.

Sendo a geografia estudiosa acerca da interação integrada de sociedade e natureza no espaço geográfico, como esperar que melhor se compreenda algo tão dinâmico, assimétrico e amplo, restrito apenas ao próximo, ao alinhado desencadeamento de fatos e do vivido? Daí a importância de um ensino de geografia que não fique restrito apenas a uma escala do lugar sem conexões com outras escalas de tempo e espaço, mas que o leve à um nível de abstração mais alta. 


\section{CAPÍTULO 7 VERIFICANDO AS APRENDIZAGENS APÓS A SEQUÊNCIA DIDÁTICA}

Neste capítulo tratamos sobre a elaboração final $n^{\circ} 2$, ou seja, a dissertação em que os alunos foram solicitados a elaborar um texto tratando sobre a personagem principal da animação Vida Maria pensando em dois contextos diferentes: a vinda de Maria da região Nordeste do país em direção à metrópole paulistana nas décadas de 50, 60 ou 70 do século passado e sua vinda nos dias atuais. Nosso objetivo com essa atividade fora a de verificar se os estudantes estavam trabalhando noutras escalas espaço-temporais que não somente do lugar que lhe é mais próximo, mas articulando as escalas de tempo e espaço de outros lugares. Assim, fazemos uma análise geral das quatro turmas de $8^{\mathrm{a}}$ séries participantes da pesquisa em relação ao desempenho que obtiveram nesta etapa final da Sequência Didática e se começaram a operar por conceitos científicos num maior nível de abstração.

\subsection{A DISSERTAÇÃO FINAL E NOÇÃO DE TEMPO-ESPAÇO}

Nesta etapa, esperávamos verificar se houveram avanços nas aprendizagens dos estudantes, como, por exemplo, em relação ao uso de vocabulário apropriado, conceitos científicos de geografia, saber escrever de modo menos impulsivo e suas abstrações em relação ao eixo tempo e espaço. Assim, procuramos observar como os alunos se organizavam a partir dos elementos presentes na folha de apoio que continha determinados indícios para que os apoiassem na elaboração de suas dissertações. A folha exigia determinadas condutas por parte dos estudantes, como requerer uma análise de comportamento exploratório considerando as informações e dados nela apresentados, distinguindo as informações relevantes das irrelevantes, para que pudessem desenvolver suas elaborações com melhores inferências e hipóteses.

A folha de apoio possuía numa primeira linha duas imagens da animação Vida Maria com aspectos da região de caatinga. Noutra linha, constava a imagem de uma fábrica desativada, representando as rugosidades de um passado de industrialização que deixara como permanências um galpão em estado de ruínas. $\mathrm{Na}$ mesma linha havia a imagem de uma indústria automatizada. Na mesma folha era apresentado dois gráficos tratando sobre as décadas de 1970 e 2012, mostrando a redução no total de nordestinos na região metropolitana de São Paulo. 
A folha de apoio não continha fragmentos de textos que pudessem tirar o propósito da produção textual do aluno servindo como uma possível cópia, colocando-o na condição de receptor passivo, mas um elaborador ativo de seu texto com base no conhecimento construído ao longo das atividades modulares da Sequência Didática.

Figura 13 - Aluna realizando dissertação (elaboração final 2)

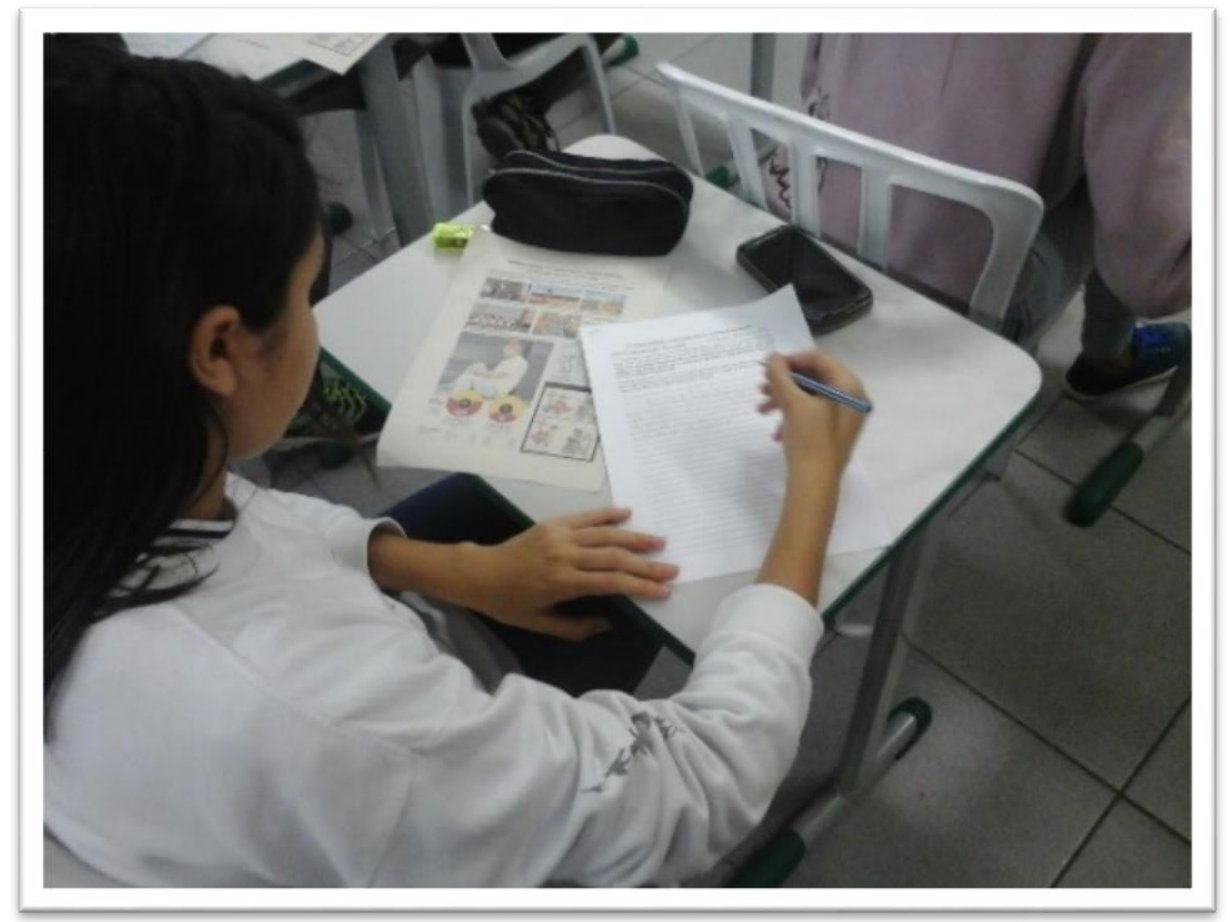

Autor: Carlos Eduardo Fonseca (2016).

A elaboração final no 2 (dissertação) consistia numa problematização em que o aluno fora solicitado a dissertar conforme explicitado no enunciado a seguir.

1 - Imagine que a menina Maria, da animação Vida Maria, pudesse ter seu destino modificado, tendo uma vida diferente, não circunscrita ao quintal de sua casa na região semiárida nordestina. Elabore um texto ${ }^{264}$ pensando em duas situações: Maria migrando para a metrópole paulistana nas décadas de 50, 60 ou 70 do século passado; e a vida de Maria chegando na grande metrópole nos dias atuais.

Por se tratar da elaboração final $n^{\circ} 2$, tivemos como objetivo verificar se o aluno avançou no sentido de se utilizar das informações coletadas na folha de apoio em seu campo perceptual significativamente e com transcendência, ou seja, fazendo a transferência de ao menos parte do que fora trabalhado no decorrer da Sequência Didática.

${ }^{264}$ A atividade trazia a seguinte instrução: "A redação deverá ter título, conter um mínimo de 18 linhas, evitar rasuras, conter parágrafos, pontuação e atenção ao bom uso da língua portuguesa. As imagens e gráficos da página anterior deverão servir como fontes de apoio ao texto". 
Ao se reportar sobre a vinda de Maria à metrópole paulistana a partir da segunda metade do século passado, alguns estudantes discorreram sobre as perspectivas de empregabilidade e da saída de uma vida circunscrita a um lugar restritivo, delimitado, no caso, o quintal da casa de Maria. De acordo com uma aluna em sua elaboração textual:

\section{Quadro 49 - Fragmento de elaboração textual final no 2 do aluno na Seq. Didática}

\begin{tabular}{|c|c|}
\hline $\begin{array}{l}\text { Emile Vitória } \\
\text { Oliveira } \\
\text { Silva, } 8^{\mathrm{a}} \mathrm{A}\end{array}$ & 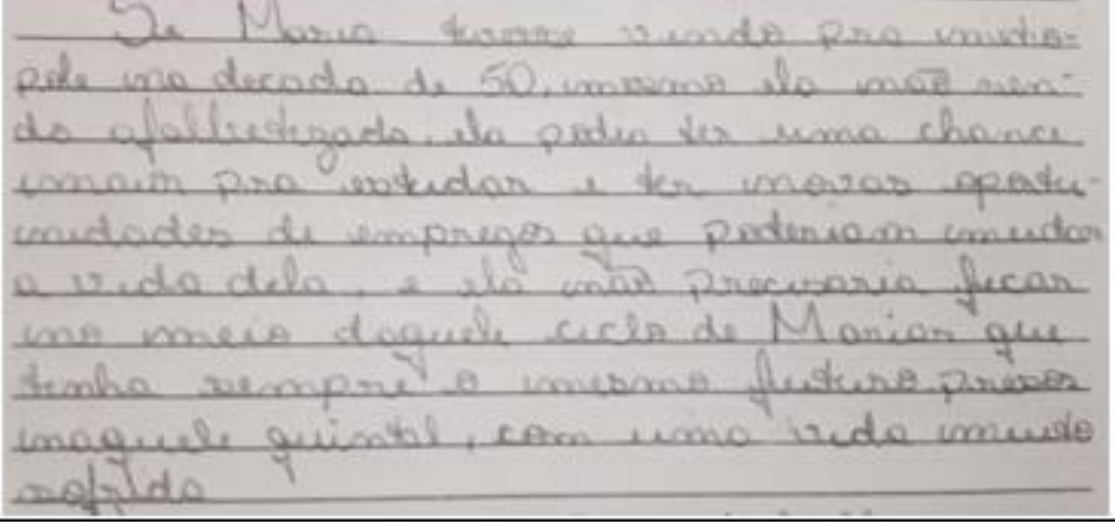 \\
\hline Transcrição & $\begin{array}{l}\text { Se Maria tivesse vindo pra metropole na decada de } 50 \text {, mesmo ela não } \\
\text { sendo alfabetizada, ela podia ter uma chance maior pra estudar e ter novas } \\
\text { oportunidades de empregos que poderiam mudar a vida dela, e ela não } \\
\text { precisaria ficar no meio daquele ciclo de Marias que tinha sempre o mesmo } \\
\text { futuro presos naquele quintal, com uma vida muito sofrida. }\end{array}$ \\
\hline
\end{tabular}

Fonte: Acervo da pesquisa de Sequência Didática do autor.

A estudante se reportou à década de 50, como um período em que Maria teria maiores oportunidades caso viesse para a metrópole paulistana, pois sairia de um ciclo de Marias sem futuro, presas num quintal e com uma vida sofrida. Ou seja, a aluna considerou o lugar que Maria estava inscrita como de estagnação, limitado, ao contrário do que poderia haver caso a personagem tivesse migrado.

Noutro exemplo temos o estudante, que apesar das dificuldades em relação à escrita, elaborou uma história considerando a vida da menina Maria em dois momentos distintos: até os vinte e cinco anos, quando morava no sertão, e depois dessa idade, quando teria rumado para São Paulo por meio de um pau-de-arara. O aluno trabalhou com a escala de algo mais próximo, assim como, também, com a escala de um outro lugar, sobretudo, quando enfatizou que a menina era do sertão do Nordeste, por exemplo, e que após a morte de sua mãe, ela viria para São Paulo. Trata-se de pequenos fragmentos, imersos num texto carregado de erros gramaticais, mas que demonstra que o estudante está operando por conceitos e trabalhando com uma escala que transcende a visão estreita e restrita ao "lugar do aluno". 
Quadro 50 - Fragmento de elaboração textual final $n^{\circ} 2$ do aluno

\begin{tabular}{|c|c|}
\hline $\begin{array}{l}\text { Samuel P. } \\
\text { Basilio, } 8^{\mathrm{a} B}\end{array}$ & 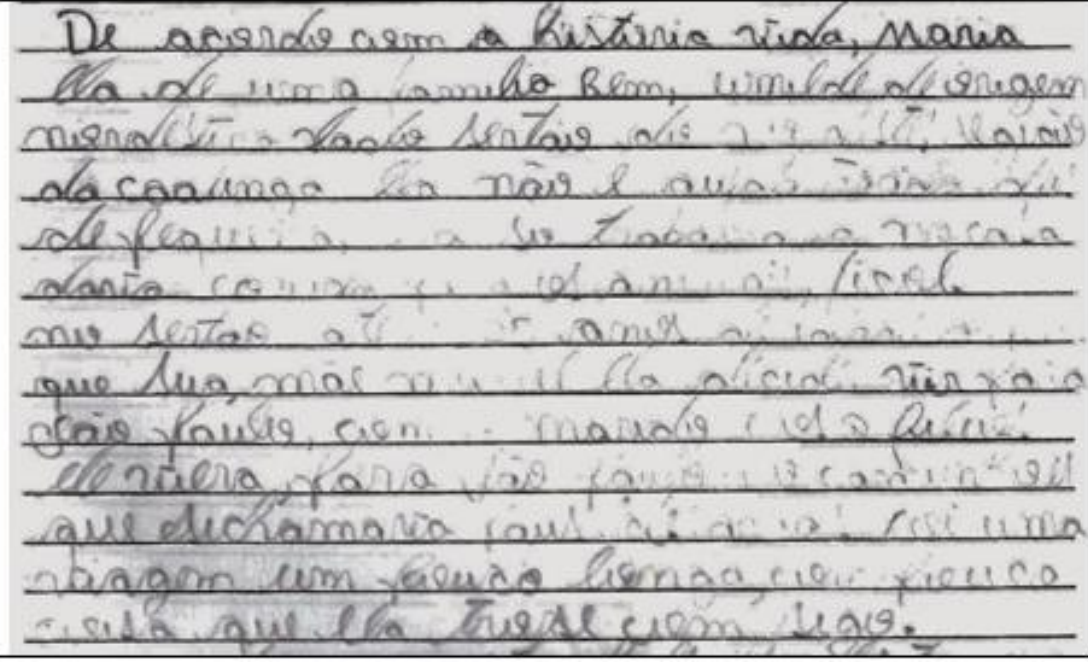 \\
\hline Transcrição & $\begin{array}{l}\text { De acordo com a história vida, Maria ela de uma familia Bem, umilde de } \\
\text { origem nordestina lado sertao do Nordeste, região da caatinga ela não e } \\
\text { alfabetizada deis de pequena, ela so trabalhava na casa dava comida pra os } \\
\text { animais, ficol no sertao ate os } 25 \text { anos de idade depois que Sua mãe morrel } \\
\text { ela decide vir para São Paulo, com o marido e os } 2 \text { filios ela viera, para São } \\
\text { Paulo no caminhoes que sechamava Paus de arras foi uma viagem um pouco } \\
\text { longa, com pouca coisa que ela trouse com sigo. }\end{array}$ \\
\hline
\end{tabular}

Fonte: Acervo da pesquisa de Sequência Didática do autor.

E ainda considerando em nossa análise o fragmento da elaboração de uma aluna de outra sala, temos que:

\section{Quadro 51 - Fragmento de elaboração textual final $n^{\circ} 2$ do aluno na Seq. Didática}

\begin{tabular}{|c|c|}
\hline $\begin{array}{l}\text { Tifany Silva } \\
\text { de Melo, } 8^{\mathrm{a}} \mathrm{C}\end{array}$ & 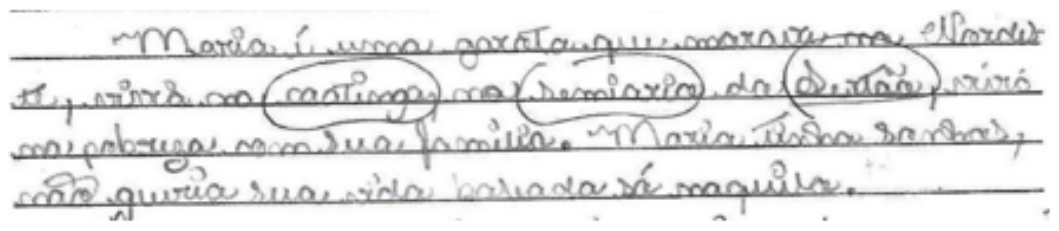 \\
\hline Transcrição & $\begin{array}{l}\text { Maria é uma garota que morava no Nordeste, vivia na caatinga, no } \\
\text { semiarido do Sertão, vivia na pobreza com sua familia. Maria tinha sonhos, } \\
\text { não queria sua vida baseada só naquilo. }\end{array}$ \\
\hline
\end{tabular}

Fonte: Acervo da pesquisa de Sequência Didática do autor.

O trecho acima evidencia que a estudante também trabalhou com outra escala que não somente a do lugar que lhe é mais próximo e imediato, pois ao considerar em seu texto que Maria morava no Nordeste, na caatinga e que por ter sonhos "não queria sua vida baseada só naquilo", depreendemos que a estudante considerou o lugar de Maria como um espaço delimitado e limitante para o crescimento e desenvolvimento da personagem. 
Alguns estudantes perceberam que migração sentido Nordeste-Sudeste ocorrente entre as décadas de 50 e meados dos anos 70, estava fortemente atrelada às possibilidades de empregabilidade que a região metropolitana de São Paulo oferecia, sobretudo no setor industrial, como é possível verificar no exemplo a seguir.

\section{Quadro 52 - Fragmento de elaboração textual final $n^{\circ} 2$ do aluno na Seq. Didática}

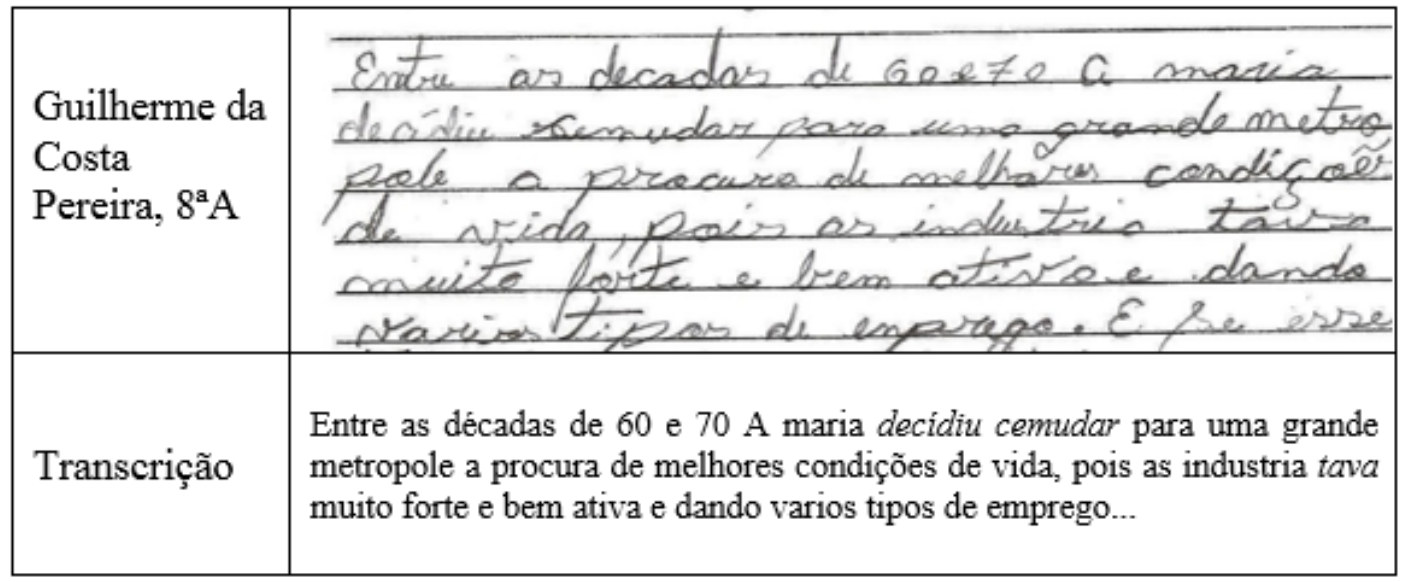

Fonte: Acervo da pesquisa de Sequência Didática do autor.

Com o decorrer das atividades realizadas na Sequência Didática e das atividades que tinham como premissa a perspectiva da Experiência de Aprendizagem Mediada, o conceito de migração, aos poucos fora sendo assimilado pelos estudantes, como podemos verificar no fragmento da elaboração de uma estudante.

Quadro 53 - Fragmento de elaboração textual final $n^{\circ} 2$ do aluno na Seq. Didática

\begin{tabular}{|c|c|}
\hline $\begin{array}{l}\text { Beatriz Silva } \\
\text { de Oliveira, } \\
8^{a} \mathrm{~B}\end{array}$ & 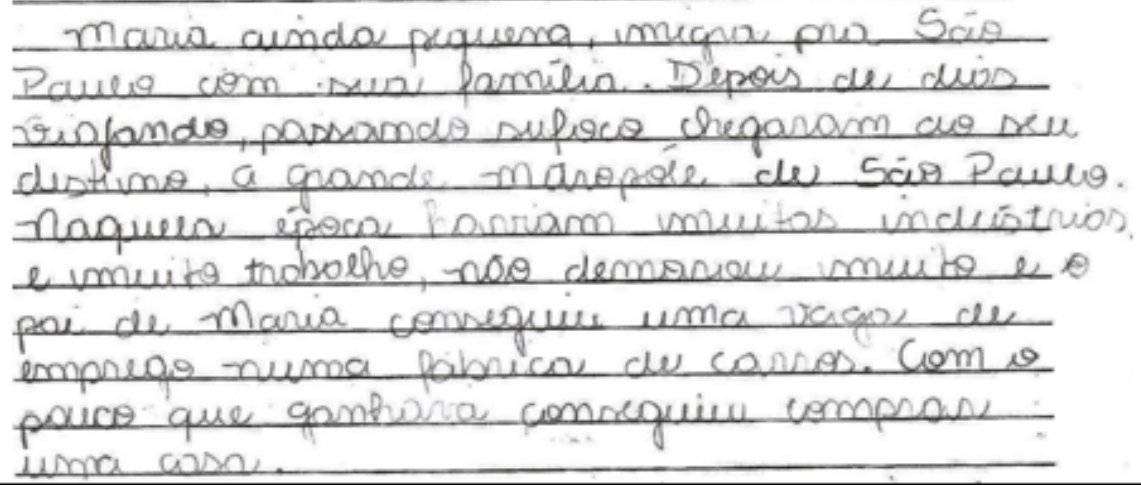 \\
\hline Transcrição & $\begin{array}{l}\text { Maria ainda pequena, migra pra São Paulo com sua familia. Depois de } \\
\text { dias viajando, passando sufoco chegaram ao seu destino, a grande metrópole } \\
\text { de São Paulo. Naquela época haviam muitas indústrias, e muito trabalho, } \\
\text { não demorou muito e o pai de Maria conseguiu uma vaga de emprego numa } \\
\text { fábrica de carros. Com o pouco que ganhava conseguiu comprar uma casa. }\end{array}$ \\
\hline
\end{tabular}

Fonte: Acervo da pesquisa de Sequência Didática do autor. 
As transformações tecnológicas pelas quais o mundo fora passando, consequentemente impactando também o Brasil, foram identificadas pelos alunos.

\section{Quadro 54 - Fragmento de elaboração textual final $n^{\circ} 2$ na Seq. Didática}

\begin{tabular}{|c|c|}
\hline $\begin{array}{l}\text { Luiz } \\
\text { Fernando } \\
\text { Matias } \\
\text { Pereira, } 8^{\mathrm{a}} \mathrm{C}\end{array}$ & 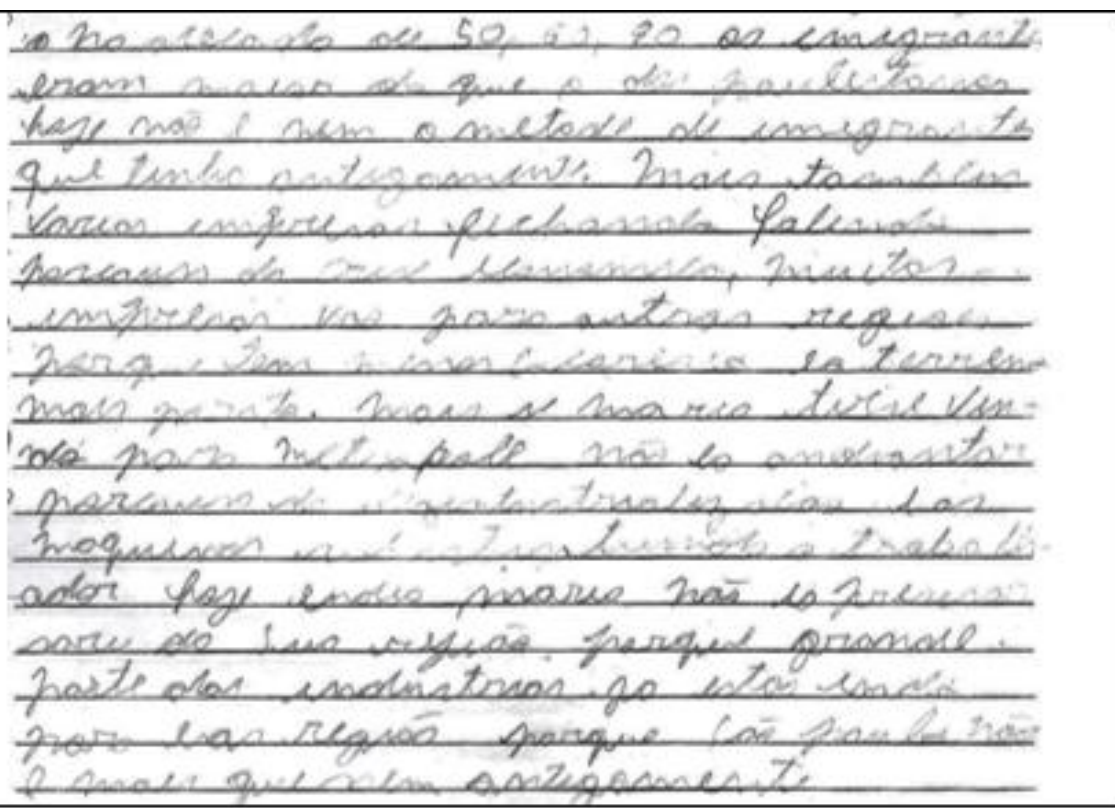 \\
\hline Transcrição & $\begin{array}{l}\text { [...] Na decada de } 50,60,70 \text { os imigrantes eram maior do que o dos } \\
\text { paulistanos hoje não é nem a metade de imigrantes que tinha antigamente. } \\
\text { Mais tambem varias empresas fechando falindo porcausa da crise } \\
\text { economica, muitas empresas vão para outras regiões porque tem menos } \\
\text { cocoresia eo terreno mais barato. Mais se Maria tivese vindo para } \\
\text { metropole não ia andiantar porcausa da dizintustrialização e as maquinas } \\
\text { substituindo o trabalhador hoje endia maria não ia precisar sair da sua região } \\
\text { porque grande parte das industrias já estão indo para essas regiões porque } \\
\text { São paulo não e mais que nem antigamente. }\end{array}$ \\
\hline
\end{tabular}

Fonte: Acervo da pesquisa de Sequência Didática do autor.

O aluno do exemplo anterior demonstrou ter trabalhado com a escala temporal do passado e do presente, contextualizando os períodos e evidenciando que atualmente haveria desemprego devido a desindustrialização e a concorrência entre as empresas, fazendo com que muitas delas se desloquem para outras regiões. Ainda aponta o fato de as tecnologias estarem substituindo os trabalhadores. Em que pese o uso equivocado do termo "imigrantes", o aluno demonstrou compreensão do fenômeno migratório e não ficou restrito a uma escala local sem conexões com outras escalas de tempo e espaço.

Noutro exemplo temos a ideia de uma região Nordeste que atrai os indivíduos devido ou aos programas sociais governamentais ou as possibilidades de empregabilidade que se configura na região. 
Quadro 55 - Fragmento de elaboração textual final $n^{0} 2$ do aluno na Seq. Didática

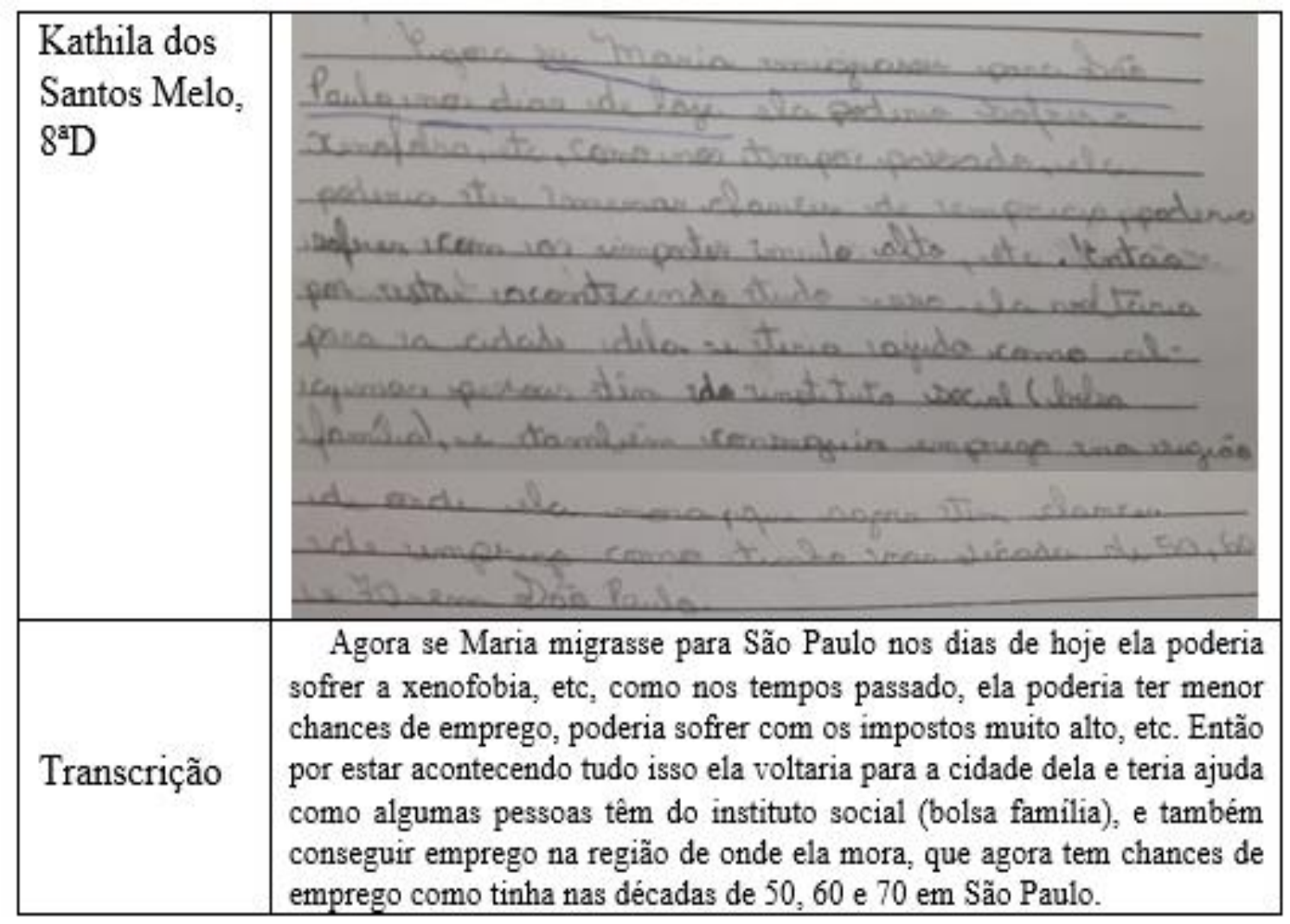

Fonte: Acervo da pesquisa de Sequência Didática do autor

A aluna supracitada trabalhou com duas escalas de tempo, principalmente ao discorrer que a menina Maria poderia "conseguir emprego na região" em que vivia, pois, conforme a estudante, teria na cidade nordestina da personagem "chances de emprego como tinha nas décadas de 50, 60 e 70 em São Paulo”.

Os alunos, em sua maioria, consideraram como algo não promissor a vida de Maria restrita ao lugar de moradia na região de caatinga, como explicitara um dos estudantes, ao se reportar a vida da jovem como limitada "naquele ciclo repetitivo de Marias”. Tal visão encontra correlação com o que pudemos verificar nas entrevistas que os próprios alunos realizaram com os migrantes nordestinos, pois apesar de muitos deles terem dito gostar do Distrito de Pedreira, parte significativa (59\%) respondeu que gostaria de morar em outro lugar, enquanto $30 \%$ disse não ter vontade de se mudar. Tal quadro vem evidenciar que a apesar de tratar-se de uma população que está delimitada fisicamente a um determinado lugar - e por razões variadas - tem perspectivas de mudança físico-espacial.

Em suas dissertações finais, pudemos identificar o uso de determindas palavras que consideramos palavras-chave durante o processo de Experiência de Aprendizagem 
Mediada, tais como indústrias, desindustrialização, desconcentração industrial, caatinga, semiárido e sertão. Não estamos aqui considerando migração, migrantes ou migrar, pois entendemos que os estudantes construíram esses conceitos, que pode ser percebido em trechos já apresentados de suas elaborações.

O gráfico seguinte apresenta a quantidade de alunos que se utilizou de determinadas palavras, sendo que neste caso, estamos considerando todos aqueles que realizaram a dissertação, independentemente de terem ou não realizado a primeira ou segunda elaboração da Sequência Didática.

\section{Gráfico 41 - Quantidade de alunos que mais utilizou determinadas palavras- chave na dissertação final}

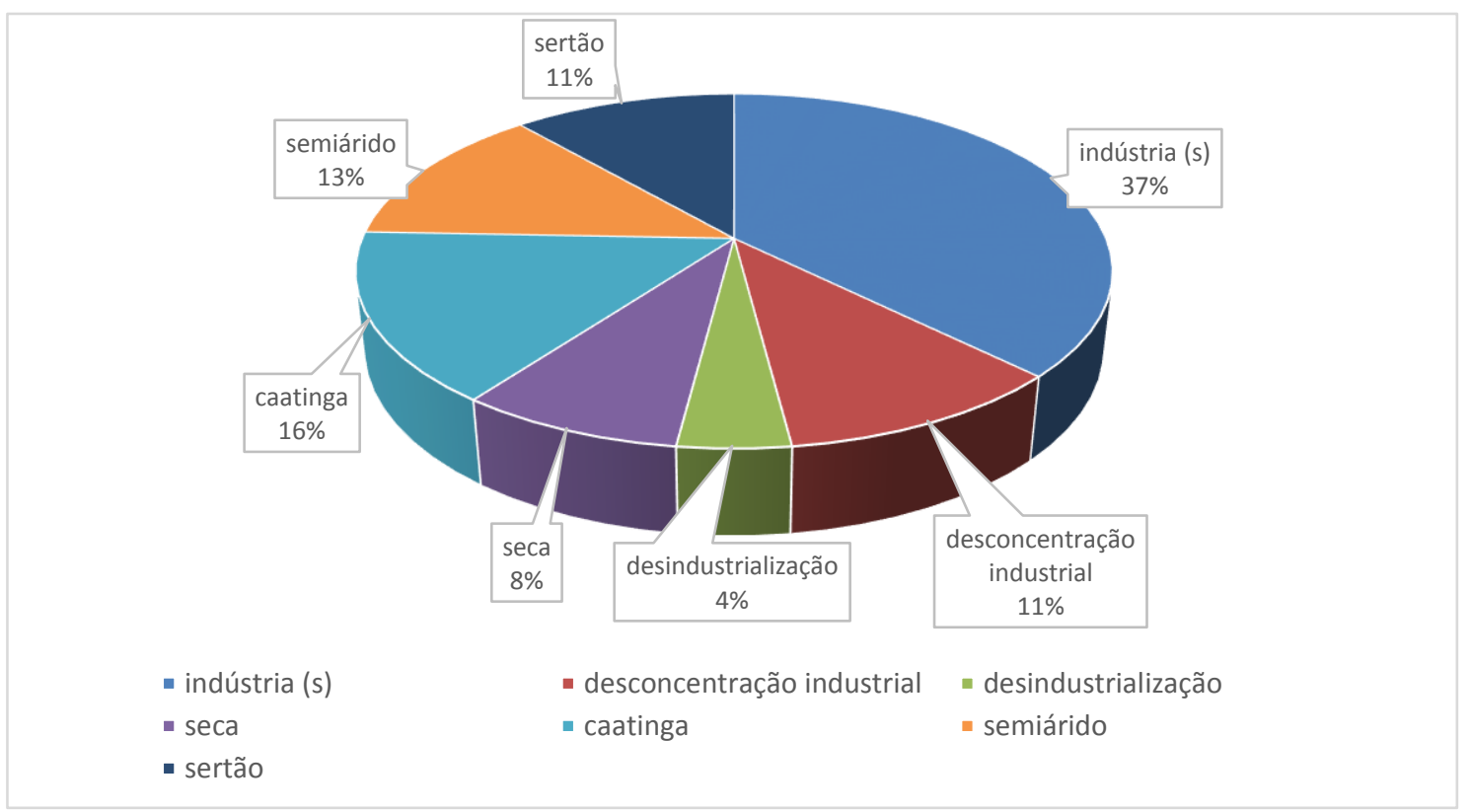

Fonte: Elaborado pelo autor (2018).

De um total de 95 alunos $^{265}$, 46 se utilizaram da palavra "indústria" (ou "indústrias") em suas elaborações; sendo que a segunda palavra mais usada fora "caatinga", por 19 alunos, seguida das palavras "semiárido" e "sertão", por 16 e 14 alunos, respectivamente. A quinta palavra-chave mais utilizada foi "desconcentração industrial", por um total de 13 estudantes, seguida por "seca" e "desindustrialização", 10 e 5 alunos, respectivamente.

265 Diferentemente da análise das elaborações dos estudantes, que consideramos apenas para a amostragem os que realizaram a elaboração inicial, a final $\mathrm{n}^{\circ} 1$ e a dissertação (totalizando 71 alunos), para verificação das palavras mais usadas na redação final, optamos por considerar todos que dela participaram, independentemente de terem ou não deixado de realizar uma das elaborações. 
Podemos observar que com exceção da palavra indústria (37\% dos alunos a utilizaram), as palavras caatinga, semiárido e sertão, com uso de 16\%, 13\% e 11\%, respectivamente, evidencia que começaram os alunos a operar por conceitos conectando a escala do lugar a outras escalas geográficas.

Se considerarmos as palavras mais utilizadas pelos estudantes - porém, agora, tendo como amostra apenas os que realizaram a elaboração inicial, a elaboração final 1 e a final 2 (dissertação), obtivemos o seguinte quadro:

Figura 14 - Nuvem com as palavras mais utilizadas pelos estudantes das quatro turmas que realizaram as três elaborações

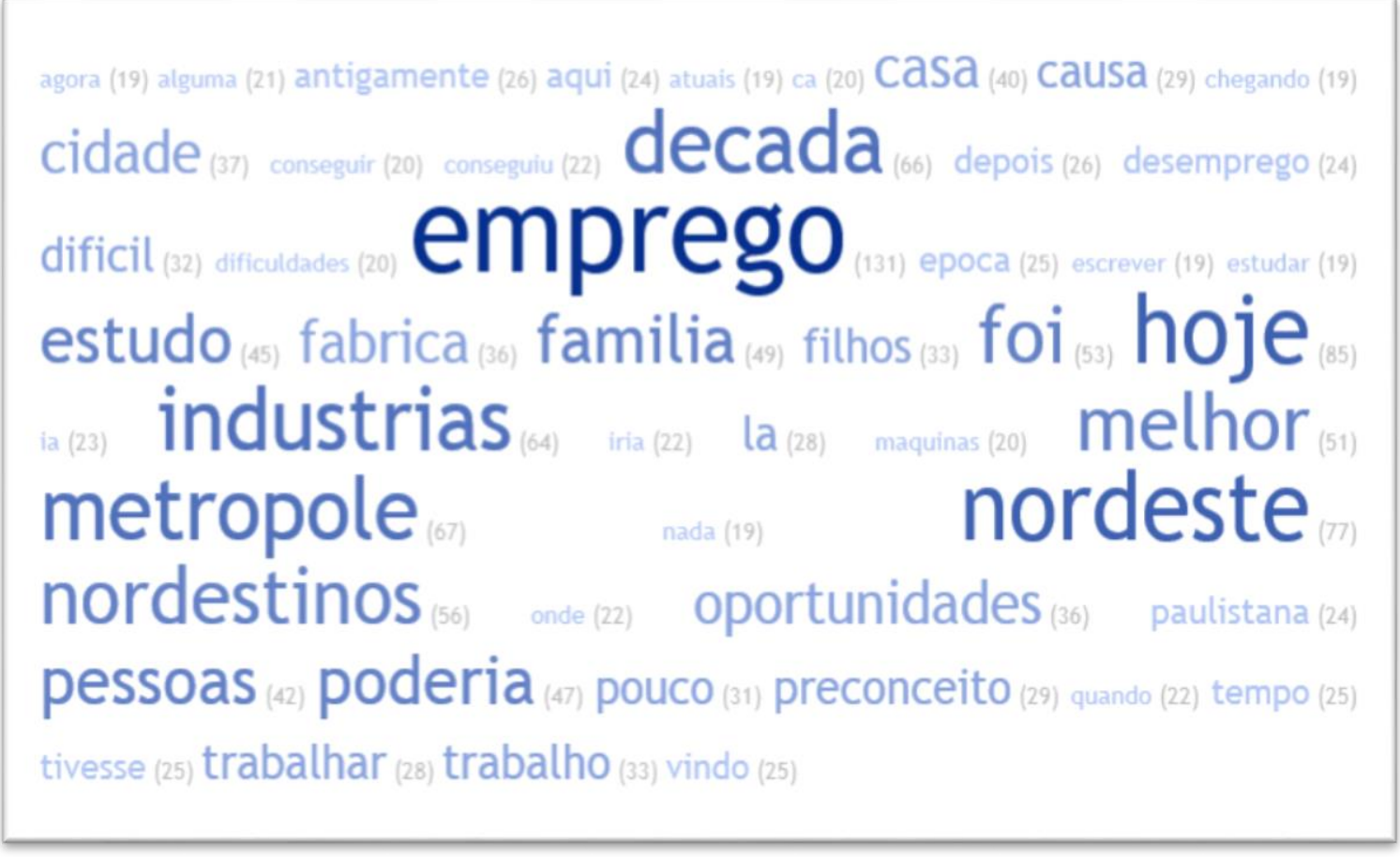

Fonte: Organizado pelo autor (2018), por meio do programa Tagcrowd.

A palavra mais citada foi "emprego", aparecendo 131 vezes nas dissertações, o que vem reforçar o que já apontávamos no capítulo anterior quando evidenciávamos que os fatores econômicos eram citados significativamente pelos estudantes nas questõesproblema, ora para indicar o que atraia os migrantes nordestinos à metrópole paulistana nas décadas de 50, 60 e 70, ora o que contribuia para que deixassem a região metropolitana e voltassem para suas cidades de origem, mais especificamente nas últimas décadas. 
A segunda palavra mais citada foi "hoje", aparecendo 85 vezes, o que nos dá mostras de que parte significativa dos estudantes estavam se reportando a atualidade, lidando com uma escala temporal do "hoje", do "agora", muito mais do que com o passado, pois podemos depreender que a palavra "década", 66 vezes apontada, fora empregada em referencia às três primeiras décadas da segunda metade do século passado. Tal quadro evidencia que apesar de terem trabalhado com a escala temporal do passado, é mais forte em suas elaborações lidar com o tempo presente.

Temos um indício de que começam a operar conectando a escala do lugar à outras escalas espaciais, pois a palavra metrópole (em referência à paulistana) apareceu 67 vezes, ao passo que a palavra Nordeste fora apontada 77 vezes. Ou seja, passaram a pensar numa outra escala ao considerar o movimento migratório da personagem Maria. Vale ressaltar, que o enunciado da atividade pedia para o aluno pensar em duas situações de Maria migrando para a metrópole, o que por si só, poderia tender para que o aluno considerasse muito mais os fatores de atração da região metropolitana, porém, conseguiram fazer a conexão com os fatores que também compeliam a menina a sair da região nordestina, e em determinados, casos retornar à sua região de origem.

\subsection{ANÁLISE DO DESEMPENHO DOS ALUNOS NAS PRODUÇÕES TEXTUAIS}

Tínhamos como um dos objetivos com a aplicação da Sequência Didática, que ao final das atividades os estudantes conseguissem em suas elaborações mencionar aspectos espaço-temporais, no passado e no presente, ainda que a problematização da questão pudesse tender (propositadamente) para que o aluno se detivesse mais ao que estava ocorrendo na metrópole paulistana, a fim de verificarmos se ele se reportaria a outra escalas de tempo e de espaço que não daquilo que num primeiro momento poderia lhe parecer mais próximo.

Antes, porém, das referidas análises, trouxemos um gráfico contendo a participação dos estudantes nas elaborações inicial, final $n^{\circ} 1$ e dissertação. O gráfico traz uma amostra por salas. Vale ressaltar que não estamos considerando as entrevistas com os migrantes nordestinos nem a atividade com o instrumento de comparação e identificação tendo por base as obras de Candido Portinari. 


\section{Gráfico 42 - Alunos participantes das elaborações inicial, final 1 e dissertação}

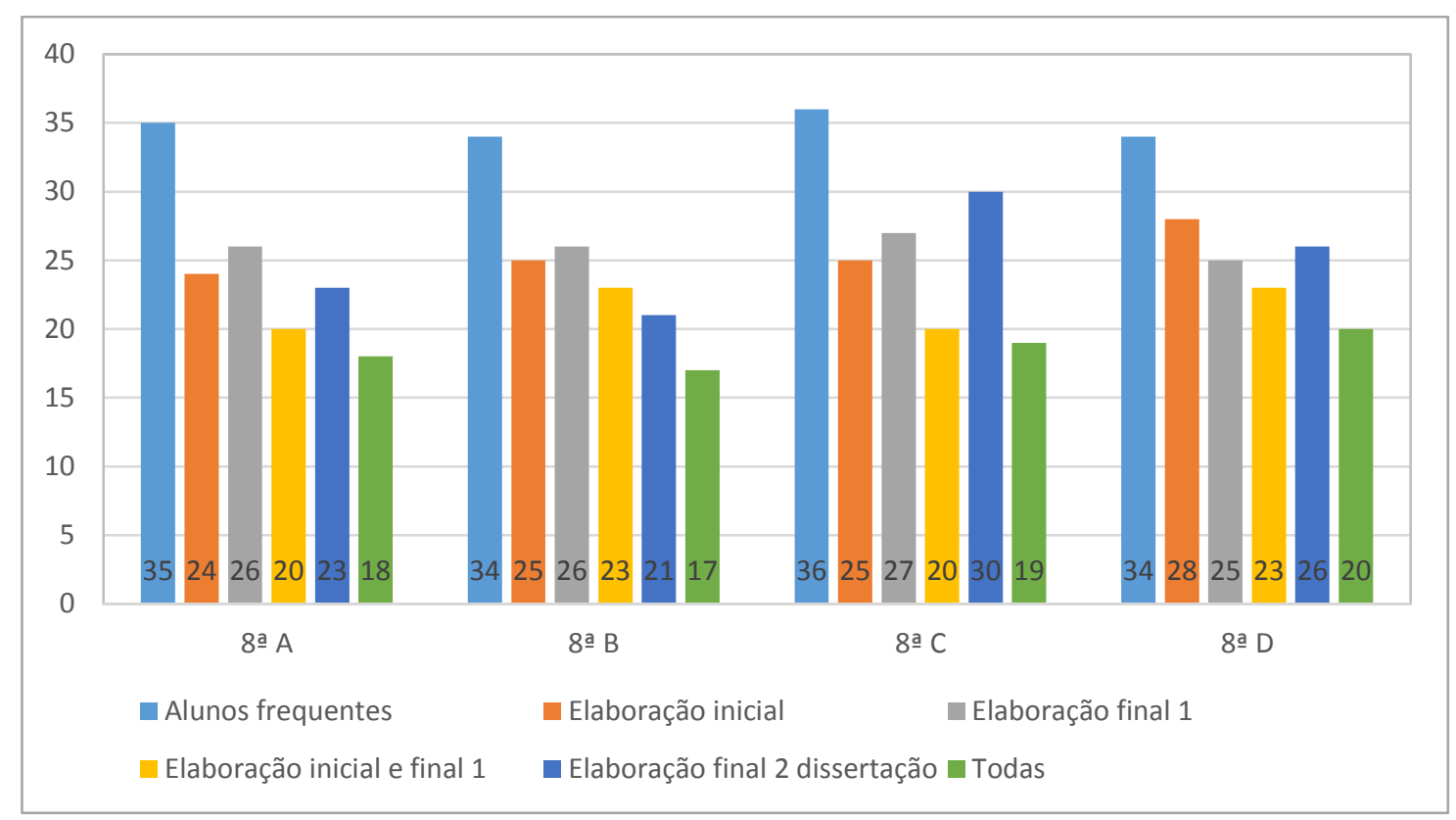

Fonte: Elaborado pelo autor (2018).

$\mathrm{Na} 8^{\mathrm{a}}$ série A, com um total de 35 alunos, 24 realizaram a elaboração inicial, 26 a elaboração final $n^{\circ} 1$ e um total de 20 estudantes que fizeram ambas; ainda, 23 realizaram a elaboração final $n^{\circ} 2$ (dissertação) e, ao todo, 18 estudantes fizeram todas as elaborações. Já a $8^{\text {a }}$ série $\mathrm{B}$, com um total de 34 estudantes, teve 25 aos quais responderam a elaboração inicial e 26 a elaboração final $n^{\circ} 1 ; 23$ alunos participaram de ambas elaborações, 21 fizeram a elaboração final $n^{\circ} 2$ (dissertação) e um total de 17 realizaram todas as elaborações.

Em relação à $8^{\mathrm{a}}$ série $\mathrm{C}$, com 36 alunos frequentes, houve a participação de 25 na primeira elaboração, 27 na elaboração final $n^{\circ} 1$, um total de 20 estudantes realizando tanto a primeira produção quanto a segunda, 30 alunos na elaboração final $n^{\circ} 2$ e ao todo 19 estudantes realizando todas as elaborações. Por fim, na $8^{\text {a }}$ série D, com 34 alunos, tivemos 28 que fizeram a primeira elaboração, 25 a segunda e 23 participando de ambas elaborações, 26 na elaboração final $n^{\circ} 2$ e um total de 20 estudantes que realizaram todas elaborações e resolução de situações-problema.

Em nossa análise, pode parecer redundante a especificação "no passado e no presente", mas nos detivemos à capacidade do aluno em trabalhar com o movimento de ida e de retorno do Sudeste (espacial, passado e presente), assim como o momento histórico em que isso ocorreu (temporal, passado e presente). 
Para averiguar a evolução, manutenção ou involução do nível de conhecimento, comparamos o desempenho dos alunos que participaram das elaborações iniciais e finais 1 e dissertação. Portanto, seguindo nosso método qualitativo para o quantitativo, foi viável calcular essas informações atribuindo valores para cada critério e verificando se este foi ou não atendido. Critérios esses que envolviam:

\section{Quadro 56 - Critérios utilizados na análise das dissertações sobre Vida Maria}

\begin{tabular}{|c|c|}
\hline Eixo espaço-temporal & $\begin{array}{l}\text { Capacidade de relacionar, em sua resposta, o movimento inicial de } \\
\text { migração nordestina das décadas de } 50,60 \text { e } 70 \text {, seguido pelo } \\
\text { movimento de retorno. }\end{array}$ \\
\hline Abstração & $\begin{array}{l}\text { Se trabalhou em sua produção elementos aquém, além ou dentro do } \\
\text { esperado, de acordo com o que se foi trabalhado na Sequência } \\
\text { Didática }\end{array}$ \\
\hline Criticidade & $\begin{array}{l}\text { Se apresenta senso comum, senso científico, ambos ou nenhum } \\
\text { deles em sua resposta. }\end{array}$ \\
\hline Coerência semântica: & $\begin{array}{l}\text { (Nenhuma/parcial/total), se o aluno se contradiz em seu texto de } \\
\text { alguma forma. }\end{array}$ \\
\hline Coerência temática & (Nenhuma/parcial/total), se o aluno se adequou ao tema proposto. \\
\hline Coerência sequencial & $\begin{array}{l}\text { (Nenhuma/parcial/total), se o aluno apresenta um adequado } \\
\text { encadeamento de ideias. }\end{array}$ \\
\hline Redundância & $\begin{array}{l}\text { (Nenhuma, parcial ou total), a fim de se notar sua habilidade em } \\
\text { utilizar sinônimos, alterar a estrutura de sua frase, argumentação } \\
\text { como um todo, para evitar pleonasmos e outros tipos de repetições. }\end{array}$ \\
\hline Vinda ao Sudeste & $\begin{array}{l}\text { Aspectos sociais, econômicos, políticos e ambientais de atração e } \\
\text { repulsão ao Sudeste. }\end{array}$ \\
\hline Movimento de retorno & $\begin{array}{l}\text { Os aspectos anteriores, acrescidos do cultural, também em atração e } \\
\text { repulsão, porém rumo ao Nordeste. }\end{array}$ \\
\hline $\begin{array}{l}\text { Utilização da coletânea (folha } \\
\text { de apoio) }\end{array}$ & Se o aluno é capaz de relacionar seu texto com os textos de apoio. \\
\hline $\begin{array}{l}\text { Prejuízo à redação pela não } \\
\text { utilização da coletânea }\end{array}$ & $\begin{array}{l}\text { Se o não uso comprometeu a qualidade de sua produção ou se } \\
\text { soube fazer uso de outros recursos. }\end{array}$ \\
\hline
\end{tabular}

Fonte: Elaborado pelo autor (2018). 
Houve uma atribuição de valores por nós às redações dos alunos a fim de analisarmos o impacto da Sequência Didática. Para tanto, averiguamos que, na melhor das hipóteses, um estudante poderia abordar em seu texto o movimento migratório inicial e de retorno, mencionando as décadas em que os eventos ocorreram e onde ocorreram. Aqui, teria apresentado aspectos espaço-temporais completos e o desempenho do aluno seria medido da seguinte maneira:

Figura 15 - Exemplo de eixo tempo-espaço para apoiar nossas análises dos textos

\begin{tabular}{|c|c|c|c|c|}
\hline & \multicolumn{4}{|c}{ Eixos } \\
\hline $\begin{array}{c}\text { Qualidade da } \\
\text { resposta } \\
\text { Nenhum }\end{array}$ & $\begin{array}{c}\text { M1 } \\
\text { (Migração ao } \\
\text { Sudeste) }\end{array}$ & $\begin{array}{c}\text { M2 } \\
\text { (Migração de } \\
\text { retorno) }\end{array}$ & $\begin{array}{c}\text { Passado (Da década de } \\
50 \text { anos 60,70 e início } \\
\text { de 80) }\end{array}$ & $\begin{array}{c}\text { Presente } \\
\text { (Final dos } \\
\text { anos 90) }\end{array}$ \\
\hline $\begin{array}{c}\text { Incompleto } \\
\text { Parcial }\end{array}$ & & & & \\
\hline Total & $\mathrm{X}$ & $\mathrm{X}$ & $\mathrm{X}$ & \\
\hline
\end{tabular}

Fonte: Organizado pelo autor (2018).

Para isso, utilizamos um gráfico quadridimensional (gráfico 43) em que os eixos de tempo e espaço indicam a qualidade da resposta do aluno, que pode ter trabalhado características espaciais e/ou temporais das migrações inicial (M1), de retorno (M2) ou de ambas (M1 e M2) em suas respectivas décadas, como indicado na legenda. O tamanho dos círculos no gráfico infracitado indica a quantidade de indivíduos em dada categoria.

Para nossa análise, especificamente no tocante à dissertação acerca da situaçãoproblema referente à animação Vida Maria ${ }^{266}$, consideramos como amostra válida os alunos que realizaram além da referida dissertação as elaborações inicial e final 1, tendo em vista que participaram de forma integral da Sequência Didática, sendo possível observar melhor seus efeitos sobre eles.

\footnotetext{
${ }^{266} \mathrm{O}$ intuito da questão-problema da dissertação referente à animação Vida Maria, fora de que os alunos pudessem criar uma história para a personagem considerando dois contextos distintos de tempo e espaço. Ou seja, pensar no movimento migratório da personagem entre as décadas de 50 à meados de 70 do século passado, e em décadas recentes, sendo esperado, inclusive que os estudantes também se reportassem à um possível movimento de retorno de Maria à sua cidade ou região de origem. O objetivo não fora de que os alunos descrevessem o que compreenderam do filme.
} 


\section{Gráfico 43 - Correlação espaço-temporal e nível de resposta dos estudantes}

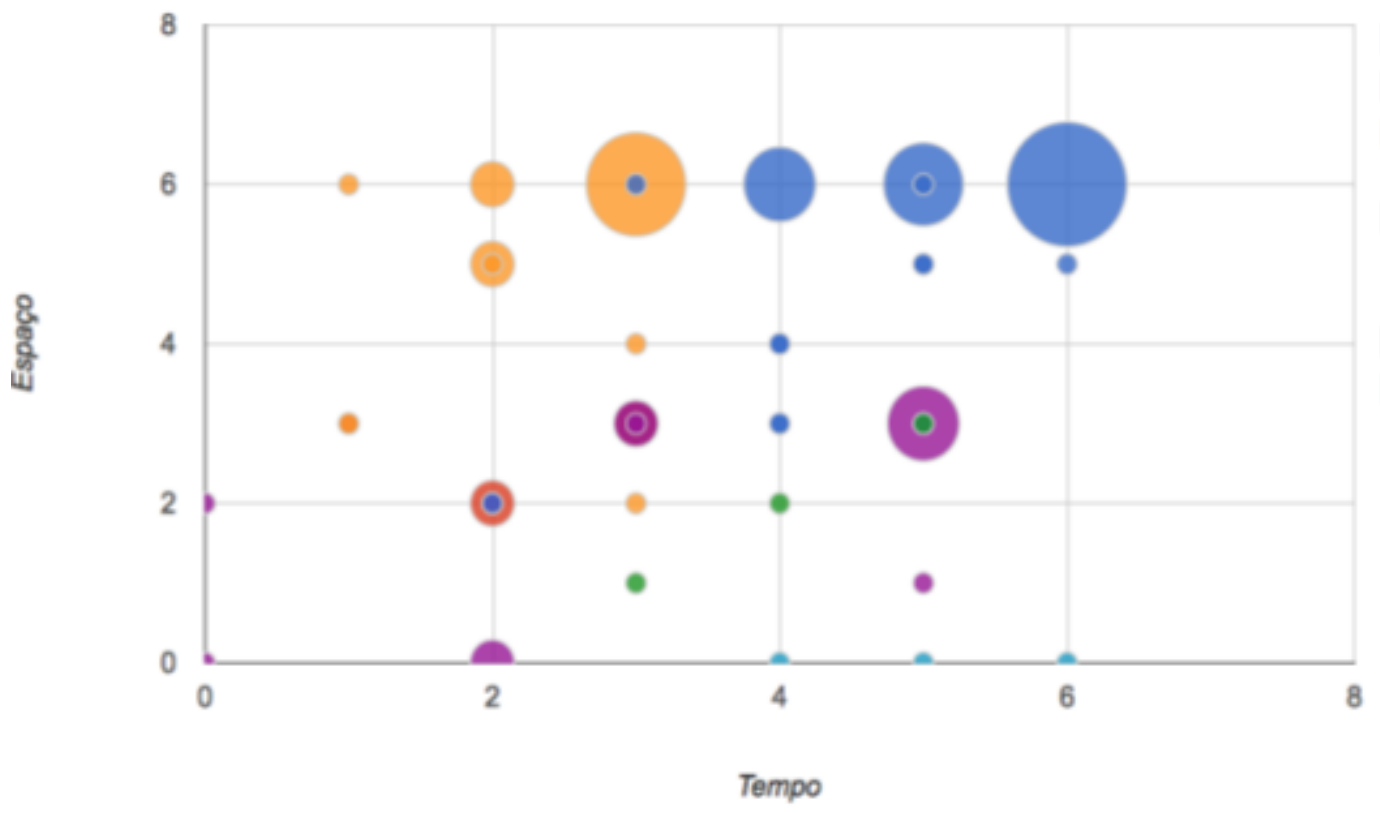

M1 e M2 e suas respectivas décadas

M1 e suas décadas

M1 e suas décadas e décadas atuais sem M2

M1 sem suas décadas e M2 com décadas

M1 e M2 sem suas respectivas décadas

Outros

Fonte: Organizado pelo autor (2018). Programa Google Charts e JSFiddle.

Colaboração técnica de Camila Fonseca Amorim da Silva.

É perceptível que, dos 71 alunos que realizaram todas as elaborações (elaboração inicial, elaboração final 1 e dissertação), o maior grupo numa mesma categoria foi na de maior resultado: 10 alunos trabalharam o necessário sobre o tema em nível máximo em todos os critérios e outros grupos, em inferior quantidade, também atenderam a todos os critérios, porém com qualidade um pouco menor em sua redação. É perceptível que a maioria desses alunos, representados pela legenda azul, tendem a ficar em regiões próximas do gráfico.

Após esse conjunto de estudantes, prosseguiram mais grupos com inferências espaciais do que temporais - 17 tiveram o espaço como categoria máxima deixando de abordar um dos aspectos da questão temporal (como se nota na parte superior do gráfico) - nestes, também predominou a abordagem de todos os aspectos, ainda que em menor nível. Entretanto, possuem mais abstração em abordar aspectos do espaço no passado do que o contrário. 
Noutras palavras, é mais simples aos alunos atingirem maior qualidade da resposta no eixo espaço pela tendência ao lugar, por ser algo mais concreto do que o conceito de tempo. Entretanto, dentro da categoria temporal, demonstraram mais facilidade com a menção ao passado do que com o presente. Uma das hipóteses levantadas para essa última situação é a possibilidade dos jovens não terem se atentado ao enunciado, que pedia uma abordagem de dois momentos, e não de um ou de outro.

Apenas 2 alunos mencionaram exclusivamente o aspecto temporal em nível máximo. Dentro da categoria "Outros", apenas um estudante zerou em todos os itens. Nesta análise, dois alunos foram desconsiderados, um por caligrafia ilegível e outro por ter redigido em torno de apenas quatro palavras.

No gráfico 44, procuramos verificar a assimilação ou não dos textos de apoio (coletânea com imagens e gráficos) e como isso interferiu ou não em suas redações. Para isso, verificamos abaixo duas categorias: assimilação e não assimilação, e subcategorias que podem conter "total", "parcial", "insuficiente" e "nula". Na categoria "assimilação" isso significa o nível de compreensão e utilização dos textos de apoio pelo aluno; em "não assimilação", inferem se a produção textual foi afetada pela não utilização ou descompreensão da coletânea.

\section{Gráfico 44 - Assimilação ou não assimilação dos textos de apoio e impacto disso nas produções textuais}

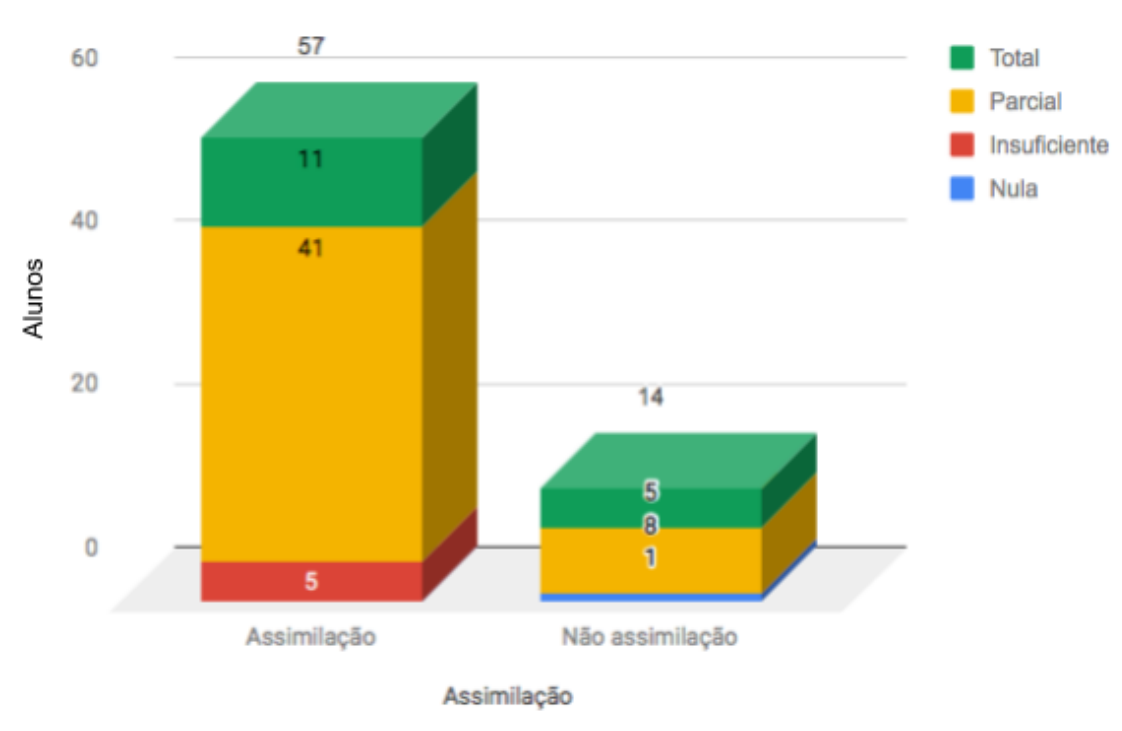

Fonte: Organizado pelo autor (2018). Programa Google Charts e JSFiddle.

Colaboração técnica de Camila Fonseca Amorim da Silva.

Com base no gráfico supracitado, verifica-se tanto a qualidade do texto dos alunos (total, parcial, incompleta ou nula) que assimilaram a coletânea de imagens e 
dados da folha de apoio como os que não o fizeram, e se isso interferiu em sua produção (também de forma total, parcial ou nula).

A maioria dos alunos $(80,28 \%)$ assimilou os textos de apoio. Dos que assimilaram, 71,93\% apresentaram nível mediano em sua resposta; 19,3\% obtiveram total e uma minoria de $8,77 \%$ insuficiente. Noutras palavras, a maior parte dos estudantes ficou na média, e houve quase o dobro de alunos com desenvolvimento total em relação aos incompletos, além de não haver um aluno sequer na categoria nulo sob essa análise. Dentre os que inutilizaram a folha de apoio, isso afetou em demasia seu texto em $35,71 \%$ dos casos, além daqueles com prejuízo parcial $(57,14 \%)$ e apenas um que, apesar de negligenciar a coletânea, fê-la de modo que não acarretou perdas em sua elaboração textual. Em suma, grande parte dos alunos souberam relacionar parcialmente a coletânea com sua redação. A maioria que inutilizou os textos prejudicou parcialmente sua produção, seguida por aqueles que o fizeram totalmente, ao passo que apenas uma minoria conseguiu se sobressair sem utilizá-los.

Primando por compreendermos as generalidades e/ou particularidades do desempenho dos estudantes, fizemos uma análise geral, sem divisões por turmas (gráfico 45), e outra com as salas A, B, C e D (gráfico 46, da página seguinte), a fim de se comparar se os destaques evidenciados entre as mesmas seguem os padrões observados nas elaborações iniciais e finais 1 e/ou se apresentam novas características. Consideramos apenas os alunos que fizeram todas as elaborações. Com isso, desenvolvemos os seguintes histogramas (gráficos com distribuições de frequências):

\section{Gráfico 45 - Desempenho na dissertação geral dos estudantes}

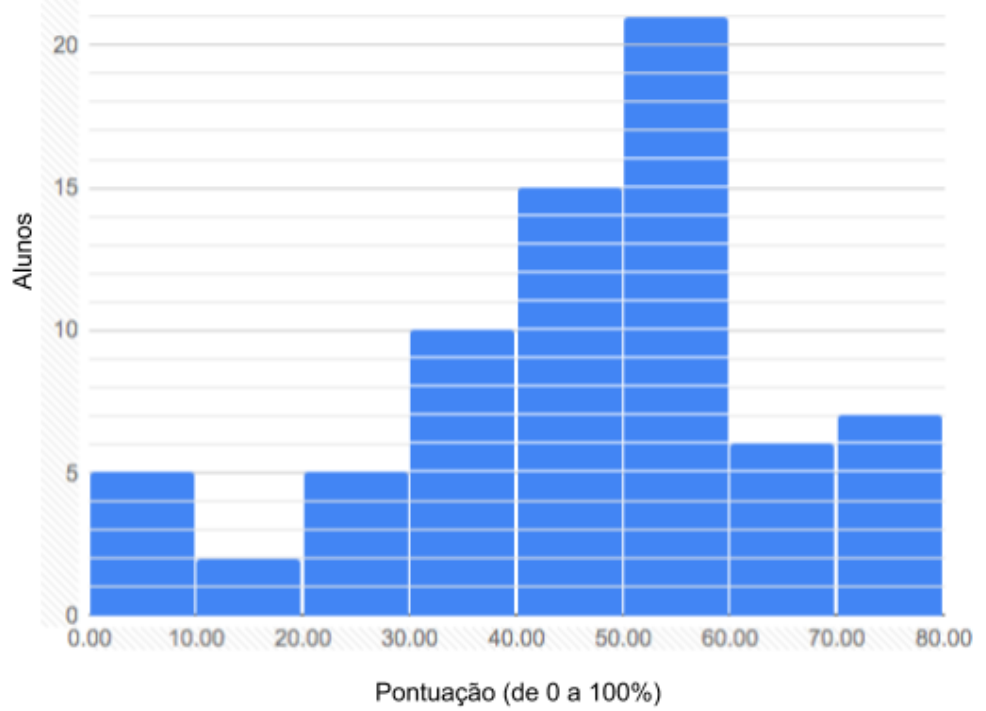

Fonte: Organizado pelo autor (2018). Programa Google Charts e JSFiddle. Colaboração técnica de Camila Fonseca Amorim da Silva. 
Nenhum aluno zerou na dissertação, sendo que apenas 7,04\% ficaram próximos desse valor, que corresponderia a alunos que pouco desenvolveram sua produção. Em suma, pontuações mais baixas (inferiores ou iguais a 30), mas não próximas de zero foram menos frequentes também, com 9,86\% (a mais rara foi entre 10 e 20 pontos, com $2,82 \%$ de ocorrência) do que as intermediárias, com 73,24\%, mas superior às elevadas (acima ou iguais a 70), que permanecem uma elite de 9,86\%. Podemos dizer que há uma tendência em se ter um avanço intermediário, e o contrário se aplica aos extremos do gráfico, sendo mais simples haver alunos com desempenho mediano do que aquém ou superior ao desempenho dos demais.

Examinando a categoria intermediária, mais comum, dentro da mesma há especificidades: há um crescente desde o início dela (que já se seguia a partir da categoria anterior, a partir dos 10 pontos) até 60 pontos, e um salto entre 40 e 60 , com $8,45 \%$ de aumento, quase que o dobro de algumas categorias e muito mais que o mesmo ao compará-lo com outras, tanto inferiores quanto superiores na sequência.

Poderíamos indagar se, caso a aplicação da Sequência Didática envolvesse a atuação doutros professores nas demais disciplinas e seus conteúdos, seria possível uma maior parcela de alunos na "elite" supracitada, pois a mencionada sequência seria um contínuo na vida desses estudantes, promovendo em maior grau, pois, o pensamento noutras escalas, já que a interdisciplinaridade desses campos poderia permitir que uma área reforçasse a outra, ampliando o conhecimento do jovem.

Considerando o gráfico 46, fazendo uma análise semelhante a anterior por averiguar o desempenho na dissertação, mas diferente ao considerar uma análise por turmas, verificamos que há particularidades.

\section{Gráfico 46 - Desempenho na dissertação por turmas $\left(8^{\mathrm{a}}\right.$ séries A, B, C e D)}

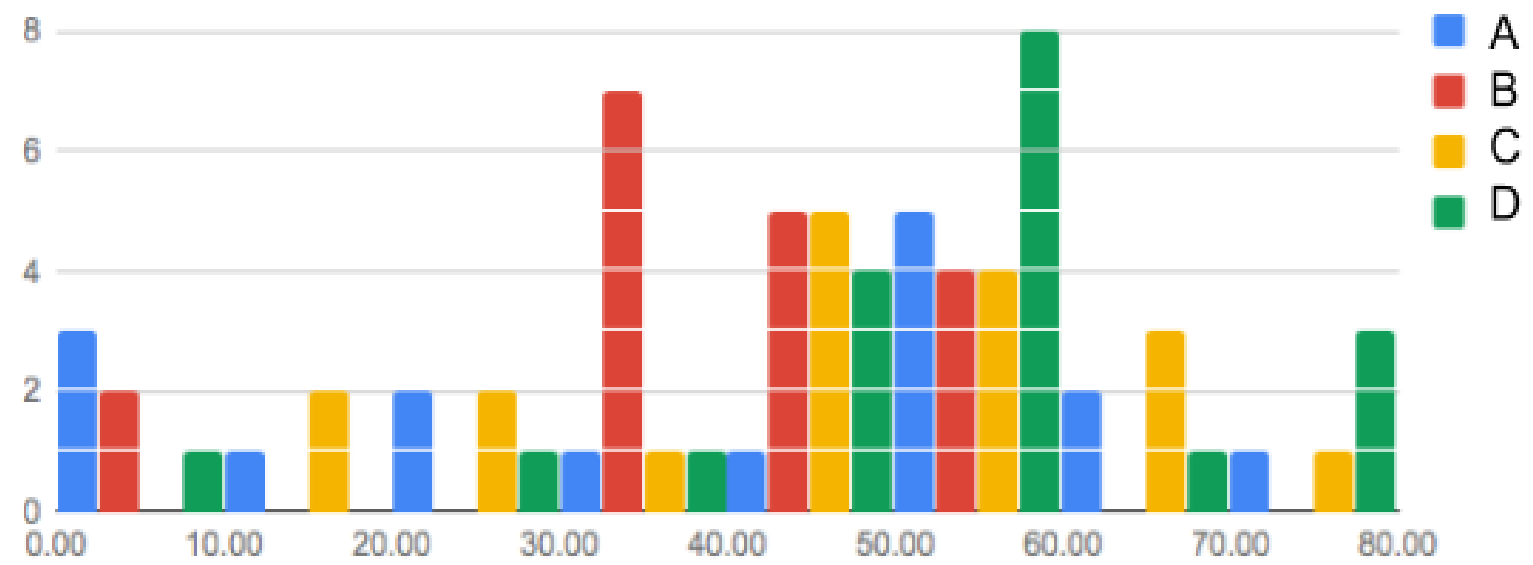

Fonte: Organizado pelo autor (2018). Programa Google Charts e JSFiddle. Colaboração técnica de Camila Fonseca Amorim da Silva. 
Por um outro olhar, na análise por turmas, evidencia-se que há particularidades entre elas. $\mathrm{Na} 8^{\mathrm{a}}$ série $\mathrm{A}$, sua presença se fez em todas as categorias, ainda que em diferentes proporções. Foi responsável por $60 \%$ das notas mais próximas de zero, e por metade e um terço, respectivamente, das notas mais baixas subsequentes até 30. A partir da categoria intermediária, sua presença é mais perceptível nas categorias 40 e 50.

A $8^{\mathrm{a}}$ série B foi a mais responsável pelas notas em torno de 30 , com $63,64 \%$ de influência, sendo que algo semelhante vale por sua atuação nas duas categorias seguintes, não em termo percentual, pois há mais turmas que também se fazem mais presentes, mas em relação a ser uma categoria que, em relação a ela mesma, se mostrou mais presente do que em outras que participou, além de uma certa participação nas notas próximas a zero, sendo $40 \%$ desse total. Nela, foi mais comum alunos terem um desempenho mediano, porém mais próximo a um mediano limítrofe, próximo de estar abaixo da média, assim como um desempenho baixo.

No caso da turma $\mathrm{C}$, esta não se apresentou nos pontos mais extremos de notas mais baixas, mas o fez no caso das mais altas, ainda que apenas $25 \%$. Entretanto, se fez bem presente nas categorias intermediárias, e foi a mais presente na categoria que se inicia as notas acima da média, com $60 \%$ de presença.

Já na $\mathrm{D}$, esta foi a sala que melhor se demonstrou na atividade. Assim como na $\mathrm{C}$, nenhum aluno tirou uma nota próxima a zero ou na categoria 10, mas também não o fizera na 20. A categoria mais baixa na qual apareceu foi a 30 , com uma pequena participação de $9,09 \%$. Sua presença se faz evidente na categoria 60 , sendo a sala mais responsável pelo reflexo dessa categoria no histograma anterior, além de ser a única com 3 alunos com nota superior a 80, correspondendo a $75 \%$ daqueles que a conseguiram.

\subsection{AS VOZES DOS ESTUDANTES}

Após a finalização da Sequência Didática, procuramos ouvir alguns estudantes, a fim de que pudéssemos ter um olhar para além das produções textuais que haviam realizado e verificar qual significado tivera sobre eles a Experiência de Aprendizagem Mediada e o estudo da migração nordestina, a desconcentração industrial e a desindustrialização de determinados pontos da metrópole paulistana. As falas dos alunos foram capturadas entre os dias 22 e 25 de novembro de 2016, ora pelo próprio professor, ora por algum estudante que conduzia a entrevista, priorizando a 
espontaneidade e o protagonismo juvenil, ao invés de um roteiro com perguntas fixas; no entanto, nem todos os alunos aceitaram participar.

As falas aqui transcritas ${ }^{267}$ versam sobre assuntos relacionados à Sequência Didática, como pode se ver a seguir.

Professor Carlos - Emili eu vi uma mudança muito brusca em sua postura em sala de aula (...); foi uma das alunas que vi mais interessada. Eu gostaria que... você falasse dessa postura que você passou a ter... se envolver de uma forma profunda na aula. O que que houve?

Emili - Eu acho que talvez pela mudança de ambiente, eu acho que isso resultou no meu comportamento. E eu me sinti mais interessada pela aula por naõ ficar só naquele negócio de copiar... copiar lição da lousa. Professor - Teve alguma situação da aula que te chamou mais atenção? 'Poxa', isso daqui poderia servir de exemplo para outros professores, que você tenha gostado?

Emili - Talvez ter usado os gráficos, naõ ter só ficado na lousa, mas ter feito um outro tipo de aula, como você fez, levar pra outro local, meio que... como eu posso dizer, outra dinâmica.

Prof. Carlos - Emili você acha que o aluno passou a ter voz ali naquela aula? Ele teve participação?

Emili - Achei, porque, tipo assim... aqui na sala é uma coisa de cópia... então não tem o que falar; só copia... e se aprendeu, aprendeu. Lá foi totalmente diferente, porque todo mundo interagiu.

O enunciado da estudante nos dá importantes evidências do significado que houve para a aluna ao realizar atividades didático-pedagógicas noutros ambientes de aula. O fato de terem acessado a sala de vídeo e a sala de leitura, num espaço onde havia significativamente menos barulho ou ruídos, destoante das tradicionais atividades como copiar lição da lousa, mas utilizando-se de gráficos, de outro tipo de aula, teria resultado em outra dinâmica que servira como estímulo à estudante.

Professor Carlos - Danilo... você falou da desindustrialização de São Paulo, mas a gente conseguiu relacionar a desindustrialização de São Paulo com outros assuntos?

Danilo - ... com os nordestinos migrando aqui pra metrópole. Tipo, nas décadas de 50, 60 até a 70.

Professor - E você acha que é importante para o aluno estudar os migrantes nordestinos?

Danilo - Acho né... porque a maioria de nós temos migrantes que vieram pra cá pra São Paulo pra tentar uma vida melhor...

\footnotetext{
267 Os trechos aqui transcritos referem-se as falas de alguns estudantes que aceitaram gravar em áudio suas impressões sobre a Sequência Didática "Desconcentração industrial, desindustrialização e migração de retorno".
} 
Após responder as questões por nós colocadas, o estudante Danilo entrevistou alguns de seus colegas de turma.

Danilo - E você Filipi Andrade, você gostou da forma que o professor usou esse último bimestre pra ensinar a gente?

Filipe - Ah, com certeza né, tipo... porque... tá muito repetitivo o ensino, tipo, o professor chega na sala enche a "a lição de lousa" (sic) e pede pra vistar. E o professor não... foi diferente... teve... deu liberdade para o aluno se expressar, não foi uma visão só... que nem história; história tem vários pontos de vistas da história, de um determinado assunto... e com o professor de geografia nós podemos ver isso... cada aluno podia se expressar e foi muito legal ter essa experiência.

Danilo - Mas na sua opinião, um professor que se prende aos livros é melhor do que o que o professor Carlos fez? Ou você acha que o que o professor Carlos fez é uma coisa diferente, que no ensino hoje em dia seria bom que acontecesse?

Filipe - Com certeza, se todos os professores fizessem o que o professor Carlos fez seria muito melhor o ensino, porque nós 'aprende' bem mais do que quando o professor chega e só passa lição; porque é uma coisa bem mais ampla, mais... bem melhor do que 'os' ensino vem sendo ensinado aqui na escola.

Após entrevistar seu colega Filipi, Danilo se dirige a outros dois colegas de turma, Luís e Giovanni.

Danilo - Luis, vamos aqui dar uma palavrinha. O que que você achou da forma que o professor usou esse último bimestre pra ensinar a gente? Você gostou de ter descido lá embaixo?

Luis - Inusitado... uma maneira boa de se aprender.

Danilo - Se os outros professores fizessem isso com a gente você ia gostar?

Luis - Lógico, será uma ótima maneira, porque na... lá embaixo a produtividade pode ser muito maior do que aqui. Porque aqui, acho que a atenção é mais celular, porque a gente está parecendo robô... é a mesma coisa, tipo lousa, lição... mais nada, só isso. Lá eu achei uma ideia muito boa.

Danilo - então você achou uma forma positiva o professor de desprender a gente 'aos' livros $e$ às apostilas e ensinar a gente de uma forma mais livre?

Luis - Sim.

Danilo - Giovanni de Jesus o que você achou do que o professor está 'passando' pra gente, é algo diferente que acontecu com você ou você já teve experiência com outros professores?

Giovanni - Ah... a experiência é única né 'véi'... tipo assim, ele foi o único professor que tratou disso até agora, que é um pouco histórico... mesmo que eu não goste tanto assim da cultura do Brasil, mas é sempre bom saber sobre as coisas. 
Danilo - Mesmo você e ele tendo ideais diferentes você concorda que a forma de ensino que ele usou com a gente é algo que pode ser levado pra vida? E abranger outras matérias não só a Geografia?

Giovanni - 'Mano', assim, não importa o ideal político, tanto esquerda quanto direita poderiam fazer isso, de qualquer maneira e seria bom se todas materias tivess...

Danilo - A educação mediada dessa forma seria melhor?

Giovanni - É, muito melhor né, pra certo tipo de pessoa. Bom, se você é um cara que se adapta a tudo você vai aprender de qualquer forma, mas dessa forma é mais eficiente pra todos.

As falas dos estudantes nos dão mostras da urgência em se repensar as práticas didático-pedagógicas, principalmente aquelas atreladas ao excessivo uso do livro didático, de resoluções técnicas de questões da apostila ou às cansativas cópias de longos textos expostos na lousa e nos manuais didáticos; da mesma forma, os estudantes ressaltam o significado das atividades escolares noutros ambientes, assim como a relevância em se realizar discussões com os alunos reunidos e interagindo em grupos.

Noutro momento, fizemos alguns questionamentos buscando compreender o que há de diferente em realizar atividades em outros ambientes de aula e se seria válido que outras disciplinas se utilizassem da Experiência de Aprendizagem Mediada.

Professor - Vocês gostariam que outras aulas (disciplínas) seguissem esse método que a gente seguiu aqui?

Classe - Sim.

Professor - Por que você acha que fica mais fácil de aprender com esse método?

Layla - Porque na aula normal o professor só passa na lousa e a pessoa copia, nem presta atenção no texto. Quando a aula é assim, em grupo, ela presta atenção no que o outro 'tá' falando e entende mais.

Professor - Você sente que os alunos puderam participar mais?

Layla - Sim.

Professor - Pode dar algum exemplo?

Layla - Porque a gente fica mais focado na aula.

Professor - Olha a palavra que ela usou: a gente fica mais 'focado' na aula. Mas por que mais focados?

Gabriela: Porque todos estão interagindo.

Professor - A centralidade não está no conteúdo, está no aluno.

Kaique - $O$ mais importante é interagir com o aluno.

Partimos da premissa de que a centralidade da aula deve estar no aluno e não no professor, no entanto, como nos apresenta Alain Touraine (2004, p. 36) muitos se escandalizam sendo contrários à essa ideia, considerando que a escola deveria orintar-se 
preferencialmente ao saber ou à sociedade, evidenciando sobremaneira a oposição entre a escola para o sujeito e a escola para a sociedade. Conforme o autor:

\begin{abstract}
Continuo a afirmar, de maneira nada hedonista, que a escola deve ser centrada no aluno, no estudante, no indivíduo, ajudando-os a se tornarem sujeitos, sendo o conhecimento, de fato, um elemento fundamental para tornar-se um sujeito [...]. Estamos todos engajados, positiva ou negativamente, na construção ou destruição de nós como sujeitos, em todos os aspectos de nossa vida. O que está em jogo em nosso tipo de sociedade é a criação ou a destruição do sujeito $^{268}$.
\end{abstract}

Ademais, o papel da escola deve ser o de valorizar e fomentar o espírito crítico e científico, considerando a necessidade em se constituir um sujeito com autonomia intelectual, sem, contudo, deixar de se atentar às individualidades e especificidades do aluno, não confundido individualismo com individualidade.

Assim, na estapa final da Sequência Didática nos atentatamos aos enunciados dos estudantes a fim de que pudessem explicitar suas percepções em relação às atividades modulares que foram desenvolvidas tanto em grupos quanto individualmente.

Layla - (dirigindo-se ao professor) ... você puxou a questão para como a gente escreve; a gente escrevia sem a 'formação', agora a gente interpreta o texto e dá a opinião formada sem ficar: 'ah, eu acho', 'bom', 'na minha opinião'. (...) Agora a gente presta mais atenção nos enunciados, nas legendas, títulos, porcentagens dos gráficos, para gente relacionar com as outras imagens 'pra' fazer uma redação boa. Professor - Vocês acham que agora vocês vão interpretar um gráfico de um modo diferente de antes?

Gabriela - Sim.

Professor - Por que sim?

Gabriela - Porque agora vamos observar os detalhes.

(...)

Gabriela - As estatísticas, os números...

Professor - 'Tá', mas tem mais coisas...

Kailaine - A data em que foi feito.

Professor - O que mais além da data? Layla tá dizendo o que?

Layla - O título, subtítulo... (Kaique tá falando o ano)... a legenda.

A importância da mediação humana a partir de critérios que tenha como premissa a formação de um sujeito criativo, inventivo, crítico e pró-ativo, se justifica, pois, o uso excessivo ou o simples acesso aos recursos tecnológicos, não necessariamente assegura aos estudantes lidar de forma eficaz com as problematizações colocadas pelo mundo contemporâneo, daí a premência em uma escola que se atente à

${ }^{268}$ TOURAINE, A. A busca de si: diálogo sobre o sujeito. Rio de Janeiro: Bertrand Brasil, 2004. 
interatividade, a modificabilidade, ao aprender a aprender e ao aprender a pensar. Castells (2003, p. 227) referindo-se a educação, salienta num sentido amplo e fundamental:

[...] a aquisição da capacidade intelectual de aprender a aprender ao longo de toda a vida, obtendo a informação que está digitalmente armazenada, recombinando-a e usando-a para produzir conhecimento para qualquer fim que tenhamos em mente. Esta simples declaração põe em xeque todo o sistema educacional desenvolvido durante a era industrial. Não há reestruturação mais fundamental. E muitos poucos países e instituições estão verdadeiramente voltados para ela, porque, antes de começarmos a mudar a tecnologia, a reconstruir as escolas, a reciclar os professores, precisamos de uma nova pedagogia baseada na interatividade, na personalização e no desenvolvimento da capacidade de autonomia de aprender a pensar ${ }^{269}$.

A importância do ensino de geografia enquanto uma uma ciência que possibilita o desenvolvimento cognitivo e intelectual dos estudantes, se evidencia e se faz necessária nesse mundo de meio técnico-científico-informacional, pois em que pese o sobrelevado acesso aos recursos tecnológicos e digitais, não são todos que tem acesso a tais recursos, e os que os têm nem sempre os utiliza de modo ativo, crítico e consciênte. De acordo com Jenkins (2009, p. 358, 359):

A cultura contemporânea está cada vez mais participativa, especialmente se comparada com as ecologias de mídias anteriores, principalmente as dependentes da mídia tradicional. No entanto, nem todo mundo tem permissão de participar, nem todo mundo é capaz de participar, nem todo mundo quer participar e nem todo mundo que participa o faz em igualdade de condições ${ }^{270}$.

Torna-se preciso a reflexão sobre o tipo de mediação a que esses jovens estão submetidos, pois as mídias digitais por si só não medeiam. São jovens imersos em redes sociais e em aplicativos que se ampliam exponencialmente e numa velocidade imensurável. Ademais, é ainda presente na vida de crianças e adolescentes a televisão, onde estão expostos a um desenfreado fomento ao consumo e ao individualismo, seja por meio de uma programação aberta ou fechada. No Brasil a televisão é ainda o principal meio de comunicação, chegando à um total de $98 \%$ da população e recebendo um total de $55 \%$ de investimentos de órgãos publicitários ${ }^{271}$. Castells (1999, p. 421) nos ajuda a compreender o papel desempenhado pela televisão nesta era da informação e da sociedade em rede:

${ }^{269}$ CASTELLS, M. A galáxia da internet: reflexões sobre a internet, os negócios e a sociedade. Rio de Janeiro: Zahar, 2003.

${ }^{270}$ JENKINS, Henry. Cultura da convergência. $2^{\mathrm{a}}$ ed. São Paulo: Aleph, 2009.

271 Meios de comunicação - Janeiro à Junho, 2016. Kantar Ibope Media. Disponível em: $<$ https//www.kantaribopemedia.com/meios-de-cominicacao-janeiro-a-junho-2016/>. Acesso em $15 / 09 / 2017$ 
O poder real da televisão [...] é que ela arma o palco para todos os processos que se pretendem comunicar à sociedade em geral, de política à negócios, inclusive esporte e arte [...] a política e os políticos ausentes da televisão nas sociedades desenvolvidas simplesmente não tem chance de obter apoio popular, visto que as mentes das pessoas são informadas fundamentalmente pelos meios de comunicação, sendo a televisão o principal deles ${ }^{272}$.

Um dos principais objetivos com a aplicação da Sequência Didática fora a tentativa e o esforço em possibilitar ao aluno - sujeito dessa sociedade em rede - que se desenvolvesse cognitiva e intelectualmente, superando suas dificuldades e fragilidades diagnosticadas em suas elaborações iniciais e aprendendo geografia de forma significativa. Aliás, um dos estudantes apontou para tal questão, como vemos no trecho a seguir:

Professor - Cleisson, eu queria ouvir sua opinião sobre o método que usamos e eu gostaria que você comentasse um pouco.

Cleisson - 'Tá' filmando não?

Professor - Não, eu não 'tô' filmando, estou só gravando, captando o áudio.

Cleisson - Ah... eu gostei.

Professor - Por que?

Cleisson - Porque foi interessante; porque você começou com a gente, viu como a gente estava no começo, aí foi evoluindo. Cada lição que você passava e aí a gente evoluia mais.

Professor - Gente, olha só que coisa interessante que ele 'tá falando. Ele pegou um ponto chave. Ele está falando que eu pude ver as dificuldades que vocês estavam no começo; que foi quando eu 'dei' aquela elaboração inicial... e porquê realmente vocês foram melhorando.... Tiveram avanços....

Cleisson - Eu gostei que a gente não ficou só aqui na sala, foi trabalhar em lugares novos. Aí deu até 'pra' gente prestar mais atenção lá.

Professor - Você percebeu que lá embaixo a disposição das carteiras era outra?

Cleisson - As cadeiras eram em grupo, tudo em grupo.

Professor - Você acha que é importante o aluno sentar em grupo?

Cleisson - Sim, eles 'conversa' entre eles, discute.

A interação professor-aluno e aluno-aluno fora algo que os estudantes sublinharam como sendo significativo para a efetivação das aprendizagens. Do mesmo modo, o fato de terem realizado as atividades na sala de leitura e reunidos em pequenos grupos tivera grande importância no processo de ensino-aprendizagem.

${ }^{272}$ CASTELLS, M. A sociedade em rede: a era da informação: economia, sociedade e cultura. vol.1. $6^{\text {a }}$ ed. São Paulo: Paz e Terra, 1999. 
Professor - Giovanni... e você? Sua fala sobre a importancia de a gente fazer uma atividade na sala de leitura, por exemplo, de seguir outros métodos que não aquilo de ficar preso em livros; trabalhar com as imagens, você acha que isso acrescenta, sim ou não, e por que?

Giovanni - Então né... eu acho que acrescenta porque a maioria das aulas da escola pública, sem citar nomes, é baseado na cópia. Daí o senhor chegou com um método de aula totalmente diferente, daquele jeito, que foi em outra sala, em outro ambiente... e um assunto que, sei lá, a gente não imaginava que ia debater sobre esse assunto, que era dos migrantes nordestinos vindo 'pra' São Paulo e a desindustrialização, que meio que se conectam né...

O mundo contemporâneo apresenta notadamente uma série de desafios e situações-problema que exige dos indivíduos determinadas habilidades e capacidades para lidar com as novas problematizações que carecem de respostas e resoluções. Desse modo, poderíamos considerar que por serem os jovens escolares "nativos digitais", imersos no emaranhado das redes no mundo de meio-técnico-científico-informacional, porém destituídos de uma efetiva mediação humana, seria suficiente para terem assegurados em sua formação um significativo desenvolvimento humano, cognitivo e intelectual? Estaria a escola e os professores do século XXI atentos às transformações do mundo e da necessidade em não se deixar crianças e adolescentes lançados à própria sorte por considerar que possuem variadas habilidadaes para operar os aparelhos eletrônicos e digitais? Ou deveríamos mais do que acolhê-los, mas mediá-los para que tenham sua autonomia intelectual e cognitiva, e para que possam efetivamente transformar o mundo?

A educação é o ponto em que decidimos se amamos o mundo o bastante para assumirmos a responsabilidade por ele e, com tal gesto, salvá-lo da ruína que seria inevitável não fosse a renovação e a vinda de novos jovens. A educação é, também, onde decidimos se amamos as nossas crianças o bastante para não expulsá-las de nosso mundo e abandoná-las a seus próprios recursos, e tampouco arrancar de suas mãos a oportunidade de empreender alguma coisa nova e imprevista para nós, preparando-as em vez disso com antecedência para a tarefa de renovar um mundo comum ${ }^{273}$ (ARENDT, 1990, p. 247).

Castells (2015) também reforça o papel decisivo da educação para formar jovens com capacidades e potenciais de transformação ativa do mundo e sua preocupação com a educação enquanto instituição mais atrasada e conservadora em todos os países. Para o sociólogo:

[...] já vivemos hibridamente em presença física e presença virtual na rede. Em um mundo assim, a educação é decisiva para aproveitar as imensas oportunidades que a conexão permanente e o acesso as bases de dados oferecem. Isso pode se aplicar a todos os âmbitos da economia e da vida

${ }^{273}$ ARENDT, Hannah. Entre o passado e o futuro. São Paulo: Perspectiva, 1990. 
cotidiana. Mas essa mesma educação tem que mudar, isso é o mais importante, pelo fato de a educação ser, talvez, a instituição mais atrasada e conservadora em todos os países. Não se trata de educar só pela internet. Trata-se de uma educação que forme pessoas com capacidade metal autônoma de processos, informação e aplicá-la a cada tarefa e projeto de vida ${ }^{274}$ (CASTELLS, 2015, $\mathrm{s} / \mathrm{p})$.

A participação dos estudantes ao término da Sequência Didática, sendo entrevistados ora pelo professor, ora por um colega de turma, serviu sobremaneira para que pudéssemos estimular o protagonismo juvenil destes sujeitos escolares, como pode ser visualizado nas imagens que compõem esta e as próximas páginas. No entanto, pelo fato de não estar compondo o plano inicial da Sequência Didática, tal entrevista se deu de modo espontâneo e alguns estudantes não concordaram em participar, evidenciando, sobretudo, timidez.

\section{Figura 16 - Aluno entrevistando colega seu colega de turma}

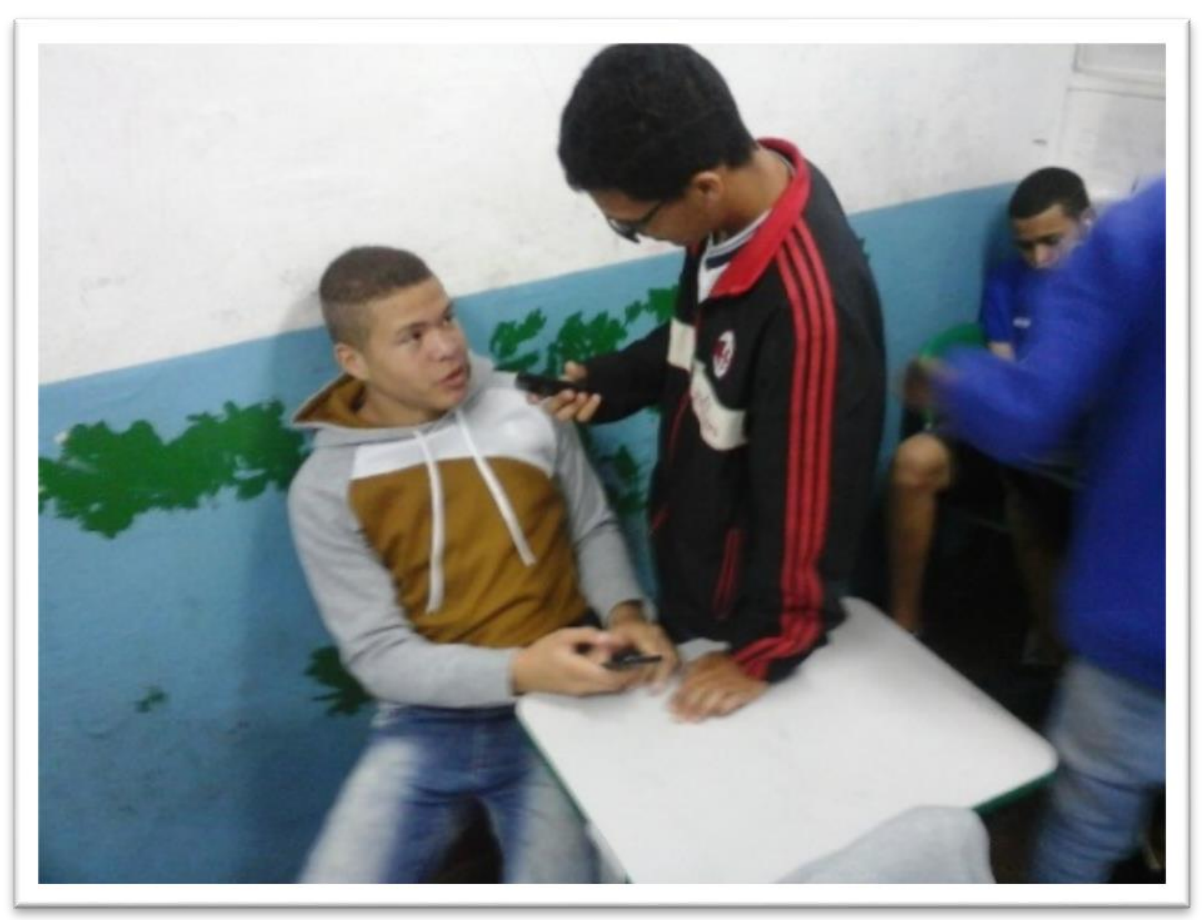

Autor: Carlos Eduardo Fonseca (2016).

A realização da entrevista entre os estudantes se deu no ambiente habitual das aulas, pois a maior parte das atividades da Sequência Didática foram realizadas em outro ambiente, ora na sala de leitura, ora na sala multiuso.

${ }^{274}$ CASTELLS, Manuel. Entrevista à Malú Fontes. Fronteiras do Pensamento, Correio da Bahia, 2015. Disponível em https://www.fronteiras.com/entrevistas/manuel-castells-a-comunicacao-em-rede-estarevitalizando-a-democracia. <Acesso em 22 de abril de 2017>. 
Figura 17 - Aluno realizando entrevista com grupo de colegas

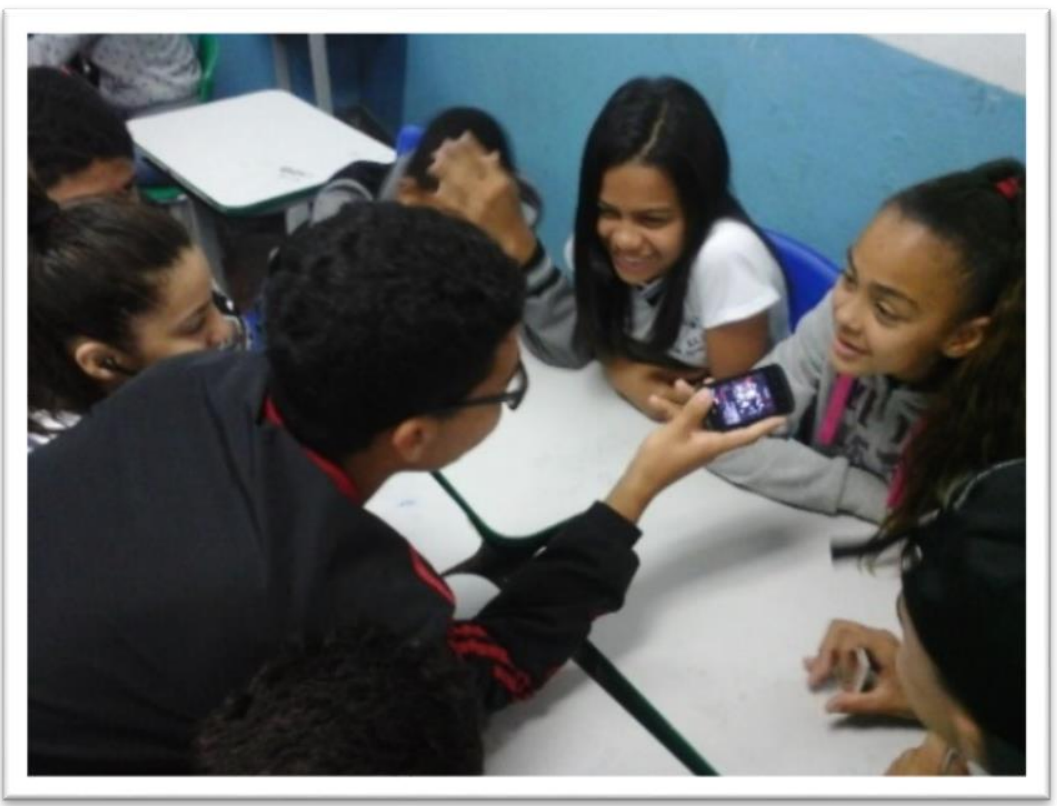

Autor: Carlos Eduardo Fonseca (2016).

Figura 18 - Aluna sendo entrevistada pelo professor

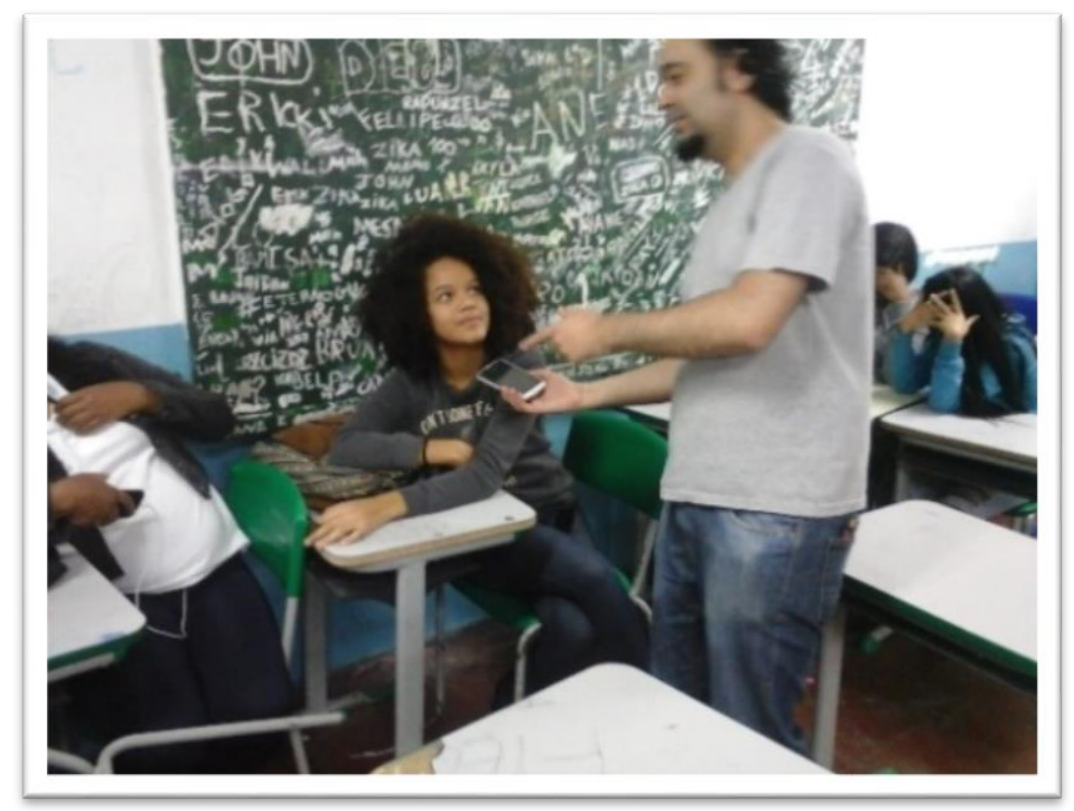

Autor: Cleisson G. Santos (2016).

As atividades realizadas com a aplicação da Sequência Didática considerando alguns dos aportes teóricos de Feuerstein e Vigotski, nos serviram para evidenciar o significado da interação humana, da linguagem em suas diferentes modalidades e da Experiência de Aprendizagem Mediada para a formação de um sujeito que passa a constituir um pensamento científico, mais elaborado e complexo. 


\section{Figura 19 - Aluno sendo entrevistado por professor}

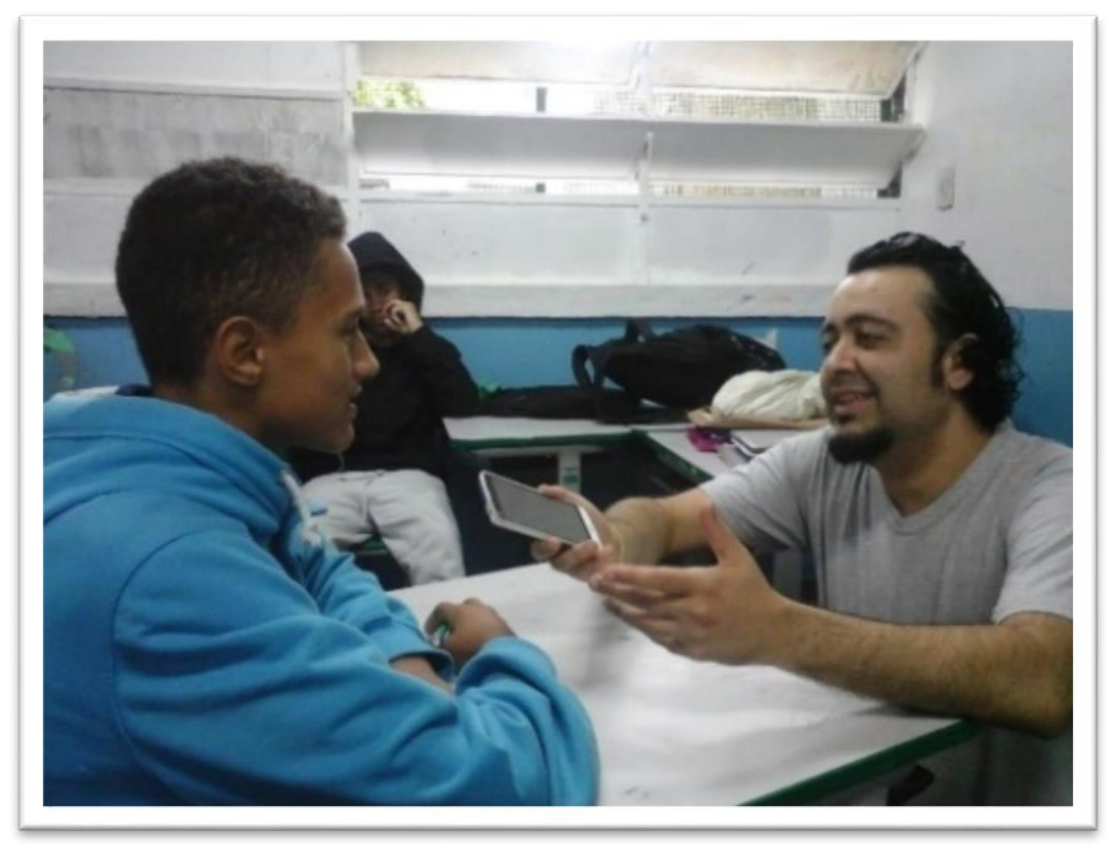

Autor: Cleisson G. Santos (2016).

Apesar de ter sido uma Sequência Didática aplicada num espaço de tempo relativamente curto, pudemos capturar elementos significativos a respeito da necessidade em se repensar a educação, a escola, o ensino, o professor, a partir de concepções voltadas ao desenvolvimento do ser humano como sujeito pleno, crítico e social. Enquanto as aulas de geografia forem pensadas de modo a atender as demandas mercadológicas, num modelo neoliberal e tecnicista, destituída de uma filosofia ética e de aportes teóricos que deem sustentação à uma efetiva aprendizagem para a vida, que atrele o desenvolvimento cognitivo, intelectual, científico, ficaremos tão somente presos a um ensino de geografia de uma escala de tempo-espaço do imediato e sem sair do lugar. 


\section{CONSIDERAÇÕES FINAIS}

Vivemos a era da conectividade, das relações virtuais, da cibercultura, do ciberespaço e de um sem número de mídias digitais nesse tempo de meio técnicocientífico-informacional. A noção de lugar enquanto "lócus" de relações face a face, com contatos de vizinhança e sentimentos de afetividade e pertencimento, há muito já não é a realidade das novas gerações, em que pese, ser ainda um ponto de referência e de escala para a maioria dos indivíduos.

Portanto, vive-se um paradoxo, pois se a sociedade está imersa num emaranhado de redes em que as noções de "próximo" e "distante" tornam-se complexas e variáveis, há de se refletir se o aluno da educação básica, operando aparelhos digitais e eletrônicos com dada facilidade seria efetivamente um "nativo digital". Ou seja, estaria este jovem em potencial condições de enfrentar o mundo atual, agindo de forma prospectiva, questionando, refletindo, indagando e com espírito de criticidade? E ainda, não estariam muitos deles lançados à própria sorte, bombardeados por um sem fim número de estímulos diretos e carecendo de adequada mediação humana?

Ao mesmo tempo em que o mundo se mostra cada vez mais complexo, dinâmico e incerto, e que as novas tecnologias da informação e da comunicação crescem exponencialmente, há ainda nos bancos escolares não somente práticas "pedagógicas" arcaicas, superadas, e sobretudo, prescritivas, mas no tocante ao ensino de geografia paira uma certa visão limitante de mundo quando circunscrita ao "lugar do aluno", sem conexões com outras escalas do problema ou fenômeno estudado.

Convém enfatizar, que o fato de termos trabalhado em nossa pesquisa com uma atividade em que os estudantes foram solicitados a realizar entrevistas com migrantes nordestinos do Distrito de Pedreira, é possível que alguns leitores a considerem como uma contradição em relação à nossa tese. Ora, pode dar a entender que reiteramos a tese pois, o aluno realizara atividade no entorno da escola, de seu local de moradia, ou ainda, daquilo que lhe é mais "próximo" e "imediato".

Entretanto, não se tratou de um estudo focado na observação da paisagem local ou de uma entrevista relacionada às ocupações dos moradores e suas perspectivas em relação ao lugar em que vivem, apenas. O nível de abstração requerido na referida atividade se evidencia quando os alunos lidam com representações de outros lugares, no caso, da região nordestina do país. Logo nas primeiras perguntas o interlocutor fora 
solicitado a responder de qual estado viera. Assim, ao se reportarem a uma outra escala de espaço e de tempo o aluno tende a pensar não mais de modo restrito aos aspectos “visíveis" e mais imediatos, mas opera com níveis de abstração mais elaborados ao lidar com as memórias e representações de mundo de seus entrevistados.

Portanto, a escala do lugar, do fenômeno estudado, transcendeu ao "lugar do aluno", pois buscou conexões com outras escalas espaço-temporais; e esse foi o esforço que fizemos no decorrer de toda a Sequência Didática com as atividades modulares. Por outro lado, tais atividades - e, de modo mais específico as elaborações iniciais -, nos deram mostras de que os alunos têm uma forte tendência a operar mentalmente focados no lugar, ou seja, aos aspectos de uma realidade cotidiana mais "imediata", paradoxalmente estando estes jovens - ainda que parcialmente - num mundo de meio técnico-científico-informacional.

Quando solicitados a identificar os fatores de repulsão no Nordeste que compeliram os migrantes a se deslocarem em direção a metrópole paulistana, muitos estudantes não se reportaram em suas primeiras elaborações aos fenômenos ocorridos na região nordestina, mas àquilo que visualizam em sua realidade mais imediata. Desse modo, apontavam a busca por novos empregos e melhorias de vida na metrópole de São Paulo. Do mesmo modo, quando indagados em relação ao que poderia estar contribuindo para um possível movimento de retorno de migrantes nordestinos para suas regiões ou cidade de origem, as elaborações iniciais davam conta da violência urbana, da pobreza na metrópole ou da falta de emprego. Ou seja, poucos se atentavam para o que poderia estar acontecendo em outra escala, de outro lugar.

Nas etapas finais da Sequência Didática parte dos estudantes passou paulatinamente a operar considerando outras escalas de tempo e espaço do problema estudado; apontavam os programas sociais de incentivo às populações no Nordeste, a criação de novos postos de trabalho e até as indústrias que se deslocavam da metrópole paulistana para outras regiões do país, sobretudo para a região nordestina. A partir daí pudemos verificar que o lugar passava a não mais a ser visto de modo estanque, isolado, fragmentado, mas conectado à fenômenos e fatores outros manifestados em outras dimensões de tempo e espaço.

Vale lembrar, que não desconsideramos o lugar enquanto importante categoria da geografia no processo de ensino e aprendizagem, mas consideremos que se busque transcender ao lugar, rompendo com estudos isolados e fechados em si. 
A pesquisa, em seu "término" nos gera uma sensação de incompletude, pois enquanto pesquisador-professor há a ideia de que poderíamos ter feito mais, ousado mais, tentado mais. Porém, o fato de termos feito um esforço em desenvolver intelectualmente os estudantes, utilizando-nos de uma Sequência Didática por nós elaborada, e de aportes teóricos e metodológicos que acreditamos ser extremamente sofisticados e com uma perspectiva de uma geografia não uniescalar, acreditamos que um importante passo fora dado em direção a um estudo que transcenda a escala do "lugar do aluno" e busque a conexões com outras escalas de tempo e espaço.

Os resultados mostraram que os alunos inicialmente tendem a pensar a partir do lugar, principalmente quando explicam a repulsa do nordestino em direção à metrópole paulistana, evidenciando mais fatores de atração da referida metrópole e citando menos os elementos de repulsão no Nordeste. Porém, após o processo de aprendizagem mediada - em que pese ainda terem sobrelevado em suas elaborações finais os fatores de atração quando reportando-se ao movimento migratório de nordestinos em direção à metrópole paulistana ou os de repulsão, quando tratado do movimento de retorno começaram a pensar não mais restritivos a uma escala apenas local, mas com conexões.

Ora, se há uma tendência de o aluno pensar restritivo ao "seu lugar", com baixos níveis de abstração e complexidade, não considerando outras escalas do problema estudado, é preciso então superarmos um ensino de geografia calcado sobremaneira naquilo que é mais imediato e concreto ao aluno. Está cada dia mais evidente que os problemas se tornam mundiais, e um pensamento que se pretende mais elaborado e complexo, não será suficiente se preso e restrito ao "lugar do aluno", com poucas ou nulas conexões com outras escalas de tempo e espaço. 


\section{REFERÊNCIAS}

ALMEIDA, Maria da Conceição de. Introdução: mapa inacabado da complexidade. In: SILVA, Aldo Dantas da; GALENO, Alex. (Orgs.). Geografia, ciência do complexus: ensaios transdisciplinares. $2^{\mathrm{a}}$ ed. Porto Alegre: Sulina, 2008.

ALMEIDA, Rosângela Doin de; PASSINI, Elza Yasuko. O espaço geográfico: ensino e representação. $5^{\mathrm{a}}$ ed. São Paulo: Contexto, 2011.

ALVES, Giovanni. O novo (e precário) mundo do trabalho: reestruturação produtiva e crise do sindicalismo. São Paulo: Boitempo, 2005.

, Giovanni. Trabalho e subjetividade: o espírito do toyotismo na era do capitalismo manipulatório. $1^{\mathrm{a}}$ ed. São Paulo: Boitempo, 2011.

ANDRADE, Manuel Correia. A terra e o homem no Nordeste. $2^{\text {a }}$ ed. São Paulo: Brasiliense, 1964.

ANTUNES, Ricardo. Adeus ao Trabalho? Ensaio sobre as metamorfoses e a centralidade do mundo do trabalho. 16 ${ }^{\mathrm{a}}$ ed. São Paulo: Cortez, 2015.

ANTUNES, Ricardo. Século XXI: nova era da precarização estrutural do trabalho? In: ANTUNES, R; BRAGA, Ruy. (Orgs.). Infoproletários: degradação real do trabalho virtual. São Paulo: Boitempo, 2009.

ANTUNES, Ricardo; ALVES, Giovanni. As mutações no mundo do trabalho na era da mundialização do capital. In: Educ. Soc., Campinas, vol. 25. n. 87, p. 335-351, maio/agos. 2004. Caderno Cedes.

ARENDT, Hannah. Entre o passado e o futuro. São Paulo: Perspectiva, 1990.

BACHELARD, Gaston. A formação do espírito científico: contribuição para uma psicanálise do conhecimento. Rio de Janeiro: Contraponto, 1996.

BAENINGER, R. A nova configuração urbana no Brasil: desaceleração metropolitana e redistribuição da população. In: ENCONTRO NACIONAL DE ESTUDOS POPULACIONAIS DA ABEP, II., 1998. Caxambu, Anais. 1998.

Rosana. São Paulo e suas migrações no final do século 20. São Paulo em perspectiva. v. 19, n. 3, p. 84-96, jul/set, 2005.

Rosana. Rotatividade migratória: um novo olhar para as migrações internas no Brasil. In: Revista interdisciplinar da mobilidade humana. Vo. 20, n. 39, p. 77-100. Jul/dez. 2012.

BARATO, Jarbas Novelino. Escritos sobre tecnologia educacional \& educação profissional. São Paulo: Editora SENAC, 2002.

BAUMAN, Zygmunt. Globalização: as consequências humanas. Rio de Janeiro: Jorge Zahar, 1999. 
BAUMAN, Zygmunt; DONSKIS, Leonidas. Cegueira Moral. Rio de Janeiro: Editora Zahar, 2014.

BEYER, Hugo Otto. O fazer psicopedagógico: a abordagem de Reuven Feuerstein a partir de Vygotsky e Piaget. Porto Alegre: Mediação, 1996.

BOURDIEU, Pierre. Contrafogos. Rio de Janeiro: Zahar, 1998.

BRUNHES, Jean. Geografia Humana. Rio de Janeiro: Editora Fundo de Cultura, 1962.

BUITONI, Marísia Margarida Santiago (Coord.). Geografia: ensino fundamental. V. 22. Brasília: Ministério da Educação, Secretaria de Educação Básica, 2010.

CALLAI, Helena Copetti \& ZARTH, Paulo Afonso. O estudo do município e o ensino de história e geografia. Ijuí: UNIJUÍ, 1988.

CALLAI, Helena Copetti. O ensino de geografia: recortes espaciais para análise. In: CASTROGIOVANNI, Antonio Carlos et al. Geografia em sala de aula: práticas e reflexões. $3^{\text {a }}$ ed. Porto Alegre: Editora da Universidade/UFRGS/Associação dos Geógrafos Brasileiros - Seção Porto Alegre, 2001.

CALLAI, Helena C. Estudar o lugar para compreender o mundo. In: CASTROGIOVANNI. Antonio Carlos et al. Geografia em sala de aula: práticas e textualizações no cotidiano. $11^{\circ}$ ed. Porto Alegre: Mediação, 2014.

CANO, Wilson. Desconcentração produtiva regional do Brasil: 1970-2005. São Paulo: Editora UNESP, 2008.

CASTANHO, Maria Eugênia L. M. Da discussão e do debate nasce a rebeldia. In: VEIGA, Ilma Passos Alencastro (Org.). Técnicas de ensino. Por que não? Campinas, SP: Papirus, 2008.

CARDOSO, Heloísa. Supervisão: um exercício de democracia ou de autoritarismo? In: ALVES, Nilda. (Coord.). Educação e supervisão: o trabalho coletivo na escola. $4^{\mathrm{a}}$ ed. São Paulo: Cortez/Autores Associados, 1988.

CARON, François. História contemporânea e desenvolvimentos tecnocientíficos. In: MORIN, Edgar. A religação dos saberes: o desafio do século XXI. $2^{a}$ ed. Rio de Janeiro: Bertrand Brasil, 2002.

CASTELLS, Manuel. A sociedade em rede: a era da informação: economia, sociedade e cultura. vol.1. 6 $6^{\text {a }}$ ed. São Paulo: Paz e Terra, 1999.

, Manuel. A galáxia da internet: reflexões sobre a internet, os negócios e a sociedade. Rio de Janeiro: Zahar, 2003.

, Manuel. Internet e sociedade em rede. In: MORAES, Dênis de. (org.). Por uma outra comunicação. Rio de Janeiro: Record, 2003b.

, Manuel. Entrevista à Malú Fontes. Fronteiras do Pensamento. Correio da Bahia, 2015. Disponível em https://www.fronteiras.com/entrevistas/manuel-castells- 
a-comunicacao-em-rede-esta-revitalizando-a-democracia. <Acesso em 22 de abril de 2017>.

CAVALCANTI, Lana de Souza. A cidade ensinada e a cidade vivida: encontros e reflexões no ensino de Geografia. In: CAVALCANTI, L. S. (org.). Temas de geografia na escola básica. $1^{\mathrm{a}}$ ed. Campinas, SP: Papirus, 2013.

CLAVAL, Paul. História da Geografia. Lisboa/Portugal: Edições 70, 2006. Paul. Epistemologia da geografia. Florianópolis: Editora da UFSC, 2011. , Paul. Terra dos Homens: a geografia. $1^{\text {a }}$ ed. São Paulo: Contexto, 2014.

COLOMER, T. Ensinar a ler, ensinar a compreender. Porto Alegre: Artmed, 2002.

CONTI, J. B. A Reforma do Ensino de 1971 e a situação da Geografia. Boletim Paulista de Geografia, São Paulo, n. 51, p. 57-70, 1976.

CORIAT, Benjamin. Pensar pelo avesso: o modelo japonês de trabalho e organização. Rio de Janeiro: Revan: UFRJ, 1994.

CORRÊA, Roberto Lobato. Entrevista. In: Revista Discente Expressões Geográficas. Florianópolis: SC, nº 1, p. 01-14, jun/2005.

Roberto Lobato. Espaço, um conceito-chave da geografia. In: CASTRO, Iná Elias de; GOMES, Paulo Cesar da Costa; CORRÊA, Roberto Lobato. Geografia, conceitos e temas. $11^{\circ}$ ed. Rio de Janeiro: Bertrand Brasil, 2008.

DA ROS, Silvia Zanatta. Pedagogia e mediação em Reuven Feuerstein: o processo de mudanças e adultos com história de deficiência. São Paulo: Plexus Editora, 2002.

DELORS, Jacques. Educação: um tesouro a descobrir. Relatório para UNESCO da Comissão Internacional sobre educação para o século XXI. São Paulo: Cortez, 1998.

DREIFUSS, René Armand. 1964: a conquista do Estado: ação política, poder e golpe de classe. $3^{\text {a }}$ ed. Petrópolis: Vozes, 1981.

, René Armand. Tecnobergs globais, mundialização e planetarização. In: MORAES, Dênis de. (Org.). Por uma outra comunicação: mídia, mundialização cultural e poder. Rio de Janeiro: Record, 2003.

ECHEVERRÍA, M. D. P; POZO, J. I. Aprender a resolver problemas e resolver problemas para aprender. In: POZO, J. I. (Org.). A solução de problemas: aprender a resolver problemas, resolver para aprender. Porto Alegre: Artmed, 1998.

FERRÉS, Joan. Vídeo e educação. 2ª ed. Porto Alegre: Artes Médicas, 1996.

FEUERSTEIN, Reuven. Entrevista à Rita Moraes. Direito à inteligência. Revista Isto É. Edição 1545, 12 de maio de 1999.

Reuven. Entrevista à CASADOS, Sergio Noguez. El desarrollo del potencial de aprendizaje. Entrevista a Reuven Feuerstein. In: Revista electrónica de investigación educativa. Vol. 4, n. 2, 2002. 
FEUERSTEIN, Reuven; FEUERSTEIN, Rafael S; FALIK, Louis H. Além da inteligência: aprendizagem mediada e a capacidade de mudança do cérebro. Petrópolis, Rio de Janeiro: Editora Vozes, 2014.

FONSECA, Vitor da. Aprender a aprender: a educabilidade cognitiva. Porto Alegre: Artmed, 1998.

FREINET, Célestin. Las técnicas audiovisuales. $3^{\text {a }}$ ed. Barcelona: Editorial Laia, 1979. GEORGE, Pierre. Geografia industrial do mundo. $6^{\mathrm{a}}$ ed. Rio de Janeiro: Bertrand Brasil, 1991.

GIDDENS, Anthony. As consequências da modernidade. São Paulo: Editora Unesp, 1991.

1996.

A. Para além da esquerda e da direita. São Paulo, Editora da Unesp,

, Anthony. Mundo em descontrole: o que a globalização está fazendo de nós. Rio de Janeiro: Record, 2000.

GOLDENSTEIN, L; SEABRA, M. Divisão territorial do trabalho e nova regionalização. Revista do Departamento de Geografia. São Paulo, n. 1. p. 21-47, 1982.

GOMES, Cristiano Mauro Assis. Feuerstein e a construção mediada do conhecimento. Porto Alegre: Artmed, 2002.

HAESBAERT, Rogério. Concepções de território para entender a desterritorialização. In: SANTOS, Milton et al. Território, territórios: ensaios sobre o ordenamento territorial. Niterói: Lamparina, 2007.

Rogério. Desterritorialização: entre as redes e os aglomerados de exclusão. In: In: CASTRO, Iná Elias de; GOMES, Paulo Cesar da Costa; CORREAA, Roberto Lobato. Geografia: conceitos e temas. Rio de Janeiro: Bertrand Brasil, 2001.

HARGREAVES, Andy; EARL, Lorna; RYAN, Jim. Educação para mudança: recriando a escola para adolescentes. Porto Algre: Artmed Editora, 2001.

HARVEY, David. Condição pós-moderna: uma pesquisa sobre as origens da mudança cultural. 25a ed. São Paulo: Editora Loyola, 2014.

HELLER, Agnes. Uma crise global da civilização: os desafios futuros. In: HELLER, Agnes et al. A crise dos paradigmas em ciências sociais e os desafios para o século XXI. Rio de Janeiro: Contraponto, 1999.

HERNÁNDEZ, Fernando. Cultura visual, mudança educativa e projeto de trabalho. Porto Alegre: Artes Médicas Sul, 2000.

JAPIASSU, Hilton. A crise das ciências humanas. São Paulo: Editora Cortez, 2012.

JENKINS, Henry. Cultura da convergência. $2^{a}$ ed. São Paulo: Aleph, 2009. 
KAERCHER, Nestor André. A geografia é o nosso dia-a-dia. In: CASTROGIOVANNI, Antonio Carlos et al. Geografia em sala de aula: práticas e reflexões. $3^{a}$ ed. Porto Alegre: Editora da Universidade/UFRGS/Associação dos Geógrafos Brasileiros. São Paulo/Porto Alegre, 2001.

KAISER, Bernard. O geógrafo e a pesquisa de campo. In: Boletim Paulista de Geografia. São Paulo, n. 84, p. 93-104, 2006.

KOZULIN, Alex. Instrumentos psicológicos: la educación desde una perspectiva sociocultural. Barcelona: Paidós, 2000.

Alex. O conceito de atividade na psicologia soviética: Vygotsky, seus discípulos, seus críticos. In: DANIELS, Harry. (org.). Uma introdução a Vygotsky. São Paulo, SP: Edições Loyola, 2002.

KROPOTKIN, Piotr. O que a geografia deveria ser. In: RECLUS, É; KROPOTKIN, Piotr. Escritos sobre educação e geografia. $1^{a}$ ed. São Paulo: Terra Livre, 2014.

KUENZER, Acácia Zeneida. Trabalho e escola: a aprendizagem flexibilizada. XI Anped Sul - Reunião Científica Regional da Anped: educação, movimentos sociais e políticas governamentais, UFPR, Curitiba, 24-27 jul. 2016.

LABEYRIE, Jacques. Introdução ao estado atual do mundo. In: MORIN, Edgar. A religação dos saberes: o desafio do século XXI. $2^{\text {a }}$ ed. Rio de Janeiro: Bertrand Brasil, 2002.

LA BLACHE, Paul Vidal de. O Princípio da Geografia Geral. Geographia, Revista do Programa de Pós-Graduação em Geografia da UFF. Niterói/Rio de Janeiro, UFF/EGG, nº 6, ano III, p. 135-147, 2002.

LEMES, Mariana Martins. Interferências no tempo-espaço da aula: percepções dos professores sobre a política educacional de São Paulo. Dissertação Mestrado. Faculdade de Filosofia, Letras e Ciências Humanas da Universidade de São Paulo. Departamento de Geografia, 2017.

LEMOS, André; LÉVY, Pierre. O futuro da internet: em direção a uma ciberdemocracia planetária. São Paulo: Paulus, 2010.

LÉVY, Pierre. O que é o virtual? 1ª ed. São Paulo: Editora 34, 1996.

Pierre. Cibercultura. São Paulo: Editora 34, 1999.

LIMA, E. S. Indagações sobre currículo: currículo e desenvolvimento humano/Elvira Souza Lima; organização do documento Jeanete Beauchamp; Sandra Denise Pagel; Aricélia Ribeiro do Nascimento - Brasília: Ministério da Educação, Secretaria da Educação Básica, 2007.

LURIA, A. R. Pensamento e linguagem: as últimas conferências de Luria. Porto Alegre: Artes Médicas, 1986.

MAMIGONIAN, Armen. Entrevista. In: Geosul, n. 3, $1^{\circ}$ sem, 1987. 
MARANGONI, Ana Maria Marques Camargo. Questionários e entrevistas: algumas considerações. In: VENTURI, Luis Antonio Bittar. (Org.). Praticando Geografia: técnicas de campo e laboratório. São Paulo: Oficina de textos, 2008.

MIRANDA, Maria Eliza. Contribuição ao debate atual sobre a formação de professores no Brasil: pela formação de futuras gerações na perspectiva da reconstrução do sóciocultural. Revista do Departamento de Geografia, n. 20, p. 11-22, 2010.

Maria Eliza. A atualidade de Pierre Monbeig e o direito de aprender geografia. Revista do Departamento de Geografia, p. 56/67, 2012.

Maria Eliza. A reinvenção da prática docente: interfaces e aproximações para a ressignificação da prática docente. In: $14^{\circ}$ EGAL - Encontro de Geógrafos da América Latina, 2013, Lima - PERU. Situación y Perspectivas de la Enseñanza Aprendizaje de la Geografía en América Latina, 2013.

MOLINA, Olga. Ler para aprender: desenvolvimento de habilidades de estudo. São Paulo: Editora Pedagógica e Universitária Ltda, 1992.

MONBEIG, Pierre. A geografia no ensino secundário. Boletim Geográfico. v. 2, n. 26, 1945.

Pierre. Papel e valor do ensino da geografia e de sua pesquisa. IBGE Conselho Nacional de Geografia, Rio de Janeiro, 1956.

, Pierre. Pioneiros e fazendeiros de São Paulo. São Paulo: Hicitec, 1984.

MONBEIG, Pierre; AZEVEDO, Aroldo de; CARVALHO, Maria da Conceição Vicente de. O ensino secundário de geografia. Geografia, AGB (Críticas e notas). Ano I, n. 4, 1935, p. 77-83.

MORAN, José Manuel. Inferências dos meios de comunicação no nosso conhecimento. In: Revista Brasileira de Comunicação. São Paulo: INTERCOM, vol. XVII, no. 02, 1994.

MORIN, Edgar. A cabeça bem-feita: repensar a reforma, reformar o pensamento. $9^{\text {a }}$ ed. Rio de Janeiro: Bertrand Brasil, 2004.

, Edgar. Para sair do século XX. Rio de Janeiro: Editora Nova Fronteira, 1986.

Edgar. In: MORIN, Edgar; ALMEIDA, Maria da Conceição; CARVALHO, Edgard Assis de. (Orgs.). Educação e complexidade: os sete saberes e outros ensaios. $3^{a}$ ed. São Paulo: Cortez, 2005.

Edgar. Os sete saberes necessários à educação do futuro. $2^{a}$ ed. São Paulo: Cortez; Brasília, DF: UNESCO, 2011.

NASCIMENTO, Tiago Carlos Lima do. O caminho para as secas: as imigrações para o semiárido setentrional. Dissertação de mestrado. Universidade Federal do Rio Grande do Norte. Departamento de Ciências Autuarias. Programa de Pós Graduação em Demografia, 2015. 
NEGRI, Barjas. Concentração e desconcentração industrial em São Paulo (18801990). Campinas, Editora da Unicamp, 1996.

NIDELCOFF, Maria Teresa. A escola e a compreensão da realidade. $3^{\text {a }}$ ed. São Paulo: Editora Brasiliense, 1980.

OLIVEIRA, Antonio Tadeu Ribeiro de. Reflexão teórica. Algumas abordagens teóricas a respeito do fenômeno migratório. In: OLIVEIRA, Luiz Antônio Pinto de; OLIVEIRA, Antonio Tadeu Ribeiro de. (Orgs.). Reflexões sobre os deslocamentos populacionais no Brasil. Estudos e Análises. Informações demográficas e socioeconômica. n. 4. IBGE. Rio de Janeiro, 2011.

OLIVEIRA, Maria Beatriz Villela de. Construção da linguagem, construção do mundo. In: VEIGA, Ilma Passos Alencastro; CARDOSO, Maria Helena Fernandes. (Orgs.). Escola fundamental: currículo e ensino. Campinas, SP: Papirus, 1991.

ORTIZ, Renato. Mundialização e cultura. São Paulo: Brasiliense, 1994.

PIAGET, Jean. Psicologia e pedagogia. $2^{\text {a }}$ ed. Rio de Janeiro/São Paulo: Editora Foresense, 1972.

Fontes, 2012.

Jean. Epistemologia genética. $4^{\mathrm{a}}$ ed. São Paulo: Editora WMF Martins

POZO, J. I. A solução de problemas - aprender a resolver, resolver para aprender. (Org.). Porto Alegre: Artmed, 1998.

PRADO, Simone Marassi. Formação do professor de geografia: vozes e discursos da escola e da universidade. Dissertação de mestrado. Faculdade de Filosofia, Letras e Ciências Humanas da Universidade de São Paulo, 2014.

PRESTES, Zoia. Quando não é quase a mesma coisa: traduções de Lev Semionovitch Vigotski no Brasil. Campinas, SP: Autores Associados, 2012.

RAFFESTIN, Claude. Por uma geografia do poder. São Paulo: Ática, 1993.

RAMONET, Ignacio. Geopolítica do caos. $4^{\text {a }}$ ed. Petrópolis, RJ: Vozes, 2001.

RECLUS, Élisée. A natureza da geografia. In: ANDRADE, Manuel Corrêa de. Élisée Reclus: geografia. São Paulo: Ática, 1985.

SANTOS, Laudenides Pontes dos. A relação da geografia e o conhecimento cotidiano vivido no lugar. In: Geografia: Ensino \& Pesquisa, vol. 16, n. 3, set/dez. 2012.

SANTOS, Milton. Metrópole corporativa fragmentada: o caso de São Paulo: Nobel, 1990.

Milton. Entrevista. Canal Ciência: portal de divulgação científica e tecnológica, 1998. Disponível

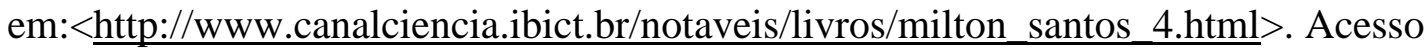
em 11 de abril de 2016. 
M. Os deficientes Cívicos. Folha de São Paulo. Caderno Mais!, Sessão Brasil 500 d. C. P. 5-8, 24 jan.1999b.

M. A natureza do espaço: técnica e tempo, razão e emoção. $4^{\mathrm{a}}$ ed. São Paulo: Editora da Universidade de São Paulo, 2012.

SANTOS, Milton. Técnica, espaço, tempo: globalização e meio técnico-científicoinformacional. $5^{\text {a }}$ ed. São Paulo: Edusp, 2013.

SCHNEUWLY, Bernard. Entrevista. In: Nova Escola: entrevista com Bernard Schneuwly. Nov, 2002.

SERRES, Michel. Tempo de crise. Rio de Janeiro: Bertrand Brasil, 2017.

SILVA, Edileuza Fernandes da. A aula no contexto histórico. In: VEIGA, Ilma Passos Alencastro. (org.). Aula: gênese, dimensão, princípios e práticas. $2^{a}$ ed. Campinas, SP: Papirus, 2011.

SILVA, Janssen Felipe da. Introdução: avaliação do ensino e da aprendizagem numa perspectiva formativa reguladora. In: SILVA, Janssen Felipe da; HOFFMANN, Jussara; ESTEBAN, Maria Teresa. (Orgs.). Práticas avaliativas e aprendizagens significativas: em diferentes áreas do currículo. Porto Alegre: Mediação, 2003.

SINGER, Paul. Os últimos 40 dos 450 anos de São Paulo. In: SZMRECSÁNYI, Tamás (Org.). História econômica da cidade de São Paulo. São Paulo: Globo, 2004.

SOARES, M. Letramento: um tema em três géneros. Belo Horizonte: Autêntico, 2002.

SORRE, Maximiliem. Fundamentos da geografia humana. In: MAGALE, Januário Francisco. (Org.). Max Sorre: geografia. São Paulo: Ática, 1984.

SOUZA, Maria Adelia Aparecida de. In: Entrevista. Revista Discente Expressões Geográficas. Florianópolis: SC, nº 03, p. 01-19, maio/2007.

SOUZA, Solange Jobim. Infância e linguagem: Bakhtin, Vygotsky e Benjamim. Campinas, São Paulo: Papirus, 2008.

TOURAINE, A. A busca de si: diálogo sobre o sujeito. Rio de Janeiro: Bertrand Brasil, 2004.

Alain. Um novo paradigma para compreender o mundo de hoje. Petrópolis: Editora Vozes, 2006.

TRAGTENBERG, M. Sobre educação, política e sindicalismo. Editora Unesp, 2004.

VIEIRA, J. A. Novas perspectivas para o texto: uma visão multissemiótica. In: VIEIRA, J. A. (Org.). Reflexões sobre a língua portuguesa: uma abordagem multimodal. Petrópolis: Vozes, 2007.

VIGOTSKI, Lev Semenovich. A formação social da mente: o desenvolvimento dos processos psicológicos superiores. $7^{\mathrm{a}}$ ed. São Paulo: Martins Fontes, 2007. 
Lev Semenovich. Pensamento e Linguagem. $4^{\text {a }}$ ed. São Paulo: Martins Fontes, 2008.

Lev Semenovich. A construção do pensamento e da linguagem. $2^{\mathrm{a}}$ ed. São Paulo: Martins Fontes, 2009.

VIGOTSKI, Lev Semenovich. Psicologia pedagógica. $3^{\text {a }}$ ed. São Paulo: Ed WMF Martins Fontes, 2010.

VIRILIO, Paul. Discussão e liberdade de movimento. In: VIRILIO, P; LOTRINGER, Sylvere. Guerra pura: a militarização do cotidiano. São Paulo: Brasiliense, 1984.

VITTE, Antônio Carlos. A geografia física no Brasil: um panorama quantitativo a partir de periódicos nacionais (1928-2006). Revista da ANPEGE, v. 4, 2008.

VOLPATO, Gilson L; BARRETO, R. E; UENO, H. M; VOLPATO, E. de S. N; GIAQUINTO, P. C \& FREITAS. G. de. Dicionário crítico para redação científica. Botucatu: Best Writing, 2013.

WEREBE, Maria José Garcia. Grandezas e misérias do ensino no Brasil: corpo e alma do Brasil. $3^{a}$ ed. São Paulo: Difusão Europeia, 1968.

YUS, Rafael. Educação integral: uma educação holística para o século XXI. Porto Alegre: Artmed, 2002. 


\section{APÊNDICES \\ APÊNDICE A \\ Termo de anuência do diretor (a) de escola}

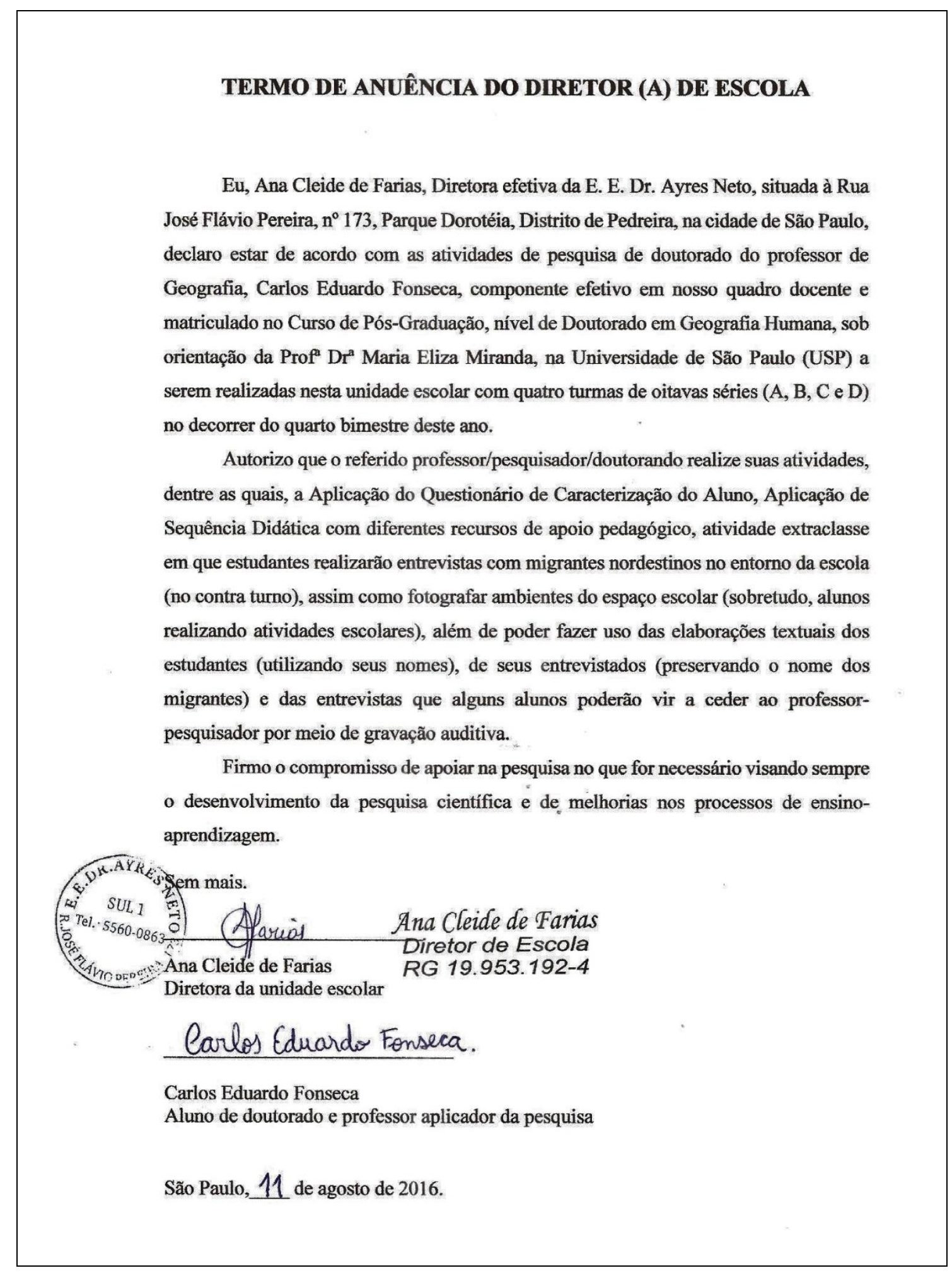




\section{APÊNDICE B}

\section{Questões-problema utilizadas nas laborações inicial e final (1)}

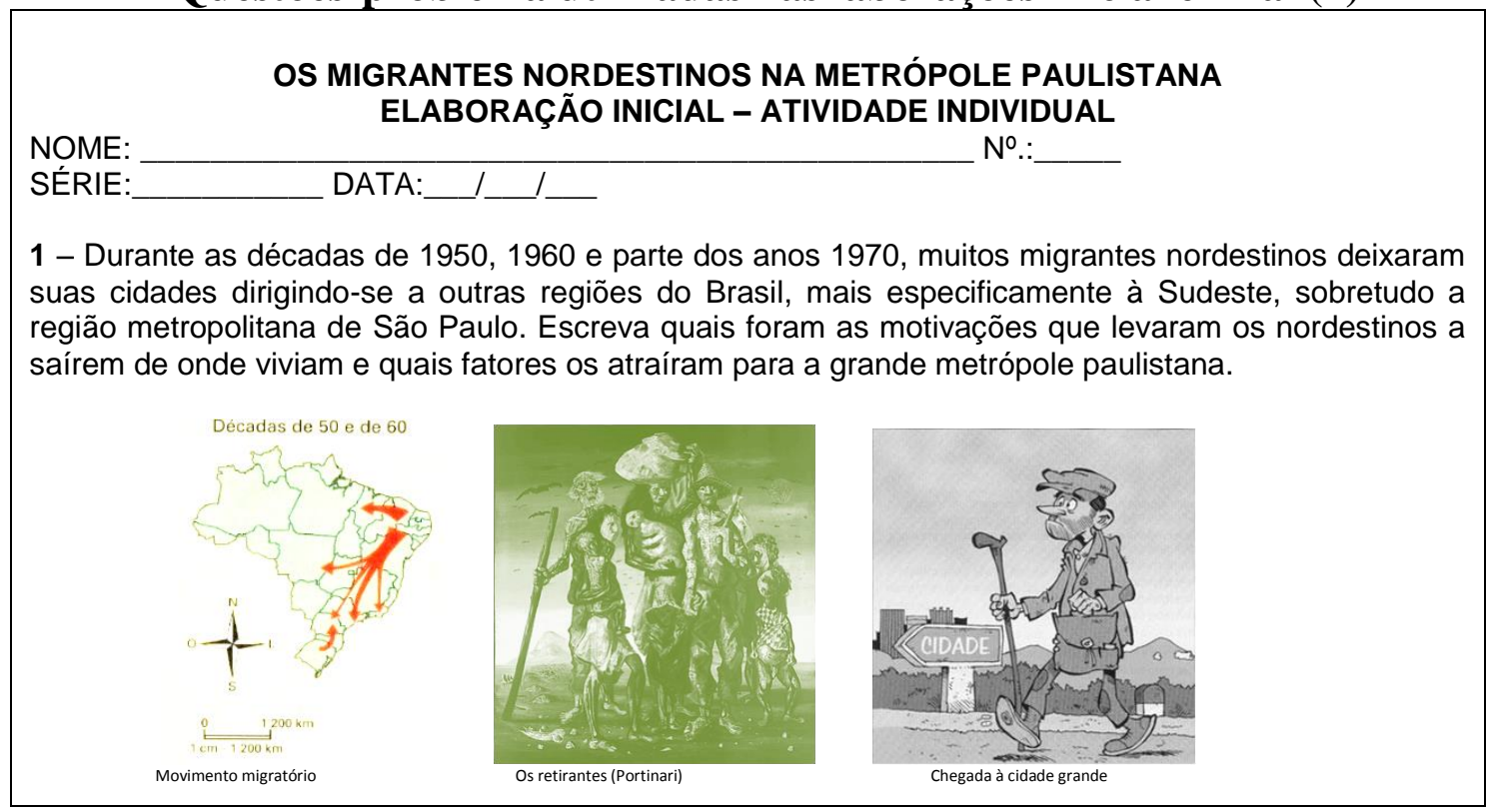

2 - Se entre as décadas de 1950 até o final da década de 1970 verificávamos um forte fluxo de migrantes nordestinos dirigindo-se à metrópole paulistana, nas últimas décadas temos visto uma significativa diminuição nesse fluxo migratório e até mesmo uma inversão, ou seja, o retorno de nordestinos às suas cidades de origem. Quais fatores podem explicar essa mudança migratória, isto é, o movimento de retorno?
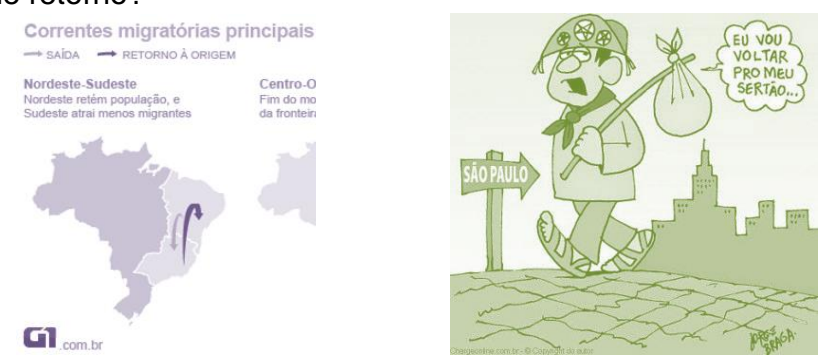

3 - A artista Tarsila do Amaral pintou no ano de 1933 a obra "Operários" (figura A), onde é possível perceber elementos que representavam a vida urbana da época, as relações sociais e de trabalho. A figura B representa a distribuição das indústrias no estado de São Paulo até os anos de 1975 e depois até o ano de 1986. Por fim (figura C), há a obra "O desempregado", de 1999, do artista plástico Hilário Sineiro Machado. Quais relações podemos fazer entre as três imagens apresentadas.

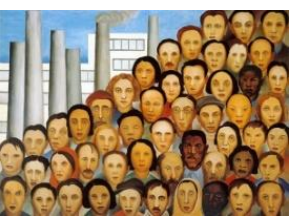

Figura A

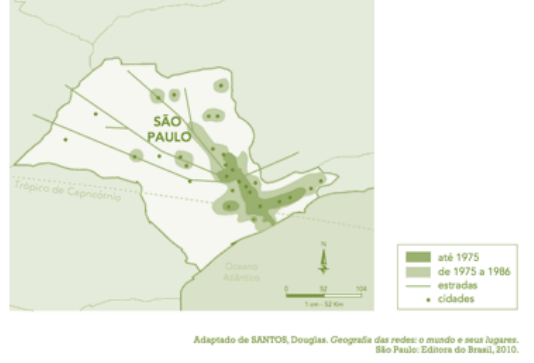

Figura B

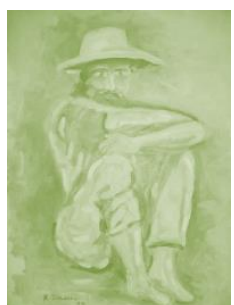

Figura C

Imagens retiradas das fonte: http://geografalando.blogspot.com.br; Catálogo Raisonné C. Portinari (2004),

https://cardapiopedagogico.blogspot.com.br; http://g1.globo.com/brasil; https://cardapiopedagogico.blogspot.com.br; http://www.brasil.gov.br/educacao; http://www.geografiaparatodos.com.br. Acesso em 12 de agosto de 2016. 


\section{APÊNDICE C}

\section{Modelo de questionário de entrevista com migrante nordestino}

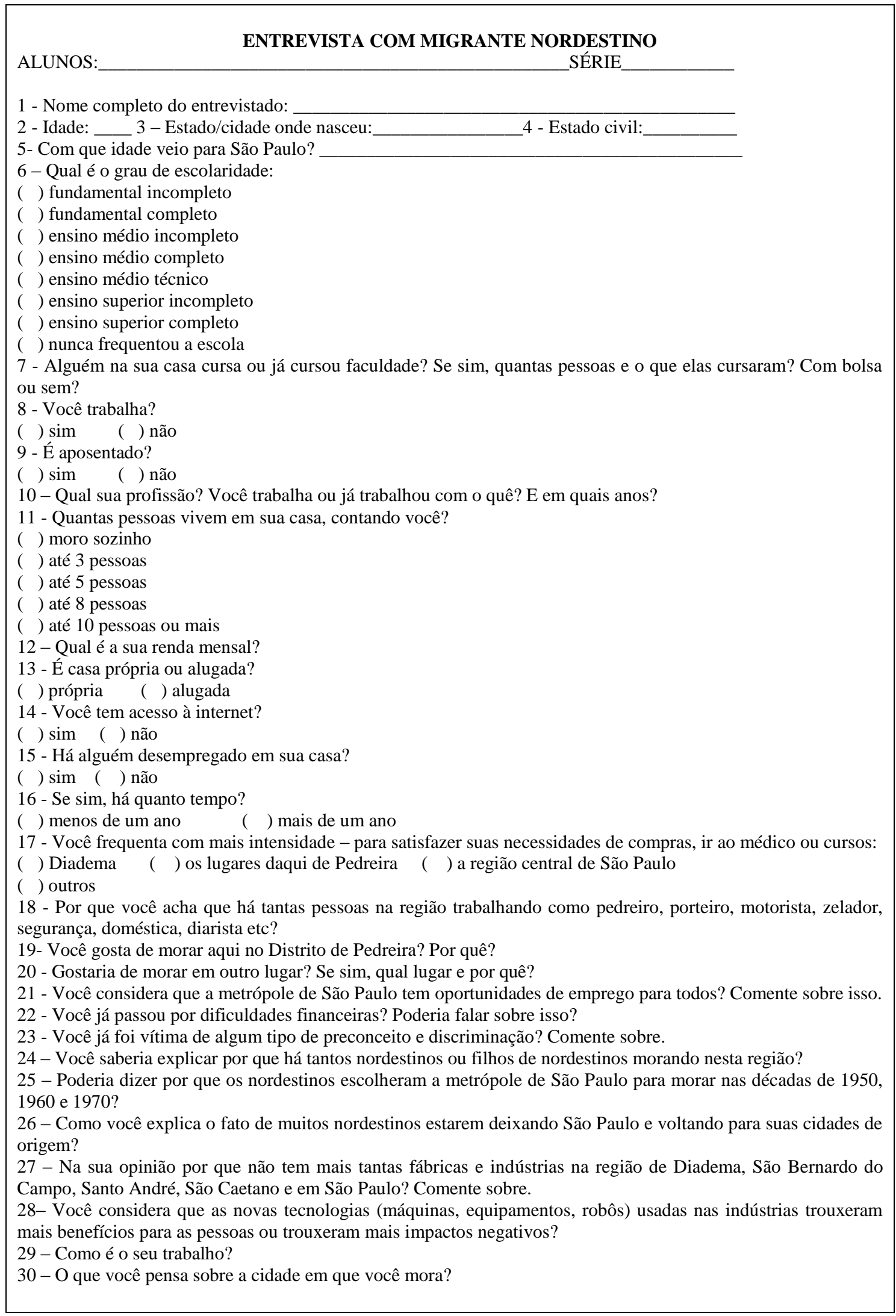




\section{APÊNDICE D}

\section{Modelo de instrumento utilizado para mediação com imagens em processo de Experiência de Aprendizagem Mediada}

Analise atentamente as imagens e responda em uma folha separada as questões que constam no final da página.

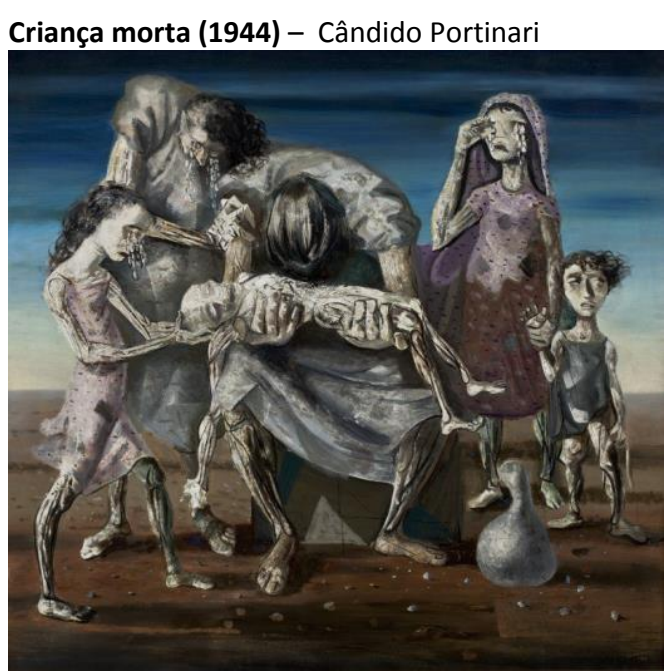

Fonte: Catálogo Raisonné C. Portinari (2004)

Retirantes (1944) - Cândido Portinari

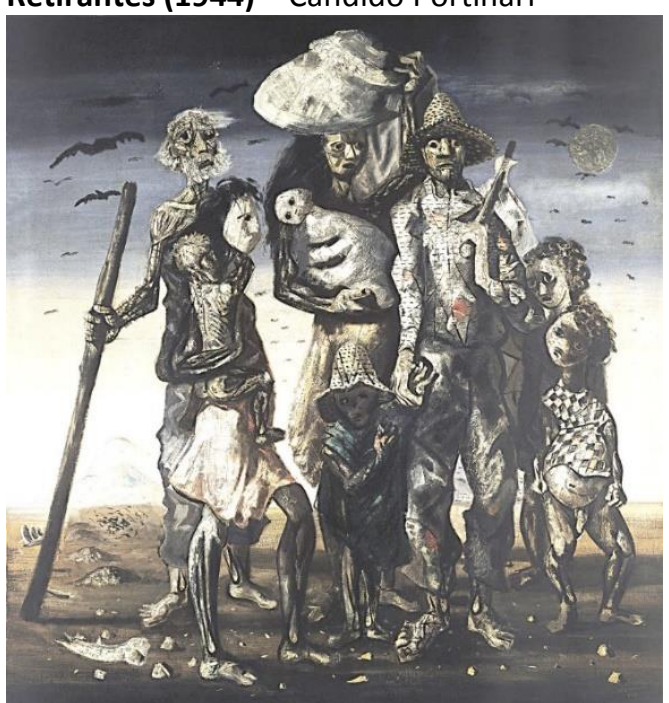

Fonte: Catálogo Raisonné C. Portinari (2004)

$\mathbf{1}$ - O que teria levado a criança representada na primeira imagem à morte?

2 - Quais objetos podemos identificar nesta primeira imagem? Qual seria sua utilidade deles?

3 - Quais as características dos solos apresentados nas duas imagens?

4 - Identifique na obra "Retirantes" elementos que caracterizam o lugar como semiárido ou sertão nordestino.

5 - Quantas pessoas aparecem no quadro "Retirantes"?

6 - Quais semelhanças e diferenças é possível estabelecer entre as duas imagens? 


\section{APÊNDICE E}

\section{Modelo de enunciado da elaboração final $n^{0} 2$} NOME:

SEQUÊNCIA DIDÁTICA - ELABORAÇÃO FINAL №2 (DISSERTAÇÃO) - ATIVIDADE INDIVIDUAL NOME:

№

SÉRIE: DATA:

1 - Imagine que a menina Maria, da animação Vida Maria, pudesse ter seu destino modificado, tendo uma vida diferente, não circunscrita ao quintal de sua casa na região semiárida nordestina. Elabore um texto pensando em duas situações: Maria migrando para a metrópole paulistana nas décadas de 50, $\mathbf{6 0}$ ou $\mathbf{7 0}$ do século passado; e a vida de Maria chegando na grande metrópole nos dias atuais. A redação deverá ter título, conter um mínimo de 18 linhas, evitar rasuras, conter parágrafos, pontuação e atenção ao bom uso da língua portuguesa. As imagens e gráficos da página anterior deverão servir como fontes de apoio ao texto. 


\section{APÊNDICE F}

\section{Modelo de folha de apoio utilizada na elaboração final $\mathbf{n}^{0} 2$ (dissertação)}

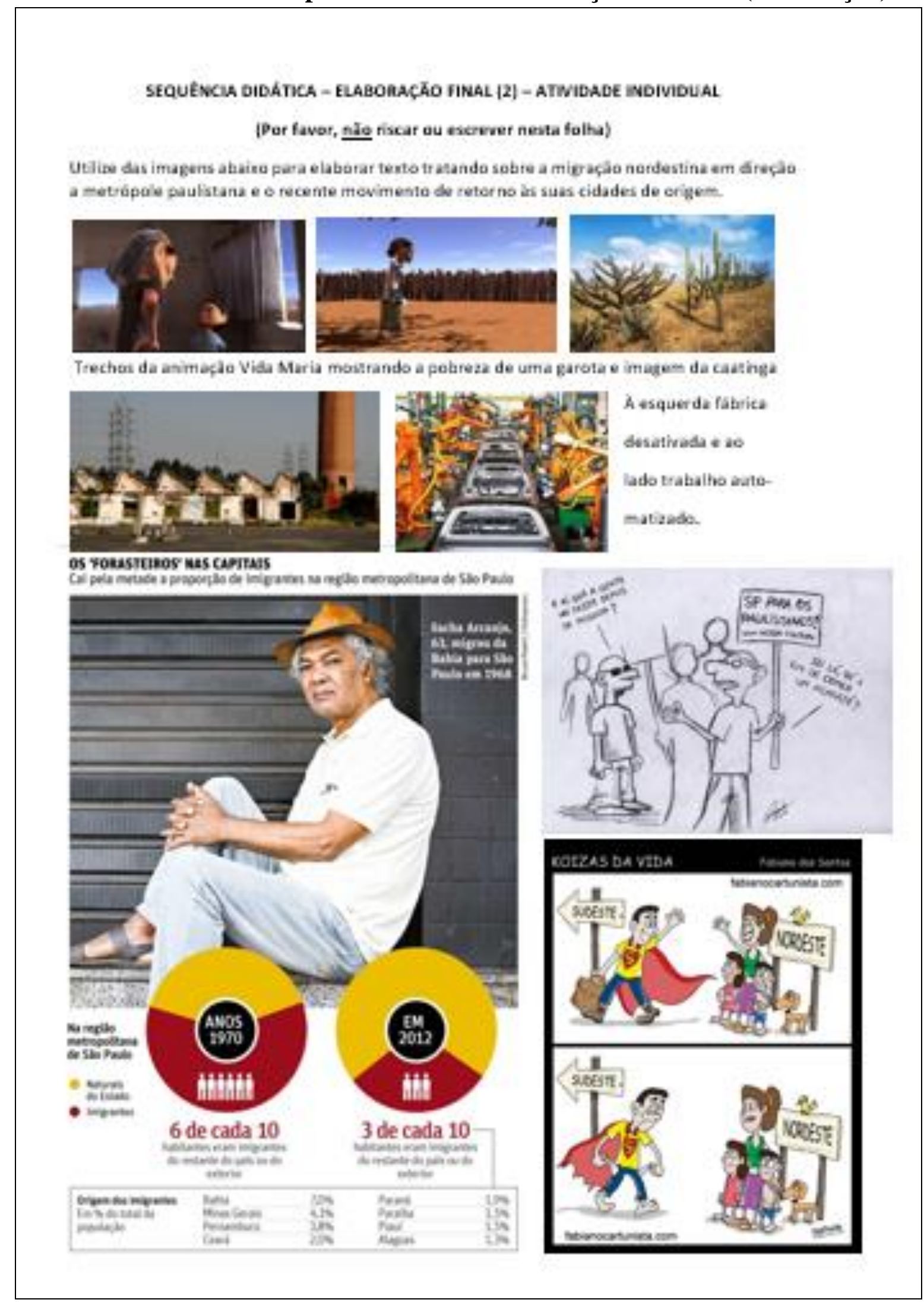




\title{
ANEXOS
}

\section{ANEXO - A}

\section{Texto utilizado em sala de leitura no processo de Aprendizagem Mediada}

\author{
Em seis anos, mais de $\mathbf{4 0 0}$ mil nordestinos voltaram para cidade de origem \\ Carlos Madeiro - Especial para o UOL Notícias - Em Maceió (10/01/2010)
}

Números apontam para uma inversão de sentido na rota dos nordestinos para o sul do país nos últimos anos. A professora do departamento de Economia da UFPB (Universidade Federal da Paraíba) Liedje Siqueira revela que a migração de retorno começou a existir em meados desta primeira década do século 21. Entre 2002 e 2007, os números mostram que mais de 400 mil voltaram para casa.

Com frustração ou sucesso, nordestinos fazem caminho inverso e retornam.

"A migração de retorno para o Nordeste é um fenômeno relativamente novo. De fato, com base nos dados da Pnad [Pesquisa Nacional por Amostra de Domicílios] 2007, observa-se, por exemplo, que das 862 mil pessoas que vieram morar na região Nordeste, entre os anos de 2002 e 2007 , aproximadamente $47,5 \%$ eram pessoas que estavam voltando aos seus locais de nascimento", contou.

Os dados revelam que o Estado de São Paulo, que sempre foi o maior receptor dos nordestinos, tornou-se hoje o maior "exportador" de volta dos mesmos - $61 \%$ dos que retornaram vieram de SP. "Por dois anos consecutivos, em 2006 e 2007, este Estado enviou mais pessoas a outros locais do que recebeu. Isto resultou em um saldo migratório negativo, entre os anos de 2002 e 2007, no valor de 135 mil pessoas. A maior parte é de nordestinos que perfizeram o caminho de volta.

Segundo a professora, a Pnad mostra que o retorno acontece, na maioria das vezes, por falta de oportunidade. "Cerca de $60 \%$ dos que retornaram eram do sexo masculino e aproximadamente $78 \%$ tinham menos de 49 anos. Estas informações mostram que eles estavam em plena capacidade produtiva de trabalho. Observou-se que somente 33,01\% conseguiram um emprego formal. Outros $35 \%$ se encontravam em atividades consideradas autônomas", conta. Programas sociais e esgotamento industrial

Para o professor de economia regional da Ufal (Universidade Federal de Alagoas), Cícero Péricles, alguns fatores regionais são determinantes nessa mudança de rota. "Os registros da migração coincidem com o esgotamento dos destinos tradicionais dos pobres do Nordeste: as fronteiras agrícolas, como na Amazônia e Centro-Oeste; com a perda de atração na construção civil do Sudeste e com o maior padrão de exigência no setor da indústria paulista, onde a mão-de-obra nordestina não encontra colocação. Outro elemento importante é que as condições sociais da região [Nordeste] melhoraram muito nos últimos anos", explica, ressaltando que o Nordeste cresce em ritmo mais acelerado do que nas demais regiões.

Para o economista, um dado importante que os números revelam é que mais da metade das famílias nordestinas pobres recebe algum benefício federal, seja do Bolsa Família ou da Previdência Social. "Isso é determinante na contenção da miséria. Das 14,5 milhões de famílias no Nordeste, sete milhões recebem da Previdência e 5,6 milhões recebem o Bolsa Família. O salário mínimo, forma de pagamento de dois terços dos assalariados na região, tem impactos no Nordeste maior do que em qualquer outra região. Como hoje existem alguns polos de desenvolvimento econômico, junto com esse colchão social, as pessoas acabam apostando mais na vida por aqui", afirmou. Péricles diz ainda que, nos últimos dez anos, as secas tiveram impactos minimizados pelas políticas públicas, o que fortaleceu o vínculo com a região. "Aí acontece outro fenômeno importante: o Nordeste se urbanizou e conta com $70 \%$ da população nas cidades. Hoje é mais comum a migração rural para as pequenas cidades, e daí para as grandes. O fenômeno que se percebe é que, ao invés de ir direto para São Paulo, ele tenta a vida numa capital nordestina", explicou o economista. 


\section{ANEXO - B}

\section{Texto utilizado em sala de leitura no processo de Aprendizagem Mediada}

\section{Com frustração ou sucesso, nordestinos fazem caminho inverso e deixam o sul do país} Carlos Madeiro - Especial para o UOL Notícias - Em Maceió - 10/01/2010

Em 1938, o escritor Graciliano Ramos contou a história do retirante Fabiano. O livro "Vidas Secas" retrata o Nordeste e a retirada dos sertanejos para outras regiões do país. Passadas décadas de migração, o nordestino começa a fazer a viagem de volta. "Se fosse hoje, Graciliano contaria o Nordeste sob a ótica do Bolsa Família e da Previdência, e com a volta dessa família nordestina sem perspectiva em São Paulo", compara o professor de economia regional da Ufal (Universidade Federal de Alagoas) Cícero Péricles. Em seis anos, mais de 400 mil nordestinos voltaram para sua cidade de origem. Os famosos paus-de-arara, que durante boa parte do século 20 foram o símbolo da migração nordestina para o "Sul", deram lugar aos ônibus que trazem os nordestinos de volta à terra natal. Ao contrário do que existia até o início desta década, hoje os números apontam que a região Nordeste recebe mais pessoas do que envia.

A esperança em ter uma vida melhor levou milhões deles a tentar a vida em outras regiões, em especial o Sudeste. Morar no sul do país sempre foi um sonho de quase todo sertanejo nordestino, como o trabalhador rural Leonardo Tavares, 22. Morador da zona rural do município da Pedra, no sertão de Pernambuco, o jovem conta que o desejo de morar em São Paulo, virou frustração no ano passado. "Não posso dizer que realizei o sonho porque pensei que era uma coisa e era outra. Eu fui trabalhar à noite, em uma usina de cana, e era muito perigoso. Então voltei com seis meses de trabalho", afirma.

De São Paulo, ele conta que trouxe apenas $\mathrm{R} \$ 2.000$, que investiu para comprar um terreno. Em Pernambuco, voltou a trabalhar no roçado e vive na casa dos pais, que são aposentados e recebem um salário mínimo cada um. "Hoje voltei para casa e jamais retornarei a São Paulo. Vou construir minha casinha no terreno que comprei e viver aqui, perto de minha família", conta.

Há também quem volte para perto da família por ter perdido o emprego. 0 técnico em mecânica João Abelardo, 49, morou por 17 anos em São Paulo e voltou em 2008 após ser demitido, no ano passado, de uma montadora em São Caetano, no ABC paulista. "Falaram que era a crise mundial. Muitos foram demitidos. Como estava difícil arrumar emprego e tinha um dinheirinho, voltei para minha cidade [Arapiraca, no agreste de Alagoas]. Vou pegar o dinheiro que ganhei e tentar montar o meu negócio", disse.

Sucesso no Rio

Entre os inúmeros casos de retorno frustrado, alguns regressos do Sudeste acontecem após carreiras bem sucedidas. Depois de 32 anos trabalhando como jockey, Juvenal Machado deixou a fama de recordista em vitórias no GP Brasil de Turfe (cinco vezes campeão) e retornou ao alto sertão de Alagoas, em 2002. Ele hoje mora na cidade de Delmiro Gouveia e tem uma fazenda onde cria animais e, claro, ainda monta cavalos. Apesar do sucesso como atleta, Juvenal conta que, assim como todo nordestino, teve que "ralar" muito para alcançar a fama.

Em julho do ano passado, ele virou tema do documentário "Lá vem o Juvenal" - numa referência à frase que marcou as narrações do locutor oficial do Jockey Club do Rio de Janeiro, Ernani Pires Ferreira. Mas a aposta no Sudeste ainda é uma tônica do nordestino que quer melhorar de vida. A jornalista Andréia Amorim arrumou as malas e deixou Garanhuns, terra do presidente Lula em Pernambuco, para tentar a vida em São Paulo como cantora de rock lírico no ano passado. "Decidi morar em São Paulo porque é uma cidade cosmopolita, que abriga todos os gêneros, todas as tribos. Primeiro morei em Campinas, mas agora estou na capital. Me mudei com a intenção de viver de música mesmo, divulgar o trabalho, e a receptividade tem sido muito boa", comemora a cantora, que quer voltar ao Nordeste apenas para fazer shows. 


\title{
ANEXO - C \\ Texto utilizado em sala de leitura no processo de Aprendizagem Mediada
}

\author{
Refletindo sobre a desindustrialização em São Paulo \\ Confins - Revista franco-brasileira de geografia 7 | 2009: Número 7 (ADAPTADO) \\ Rafael Faleiros de Padua
}

Para pensar a desindustrialização em São Paulo no momento atual tomamos por ponto de partida o fato de que a industrialização foi a força indutora da urbanização galopante que a cidade passou no século XX. A metrópole que hoje tem 10 milhões de habitantes (a região metropolitana, formada por 39 municípios, tem perto de 20 milhões de habitantes), se constituiu, sobretudo a partir da segunda metade do século XX, em um grande parque industrial, concentrando a maior parte da produção industrial do Brasil, o que faz com que, a partir da década de 1970, se torne a principal cidade do país (economicamente e culturalmente). Nessa breve exposição, buscamos ressaltar que a urbanização de São Paulo e a sua condição de metrópole hegemônica do Brasil se deve ao seu crescimento industrial.

A industrialização de São Paulo se deu em dois períodos principais - o primeiro vai do final do século XIX até a década de 1930. O segundo começa na década de 1930 timidamente, mas toma força decisiva a partir da década de 1950, a partir de esforços do governo federal em direção a uma industrialização pesada no país, buscando superar a condição de país exportador de matérias-primas (produtos primários) e importador de produtos industrializados.

No entanto, é na década de 1950 que se dá o principal esforço em direção a uma verdadeira industrialização do país, no governo desenvolvimentista de Juscelino Kubischek, quando há o incentivo para que grandes grupos industriais estrangeiros se instalem no Brasil e para que se constitua uma consistente indústria de base e um verdadeiro parque industrial diversificado.

Também neste momento a cidade de São Paulo e sua região foram privilegiados na instalação das indústrias, por possuírem maior infra-estrutura. Essa política em favor da indústria induziu grandes movimentos migratórios no país, sobretudo tendo como ponto de partida a região Nordeste, deprimida economicamente, e ponto de chegada a região Sudeste, principal região da industrialização. É na década de 1950-1960 que se inverte a relação população rural/população urbana, quando esta última passa a ser mais numerosa que a primeira. São Paulo nesse momento (1950-década de 1980) recebe milhões de migrantes nacionais, que vão fazer parte da massa de trabalhadores da grande indústria, formando as grandes periferias da metrópole.

Com o próprio desenvolvimento da atividade industrial e a metropolização de São Paulo, a cidade se densifica. A urbanização ocupa os vazios, os espaços industriais ficam congestionados. Este é um fenômeno que ocorre tanto nas áreas de industrialização mais antiga (mais centralizadas) quanto nas áreas de industrialização recente (periféricas em relação às áreas mais valorizadas da cidade). Esse processo de densificação da cidade acarreta, como dissemos anteriormente, o congestionamento de áreas industriais, assim como a valorização dos terrenos industriais (e consequente aumento dos impostos territoriais). Ou seja, são fatores que desestimulam a realização da atividade industrial em alguns lugares da metrópole.

A desindustrialização é um fenômeno observado nas grandes cidades capitalistas industrializadas, tanto do mundo desenvolvido quanto do mundo subdesenvolvido. Em São Paulo, a desindustrialização é identificável localmente, ou seja, em lugares determinados (e delimitados) da metrópole, onde a indústria era a atividade econômica principal e deixa de sê-lo, dando lugar a outras atividades ou deixando o espaço degradado ou em processo de deterioração. Assim, não podemos dizer que a metrópole de São Paulo como um todo se desindustrializa, e sim que áreas da metrópole se desindustrializam, mesmo porque a indústria ainda tem um peso considerável no conjunto das atividades econômicas da metrópole. Podemos dizer que São Paulo passa por uma desconcentração industrial relativa, perdendo parte de seu peso industrial em relação ao interior do Estado de São Paulo e em relação ao resto do país. Por outro lado, a gestão das empresas se situa cada vez mais em São Paulo, que se consolida cada vez mais como metrópole dos negócios e elo da economia nacional com a economia mundial.

Identificamos diferentes comportamentos da desindustrialização paulistana. Nas áreas de industrialização antiga, que acompanham o percurso das linhas férreas, observa-se maiores dificuldades a uma efetiva reutilização de terrenos e consequentemente uma maior dificuldade de revalorização. São áreas mais centrais, onde a própria densificação da metrópole impõe uma acessibilidade dificultada e um maior congestionamento. Por outro lado, em algumas áreas de industrialização mais recente (segunda metade do século XX), a reutilização de terrenos provenientes da desindustrialização é mais efetiva. São áreas próximas à Avenida Marginal do Rio Pinheiros, com disponibilidade de grandes terrenos com a acessibilidade facilitada pela avenida. $O$ fato de se localizarem nas zonas oeste e sudoeste da cidade também facilita uma tendência a uma revalorização mais efetiva desses espaços de desindustrialização, tendo em vista que o eixo de valorização se encaminha para esta região (vetor sudoeste, com a expansão dos setores de gestão, financeiro, eventos, etc.).

Em alguns lugares das áreas de industrialização antiga observa-se, pontualmente, a instalação de escritórios e novos condomínios residenciais, como na Água Branca, Barra Funda e Moóca, o que não representa uma tendência a uma revalorização do conjunto dos terrenos desses espaços de desindustrialização, que permanecem como espaços reserva para possíveis novas revalorizações futuras. Em uma cidade extremamente densificada como São Paulo, os espaços de desindustrialização se tornam possibilidades de criação de novas fronteiras econômicas para os agentes hegemônicos da produção do espaço. 
ANEXO - D

Modelo de instrumento com gráfico e imagem utilizada em atividade mediada

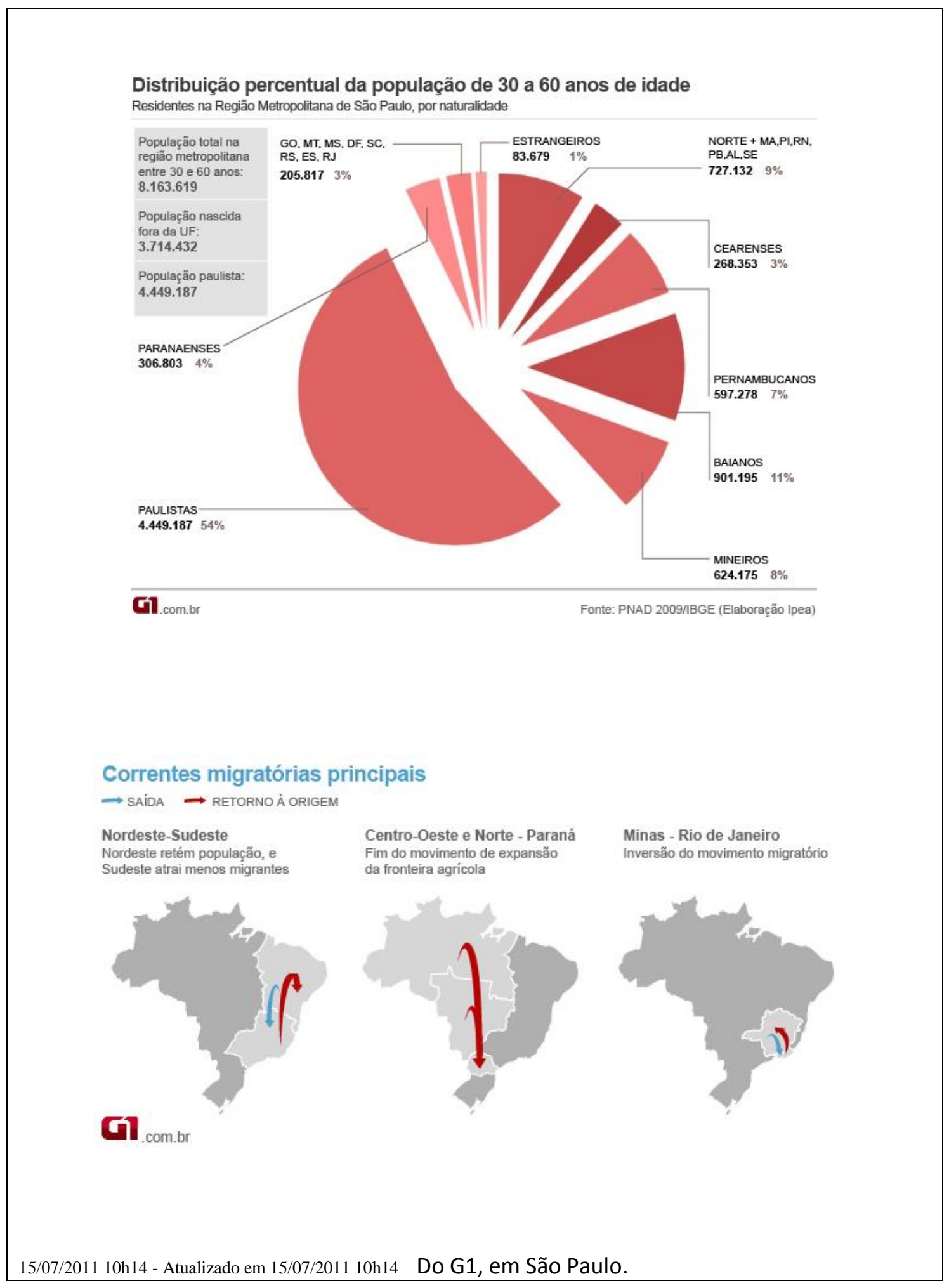




\section{ANEXO - E \\ Respostas dos alunos em relação à rotina diária}

Rebeca Valentim Nunes, $8^{\mathrm{a}} \mathrm{A}$

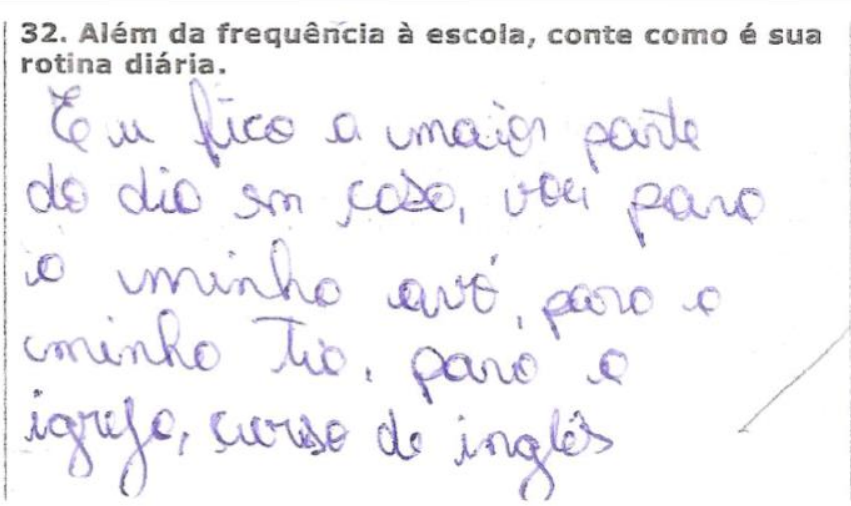

Artur Pereira de Alcântara, $8^{\mathrm{a}} \mathrm{A}$

32. Além da frequência à escola, conte como é sua rotina diária.

$$
\begin{aligned}
& \text { EU FICO MAAS AM CASA } \\
& \text { MERHENDO EM REDES } \\
& \text { SOCIAKS PELD CELULAR } \\
& \text { P PRLO COMPUTADOR }
\end{aligned}
$$

Patrícia Vitória Moreira da Silva, $8^{\mathrm{a}} \mathrm{B}$

32. Além da frrequência à escola, conte como é sua

chegour em cosa, assistir TV, comer, meser no computodor, mecer ne celular a in dormir

Guilherme Gomes da Silva, $8^{\mathrm{a}} \mathrm{B}$

32. Além da frequência à escola, conte como é sua rotina diária.

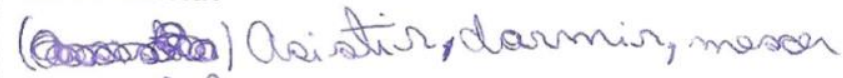
no eelular.

arsiveto tir.

Gooto de jogen mo (aro) celular ovin musica cessivatio

wides a ete. 
Inácio José dos Santos, $8^{\mathrm{a} C}$

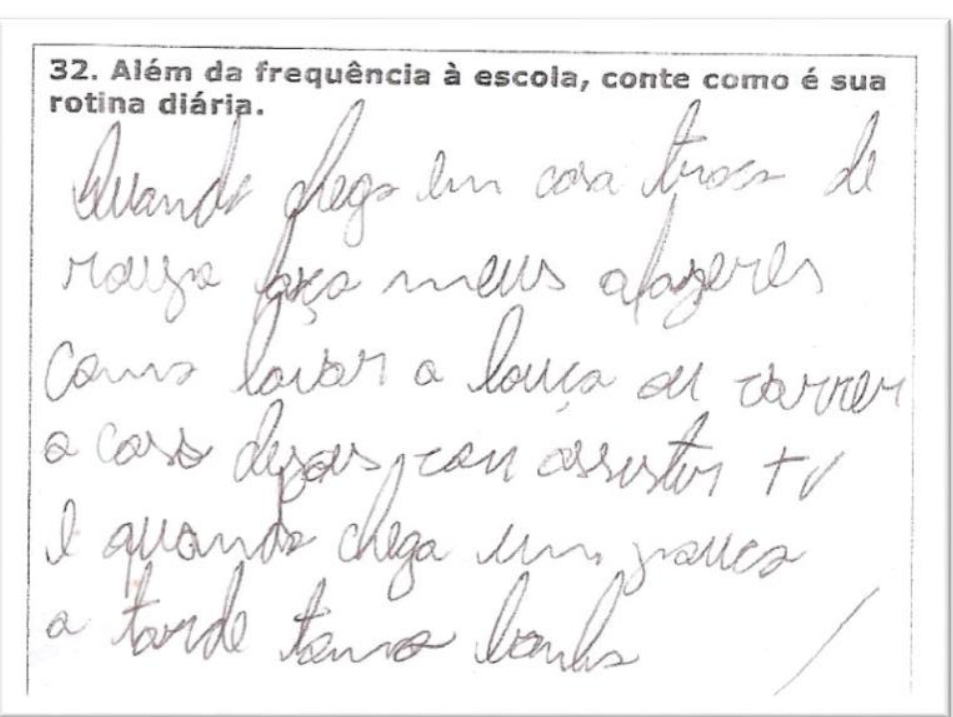

Luiz Fernando Matias, $8^{\mathrm{a} C}$

32. Além da frequência à escola, conte como é sua rotina diária.

Escale cara decaro los escela waly mada

Luiz Augusto da Silva Santos, $8^{\mathrm{a} D}$

32. Além da frequência à escola, conte como é sua rotina diária.

five em UASA Dugme, escute masica Comp

Vinícius Carlos dos Santos Oliveira, $8^{\mathrm{a} D}$

32. Além da frequência à escola, conte como é sua rotina diária.

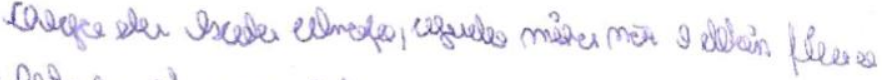

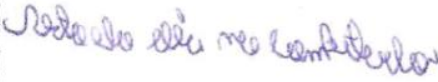




\section{ANEXO - F \\ Rotina dos alunos que trabalham fora ou ajudam em casa}

Flávia Cristina Correia dos Santos, $8^{\mathrm{a}} \mathrm{A}$

32. Além da frequência à escola, conte como é sua rotina diária.

Minha Rotina wiaria é acordar

de mankáa e fazer café para va

minha unas, depiois vou me aren.

man piara vim para uscola. vou

para uscola, quando chego da

iscola tomo banbo, almoco, e

The arrumo para pazn um bico

para vajuda mineva maio, cdeposs

vou direto pro curro, e vau para.

Casa duscanca para voltan ca

Ustuda no iautro dia cle ma unà.

Cleiton dos Santos Santana, $8^{\mathrm{a} B}$

32. Além da frequência à escola, conte como é sua rotina diária.

(Q)

SAIODA FSCOLA WO TRAUALHA

MECAMNICO

João Vitor Bonfim, $8^{\mathrm{a} B}$.

32. Além da frequência à escola, conte como é sua rotina diária.

Ulegp in coso 12:40 olmo,o Dipaes veu hosachon

das 13:00 dé as 17.00 ai vere

pre cosa bino zonlvo youre

viar momiza c elfais

assio TV ar vian asseser

$11 \mathrm{~min}$.

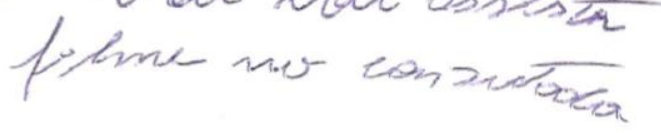


Vitória Cordeiro Rosa, $8^{\mathrm{a} C}$

32. Além da frequência à escola, conte como é sua rotina diária.

clags do excelo uas havall on

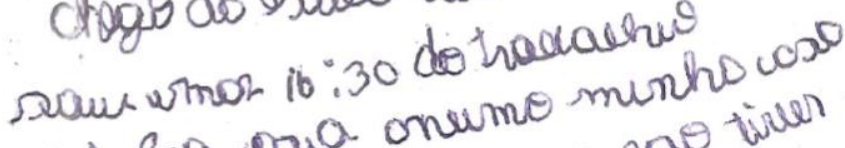

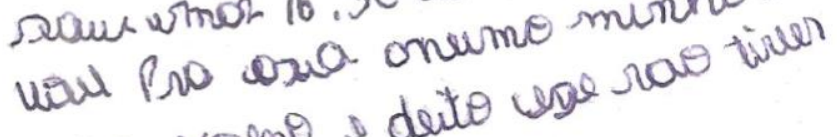
rano vadero i deito war

Joice Silva dos Santos, $8^{\mathrm{a} D}$

32. Além da frequência à escola, conte como é sua rotina diária.

FAC COMPA PARA méS IRMACES

Hevo mi Uhaffema" A escola, Chego

eme arRumo Para O CLRSO. 
ANEXO - G

\section{Respostas dos alunos em relação à rotina diária e uso das redes sociais}

Mariana Alves de Souza, $8^{\mathrm{a}} \mathrm{A}$

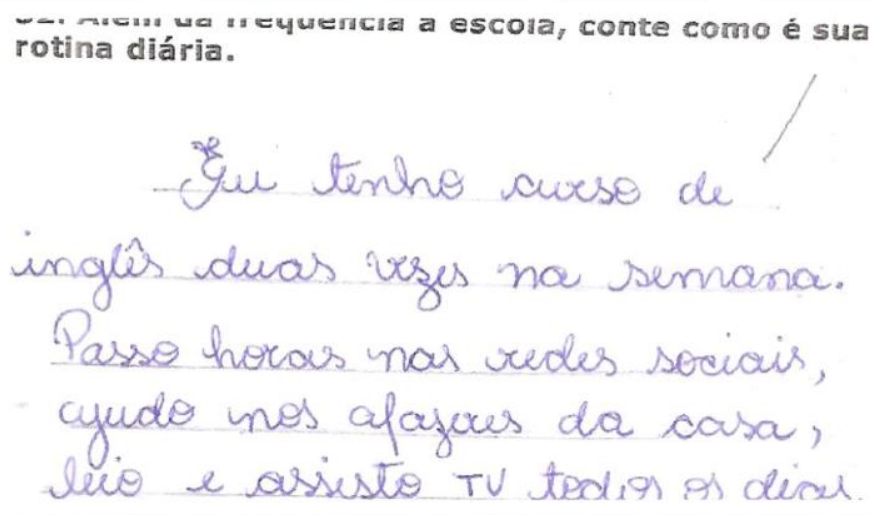

Isabella de Souza Abreu, $8^{\mathrm{a} B}$

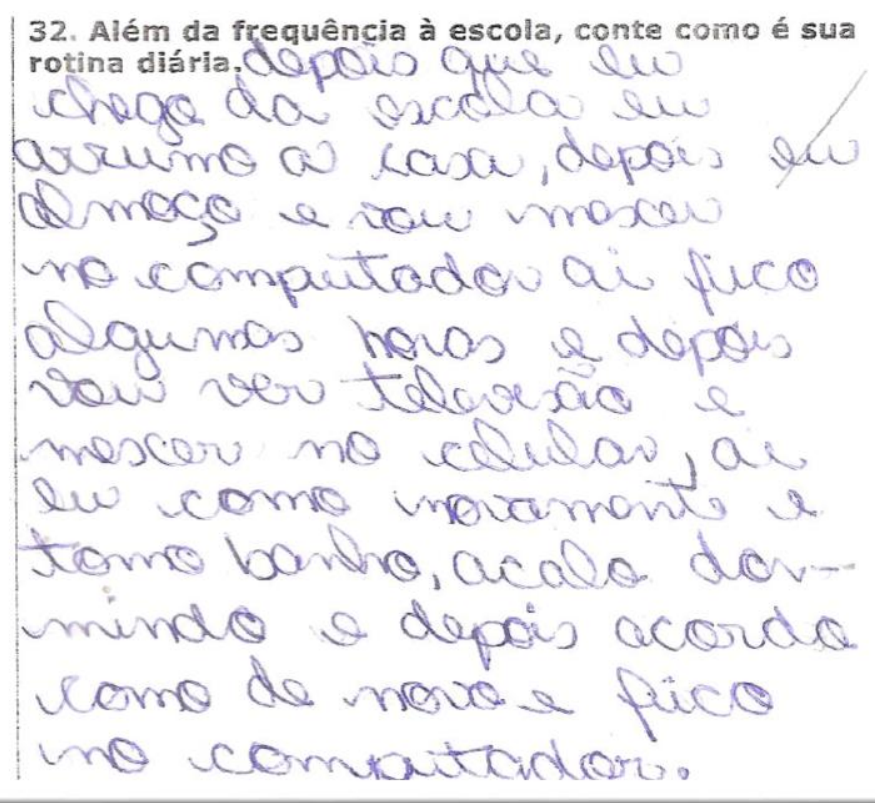

Thaís Serafim Rodrigues de Sousa, $8^{\mathrm{a} C}$

Tostas vas usequndas adenais do elscolos,

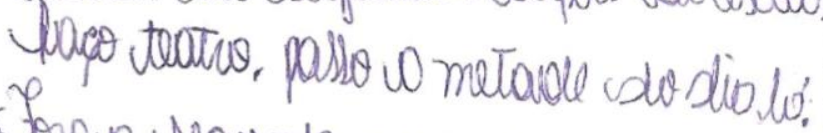

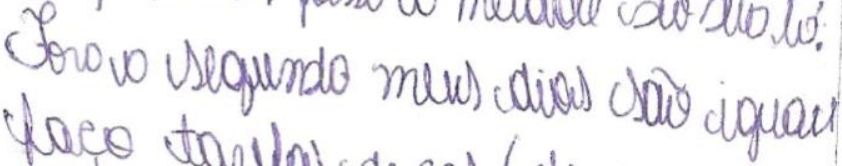
taeco tarytai so cablicle uz chrquans. lu cestundo), fico me distroundo

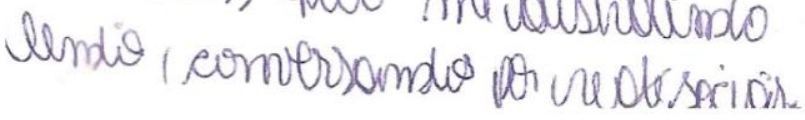


Aislan Oliveira Santos, $8^{\mathrm{a} D}$

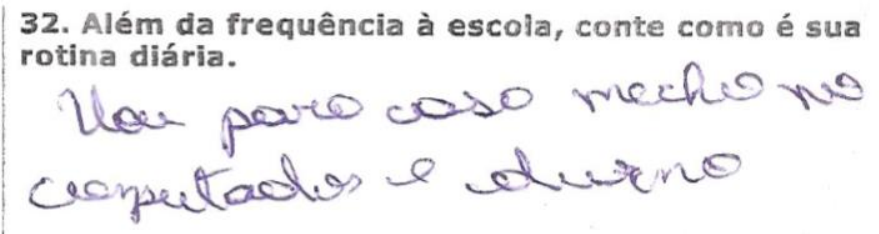




\section{ANEXO - H}

Respostas a questão do instrumento de comparação e identificação que pedia para o aluno identificar os objetos da primeira imagem (Criança Morta)

Nicolas Fonseca Grubert, $8^{\mathrm{a}} \mathrm{A}$

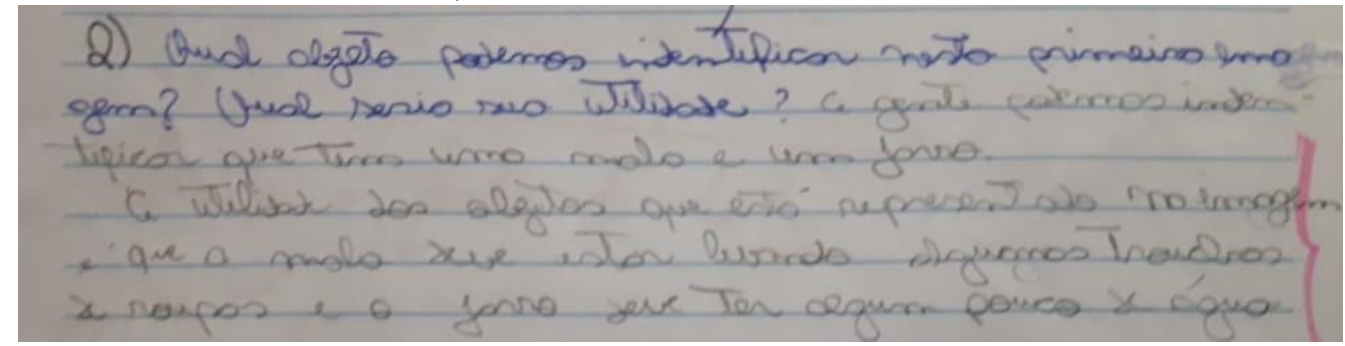

Paulo Vitor Souza, $8^{\mathrm{a} B}$

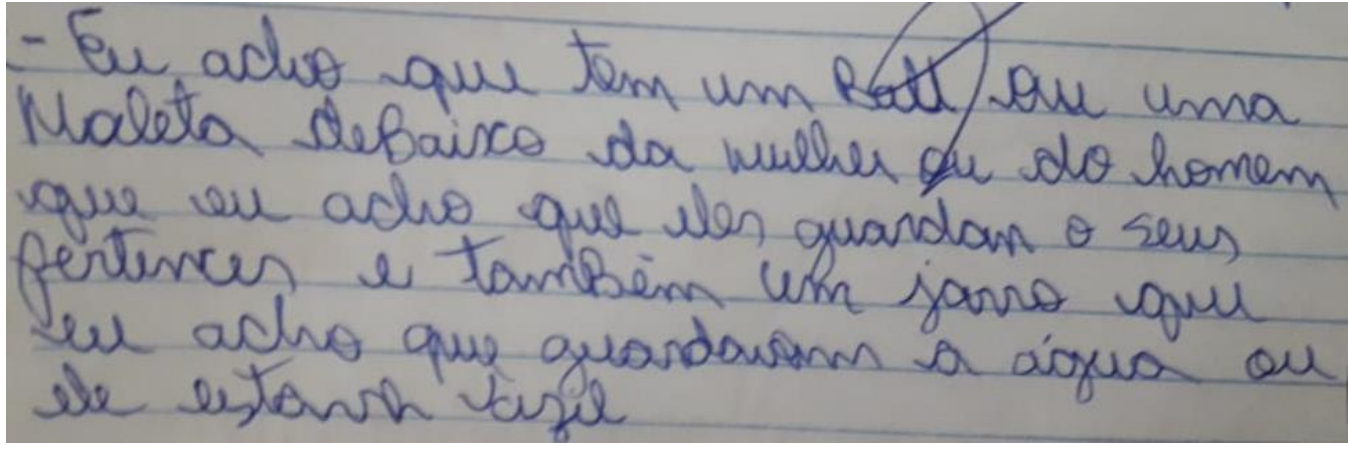

Erika Vitória Ricardo, $8^{\mathrm{a}} \mathrm{C}$

(2) Muringa e co caico, if moringo e caso eles acho-
rem aguo e tals e io caico yparo use usentarem
e oque mostram no imagem

Lorrane Ribeiro Lima, $8^{\mathrm{a} D}$

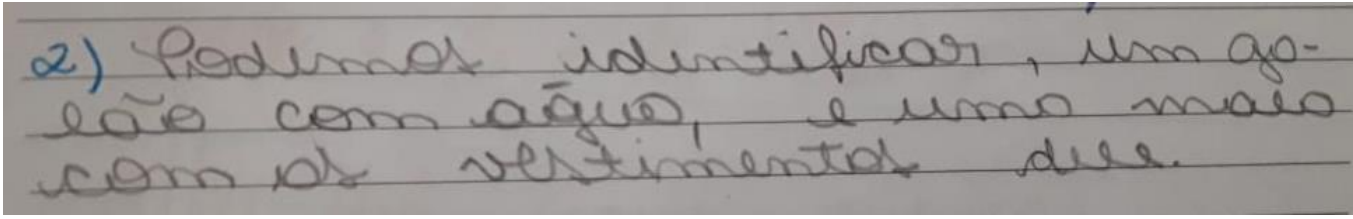




\section{ANEXO - I}

\section{Resposta à questão do instrumento de comparação e identificação}

Letícia Ferreira Lima, $8^{\mathrm{a}} \mathrm{A}$

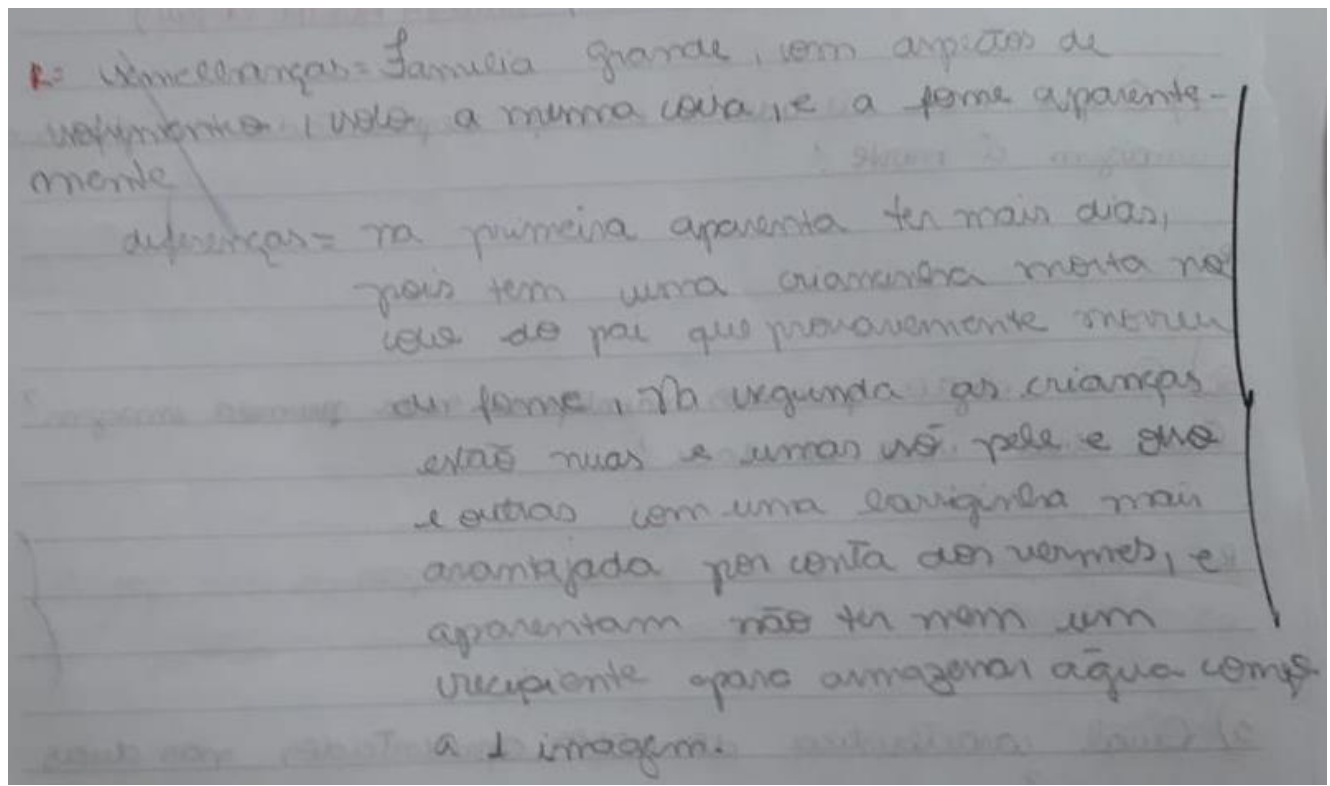

Beatriz Silva de Oliveira, $8^{\mathrm{a} B}$

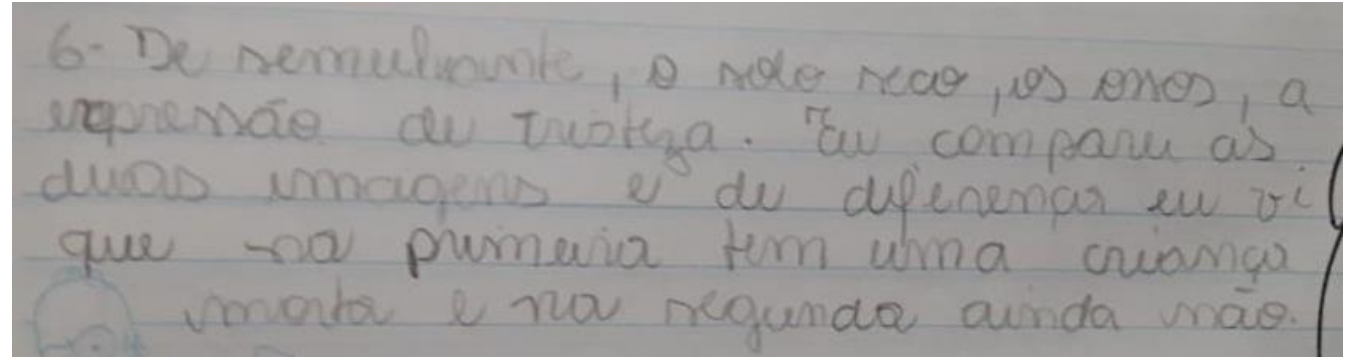

Filipe A. Souza, $8^{\mathrm{a} C}$

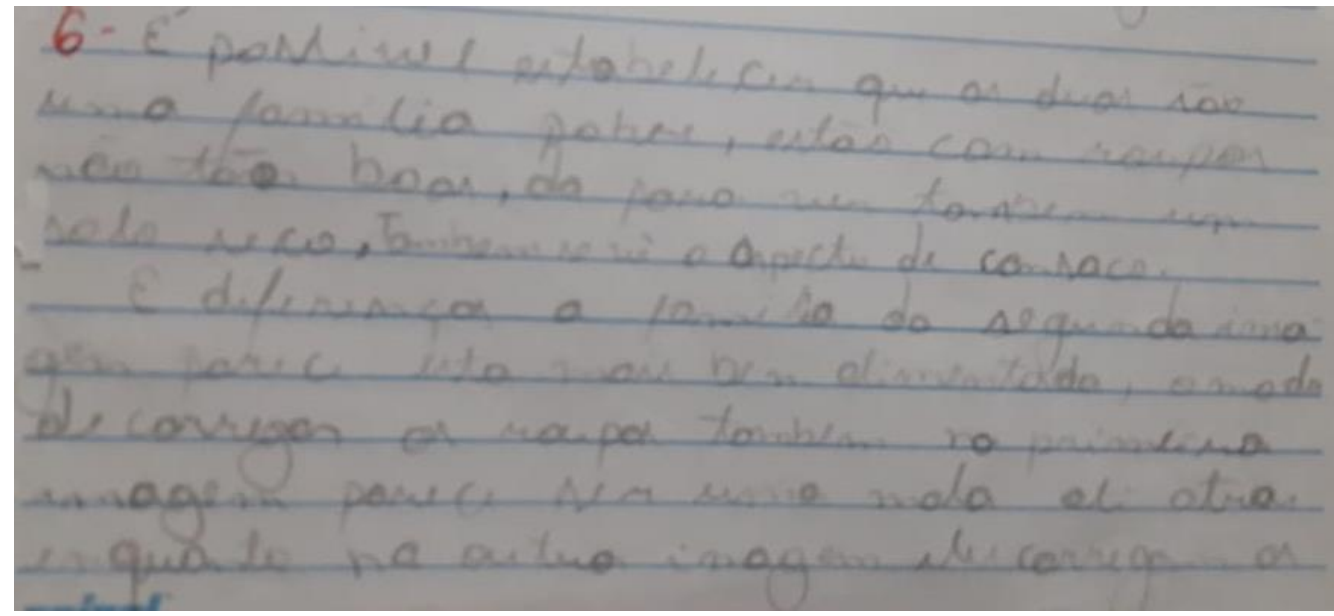


Aline Monteiro de Sousa, $8^{\mathrm{a}} \mathrm{D}$

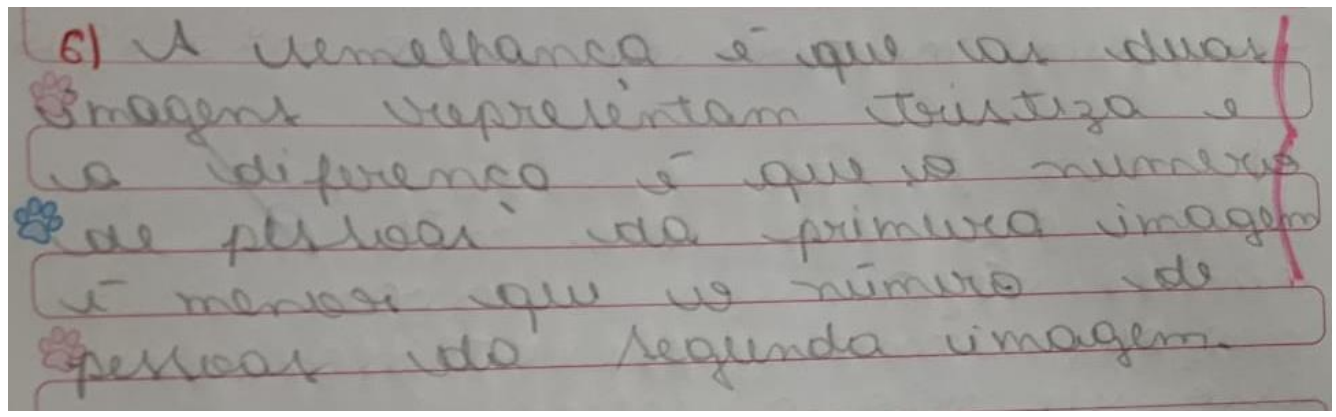




\section{ANEXO - J}

Fragmentos de respostas de estudantes à atividade contendo gráfico

Layla Rocha e Silva, $8^{a} \mathrm{D}$

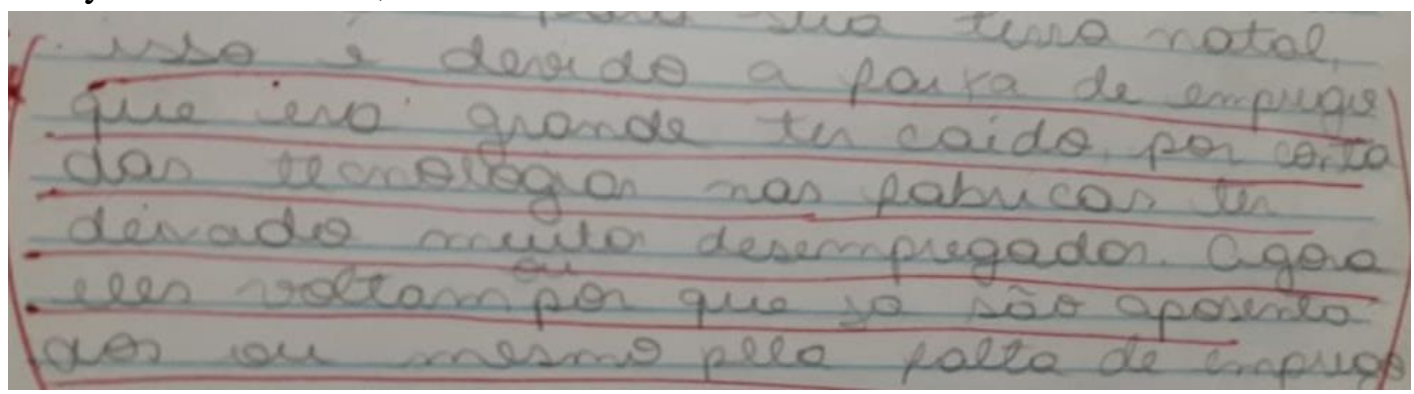

Carlos Eduardo Pereira da Silva, $8^{\mathrm{a}} \mathrm{C}$

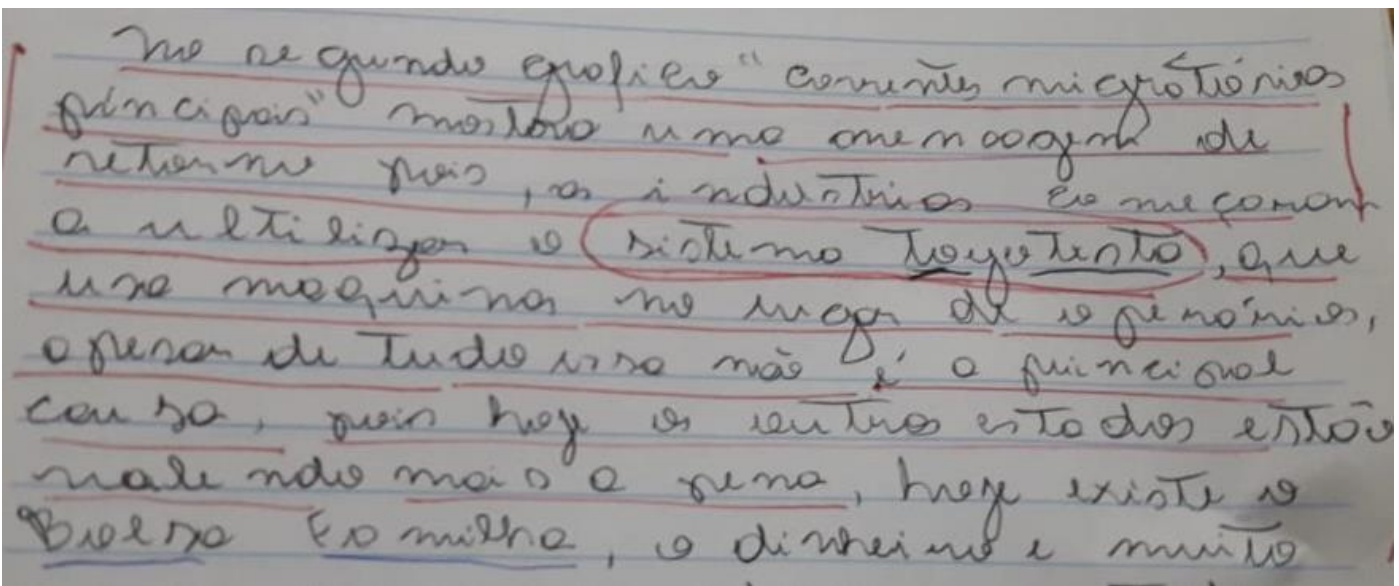

Giovanne de Jesus Reis, $8^{\mathrm{a}} \mathrm{D}$

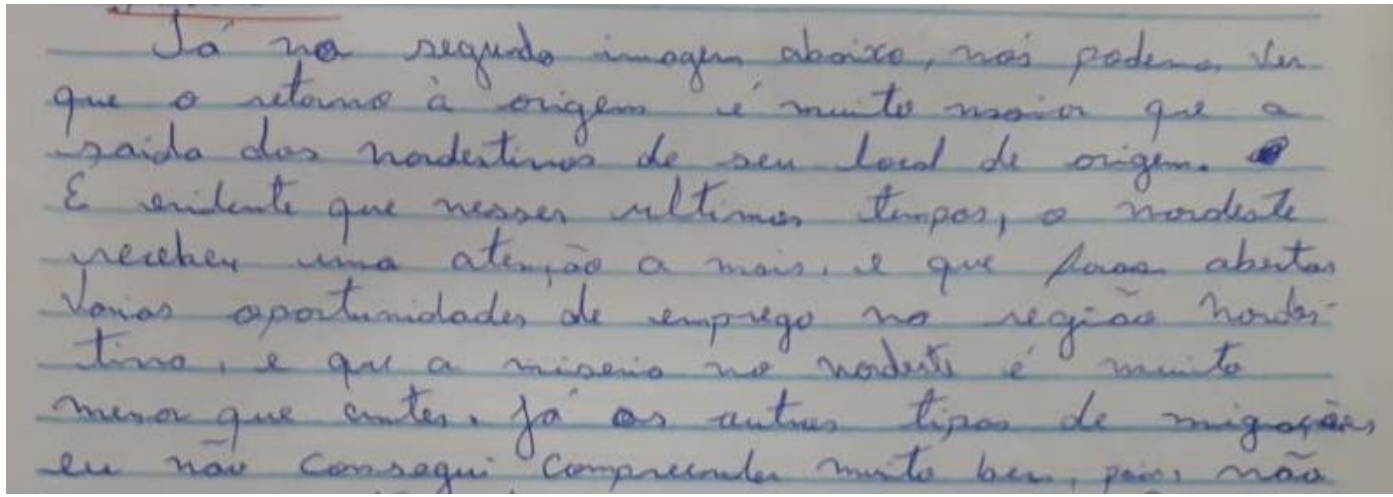

